\title{
Review of Section XI Inservice Inspection Program Effectiveness
}

\author{
J. F. Cook, Sr.
}

Published August 1993

\author{
Idaho National Engineering Laboratory \\ EG\&G Idaho, Inc. \\ Idaho Falls, Idaho 83415-2209
}

\author{
Prepared for the \\ Division of Engineering \\ Office of Nuclear Regulatory Research \\ U.S. Nuclear Regulatory Commission \\ Washington, DC 20555 \\ Under DOE Idaho Operations Office \\ Contract DE-AC07-76ID01570 \\ FIN A6367, Task 24
}




\begin{abstract}
To evaluate the effectiveness of Section XI, Division 1, "Rules for Inservice Inspection of Nuclear Power Plant Components," of the American Society of Mechanical Engineers Eoiler and Pressure Vessel Code, searches were performed of the Licensing Event Report and Nuclear Plant Reliability Data System computerized data bases, and a review was made of inservice inspection summary reports. It was found that the Section XI examinations and tests detect flaws in welds and plant components and result in subsequent corrective action. This study also shows that the format and topics of information provided in Section XI-prescribed inservice inspection summary reports vary widely.
\end{abstract}

This work was funded under:

U. S. Nuclear Regulatory Commission

FIN No. A6367, Task 24

W. C. Liu, NRC Program Manager 


\section{SUMMARY}

This is the fifth in a series of reports evaluating inservice inspection (ISI) examinations of commercial nuclear power plants. This work was performed by EG\&G Idaho, Inc. at the Idaho National Engineering Laboratory (INEL) for the Nuclear Regulatory Commission (NRC) under Task. 24 of FIN A6367. The data studied for this report were compiled from licensee inservice inspection summary reports, the Licensing Event Report (LER) data base and the Nuclear Plant Reliability Data System (NPRDS) data base.

The purpose of this phase of Task 24 was to further evaluate the effectiveness of Section XI, Division 1, of the American Society of Mechanical Engineers (ASME) Boiler and Pressure Vessel (B\&PV) Code examination requirements and to recommend changes for improvement if necessary.

This study revealed that ASME B\&PV Section XI Code examinations are detecting relevant conditions in welds and plant components. This study also identified the need to clarify some requirements in certain subsections of Section XI. 


\section{CONTENTS}

ABSTRACT $\ldots \ldots \ldots \ldots \ldots \ldots \ldots \ldots \ldots \ldots \ldots \ldots \ldots \ldots \ldots \ldots \ldots \ldots \ldots \ldots \ldots$

SUMMARY $\ldots \ldots \ldots \ldots \ldots \ldots \ldots \ldots \ldots \ldots \ldots \ldots \ldots \ldots \ldots \ldots \ldots$

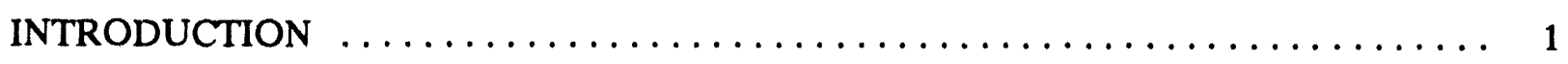

DATA BASE SEARCH TECHNIQUES AND RESULTS $\ldots \ldots \ldots \ldots \ldots \ldots \ldots \ldots$

ISI SUMMARY REPORTS $\ldots \ldots \ldots \ldots \ldots \ldots \ldots \ldots \ldots \ldots \ldots \ldots \ldots \ldots \ldots$

CONCLUSIONS $\ldots \ldots \ldots \ldots \ldots \ldots \ldots \ldots \ldots \ldots \ldots \ldots \ldots \ldots \ldots \ldots \ldots \ldots$

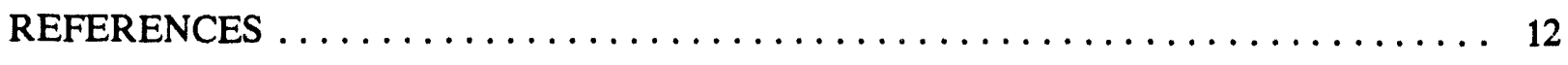

Appendix A-LER Information $\ldots \ldots \ldots \ldots \ldots \ldots \ldots \ldots \ldots \ldots \ldots \ldots \ldots \ldots \ldots \ldots \ldots \ldots \ldots \ldots \ldots \ldots$

Appendix B-NPRDS Information $\ldots \ldots \ldots \ldots \ldots \ldots \ldots \ldots \ldots \ldots \ldots \ldots \ldots \ldots \ldots \ldots \ldots$

Appendix C-Excerpts from ISI Summary Reports $\ldots \ldots \ldots \ldots \ldots \ldots \ldots \ldots \ldots \ldots$ C-1

Appendix D-Inquiry on Overlap of ISI Intervals $\ldots \ldots \ldots \ldots \ldots \ldots \ldots \ldots \ldots \ldots \ldots$

\section{TABLES}

1. Summary of LER Information $\ldots \ldots \ldots \ldots \ldots \ldots \ldots \ldots \ldots \ldots \ldots \ldots \ldots$

2. Distribution of NPRDS Referenced NDE Methods $\ldots \ldots \ldots \ldots \ldots \ldots \ldots \ldots \ldots$

3. Distribution of Section XI Code Edition/Addenda $\ldots \ldots \ldots \ldots \ldots \ldots \ldots \ldots$ 


\title{
Review of Section XI Inservice Inspection Program Effectiveness
}

\author{
INTRODUCTION
}

This is the fifth in a series of reports on the effectiveness of inservice inspection (ISI) examinations performed by commercial nuclear power plants per the requirements of Section XI, Division 1, of the American Society of Mechanical Engineers (ASME) Boiler and Pressure Vessel (B\&PV) Code. ${ }^{1}$ The first report ${ }^{2}$ evaluated examinations performed by 12 nuclear facilities and reviewed 96 Licensee Event Report (LER) abstracts to determine if Section XI requirements were instrumental in discovering conditions reported. The second report ${ }^{3}$ was a review of the ISI administrative system, the third report ${ }^{4}$ evaluated the effectiveness of Section XI steam generator examination requirements, and the fourth report ${ }^{5}$ evaluated additional ISI summary reports to determine the effectiveness of Section XI examinations and develop recommendations for ASME Code revisions. The purpose of this phase of Task 24 of FIN A6367 was to further evaluate ISI effectiveness by reviewing operational data in connestion with Licensing Event Reports (LERs), the iNuclear Plant Reliability Data System (NPRDS), and additional ISI summary reports to determine the effectiveness of Section XI examinations and develop recommendations, if necessary, for Section XI ASME B\&PV Code revisions.

This report includes a compilation and analysis of data contained in LERs, the NPRDS, and selected summary reports of ISI examinations that licensees submit to the NRC. These reports are due within 90 days of the end of each series of examinations performed during a refueling outage. 


\section{DATA BASE SEARCH TECHNIQUES AND RESULTS}

The LER data base was searched for records that included detection by inspection/testing and 'Section XI' in the abstract. It was necessary to perform a text scan of the abstracts since no field in the LER data base covers Section XI directly. Seventy of 38,097 LERs met this search criterion. Most of these dealt with Section XI inservice testing of pumps and valves or referenced Section XI for repair and replarement. Since this report deals with the etfectiveness of Section XI nondestructive examinations, the testing and repair/replacement LERs were not reviewed extensively. The 17 LERs that reference Section XI examinations are included in Appendix $A$ and summarized in Table 1. In addition, Appendix $A$ also includes four additional LERs (Form Numbers $48,50,55$, and 58 ) that reference Section XI, but do not pertain to examinations.

The search conditions used for the NPRDS was safety class 1,2 , or 3 and detection by inservice inspection or testing. This provided 3,038 failures from a total of 146,107 failure records. Details for 99 pipe failures and 25 vessel failures in this group were then printed to disk, edited to clean up the format, and further analyzed. These records are provided in Appendix B. Table 2 summarizes the NDE methods referenced in the records contained in Appendix B.

An LER record may contain multiple components, but each component will have a single record in the NPRDS system. More data were found in the NPRDS search, since having "Section $\mathrm{XI}$ " in the text was not a limitation used in the NPRDS search. Some data in the NPRDS match records in the LER data base (e.g., the Form 7 LER corresponds with the last pipe record for Millstone 1 in Appendix B). However, the Form 8 LER did not show up in the NPRDS search.

These data bases provide a much quicker means of locating the information on Section XI examinations that find significant conditions. This is because only one plant and about one year of examinations are included in any single summary report and because the summary reports cannot be searched using a computer, while the data bases cover all plants for the history of the plants and are searched using a computer. 
Table 1. Summary of LER Information

\begin{tabular}{|c|c|c|c|}
\hline $\begin{array}{c}\text { LER } \\
\text { Form } \\
\text { No. }\end{array}$ & Component & Condition Found & $\begin{array}{c}\text { NDE } \\
\text { Method }\end{array}$ \\
\hline 3 & main steam piping welds & fabrication flaws & RT \\
\hline 4 & $\begin{array}{l}\text { feedwater system piping } \\
\text { welds }\end{array}$ & fabrication flaws & RT \\
\hline 5 & pipe supports & failed attachment welds & VT \\
\hline 6 & steam generator tubing & $\begin{array}{l}\text { stress corrosion cracking and } \\
\text { pitting }\end{array}$ & ET \\
\hline 7 & class 1 stainless piping & crack in weld & NS \\
\hline 8 & piping & inclusions & UT \\
\hline 11 & valve & weld-related flaw & UT \\
\hline 16 & nozzle to shell weld & slag in weld root area & UT \\
\hline 30 & piping & improper valve lineup & VT \\
\hline 32 & piping & $\begin{array}{l}\text { intergranular stress } \\
\text { corrosion cracking }\end{array}$ & UT \\
\hline 44 & RHR class 1 piping & $\begin{array}{l}\text { flaw (leak) in plug type } \\
\text { repair weld }\end{array}$ & VT \\
\hline 45 & piping welds & fabrication flaws & RT \\
\hline 52 & clasis 1 piping welds & unacceptable flaw & NS \\
\hline 57 & steam generator tubing & $\begin{array}{l}\text { stress corrosion cracking and } \\
\text { pitting }\end{array}$ & ET \\
\hline 61 & check valves & plugging & VT \\
\hline 62 & check valve & missing spring & VT \\
\hline 69 & steam generator tubing & $\begin{array}{l}\text { stress corrosion cracking and } \\
\text { pitting }\end{array}$ & ET \\
\hline
\end{tabular}

* ET, RT, UT, VT and NS respectively indicate eddy current, radiographic, ultrasonic, visual and not specified nondestructive examination methods. 
Table 2. Distribution of NPRDS Referenced NDE Methods

\begin{tabular}{|c|c|c|c|c|c|c|}
\hline Component & LT & RT & PT & $\mathbf{V T}$ & UT & NS \\
\hline class 1 piping & & & 18 & 7 & 25 & 8 \\
\hline class 2 piping & 1 & 2 & 11 & 10 & 9 & 2 \\
\hline class 3 piping & 2 & & & 4 & 1 & \\
\hline vessels & & & 1 & 23 & 1 & \\
\hline Total & 3 & 2 & 30 & 44 & 36 & 10 \\
\hline
\end{tabular}

* LT, RT, PT, UT, VT and NS respectively indicate leak or flow test, radiography, penetrant, ultrasonic, visual and not specified nondestructive examination methods. 


\section{ISI SUMMARY REPORTS}

Information was compiled from 15 ISI summary reports of 15 nuclear facilities (see Appendix $D$ for excerpts from selected summary reports). Twelve of these facilities were pressurized water reactors (PWRs) and three were boiling water reactors (BWRs). Four reactor suppliers are represented, (i.e., six were Westinghouse (W) and three each were General Electric (GE), Combustion Engineering (CE), and Babcock and Wilcox (BW). Table 1 shows the different edition/addenda of Section XI of the ASME B\&PV Code referenced in the reviewed ISI summary reports.

Table 3. Distribution of Section XI Code Edition/Addenda.

\begin{tabular}{llll}
\hline $80-\mathrm{W} 80^{\circ}$ & $80-\mathrm{W} 81$ & $83-\mathrm{S} 83$ & 86 edition \\
\hline 2 plants & 5 plants & 6 plants & 2 plants \\
\hline Indicates the 1980 Edition with the Winter 1980 Addenda. & \\
\hline
\end{tabular}

Review comments on the 15 selected summary reports follow:

Plant $A(B \& W)-80$-W80 Code. This includes the NIS-1 form with 398 pages following that are not uniformly numbered. No NIS-2's are contained as they are not required by the Code addenda used. A computerized seven-page repair/replacement log is supplied instead.

'Alternative' inspections are included in a status table but no definition of 'alternative' is supplied. These apparently are examinations performed in lieu of the Code-required examinations and covered by relief requests. A 103-page inspection plan is included, followed by 56 pages of computerized results, with relief requests referenced for limited coverage examinations. This is information that should be a regulation requirement for all summary reports. Narrative Class 1 and 2, plus augmented and alternative examination results, then follow and are shown in Appendix C. Much ultrasonic data on resolving indications in components using amplitude drop sizing techniques that have long been known to have limitations, but are specified by the Code addenda used, are included. Another problem resolution, including UT sizing using a tip diffraction technique, is included. A fracture mechanics analysis report for resolution of one UT detected flaw is included, but it is marked "Proprietary."

Plint B $(G E)$ - 80-W80 Code. Class 3 results are included although not required by the Code. A table of ISI inspection periods, and outage history and plans for the interval are included. This would be good to have as a Code requirement for inclusion in all summary reports. Augmented (noncode) examinations are included. GE did many of the RPV exams under contract. The GERIS automated system was used on nozzle-to-vessel welds. A summary table of examination limitations is provided with a commitment to either complete the required examinations at a later outage or request relief. A table of 'significant' indications is included. An extensive package of NIS-2 forms take most of the report volume, but a computer-generated summary table of repairs and replacements is included that provides the information in a much 
more usable tormat than the NIS-2 forms. This is a better format for the information in a summary report, and a Code change to eliminate the NIS- 2 form may be beneficial.

Plant $C(B \& W)$ - 80-W81 Code. This report was about a month later than the Code required 90 days after examination completion. It does reference a letter that requested an extension due to an unexpected heavy workload. It includes an examination table with no result or limitations included (another 'plan-type' table similar to Indian Point 3). Qualitative results are included in the text on supports (a few with minor problems), augmented examinations for IGSCC, pure water stress corrosion cracking, and other piping weld indications (dripping associated with crack-like indications on noncode, nonsafety piping). Apparent slag indications reexamined in reactor coolant pumps were reported as 'shrinking in size due to refincments made in the UT equipment.' It discusses use of Code Case N-481, which provides for analysis in lieu of examination of reactor coolant pump casing welds.

Plant $D(W)$ - 80-W81 Code. This includes a technical report justifying an IWA-2240 alternative ultrasonic examination calibration block. This is a case where an alternative to a specific Code requirement is permitted by the Code and a relief request to NRC is not necessary. A summary of repairs and replacements is provided.

Plant $E(C E)$ - 80-W81 Code. The NIS-1 form references a summary report that includes items 1 through 6 from the NIS-1 form on every page. Class 3 results are included, even though they are not required by the Code. A summary table (index) of the NIS-2 forms is included. Review of the section, "Abstract of Conditions Noted and Corrective Actions Taken," showed that rejectable piping welds were found by surface examinations and that the indications were removed by grinding. The examination sample was not expanded as required by the Code. They state: "The initial indications on both welds were most likely left over from construction. No additional welds were inspected as a result of these minor indications."

Plant $F(G E)$ - 80-W81 Code. The cover letter summarizes several augmented examinations. The report takes an exception to the NIS-1 requirement that supplemental sheets include 6 items of information. Other reports also do not follow that requirement. A change to the form should be initiated to resolve this issue. Many contractors were used. EPRI-qualified UT examiners were used for all examination of IGSCC-susceptible materials. Clad overlay repairs are discussed. A summary table of all reportable indications is included. The examination summary tables do include results and quantitative limitations. The report does not include Form NIS-2, since it is not required by the Code used, but it includes a summary table of repairs and replacements. This is a better format for the information in a summary report, and a Code change to eliminate the NIS-2 form may be beneficial.

Plant $G(G E)$ - 80-W81 Code. A useful summary of examinations and results broken down into broad categories is included in front of the NIS-1 form, which contained much of the same information repeated in a less usable form. A narrative of the repairs and replacements, plus a summary, is provided which facilitates review. Indications are noted, but there is no reference to expanded examination samples as required by Section XI of the ASME B\&PV Code. Relief requests are referenced on the examination data tables included with the NIS-1 form. 
Plant $H(W) \cdot 83-$ S83 Code. Results are included in a notes section, which follows the examination summary table. A brief index to the NIS-2 forms is provided. A note is made regarding a $25 \%$ through-wall limitation of cast stainless steel ultrasonic examinations with a relicf request referenced.

Plant $I(W)-83$-S83 Code. Another problem similar to the Plant E regarding not doing required sample expansion was found. Results are included in a notes section that follows the examination summary table. A brief index to the NIS-2 forms is provided. Reference to other NRC submittals on steam generator tubing examinations, fracture mechanics analysis of flaws in nozzle-to-vessel welds, and relief requests is made. A note is made regarding a $25 \%$ through-wall limitation of cast stainless steel ultrasonic examinations with a relief request referenced.

Plant $J(C E)$ - 83-S83 Code. Another large package, 63 NIS-2s, were not included due to 'administrative and clerical' problems. They committed to supply the missing NIS-2s with the next ISI summary report. Page 4 of the NIS-1 (Appendix C) gives a brief summary of the ISI results. SWRI was ISI contractor. The organization supplied a three-volume report that was submitted in total. Useful examination summary tables with results are provided. Additional unnecessary detail for a summary report includes handwritten individual examination data sheets and copies of examination personnel certifications.

Plant $K(C E)$ - 83-S83 Code. No index of the 1 in. thick stack of NIS-2s was provided. A component-by-component summary of results in the format supplied by the contractor, SWRI, is provided. This requires going through an extensive page-by-page and line-by-line search to find where ISI detected problems. A brief half-page summary of steam generator eddy current tests is provided.

Plant $L(W)$ - 83-S83 Code. Dynacon Systems was contractor. This summary report consisted of extracts from the Dynacon-supplied ISI report. The 58 pages included about 33 pages of copies of the Code examination requirement figures. It included tables of planned examinations, without results or examination limitations included. It includes the required NIS-1 Form, but no NIS-2 forms as required by Section XI. It references the 1986 edition of Section XI for use of Appendix VI, which covers performance demonstration for UT of bolting. It briefly mentions 36 recordable indications, 10 surface (components not given) and 26 visual (all on IWF supports). It mentions limited examinations (geometry, access, etc.), but does not give details or reference relief requests.

Plant $M(W)$ - 83-S83 Code. SWRI was contractor. Portions of the SWRI report to the licensee are included; some appendices that include details not required in summary reports were missing. The completed form NIS-1 includes normal ISI, steam generator ET results, and IST results. Usually, these are in separate reports and submittals. A summary table of ISI results is included. Examinations not required by Section XI for erosion/corrosion are discussed. One indication was found outside the Code examination area, but on a Code component. The disposition (Appendix $C$ ) states that the material removal specified to remove the indication does not require a Code job package. Since this is a Code item, a Section XI Code repair should have been performed. A summary of the repairs and replacements is provided. Some are covered by NIS-2 forms, but most are covered by NR-1 forms, which reference an NR stamp and are available from the National Board. 
Plant $N(W)-86$ Code. This was the largest volume summary report reviewed (an $111 / 2$ in. thick pile of paper, including a 2 in. thick steam generator eddy current report prepared by $C E$ ). It includes the ET procedure, the employer-written practice for personnel certification, plus all of the personnel certifications, which are proprietary. The licensee submitted the entire contractor report rather than providing a summary report. In a similar manner all the ISI results, three volumes, prepared by the contractor NES, make up the remaining parts of the report. There are about 117 pages of NIS-2 forms with no summary table. Excessive detail such as the examination plan, individual result sheets for each examination, and calibration data sheets are included. This is not a summary report, but the original vendor-supplied plant ISI data. One item of interest discovered is an evaluation of a nozzle indication, which involved extensive resources with multiple UT examinations by different organizations plus radiography to find whether the indication was an inservice flaw or an existing fabrication tlaw (see Appendix C).

Plant $O(B \& W)$ - 86 Code. This report covers both first- and second-interval examinations that occurred during overlapping dates in the same refueling outage. It appears that this practice may violate the intent of the Code. A plant should be operated for a minimum of one refueling outage before credit can be taken for examinations performed in the interval. The Code requirements need to be expanded to clarify the intent. The report lists at least one examination of a reactor vessel shell-to-flange weld that is credited for both intervals when only one examination was performed. There are other duplicate credits of noizle-to-shell welds and nozzle radii. All duplicates could be found if a computer search were available. It would be beneficial to the licensees and NRC if the summary information were submitted in computerized form. The examination summary tables do include information on examination limitations, and a summary table of indications, showing all but one indication associated with supports, is provided. Only six pages of NIS-2 forms are attached.

The above review comments and the excerpted summary reports in Appendix $C$ show wide interpretation of what should be in the ISI summary report and show it may be beneficial to not require submittal of the NIS-2 forms, but to use a summary table of the repairs and replacements for the summary report. Also, the large volume of data could be better submitted on a computerized format, which would both reduce paper work and facilitate review. Future effort should be applied to prepare a Section XI appendix on format and content of summary reports. This action should also include an option for submitting computerized data.

The first Section XI of the ASME B\&PV Code published in 1971 was written for Class 1 and required that summary reports for all examinations and tests be submitted to the NRC. The Winter 1972 Addenda added Class 2 and only required reports for examinations, not tests. Further, it only required reports for examinations that resulted in repairs or replacements. The Summer 1973 Addenda incorporated Subsections IWP (purnps) and IWV (valves). Class 3 was added in the 1974 Edition. Article IWA-6000, Records and Reports, of the 1974 Edition required summary reports to be submitted for all examinations and tests for Class 1 and Class 2 components, but excluded Class 3. It is possible that the addition of Class 3 was overlonked by the $[$ up responsible for IWA-6000. Correction of this omission is in progress in the ASME B\&PV Code Committee.

Subsubarticle IWA-6210, Owner's Responsibility, presently requires that Owners prepare preservice and inservice inspection summary reports for all Class 1 and Class 2 pressure-retaining 
components and their supports. Subsubarticle IWA-6220, Preparation, states that inservice inspection summary reports shall be prepared at the completion of each inspection conducted during a refueling outage and that examinations, tests, replacements, and repairs conducted since the preceding summary report shall be inclıded. Subsubarticle IWA-6230, Summary Report Submittal, requires the Owner to file inservice inspection summary reports with the enforcement and regulatory authorities having jurisdiction at the plant site within 90 days of completion of the inservice inspection conducted during each refueling outage.

The Plant C licensee missed the IWA-6230 deadline for summary report submittal by about a month, but referenced a letter that requested an extension due to an unexpected heavy workload.

The Plant $\mathrm{O}$ licensee performed examinations for the first and second intervals in one refueling outage and provided a joint summary report for the two intervals. This joint submittal included credit for one examination counting for two intervals. This practice does not comply with the intent of Section XI, and B\&PV Code action to resolve this issue has been initiated as shown in Appendix E. Some licensees are misinterpreting the provisions of IWA-2430(d) of Section XI, which permits extending or decreasing an inspection interval by as much as one year to provide overlapping of intervals.

Subsubarticle IWA-6220, which requires that summary reports include all examinations and tests for Class 1 and Class 2 components, is being misinterpreted by many facilities. None of the facilities in this study included results of testing pumps or valves. Resolution of this problem will now requires action by the ASME Committee on Operation and Maintenance (OM) of Nuciear Power Plants, since inservice testing of pumps and valves is now controlled by the ASME OM Code. The ASME OM Code does not presently reguire summary reports.

Though required to report only on Class 1 and Class 2 components, the Plant B and Plant E summary reports included Class 3 results. Previously, 11 of 27 reports reviewed contained Class 3 results. Section XI should require the summary reports to include the results of all examinations and tests, regardless of class. The proposed change to accomplish this is in progress in the B\&PV Committee. This is a low-impact change, since IWA-6210(b) already requires preparation of the records used to make up the summary report.

The Plant $\mathrm{E}$ and Plant I licensees did not expand the examination sample as required by Section XI when rejectable results are found in the initial sample.

Some of reports included augmented examinations, although this is not a requirement. Inclusion of augmented examinations in all summary reports should be required in the proposed FIN A6367 Task 38 action to place the Section XI submittal requirements to the NRC in 10 CFR 50.55a.

Below are some NRC documents that licensees reference for augmented examinations:

1. NRC Bulletin 82-02, "Degradation of Threaded Fasteners in the Reactor Coolant Pressure Boundary of Power Plants"

2. NRC I.E. Bulletin 79-13, "Cracking in Feedwater System Piping" 
3. NRC Bulletin 88-08, "Thermal Stresses in Piping Connected to Reactor Coolant Systems"

4. NRC Bulletin 87-01, "Thinning of Pipe Walls in Nuclear Power Plants"

5. Summary NUREG 0578, "TMI Lessons Learned"

6. NRC Bulletin 82-03, "Stress Corrosion Cracking in Thick-Wall, Large-Diameter Stainless Steel, Recirculation System Piping at BWR Plants"

7. NRC Bulletin 83-02, "Stress Corrosion Cracking in Thick-Wall, Large-Diameter Stainless Steel, Recirculation System Piping at BWR Plants"

A decision that resulted from this study is that Title 10 Part 50 of the Code of Federal regulations should be amended. $10 \mathrm{CFR} \S 50.55 \mathrm{a}(\mathrm{g})(5)(\mathrm{IV})$ states that where an examination or test is determined to be impractical and not included in the licensee's revised ISI program, the relief requests shall be submitted not later than 12 months after the 120-month interval. A facility can repeatedly not perform a required examination for 11 years. Also, by the time a problem is identified, after the completion of the ISI interval, it is too late to implement corrective action.

It is suggested that $10 \mathrm{CFR} \S 50.55 \mathrm{a}$ be revised to require that relief requests either be referenced in or be submitted with the summary reports. 


\section{CONCLUSIONS}

This study revealed that Section XI examinations are of value in detecting relevant conditions in welds and plant components.

Problems were identified regarding ISI interval scheduling of examinations and examination sample expansion. Also, Seciion XI should be changed to include all Section XI examination and test results in the summary reports.

Confusion regarding the content of ISI summary reports was noted. Future effort should be applied to prepare a Section XI appendix on format and content of summary reports. This action should also include an option for submittal of computerized data to reduce paper volume and facilitate information review.

It may be beneficial to not require submittal of the NIS- 2 forms, but to use a summary table of the repairs and replacements for the summary report.

Another recommendation, because limited examinations were reported that were not covered by relief requests, is to change $10 \mathrm{CFR} \S 50.55 \mathrm{a}$ to require relief requests to be referenced or submitted with the summary reports so that corrective action or substitute examinations can be identified and implemented before the start of the next inspection interval. 


\section{REFERENCES}

1. "American Society of Mechanical Engineers Boiler and Pressure Vessel Code," Section XI, Division 1.

2. D. A. Aldrich, J. F. Cook, Evaluation of ASME Code, Section XI, Division 1, Inservice Inspection, EGG-SD-7797, December 1987.

3. J. F. Cook, Review of the Inservice Inspection Administrative System, EGG-MS-8130, August 1988.

4. D. A. Aldrich, J. F. Cook, Effectiveness of Steam Generator Inservice Examinations, EGG-MS-8417, April 1989.

5. D. A. Aldrich, J. F. Cook, Effectiveness of Inservice Inspection Examinations, EGG-MS-8848, May 1990. 
Appendix A

\section{LER Information}


A-2 


\section{Appendix A}

\section{LER Information}

FORM 3 LER SCSS DATA

12-24-92

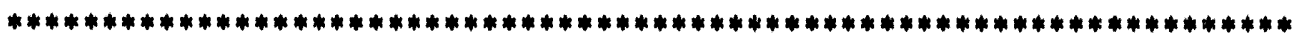

DOCKET YEAR LER NUMBER REVISION DCS NUMBER NSIC EVENT DATE

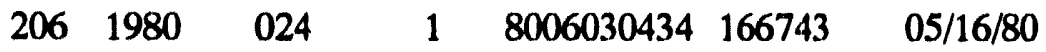

DOCKET:206 SAN ONOFRE 1 TYPE:PWR

REGION: 5 NSSS:WE

ARCHITECTURAL ENGINEER: BECH

FACILITY OPERATOR: SOUTHERN CALIFORNIA EDISON CO.

SYMBOL: SCE

\section{ABSTRACT}

POWER LEVEL - 000\%. CAUSE - INSTALLATION ERROR. WHILE PERFORMING RADIOGRAPHIC EXAMINATION OF MAIN STEAM LINES INSIDE CONTAINMENT, SIX

WELDS WERE FOUND WITH INDICATIONS IN EXCESS OF THOSE PERMITTED BY ASME

B\&PV CODE, SECTION I. FIVE OF THE WELDS HAVE FLAWS CONSISTING OF SLAG

INCLUSIONS AND/OR LACK OF PENETRATION. ONE WELD HAS THREE SMALL CRACKS IN THE ROOT. THE INDICATIONS APPARENTLY HAVE EXISTED IN THE LINE FROM ORIGINAL PLANT CONSTRUCTION. ALL WELDS WERE REPAIRED UNDER SECTION XI REQUIREMENTS.

-.-.-STEP: 1

CAUSE:SA --INTRINSIC HUMAN ERROR

PRIMARY SYSTEM:PC -.-CONSTRUCTION ACTIVITY

COMPONENT:PZ -.UNKNOWN PERSONNEL

TIMING:M --ACTUAL PREEXISTING, UNDETECTED

PERFORMANCE:T --TOTAL FAULT

DETECTION:R --REVIEW OF PROCEDURE/ TEST RESULTS

EFFECT:UA --COMMISSION OF UNDESIRED TASK, ANALYSIS, OR STEP

-..---STEP: 2

THIS STEP IS DIRECTLY LINKED TO STEP 1

CAUSE:PA --WELD-RELATED FLAW

PRIMARY SYSTEM:FA --MAIN STEAM

SECONDARY SYSTEM:SA --PRIMARY REACTOR CONTAINMENT (PWR)

COMPONENT:PIEC--PIPE, GREATER THAN 16 INCH DIAMETER, CARBON STEE 
VENDOR:B130--BECHTEL CORP.

QUANTITY:5 -.-

TRAIN:Z ..UNKNOWN

TIMING:P -.POTENTIAL

PERFORMANCE:PR -.PARTIAL FAULT/REPAIR

DETECTION:I --TESTING/ INSPECTION

EFFECT:BP --EXTERNAL SYSTEM LEAKAGE, UNKNOWN RATE

-.--.-STEP: 3

THIS STEP IS DIRECTLY LINKED TO STEP 1

CAUSE:PA --WELD-RELATED FLAW

PRIMARY SYSTEM:FA --MAIN STEAM

COMPONENT:PIEC--PIPE, GREATER THAN 16 INCH DIAMETER, CARBON STEE

VENDOR:B130--BECHTEL CORP.

DIFFERENTIATOR:2 -.

TIMING:M --ACTUAL PREEXISTING, UNDETECTED

PERFORMANCE:PR -.PARTIAL FAULT/REPAIR

DETECTION:I -.TESTING/INSPECTION

EFFECT:DE -.-CRACK

INITIAL UNIT CONDITIONS: $\mathrm{H}$ REFUELING

UNIT EFFECT: XX NO SIGNIFICANT EFFECT

EFFECT ON ENVIRONMENT: N NO RELEASE

EFFECT ON PERSONNEL: $N$ NO EXPOSURE

FORM 4 LER SCSS DATA

$12-24-92$

*************************************************************

DOCKET YEAR LER NUMBER REVISION DCS NUMBER NSIC EVENT DATE $\begin{array}{lllllll}206 & 1980 & 027 & 0 & 8007010537 & 160255 & 05 / 18 / 80\end{array}$

DOCKET:206 SAN ONOFRE 1 TYPE:PWR

REGION: 5 NSSS:WE

ARCHITECTURAL ENGINEER: BECH

FACILITY OPERATOR: SOUTHERN CALIFORNIA EDISON CO.

SYMBOL: SCE

ABSTRACT

POWER LEVEL - 000\%. CAUSE - FAULTY WELDS. RADIOGRAPHIC EXAMINATION OF

FEEDWATER SYSTEM WELDS INSIDE CONTAINMENT FOUND SEVEN (7)

UNACCEPTABLE DEFECTS. FIVE (5) CASES OF LACK OF PENETRATION, ONE (1) 
CASE OF POROSITY, AND ONE (1) CASE OF SLAG INCLUSION. ALL DEFECTS WERE

ORIGINAL CONSTRUCTION DEFECTS. SEVEN (7) WELDS WERE REPAIRED UNDER

THE REPAIR REQUIREMENTS OF ASME B\&PV CODE SECTION XI.

-...-.STEP: 1

CAUSE:SA --INTRINSIC HUMAN ERROR

PRIMARY SYSTEM:PC -.-CONSTRUCTION ACTIVITY

COMPONENT:PZ -.UNKNOWN PERSONNEL

TIMING:M --ACTUAL PREEXISTING, UNDETECTED

PERFORMANCE:T -.TOTAL FAULT

DETECTION:I --TESTING/INSPECTION

EFFECT:UA -..COMMISSION OF UNDESIRED TASK, ANALYSIS, OR STEP

-...-STEP: 2

THIS STEP IS DIRECTLY LINKED TO STEP 1

CAUSE:PA --WELD-RELATED FLAW

PRIMARY SYSTEM:FI -.-CONDENSATE AND FEEDWATER

SECONDARY SYSTEM:SA --PRIMARY REACTOR CONTAINMENT (PWR)

COMPONENT:PICZ--PIPE, $>6$ AND $<=10$ INCH DIAMETER, UNKNOWN MATERI

VENDOR:B130--BECHTEL CORP.

QUANTITY:7 -.

TRAIN:Z -.UNKNOWN

TIMING:P -.POTENTIAL

PERFORMANCE:PR -.PARTIAL FAULT/REPAIR

DETECTION:I -.TESTING/ INSPECTION

EFFECT:BP --EXTERNAL SYSTEM LEAKAGE, UNKNOWN RATE

INITIAL UNIT CONDITIONS: H REFUELING

UNIT EFFECT: XX NO SIGNIFICANT EFFECT

EFFECT ON ENVIRONMENT: N NO RELEASE

EFFECT ON PERSONNEL: $N$ NO EXPOSURE

FORM $5 \quad$ LER SCSS DATA $12-24-92$

***********************************************************

DOCKET YEAR LER NUMBER REVISION DCS NUMBER NSIC EVENT DATE $\begin{array}{lllllllll}206 & 1982 & 009 & 0 & 8204220328 & 173061 & 04 / 05 / 82\end{array}$

DOCKET:206 SAN ONOFRE 1 TYPE:PWR

REGION: 5 NSSS:WE

ARCHITECTURAL ENGINEER: BECH 
FACILITY OPERATOR: SOUTHERN CALIFORNIA EDISON CO. SYMBOL: SCE

\begin{abstract}
DURING SCHEDULED ISI INSPECTION, VISUAL EXAMINATION REVEALED FAILED ATTACHMENT WELDS ON TWO FEEDWATER SYSTEM PIPE SUPPORTS. AN EXPANDED

INSPECTION OF THE SYSTEM DISCOVERED A TOTAL OF FOUR SUPPORT WELD FAILURES. INITIAL SEISMIC ANALYSIS INDICATES SYSTEM STRUCTURAL INTEGRITY WOULD BE MAINTAINED UNDER ORIGINAL STATION DESIGN CRITERIA.
\end{abstract}

A SPECIFIC CAUSE OF FAILURE HAS NOT BEEN DETERMINED. A METALLURGICAL

AND DESIGN ANALYSIS OF THESE SUPPORTS IS IN PROGRESS TO DETERMINE THE

CAUSE OF FAILURE. ALL FAILED SUPPORTS ARE BEING REPLACED IN ACCORDANCE WITH ASME BOILER AND PRESSURE VESSEL CODE SECTION XI.

-....-STEP: 1

CAUSE:SZ ..UNKNOWN HUMAN FACTOR CAUSE

PRIMARY SYSTEM:PI -.INSTALLATION ACTIVITY

COMPONENT:PZ -.UNKNOWN PERSONNEL

TIMING:M -.ACTUAL PREEXISTING, UNDETECTED

PERFORMANCE:T --TOTAL FAULT

DETECTION:I --TESTING/ INSPECTION

EFFECT:UA --COMMISSION OF UNDESIRED TASK, ANALYSIS, OR STEP

-......STEP: 2

THIS STEP IS DIRECTLY LINKED TO STEP 1

CAUSE:PA -..WELD-RELATED FLAW

PRIMARY SYSTEM:FI ..CONDENSATE AND FEEDWATER

COMPONENT:SPT -.SUPPORT

VENDOR:B13()-BECHTEL CORP. QUANTITY:4 ..

TRAIN:M --MULTIPLE

TIMING:M -.ACTUAL, PREEXISTING, UNDETECTED

PERFORMANCE:TR -.TOTAL FAULT/REPAIR

DETECTION:I -TESTING/ INSPECTION

EFFECT:DA -.BREAK/ SHEAR

STEP: 3

THIS STEP IS DIRECTLY LINKED TO STEP 2

CAUSE:NN --SEISMIC ACTIVITY

PRIMARY SYSTEM:FI ..CONDENSATE AND FEEDWATER

SECONDARY SYSTEM:ZZ ...UNKNOWN 

MATERI

COMPONENT:PICZ.-PIPE, $>6$ AND $<=10$ INCH DIAMETER, UNKNOWN

QUANTITY:3 -.

TRAIN:M -.MULTIPLE

TIMING:P -.POTENTIAL

PERFORMANCE:T --TOTAL FAULT

DETECTION:R -.REVIEW OF PROCEDURE/ TEST RESULTS

EFFECT:BP -.EXTERNAL SYSTEM LEAKAGE, UNKNOWN RATE

INITIAL UNIT CONDITIONS: I COLD SHUTDOWN

UNIT EFFECT: $X X$ NO SIGNIFICANT EFFECT

EFFECT ON ENVIRONMENT: N NO RELEASE

EFFECT ON PERSONNEL: N NO EXPOSURE

FORM $6 \quad$ LER SCSS DATA $12-24-92$

DOCKET YEAR LER NUMBER REVISION DCS NUMBER NSIC EVENT DATE

$\begin{array}{llllllll}213 & 1987 & 012 & 1 & 8807070550 & 209694 & 08 / 01 / 87\end{array}$

DOCKET:213 CONNECTICUT YANKEE TYPE:PWR

REGION: 1 NSSS:WE

ARCHITECTURAL ENGINEER: SWXX

FACILITY OPERATOR: CONN. YANKEE ATOMIC POWER CO.

SYMBOL: CYA

COMMENTS

STEP 4: MODEL 27 WITH INCONEL SB-166 TUBES. STEP 3: CAUSE EF - PRIMARY WATER STRESS CORROSION CRACKING AND PITTING.

ABSTRACT

POWER LEVEL - 000\%. SCHEDULED STEAM GENERATOR EDDY CURRENT

TESTING

(ECT) HAS BEEN CONDUCTED DURING THE CURRENT REFUELING OUTAGE IN ACCORDANCE WITH ASME SECTION XI AND TECHNICAL SPECIFICATION 4.10.1, "INSERVICE INSPECTION OF STEAM GENERATOR TUBES." ON AUGUST 1, 1987, IT WAS DETERMINED THAT ECT DATA PLACED STEAM GENERATOR \#1 INTO THE C.3

CATEGORY. THE STEAM GENERATOR \# 1 INSPECTION PLAN WAS EXPANDED FROM

456 TUBES TO 100) PERCENT (3,654 TUBES). ALSO, STEAM GENERATORS 2, 3, AND 4 INSPECTION PLANS WERE EXPANDED TO INCLUDE TWO TIMES THE ORIGINAL

SAMPLE SIZE. SUBSEQUENTLY, ON AUGUST 6, 1987, ECT DATA FOR STEAM 
GENERATOR \#2 PLACED IT IN CATEGORY C-3, THUS REQUIRING EXPANSION OF

THE ECT PROGRAM TO 100 PERCENT OF THE TUBES IN ALL FOUR STEAM GENERATORS AS PROVIDED FOR BY TECHNICAL SPECIFICATIONS. AS A RESULT

OF THE INSPECTION, A TOTAL OF 353 TUBES WERE PLUGGED. THE MAJOR CAUSE

OF THE TUBE DEFECTS WAS ATTRIBUTED TO PRIMARY WATER STRESS CORROSION

CRACKING AND, TO A LESSER EXTENT, PITTING. THIS EVENT IS REPORTABLE IN ACCORDANCE WITH 10CFR50.73(A)(2)(I) SINCE IT INVOLVES A CONDITION PROHIBITED BY TECHNICAL SPECIFICATIONS. THIS REVISED REPORT IS BEING ISSUED TO PROVIDE ADDITIONAL INFORMATION ON THE IDENTIFIED CAUSES AND

THE CORRECTIVE ACTIONS TAKEN.

-...-.-STEP: 1

CAUSE:SA --INTRINSIC HUMAN ERROR

PRIMARY SYSTEM:PD --DESIGN ACTIVITY

COMPONENT:PZ .-UNKNOWN PERSONNEL

TIMING:M -.ACTUAL PREEXISTING, UNDETECTED

PERFORMANCE:T -.TOTAL FAULT

DETECTION:I -.TESTING/ INSPECTION

EFFECT:UA ..COMMISSION OF UNDESIRED TASK, ANALYSIS, OR STEP

STEP: 2

THIS STEP IS DIRECTLY LINKED TO STEP 1

SUBLINK:A

CAUSE:ZZ ..UNKNOWN

PRIMARY SYSTEM:AH ..STEAM GENERATOR (PWR)

COMPONENT:TBG -.TUBING

VENDOR:W120-.-WESTINGHOUSE ELECTRIC CORP.

QUANTITY:14 ..

TRAIN:M -.MULTIPLE

TIMING:M --ACTUAL PREEXISTING, UNDETECTED

PERFORMANCE:TR -.TOTAL FAULT/REPAIR

DETECTION:I -.TESTING/INSPECTION

EFFECT:DB -.BEND/DEFORM

-......STEP: 3

THIS STEP IS DIRECTLY LINKED TO STEP 1

SUBLINK:A

CAUSE:EF -..CORROSION/ OXIDATION

PRIMARY SYSTEM:AH .-STEAM GENERATOR (PWR)

COMPONENT:TBG -.TUBING

VENDOR:W120..WESTINGHOUSE ELECTRIC CORP. QUANTITY:39 .. 
TRAIN:M -.MULTIPLE

DIFTERENTIATOR:2 -.

TIMING:M --ACTUAL PREEXISTING, UNDETECTED

PERFORMANCE:TR .-TOTAL FAULT/REPAIR

DETECTION:I -.TESTING/ INSPECTION

EFFECT:DE ...CRACK

STEP: 4

THIS STEP IS DIRECTLY LINKED TO STEP 2 AND STEP 3

CAUSE:RC --RESULTANT COMPONENT FAULT

PRIMARY SYSTEM:AH --STEAM GENERATOR (PWR)

COMPONENT:SG ...STEAM GENERATOR

VENDOR:W120-.WESTINGHOUSE ELECTRIC CORP.

QUANTITY:4 -.

TRAIN:M -MULTIPLE

TIMING:P -.POTENTIAL

PERFORMANCE:TR .-TOTAL FAULT/REPAIR

DETECTION:I --TESTING/ INSPECTION

EFFECT:BD ..-WITHIN SYSTEM LEAKAGE, UNKNOWN RATE

INITIAL UNIT CONDITIONS: I COLD SHUTDOWN

UNIT EFFECT: $X X$ NO SIGNIFICANT EFFECT

EFFECT ON ENVIRONMENT: $N$ NO RELEASE

EFFECT ON PERSONNEL: $N$ NO EXPOSURE

FORM 7 LER SCSS DATA 12.24 .92

***********************************************************

DOCKET YEAR LER NUMBER REVISION DCS NUMBER NSIC EVENT DATE $\begin{array}{llllllll}245 & 1987 & 020 & 1 & 8708190264 & 205751 & 06 / 26 / 87\end{array}$

DOCKET:245 MILLSTONE 1 TYPE:BWR

REGION: 1 NSSS:GE

ARCHITECTURAL ENGINEER: EBAS

FACILITY OPERATOR: NORTHEAST NUCLEAR ENERGY CO.

SYMBOL: NNE

ABSTRACT

POWER LEVEL - 000\%. ON JUNE 26, 1987 AT 1010 HOURS, WHILE THE UNIT WAS SHUT DOWN FOR REFUELING, AN INDICATION WAS DISCOVERED ON CLASS I STAINLESS STEEL PIPING INSIDE THE DRYWELL. THE INDICATION WAS FOUND ON THE 22 INCH RECIRCULATION SYSTEM (AD) PIPE WELD RMBJ-1 (PIPE TO CAP 
WELD) DURING INSERVICE INSPECTION (ISI) OF THE RECIRCULATION SYSTEM. THE INDICATION WAS REVIEWED BY GENERATION MECHANICAL ENGINEERING

AGAINST THE ACCEPTANCE CRITERIA OF A.S.M.E. SECTION XI, AND ON JULY 1, 1987 WAS DECLARED AS BEING AN UNACCEPTABLE FLAW AND THUS REPORTABLE.

THE WELD IN QUESTION WILL BE REPAIRED USING THE WELD OVERLAY TECHNIQUE AND A PRESSURE TEST OF THE SYSTEM WILL BE PERFORMED.

THE

OVERLAY WAS COMPLETED AND A PRESSURE TEST WAS SATISFACTORILY PERFORMED

ON AUGUST 9, 1987.

-....-STEP: 1

CAUSE:PA ..WELD-RELATED FLAW

PRIMARY SYSTEM:AI --RECIRCULATING WATER (BWR)

COMPONENT:PIES.-PIPE, GREATER THAN 16 INCH DIAMETER, STAINLESS S VENDOR:G080--GENERAL ELECTRIC CO.

TIMING:M --ACTUAL PREEXISTING, UNDETECTED

PERFORMANCE:PR -.PARTIAL FAULT/REPAIR

DETECTION:I -.TESTING/INSPECTION

EFFECT:DE -..CRACK

STEP: 2

THIS STEP IS DIRECTLY LINKED TO STEP 1

SUBLINK:X

CAUSE:EF -..CORROSION/ OXIDATION

PRIMARY SYSTEM:AI --RECIRCULATING WATER (BWR)

COMPONENT:PIES.-PIPE, GREATER THAN 16 INCH DIAMETER, STAINLESS S VENDOR:G080--GENERAL ELECTRIC CO.

TIMING:M --ACTUAL PREEXISTING, UNDETECTED

PERFORMANCE:PR ..PARTIAL FAULT/REPAIR

DETECTION:I -.TESTING/ INSPECTION

EFFECT:DE -..CRACK

INITIAL UNIT CONDITIONS: $H$ REFUELING UNIT EFFECT: $X X$ NO SIGNIFICANT EFFECT

EFFECT ON ENVIRONMENT: N NO RELEASE EFFECT ON PERSONNEL: N NO EXPOSURE

FORM $8 \quad$ LER SCSS DATA $12-24-92$

DOCKET YEAR LER NUMBER REVISION DCS NUMBER NSIC EVENT DATE $\begin{array}{lllllll}245 & 1987 & 022 & 0 & 8708(040266 & 205590 & 07 / 02 / 87\end{array}$ 
DOCKET:245 MILLSTONE 1

REGION: 1

TYPE:BWR

ARCHITECTURAL ENGINEER: EBAS

FACILITY OPERATOR: NORTHEAST NUCLEAR ENERGY CO.

SYMBOL: NNE

COMMENTS

WATCH LIST 975 - STRESS CORROSION CRACKING.

ABSTRACT

POWER EVEL - 000\%. ON JULY 2, 1987 AT 1500 HOURS, WHILE THE UNIT WAS

SHUT DOWN FOR REFUELING, INSERVICE INSPECTION ULTRASONIC TESTING

IDENTIFIED UNACCEPTABLE INCLUSIONS IN THE (BL) RETURN LINE PIPING.

THE INCLUSIONS ARE IN THE INSPECTION ZONE OF WELD ICBC-F-14 ON THE 8" STAINLESS STEEL RETURN LINE AND EXTEND AXIALLY FOR APPROXIMATELY 26

INCHES IN THE PIPING MATERIAL. THE INCLUSIONS WERE REVIEWED BY GENERATION MECHANICAL ENGINEERING AGAINST THE ACCEPTANCE

CRITERIA OF

ASME SECTION XI AND WAS DECLARED AS BEING AN UNACCEPTABLE FLAW AND

THUS REPORTABLE. THE PIPE IN QUESTION WAS REPLACED USING A

MATERIAL

THAT IS MORE RESISTANT TO INTERGRANULAR STRESS CORROSION CRACKING AND

A SYSTEM HYTROSTATIC TEST WILL BE PERFORMED.

-.----STEP: 1

CAUSE:EF --CORROSION/OXIDATION

PRIMARY SYSTEM:BB --ISOLATION CONDENSER (BWR)

COMPONENT:PICS--PIPE, $>6$ AND $<=10$ INCH DIAMETER, STAINLESS STEE

VENDOR:D240--DRAVO, INC.

TIMING:M --ACTUAL PREEXISTING, UNDETECTED

PERFORMANCE:PR --PARTIAL FAULT/REPAIR

DETECTION:I --TESTING/ INSPECTION

EFFECT:DE --CRACK

STEP: 2

THIS STEP IS DIRECTLY LINKED TO STEP 1

SUBLINK:X

CAUSE:PA --WELD-RELATED FLAW

PRIMARY SYSTEM:BB --ISOLATION CONDENSER (BWR)

COMPONENT:PICS--PIPE, $>6$ AND $<=10$ INCH DIAMETER, STAINLESS STEE

VENDOR:D240--DRAVO, INC.

TIMING:M --ACTUAL PREEXISTING, UNDETECTED 
PERFORMANCE:PR --PARTIAL FAULT/REPAIR

DETECTION:I --TESTING/ INSPECTION

EFFECT:DE --CRACK

INITIAL UNIT CONDITIONS: $\mathrm{H}$ REFUELING

UNIT EFFECT: XX NO SIGNIFICANT EFFECT

EFFECT ON ENVIRONMENT: $N$ NO RELEASE

EFFECT ON PERSONNEL: N NO EXPOSURE

FORM $11 \quad$ LER SCSS DATA 12-24-92

*********************************************************************

DOCKET YEAR LER NUMBER REVISION DCS NUMBER NSIC EVENT DATE $\begin{array}{lllllll}259 & 1981 & 037 & 3 & 8311090350 & 187466 & 06 / 29 / 81\end{array}$

DOCKET:259 BROWNS FERRY 1 TYPE:BWR

REGION: 2 NSSS:GE

ARCHITECTURAL ENGINEER: TVAX

FACILITY OPERATOR: TENNESSEE VALLEY AUTHORITY SYMBOL: TVA

COMMENTS

IE BULLETIN 83-02

ABSTRACT

REACTOR WATER CLEANUP SYSTEM INBOARD PRIMARY CONTAINMENT

ISOLATION

VALVE 69-1 WAS ULTRASONICALLY INSPECTED ON 6/21/81. AN INDICATION WAS

OBSERVED ON THE VESSEL SIDE OF THE VALVE WELD. (TFCH SPEC 3.6.G.) A SUBSEQUENT RADIOGRAPH SHOWED NO INDICATIONS. ON 6/24/81 A UT INSPECTION BY A LEVEL II INSPECTOR CONFIRMED AN INDICATION. PREVIOUS

SIMILAR EVENT: BFRO-50-259/80-004. FOR CAUSE SEE ATTACHED METALLURGICAL REPORT. THE VELAN MODEL 900 LB. 6 INCH. (SS) STAINLESS STEEL GATE VALVE, RATED AT 1146 PSI AT $500 \mathrm{~F}$ (NORMAL OPERATING PRESSURE 960 PSI) WAS REPLACED. THE INDICATION IS ACCEPTABLE UNDER THE SUMMER 1978 ADDENDA TO ASME SECTION XI CODE. THIS IS CONSIDERED A RANDOM EVENT.

-.-.-STEP: 1

CAUSE:PA --WELD-RELATED FLAW

PRIMARY SYSTEM:DB --CONTAINMENT ISOLATION 
SECONDARY SYSTEM:WP --REACTOR WATER CLEANUP (BWR)

COMPONENT:ISVS--VALVE, ISOLATION/ SHUTOFF, STAINLESS STEEL VENDOR:V085--VELAN VALVE CORP.

TIMING:M --ACTUAL PREEXISTING, UNDETECTED

PERFORMANCE:TR --TOTAL FAULT/REPAIR

DETECTION:I -.TESTING/INSPECTION

EFFECT:BK --EXTERNAL SYSTEM LEAKAGE, SMALL

STEP: 2

THIS STEP IS DIRECTLY LINKED TO STEP 1 SUBLINK:X

CAUSE:EF --CORROSION/ OXIDATION

PRIMARY SYSTEM:DB -.-CONTAINMENT ISOLATION

SECONDARY SYSTEM:WP --REACTOR WATER CLEANUP (BWR)

COMPONENT:ISVS--VALVE, ISOLATION/ SHUTOFF, STAINLESS STEEL

VENDOR:V085--VELAN VALVE CORP.

TIMING:M --ACTUAL PREEXISTING, UNDETECTED

PERFORMANCE:TR --TOTAL FAULT/REPAIR

DETECTION:I -.TESTING/ INSPECTION

EFFECT:BK --EXTERNAL SYSTEM LEAKAGE, SMALL

INITIAL UNIT CONDITIONS: $\mathrm{H}$ REFUELING

UNIT EFFECT: XX NO SIGNIFICANT EFFECT

EFFECT ON ENVIRONMENT: $N$ NO RELEASE

EFFECT ON PERSONNEL: N NO EXPOSURE

FORM $16 \quad$ LER SCSS DATA 12-24-92

*****************************************************************

DOCKET YEAR LER NUMBER REVISION DCS NUMBER NSIC EVENT DATE $\begin{array}{llllllll}266 & 1984 & 002 & 0 & 8404110360 & 189150 & 02 / 28 / 84\end{array}$

DOCKET:266 POINT BEACH 1 TYPE:PWR

REGION: 3 NSSS:WE

ARCHITECTURAL ENGINEER: BECH

FACILITY OPERATOR: WISCONSIN ELECTRIC POWER CO.

SYMBOL: WEP

ABSTRACT

POWER LEVEL - 000\%. DURING UNIT 1 REFUELING 11, AN INSPECTION OF THE REACTOR VESSEL OUTLET NOZZLE-TO-SHELL WELDS WAS PERFORMED USING PROGRAMMED AND REMOTE MECHANIZED ULTRASONICS. THIS EXAMINATION WAS A 
PART OF THE FIRST PERIOD INSERVICE INSPECTION FOR THE SECOND TEN-YEAR

INTERVAL. FOUR INDICATIONS IN THE "A" NOZZZLE AND SEVEN INDICATIONS IN

THE "C" NOZZLE WERE RECORDED, SIZED, AND EVALUATED. ON 02/28/84, THE LICENSEE WAS NOTIFIED THAT THERE WAS ONE INDICATION IN EACH OF THE OUTLET NOZZLE WELDS THAT EXCEEDED THE CODE ALLOWABLE SIZE. THESE

INDICATIONS ARE LOCATED IN THE ROOT AREA OF THE WELDS AND ARE BELIEVED, BY THE EVALUATOR, TO BE SLAG. THE LICENSEE'S CONSULTANT (SWRI) HAS PERFORMED BEAM SPREAD EXPERIMENTS ON THE POINT BEACH CALIBRATION BLOCK AND FRACTURE ANALYSIS OF THE FLAW INDICATIONS. FINAL RESULTS FROM THESE STUDIES BY SWRI INDIVIDUALLY DEMONSTRATE THAT

THE INDICATIONS MEET THE ACCEPTANCE CRITERIA OF ASME SECTION XI, THEREBY CONFIRMING THE CONTINUED SERVICEABILITY OF THE REACTOR VESSEL.

-.---STEP: 1

CAUSE:SA --INTRINSIC HUMAN ERROR

PRIMARY SYSTEM:PF --FABRICATION ACTIVITY

COMPONENT:PCP --CONTRACTOR PERSONNEL

TIMING:M --ACTUAL PREEXISTING, UNDETECTED

PERFORMANCE:T --TOTAL FAULT

DETECTION:I --TESTING/ INSPECTION

EFFECT:UA --COMMISSION OF UNDESIRED TASK, ANALYSIS, OR STEP

STEP: 2

THIS STEP IS DIRECTLY LINKED TO STEP 1

CAUSE:PA --WELD-RELATED FLAW

PRIMARY SYSTEM:AF ...PRESSURIZER (PWR)

COMPONENT:NZL --NOZZLE

VENDOR:B015--BABCOCK \& WILCOX COMPANY

QUANTITY:2 -.

TRAIN:M --MULTIPLE

TIMING:M --ACTUAL PREEXISTING, UNDETECTED

PERFORMANCE:TR --TOTAL FAULT/REPAIR

DETECTION:I --TESTING/ INSPECTION

EFFECT:DE --CRACK

INITIAL UNIT CONDITIONS: $\mathrm{H}$ REFUELING

UNIT EFFECT: XX NO SIGNIFICANT EFFECT

EFFECT ON ENVIRONMENT: N NO RELEASE

EFFECT ON PERSONNEL: $N$ NO EXPOSURE 


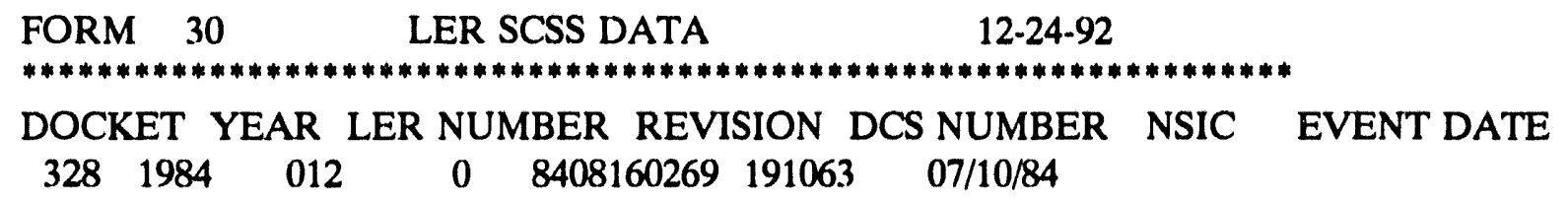

DOCKET:328 SEQUOYAH 2 TYPE:PWR

REGION: 2 NSSS:WE

ARCHITECTURAL ENGINEER: TVAX

FACILITY OPERATOR: TENNESSEE VALLEY AUTHORITY

SYMBOL: TVA

\begin{abstract}
POWER LEVEL - 100\%. DURING SURVEILLANCE TESTING FOR EXTERNAL (TO CONTAINMENT) PIPING LEAKAGE, BOTH TRAINS OF THE RESIDUAL HEAT REMOVAL SYSTEM WERE INOPERABLE FOR 2 HRS, 47 MINS ON 7-10-84 WHEN VALVE HCV-74-34 (RHR TU RWST RECIRC LINE ISOLATION VALVE) WAS OPENED AS PART

OF THE PROCEDURE FOR CHECKING RHR PIPE LEAKAGE. REVIEW OF THE RHR

SYSTEM DETERMINED THAT THE LEAKAGE INSPECTION COULD BE SATISFIED WITH

THE RWST HEAD PRESSURE ON THE RHR-RWST RECIRC LINE AND HCV-74-34 NEED

NOT BE OPENED. A PROCEDURE CHANGE WAS ISSUED TO DELETE THE REQUIREMENT TO OPEN HCV-74-34, AND THE INSPECTION WAS SATISFACTORILY

COMPLETED ON 7-11-84. ALL SIMILAR INSTRUCTIONS PERTAINING TO SECTION XI EXTERNAL LEAKAGE INSPECTIONS ARE BEING REVIEWED TO ENSURE ADDITIONAL IMPROPER VALVE LINEUPS ARE NOT BEING REQUIRED.
\end{abstract}

-.-.-.STEP: 1

CAUSE:SB --TASK DESCRIPTION INADEQUACY

PRIMARY SYSTEM:PT --TEST/ CALIBRATION ACTIVITY

COMPONENT:PUZ --UNKNOWN UTILITY PERSONNEL

TIMING:M --ACTUAL PREEXISTING, UNDETECTED

PERFORMANCE:T --TOTAL FAULT

DETECTION:I -.TESTING/INSPECTION

EFFECT:UA -.-COMMISSION OF UNDESIRED TASK, ANALYSIS, OR STEP

-.---STEP: 2

THIS STEP IS DIRECTLY LINKED TO STEP 1

CAUSE:RC --RESULTANT COMPONENT FAULT

PRIMARY SYSTEM:BF --RESIDUAL HEAT REMOVAL (PWR)

SECONDARY SYSTEM:CD --BORATED/ REFUELING WATER STORAGE (PWR) 
COMPONENT:ISVZ.-VALVE, ISOLATION/ SHUTOFF, UNKNOWN MATERIAL

TIMING:A --ACTUAL IMMEDIATE

PERFORMANCE:T --TOTAL FAULT

DETECTION:I --TESTING/ INSPECTION

EFFECT:AK --TRANSFER OPEN

-......STEP: 3

THIS S'IEP IS DIRECTLY LINKED TO STEP 2

CAUSE:RT --RESULTANT TOTAL SYSTEM FAULT

PRIMARY SYSTEM:BF -.RESIDUAL HEAT REMOVAL (PWR)

COMPONENT:XXX --ENTIRE SYSTEM

TIMING:P -.POTENTIAL

PERFORMANCE:T --TOTAL FAULT

DETECTION:F -.OPERATIONAL ABNORMALITY

EFFECT:KB -.FAILURE TO OPERATE

INITIAL UNIT CONDITIONS: E STEADY-STATE OPERATION

UNIT EFFECT: $X X$ NO SIGNIFICANT EFFECT

EFFECT ON ENVIRONMENT: N NO RELEASE

EFFECT ON PERSONNEL: $N$ NO EXPOSURE

FORM $32 \quad$ LER SCSS DATA 12-24-92

DOCKET YEAR LER NUMBER REVISION DCS NUMBER NSIC EVENT DATE $\begin{array}{lllllll}333 & 1984 & 021 & 0 & 8411190152 & 192246 & 10 / 12 / 84\end{array}$

DOCKET:333 FITZPATRICK TYPE:BWR

REGION: $1 \quad$ NSSS:GE

ARCHITECTURAL ENGINEER: SWXX

FACILITY OPERATOR: POWER AUTHORITY OF THE STATE OF NY SYMBOL: PNY

ABSTRACT

POWER LEVEL - $000 \%$. INSERVICE INSPECTION PERFORMED IN CONJUNCTION WITH

THE APPLICATION OF INDUCTION HEATING STRESS IMPROVEMENT (IHSI)

REVEALED INDICATIONS OF INTERGRANULAR STRESS CORROSION CRACKING (IGSCC) IN SEVEN 12 INCH DIAMETER RECIRCULATION RISER WELDS AND IN FOUR 28 INCH DIAMETER RECIRCULATION SUCTION PIPE WELDS. FIVE OF THE

12 INCH PIPING JOINTS WERE REPAIRED BY WELD OVERLAYS WHICH PROVIDED

FULL STRUCTURAL DESIGN MARGINS FOR THIS PIPING. THE REMAINING SIX 
WELDS WERE EVALUATED IN ACCORDANCE WITH SECTION XI 1983 EDITION, ASME

BOILER AND PRESSURE VESSEL CODE AS MODIFIED BY NRC GENERIC LETTER 84-11. IN ALL SIX CASES, THE INDICATIONS WERE SHOWN NOT IO AFFECT THE DESIGN STRUCTURAL MARGINS OF THIS PIPING FOR LENGTHS OF TIME EXCEEDING THAT PERIOD UNTIL THE NEXT SCHEDULED REFUELING OUTAGE.

ADDITIONALLY, THE APPLICATION OF IHSI ON THESE WELDS SHOULD FURTHER

INHIBIT CRACK PROPAGATION THEREBY INCREASING THEIR ACCEPTABILITY FOR

FUTURE OPERATION WITHOUT REPAIR. BOTH THE JOINTS REPAIRED BY WELD

OVERLAY AND THOSE WITH UNREPAIRED FLAWS HAVE BEEN SHOWN TO MEET THE

REQUIREMENTS OF THE JAFNPP TECH SPECS, 4.6.F. DETAILED WELD BY WELD INFORMATION CONCERNING EXAMINATION, REPAIR AND STRUCTURAL ANALYSIS WAS

PROVIDED TO THE DIRECTOR OF NRR ON 10-21-84 IN LETTER JAFP 84-0979.

-...-.STEP: 1

CAUSE:SA --INTRINSIC HUMAN ERROR

PRIMARY SYSTEM:PC -.CONSTRUCTION ACTIVITY

COMPONENT:PZ -..UNKNOWN PERSONNEL

TIMING:M --ACTUAL PREEXISTING, UNDETECTED

PERFORMANCE:T --TOTAL FAULT

DETECTION:I -.TESTING/ INSPECTION

EFFECT:UA -.COMMISSION OF UNDESIRED TASK, ANALYSIS, OR STEP

-...-.STEP: 2

THIS STEP IS DIRECTLY LINKED TO STEP 1

CAUSE:CE -..WEAR/ AGE/ END OF LIFE

PRIMARY SYSTEM:AI --RECIRCULATING WATER (BWR)

COMPONENT:PIDZ--PIPE, $>10$ AND $<=16$ INCH DIAMETER, UNKNOWN MATERI

VENDOR:K055--KELLOGG, M.W. CO., THE

QUANTITY:7 ..

TIMING:M --ACTUAL PREEXISTING, UNDETECTED

PERFORMANCE:TR --TOTAL FAULT/REPAIR

DETECTION:I --TESTING/ INSPECTION

EFFECT:DE -.CRACK

-......STEP: 3

THIS STEP IS DIRECTLY LINKED TO STEP 2

SUBLINK:X

CAUSE:PA --WELD-RELATED FLAW

PRIMARY SYSTEM:AI --RECIRCULATING WATER (BWR) 

MATERI

COMPONENT:PIDZ.-PIPE, $>10$ AND $<=16$ INCH DIAMETER, UNKNOWN

VENDOR:K055--KELLOGG, M.W. CO., THE

QUANTITY:7 -.

TIMING:M -.ACTUAL PREEXISTING, UNDETECTED

PERFORMANCE:TR -.TOTAL FAULT/REPAIR

DETECTION:I --TESTING/INSPECTION

EFFECT:DE -.-CRACK

-...-.STEP: 4

THIS STEP IS DIRECTLY LINKED TO STEP 1

CAUSE:CE -.WEAR/ AGE/ END OF LIFE

PRIMARY SYSTEM:AI --RECIRCULATING WATER (BWR)

COMPONENT:PIEZ-.PIPE, GREATER THAN 16 INCH DIAMETER, UNKNOWN MAT

VENDOR:K055-.KELLOGG, M.W. CO., THE

QUANTITY:4 -.

TIMING:M -ACTUAL PREEXISTING, UNDETECTED

PERFORMANCE:TR -.TOTAL FAULT/REPAIR

DETECTION:I -.TESTING/ INSPECTION

EFFECT:DE -.CRACK

-.....STEP: 5

THIS STEP IS DIRECTLY LINKED TO STEP 4

SUBLINK:X

CAUSE:PA --WELD-RELATED FLAW

PRIMARY SYSTEM:AI -.RECIRCULATING WATER (BWR)

COMPONENT:PIEZ--PIPE, GREATER THAN 16 INCH DIAMETER, UNKNOWN MAT

VENDOR:K055--KELLOGG, M.W. CO., THE

QUANTITY:4 -.

TIMING:M --ACTUAL PREEXISTING, UNDETECTED

PERFORMANCE:TR --TOTAL FAULT/REPAIR

DETECTION:I -.TESTING/ INSPECTION

EFFECT:DE -.-CRACK

INITIAL UNIT CONDITIONS: $Z$ UNKNOWN/ NOT APPLICABLE

UNIT EFFECT: $X X$ NO SIGNIFICANT EFFECT

EFFECT ON ENVIRONMENT: $N$ NO RELEASE

EFFECT ON PERSONNEL: N NO EXPOSURE

FORM $44 \quad$ LER SCSS DATA 12-24-92

DOCKET YEAR LER NUMBER REVISION DCS NUMBER NSIC EVENT DATE 
$\begin{array}{cccccc}373 \quad 1986 & 019 & 0 & 8606240625 & 199782 & 05 / 21 / 86 \\ * * * * * * * * * * * * * * * * * * * * * * * * * * * * * * * * * * * * * * * * * * * * * * * * * * * * * *\end{array}$

DOCKET:373 LA SALLE 1 REGION: 3 NSSS:GE

TYPE:BWR

ARCHITECTURAL ENGINEER: SLXX

FACILITY OPERATOR: COMMONWEALTH EDISON CO.

SYMBOL: CWE

COMMENTS

STEP 1: CAUSE PA. SLAG OR OTHER DEFECT IN A PLUG.'TYPE REPAIR WELD.

ABSTRACT

POWER LEVEL - $000 \%$. TWO THROUGH WALL LEAKS WERE IDENTIFIED DURING THE

ASME SECTION XI LEAKAGE TEST ON THE CLASS 1 PORTION OF THE RESILUAL HEAT REMOVAL (RHR) "B" AND "C" LOW PRESSURE COOLANT INJECTION (LPCI) LOOPS. THE LEAKAGE WAS COMING FROM PRESERVICE PLUG.TYPE REPAIR WELDS

IN THE VICINITY OF THE 1E12-F092B AND 1E12-F092C VALVES. THE LEAKING PLUGS WILL BE REPAIRED DURING THE PRESENT UNIT I REFUEL OUTAGE. THE

UNIT WAS IN COLD SHUTDOWN.

-.....STEP: 1

SUBLINK:A

CAUSE:PA -.WELD-RELATED FL.AW

PRIMARY SYSTEM:BH -.RESIDUAL HEAT REMOVAL (BWR)

SECONDARY SYSTEM:SC - -REACTOR DRYWELL (BWR)

COMPONENT:PIZC.-PIPE, UNKNOWN DIAMETER, CARBON STEEL

QUANTITY:2 ‥

TRAIN:M -.MULTIPLE

TIMING:M -.ACTUAL PREEXISTING, UNDETECTED

PERFORMANCE:PR ..PARTIAL FAULT/REPAIR

DETECTION:I -.TESTING/ INSPECTION

EFFECT:BK --EXTERNAL SYSTEM LEAKAGE, SMALL

-...-STEP: 2

SUBLINK:A

CAUSE:PA -.WELD.RELATED FLAW

PRIMARY SYSTEM:BH --RESIDUAL HEAT REMOVAL (BWR)

SECONDARY SYSTEM:SC --REACTOR DRYWELL (BWR)

COMPONENT:PIZC..PIPE, UNKNOWN DIAMETER, CARBON STEEL DIFFERENTIATOR:2 -.

TIMING:P ..POTENTIAL

PERFORMANCE:TR ..TOTAL FAULT/REPAIR

DETECTION:F ..OPERATIONAL ABNORMALITY 


\section{EFFECT:BP ..EXTERNAL SYSTEM LEAKAGE, UNKNOWN RATE}

STEP: 3

THIS STEP IS DIRECTLY LINKED TO STEP 1 AND STEP 2

INITIAL UNIT CONDITIONS: I COLD SHUTDOWN

UNIT EFFECT: $X X$ NO SIGNIFICANT EFFECT

\section{-.....STEP: 4}

THIS STEP IS DIRECTLY LINKED TO STEP 1

EFFECT ON ENVIRONMENT: $R$ RADIOLOGICAL RELEASE TO CONTAINMENT EFFECT ON PERSONNEL: $N$ NO EXPOSURE

-......STEP: 5

INITIAL UNIT CONDITIONS:

UNIT EFFECT: HA AFFECTED OTHER UNIT(S)

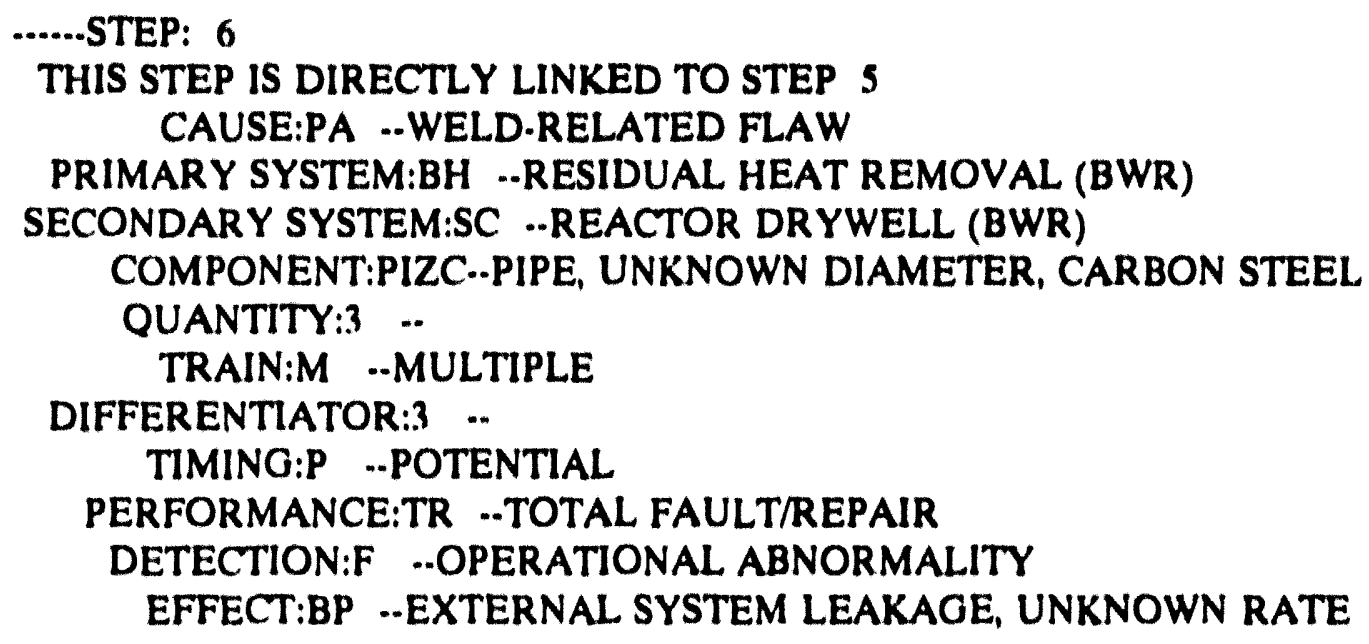

INITIAL UNIT CONDITIONS: $Z$ UNKNOWN/ NOT APPLICABLE UNIT EFFECT: $X X$ NO SIGNIFICANT EFFECT

EFFECT ON ENVIRONMENT: $N$ NO RELEASE

EFFECT ON PERSONNEL: N NO EXPOSURE

FORM $45 \quad$ LER SCSS DATA $\quad 12-24.92$

DOCKET YEAR LER NUMBER REVISION DCS NUMBER NSIC EVENT DATE $\begin{array}{lllllll}387 & 1982 & (\mathbf{X}) 1 & 1 & 83(1512(2430 & 183927 & 07 / 18 / 82\end{array}$ 
DOCKET:387 SUSQUEHANNA 1 REGION: 1 NSSS:GE

TYPE:BWR

ARCHITECTURAL ENOINEER: BECH

FACILITY OPERATOR: PENNSYLVANIA POWER \& LIGHT CO. SYMBOL: PPL

\begin{abstract}
WHILE PERFORMING OFFSET RADIOGRAPHY OF THE RECIRC RISER TO SWEEPOLET/REDUCER WELDS AS A SUPPLEMENTAL EXAMINATION TO THE PSI ULTRASONIC DATA, LINEAR INDICATIONS WERE FOUND ON A RECIRC RISER WELD;

A-I1M. ADDITIONAL RADIOGRAPHY WAS PERFORMED ON ALL THE RECIRC RISERS

WELDS AND ONE ADDITIONAL INDICATION WAS FOUND ON THE A.13 WELD. THE

EXTENT OF THE INDICATIONS DID NOT POSTULATE PROBABLE FAILURE. THE CAUSE OF THE LINEAR INDICATIONS WAS SLAO INCLUSION IN THE A-1IM WELD
\end{abstract}

AND SLAG INCLUSION AND PARTTAL COLD LAP (1/4") OF THE A.13 WELD. THE AFFECTED WELD AREAS WERE EXCAVATED (APPROX. 6" ON A.11M AND APPROX. 3"

ON A.13) AND WELD REPAIRED WITH A PP\&L APPROVED REPAIR PLAN IN ACCORDANCE WITH ASME SECTION XI B\&PV CODE. ALL RISER TO SWEEPOLET/REDUCER WELDS HAVE BEEN ACCEPTED. NO FUTURE ACTIONS ARE PLANNED.

-......STEP: 1

CAUSE:SA -.INTRINSIC HUMAN ERROR

PRIMARY SYSTEM:PI ..INSTALLATION ACTIVITY

COMPONENT:PZ ...UNKNOWN PERSONNEL

TIMING:M -.ACTUAL PREEXISTING, UNDETECTED

PERFORMANCE:T ..TOTAL FAULT

DETECTION:I ...TESTING/INSPECTION

EFFECT:UA ...COMMISSION OF UNDESIRED TASK, ANALYSIS, OR STEP

STEP: 2

THIS STEP IS DIRECTLY LINKED TO STEP 1

CAUSE:PA -.WELD.RELATED FLAW

PRIMARY SYSTEM:AI ..RECIRCULATING WATER (BWR) MATERI

COMPONENT:PICZ.-PIPE, $>6$ AND $<=10$ INCH DIAMETER, UNKNOWN

VENDOR:B130..BECHTEL CORP.

QUANTITY:2 -..

TRAIN:Z ..UNKNOWN

TIMING:M --ACTUAL PREEXISTING, UNDETECTED

PERFORMANCE:P ..PARTIAL FAULT 


\title{
DETECTION:I .-TESTING/INSPECTION \\ EFFECT:DE ..CRACK
}

\author{
INITIAL UNIT CONDITIONS: H REFUELING \\ UNIT EFFECT: $X X$ NO SIGNIFICANT EFFECT \\ EFFECT ON ENVIRONMENT: N NO RELEASE \\ EFFECT ON PERSONNEL: N NO EXPUSURE
}

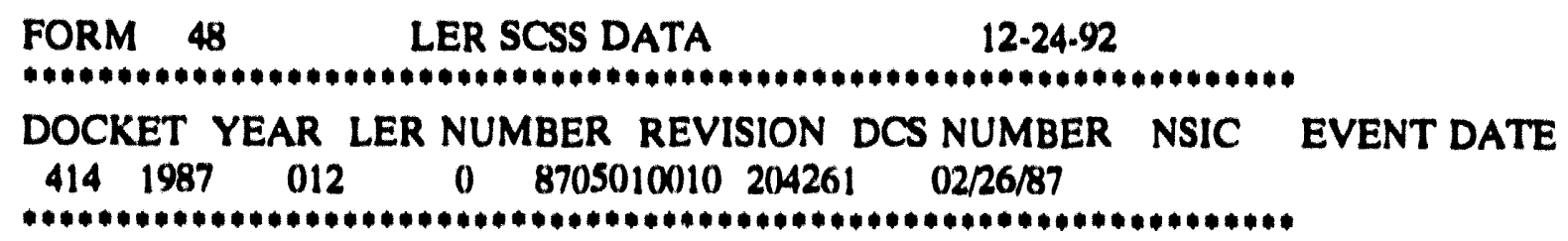

DOCKET:414 CATAWBA 2 TYPE:PWR

REGION: 2 NSSS:WE

ARCHITECTURAL ENGINEER: DUKE

FACILITY OPERATOR: DUKE POWER CO.

SYMBOL: DPC

COMMENTS

STEP 2: MODEL 306.

\begin{abstract}
POWER LEVEL - 000\%. ON FEBRUARY 26, 1987, AN INOPERABLE SNUBBER WAS FOUND DURINO REMOVAL AND REPLACEMENT ACTIVITIES. THE REMOVAI. AND

REPLACEMENT WORK HAD BEEN INITIATED TO PROVIDE TECHNICIANS ACCESS TO

THE ACTUATOR OF A STEAM GENERATOR BLOWDOWN CONTAINMENT ISOLATION

BYPASS VALVE, WHICH HAD FAILED TO MEET ITS STROKE TIME DURING ASME

SECTION XI, SUBSECTION IWV, VALVE INSERVICE TESTING PROGRAM, QUARTERLY

TESTING. ON FEBRUARY 26, AN ATTEMPT WAS MADE TO STROKE THE SNUBBER

PRIOR TO REINSTALLATION, BUT THE SNUBBER COULD NOT BE CYCLED. A NEW

SNUBBER WAS INSTALLED AT THIS POINT. ON MARCH 24, 1987, AT 0900 HOURS IT WAS FOUND THAT THE REQUIRED ENGINEERING EVALUATION WAS NOT PERFORMED WHICH RESULTED IN A TECHNICAL SPECIFICATION VIOLATION. THE

UNIT WAS IN MODES 1, POWER OPERATION, 2, STARTUP, AND 3, HOT STANDBY,
\end{abstract}


THROUGHOUT THIS INCIDENT. THIS INCIDENT HAS BEEN CLASSIFIED AS EVENT

CAUSE CODE D, DEFECTIVE PROCEDURES. THE CONTROLLING PROCEDURE FOR

SUPPORT/RESTRAINT MAINTENANCE ACTIVITIES DID NOT INCLUDE INSTRUCTIONS

FOR NOTIFICATION OF THE APPROPRIATE DUKE POWER PERSONNEL IN THE EVENT

AN INOPERABLE SNUBBER IS FOUND DURING REMOVAL AND REPLACEMENT MAINTENANCE ACTIVITIES. THE SUBJECT PROCEDURE WILL BE REVISED TO PREVENT SIMILAR INCIDENTS. AT THE TIME THE INOPERABILITY WAS DISCOVERED ON MARCH 24, DESIGN ENGINEERING WAS NOTIFIED AND AN ENGINEERING EVALUATION WAS REQUESTED.

STEP: 1

SUBLINK:A

CAUSE:ZZ ...UNKNOWN

PRIMARY SYSTEM:DB ...CONTAINMENT ISOLATION

SECONDARY SYSTEM:WF -.STEAM GENERATOR BLOWDOWN (PWR)

COMPONENT:BYVZ..VALVE, BYPASS, UNKNOWN MATERIAL

TIMING:G -..ACTUAL PREEXISTING, DETECTED

PERFORMANCE:TR -.TOTAL FAULT/REPAIR

DETECTION:I ..TESTING/ INSPECTION

EFFECT:KE -.LONG RESPONSE TIME

STEP: 2

CAUSE:ZZ ...UNKNOWN

PRIMARY SYSTEM:DB ..CONTAINMENT ISOLATION

SECONDARY SYSTEM:WF ..STEAM GENERATOR BLOWDOWN (PWR)

COMPONENT:SNB -.SNUBBER

VENDOR:P029.-PACIFIC SCIENTIFIC COMPANY

TIMING:M .-ACTUAL PREEXISTING, UNDETECTED

PERFORMANCE:TR -.TOTAL FAULT/REPAIR

DETECTION:I ..TES'TING/ INSPECTION

EFFECT:KB -.FAILURE TO OPERATE

STEP: 3

THIS STEP IS DIRECTLY LINKED TO STEP 2

CAUSE:SB -.TASK DESCRIPTION INADEQUACY

PRIMARY SYSTEM:PT ..TEST/ CALIBRATION ACTIVITY

COMPONENT:PUZ .-UNKNOWN UTILITY PERSONNEL

TIMING:M ..ACTUAL PREEXISTING, UNDETECTED

PERFORMANCE:T ..TOTAL FAULT

DETECTION:R --REVIEW OF PROCEDURE/ TEST RESULTS

EFFECT:TC ..OMISSION WITHIN ALLOTTED TIME

STEP: 4 
THIS STEP IS DIRECTLY LINKED TO STEP 3

CAUSE:RC -.RESULTANT COMPONENT FAULT

PRIMARY SYSTEM:DB -..CONTAINMENT ISOLATION

SECONDARY SYSTEM:WF .-STEAM GENERATOR BLOWDOWN (PWR)

COMPONENT:BYVZ.-VALVE, BYPASS, UNKNOWN MATERIAL

TIMING:M --ACTUAL PREEXISTING, UNDETECTED

PERFORMANCE:M -.NO FAULT

DETECTION:R --REVIEW OF PROCEDURE/ TEST RESULTS

EFFECT:PL -.TEST NOT PERFORMED

-.....-STEP: 5

THIS STEP IS DIRECTLY LINKED TO STEP 3

SUBLINK:A

CAUSE:RC -.RESULTANT COMPONENT FAULT

PRIMARY SYSTEM:DB -.-CONTAINMENT ISOLATION

SECONDARY SYSTEM:WF ..STEAM GENERATOR BLOWDOWN (PWR)

COMPONENT:PIZZ.-PIPE, UNKNOWN DIAMETER, UNKNOWN MATERIAL

QUANTITY:Z ..UNKNOWN

TIMING:M -.ACTUAL PREEXISTING, UNDETECTED

PERFORMANCE:M .-NO FAULT

DETECTION:R --REVIEW OF PROCEDURE/TEST RESULTS

EFFECT:PL -.TEST NOT PERFORMED

-....-STEP: 6

THIS STEP IS DIRECTLY LINKED TO STEP 1 AND STEP 5

INITIAL UNIT CONDITIONS: L HOT STANDBY

UNIT EFFECT: XX NO SIGNIFICANT EFFECT

EFFECT ON ENVIRONMENT: N NO RELEASE

EFFECT ON PERSONNEL: N NO EXPOSURE

FORM $50 \quad$ LER SCSS DATA 12-24-92

***********************************************************

DOCKET YEAR LER NUMBER REVISION DCS NUMBER NSIC EVENT DATE $\begin{array}{llllllll}528 & 1985 & 025 & 0 & 8507160331 & 197941 & 03 / 14 / 85\end{array}$

DOCKET:528 PALO VERDE 1 TYPE:PWR

REGION: 5 NSSS:CE

ARCHITECTURAL ENGINEER: BECH

FACILITY OFERATOR: ARIZONA PUBLIC SERVICE CO.

SYMBOL: APS

COMMENTS 
OTHER REPORTABILITY - VOLUNTARY REPORT; STEP 5: EFFECT KX - SMALL REACTIVITY ADDITIONS BY WITHDRAWING RODS.

\author{
ABSTRACT \\ POWER LEVEL - 000\%. ON MARCH 14, 1985, TECHNICAL SPECIFICATION (TS)
}

3.1.2.3 WAS DEVIATED FROM BY USING THE TRAIN "A" HIGH PRESSURE SAFETY INJECTION (HPSI) SYSTEM TO PROVIDE THE REQUIRED BORON INJECTION FLOWPATH WHEN THE ASME SECTION XI SURVEILLANCE TEST WAS NOT CURRENT ON

THE TRAIN "A" HPSI PUMP. DURING THIS TIME, PORTIONS OF THE CONTROL ELEMENT ASSEMBLY (CEA) PATCH VERIFICATION TESTING WERE PERFORMED RESULTING IN SMAL SOON AS THE LACK OF A CURRENT SURVEILLANCE TEST WAS REALIZED, THE PATCH VERIFICATION TESTING WAS STOPPED, THE ASME SECTION XI TEST FOR

TRAIN "A" HPSI WAS PERFORMED, AND THE PUMP AND ASSOCIATED BORON INJECTION FLOWPATH WAS DECLARED OPERABLE. THE OPERATOR PERFORMING THE BORATION FLOWPATH SURVEILLANCE TEST (41ST-1CH02) BELIEVED THAT THE REQUIRED ASME SECTION XI TESTS ON THE HPSI PUMP HAD BEEN SUCCESSFULLY

COMPLETED. THE EMERGENCY BORATION PROCEDURE HAS BEEN REVIEWED AND

MODIFIED AS NECESSARY TO PROVIDE IMPROVED GUIDANCE TO THE OPERATIONS

STAFF ON EMERGENCY BORATION WHILE IN MODE 5. IN ADDITION, UNIT 1 PERSONNEL HAVE BEEN INSTRUCTED TO ENSURE THAT THEY MUST VERIFY STEPS

IN THE PROCEDURE AND NOT RELY ON MEMORY OF COMPLETED SURVEILLANCE TESTING.

-..--.STEP: 1

CAUSE:SA --INTRINSIC HUMAN ERROR

PRIMARY SYSTEM:PT --TEST/ CALIBRATION ACTIVITY COMPONENT:PNO --NON-LICENSED OPERATOR. PERSONNEL

TIMING:M --ACTUAL PREEXISTING, UNDETECTED

PERFORMANCE:T --TOTAL FAULT

DETECTION:R --REVIEW OF PROCEDURE/ TEST RESULTS

EFFECT:TC -.-OMISSION WITHIN ALLOTTED TIME

STEP: 2

THIS STEP IS DIRECTLY LINKED TO STEP 1

CAUSE:RC --RESULTANT COMPONENT FAULT

PRIMARY SYSTEM:BL --INTERMEDIATE PRESSURE INJECTION (PWR)

COMPONENT:PMPZ--PUMP, UNKNOWN TYPE

TIMING:M --ACTUAL PREEXISTING, UNDETECTED 
PERFORMANCE:M --NO FAULT

DETECTION:R --REVIEW OF PROCEDURE/ TEST RESULTS

EFFECT:PL --TEST NOT PERFORMED

-.--.-STEP: 3

THIS STEP IS DIRECTLY LINKED TO STEP 2

SUBLINK:A

CAUSE:RS --RESULTANT SUBSYSTEM FAULT

PRIMARY SYSTEM:BL --INTERMEDIATE PRESSURE INJECTION (PWR)

COMPONENT:1XZ --ONE OUT OF AN UNKNOWN NUMBER OF TRAINS TIMING:P -.POTENTIAL

PERFORMANCE:T --TOTAL FAULT

DETECTION:F -.OPERATIONAL ABNORMALITY

EFFECT:HI --LOW FLOW

-..-.-STEP: 4

CAUSE:SE --PROPER HUMAN ACTION OR RESPONSE

PRIMARY SYSTEM:PT --TEST/ CALIBRATION ACTIVITY

COMPONENT:PLO --LICENSED OPERATOR PERSONNEL

DIFFERENTIATOR:2 --

TIMING:A --ACTUAL IMMEDIATE

PERFORMANCE:T --TOTAL FAULT

DETECTION:R --REVIEW OF PROCEDURE/ TEST RESULTS

EFFECT:UA --COMMISSION OF UNDESIRED TASK, ANALYSIS, OR STEP

STEP: 5

THIS STEP IS DIRECTLY LINKED TO STEP 4

SUBLINK:A

CAUSE:RC --RESULTANT COMPONENT FAULT

PRIMARY SYSTEM:AA --REACTOR CORE

COMPONENT:CRA --CONTROL ROD ASSEMBLY

QUANTITY:Z -.-UNKNOWN

TRAIN:Z -.UNKNOWN

TIMING:A --ACTUAL IMMEDIATE

PERFORMANCE:M --NO FAULT

DETECTION:I --TESTING/ INSPECTION

EFFECT:KX --OTHER (FUNCTIONAL)

STEP: 6

THIS STEP IS DIRECTLY LINKED TO STEP 3 AND STEP 5

CAUSE:RC --RESULTANT COMPONENT FAULT

PRIMARY SYSTEM:AA --REACTOR CORE

COMPONENT:FLA --FUEL ASSEMBLY

QUANTITY:A -.-

TIMING:P -.POTENTIAL

PERFORMANCE:T --TOTAL FAULT 


\title{
DETECTION:F --OPERATIONAL ABNORMALITY \\ EFFECT:PE --FLUX ANOMALY
}

\author{
INITIAL UNIT CONDITIONS: I COLD SHUTDOWN \\ UNIT EFFECT: $X X$ NO SIGNIFICANT EFFECT \\ EFFECT ON ENVIRONMENT: $N$ NO RELEASE \\ EFFECT ON PERSONNEL: N NO EXPOSURE
}

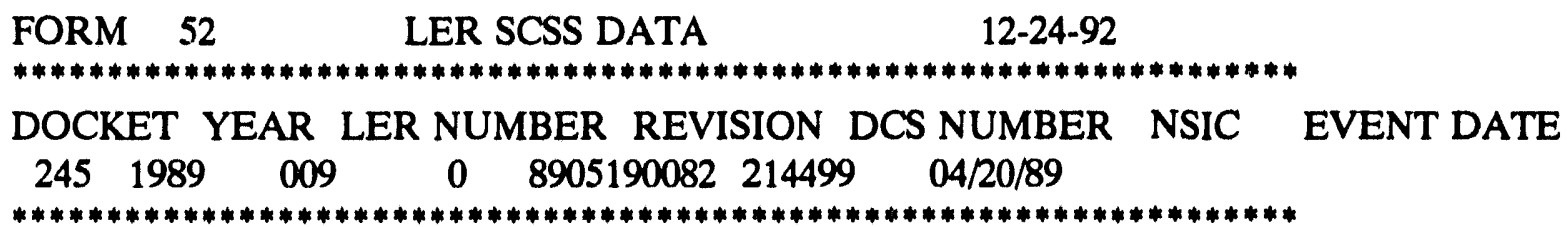

DOCKET:245 MILLSTONE 1 TYPE:BWR

REGION: 1 NSSS:GE

ARCHITECTURAL ENGINEER: EBAS

FACILITY OPERATOR: NORTHEAST NUCLEAR ENERGY CO.

SYMBOL: NNE

\begin{abstract}
POWER LEVEL - 000\%. ON 4/20/89 AT 1135 HOURS, WHILE THE UNIT WAS SHUT DOWN FOR REFUELING, AN INDICATION WAS DISCOVERED ON CLASS I

STAINLESS

STEEL PIPING INSIDE THE DRYWELL. THE INDICATION WAS FOUND ON THE 8" REACTOR WATER CLEAN-UP (CE) PIPE WELD CUAJ-5 (PIPE TO VALVE 1-CU-2 WELD) DURING INSERVICE INSPECTION (ISI) OF THE REACTOR WATER CLEAN-UP

SYSTEM. THE INDICATION WAS REVIEWED AGAINST THE ACCEPTANCE CRITERIA

OF ASME SECTION XI, AND ON 4/22/89 WAS DECLARED AS BEING AN UNACCEPTABLE FLAW AND THUS REPORTABLE. THE WELD IN QUESTIONWAS REPAIRED USING THE WELD OVERLAY TECHNIQUE, AND A HYDROSTATIC TEST WAS

PERFORMED.

-.---STEP: 1

CAUSE:EF --CORROSION/ OXIDATION

PRIMARY SYSTEM:WP --REACTOR WATER CLEANUP (BWR)

COMPONENT:PICS--PIPE, $>6$ AND $<=10$ INCH DIAMETER, STAINLESS STEE

VENDOR:E065--EBASCO SERVICES INC.

TIMING:M --ACTUAL PREEXISTING, UNDETECTED

PERFORMANCE:PR --PARTIAL FAULT/REPAIR

DETECTION:I --TESTING/INSPECTION
\end{abstract}




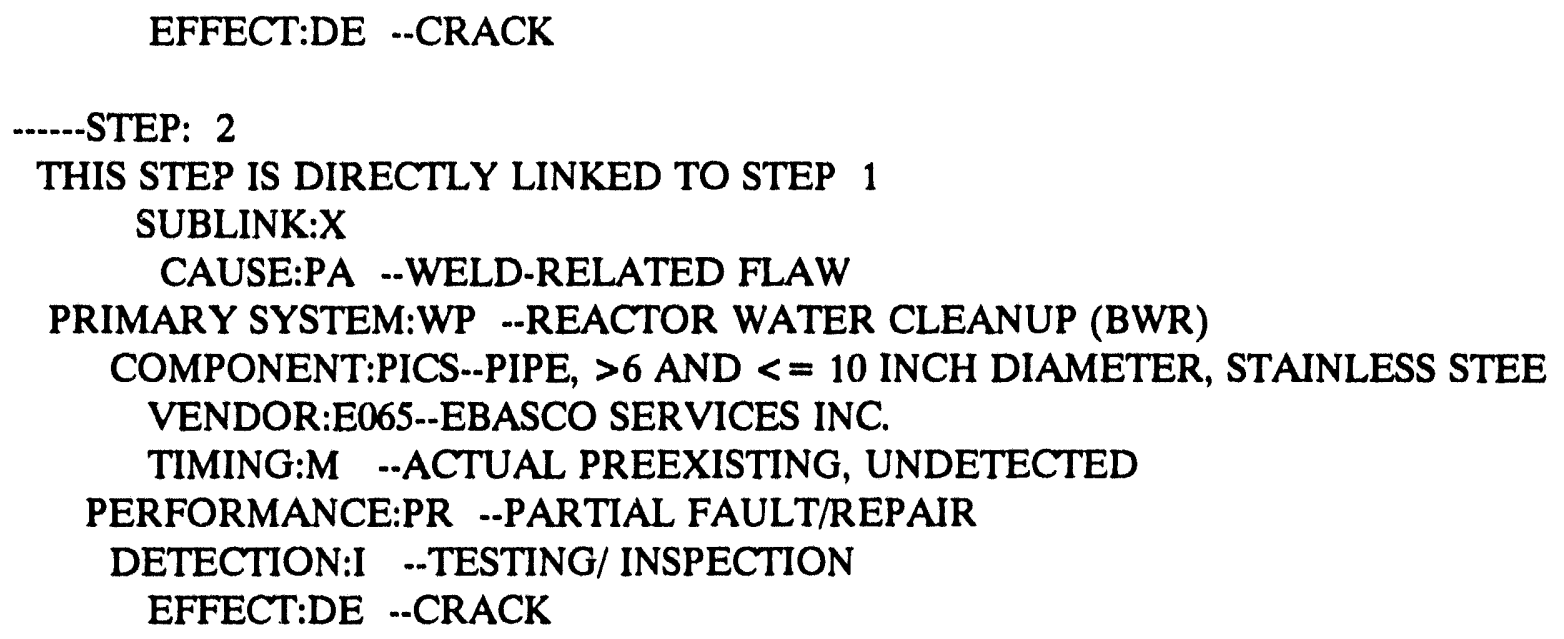

INITIAL UNIT CONDITIONS: H REFUELING UNIT EFFECT: $X X$ NO SIGNIFICANT EFFECT

EFFECT ON ENVIRONMENT: N NO RELEASE EFFECT ON PERSONNEL: $N$ NO EXPOSURE

FORM $55 \quad$ LER SCSS DATA 12-24-92

DOCKET YEAR LER NUMBER REVISION DCS NUMBER NSIC EVENT DATE $\begin{array}{lllllll}263 & 1989 & 033 & 0 & 8911280380 & 215948 & 10 / 25 / 89\end{array}$

DOCKET:263 MONTICELLO TYPE:BWR

REGION: 3 NSSS:GE

ARCHITECTURAL ENGINEER: BECH

FACILITY OPERATOR: NORTHERN STATES POWER CO. SYMBOL: NSP

COMMENTS

STEP 7: COMP X - ESF TYPE: ACTUATION OF TWO SAFETY RELIEF VALVES.

ABSTRACT

POWER LEVEL - 000\%. ON 10/25/89, WITH THE PLANT IN COLD SHUTDOWN, DURING PERFORMANCE OF THE SECTION XI ASME BOILER AND PRESSURE VESSEL

CODE REACTOR COOLANT SYSTEM LEAKAGE TEST, INITIATION OF DIVISION II LOW LOW SET LOGIC RESULTED IN THE OPERATION OF SAFETY RELIEF VALVES

"G" AND " $\mathrm{H}$ ". THE INITIATION SIGNAL OCCURRED AS A RESULT OF AN INSTRUMENT SENSING LINE PRESSURE SPIKE CAUSED BY SEATING OF AN EXCESS 
FLOW CHECK VALVE DURING TESTING. THE ROOT CAUSE OF THIS EVENT WAS

INADEQUATE TESTING PROCEDURES. INVESTIGATION AND EVALUATION OF THE

SAFETY RELIEF VALVE LINES, AND THE TEST PROCEDURE REVISION WERE DONE

PRIOR TO RECOMMENCING THE VESSEL LEAKAGE TEST. REVIEW OF ALL EXCESS

FLOW CHECK VALVE TEST PROCEDURES FOR PROPER ISOLATIONS WILL BE COMPLETED BEFORE THE NEXT SCHEDULED REFUELING OUTAGE. A REVIEW OF

THIS EVENT WILL BE INCLUDED IN TECHNICAL STAFF CONTINUING TRAINING.

-.-.-.STEP: 1

CAUSE:SB --TASK DESCRIPTION INADEQUACY

PRIMARY SYSTEM:PT -..TEST/ CALIBRATION ACTIVITY

COMPONENT:PUZ -.UNKNOWN UTILITY PERSONNEL

TIMING:A -.ACTUAL IMMEDIATE

PERFORMANCEET -.TOTAL FAULT

DETECTION:I -.TESTING/ INSPECTION

EFFECT:TA --OMISSION OF TASK, ANALYSIS, OR STEP

-..-.-STEP: 2

THIS STEP IS DIRECTLY LINKED TO STEP 1

SUBLINK:A

CAUSE:RC --RESULTANT COMPONENT FAULT

PRIMARY SYSTEM:IW --ENGINEERED SAFETY FEATURES ACTUATION

SECONDARY SYSTEM:BR --NUCLEAR BOILER OVERPRESSURE PROTECTION (BWR)

COMPONENT:HS --SWITCH, HAND

TIMING:A --ACTUAL IMMEDIATE

PERFORMANCE:T --TOTAL FAULT

DETECTION:I --TESTING/ INSPECTION

EFFECT:AM --WRONG POSITION

STEP: 3

CAUSE:SE --PROPER HUMAN ACTION OR RESPONSE

PRIMARY SYSTEM:PT -.TEST/ CALIBRATION ACTIVITY

COMPONENT:PUZ -.-UNKNOWN UTILITY PERSONNEL

DIFFERENTIATOR:2 --

TIMING:A --ACTUAL IMMEDIATE

PERFORMANCE:M --NO FAULT

DETECTION:I --TESTING/INSPECTION

EFFECT:UF --COMMISSION OF A DESIRED TASK, ANALYSIS, OR STEP

STEP: 4

THIS STEP IS DIRECTLY LINKED TO STEP 3 
CAUSE:RC --RESULTANT COMPONENT FAULT

PRIMARY SYSTEM:BR --NUCLEAR BOILER OVERPRESSURE PROTECTION (BWR)

COMPONENT:CVZ ..VALVE, CHECK, UNKNOWN MATERIAL

TIMING:A --ACTUAL IMMEDIATE

PERFORMANCE:M -.NO FAULT

DETECTION:I --TESTING/ INSPECTION

EFFECT:AP -.TRANSFER CLOSED

.....-STEP: 5

THIS STEP IS DIRECTLY Li. KED TO STEP 4 SUBLINK:A

CAUSE:RC --RESULTA VT COMPONENT FAULT

PRIMARY SYSTEM:IW -.-ENC INEERED SAFETY FEATURES ACTUATION

SECONDARY SYSTEM:BR --NUCLEAR BOILER OVERPRESSURE PROTECTION (BWR)

COMPONENT:SL --SENSING LINE

TIMING:A --ACTUAL IMMEDIATE

PERFORMANCE:T --TOTAL FAULT

DETECTION:I --TESTING/ INSPECTION

EFFECT:HK --HIGH STATIC PRESSURE

-..-.-STEP: 6

THIS STEP IS DIRECTLY LINKED TO STEP 2 AND STEP 5

CAUSE:RC - -RESULTANT COMPONENT FAULT

PRIMARY SYSTEM:IW --ENGINEERED SAFETY FEATURES ACTUATION

SECONDARY SYSTEM:BR --NUCLEAR BOILER OVERPRESSURE PROTECTION (BWR)

COMPONENT:PT --TRANSMITTER, PRESSURE

TIMING:A --ACTUAL IMMEDIATE

PERFORMANCE:T --TOTAL FAULT

DETECTION:I --TESTING/INSPECTION

EFFECT:LE --ERRONEOUS/ NO SIGNAL

STEP: 7

THIS STEP IS DIRECTLY LINKED TO STEP 6

CAUSE:VW -.PROCEDURAL DEFICIENCY

INITIAL UNIT CONDITIONS: I COLD SHUTDOWN

UNIT EFFECT: EB UNINTENTIONAL AUTOMATIC ESF ACTUATION

EFFECT ON ENVIRONMENT: N NO RELEASE

EFFECT ON PERSONNEL: N NO EXPOSURE

FORM 57

LER SCSS DATA

$12-24-92$ 
DOCKET YEAR LER NUMBER REVISION DCS NUMBER NSIC EVENT DATE

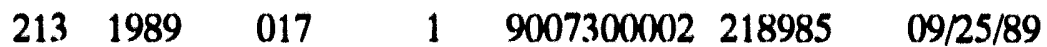

********************************************************************)

DOCKET:213 CONNECTICUT YANKEE TYPE:PWR REGION: $1 \quad$ NSSS:WE

ARCHITECTURAL ENGINEER: SWXX

FACILITY OPERATOR: CONN. YANKEE ATOMIC POWER CO.

SYMBOL: CYA

COMMENTS

STEPS 2,5,8: CAUSE EF - PRIMARY WATER STRESS CORROSION CRACKING. STEPS

2,3,5,6,8,9: INCONNEL 600 SB-166. STEPS 4,7,10: MODEL 27.

\begin{abstract}
POWER LEVEL - $000 \%$. SCHEDULED STEAM GENERATOR EDDY CURRENT

TESTING

(ECT) HAS BEEN CONDUCTED DURING THE CURRENT REFUELING OUTAGE IN ACCORDANCE WITH ASME SECTION XI AND TECHNICAL SPECIFICATION 4.10.1, "INSERVICE INSPECTION OF STEAM GENERATJOR TUBES." ON SEPTEMBER 25, 1989, AT APPROXIMATELY 1330 HOURS, WIT'A THE PLANT IN MODE 6, IT WAS DETERMINED THAT FINAL ECT DATA PLACED STEAM GENERATOR \#2 INTO THE C-3

CATEGORY. AS PLANNED, 100\% OF STEAM GENERATOR \#2 TUBES (3493 TUBES) WERE INSPECTED. SUBSEQUENTLY, ON OCTOBER 4, 1989 FINAL ECT RESULTS FOR NO. 4 STEAM GENERATOR PLACED IT IN CATEGORY C-3, THUS REQUIRING
\end{abstract}

EXPANSION OF THE ECT PROGRAM TO 100 PERCENT OF THE TUBES IN ALL FOUR

STEAM GENERATORS AS ORIGINALLY PLANNED. THE MAJOR CAUSE OF THE TUBE

DEFECTS WAS ATTRIBUTED TO PRIMARY WATER STRESS CORROSION CRACKING AND,

TO A LESSER EXTENT, PITTING. AS A RESULT OF THE INSPECTION, A TOTAL OF 159 TUBES WERE PLUGGED. THIS EVENT IS REPORTABLE PER 10CFR50.73(A)(2)(I)(B) SINCE IT INVOLVES A CONDITION PROHIBITED BY THE PLANT'S TECHNICAL SPECIFICATIONS. THIS SUPPLEMENTAL REPORT IS BEING ISSUED TO PROVIDE ADDITIONAL INFORMATION ON THE IDENTIFIED CAUSES AND

CORRECTIVE ACTION TAKEN.

-...-.STEP: 1

CAUSE:SZ -.UNKNOWN HUMAN FACTOR CAUSE

PRIMARY SYSTEM:PZ ..UNKNOWN ACTIVITY

COMPONENT:PZ -.UNKNOWN PERSONNEL 
TIMING:M -.ACTUAL PREEXISTING, UNDETECTED

PERFORMANCE:T ..TOTAL FAULT

DETECTION:R -.REVIEW OF PROCEDURE/ TEST RESULTS

EFFECT:UA -.-COMMISSION OF UNDESIRED TASK, ANALYSIS, OR STEP

STEP: 2

THIS STEP IS DIRECTLY LINKED TO STEP 1

CAUSE:EF ...CORROSION/OXIDATION

PRIMARY SYSTEM:AH -.STEAM GENERATOR (PWR)

COMPONENT:TBG ...TUBING

QUANTITY:M --MULTIPLE

TIMING:M --ACTUAL, PREEXISTING, UNDETECTED

PERFORMANCE:PR ..PARTIAL FAULT/REPAIR

DETECTION:I -.TESTING/ INSPECTION

EFFECT:BD .-WITHIN SYSTEM LEAKAGE, UNKNOWN RATE

STEP: 3

THIS STEP IS DIRECTLY LINKED TO STEP 2

SUBLINK:X

CAUSE:FA -.EROSION

PRIMARY SYSTEM:AH ..STEAM GENERATOR (PWR)

COMPONENT:TBG ...TUBING

QUANTITY:M --MULTIPLE

TIMING:M -.ACTUAL PREEXISTING, UNDETECTED

PERFORMANCE:PR ..PARTIAL FAULT/REPAIR

DETECTION:I --TESTING/INSPECTION

EFFECT:BD ..WITHIN SYSTEM LEAKAGE, UNKNOWN RATE

STEP: 4

THIS STEP IS DIRECTLY LINKED TO STEP 2

SUBLINK:A

CAUSE:RC ..RESULTANT COMPONENT FAULT

PRIMARY SYSTEM:AH -.STEAM GENERATOR (PWR)

COMPONENT:SG -.STEAM GENERATOR

VENDOR:W120--WESTINGHOUSE ELECTRIC CORP.

TIMING:M -.ACTUAL PREEXISTING, UNDETECTED

PERFORMANCE:PR ..PARTIAL FAULT/REPAIR

DETECTION:I -.TESTING/INSPECTION

EFFECT:BD ...WITHIN SYSTEM LEAKAGE, UNKNOWN RATE

STEP: 5

THIS STEP IS DIRECTLY LINKED TO STEP 1

CAUSE:EF ..CORROSION/OXIDATION

PRIMARY SYSTEM:AH -.STEAM GENERATOR (PWR)

COMPONENT:TBG .-TUBING

QUANTITY:M -.MULTIPLE

TRAIN:2 .. 
DIFFERENTIATOR:2 -.

TIMING:M ..ACTUAL PREEXISTING, UNDETECTED

PERFORMANCE:PR ..PARTIAL FAULT/REPAIR

DETECTION:I -.TESTING/ INSPECTION

EFFECT:BD -.WITHIN SYSTEM LEAKAGE, UNKNOWN RATE

-......STEP: 6

THIS STEP IS DIRECTLY LINKED TO STEP 5

SUBLINK:X

CAUSE:FA --EROSION

PRIMARY SYSTEM:AH --STEAM GENERATOR (PWR)

COMPONENT:TBG ..TUBINO

QUANTITY:M -.MULTIPLE

TRAIN:2 ..

DIFFERENTIATOR:2 ..

TIMING:M -.ACTUAL PREEXISTING, UNDETECTED

PERFORMANCE:PR ..PARTIAL FAULT/REPAIR

DETECTION:I -.TESTING/INSPECTION

EFFECT:BD ..WITHIN SYSTEM LEAKAGE, UNKNOWN RATE

......STEP: 7

THIS STEP IS DIRECTLY LINKED TO STEP 5

SUBLINK:A

CAUSE:RC -.RESULTANT COMPONENT FAULT

PRIMARY SYSTEM:AH --STEAM GENERATOR (PWR)

COMPONENT:SG -.STEAM GENERATOR

VENDOR:W120.-WESTINGHOUSE ELECTRIC CORP.

TRAIN:2 -.

DIFFERENTIATOR:2 ..

TIMING:M .-ACTUAL PREEXISTING, UNDETECTED

PERFORMANCE:PR ..PARTIAL FAULT/REPAIR

DETECTION:I -.TESTING/INSPECTION

EFFECT:BD -.-WITHIN SYSTEM LEAKAGE, UNKNOWN RATE

-.....STEP: 8

THIS STEP IS DIRECTLY LINKED TO STEP 1

CAUSE:EF ...CORROSION/ OXIDATION

PRIMARY SYSTEM:AH -.STEAM GENERATOR (PWR)

COMPONENT:TBG -.-TUBING

QUANTITY:M -.MULTIPLE

TRAIN:3 -.

DIFFERENTIATOR:3 -..

TIMING:M -.ACTUAL PREEXISTING, UNDETECTED

PERFORMANCE:PR ..PARTIAL FAULT/REPAIR

DETECTION:I -.TESTING/ INSPECTION

EFFECT:BD -.-WITHIN SYSTEM LEAKAGE, UNKNOWN RATE 


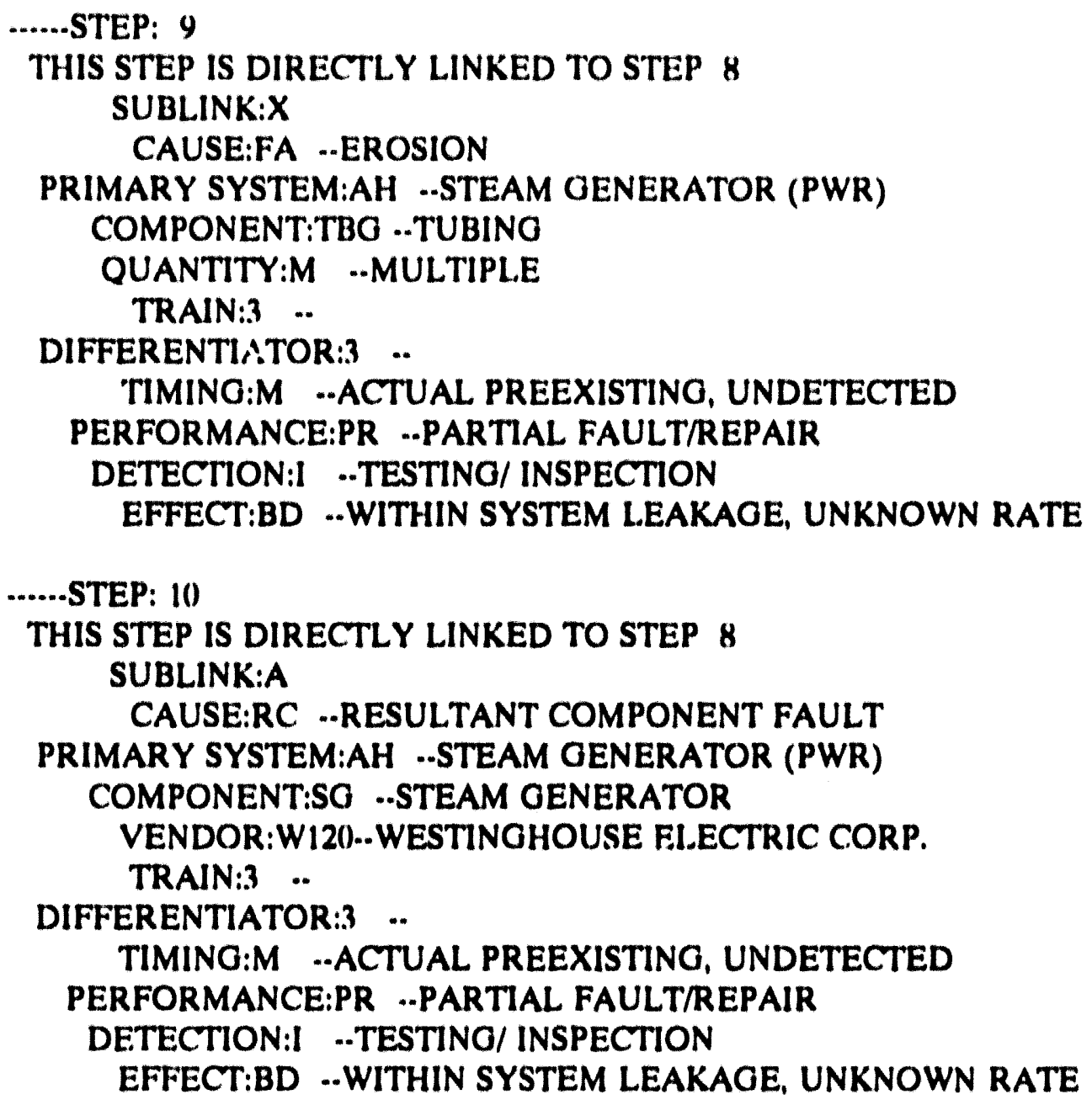

-.....STEP: 11

THIS STEP IS DIRECTLY LINKED TO STEP 4 AND STEP 7 AND STEP 10

INITIAL UNIT CONDITIONS: H REFUELING UNIT EFFECT: XX NO SIGNIFICANT EFFECT

EFFECT ON ENVIRONMENT: N NO RELEASE EFFECT ON PERSONNEL: N NO EXPOSURE

FORM $58 \quad$ LER SCSS DATA 12-24.92

. DOCKET YEAR LER NUMBER REVISION DCS NUMBER NSIC EVENT DATE $\begin{array}{llllllll}255 & 1989 & 025 & 0 & 8912280118 & 216257 & 11 / 21 / 89\end{array}$ 
ARCHITECTURAL ENGINEER: BECH

FACILITY OPERATOR: CONSUMERS POWER CO. SYMBOL: CPC

COMMENTS

STEP 2: MODEL NO. 12011(CF8M) FJMNPOTYZ. STEPS 3,4: MODEL NO. 88RR-(101.

ABSTRACT

POWER LEVEL - 000\%. ON 11/21/89 AT 0225 POWER OPERATED RELIEF VALVE (PORV), PRV-1042B (AB;RV) INSTANTANEOUSLY OPENED FOLLOWINO THE MANUAL

OPENING OF ITS ASSOCIATED MOTOR OPERATED BLOCK VALVE (MOV), MO.10242

(AB;ISV). BOTH MOV AND PORV, AND THE REDUNDANT VALVES MO-1043A AND

PRV-1043B, HAD RECENTLY BEEN REPLACED DURINO ONGOINO MAINTENANCE

OUTAGE. THE MOV WAS OPENED WITH THE REACTOR SUBCRITICAL AND THE PRIMARY COOLANT SYSTEM (PCS) AT 2154 PSIA TO PERMIT ASME SECTION XI

LEAK TESTING OF THE WELDS MADE DURINO VALVE INSTALLATION. APPROX. 24

SECS FOLLOWING THE OPENING OF THE PORV, THE REACTOR AUTOMATICALLY

TRIPPED DUE TO THE RECEIPT OF ALL 4 THERMAL MARGIN LOW PRESSURE (TMLP)

SIGNALS. APPROX. 3 MINS LATER A SAFETY INJECTION ACTUATION SIGNAL (SIAS) WAS RECEIVED WHEN PCS PRESSURE DROPPED TO THE SAFETY INJECTION

SYSTEM ACTUATION PRESSURE OF 1605 PSIA. ALL. SAFETY INJECTION EQUIPMENT THEN STARTED OR OTHERWISE PERFORMED ITS DESION FUNCTION.

BOTH DIESEL GENERATORS STARTED ON LOW BUS VOLTAGE, BUT NO EQUIPMENT

WAS AUTOMATICALLY LOADED ONTO THE DIESEL GENERATORS. WITH THE PCS AT

1565 PSIA THE PORV CLOSED AND THE MOV FULLY CLOSED. AN UNUSUAL EVENT

WAS DECLARED DUE TO THE PORV OPENING AT 0256. THE PORV AND THE MOV

WHICH OPENED WERE REMOVED FROM THE PLANT AND INSPECTED AND TESTED.

THE VALVE OPERATING CHARACTERISTICS WERE DETERMINED, AND THE PLANT

OPERATORS TRAINED AND OPERATING PROCEDURES MODIFIED TO REFLECT THOSE

CHARACTERISTICS. 
-...STEP: 1

CAUSE:SB ..TASK DESCRIPTION INADEQUACY

PRIMARY SYSTEM:PT ..TEST/ CALIBRATION ACTIVITY

COMPONENT:PUZ ...UNKNOWN UTILITY PERSONNEL

TIMING:A ..ACTUAL IMMEDIATE

PERFORMANCE:T ..TOTAL FAULT

DETECTION:I -.TESTING/ INSPECTION

EFFECT:UA ..COMMISSION OF UNDESIRED TASK, ANALYSIS, OR STEP

-.....STEP: 2

THIS STEP IS DIRECTLY LINKED TO STEP 1

CAUSE:RC -.RESULTANT COMPONENT FAULT

PRIMARY SYSTEM:AF ..PRESSURIZER (PWR)

COMPONENT:ISVZ..VALVE, ISOLATION/ SHUTOFF, UNKNOWN MATERIAL

VENDOR:E095--EDWARDS VALVES DIV

TIMING:A -.ACTUAL IMMEDIATE

PERFORMANCE:T ..TOTAL FAULT

DETECTION:I ..TESTING/INSPECTION

EFFECT:AK ..TRANSFER OPEN

STEP: 3

THIS STEP IS DIRECTLY LINKED TO STEP 2

CAUSE:RC -.RESULTANT COMPONENT FAULT

PRIMARY SYSTEM:AF ..PRESSURIZER (PWR)

COMPONENT:ORVZ.-VALVE, RELIEF W/OPERATOR, UNKNOWN MATERIAL VENDOR:TO20-.TARGET ROCK CORP.

TIMING:A ..ACTUAL IMMEDIATE

PERFORMANCE:T .-TOTAL FAULT

DETECTION:F ..OPERATIONAL ABNORMALITY

EFFECT:HK ..HIGH STATIC PRESSURE

STEP: 4

THIS STEP IS DIRECTLY LINKED TO STEP 3 SUBLINK:X

CAUSE:RC ..RESULTANT COMPONENT FAULT

PRIMARY SYSTEM:AF ..PRESSURIZER (PWR)

COMPONENT:ORVZ.-VALVE, RELIEF W/OPERATOR, UNKNOWN MATERIAL VENDOR:T02()--TARGET ROCK CORP.

TIMING:A -.ACTUAL IMMEDIATE

PERFORMANCE:T ..TOTAL FAULT

DETECTION:F ..OPERATIONAL ABNORMALITY

EFFECT:AK -.TRANSFER OPEN

-.....STEP: 5

THIS STEP IS DIRECTLY LINKED TO STEP 3

CAUSE:RC - -RESULTANT COMPONENT FAULT

PRIMARY SYSTEM:AF ..PRESSURIZER (PWR) 
COMPONENT:PZR -.PRESSURIZER

TIMING:A -.ACTUAL IMMEDIATE

PERFORMANCE:T ..TOTAI. FAULT

DETECTION:F ..OPERATIONAL ABNORMALITY

EFFECT:HL -.LOW STA'ITIC PRESSURE

-......STEP: 6

THIS STEP IS DIRECTLY LINKED TO STEP 5

CAUSE:VW ..PROCEDURAL DEFICIENCY

INITIAL UNIT CONDITIONS: $Z$ UNKNOWN/ NOT APPLICABLE

UNIT EFFECT: AC AUTOMATIC SCRAM

STEP: 7

THIS STEP IS DIRECTLY LINKED TO STEP 5

CAUSE:VW -.PROCEDURAL DEFICIENCY

INITIAL UNIT CONDITIONS: $Z$ UNKNOWN/ NOT APPLICABLE

UNIT EFFECT: EA AUTOMATIC ESF ACTUATION

-......STEP: 8

THIS STEP IS DIRECTLY LINKED TO STEP 7

SUBLINK:X

CAUSE:RE -.SHUTDOWN/ ESF RESULTANT INFORMATION

INITIAL UNIT CONDITIONS: $Z$ UNKNOWN/ NOT APPLICABLE

UNIT EFFECT: EA. AUTOMATIC ESF ACTUATION

EFFECT ON ENVIRONMENT: N NO RELEASE

EFFECT ON PERSONNEL: N NO EXPOSURE

FORM $61 \quad$ LER SCSS DATA $12-24-92$

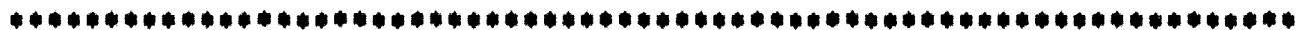

DOCKET YEAR LER NUMBER REVISION DCS NUMBER NSIC EVENT DATE $\begin{array}{lllllll}333 & 1990 & 012 & 1 & 9009050012 & 219453 & 04 / 04 / 90\end{array}$

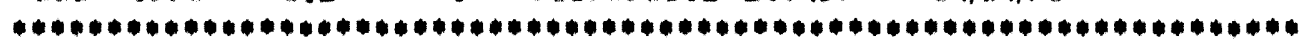

DOCKET:333 FITZPATRICK TYPE:BWR

REGION: 1 NSSS:GE

ARCHITECTURAL ENGINEER: SWXX

FACILITY OPERATOR: POWER AUTHORITY OF THE STATE OF NY SYMBOL: PNY

COMMENTS

OTHER REPORTABILITY - VOLUNTARY. WATCH-LIST 933: GENERIC LETTER 89-13. 
STEPS 2-5: MODEL NOS. B1(1)-(1)14B-2T, W7-234B-2TY, W8-234B-2TY. STEP 13: COMP MSC - VALVE DISC. STEPS 14,15: MODEL NO. 151AWE.

ABSTRACT

POWER LEVEL - $000 \%$. DURING THE 1990 REFUEL OUTAGE, 61 CHECK VALVES IN

THE NORMAL (NSW) (KG) AND EMERGENCY SERVICE WATER (ESW) (BI) WERE OPENED AND VISUALLY INSPECTED. THIRTY-SEVEN OF THE VALVES WERE FROM

THE ASME SECTION XI IST PROGRAM AND 24 WERE FROM THE CHECK VALVE PREVENTIVE MAINTENANCE (PM) PROGRAM. TWENTY IST AND 10 PM PROGRAM

VALVES WERE INITIALLY DECLARED INOPERABLE DUE TO FAILING THE VISUAL

INSPECTION CRITERIA. HOWEVER, THE IST CHECK VALVES WERE SHOWN TO $B E$

OPERABLE BY ACTUAL. FLOW TEST OR CALCULATION. OTHER EFFORTS INCLUDED

INTERNAL INSPECTION OF 5(X)' OF SMALL BORE PIPING AND 10)

SAFETY-RELATED

COOLERS AND AIR HANDLING UNITS (AHUS). OF THESE COOLERS AND AHUS, 2

WERE FOUND TO HAVE 25\% TUBE PLUGGING WITH SILT/SAND, BUT SHOWN ABLE TO

REMOVE DESIGN BASIS HEAT LOAD. OF THE 5(X)' OF PIPING, 200' WERE FOUND 10\%.30\% RESTRICTED IN CROSS-SECTIONAL AREA, BUT A CALCULATION

DEMONSTRATED THAT FLOW CONTROL VALVES WERE HYDRAULICALLY LIMITING. IN

ALL, THE ESW SYSTEM WAS CONSIDERED CAPABLE OF PERFORMING THE DESIGN

SAFETY FUNCTION. THE AFFECTED VALVES, COOLERS, AND PIPING WERE CLEANED OR REPLACED AS NECESSARY AND RETURNED TO SERVICE. THE INTAKE

BAYS WERE ALSO CLEANED. PERIODIC FLUSHING AND PERFORMANCE TESTING

SHOULD PREVENT RECURRENCE. LERS 88-(0)5, 88-(0)9, AND 89-015 ARE RELATED.

-......STEP: 1

CAUSE:SA -.INTRINSIC HUMAN ERROR

PRIMARY SYSTEM:PD --DESIGN ACTIVITY

COMPONENT:PZ -.UNKNOWN PERSONNEL

TIMING:M -.ACTUAL PREEXISTING, UNDETECTED

PERFORMANCE:T -.TOTAL FAULT

DETECTION:R --REVIEW OF PROCEDURE/ TEST RESULTS

EFFECT:UA -.COMMISSION OF UNDESIRED TASK, ANAL.YSIS, OR STEP 
STEP: 2

THIS STEP IS DIRECTLY LINKED TO STEP 1 SUBLINK:A

CAUSE:PH --FOREIGN OBJECT/ MATERIAL

PRIMARY SYSTEM:KW --RAW SERVICE WATER

COMPONENT:CVZ --VALVE, CHECK, UNKNOWN MATERIAL

VENDOR:V085--VELAN VALVE CORP.

QUANTITY:5 --

TRAIN:M --MULTIPLE

TIMING:P --POTENTIAL

PERFORMANCE:TR --TOTAL FAULT/REPAIR

DETECTION:I --TESTING/ INSPECTION

EFFECT:AR --FAILURE TO CLOSE

STEP: 3

THIS STEP IS DIRECTLY LINKED TO STEP 2

SUBLINK:X

CAUSE:EF --CORROSION/ OXIDATION

PRIMARY SYSTEM:KW --RAW SERVICE WATER

COMPONENT:CVZ --VALVE, CHECK, UNKNOWN MATERIAL

VENDOR:V085--VELAN VALVE CORP.

QUANTITY:5 -.-

TRAIN:M --MULTIPLE

TIMING:P -.-POTENTIAL

PERFORMANCE:TR --TOTAL FAULT/REPAIR

DETECTION:I --TESTING/ INSPECTION

EFFECT:AR --FAILURE TO CLOSE

STEP: 4

THIS STEP IS DIRECTLY LINKED TO STEP 1

SUBLINK:A

CAUSE:PH --FOREIGN OBJECT/ MATERIAL

PRIMARY SYSTEM:CB --ESSENTIAL RAW COOLING/ SERVICE WATER

COMPONENT:CVZ --VALVE, CHECK, UNKNOWN MATERIAL

VENDOR:V085--VELAN VALVE CORP.

QUANTITY:8 --

TRAIN:M --MULTIPLE

DIFFERENTIATOR:2

TIMING:P --POTENTIAL

PERFORMANCE:TR --TOTAL FAULT/REPAIR

DETECTION:I --TESTING/ INSPECTION

EFFECT:AL --FAILURE TO OPEN

STEP: 5

THIS STEP IS DIRECTLY LINKED TO STEP 4

SUBLINK:X 


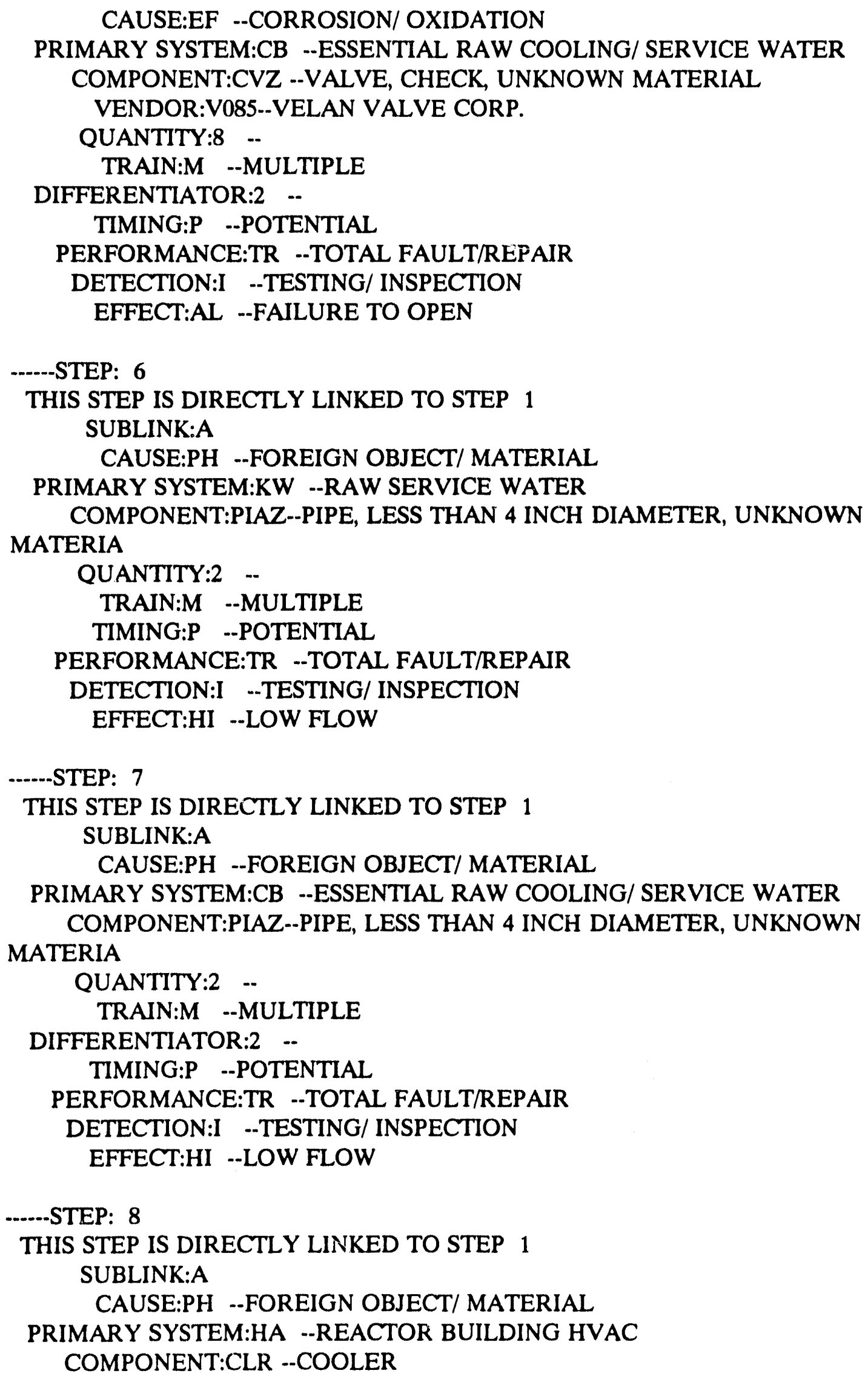

THIS STEP IS DIRECTLY LINKED TO STEP 1 SUBLINK:A CAUSE:PH --FOREIGN OBJECT/ MATERIAL

PRIMARY SYSTEM:CB --ESSENTIAL RAW COOLING/ SERVICE WATER COMPONENT:PIAZ--PIPE, LESS THAN 4 INCH DIAMETER, UNKNOWN MATERIA QUANTITY:2 -.-

TRAIN:M --MULTIPLE

DIFFERENTIATOR:2 -.

TIMING:P --POTENTIAL

PERFORMANCE:TR --TOTAL FAULT/REPAIR

DETECTION:I --TESTING/INSPECTION

EFFECT:HI --LOW FLOW

-..-.-STEP: 8

THIS STEP IS DIRECTLY LINKED TO STEP 1

SUBLINK:A

CAUSE:PH --FOREIGN OBJECT/ MATERIAL

PRIMARY SYSTEM:HA --REACTOR BUILDING HVAC

COMPONENT:CLR --COOLER 


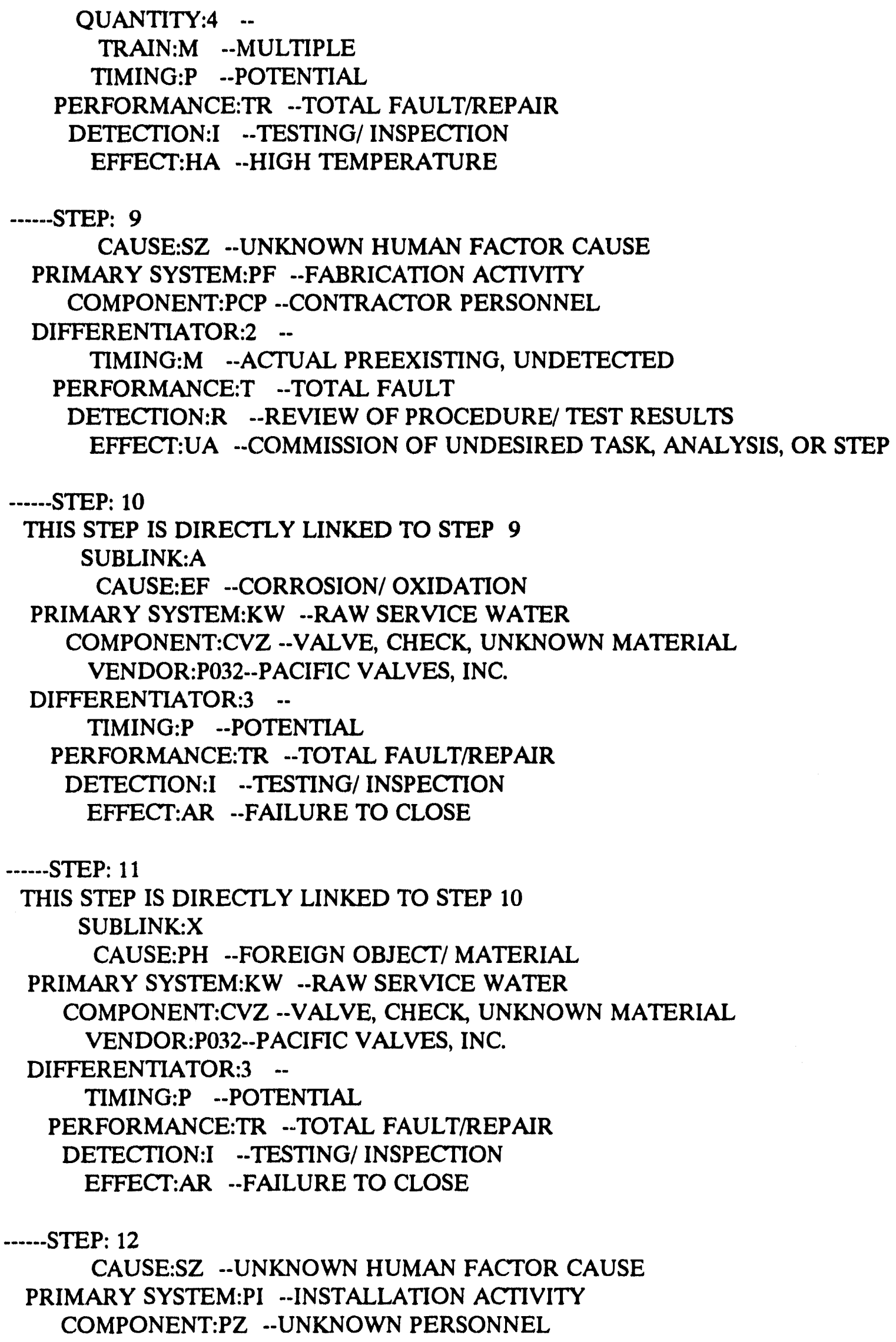

THIS STEP IS DIRECTLY LINKED TO STEP 9 SUBLINK:A

THIS STEP IS DIRECTLY LINKED TO STEP 10 SUBLINK:X

CAUSE:PH --FOREIGN OBJECT/MATERIAL

PRIMARY SYSTEM:KW --RAW SERVICE WATER

COMPONENT:CVZ --VALVE, CHECK, UNKNOWN MATERIAL

VENDOR:P032--PACIFIC VALVES, INC.

DIFFERENTIATOR:3 -TIMING:P --POTENTIAL PERFORMANCE:TR -.TOTAL FAULT/REPAIR

DETECTION:I --TESTING/INSPECTION

EFFECT:AR --FAILURE TO CLOSE

-----STEP: 12

CAUSE:SZ --UNKNOWN HUMAN FACTOR CAUSE

PRIMARY SYSTEM:PI --INSTALLATION ACTIVITY

COMPONENT:PZ -.UNKNOWN PERSONNEL 
DIFFERENTIATOR:3 --

TIMING:M --ACTUAL PREEXISTING, UNDETECTED

PERFORMANCE:T --TOTAL FAULT

DETECTION:R --REVIEW OF PROCEDURE/ TEST RESULTS

EFFECT:UA --COMMISSION OF UNDESIRED TASK, ANALYSIS, OR STEP

-.--.-STEP: 13

THIS STEP IS DIRECTLY LINKED TO STEP 12

CAUSE:RC --RESULTANT COMPONENT FAULT

PRIMARY SYSTEM:KW --RAW SERVICE WATER

COMPONENT:MSC --MISCELLANEOUS SUBCOMPONENT

TIMING:M --ACTUAL PREEXISTING, UNDETECTED

PERFORMANCE:TR --TOTAL FAULT/REPAIR

DETECTION:K --MAINTENANCE

EFFECT:AB --MALADJUSTED/MISPOSITIONED

-..-.-STEP: 14

THIS STEP IS DIRECTLY LINKED TO STEP 13

SUBLINK:A

CAUSE:EF -.-CORROSION/ OXIDATION

PRIMARY SYSTEM:KW --RAW SERVICE WATER

COMPONENT:CVZ .-VALVE, CHECK, UNKNOWN MATERIAL

VENDOR:C255--CHAPMAN VALVE \& MFG

DIFFERENTIATOR:4 --

TIMING:P --POTENTIAL

PERFORMANCE:TR --TOTAL FAULT/REPAIR

DETECTION:I --TESTING/ INSPECTION

EFFECT:AR --FAILURE TO CLOSE

-.----STEP: 15

THIS STEP IS DIRECTLY LINKED TO STEP 14

SUBLINK:X

CAUSE:PH --FOREIGN OBJECT/MATERIAL

PRIMARY SYSTEM:KW --RAW SERVICE WATER

COMPONENT:CVZ --VALVE, CHECK, UNKNOWN MATERIAL

VENDOR:C255--CHAPMAN VALVE \& MFG

DIFFERENTIATOR:4 --

TIMING:P -.POTENTIAL

PERFORMANCE:TR --TOTAL FAULT/REPAIR

DETECTION:I --TESTING/ INSPECTION

EFFECT:AR --FAILURE TO CLOSE

STEP: 16

THIS STEP IS DIRECTLY LINKED TO STEP 1

SUBLINK:A

CAUSE:PH -.FOREIGN OBJECT/ MATERIAL

PRIMARY SYSTEM:CB --ESSENTIAL RAW COOLING/ SERVICE WATER 


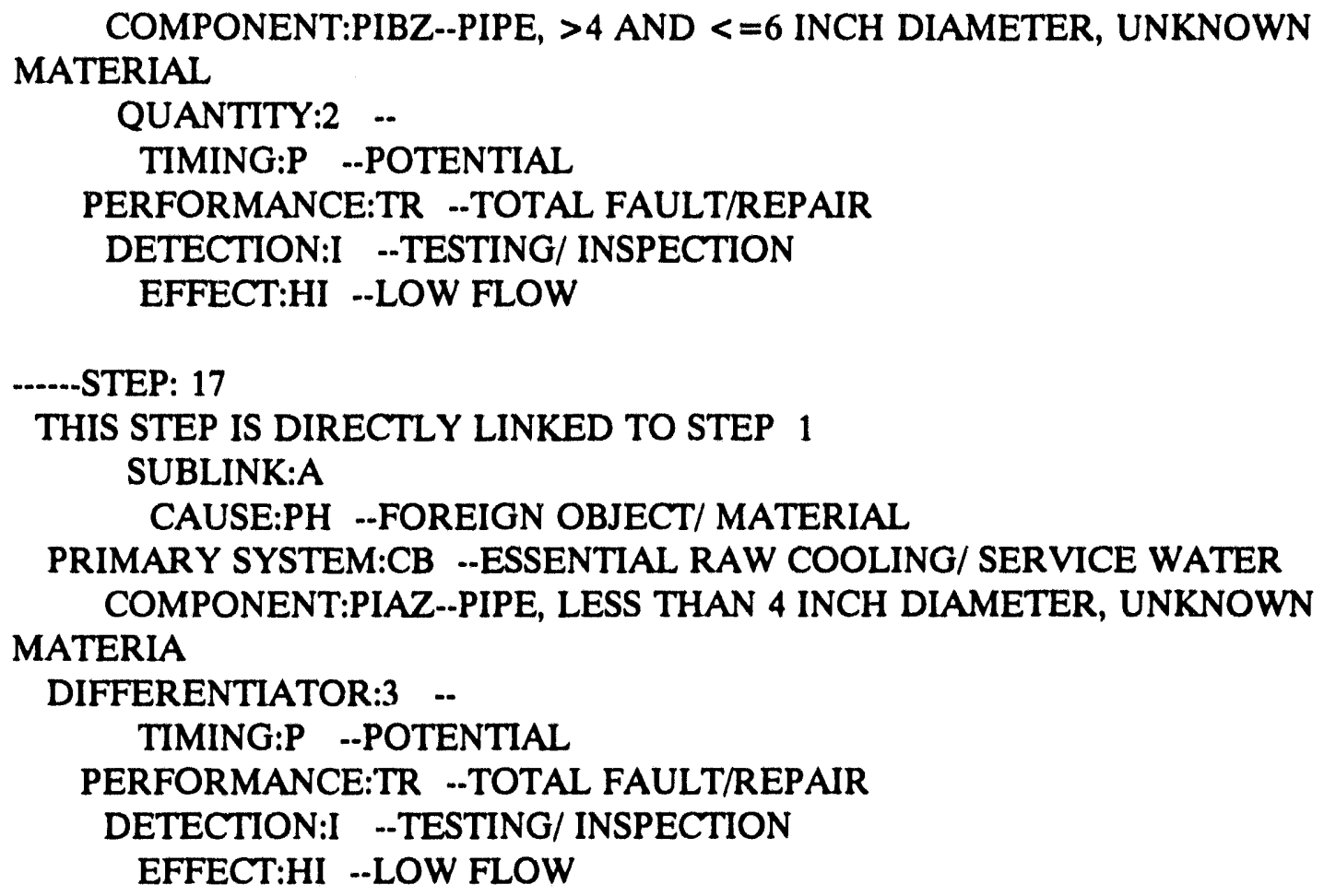

THIS STEP IS DIRECTLY LINKED TO STEP 1 SUBLINK:A

CAUSE:PH --FOREIGN OBJECT/ MATERIAL

PRIMARY SYSTEM:CB --ESSENTIAL RAW COOLING/ SERVICE WATER COMPONENT:PIAZ--PIPE, LESS THAN 4 INCH DIAMETER, UNKNOWN

MATERIA

DIFFERENTIATOR:3 --

TIMING:P -.POTENTIAL

PERFORMANCE:TR -.TOTAL FAULT/REPAIR

DETECTION:I --TESTING/ INSPECTION

EFFECT:HI --LOW FLOW

-.-.-STEP: 18

THIS STEP IS DIRECTLY LINKED TO STEP 1

SUBLINK:A

CAUSE:PH --FOREIGN OBJECT/ MATERIAL

PRIMARY SYSTEM:HA --REACTOR BUILDING HVAC

COMPONENT:AHU --AIR HANDLING/CONDITIONING UNIT (HEATING AND VENT

QUANTITY:2 --

TRAIN:M --MULTIPLE

TIMING:P -.POTENTIAL

PERFORMANCE:TR --TOTAL FAULT/REPAIR

DETECTION:I --TESTING/ INSPECTION

EFFECT:HA --HIGH TEMPERATURE

STEP: 19

THIS STEP IS DIRECTLY LINKED TO STEP 1

SUBLINK:A

CAUSE:PH --FOREIGN OBJECT/MATERIAL

PRIMARY SYSTEM:KW --RAW SERVICE WATER

COMPONENT:CVZ --VALVE, CHECK, UNKNOWN MATERIAL

VENDOR:P032--PACIFIC VALVES, INC.

TRAIN:2 -.

DIFFERENTIATOR:5 --

TIMING:P --POTENTIAL

PERFORMANCE:TR --TOTAL FAULT/REPAIR

DETECTION:I --TESTING/ INSPECTION 
EFFECT:AR --FAILURE TO CLOSE

-..-.-STEP: 20

THIS STEP IS DIRECTLY LINKED TO STEP 19 SUBLINK:X

CAUSE:EF -.-CORROSION/ OXIDATION

PRIMARY SYSTEM:KW --RAW SERVICE WATER

COMPONENT:CVZ -.VALVE, CHECK, UNKNOWN MATERIAL

VENDOR:P032--PACIFIC VALVES, INC.

TRAIN:2 -.

DIFFERENTIATOR:5 -.

TIMING:P --POTENTIAL

PERFORMANCE:TR -.TOTAL FAULT/REPAIR

DETECTION:I --TESTING/ INSPECTION

EFFECT:AR --FAILURE TO CLOSE

-.-.-.STEP: 21

THIS STEP IS DIRECTLY LINKED TO STEP 2 AND STEP 4

AND STEP 6 AND STEP 7 AND STEP 8 AND STEP 10

AND STEP 14 AND STEP 16

AND STEP 17 AND STEP 18 AND STEP 19

INITIAL UNIT CONDITIONS: $\mathrm{H}$ REFUELING

UNIT EFFECT: XX NO SIGNIFICANT EFFECT

EFFECT ON ENVIRONMENT: $N$ NO RELEASE

EFFECT ON PERSONNEL: N NO EXPOSURE

FORM $62 \quad$ LER SCSS DATA 12-24-92

DOCKET YEAR LER NUMBER REVISION DCS NUMBER NSIC EVENT DATE $\begin{array}{lllllll}333 & 1990 & 014 & 0 & 9005160149 & 218172 & 04 / 10 / 90\end{array}$

DOCKET:333 FITZPATRICK TYPE:BWR

REGION: 1 NSSS:GE

ARCHITECTURAL ENGINEER: SWXX

FACILITY OPERATOR: POWER AUTHORITY OF THE STATE OF NY SYMBOL: PNY

COMMENTS

STEP 2: COMP MSC - SPRING.

ABSTRACT

POWER LEVEL - 000\%. ON APRIL 10, 1990, A SPRING WAS DISCOVERED TO BE MISSING FROM A 2 INCH STOP AND SPRING ASSISTED PISTON CHECK VALVE 
ABSTRACT
POWER LEVEL - 000\%. ON APRIL 10, 1990, A SPRING WAS DISCOVERED TO BE MISSING FROM A 2 INCH STOP AND SPRING ASSISTED PISTON CHECK VALVE (23HPI-13). THE VALVE WAS OPENED DURING PERFORMANCE OF AN ASME SECTION XI IN-SERVICE TESTING PROGRAM DURING A PLANT REFUELING OUTAGE WHICH STARTED MARCH 31, 1990. WITHOUT THE SPRING THE VALVE WAS INOPERABLE IN THE HORIZONTAL VALVE STEM ORIENTATION USED FOR THIS INSTALLATION. TECHNICAL SPECIFICATION TABLE 3.7-1 DESIGNATES THIS AS A CONTAINMENT ISOLATION VALVE. TABLE 4.7-2 EXEMPTS IT FROM TYPE "C" LOCAL LEAK RATE TESTING BECAUSE IT IS WATER SEALED. THE VALVE IS THE

LAST OF TWO CHECK VALVES IN THE DRAIN LINE FLOW PATH TO THE TORUS FROM

THE EXHAUST LINE OF THE HIGH PRESSURE COOLANT INJECTION (HPCI) (BJ) TURBINE. THE ISOLATION FUNCTION WOULD HAVE BEEN PERFORMED BY THE

UPSTREAM CHECK VALVE ALTHOUGH IT IS NOT A DESIGNATED CONTAINMENT

ISOLATION VALVE. THE VALVE WAS OPENED FOR MAINTENANCE IN 1976 AND 1977 WITH NO RECORD OF SPRING REMOVAL. A CURRENT ENGINEERING REVIEW

SUPPORTS A CONCLUSION THAT TURBINE EXHAUST PRESSURE MAY NOT HAVE BEEN

SUFFICIENT UNDER SOME OPERATING CONDITIONS (DUE TO PRESSURE DROP THROUGH THE STEAM TRAP AND CHECK VALVES) TO OPEN THE CHECK VALVE WITH

THE SPRING INSTALLED. THE CHECK VALVE WILL BE ROTATED TO A STEM VERTICAL POSITION (WHICH DOES NOT REQUIRE A SPRING ASSIST TO CLOSE). THE SPRING WILL ALSO BE REMOVED FROM THE NEXT UPSTREAM CHECK VALVE.

-...-.STEP: 1

CAUSE:SZ --UNKNOWN HUMAN FACTOR CAUSE

PRIMARY SYSTEM:PI --INSTALLATION ACTIVITY

COMPONENT:PUZ -.UNKNOWN UTILITY PERSONNEL

TIMING:M --ACTUAL PREEXISTING, UNDETECTED

PERFORMANCE:T --TOTAL FAULT

DETECTION:R --REVIEW OF PROCEDURE/ TEST RESULTS

EFFECT:TA --OMISSION OF TASK, ANALYSIS, OR STEP

-...-STEP: 2

THIS STEP IS DIRECTLY LINKED TO STEP 1

SUBLINK:A

CAUSE:RC --RESULTANT COMPONENT FAULT

PRIMARY SYSTEM:DB -.CONTAINMENT ISOLATION 
SECONDARY SYSTEM:BN --HIGH PRESSURE COOLANT INJECTION (BWR) COMPONENT:MSC -.MISCELLANEOUS SUBCOMPONENT

TIMING:M --ACTUAL PREEXISTING, UNDETECTED

PERFORMANCE:TR -.TOTAL FAULT/REPAIR

DETECTION:I -.TESTING/ INSPECTION

EFFECT:AA --MISSING

STEP: 3

THIS STEP IS DIRECTLY LINKED TO STEP 2

CAUSE:SZ ..UNKNOWN HUMAN FACTOR CAUSE

PRIMARY SYSTEM:PM -.MAINTENANCE/ REPAIR ACTIVITY

COMPONENT:PUZ ..UNKNOWN UTILITY PERSONNEL

DIFFERENTIATOR:2 -.

TIMING:M -.ACTUAL PREEXISTING, UNDETECTED

PERFORMANCE:T -.TOTAL FAULT

DETECTION:R --REVIEW OF PROCEDURE/ TEST RESULTS

EFFECT:UA -.COMMISSION OF UNDESIRED TASK, ANALYSIS, OR STEP

-...-.STEP: 4

THIS STEP IS DIRECTLY LINKED TO STEP 3

SUBLINK:A

CAUSE:RC --RESULTANT COMPONENT FAULT

PRIMARY SYSTEM:DB -.-CONTAINMENT ISOLATION

SECONDARY SYSTEM:BN --HIGH PRESSURE COOLANT INJECTION (BWR)

COMPONENT:CVZ ..VALVE, CHECK, UNKNOWN MATERIAL

VENDOR:V085-.VELAN VALVE CORP.

TIMING:M --ACTUAL PREEXISTING, UNDETECTED

PERFORMANCE:TR --TOTAL FAULT/REPAIR

DETECTION:I -.TESTING/ INSPECTION

EFFECT:AB -.MALADJUSTED/MISPOSITIONED

....-.-STEP: 5

THIS STEP IS DIRECTLY LINKED TO STEP 4

SUBLINK:X

CAUSE:RC --RESULTANT COMPONENT FAULT

PRIMARY SYSTEM:DB --CONTAINMENT ISOLATION

SECONDARY SYSTEM:SD --REACTOR TORUS/ SUPPRESSION POOL (BWR)

COMPONENT:CVZ -.VALVE, CHECK, UNKNOWN MATERIAL

VENDOR:V085-.VELAN VALVE CORP.

TIMING:M --ACTUAL PREEXISTING, UNDETECTED

PERFORMANCE:TR --TOTAL FAULT/REPAIR

DETECTION:I -.TESTING/INSPECTION

EFFECT:AB --MALADJUSTED/MISPOSITIONED

STEP: 6

THIS STEP IS DIRECTLY LINKED TO STEP 2 AND STEP 4 
CAUSE:RC -.RESULTANT COMPONENT FAULT

PRIMARY SYSTEM:DB -..CONTAINMENT ISOLATION

SECONDARY SYSTEM:BN -.HIGH PRESSURE COOLANT INJECTION (BWR)

COMPONENT:VOK ..VALVE OPERATOR, PISTON

TIMING:M -.ACTUAL PREEXISTING, UNDETECTED

PERFORMANCE:TR ..TOTAL FAULT/REPAIR

DETECTION:I ..TESTING/ INSPECTION

EFFECT:KB -.FAILURE TO OPERATE

-.....STEP: 7

THIS STEP IS DIRECTLY LINKED TO STEP 6

CAUSE:RC - -RESULTANT COMPONENT FAULT

PRIMARY SYSTEM:DB ...CONTAINMENT ISOLATION

SECONDARY SYSTEM:BN -.HIGH PRESSURE COOLANT INJECTION (BWR)

COMPONENT:CVZ ..VALVE, CHECK, UNKNOWN MATERIAL

VENDOR:V085.-VELAN VALVE CORP.

TIMING:M ..ACTUAL PREEXISTING, UNDETECTED

PERFORMANCE:TR -.TOTAL FAULT/REPAIR

DETECTION:R --REVIEW OF PROCEDURE/ TEST RESULTS

EFFECT:BI ..BETWEEN SYSTEMS LEAKAGE, UNKNOWN RATE

STEP: 8

THIS STEP IS DIRECTLY LINKED TO STEP 7

SUBLINK:X

CAUSE:RC --RESULTANT COMPONENT FAULT

PRIMARY SYSTEM:DB ...CONTAINMENT ISOLATION

SECONDARY SYSTEM:SD -.REACTOR TORUS/ SUPPRESSION POOL (BWR)

COMPONENT:CVZ -.VALVE, CHECK, UNKNOWN MATER.IAL

VENDOR:V085--VELAN VALVE CORP.

TIMING:M .-ACTUAL PREEXISTING, UNDETECTED

PERFORMANCE:TR -.TOTAL FAULT/REPAIR

DETECTION:R -.REVIEW OF PROCEDURE/ TEST RESULTS

EFFECT:BI -.BETWEEN SYSTEMS LEAKAGE, UNKNOWN RATE

STEP: 9

THIS STEP IS DIRECTLY LINKED TO STEP 7

CAUSE:RC -.RESULTANT COMPONENT FAULT

PRIMARY SYSTEM:BN -.HIGH PRESSURE COOLANT INJECTION (BWR)

COMPONENT:PIZZ-.PIPE, UNKNOWN DIAMETER, UNKNOWN MATERIAL

TIMING:M ..ACTUAL PREEXISTING, UNDETECTED

PERFORMANCE:T --TOTAL FAULT

DETECTION:R --REVIEW OF PROCEDURE/ TEST RESULTS

EFFECT:HH -.HIGH FLOW

STEP: 10

THIS STEP IS DIRECTLY LINKED TO STEP 9

CAUSE:NB -..WATER SPRAY/ FLOOD/CONDENSATION 
PRIMARY SYSTEM:BN -.HIGH PRESSURE COOLANT INJECTION (BWR) COMPONENT:TRB ..TURBINE TIMINO:P ..POTENTIAL PERFORMANCE:T ..TOTAL FAULT

DETECTION:R .REVIEW OF PROCEDURE/ TEST RESULTS EFFECT:KC ..CESSATION OF OPERATION

-......STEP: 11

THIS STEP IS DIRECTLY LINKED TO STEP 10 CAUSE:RT ..RESULTANT TOTAL SYSTEM FAULT

PRIMARY SYSTEM:BN ..HIOH PRESSURE COOLANT INJECTION (BWR) COMPONENT:XXX -.ENTIRE SYSTEM TIMING:P ..POTENTIAL. PERFORMANCE:T ..TOTAL FAULT

DETECTION:R -REVIEW OF PROCEDURE/ TEST RESULTS EFFECT:HI -.LOW FLOW

INITIAL UNIT CONDITIONS: H REFUELING UNIT EFFECT: $X X$ NO SIGNIFICANT EFFECT

EFFECT ON ENVIRONMENT: N NO RELEASE EFFECT ON PERSONNEL: N NO EXPOSURE

FORM $69 \quad$ LER SCSS DATA $\quad 12.24 .92$

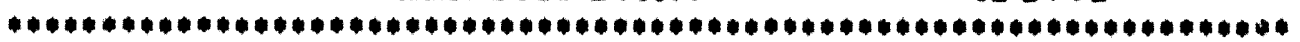

DOCKET YEAR LER NUMBER REVISION DCS NUMBER NSIC EVENT DATE $\begin{array}{lllllll}213 & 1991 & 023 & 1 & 9205190307 & 224793 & 11 / 10 / 91\end{array}$

DOCKET:213 CONNECTICUT YANKEE TYPE:PWR REGION: 1 NSSS:WE

ARCHITECTURAL ENGINEER: SWXX

FACILITY OPERATOR: CONN. YANKEE ATOMIC POWER CO. SYMBOL: CYA

COMMENTS

STEPS 2,3: INCONEL 600 SB-166 TUBES. STEP 4: MODEL NO. 27.

ABSTRACT

POWER LEVEL - 000\%. SCHEDULED STEAM GENERATOR (SG) EDDY CURRENT TESTING (ECT) HAS BEEN CONDUCTED DURING THE 1991/1992 REFUELING OUTAGE

IN ACCORDANCE WITH ASME SECTION XI AND TECHNICAL SPECIFICATION 4.4.5. 
ON NOVEMBER 9 AT APPROXIMATELY 1600 HOURS, WITH THE PLANT IN MODE 6 (REFUELINO), IT WAS DETERMINED THAT ANALYZED ECT DATA PLACED SG NO. 2

INTO THE C.3 CATEOORY. A PROMPT REPORT OF THIS EVENT WAS MADE UNDER 10CFR50.72(B)(2)(1). SUBSEOUENTLY, ON NOVEMBER 10, 1991, ANALYZED ECT RESULTS FOR SO NO. 1 PLACED IT IN CATEGORY C.3, THUS REQUIRINO EXPANSION OF THE ECT PROGRAM TO 100 PERCENT OF THE TUBES IN ALL FOURS

SO'S. THE MAJOR CAUSE OF THE TUBE DEFECTS WAS ATTRIBUTED TO PRIMARY

WATER STRESS CORROSION CRACKING AND, TO A LESSER EXTENT, PITTINO. AS

A RESULT OF THE INSPECTIONS, A TOTAL OF 130 TUBES WERE PLUGOED. THIS SUPPLEMENTAL. REPORT IS BEING ISSUED TO PROVIDE ADDITIONAL INFORMATION ON THE IDENTIFIED CAUSES AND CORRECTIVE ACTION TAKEN. THIS EVENT IS

REPORTABLE PER 10CFR50.73(A)(2)(I)(B) SINCE IT INVOLVES A CONDITION PROHIBITED BY THE PLANT'S TECHNICAL SPECIFICATIONS.

-.....STEP: 1

CAUSE:SZ ..UNKNOWN HUMAN FACTOR CAUSE

PRIMARY SYSTEM:PZ ...UNKNOWN ACTIVITY COMPONENT:PZ ..UNKNOWN PERSONNEL

TIMING:M ..ACTUAL PREEXISTING, UNDETECTED

PERFORMANCE:T ..TOTAL FAULT

DETECTION:R --REVIEW OF PROCEDURE/ TEST RESULTS

EFFECT:UA -..COMMISSION OF UNDESIRED TASK, ANALYSIS, OR STEP

STEP: 2

THIS STEP IS DIRECTLY LINKED TO STEP 1

CAUSE:CA -.MECHANICAL OVERLOAD

PRIMARY SYSTEM:AH ..STEAM GENERATOR (PWR)

COMPONENT:TBG ..TUBING

VENDOR:W120.-WESTINGHOUSE ELECTRIC CORP. QUANTITY:130 ..

TRAIN:M -.MULTIPLE

TIMING:M -.ACTUAL PREEXISTING, UNDETECTED

PERFORMANCE:TR ..TOTAL FAULT/REPAIR

DETECTION:I ...TESTING/ INSPECTION

EFFECT:DE ...CRACK

-......STEP: 3

THIS STEP IS DIRECTLY LINKED TO STEP 2 SUBLINK:X 


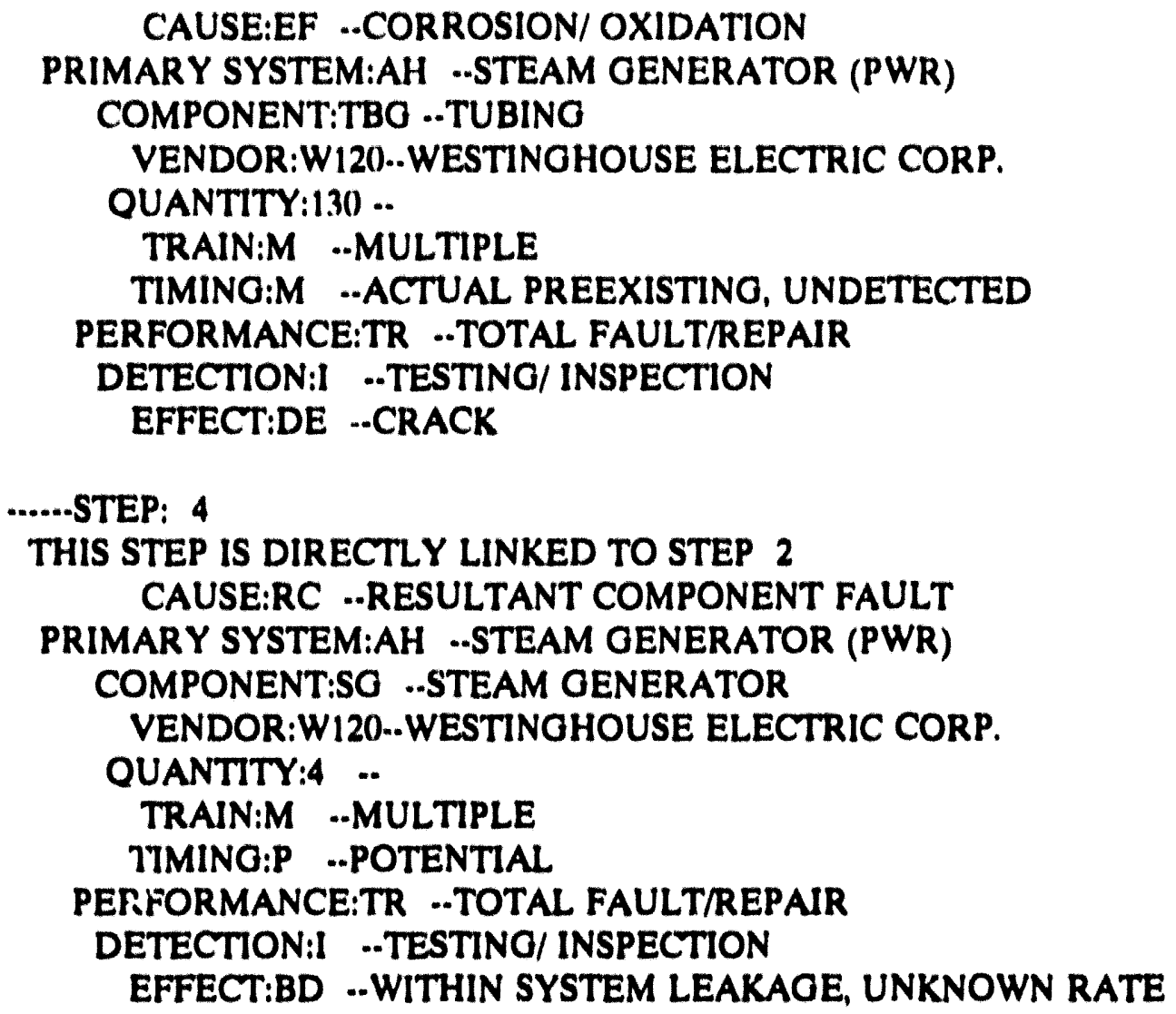

THIS STEP IS DIRECTLY LINKED TO STEP 2

CAUSE:RC -.RESULTANT COMPONENT FAULT

PRIMARY SYSTEM:AH ..STEAM GENERATOR (PWR)

COMPONENT:SO ..STEAM OENERATOR

VENDOR:W120..WESTINGHOUSE ELECTRIC CORP.

QUANTITY:4 ..

TRAIN:M ..MULTIPLE

TIMING:P ..POTENTIAL

PERFORMANCE:TR ..TOTAL FAULT/REPAIR

DETECTION:I -.TESTINO/INSPECTION

EFFECT:BD ...WITHIN SYSTEM LEAKAGE, UNKNOWN RATE

INITIAL UNIT CONDITIONS: $H$ REFUELING

UNIT EFFECT: $X X$ NO SIGNIFICANT EFFECT

EFFECT ON ENVIRONMENT: $N$ NO RELEASE

EFFECT ON PERSONNEL: N NO EXPOSURE 
Appendix B

NPRDS Information

B-1 


\section{Appendix B}

\section{NPRDS Information}

\section{Nuclear Plant Reliability Data system Query Report}

ior: Peggy Cross-Prather

U.S. Nuclear Regulatory Commission

Report-Id: NPRSOIAA

Job Number: 7590

Run Date: 03/01/93

Run Time: 15:51

introduction:

The attached report was generated by your query of the NPRDS data base. 1 summary of your query is listed below.

UUERY

'ou selected the following search condition(s):

Selected safety Classs are safety class 1, Safety class 2, and Safety class 3

Selected Detection is In-Service Inspection/Testing

IISPLAY AND SORT:

'he following fields are displayed in the order you specified. The sort equence you chose is also indicated.

Sort

Sequence Field Name

Number of Failures

Component 


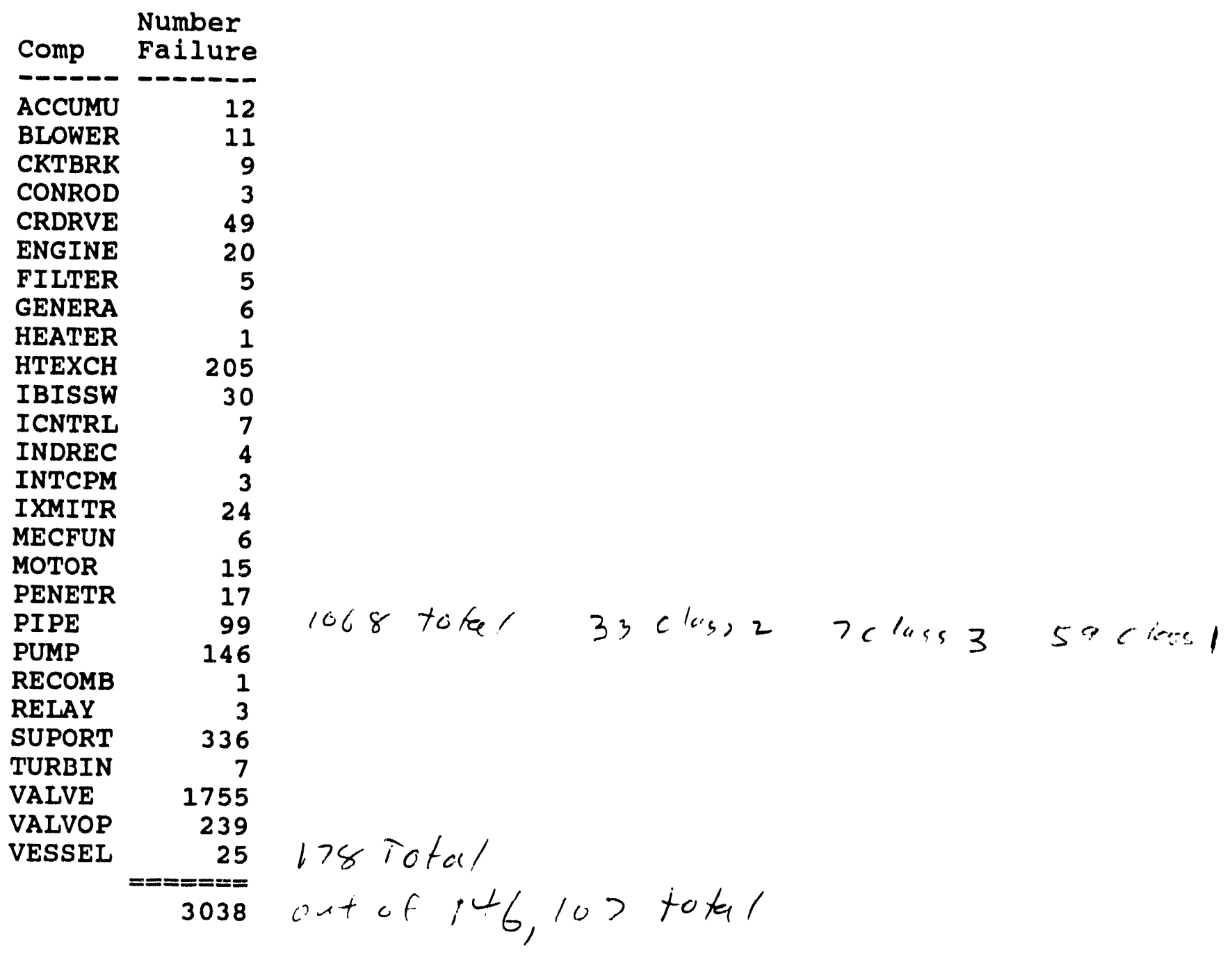


Component Code

ACCUMU

AIRDRY

BATTRY

BLOWER

CKTBRK

CONROD

CRDRVE

DEMIN

ENGINE

FILTER

GENERA

HEATER

HTEXCH

IBISSW

ICNTRL

INDREC

INTCPM

IPWSUP

ISODEV

IXMITR

\section{Component Type}

Accumulators

Air/Gas Dryers

Batteries and Chargers

Blowers

Circuit Closers/Interrupters

Control Rods

Control Rod Drive Mechanisms

Demineralizers

Engines, Internal Combustion

Filters

Generators

Heaters, Electric

Heat Exchangers

Instrumentation, Bistable/Switch

Instrumentation, Controllers

Instrumentation, Indicators/Recorders

Instrumentation, Integrator/Computation Module Instrumentation, Electric Power Supply

Instrumentation, Isolation Devices

Instrumentation,

Transmitter/Primary

Detector/Element 
Component Type

MECFUN

Mechanical Function Units

MOTOR

Motors

PENETR

Penetrations, Primary Containment

PIPE

Pipes, Fittings

PUMP

Pumps

RECOMB

Recombiners

RELAY

Relays

TRANSF

Transformers

TURBIN

Turbines

VALVE

Valves and Dampers

VALVOP

Valve Operators

VESSEL

Vessels, Pressure 


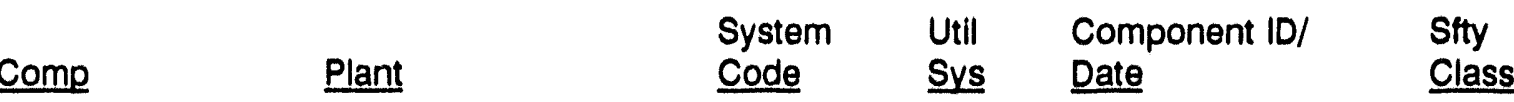

PIPE CONNECTICUT YANKEE 1 WAD SWS WS-151-151

The six-inch service water return pipe from the number 4 containment air recirculation fan had a thru wall leakage near pipe support PS.7. The hole was discovered after removing the insulation for inspection. The hole was a result of pitting on the outside diameter of the pipe. The exact cause of pitting was unknown. The hole was approximately one tenth of an inch. The pipe is scheduled to be repaired by welding a sleeve on the pipe surface in conjunction with weld overlay over pitting areas.

$\begin{array}{lllll}\text { PIPE } & \text { DRESDEN } 3 & 0300 & 3.0308-3 & 1\end{array}$ $03 / 20 / 78$

During unit refueling outage, ultrasonic inspection of safe end-to-pipe weld on CRD return line revealed indications of cracking. The cause of the cracking is due to fatigue. The pipe was removed and replaced.

$$
\begin{array}{lllll} 
& \text { PIPE } & \text { FITZPATRICK } 1 & \begin{array}{l}
93-A E G-301-36 A \\
01 / 15 / 91
\end{array} & 1^{*}
\end{array}
$$

During unit shutdown while performing inservice inspection pressure testing of ' $A$ ' emergency diesel generator air start system piping, air compressor 'A2' discharge check valve piping was found leaking air in excess of procedural limits (zero leakage). Though process fluid containment function was degraded, system was fully operable. Plant operation was not affected. Air was found to be leaking from a threaded pipe joint on the valve discharge piping. Actual cause of leakage was not determined. Check valve discharge piping was removed, pipe threads were cleaned and new sealant was applied. Piping was reinstalled and threaded joints were snoop tested and verified leak free per ISI procedural requirements.

$$
\text { PIPE HOPE CREEK } 1 \text { CBA } \quad \text { BB } \begin{array}{ll}
1-B B-013-V C A-28 & 1 \\
02 / 19 / 91 &
\end{array}
$$

The plant was in mode 5, refueling outage 4, when the inservice test group reported that during penetrant examination of an ' $A$ ' loop reactor recirculation pipe weld linear indications were discovered that exceeded ASME Code allowance. There was no significant affect on the system or operation of the plant. The component was degraded and repair was required prior to plant startup. The defects/cracks were attributed to low ferrite content in the weld material during spool fabrication by the manufacturer. The low ferrite caused hot-short cracking. A deficiency report (DR) HMT-92-109, was issued and dispositioned. The system engineer notified the supplier and a metallurgical analysis of the weld sample was performed. The DR disposition included Code Job Package (CJP) H92-090. The linear indications were removed and prepared for rewelding, the reweld was blended, satisfactorily tested, and returned to senvice. (92-11-90); WO-920923144

\footnotetext{
* It appears an error was made in noting this as Safety Class 1.
} 


$\begin{array}{cccccr}\text { Comp } & \text { Plant } & \begin{array}{l}\text { System } \\ \text { Code }\end{array} & \begin{array}{l}\text { Util } \\ \text { Sys }\end{array} & \begin{array}{l}\text { Component ID/ } \\ \text { Date }\end{array} & \begin{array}{r}\text { Stty } \\ \text { Class }\end{array} \\ \text { PIPE } & \text { INDIAN POINT } 3 & \text { WAD } & \text { SWS } & \begin{array}{l}\text { LINE-12 } \\ 05 / 01 / 88\end{array} & 1\end{array}$

Numerous pinhole leaks were found on piping of fan cooler unit service water discharge sample valve SWN-61-1 during preparation for system hydro test. The leak was not enough to effect the system or plant. The case of the failure was corrosion of 304 stainless steel pipe. The pipe was replaced. (17046)
PIPE
MILLSTONE 1
CFA
SD
CCBJ-6
$11 / 06 / 80$
1

During Class 1 \& 2 ISI liquid penetrant examination on pipe, identified a crack adjacent to weld, but not thru wall. Pipe inside drywell on supply line from LPCI system. Primary cause for failure is intergranular stress corrosion cracking. However, substantial transgranular cracking was evident. Replaced pipe section with low carbon stainless steel pipe. Tested satisfactorily.
PIPE
MILLSTONE 1
CFA
SD
CUAJ-1 $11 / 06 / 80$

During Class 1 \& 2 ISI liquid penetrant examination on plpe, identifled a crack adjacent to weld, but not thru wall. Pipe inside drywell on supply to cleanup system. Primary cause for failure is intergranular stress corrosion cracking. However, substantial transgranular cracking was evident. Replaced pipe section with low carbon stainless steel pipe. Tested satisfactorily.
PIPE
MILLSTONE 1
CFA
SD
SCAJ-CU1 $11 / 06 / 80$

During Class 1 \& 2 ISI liquid penetrant examination on pipe, identified a crack adjacent to weld (weld-o-let), but not thru wall. Pipe inside drywell supply shutdown cooling system primary cause for fallure is intergranular stress corrosion cracking. However, substantial transgranular cracking was evident. Replaced pipe section with low carbon stainless steel pipe. Tested satisfactorily.
PIPE
MILLSTONE 1
CFA
SD
SCAJ-1 $11 / 06 / 80$

During Class 1 \& 2 ISI liquid penetrant examination on pipe, identified a crack adjacent to weld, but not thru wall. Pipe inside drywell on supply to shutdown cooling system. Primary cause for failure is intergranular stress corrosion cracking. However, substantial transgranular cracking was evident. Replaced pipe section with low carbon stainless steel pipe. Tested satisfactorily.

$$
\text { PIPE MILLSTONE } 1 \text { CFA SD } \begin{aligned}
& \text { SCAJ-2 } \\
& 11 / 06 / 80
\end{aligned}
$$

During Class 1 \& 2 ISI liquid penetrant examination on pipe, identified a crack adjacent to weld, but not thru wall. Pipe inside drywell on supply to shutdown cooling system. Primary cause for failure is intergranular stress corrosion cracking. However, substantial transgranular cracking was evident. Replaced pipe section with low carbon stainless steel pipe. Tested satisfactorily. 


$\begin{array}{lllllr}\text { Comp } & \text { Plant } & \begin{array}{l}\text { System } \\ \text { Code }\end{array} & \begin{array}{l}\text { Util } \\ \text { Sys }\end{array} & \begin{array}{l}\text { Component ID/ } \\ \text { Date }\end{array} & \begin{array}{r}\text { Stty } \\ \text { Class }\end{array} \\ \text { PIPE } & \text { MILLSTONE 1 } & \text { CFB } & \text { IC } & \begin{array}{l}\text { ICAJ-1 } \\ 111 / 06 / 80\end{array} & 1\end{array}$

During Class 1 \& 2 ISI liquid penetrant examination on pipe, identified crack adjacent to weld, but not thru wall. Pipe inside drywell on supply to isolation condenser system. Primary cause for failure is Intergranular stress corrosion cracking. However, substantial transgranular cracking was evident. Replaced pipe section with low carbon stainless steel pipe. Tested satisfactorily.
PIPE MILLSTONE 1
CFB
IC
ICAJ-10
$11 / 06 / 80$

During Class $1 \& 2$ ISI liquid penetrant examination on pipe, identified crack adjacent to weld, but not thru wall. Pipe inside drywell on supply to isolation condenser system. Primary cause for failure is intergranular stress corrosion cracking. However, substantial transgranular cracking was evident. Replaced pipe section with low carbon stainless steel pipe. Tested satisfactorily.
PIPE MILLSTONE 1
CFB
IC
ICAJ-11
$11 / 06 / 80$

During Class 1 \& 2 ISI liquid penetrant examination on pipe, identified crack adjacent to weld, but not thru wall. Pipe inside drywell on supply to isolation condenser system. Primary cause for failure is intergranular stress corrosion cracking. However, substantial transgranular cracking was evident. Replaced pipe section with low carbon stainless steel pipe. Tested satisfactorily.
PIPE MILLSTONE 1
CFB
IC
ICAJ-14
$11 / 06 / 80$

During Class 1 \& 2 ISI liquid penetrant examination on pipe, identified crack adjacent to weld, but not thru wall. Pipe outside drywell on supply to isolation condenser system. Primary cause for failure is intergranular stress corrosion cracking. However, substantial transgranular cracking was evident. Replaced pipe section with low carbon stainless steel pipe. Tested satisfactorily.
PIPE MILLSTONE 1
CFB
IC
ICAJ-2
$11 / 06 / 80$

During Class $1 \& 2$ ISI liquid penetrant examination on pipe, identifled crack adjacent to weld, but not thru wall. Pipe inside drywell on supply to isolation condenser system. Primary cause for failure is intergranular stress corrosion cracking. However, substantial transgranular cracking was evident. Replaced pipe section with low carbon stainless steel pipe. Tested satisfactorily.

PIPE MILLSTONE 1

Same as 1 CAJ.2 above.
CFB

CFB

CFB
IC

ICAJ-3 $11 / 06 / 80$
1

$$
\text { PIPE MILLSTONE } 1
$$

Same as 1 CAJ-2 above.

$$
\text { FIPE MILLSTONE } 1
$$

Same as 1 CAJ-2 above. 


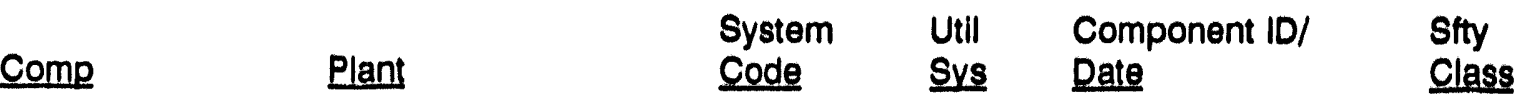

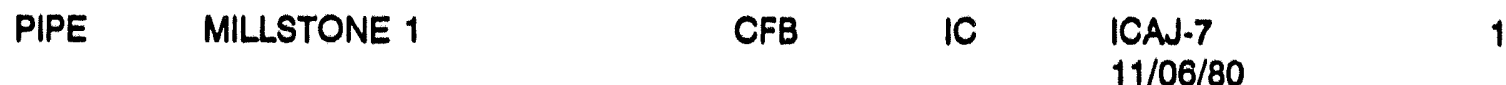

Same as 1 CAJ-2 above.

PIPE MILLSTONE 1

CFB

IC

ICAJ-8

1

Same as 1 CAJ-2 above.

PIPE MILLSTONE

CFB

IC

ICAJ-9

$11 / 06 / 80$

1

Same as 1 CAJ-2 above.

PIPE MILLSTONE

SDC

SCAJ-CU-1

$11 / 06 / 80$

During Class 1 \& 2 ISI liquid penetrant examination on pipe, identifled cracks on both sides of welds, but not thru wall. Pipe inside drywell on supply to cleanup system. Primary cause for fallure is intergranular stress corrosion cracking. However, substantlal transgranular cracking was evident. Replaced pipe section with low carbon stainless steel plpe. Tested satisfactorily.

$$
\begin{array}{lll}
\text { PIPE MILLSTONE } 1 & \text { CFA } & \text { SDCC-146 } \\
02 / 09 / 81
\end{array}
$$

A flaw indication in the plping on LPCI B loop was found between penetration and inboard isolation check valve. Weld degradation is believed to be intergranular stress corrosion cracking. However, some transgranular cracking may be present. Replaced piping section from penetration to inboard isolation check valve (304 SS).

PIPE MILLSTONE 1

A crack has been identified on one core spray sparger junction box weld. residual stress. Stress corrosion cracking may have played a part. Installed (These clamps have been installed at other plants for same problem.)
SDC
CUAJ-11

04/27/84
C.S.SPGR.D 09/25/82

Believed to be high weld sparger hold clamp.

$$
\text { PIPE MILLSTONE } 1
$$

A crack indication was detected by ultrasonic testing of an 8 inch cleanup system line. The indication measured. 0.08 in. deep by 0.75 in. long. Intergranular stress corrosion cracking is suspected; within the heat affected zone. The affected area of plpe was removed and replaced with type $304 \mathrm{ss}$ (with $<0.02$ carbon) schedule 80 pipe.

$$
\begin{array}{lll}
\text { PIPE MILLSTONE } 1 & \text { SDC } & \text { CUAJ-15 } \\
04 / 27 / 84
\end{array}
$$

1

A crack indication was detected by ultrasonic testing of a 8 inch cleanup system line. The indication measured $0.34 \mathrm{in}$. deep by $6 \mathrm{in}$. long. Intergranular stress corrosion cracking is suspected; within the heat affected zone. The affected area of pipe was removed and replaced with type 304 ss (with < 0.02 carbon) schedule 80 pipe. 


\begin{tabular}{|c|c|c|c|c|}
\hline Comp & Plant & $\begin{array}{l}\text { System } \\
\text { Code }\end{array}$ & $\begin{array}{l}\text { Util } \\
\text { Sys }\end{array}$ & $\begin{array}{l}\text { Component ID/ } \\
\text { Date }\end{array}$ \\
\hline & MILLSTONE 1 & SDC & & $\begin{array}{l}\text { CUAJ-19 } \\
04 / 27 / 84\end{array}$ \\
\hline
\end{tabular}

A crack indication was detected by ultrasonic testing of a $8 \mathrm{in}$. cleanup system line. The indlcation measured $0.30 \mathrm{in}$. deep by $10 \mathrm{in}$. long. Intergranular stress corrosion cracking is suspected; within the heat affected zone. The affected area of pipe was removed and replaced with type 30488 (with < 0.02 carbon) schedule 80 pipe.

PIPE MILLSTONE $1 \quad$ SDC $\quad$ CUAJ-19A 1

A crack indication was detected by ultrasonic testing of a 8 in. cleanup system line. The indication measured $0.39 \mathrm{in}$. deep by 360 degrees in length. Intergranular stress corrosion cracking is suspected; within the heat affected zone. The affected area of pipe was removed and replaced with type 304 ss (with < 0.02 carbon) schedule 80 pipe.

$\begin{array}{llll}\text { PIPE } & \text { MILLSTONE } 1 & \text { CUAJ-22 } & 1\end{array}$

A crack indication was detc sted by uttrasonic testing of a $8 \mathrm{in}$. cleanup system line. The indication measured 0.08 in. deep by 1.75 in. long. Intergranular stress corrosion cracking is suspected; within the heat affected zone. The affected area of plpe was removed and replaced with type 30488 (with < 0.035 carbon) schedule 160 pipe (80 degree elbow).

$\begin{array}{llll}\text { PIPE } & \text { MILLSTONE } 1 & \text { CUAN.24 } & 1\end{array}$ A crack indication was detected by ultrasonic testing of a $8 \mathrm{in}$. cleanup system line. The indication measured 0.11 in. deep by $2.5 \mathrm{in}$. long. Intergranular stress corrosion cracking is suspectedi within the heat affected zone. The affected area of plpe was removed and replaced with type 30488 (with < 0.035 carbon) schedule 160 plpe (90 degree elbow).

$\begin{array}{llll}\text { PIPE } & \text { MILLSTONE } 1 & \text { CUAJ-25 } & 1\end{array}$

A crack indication was detected by liquid penetrant testing of an 8 inch cleanup system line. The indication measured as 5 linear indications. Intergranular stress corrosion cracking is suspected; within the heat affected zone. The affected area of plpe was removed and replaced with type 30488 (with < 0.035 carbon) schedule 160 plpe (90 Degrees elbow).

$\begin{array}{llll}\text { PIPE } & \text { SILLSTONE } 1 & \text { CUAJ-9 } & 1\end{array}$

A crack indication was detected by ultrasonic testing of an 8 inch cleanup system line. The indication measured $0.11 \mathrm{in.} \mathrm{deep} \mathrm{by} 2 \mathrm{in.}$ long. Intergranular stress corrosion cracking is suspected; within the heat affected zone. The affected area of pipe was removed and replaced with type $304 \mathrm{ss}$ (with < 0.02 carbon) schedule 80 pipe. 


\begin{tabular}{|c|c|c|c|c|}
\hline Comp & Plant & $\begin{array}{l}\text { System } \\
\text { Code }\end{array}$ & $\begin{array}{l}\text { UtII } \\
\text { Sys }\end{array}$ & $\begin{array}{l}\text { Component ID/ } \\
\text { Date }\end{array}$ \\
\hline PIPE & MILLSTONE 1 & SFA & LPCI & $\begin{array}{l}\text { CSBC.G.1 } \\
04 / 27 / 84\end{array}$ \\
\hline
\end{tabular}

A crack Indication was detected by ultrasonic testing of 10 inch core spray line. The indication measured $0.1 \mathrm{ln}$. deep by 360 degrees intermittent. Intergranular stress corrosion cracking is suspected within the heat affected zone. The affected area of pipe was removed and was replaced with type 30488 with $<0.02$ carbon-schedule 80 pipe.
PIPE
MILLSTONE 1
SFA
LPCI
CSBJ-12
$04 / 27 / 84$

A crack indication was detected by ultrasonic testing of a $10 \mathrm{in}$. core spray line. The indication measured $0.25 \mathrm{in}$. deep by 6 in. long. Intergranular stress corrosion cracking is suspected within the heat affected zone. The affected area of plpe was removed and was replaced with type $3048 s$ with < 0.02 carbon-schedule 80 plpe.
PIPE
MILLSTONE 1
CBA
301
RRAJ 4
05/07/84

A crack indication was detected by ultrasonic testing of a 12 inch reactor recirculation riser pipe. The indication measured 0.20 inch deep by 4 inch long. Intergranular stress corrosion cracking is suspected within the heat affected zone. The affected area of plpe was repaired by weld overlay process. A llcensee event report was submitted.
PIPE
MILLSTONE 1
CBA
301
RRBJ-1
$05 / 07 / 84$

1

A crack Indication was detected by ultrasonic lesting of a 12 inch reactor recirculation riser pipe. The Indication measured 0.03 inch deep by 1.6 inch long. Intergranular atiess corrosion cracking is suspected within the heat affected zone. The affected area of plpe was repaired by weld overlay process. Also induction heat stress improvement process was completed on the affected area. A licensee event report was submitted.

$$
\text { PIPE MILLSTONE } 1
$$

CBA

301

RRBJ.2

$05 / 07 / 84$

A crack indication was detected by ultrasonic testing (also a visual leaker) of a 12 inch reactor recirculation riser pipe. The indication measured thru-wall by 1/4 inch long. Intergranular stress corrosion cracking is suspected within the heat affected zone. The affected area of pipe was repaired by weld overlay process. Also induction heat stress improvement process was completed on the affected area. A licensee event report was submitted. 


\begin{tabular}{|c|c|c|c|c|}
\hline Comp & Plant & $\begin{array}{l}\text { System } \\
\text { Code }\end{array}$ & $\begin{array}{l}\text { UiII } \\
\text { Svg }\end{array}$ & $\begin{array}{l}\text { Component ID/ } \\
\text { Date }\end{array}$ \\
\hline & MILLSTONE 1 & CBA & 301 & $\begin{array}{l}\text { RRCJ-3 } \\
08 / 07 / 84\end{array}$ \\
\hline
\end{tabular}

A crack indication was detected by ultrasonic testing of a 12 inch reactor recirculation riser pipe. The Indication measured 0.10 inch deep by 5 inch long. Intergranular stress corrosion cracking is suspected within the heat affected zone. The affected area of plpe was repaired by weld overlay process. Also induction heat stress improvement process was completed on the affected area. A llcensee event report was submitted.
PIPE MILLSTONE 1
CBA
301
RREJ.3
08/07/84

A crack Indication was detected by ultrasonic testing of a 12 inch reactor recirculation riser pipe. The Indication measured 0.32 inch deep by 5 inch $\mathrm{k} \mathrm{ng}$. Intergranular stress corrosion cracking is suspected within the heat affected 20ne. The a:fected area of plpe was repaired by weld overlay process. A llcensee event report was submitterd.
PIPE MILLSTONE 1
CBA
301
RRFJ-1 08/07/84

A crack Indication was detected by ultrasonic teating of a 12 inch reactor recirculation riser pipe. The Indication measured 0.13 inch deep by 12 inch long. Intergranular stress corrosion cracking is suspected within the heat affected zone. The affected area of plpe was repalred by weld overlay process. A licensee ovent report was submitted.
PIPE MILLSTONE 1
CBA
301
JPAF-2-8E
$11 / 22 / 86$

During inservice inspection, found utrasonic indications of jet pump instrument assembly 4 inch safe end to 4 inch $\times 8$ inch eccentric reducer. 0.042 inch deep $\times 0.6$ inch long. Intergranular stress corrosion cracking. Weld cracks were repaired by weld overlay technique and pressure tested satisfactorily. A licensee ovent report was submitted.
PIPE
MILLSTONE 1
CBA
301
JPAJ-2
$11 / 22 / 86$

During inservice inspection, found ultrasonic indications on jet pump instrument assembly 12 inch eccentric reducer to 12 inch plpe. Flaws 1 and 2 are 0.1 inch $\times 4.66$ inch. Intergranular stress corrosion cracking. Weld cracks were repaired by weld overlay technique and pressure tested satisfactorily. 
$\begin{array}{lllll}\text { Comp } & \text { System } & \text { Util } & \text { Component ID/ } & \text { Stty } \\ \text { Plant } & \text { Code } & \text { Sys } & \text { Date } & \text { Clase }\end{array}$

PIPE MILLSTONE 1 CBA $301 \quad \begin{aligned} & \text { JPBF.2.SE } \\ & 11 / 29 / 85\end{aligned}$ $11 / 22 / 85$

During inservice inspection, found uttrasonic test Indications (IGSCC) on jet pump instrument aseembly 4 inch sele end to 4 inch $\times 8$ inch eccentric reducer. Flaw $1-0.09$ inch $\times 0.5$ inch. Flaw 2 . 0.06 inch $\times 0.26$ inch. Intergranular stress corrosion cracking. Weld cracks were repaired by weld overlay technique and pressure tested satisfactorlly.

PIPE MILLSTONE 1

CBA

301

JPBJ.2

$11 / 22 / 86$

1

During inservice inspection, found ultrasonic test indications on jet pump instrument aseembly 12 inch eccentric reducer to 12 inch plpe. 0.172 inch deep $\times 360$ deg. Intergranular stress corrosion cracking. Unt in refueling. Wold cracks were repaired by weld overlay technlque and pressure teated satisfactorily. A licensee event report was submitted.

PIPE MILLSTONE 1

During performance on inservice inspection, found ultrasonic test indications of jet pump instrument assembly 12 inch pipe to 12 inch seal. 0.344 inch deep $\times 360$ deg. intergranular strese corrosion oracking. Unit in relueling. Weld cracke wore repalred by weld overlay technique and presesure tested satisfactorlity. A licensee ovent report was submitted.

\section{PIPE MILLSTONE}

CBA

301

RMBJ.1

$06 / 26 / 87$

During refueling, a crack indication was found on a plpe to cap weld. The indication was found unacceptable and needed repair. The weld was last inspected during the refueling in 1984. The cause is belleved to be intergranular stress corrosion cracking. The weld indication in question was weld overlayed with ER308/ which has immunity to igscc. A system hydrostatic test will be performed. A llcensee ovent report was submitted.

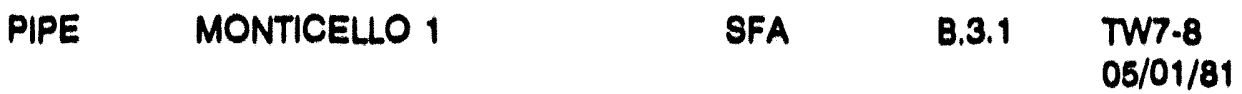

During outage, while performing annual ISI inspection on core spray loop B, several non-through-wall crack indications were discovered. Apparent cause of cracks was intergranular stress corrosion cracking. Replaced part of safe end, safe ond reducer, and all stainless steel piping up to the first manual isolation valve on both core spray loops. 


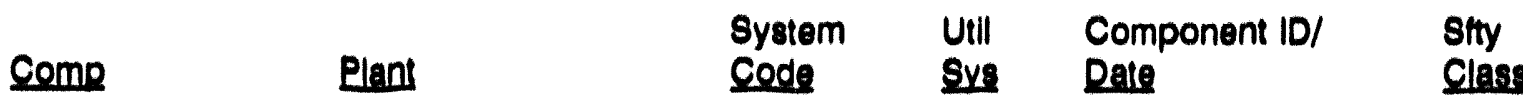

PIPE MONTICELLO 1 CBA $\quad B .1 .4 \quad$ REW.14-12 1

$09 / 28 / 82$

During ISI inspection while in cold shutdown for refuel, IGSCC Indications were found on recirc. system piping sate ende and elbows. Cause was due to intergranular stress corrosion cracking in senaltized 304 stainless steel base material. Cracks were weld repaired using a weld overlay process and E3O8I weld filler material. PIPE NINE MILE POINT $1 \quad$ SFA $80,80.1 \quad \begin{aligned} & \text { CSLOOP.11 } \\ & 08 / 07 / 84\end{aligned}$

During ultrasonic testing of the core spray system, a crack in \#11 loop pipe was discovered. The cracks were caused by chlorine induced stress corrosion. The cracks were ground out and the cavity weld repalred and ground smooth; retesting showed satisfactory results.
PIPE
PEACH BOTTOM 2
CBA
02
N8-A

Ultrasonic examination revealed a through-wall crack in the 'A' jet pump instrumentation penetration reducer to sa. and weld. Analysis indicates a pattern typlcal of intergranular stress corrosion cracking. A modified reducer design will be installed during current primary system pipe replacement outage.

\section{PIPE PEACH BOTTOM 3 \\ CBA \\ 02 \\ N8-A \\ 06/10/84} 1

Uitrasonic examination revealed crack llike indications in the 'A' jet pump instrumentation penetration reducar to safe end weld. Analysis indicates a pattern typical of intergranular stress corrosion cracking. Full structural weld overlay repairs were performed prior to returning the unit to service. Moisture detection devices were installed on the ' $A$ ' penetrations.
PIPE
PEACH BOTTOM 3
CBA
02
N8-B
$06 / 10 / 84$ 1

Ultrasonic examination revealed crack like indications in the ' $B$ ' jet pump instrumentation penetration reducer to safe end weld. Analysis indicates a pattern typical of intergranular stress corrosion cracking. Full structural weld overlay repairs were pertormed prior to returning the unit to service. Molsture detection devices were installed on the 'B' penetrations.
PIPE
SALEM 1
WAD
028
$1.8 W \cdot 72$
$07 / 04 / 91$

Unit 1 at 100 percent power. Maintenance personnel were performing a inspection on number 16 service water strainer discharge piping (1-SW.72), when they discovered a through the wall leak, and pitting of the inner wall. No train, or plant effect. This was a small hole in piping. Maintenance personnel have determined that fallure was due to normal wear out of piping, agitated by the corrosive, erosive properties of the senvice water system. The through the wall leak was welded, and pitting also. Pipe was returned to service with no leaks observed. This report was sent to our system engineers for further evaluation. (901001147) TJW 


\begin{tabular}{|c|c|c|c|c|}
\hline Comp & Plant & $\begin{array}{l}\text { System } \\
\text { Eode }\end{array}$ & $\begin{array}{l}\text { UtIl } \\
\text { Sys }\end{array}$ & $\begin{array}{l}\text { Component ID/ } \\
\text { Date }\end{array}$ \\
\hline DE & SALEM 1 & HHF & 012.263 & $\begin{array}{l}\text { RD-1S.FWR-10 } \\
01 / 01 / 92\end{array}$ \\
\hline
\end{tabular}

Unit 2 at 100 percent power. Maintenance personnel were performing a in-service inspection on number 12 steam generator feed pump recirculation piping (RD.18.FWR-10), and $t$ was found to be below acceptable minimum wall thickness. This was determined to be a reportable fallure by our system engineer. No train, or plant effect. Maintenance personnel suspect fallure cause to be from normal wear of plping wall, agitated by corrosive, erosive properties of the feedwater system. Maintenance personnel replaced the piping in kind, and pertormed other preventlve maintenance activities on the pliping system. Thls report was sent to our system engineer for further review. (920613074) TJW

$\begin{array}{llll}\text { PIPE SALEM } 2 & \text { WAD } & 28 & \begin{array}{l}2.8 W \cdot P .126 \\ 07 / 04 / 01\end{array} \\ & & & \\ & & \end{array}$

Unit two off line for feedwater plping evaluations. Maintenance personnel were performing a hydrostatic test on the service water return header plping (2-8W.P.126) for the chiller condensers, and a through the wall leak was discovered. This was a small leak, and did not effect the service water system, or the performance of the chiller condensers. No train, or plent effect. Maintenance personnel suspect fallure cause to be from normal wear out of the piping wall, agltated by the corrosive, erosive properties of the service water system. Maintenance personnel replaced the piping in kind. No leaks were obsenved when the senvice water flow was returned. This report was sent to our system engineer for further review. (820707159) TJW

$$
\text { PIPE SALEM } 2 \text { HHF } 012-263 \begin{aligned}
& 280 F .113 R 1 \\
& 06 / 16 / 82
\end{aligned}
$$

Untt two off line for feedwater piping evaluation. Our system engineers were performing a scheduled examination of the feedwater plping, and they discovered that the piping wall of the eccentric reducers down stream of number 23 steam generator inlet valve were thinning. No train, or plant effect. The piping was still able to perform lits function of fluid containment. This is considered inclpient. Maintenance personnel suspect wall thinning is due to normal wear of piping wall, agttated by aging, corrosion, and erosion. Maintenance personnel replaced the eccentric reducers in kind. This report was sent our system engineer for further roview. (920622124) TJW

$$
\text { PIPE SALEM } 2 \text { HHF } 012.263 \begin{aligned}
& 289 F .113 R 2 \\
& 06 / 16 / 92
\end{aligned}
$$

Untt two off line for feedwater plping evaluation. Our system engineers were pertorming a scheduled examination of the feedwater piping, and they discovered that the plping wall of the eccentric reducers down stream of number 24 steam generator inlet valve were thinning. No train, or plant effect. The piping was still able to perform it's function of fluid containment. This is considered inciplent. Maintenance personnel suspect wall thinning is due to normal wear of piping wall, agltated by aging. corrosion, and erosion. Maintenance personnel replaced the eccentric reducers in kind. This report was sent our system engineer for further review. (920622124) TJW 


$\begin{array}{lllllr}\text { Comp } & \text { Plant } & \begin{array}{l}\text { System } \\ \text { Code }\end{array} & \begin{array}{l}\text { Util } \\ \text { Sys }\end{array} & \begin{array}{l}\text { Component ID/ } \\ \text { Date }\end{array} & \begin{array}{l}\text { Sfty } \\ \text { Class }\end{array} \\ \text { PIPE } & \text { SALEM } 2 & \text { WAD } & 028 & \begin{array}{c}2-S W-P-112 \\ 06 / 16 / 92\end{array} & 1\end{array}$

Unit two off line for feedwater piping evaluations. Maintenance personnel were performing a hydrostatic test on the service water return header piping (2-SW-P-112) for the chiller condensers, and a through the wall leak was discovered. This was a small leak, and did not effect the service water system, or the performance of the chiller condensers. No train, or plant effect. Maintenance personnel suspect failure cause to be from normal wear out of the piping wall, agitated by the corrosive, erosive properties of the service water system. Maintenance personnel replaced the piping in kind. No leaks were observed when the service water flow was returned. This report was sent to our system engineer for further review. (920705090) TJW
PIPE
SALEM 2
WAD
028
2-SW-P-113 1

Unit two off line for feedwater piping evaluations. Maintenance personnel were performing a hydrostatic test on the service water return header piping elbow (2-SW-P-112) for the chiller condensers, and a through the wall leak was discovered. This was a small leak, and did not effect the senvice water system, or the performance of the chiller condensers. No train, or plant effect. Maintenance personnel suspect failure cause to be from normal wear out of the piping wall, agitated by the corrosive, erosive properties of the service water system. Maintenance personnel replaced the piping elbow in kind. No leaks were observed when the service water flow was returned. This report was sent to our system engineer for further review. (920705090) TJW
PIPE
BRUNSWICK 2
SFC
2E41
2-E41-22-1-604

With unit 2 in cold shutdown, maintenance personnel performing ISI testing on the high pressure coolant injection steam supply drain pot drain valve (2-E41-22-1-604) found the pipe had degraded to a wall thickness of 0.219 in. The required wall thickness for this pipe is 0.25 inch as per ASME Section III. The pipe is required to maintain system integrity. The discovery presented no problems to the system or plant since no actual leakage was found but engineering required the pipe to be replaced prior to unit 2 restart. The root cause of the wall thinning was due to normal erosion by water flow. Maintenance replaced the pipe (2-E41-22-1-604) and fittings with identical spares. Trk no 93-043 (bjb 90-aexk1)

\section{PIPE COMANCHE PEAK 1 \\ SCJ \\ CT \\ BRP-CT-1-SB-004 2 05/23/91}

With plant at 0 percent power and the system and train -GSK-01 in test, the containment spray pump $1-03$ discharge flow element orifice flange was found to be leaking externally by quality control inspector during Code leak inspection as evidenced by boron crystals on the flange. As the leak was only a seep, there was no effect on the system, train or plant. The orifice remained in service about 5 months until the first refueling outage. The cause of the failure was determined to be loose flange fasteners and/or misalignment of the 2 flanges due to previous maintenance activities. Disassembled flange, cleaned and inspected gasket surfaces, aligned flanges, replaced gaskets and torqued fasteners. Post work test showed the leak had stopped. 


\begin{tabular}{lllllr} 
Comp & \multicolumn{1}{c}{$\begin{array}{l}\text { System } \\
\text { Plant }\end{array}$} & $\begin{array}{l}\text { Util } \\
\text { Code }\end{array}$ & Sys & $\begin{array}{l}\text { Component ID/ } \\
\text { Date }\end{array}$ & $\begin{array}{l}\text { Sfty } \\
\text { Class }\end{array}$ \\
PIPE & COMANCHE PEAK & SCJ & CT & $\begin{array}{l}\text { BRP-CT-1-SB-017 } \\
05 / 23 / 91\end{array}$ & 2
\end{tabular}

With plant at 0 percent power and system train in test -GSK-1, the containment spray pump 1-01 discharge flow element orifice flange was found to be leaking externally by quality control inspector during Code leak inspection as evidenced by boron crystals on the flange. As the leak was only a seep, there was no effect on the system train or plant. The orifice remained in service about 5 months until the first refueling outage. The cause of the failure was undetermined, but was believed to be loose flange fasteners and/or misalignment of the 2 flanges. Disassembled flange, cleaned and inspected gasket surfaces, aligned flanges, replaced gaskets and torqued fasteners. Post work test showed the leak to be stopped.

$\begin{array}{lllll}\text { PIPE HATCH } 1 & \text { SCADIL } & \text { T48 } & \begin{array}{l}\text { T48-2CPI-18-PID } \\ 09 / 30 / 84\end{array} & 2\end{array}$

With the unit in cold shutdown for refueling -6 , in-service inspection was being performed on the nitrogen inerting and purge line to the drywell. A linear, through-wall crack approximately $23 / 4$ inches long was discovered in weld 1T48-2CPI-18-PID-6. The crack was caused by thermally induced stress in the area of the weld. The stress was induced by nitrogen impinging the weld area and cooling it below the nil ductility transition temperature. The crack was ground-out and repaired. The weld was then inspected via magnetic particle method; no indication was found. The setpoint for low temperature alarm for the nitrogen inerting system will be raised from 0 degree $F$ to 10 degree $F$ and the system procedures will be revised to include instructions to discontinue nitrogen flow upon low temperature alarm.
PIPE
INDIAN POINT 3
SFK
SIS
FE-927
01/10/84

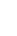

A flange leak was discovered for SI flow orifice FE-927 diuring an inservice inspection surveillance test. The studs at the flanges were loose and corroded. The studs were replaced, retorqued, and retested.

$$
\begin{aligned}
& \text { PIPE MAINE YANKEE } 1 \text { SCD } \text { CSS } 3^{\prime \prime}-\text { CS-24-302R3 } 2 \\
& \text { 10/22/85 }
\end{aligned}
$$

During a refueling shutdown and radiographic inspection of the recirculation line for containment spray pump P-61A, line number 3 in.-CS-24-302R3 was found to have a defective weld at a 90 degree elbow. Dr 5317-85 The defect was possibly present since construction. Replaced the elbow section of piping.

$$
\begin{aligned}
& \text { PIPE MILLSTONE } 1 \text { CHA CND/FDW FW-SPARGERS } 2 \\
& \text { 11/01/76 }
\end{aligned}
$$

Cracks in feed water spargers discovered by dye penetrant exam as part of in-service inspection program. Suspect stress-fatigue caused by improper design; replaced spargers. 


\begin{tabular}{|c|c|c|c|c|}
\hline Comp & Plant & $\begin{array}{l}\text { System } \\
\text { Code }\end{array}$ & $\begin{array}{l}\text { Util } \\
\text { Sys }\end{array}$ & $\begin{array}{l}\text { Component ID/ } \\
\text { Date }\end{array}$ \\
\hline PIPE & MILLSTONE 1 & CFB & IC & $\begin{array}{l}\text { ICAC-F-16A } \\
11 / 06 / 80\end{array}$ \\
\hline
\end{tabular}

During Class 2 ISI, liquid penetrant examination on pipe identified a crack adjacent to weld, but not thru wall. Pipe outside drywell on supply to isolation condenser system. Primary cause for failure is intergranular stress corrosion cracking. However, substantial transgranular cracking was evident. Replaced pipe section with low carbon stainless steel pipe. Tested satisfactorily.
PIPE
MILLSTONE 1
CFB
IC
ICAC-F-17 $11 / 06 / 80$

2

During Class 2 ISI, liquid penetrant examination on pipe identified a crack adjacent to weld, but not thru wall. Pipe outside drywell on supply to isol. Cond. Sys. Primary cause for fallure is intergranular stress corrosion cracking; however, substantial transgranular cracking was evident. Replaced pipe section with low carbon stainless steel pipe. Tested satisfactorily.
PIPE
MILLSTONE 1
CFB
IC
ICAC-F-18
$11 / 06 / 80$

2

During Class 2 ISI, liquid penetrant examination on pipe identffied a crack adjacent to weld, but not thru wall. Pipe outside drywell on supply to Isol. Cond. Sys. Primary cause for failure is intergranular stress corrosion cracking; however, substantial transgranular cracking was evident. Replaced pipe section with low carbon stainless steel pipe. Tested satisfactorily.
PIPE
MILLSTONE 1
CFB
IC
ICAC-F-19

$11 / 06 / 80$
During Class 2 ISI, liquid penetrant examination on pipe identified a crack adjacent

2 .

Durng Class thru wall. Pipe outside drywell on supply to Isol. Cond. Sys. Primary cause for fallure is intergranular stress corrosion cracking; however, substantial transgranular cracking was evident. Replaced pipe section with low carbon stainless steel pipe. Tested satisfactorily.

$$
\begin{array}{llll}
\text { PIPE MILLSTONE } 1 & \text { CFB } & \text { IC } & \text { ICAC-F-25A } \\
11 / 06 / 80
\end{array}
$$

During Class $2|S|$, liquid penetrant examination on pipe identified crack adjacent to weld, but not thru wall. Pipe outside drywell on supply to Isol. Cond. Sys. Primary cause for failure is intergranular stress corrosion cracking; however, substantial transgranular cracking was evident. Replaced pipe section with low carbon stainless steel pipe. Tested satisfactorily.

$$
\begin{array}{llll}
\text { PIPE MILLSTONE } 1 & \text { CFB IC } & \text { ICAC-F.26 } \\
& & & 11 / 06 / 80
\end{array}
$$

During Class 2 ISI, liquid penetrant examination on pipe identified crack adjacent to weld, but not thru wall. Pipe outside drywell on supply to Isol. Cond. Sys. Primary cause for failure is intergranular stress corrosion cracking; however, substantial transgranular cracking was evident. Replaced pipe section with low carbon stainless steel pipe. Tested satisfactorily. 


$\begin{array}{lllllr}\text { Comp } & \text { Plant } & \begin{array}{l}\text { System } \\ \text { Code }\end{array} & \begin{array}{l}\text { Util } \\ \text { Sys }\end{array} & \begin{array}{l}\text { Component ID/ } \\ \text { Date }\end{array} & \begin{array}{l}\text { Sity } \\ \text { Class }\end{array} \\ \text { PIPE } & \text { MILLSTONE 1 } & \text { CFB } & \text { IC } & \begin{array}{c}\text { ICAC.F-27 } \\ 11 / 06 / 80\end{array} & 2\end{array}$

During Class 2 ISI, liquid penetrant examination on pipe identified crack adjacent to weld, but not thru wall. Pipe outside drywell on supply to Isol. Cond. Sys. Primary cause for fallure is intergranular stress corrosion cracking; however, substantial transgranular cracking was evident. Replaced pipe section with low carbon stainless steel pipe. Tested satisfactorily.
PIPE
MILLSTONE 1
CFB
IC
ICAC-F-28
$11 / 06 / 80$

During Class 2 ISI, liquid penetrant examination on pipe identified crack adjacent to weld, but not thru wall. Pipe outside drywell on supply to Isol. Cond. Sys. Primary cause for fallure is intergranular stress corrosion cracking; however, substantial transgranular cracking was evident. Replaced pipe section with low carbon stainless steel pipe. Tested satisfactorily.
PIPE
MILLSTONE 1
CFB
IC
ICAC-F-22
04/19/84
2

A crack indication was detected by ultrasonic testing of a 12 in. isolation condenser line. The indication measured $0.11 \mathrm{in}$. deep by 2 in. long. Intergranular stress corrosion cracking is suspected within the heat affected zone. The affected area of pipe was removed and was replaced with type 304 ss with $<0.02$ carbon-schedule 80 pipe.
PIPE
MILLSTONE 1
CFB
IC
ICAC-F-25
04/19/84
2

A crack indication was detected by ultrasonic testing of a $12 \mathrm{in}$. Isolation condenser line. The indication measured $0.14 \mathrm{in.} \mathrm{deep} \mathrm{by} 2.75 \mathrm{in}$. long. Intergranular stress corrosion cracking is suspected within the heat affected zone. The affected area of pipe was removed and was replaced with type 304 ss with $<0.02$ carbon-schedule 80 pipe.
PIPE
MILLSTONE 1
CFB
IC
ICAC.F-3
$04 / 19 / 84$
2

A crack indication was detected by ultrasonic testing of a 16 in. isolation condenser line. The indication measured $0.18 \mathrm{in}$. deep by 4 in. long. Intergranular stress corrosion cracking is suspected within the heat affected zone. The affected area of pipe was repaired by weld overlay process.
PIPE
MILLSTONE 1
CFB
IC
ICAC-F-4
2

A crack indication was detected by ultrasonic testing of a 16 in. isolation condenser line. The indication measured $0.36 \mathrm{in}$. deep by $7 \mathrm{in}$. long. Intergranular stress corrosion cracking is suspected within the heat affected zone. The affected area of pipe was removed and replaced with type 3161 ss-schedule 120 pipe. Note: this is an elbow 90 degrees.
PIPE MILLSTONE 1
CFB
IC
ICAC-F-5

2

A crack indication was detected by liquid penetrant testing of a 16 in. isolation condenser line. Intergranular stress corrosion cracking is suspected within the heat affected zone. The affected area of pipe was removed and replaced with type 316l ss-schedule 120 pipe. 


$\begin{array}{llllll}\text { Comp } & \text { Plant } & \begin{array}{l}\text { System } \\ \text { Code }\end{array} & \begin{array}{l}\text { Util } \\ \text { Svs }\end{array} & \begin{array}{l}\text { Component ID/ } \\ \text { Date }\end{array} & \begin{array}{l}\text { Sfty } \\ \text { Class }\end{array} \\ \text { PIPE } & \text { MILLSTONE 1 } & \text { CFB } & \text { IC } & \begin{array}{l}\text { ICAC-F-6 } \\ 04 / 19 / 84\end{array} & 2\end{array}$

A crack indication was detected by ultrasonic testing of a $16 \mathrm{in}$. isolation condenser line. The indication measured $0.15 \mathrm{in}$. deep by $9 \mathrm{in}$. long. Intergranular stress corrosion cracking is suspected within the heat affected zone. The affected area of pipe was removed and replaced with type 304 ss with $<0.02$ carbon-schedule 80 pipe.
PIPE MILLSTONE 1
CFB
IC
ICAC.F-13 $10 / 31 / 85$
2

During inservice inspection on isolation condenser Class 2 steam supply line, a 12 in. pipe weld joint was found to have an unacceptable crack indication by ultrasonic testing. Believed to be intergranular stress corrosion cracking. The flaw $\sim 0.22 \mathrm{in}$. deep $\times 2.5 \mathrm{in}$. long. Two other areas within this weld area, but not as deep into pipe wall. The defective weld was weld overlayed in accordance with ASME Code Section XI, 1980 edition. The pipe will be hydrostatically tested before return to service.

$\begin{array}{llll}\text { PIPE MILLSTONE } 1 & \text { CFB } & \text { IC } & \begin{array}{l}\text { ICBC-F-14 } \\ 07 / 02 / 87\end{array}\end{array}$

An ultrasonic test identified an unacceptable inclusion in the base metal of the isolation condenser return line. This 8 inch diameter pipe extends axially for approximately 26 inches. Intergranular stress corrosion cracking of the isolation condenser return line pipe. The pipe section was replaced using a material that is more resistant to intergranular stress corrosion cracking. A system hydrostatic test was performed.

$\begin{array}{lllll}\text { PIPE } & \text { OYSTER CREEK } 1 & \text { SFA } & 212 & \begin{array}{l}\text { NZ-3-38 } \\ 04 / 10 / 89\end{array}\end{array}$

Mode switch in startup. While performing the $1000 \mathrm{lb}$ inspection a pinhole was discovered at core spray system weld \#NZ-3-38. Luak was at toe of weld to base metal. Weld configuration is pipe to elbow. 8 in. stainless steel butt weld. Test results revealed that the pinhole leak had characteristics of intergranular stress corrosion cracking. Performed complete circumferential weld overlay. Performed ultrasonic testing and a visual at $1000 \mathrm{lb}$. Startup was delayed until 5/11/89 because of this.

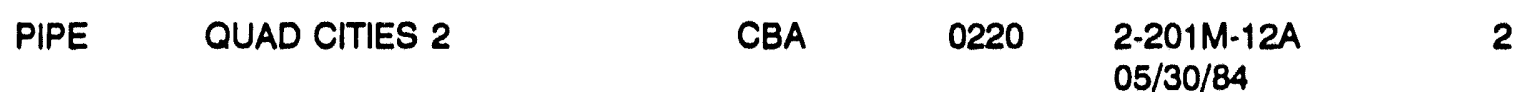

Unit 2 was in the refuel mode. On 4-1-85 a visual inspection revealed a recirculation weld area, pipe $2-201 \mathrm{M}-12 \mathrm{~A}$, with water seeping from a small crack. The unit was shutdown for refueling and maintenance making the safety consequences of this event minimal. The cause of the crack indication is postulated to be intergranular stress corrosion cracking. Materials used in original recirculation piping \& fittings are regular grade type 304 stainless steel which is known to be susceptible to stress corrosion cracking based on plant operating history. Pipe was installed by Dravo Corp. The pipe was repaired by a weld overlay/flaw removal. All analyses were performed to the guidelines specified in the ASME Code, Section XI. Prior to reactor startup, the recirculation system was hydrostatically tested in conjunction win the reactor vessel hydrostatic test at 1.1 times the system nominal operating pressure. 


\begin{tabular}{|c|c|c|c|c|}
\hline Comp & Plant & $\begin{array}{l}\text { System } \\
\text { Code }\end{array}$ & $\begin{array}{l}\text { Util } \\
\text { Sys }\end{array}$ & $\begin{array}{l}\text { Component ID/ } \\
\text { Date }\end{array}$ \\
\hline
\end{tabular}

$\begin{array}{lllll}\text { PIPE } & \text { QUAD CITIES } 2 & \text { CBA } & 0220 & 2-201 \mathrm{~K}-12 \mathrm{~A}\end{array}$

$12 / 01 / 85$
On 11-5-86 while conducting a visual inspection of prepared weld surface prior to ultrasonic examination, a small pinhole leak was found on recirculation weld 02K-S3. Ultrasonic examination confirmed the leak to be an axial oriented crack. Safety implications were minimal since unit 2 was in a refueling outage. Utility component ID-pipe 2-201K-12A. The exact cause of the crack indication has not been determined but it is postulated that intergranular stress corrosion cracking is the mode of fallure. 02K-S3 was repaired with a 'full structural' design overlay. Overlay was surface finished to permit application of EPRI technique for overlay ultrasonic examination which examines the overlay metal and the upper 25\% of the original piping material. A hydrostatic test of $1110 \mathrm{psig}$ was conducted prior to unit startup and no leaks were found.

$\begin{array}{llll}\text { PIPE } & \text { SAN ONOFRE 1 } & \text { CS 2002-3-2501 } & 2 \\ 10 / 23 / 78 & \end{array}$

With the unit refueling, engineering was performing inservice inspection testing of the charging pump discharge line and noted water seeping into an adjacent piping tunnel from the sand filled pipe trench where the discharge line was located. The sand was removed from the trench and the leaks identified by liquid penetrant and ultrasonic testing. Caused by through-wall cracking as a result of chloride stress corrosion. The piping was buried in sand with detectable chlorides which ranged from 70 to 1000 parts per million. The affected areas of the pipe were replaced with in-kind pipe of A312 type 316 schedule 160 stainless steel. The external environment (sand in the pipe trench) was not replaced. The trench was left clear and covered with concrete plugs. The piping was tested and returned to service satisfactorily.

\section{PIPE $\quad$ SAN ONOFRE 1 \\ PCG \\ CS \\ 2014-3-151R $10 / 23 / 78$}

With the unit refueling, engineering was performing inservice inspection testing on the reactor coolant pump seal water return line and noted water seeping into an adjacent piping tunnel from the sand filled pipe tunnel where the seal water line was located. The sand was removed and the leak identified by liquid penetrant and ultrasonic testing. The cause: through-wall cracking as a result of chloride stress corrosion. Piping was buried in sand with detectable chlorides which ranged from 70 to $1000 \mathrm{ppm}$. The seal water line originally consisted of A312 type 304 schedule 10 stainless steel. The affected areas of the plpe was replaced with A312 type 316 schedule 40 stainless steel. The external environment (sand in the pipe trench) was not replaced. The pipe trench was covered with concrete vault. The piping was tested satisfactorily and returned to service.

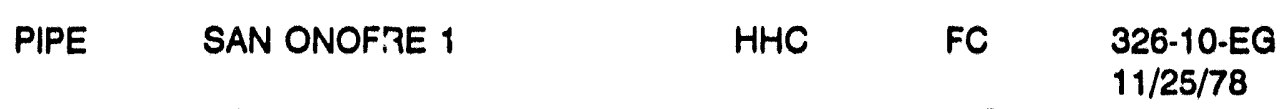

With the unit at $100 \%$ power, operations stated that the channel ' $C$ ' feedwater flow indicator exhibited a sudden increase in flow indication resulting in loss of one channel of the steam flow/feed flow mismatch trip. Investigation using radiographic examination revealed that the feedwater piping flow straightener had become dislodged from its normal position and had moved downstream where it was stopped by the feedwater flow orifice plate. Corrective action was to initiate continuous operator surveillance. The flow straightener will be repaired or replaced at the next available outage. 


\begin{tabular}{|c|c|c|c|c|}
\hline Comp & Plant & $\begin{array}{l}\text { System } \\
\text { Code }\end{array}$ & $\begin{array}{l}\text { Util } \\
\text { Sys }\end{array}$ & $\begin{array}{l}\text { Component ID/ } \\
\text { Date }\end{array}$ \\
\hline PIPE & SAN ONOFRE 1 & SCJ & CRS & $\begin{array}{l}\text { CONT-SPRAY } \\
01 / 04 / 89\end{array}$ \\
\hline
\end{tabular}

Unit was refueling with the containment spray system in test. The air flow test indicated 7 nozzles were clogged with a foreign material. The system operation was degraded, but plant operation was not affected due to refueling mode. Investigations determined the blockage of the CSS piping and nozzles was due to material comprised of sodium silicate coating which had been applied in 1977. The coating had deteriorated and separated from the CSS piping walls over time. The coating had been applied to reduce and stop corrosion. MO90112135, 90120670. NCR90070015. All affected CSS piping and nozzles were cleaned to remove the coating to the extent possible. A combination of brushing and chemical cleaning was used. An air flow test was performed satisfactorily, and the system was returned to service.

$\begin{array}{lllll}\text { PIPE TURKY POINT } 3 & \text { CFF } & \text { RHR } & \begin{array}{l}3-887 / 10-I N-S I- \\ 02 / 21 / 86\end{array} & 2\end{array}$

Unit 3 was defueled during ten year hydrostatic testing of the residual heat removal system. Ten pinhole-sized leaks were found during visual inspection of a ten inch piping elbow in the recirculation line 3-887 10-IN-SI-151R-elbow from the heat exchangers to the pumps. The leaks degraded the fluid containment function of the elbow and resulted in failure of the hydrostatic test. The system and unit were not affected. Cause of the pin hole leaks is not known. Suspect at this time a defect in the type 304 stainless steel material. Root cause is pending analysis. The defective piping elbow was cut out of and removed from the system and saved for root cause analysis. The elbow (90 degree, ten inch schedule 40, type 304 stainless steel) was replaced like for like and welded into the system. The system was released for testing. "WA910221092541, non-conformance report NCR-N91-0220, hydrostatic test number 03-6205-H-01.

$\begin{array}{llll}\text { PIPE TURKEY POINT } 3 & \text { CFF } & \text { RHR } & \begin{array}{l}3 T 229 C / 3 C-A C C U M \\ 01 / 29 / 91\end{array}\end{array}$

Unit 3 was defueled during inservice inspection hydrostatic testing of the ' $3 C^{\prime}$ ' accumulator. Released leakage from the 'nitrogen vent and supply line' to the accumulator was noted. The leakage was located on the piping between the accumulator connection nozzle and the first isolation valve (3-883H) and appeared as small beads that reappeared after wiping. The piping leakage degraded the ' $3 \mathrm{C}$ ' accumulator train. The unit was not affected. Cause of the pipe leakage was not known. Failure root cause investigation is in progress. Suspect abnormal stress, normal wear or aging/cyclic fatigue at this time. The leaking section of pipe between two 'elbow' fittings was removed and replaced (one inch, schedule 40, A312 type 304 seamless). The new plece was welded in. The pipe and train were released to operations for testing. Re: non-conformance report N91-0084 "wa910129092507

$$
\text { PIPE TURKEY POINT } 4 \text { SDB } \text { CIS } \begin{aligned}
& \text { SL-2505B-4/PEN. } \\
& 04 / 01 / 85
\end{aligned}
$$

While unit 4 was at full power, a small leak was observed at a 'tee' fitting for valve 4-991, 'pressurizer steam space sample line test connection'. The 'tee' is located just outside containment penetration eight for the pressurizer steam space sampling line. The leaking fitting degraded the containment isolation function of the piping and one train of the containment isolation system; however, the sampling system and the unit were not significantly affectud. The leak was discovered during an in-service inspection of the piping. The cause of failure is unknown. Suspect vibration as the cause. The 'tee' connector was replaced and the leakage was stopped. " $\quad 6978.64$ 


\begin{tabular}{|c|c|c|c|c|}
\hline Comp & Plant & $\begin{array}{l}\text { System } \\
\text { Code }\end{array}$ & $\begin{array}{l}\text { Util } \\
\text { Sys }\end{array}$ & $\begin{array}{l}\text { Component ID/ } \\
\text { Date }\end{array}$ \\
\hline PIPE & CALLAWAY 1 & WBD & $E G$ & $\begin{array}{l}\text { BBFE002O } \\
08 / 16 / 91\end{array}$ \\
\hline
\end{tabular}

With the unit in a refueling outage and the component cooling water system isolated for a hydrostatic test, inspection personnel discovered through in-service testing that the flow element on the cold water outlet for the reactor coolant pump ' $d$ ' thermal barrier cooling coll had a gasket leak. Due to the minor nature of the leak there was no significant affect on system or plant operations. Cause of the failure is unknown. Probable cause is normal gasket wear. Removed the flow element, cleaned all gasket seating surfaces and installed new gaskets. The flow element was reinstalled, appropriate retests performed and returned to service. (W513699)

$$
\text { PIPE MAINE YANKEE } 1 \text { HBG FWS } \begin{aligned}
& 12-\$ 1 E-2.301 \\
& 01 / 29 / 92
\end{aligned}
$$

With the plant in an unscheduled shutdown it was discovered that the pup plece for the E-11B first point feedwater heater of the main feedwater system had eroded to the point that it was in need of replacement. This was discovered during ultrasonic thickness testing. The pup plece is a section of pipe that makes up the difference between the feedwater heater inlet nozzle and the inlet steam pipe. The E-11b is one of two trains of heaters, only one of which is needed for plant operations. Although this pipe did not fall, it was degraded to the point that further erosion would result in its inability to withstand the system pressure. The system was still operable. There was no effect upon the plant operations. Cause: expected age, wear, and erosion of associated feedwater piping are the causes of this fallure. Action: it was decided to take advantage of the unscheduled shutdown to perform this repair. The old pup plece was removed and a new one was welded into place. (920472400)

$$
\begin{array}{lll}
\text { PIPE } \quad \text { MILLSTONE } 1 & \text { SW-39 } \\
03 / 21 / 89
\end{array}
$$

There was excessive leakage in the service water system header down stream of the main service water strainer. The leak was identified while pressurizing the header for the 10 year in-service inspection hydrostatic testing. There was no significant effect on the plant, but this train of the service water system was degraded. The leakage was discovered in the weld area of the 20 inch pipe SW-39 and was caused by erosion. The washout area of the weld was ground out and rewelded. No detectable leakage resulted when tested. 


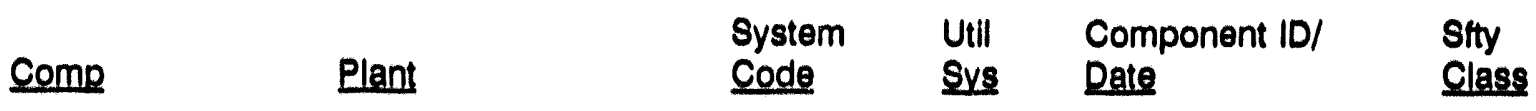

$\begin{array}{llll}\text { PIPE } & \text { WORTH ANNA } 2 & 2-S W-P I P E-444 & 06 / 19 / 89 \\ & & 0\end{array}$

With the reactor at power during the performance of an inservice inspection hydrostatic test, the service water supply pipe to the containment penetration coolers developed a pin hole leak. The system was not affected as this system is a backup means of cusling only. There was no significant effect on overall plant operations. This fallure was caused by internals corrosion of the pipe. Cut out and replaced the affected section of pipe. The component was tested satisfactorlly and returned to service. (89-504)

PIPE OYSTER CREEK $1 \quad$ CFASCK $241 \quad \begin{array}{ll}10-S W-2 & 3 \\ 07 / 10 / 85 & \end{array}$

On July 22, 1985 the plant was brought to a cold shutdown condition from $41.3 \%$ power due to both containment spray systems $1 \& 2$ being declared out of service. The cause of failure is attributed to accumulation of emergency service water (ESW) plpe coal tar lining material fragments blocking the inlet tubesheets of containment spray heat exchangers CSHX 1-3 \& 1.4. The coating failure is attributed to repeated thermal cycles of the outdoor exposed portion of ESW piping while drained during RO-10 outage. The ESW plpe downstream of pumps 52c \& 52d was inspected and hydrolazed with high pressure water to remove the coating. Approximately 50 feet of plping was cleaned. The heat exchangers $1.3 \& 1.4$ were also opened and cleaned.

$\begin{array}{lll}\text { PIPE OYSTER CREEK } 1 & \text { WAA } & 10-5 W-2 \\ 07 / 21 / 85\end{array}$

On July 22, 1985 the plant was brought to a cold shutdown condition from $41.3 \%$ reactor power due to both containment spray systems 1 and 2 being declared out of service. The cause of fallure was attributed to accumulation of emergency service water (ESW) pipe coal tar lining material fragments blocking the inlet tubesheets of containment spray heat exchangers CSHX1-1 and 1-2. The coating failure is attributed to repeated thermal cycles of the outdoor exposed portion of ESW piping while drained during the RO.10 outage. The ESW plpe downstream of pumps 52A \& $52 B$ was inspected and hydrolazed with high pressure water to remove the coating. Approximately 50 feet of piping was cleaned. The heat exchangers 1.1 \& $1-2$ were also opened and cleaned.

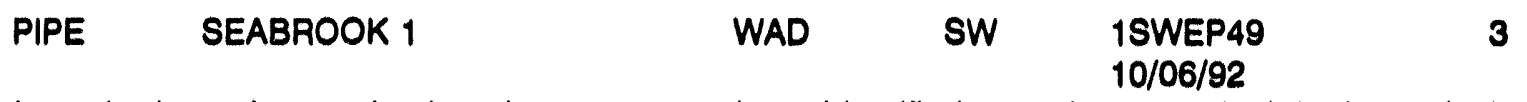

During a hydrostatic examination, the system engineer identified a service water leak in the $10 \mathrm{ir} h$ discharge expansion joint on the 'B' emergency diesel generator jacket water heat exchanger (1 of 2). This failure made the 'B' diesel inoperable, but did not affect the plant which was shutdown for a refueling outage. The root cause of the fallure is unknown, but localized corrosion contributed to the failure. Contract mechanics removed the inconel expansion joint and replaced it with a carbon steel spool piece. The spool piece will be monitored by NDE examination to monitor the corrosion rate. The system was leak tested satisfactorily then returned to service. This piping is due to be replaced during refuel 3,1994 . $92 W 004501 \mathrm{rcb}$ 


\begin{tabular}{lllllr} 
Comp & \multicolumn{1}{c}{ Plant } & $\begin{array}{l}\text { System } \\
\text { Code }\end{array}$ & $\begin{array}{l}\text { Util } \\
\text { Sys }\end{array}$ & $\begin{array}{l}\text { Component ID/ } \\
\text { Date }\end{array}$ & $\begin{array}{l}\text { Sfty } \\
\text { Clas }\end{array}$ \\
VESSEL & CALVERT CLIFFS 2 & CBG & RCS & $\begin{array}{l}\text { 2PZVPZR21 } \\
08 / 05 / 88\end{array}$ & 1
\end{tabular}

While the unit was down for refueling an inservice inspection revealed evidence of coolant leakage from a number of pressurizer vessel heater penetrations. Due to the severity of the cracks the system was declared inoperative. If the unit had been at power it would have been shut down, the outage was extended to make repairs. The cause of the leakage was found to be stress corrosion cracks due to over expanding the sleeves before welding them when the pressurizer was being bult. The sleeves were removed, new type sleeves installed by welding, and the vessel put in service.

\section{VESSEL CONNECTICUT YANKEE 1 CBH RCS $\begin{array}{lll}\text { E-1 } & 1\end{array}$}

During a 10 year inservice inspection of reactor internals, personnel found broken bolts from the core barrel to thermal shield connection on the bottom of the reactor pressure vessel. System and plant operation were not affected as the system was shut down for a refueling outage. Flow induced vibration caused movement of the core barrel leading to fallure of the bolts at the core barrel thermal shield connections. The thermal shield was permanently removed after design analysis showed it was no longer required.

VESSEL NINE MILE POINT 1

CBA

34/CRD NRO2

$11 / 01 / 82$
Inspection of control rod drive housing showed evidence of leaking. Intergranular stress corrosion of

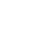
the CRD stub tube at the site of stub tube to CRD housing weld caused cracks that allowed reactor coolant to escape between reactor vessel and CRD housing. CRD housing was expanded by rolling into the base metal of the vessel wall closing off the path of leakage. Vessel was hydrostatically tested before startup.

\section{VESSEL NINE MILE POINT 1 \\ CBA \\ 34/CRD NR02 \\ 05/05/85}

During plant refueling outage, an inservice inspection of control rod drive housings 30.07 and $30-47$ at their stub tubes in reactor vessel NRO2 revealed evidence of leakage of reactor coolant at their stub tube heat affected zones, specifically at their stub tube to control rod drive housing welds. The cause of the failure was attributed to intergranular stress corrosion cracking at the control rod drive housing to reactor stub tube weld. This was caused by heat and age or cyclic fatigue of the weld material. Each control rod drive housing was rolled into its reactor vessel stub tube penetration in order to expand the housing with the base metal of the vessel wall in order to close the path of leakage. The vessel was ultrasonically tested and hydrostatically tested and returned to service. 
$\begin{array}{lllll}\text { Comp } & \text { System } & \text { Util } & \text { Component ID/ } & \text { Stty } \\ \text { Elant } & \text { Code } & \text { Sys } & \text { Date } & \text { Class }\end{array}$

VESSEL NINE MILE POINT 1

CBA

34/CRD NRO2

$06 / 13 / 85$

1

During plant shutdown for refueling, an inservice inspection of control rod drive housing 34.07 at the reactor vessel, NRO2, stub tube revealed evidence of leakage of reactor water at the stub tube heat affected zone, specifically at the stub tube to control rod drive housing weld. The cause of the leakage was attributed to intergranular stress corrosion cracking at the control rod drive housing to reactor stub tube weld. This was caused by heat and age or cyclic fatigue of the weld material. The control rod drive housing was rolled into the reactor vessel stub tube penetration in order to expand the housing into the base material of the vessel wall, thus closing the path of leakage. The heat affected zone was ultrasonically tested and hydrostatically tested and returned to service.

VESSEL NINE MILE POINT 1

CBA

34/CRD NRO2

1

$01 / 17 / 87$

With the unit shut down, a visual examination of the under vessel control rod drive penetration stub tubes revealed leakage. Two streams of llquid were leaking in excess of the 10 drops per second acceptance criteria. The leak was attributed to intergranular stress corrosion cracking at the control rod drive housing to reactor stub tube weld. Intergranular stress corrosion cracking is a result of heat, age and cyclic fatigue of the weld material. The defective stub tube was rolled. Rolling expands the housing into the base material of the vessel wall, closing the path of leakage. After rolling, the vesse! wall was ultrasonically and hydrostatically tested.

\section{VESSEL NINE MILE POINT 1 CBA 34/CRD NR02 $02 / 25 / 88$}

With the unit in an extended outage, an inservice inspection of the control rod drive housings 46-27 and 50-19 at their stub tubes in reactor vessel nro2 revealed evidence of leakage of reactor water at their stub tube heat affected zones specifically at their stub tube to control rod drive housing welds. This would have degraded system operation. Plant operation was unaffected. The cause of fallure was attributed to intergranular stress corrosion cracking at the control rod drive housing to reactor stub tube weld. This was caused by heat and age or cyclic fatigue of the weld material. Each control rod drive housing was rolled into lits reactor vessel stub tube penetration in order to expand the housing with the base metal of the vessel wall in order to close the path of leakage. The vessel was then checked for leaks and returned to service (WR 134342, 134343).

$$
\text { VESSEL NINE MILE POINT } 1 \quad \text { CBA 34/CRD } \begin{aligned}
& \text { NR02 } \\
& 06 / 04 / 89
\end{aligned}
$$

Whth the unit in an extended outage, an inservice inspection of the control rod drive housing 02-19, 30.51 , and 34.15 at their stub tubes in reactor vessel NR02 revealed evidence of leakage of reactor water at their stub tube heat affected zones, specifically at their stub tube to control rod drive housing welds. This would have degraded system operation. Plant operation was unaffected. The cause of the fallure was attributed to intergranular stress corrosion cracking at the control rod drive housing to reactor stub tube weld. This was caused by heat and age or cyclic fatigue of the weld material. Each control rod drive housing was rolled into its reactor vessel stub tube penetration in order to expand the housing with the base metal of the vessel wall in order to close the path of leakage. The vessel was then checked for leaks and returned to service (WR 183855, 183856, 183857). 


\begin{tabular}{lllllr} 
Comp & \multicolumn{1}{c}{$\begin{array}{l}\text { System } \\
\text { Plant }\end{array}$} & $\begin{array}{l}\text { Util } \\
\text { Code }\end{array}$ & $\begin{array}{l}\text { Component ID/ } \\
\text { Sys }\end{array}$ & $\begin{array}{c}\text { Sty } \\
\text { Clate }\end{array}$ \\
VESSEL & NINE MILE POINT 1 & CBA & 34/CRD & $\begin{array}{l}\text { NRO2 } \\
08 / 30 / 91\end{array}$ & 1
\end{tabular}

With the plant in cold shutdown, an inservice inspection of the control rod drive housing 10.15 at the stub tube in reactor vessel NRO2 revealed evidence of leakage of reactor water at its stub tube heat affected zones, specifically at its stub tube to control rod drlve housing welds, this would have degraded system operation. Plant operation was unaffected. The cause of the fallure was attributed to intergranular stress corrosion cracking at the control rod drive housing to reactor stub tube weld. This was caused by heat and age or cyclic fatigue of the weld material. The control rod drlve housing was rolled into its reactor vessel stub tube penetration in order to expand the housing with the base metal of the vessel wall in order to close the path of leakage. The vessel was then checked for leaks and returned to service. (WR199441)

$\begin{array}{lllll}\text { VESSEL NINE MILE POINT } 1 & \text { CBA } & 34 / C R D & \text { NR02 } & 1 \\ 04 / 15 / 92 & \end{array}$

With the unit in a forced outage, a special drywell inspection of control rod drive (CRD) housing $18-19$ at its atub tube location in reactor vessel NAO2 revealed evidence of reactor water leaking less than 1 drop per minute at the heat affected zones, specifically at the stub tube to CRD housing welds. This would degrade system operation. However, plant operation was unaffected. The cause of the failure was attributed to intergranular stress corrosion cracking caused by heat, aging, and cycllc fatigue of the CRD housing to reactor stub tube weld. Corrosion of these stress areas cause oracks resulting in a leak through the stub tube and into the annulus between the stub tube, vessel assembly and the CRD housing. WR 201379, was written to repair the leaking stub tube, the drive was removed, the CRD housing was rolled into its reactor vessel stub tube penetration in order to expand the housine with the base metal of the vessel wall thus closing the leakage path. The drive was reinstalled, a system hydro verifled no leaks and the system returned to service.

VESSEL NINE MILE POINT $1 \quad$ CBA $34 / C R D \quad \underset{04 / 16 / 92}{N} \quad 1$

With the unit in a forced outage, a special drywell inspection of control rod drive (CRD) housing 42-27 at its stub tube location in reactor vessel NRO2 revealed evidence of reactor water leaking less than 1 drop per minute at the heat aftected zones, specifically at the stub tube to CRD housing welds. This would degrade system operation. However, plant operation was unaffected. The cause of fallure was attributed to intergranular stress corrosion cracking caused by heat, aging and cyclic fatigue of the CRD housing to reactor stub tube weld. Corrosion of these stress areas caused cracks resulting in a leak through the stub tube and into the annulus between the stub tube, vessel assembly and the CRD housing. WR 201378 was written to repair the leaking stub tube. The drive was removed, the CRD housing was rolled into its reactor vessel stub tube penetration in order to expand the housing with the base metal of the vessel wall thus closing the leakage path. The drive was reinstalled, a system hydro verified no leaks and the system returned to service. 


\begin{tabular}{|c|c|c|c|c|}
\hline Comp & Plant & $\begin{array}{l}\text { System } \\
\text { Code }\end{array}$ & $\begin{array}{l}\text { Util } \\
\text { Sys }\end{array}$ & $\begin{array}{l}\text { Component ID/ } \\
\text { Date }\end{array}$ \\
\hline VESSEL & NINE MILE POINT 1 & CBA & $34 / C R D$ & $\begin{array}{l}\text { NR02 } \\
\text { OS/05/82 }\end{array}$ \\
\hline
\end{tabular}

Whth the unt in a forced outage, a special drywell inspection of control rod dilve (CRD) housing $34-31$ at its stub tube location in reactor vessel NRO2 revealed evidence of reactor water leaking less than 10 drops per minute at the heat affected zones, specifically at the stub tube to CRD housing welds. This would degrade system operation. However, plant operation was unaffected. The cause of fallure was attributed to intergranular stress corrosion cracking caused by heat, aging and cyclic fatlgue of the CRD housing to reactor stub tube weld. Corrosion of these stress areas caused cracks resulting in a leak through the stub tube and into the annulus between the stub tube, vessel assembly and the CRD housing. WR 199798 was written to repalr the leaking stub tube. The drive was removed, the CRD housing was rolled into the reactor vessel stub tube penetration in order to expand the housing with the base metal of the vessel wall thus closing the leakage path. The drive was reinstalled, a system hydro verified no leaks and the system returned to service.

\section{VESSEL NINE MILE POINT 1 \\ CBA \\ 34/CRD NRO2 05/05/92 \\ 1}

With the unit in a forced outage, a special drywell inspection of control rod drive (CRD) housing 38-11 at $r_{3} 3$ stub tube location in reactor vessel NRO2 revealed ovidence of reactor water leaking lese than 1 drop per minute at the heat affected 20 nes, spectically at the stub tube to CRD housing welds. This would degrade system operation. However, plant operation was unaffected. The cause of fallure was attributed to intergranular stress corrosion cracking caused by heat, aging and cyclic fatigue of the CRD housing to reactor stub tube weld. Corrosion of these stress areas cause cracks resulting in a leak through the stub tube and into the annulus between the stub tube, vessel assembly and the CRD housing. WR 203234 was written to repair the leaking stub tube, the drive was removed, the CRD housing was rolled into tis reactor vessel stub tube penetration in order to expand the housing with the base metal of the vessel wall thus closing the leakage path, the drive was reinstalled. A system hydro verified no leaks and the system was returned to service.

\section{VESSEL NINE MILE POINT 1 \\ CBA \\ 34/CRD NRO2 $05 / 25 / 92$}

1

With the unit in a forced outage, a special drywell inspection of control rod drive (CRD) housing 06-31 at its stub tube location in reactor vessel NRO2 revealed ovidence of reactor water leaking less than 1 drop per minute at the heat affected zones, specfically at the stub tube to CRD housing welds. This would degrade system operation. However, plant operation was unaffected. The cause of failure was attributed to intergranular stress corrosion cracking caused by heat, aging and cyclic fatigue of the CRD housing to reactor stub tube weld. Corrosion of these stress areas cause cracks resulting in a leak through the stub tube and into the annulus between the stub tube, vessel assembly and the CRD housing. WR 202155 was written to repair the leaking stub tube. The drive was removed, the CRD housing was rolled into its reactor vessel stub tube penetration in order to expand the housing with the base metal of the vessel wall thus closing the leakage path. The drive was reinstalled, a system hydro verfiled no leaks and the system was returned to service. 


\begin{tabular}{|c|c|c|c|c|}
\hline Comp & Plant & $\begin{array}{l}\text { System } \\
\text { Code }\end{array}$ & $\begin{array}{l}\text { Uill } \\
\text { Sy8 }\end{array}$ & $\begin{array}{l}\text { Component ID/ } \\
\text { Date }\end{array}$ \\
\hline ESSEL & NINE MILE POINT 1 & CBA & 34/CRD & $\begin{array}{l}\text { NA02 } \\
05 / 30 / 92\end{array}$ \\
\hline
\end{tabular}

Whith the plant in a forced outage, a special drywell inspertion of control rod drive (CRD) housing 26-47 at its stub tube location in reactor vessel NRO2 revealed evidence of resctor water leaking less than 8 drops per minute at the heat affected zones, specifically at the stub tube to CRD housing welds. This would degrade system operation. However, plant operation was unaffected. The cause of fallure was attributed to intergranular stress corrosion cracking caused by heat, aging and cycllc fatigue of the CRD housing to reactor stub tube weld. Corrosion of these stress areas caused cracks resulting in a leak through the stub tube and into the annulus between the stub tube, vessel assembly and the CRD housing. WR 203093 was written to repair the leaking stub tube. The drive was removed, the CRD housing was rolled into the reactor vessel stub tube penetration in order to expand the housing with the base metal of the vessel wall thus closing the leakage path. The dilve was reinstalled, system hydro verifled no leaks and the system was returned to service.
VESSEL NINE MILE POINT 1
CBA
34/CRD
NR02
08/30/92

With the unit in a forced outage, a special drywell inspection of control rod drive (CRD) housing 22.51 at hs stub tube location in the reactor vessel nro2 revealed evidence of reactor water leaking less than 16 drops per minute at the heat affected zones, specifically at the stub tube to CRD housing welds. This would degrade system operation. However, the plant operation was unaffected. The cause of the failure was attributed to intergranular stress corrosion cracking caused by heat, aging, and cyclic fatigue of the CRD housing to reactor stub tube weld. Corrosion of these stress areas cause cracks resulting in a leak through the stub tube and into the annulus between the stub tube, vessel assembly and the CRD housing. WR 203092 was written to repair the leaking stub tube, the drive was removed, the CRD housing was rolled into the reactor vessel stub tube penetration in order to expand the housing with the base metal of the vessel wall thus closing the leakage path. The drlve was reinstalled, a system hydro verfiled no leaks and the system was returned to service.

\section{VESSEL PILGRIM 1 \\ CBA \\ 0200 \\ 201.1 \\ $05 / 15 / 84$}

On 5/15/84 with the plant shutdown for refueling outage 06 and the reactor vessel defueled, inspection of the reactor vessel riser nozzles revealed cracks. The cracks were discovered by penetrant testing which was being performed in preparation of reinstallation of the nozzle safe ends (part of recirculation plpe replacement). The cause has been attributed to intergranular stress corrosion cracking. (Reference LER 293-83063 update, 10CFR50.73a.2.ll, significani material welding defect). The nozzle was remachined. The nozzle crack indications were ground out. The nozzle was then reweld buttered and successfully penetrant tested. The vessel was successfully hydrotested on 12/1/84. (FM84-67). (MR84-2-45). (MR84-2-10).

\section{VESSEL POINT BEACH 2 \\ $\mathrm{CBH}$ \\ RCS \\ 2.T1 \\ $11 / 12 / 90$} 1 


$\begin{array}{lllllr}\text { Comp } & \text { Plant } & \begin{array}{l}\text { System } \\ \text { Code }\end{array} & \begin{array}{l}\text { Util } \\ \text { Sys }\end{array} & \begin{array}{l}\text { Component ID/ } \\ \text { Date }\end{array} & \begin{array}{l}\text { Stty } \\ \text { Class }\end{array} \\ \text { VESSEL } & \text { PRAIRIE ISLAND 1 } & \text { CBH } & \text { 1RC } & \begin{array}{l}\text { UNIT1 } \\ 03 / 15 / 76\end{array} & 1\end{array}$

Seal weld leaks on unit one reactor vessel head penetrations at inst. port columns 34 and 37 and at CRDM plugs 2, 3 and 4. Unknown-weld related. Reactor head weld leaks were ground out and rewelded with reactor at refueling shutdown. Welds checked out ok at operating pressure.

\section{VESSEL PRAIRIE ISLAND 2 \\ $\mathrm{CBH}$ \\ 2RC \\ UNIT2REACT.

Seal weld leaks on unit 2 reactor vessel head at inst. port columns 34 and 37 and at CRDM plugs U3 and U5. Unknown-weld related. Reactor head weld leaks were ground out and rewelded with reactor at cold shutdown and reactor level below vessei flange welds then checked at $2335 \mathrm{psig.}$

\section{VESSEL SAN ONOFRE 1 \\ $\mathrm{CBH}$ \\ $\mathrm{RC}$ \\ C-1 1

Unit in refueling. Reactor vessel thermal shield was inspected for degraded supports in response to finding core barrel thermal shield support hardware loose on top of fuel at Connecticut Yankee. Found 5 of 6 flexures broken, 3 of 30 support block bolts broken and 1 of the dowel pins in a lower support block had a broken tack weld. Thermal shield supports were degraded but plant operation was not affected. The root cause was primarily wear at the 4 limiter key locations, causing increased loads on the lower support blocks. This allowed relative motion between the core barrel and the thermal shield to increase enough so that fatigue failure occurred in 5 of the 6 flexures.

MO89120482/87112715. Committed to NRC to repair the thermal shield in cycle 11 refueling. Removed thermal shield, old flexures, limiter keys, and support blocks from the vessel. Revised design flexures, limiter keys and support blocks were installed with new fasteners (piece parts). The thermal shield was inspected, installed in the vessel, and returned to service.

$$
\begin{array}{llll}
\text { VESSEL TROJAN } 1 & \text { CBH } & \text { RCS } & T-201 \\
09 / 13 / 84
\end{array}
$$

During reactor coolant system inspection, found leak on incore instrument fitting at the seal table. While attempting to tighten the fitting, the fitting failed, causing loss of coolant accident (LOCA). Previous installations had reduced the fitting's ferrule grip due to a slightly tapered tube end. Attempting to adjust under system pressure caused failure and leak. Cooled down and depressurized and drained down RCS. Applied temporary weld repair to stop leak. New design tubing coupling will be installed next outage. Trained maintenance personne! on tubing fitting assembly/disassembly work. 


$\begin{array}{lllllr}\text { Comp } & \text { Plant } & \begin{array}{l}\text { System } \\ \text { Code }\end{array} & \begin{array}{l}\text { Util } \\ \text { Sys }\end{array} & \begin{array}{l}\text { Component ID/ } \\ \text { Date }\end{array} & \begin{array}{l}\text { Sfty } \\ \text { Class }\end{array} \\ \text { VESSEL ZION 1 } & & \text { CBH } & \text { RC } & \begin{array}{c}i \pi C 001 \\ 12 / 15 / 89\end{array} & 1\end{array}$

During a scheduled containment walkdown of the primary systems by the in-service inspection group, a small leak was discovered on the reactor head instrumentation column seal (CONOSEAL). The leakage was a small bubbling at the upper and lower seal on one column and at the lower joint on a second. The unit was at hot standby and had to be shutdown to repair the leak. The cause of the event was determined to be faulty gaskets. The lower gaskets had scratches on the outside diameter sealing surface, and the upper gaskets had irregularities on the outside diameter sealing surface. The possibilities are: the faults were missed during installation inspection, and/or the faults were caused during installation. The unit was immediately brought down to cold shutdown, Mode 5. All of the port CONOSEAL gaskets were then replaced with new gaskets like in kind to those recommended by manufacturer. The unit was then brought back up to temperature and pressure. The port columns were inspected for leakage, and found to be satisfactory. (DVR 22-01-89-180)

$\begin{array}{lllll}\text { VESSEL DRESDEN } 2 & \text { CBA } & 203 & 201-1 & 2\end{array}$ In refueling during a remote visual inspection of the reactor vessel internals, it was discovered that the top 4-1/2 in. of the intermediate radiation monitor IRM-18 dry tube plunger was missing (part of the traversing incore probe system). The operation of IRM-18 was normal during the previous cycle. Irradiation assisted stress corrosion cracking. See GE SIL \# 409 for details. Component is GE part \#886D380G001. The lost part of the plunger will be found or a lost parts analysis will be performed. A work request was written to replace the broken dry tube.

$\begin{array}{lllll}\text { VESSEL DRESDEN } 3 & \text { CBA } & 203 & 3-201-1 & 2 \\ & & & 11 / 16 / 84\end{array}$

During a refueling outage, a crack indication was found in jet pump beam assembly \#11 via remote ultrasonic testing examination. Stress corrosion cracking. Replaced the beam assembly with a new one. 


\section{Appendix C}

\section{Excerpts from ISI Summary Reports}




\section{Appendix C \\ Excerpts from ISI Summary Reports}

Plant $A$

TABLE OF CONTENTS

Section

Iitle

Revision

1. Summary of Inservice Inspection

0

2. Status of Required Inspections

0

3. Final Inservice Inspection Plan for Outage $13 \quad 0$

4. Results of Inspections Performed During Outage $13 \quad 0$

5. Class 1 Inspection Results 0

6. Class 2 Inspection Results 0

7. Augmented Inspection and Alternate Examination Results 0

8. Personnel, Equipment, and Material Certifications 0

9. Problem Investigation Reports 0

10. Reference Documents 0

11. Class 1 and 2 Repairs and Replacements 0 


\subsection{Summary of Inservice Inspection}

This report describes the Inservice Inspection of Duke Power Company's Oconee Nuclear Station Init. I during the 1992 Refueling Outage (also referred to as Dutage 1?, which is in the Third Inspection Period of the Second Inspertinn Interval).

Included in this report are the final Inservice Inspection plan, the inspection results for each iten, n summary for each category of examination and corrective actinn t.aken when unacceptable conditions were found. In addition, there is a section included for repairs and replacements required cince March 23, 1991.

\subsection{Class 1 Inspection}

The Class 1 Inservice Inspection inclinded examinations on the Reactor Vessel Circumferential Head Welds, Reactor Vessel Head to Flange Weld, Reactor Vessel CRDM .l-Grnove Nozzle Welds and Incore Monitoring Partial Penetration Nozi.10 Wolds. In addition, examinations were performed on the Roartonr Vessel Closure Head Nuts, Studs. Threads in Flange, C.Incilre Washers and Bushings.

Examinations were performed on Pressurizer Lower Head to Heater Bundle Circumferential Seam Weld, Shell to Heater Bundle Long Seam Welds and Manway Studs, Nut.s and integrally-welded attachments.

Examinations were performed on Steam Generators $3 A$ and $3 B$ Upper Head to Tubesheet Welds and Nozzle tin Vessel Welds, Steam Generator 3A Lower Manway Studs and Nuts. Steam Generator 3B Upper Manway Studs and Nuts, Upper and Lower Head Inspection Cover Bolting also received examination.

Dissimilar Metal Butt Welds in the Reartor Coolant System were examined. Bolting in Core Flood Valve 3CF-14, Low Pressure Injection Valve 3 LP2 and Pressurizer Relief Valve $3 R C-4$ also received examinations.

Piping welds in Reactor Coolant. Low Pressure Injection and High Pressure Injection Systems were examined.

Visual examinations were performed on the C.lass 1 Pressure Boundary during system leakage tests. $\Lambda l<n$, visual examinations were performed on Class 1 Component Supports of the High Pressure Injection and Low Pressure Inject.inn Syct.ems and on the Reactor Pressure Vessel Support. Skirt.

The Inconel 600 tubing in Steam fenerators $3 \Lambda$ and $3 B$ was inspected by eddy current during Outage 13. The results are shown in Section 5 of this report. A detailed description of the Oconee 3 Refueling Outage 13 eddy current inspection is provided in the "Eddy Current Examination Report. Ocnnee Unit 3, August 1992 Refueling Outage $13^{\prime \prime}$ on file in the Carporate Office in Charlotte, 
Reportable indications were found on the Class 1 Inspections shown in this section. Inspections and evaluation data for each reportable indication found on Class 1 Inspections is included in Section 5 of this report.

A detailed description of each inspection is found in the final Inservice Inspection Plan in Section 3 of this report. Results of each examination are found in Section 4.

\subsection{Class 2 Inspection}

The Class 2 Inspections included examinations on Steam Generator $3 A$ Shell to Shell Weld, Shell to Nozzle Belt Welds, Low Pressure Injection Coolers $3 A$ and $3 B$ Inlet and Outlet Nozzle to Shell Welds, Steam Generators $3 A$ and $3 B$ Outlet Nozzle to Shell Welds and Core Flood Tanks $3 A$ and $3 B$ Outlet Nozzle to Head Welds. Also, examinations were performed on vessel integrally-welded attachments of Steam Generator 3B Feedwater Header Support and integrally-welded attachments of the Main Steam, Low Pressure Injection and Reactor Building Spray Systems and on Steam Generator 3B Feedwater Header.

Examinations were performed on circumferential butt welds of the Low Pressure Injection, Reactor Building Spray, Spent Fuel Cooling, High Pressure Injection, Auxillary Feedwater, Main Feedwater, Main Steam and Component Cooling Systems. Also, longitudinal welds of the Low Pressure Injection, Reactor Building Spray, Main Steam and Spent Fuel Cooling Systems. In addition, branch connection welds of the Main Feedwater and Main Steam Systems were examined.

Visual examinations were performed on the Class 2 Pressure Boundary during System Leakage and Hydrostatic Tests. Also, visual examinations were performed on Class 2 Component Supports of the Main Steam, Main Feedwater, Low Pressure Injection, Reactor Building Spray and Component Cooling Systems.

Reportable indications were found on the Class 2 Inspections shown in this section. Inspection and evaluation data for each reportable indication is included in Section 6 of this report.

A detailed description of each inspection is found in the final Inservice Inspection Plan in Section 3 of this report. Results of each examination are found in Section 4.

\subsection{Augmented Inspection}

Augmented Inspections at Oconee 3 consisted of Reactor Coolant Pump Flywheel examination, Thermal Stress Piping Examinations, Auxiliary Feedwater Header Water Hammer Examinations, and Pressurizer Sensing/Sampling Safe-End Nozzle Examinations. A 
detailed description of each examination is found in the final Inservice Inspection Plan in Section 3 of this report. Results are found in Section 4.

\subsection{Alternate Inspection}

Alternate inspections at Oconee 3 were performed on welds 3-50-453 and 3-50-45-4 (Item Numbers E03.001.001 and E03.001.002 respectively), and on Reactor Coolant Pumps $3 A 2$ and $3 B 1$ Flange.

A detailed description of each examination is found in the final Inservice Inspection Plan in Section 3 of. this report. Results are found in Section 4.

1.5 Identification Numbers

Owner: Duke Power Company, 422 S. Church Street, Charlotte, NC 28201

Plant: Oconee Nuclear Station, Highway 130/183, Seneca, SC 29679

Plant Unit: 3

Owner Certification of Authorization: N/A

Commercial Service Date: 12/16/74

$\begin{array}{llllc}\text { Item } & \begin{array}{l}\text { Manufacturer } \\ \text { Or Installer }\end{array} & \begin{array}{l}\text { Manufacturer } \\ \text { or Installer } \\ \text { Serial No. }\end{array} & \begin{array}{l}\text { State or } \\ \text { Province No. }\end{array} & \begin{array}{l}\text { National } \\ \text { Board No. }\end{array} \\ \text { Reactor Vessel } & \text { Babcock \& Wilcox } & 620-0004-51-52 & \text { N/A } & \text { N-105 } \\ \text { Steam Generator "A" } & \text { Babcock \& Wilcox } & 620-0004-55 & \text { N/A } & \text { N-107 } \\ \text { Steam Generator "B" } & \text { Babcock \& Wilcox } & 620-0004-55 & \text { N/A } & \text { N-108 } \\ \text { Pressurizer } & \text { Babcock \& Wilcox } & 620-0004-59 & \text { N/A } & \text { N-106 }\end{array}$

1.6 Authorized Nuclear Inservice Inspector(s)

Name: M. B. Chapman

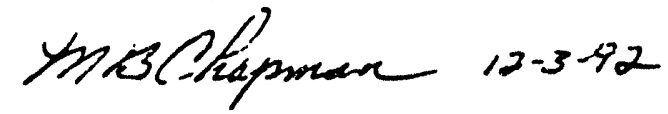

Employee: The Hartford Steam Boiler

Inspection and Insurance Company

200 Ashford Center North

Suite 300

Atlanta, GA 30338

EQA402

Page 3

Revision 0

November 19, 1992 


\subsection{Class 1 Inspection Results}

Examinations were performed during Outage 13 on the Reactor Vessel, Pressurizer, Steam Generators $3 A$ and $3 B$, Piping Welds of the Reactor Coolant, Low Pressure Injection and High Pressure Injection Systems, Valve Bolting and Supports.

\subsection{Reactor Vessel}

The Reactor Vessel Closure Head Ring to Closure Head Cap Weld received an ultrasonic examination, the Vessel Head to Flange Weld received an ultrasonic and a magnetic particle examination. No reportable indications were found.

Sixty-nine (69) Reactor Vessel Closure Head J-Groove CRDM Nozzle Penetration Welds and fifty-two (52) Reactor Vessel Incore Monitoring Nozzle Partial Penetration Welds received a visual examination. No reportable indications were found.

Thirty (30) Reactor Vessei Closure Head Nuts received a magnetic particle examination. Thirty (30) Reactor Vessel Closure Studs received an ultrasonic and a magnetic particle examination. No reportable indications were found.

The threads in Reactor Vessel Flange at $180^{\circ}$ to $0^{\circ}$ received an ultrasonic examination. No reportable conditions were found.

Reactor Vessel Closure Washers and Bushings for Studs Holes 1-9, 25-35, and 51-60 received a visual examination. No reportable conditions were found.

The Reactor Vessel Support Skirt Weld received a visual examination. No reportable conditions were found.

\subsection{Pressurizer}

The Pressurizer Lower Head to Heater Bundle Circumferential Seam Weld and Heater Bundle Longltudinal Seam Weld located at " $X$ " and "Y" Axis received ultrasonic examinations. No reportable indications were found.

Twelve (12) Pressurizer Manway Studs received an ultrasonic examination. No reportable indications were found.

Four (4) Pressurizer Support Lug Welds located at "X-axis between " $X-Y$ " axis, at " $y$ " axis and between " $Y-Z$ " axis received a magnetic particle examination. No reportable indications were found.

Twelve (12) Pressurizer Manway Nuts, Bushings and Washers received a visual examination. No reportable conditions were found. 


\subsection{Steam Generators}

Steam Generators $3 A$ and $3 B$ Upper Head to Tubesheet Welds received an Ultrasonic examination. Reportable indications in Steam Generator $3 B$ Upper Head to Tubesheet Weld, 3GSB-WG58-1 (Item Number B02.040.003), detected during Outage 6 were re-examined by ultrasonics during Outage 13 per ASME Section XI, Paragraph IWB-2420(b). A Babcock and Wilcox Flaw Evaluation, Number 32-1218901-00 was performed and it was determined that the previously reported flaw indications remains acceptable under the criteria of ASME Section XI, Paragraph IWB-3612. A copy of the evaluation report is included in Section 10 of this report. A copy of the inspection data sheets is included in this section of the report. No other reportable indications were found.

Steam Generator $3 \mathrm{~A}$ Inlet and Outlet Nozzle and Steam Generator $3 B$ Inlet Nozzle to Vessel Welds recefved ultrasonic examinations. No reportable indications were found.

Steam Generator 3A Lower Head Manway Studs and Nut.s, Steam Generator 3B Upper Head Manway Studs and Nuts and Upper and Lower Head Inspection Cover Bolting received visual examinations. No reportable conditions were found.

\subsection{Valves}

Bolting for Valves $3 C F-14,3 L P-2$ and $3 R C-4$ received a visual examination. No reportable conditions were found.

\subsection{Piping}

Dissimilar Metal Butt Welds:

Seven (7) dissimilar metal butt welds, nominal pipe size four inches and over received an ultrasonic and a dye penetrant examination. Reportable indications were found on weld 3PIB2-7 (Item Number B05.050.007A). The indications were removed, weld repaired and re-examined. The reexamination revealed no indications. Refer to Problem Investigation Report 3-092-0332 included in Section 9 of this report. The inspection data sheets for the reportable item are included in this section of the report. The inspection sample was extended to include four (4) additional welds per ASME Section XI Paragraph IWB-2430(a). No other reportable indications were found.

Two (2) dissimilar metal butt welds, nominal pipe size less than four inches, received a dye penetrant examination. No reportable indications were found. 
Similar Metal Butt Weids:

Nominal pipe size four inches and greater:

Elght (8) circumferential butt welds received an ultrasonic and a dye penetrant examination. No reportable indications were found.

Four (4) longitudinal welds recelved nd ultrasonic and a magnetic particle examination. No reportable indications were found.

Nominal pipe size less than four inches:

Twenty (20) circumferential welds received a dye penetrant examination. No reportable indications were found.

Two (2) branch pipe connection welds received a magnetic particle examination. No reportable indications were found.

Pipe Supports:

Sixteen (16) Class 1 Component Supports received a visual examination as required by ASME Section XI Article IWF-2000. No reportable conditions were found.

\subsection{Steam Generator Tubing}

The Inconel 600 tubing in the two Babcock and Wilcox once-through steam generators (OTSG's) " $A$ " and " $B$ " at Duke Power Company's Oconee Unit 3, were examined by eddy current techniques during August 1992. The tubing in the generators measures $0.625^{\prime \prime}$ nominal outside diameter $\times 0.037^{\prime \prime}$ nnominal wall thickness. The examinations were performed by Babcock and Wilcox Nuclear Services (BWNS) Company during the 13 th refueling outage.

Approximately $60 \%$ of the tubes in steam generators "A" and "B" were inspected full length with magnetic-bias bobbin coil probles. Also, all of the previously installed sleeves were examined wiht a combination bobbin/crosswound probe. Numerous tubes and rolled plugs were examined using Zetec's motorized rotating pancake coil (MRPC) probe.

The following is a summary of the results of the bobbin coll/MRPC eddy current examination for each generator.

\section{OTSGA}

- Eddy Current examinations began on $8 / 8 / 92$ and were completed on $8 / 27 / 92$.

- $\quad 74$ tubes were removed from service by plugging.

EQA402

Page 3

Revision 0

November 19, 1992 
- 9,325 tubes were examined by bobbin coll for the full length of the tube.

- 25 tubes contained indications of 40\% thru-wall (Th') or greater reported by bobbin coil.

- 90 tubes contained indications of 20 to $39 \%$ TW reported by bobbin coill.

- $\quad 147$ previously installed sleeves were examined with a combination bobbin/crosswound probe.

- $\quad 142$ tubes in the lane/wedge region were examined at the 15 th tube support plate (TSP) and upper tubesheet secondary face (UTSF) intersections using Zetec's MRPC.

- 856 special interest tubes were examined using Zetec's MRPC.

- $\quad 125$ rolled plugs were examined from the hotleg and 42 rolled plugs from the coldleg using Zetec's MRPC.

- 2 tubes that were re-expanded approximately 5" from the tube ends in the coldleg tubesheet and one in hotleg tubesheet were examined using Zetec's MRPC.

- $\quad 147$ upper rolls in sleeves were examined using Zetec's MRPC.

\section{OTSG_B:}

- Eddy Current examinations began on $8 / 8 / 92$ and were completed on $8 / 26 / 92$.

- 52 tubes were removed from service by plugging.

- 9,326 tubes were examined by bobbin coll for the full length of the tube.

- 17 tubes contained indications of $40 \%$ TW or greater reported by bobbin coll.

- 79 tubes contained indications of 20 to $39 \%$ TW reported by bobbin coll.

- 97 previously installed sleeves were examined with a combination bobbin/crosswound probe.

- 222 tubes in the lane/wedge region were examined at the 15th TSP and UTSF intersections using Zetec's MRPC.

- $\quad 700$ special interest tubes were examined using Zetec's MRPC. 
- 92 hotleg rolled plugs and 33 coldleg rolled plugs were examined using Zetec's MRPC.

- 2 tubes that were re-expanded approximately 5" from the tube end were examined using Zetec's MRPC. Of these 2 tubes, 1 was in the hotleg tubesheet and the remaining one was in the coldleg tubesheet.

- 96 upper rolls in sleeves were examined using Zetec's MRPC.

A detailed description of the Oconee 3 Refueling Outage 13 eddy current inspection is provided in the "Eddy Current Examination Report Oconee Unit 3 August 1992 Refueling Outage $13^{\prime \prime}$ on file at the Corporate Office in Charlocte, North Carolina.

\subsection{System Leakage Test}

The Class 1 Pressure Boundary was subjected to a system leakage test as required by ASME Section XI, Article IWB-5000. No reportable conditions were found.

\subsection{Class 1 Repairs and Replacements}

Repairs and replacements for work performed from March 24, 1991 to September 25, 1992 are itemized in Section 11 of this report. 
7.0 Augmented Inspection and Alternate Examination Results

Augmented inspections were performed on Reactor Coolant Pumps 3A1, 3A2, $3 B 1$ and 3B2 Flywheels, Thermal Stress Piping (NRC Bulletin 88-08), Auxiliary Feedwater Header (PSC 21-82) Water Hammer concern, and Pressurizer Sensing/Sampling Nozzle Safe-Ends.

Alternate examination were performed on Pressurizer Relief Valve Piping Welds and on Reactor Coolant Pumps $3 A 2$ and $3 B 1$.

\subsection{Reactor Coolant Pump Flywheels}

Reactor Coolant Pumps $3 A 1,3 A 2,3 B i$ and $3 B 2$ Flywheel received an ultrasonic examination. No reportable indications were found.

\subsection{Thermal Stress Piping}

Eleven (11) welds received an ultrasonic examination as required by NRC Bulletin 88-08. No reportable indications were found.

\subsection{Aux 11 lary Feedwater Header (PSC-21-82)}

Thirteen (13) welds received a magnetic particle examination in accordance with the Auxiliary Feedwater Header (PSC-21-82) Water Hammer concern. No reportable indications were found.

\subsection{Pressurizer Sensing/Sampling Nozzle Safe-Ends}

Seven (7) nozzle to safe-end welds received a dye penetrant examination. No reportable indications were found.

\subsection{Alternate Examination}

A dye penetrant examination was performed on piping welds between Pressurizer Relief Valves 3RC4 and 3RV-67.

Welds 3 and 4 (ISI I tem Number E03.001.001 and E03.001.002 respectively) on Duke Power Company Isometric Drawing System 50 ISO 45, located between Pressurizer Relief Valves $3 R C 4$ and $3 R V-67$, received a dye penetrant examination, in lieu of the applicable hydrostatic test spectfied in ASME Section XI, Table IWB-2500-1 Category B-P. These examinations were performed in accordance with the Inservice Inspection Program, Request for Relief ONS-005, submitted to the Nuclear Regulatory Commission. A copy of the request is included in Section 10 of this report. A copy of the inspection data sheets is included in this section of the report.

No reportable indications were found. 


\begin{tabular}{ll}
\hline Today's Date : 08/25/92 & PIR Serial No.: 3-092-0371 \\
Time : 10:28 & LER Serial No.: \\
Page No.: 1 & Other Rpt. No.: \\
PIP Serial No.: 3-092-0371 &
\end{tabular}

OCONEE NUCLEAR STATION

Problem Investigation Process

Problem Investigation Form

\section{Problem ID}

Occurred Time/Date : $\quad / /$ Disc Time/Date : $08 / 19 / 92$

$\begin{array}{rrrrr}\text { Unit(s): } 3 \quad \text { Status at Time Occurred: } & \text { Unit } 1 & \text { Unit } 2 & \text { Unit } 3 \\ & \text { Mode: } & \text { N/A } & \text { N/A } & 6 \\ & \text { Power: } & \text { N/A } & \text { N/A } & \text { N/A }\end{array}$

Unit Status Remarks: Refueling Outage 113

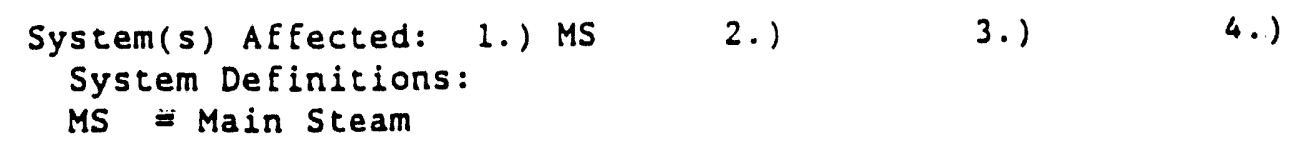

Problem Associated With Work Order No.:

Location of Problem - Bldg: $R$ Elev: 825, Column Line: A CAV. Location Remarks: STEAM GEN. 3A SHELL WELDS

Description and Cause of Problem:

During Ultrasonic Examination of ISI Item \# C01.010.002, ID 113SGA-WG8-2, and ISI Item \# C01.010.001. ID \#3SGA-WG8-1 intermitent indications were revealed 360 degrees on ID running parallel with the weld. The indications are unacceptable in accordance with ASME Section XI- 1980 Edition Winter 1980 Addenda Table IWB-3511-1.

Uriginated by: TJCOLEM Section: CES Date: 08/19/92

Revised by: TJCOLEM Section: CES Date: 08/19/92

Immediate Corrective Actions:

NONE

Originated by: TJCOLEM Section: CES Date: 08/19/92

Corrective Action Work Order No.:

Problem Identified By: TJCOLEMA Date: 08/19/92 Section: CES

Problem Entered By : TJCOLEM Dace: 08/19/92 Section: CES

\section{Significance}

Event Code(s) : 1.) 24

2.)

3.)

4.)

Event Code Definitions: 


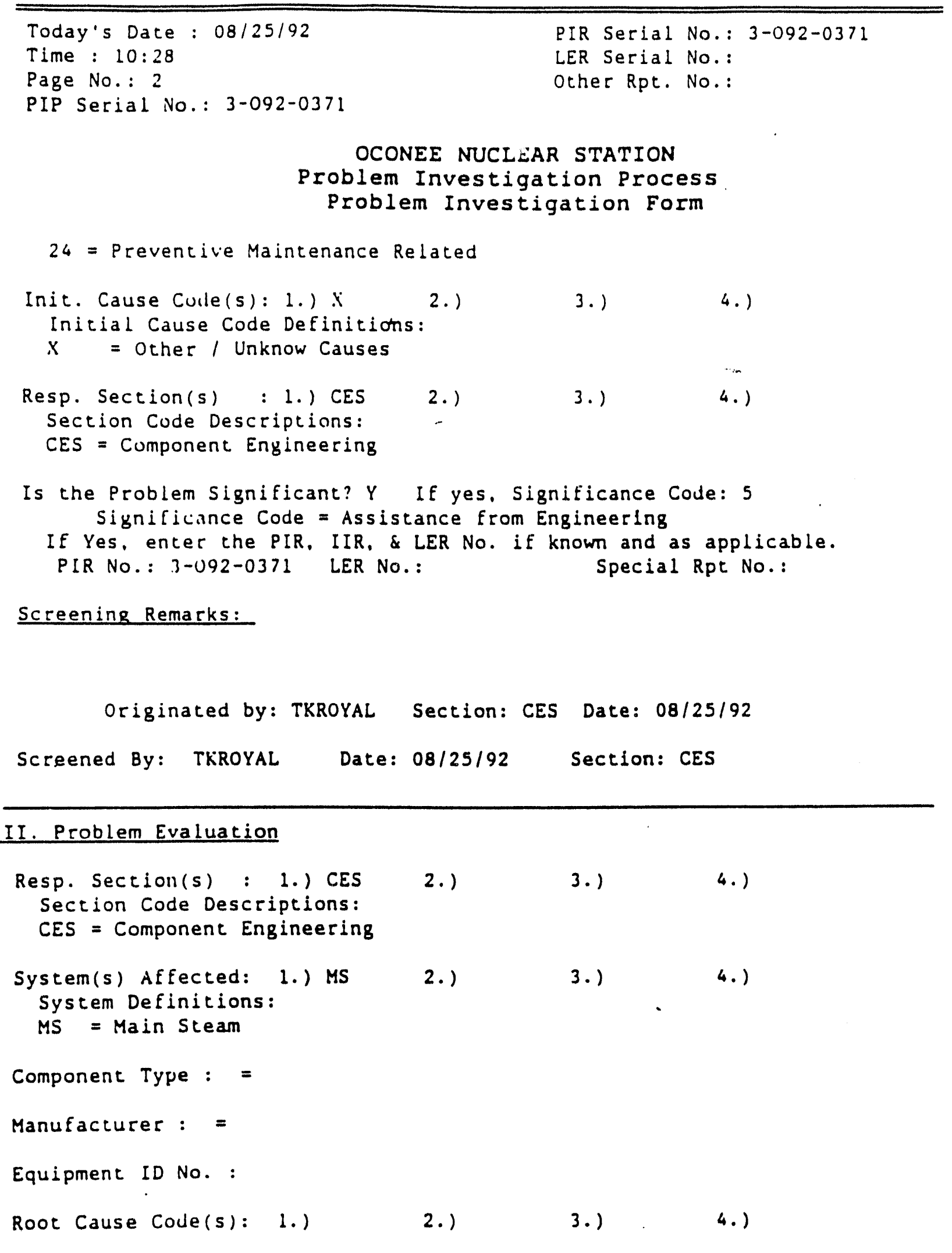




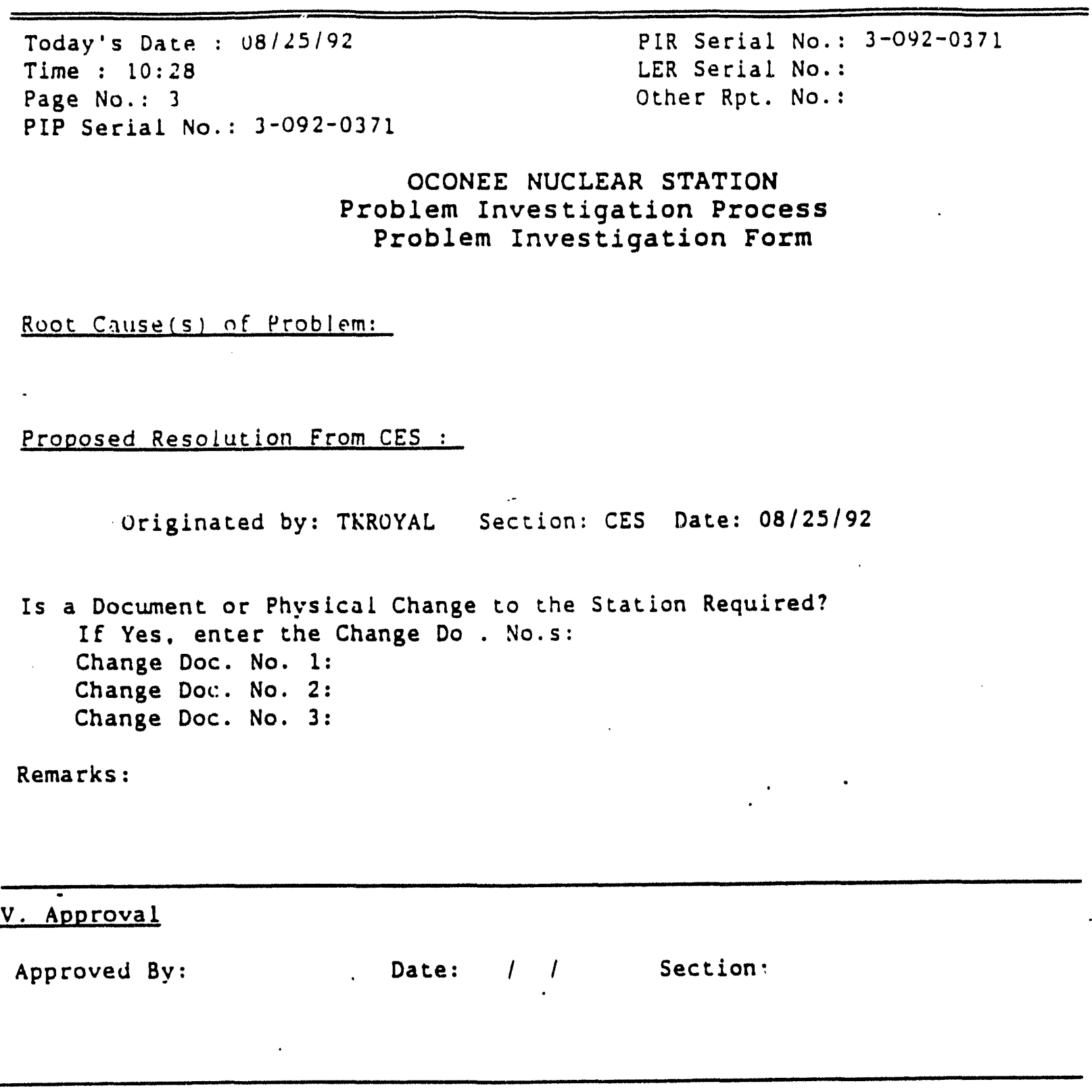

End of the Document for P[P No.: 3-092-0371

This Status of this PIP No. is : PIR 


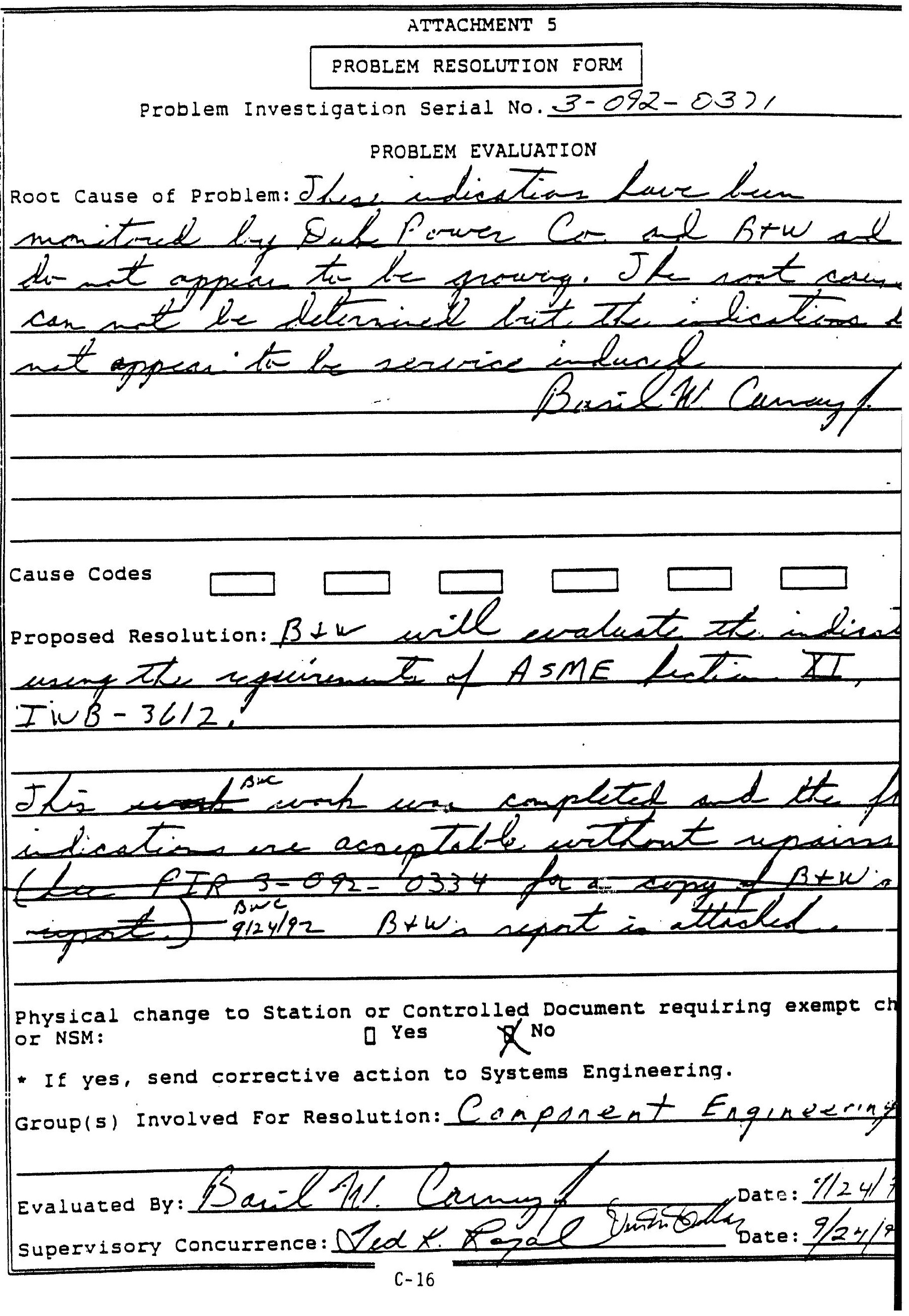


Cover Page and Approvals

Table of Contents

Examination Results

Repair/Replacements

Tables

Table I Examinations Completed by Category

Table II Limited Examinations

Table III Snubber Testing Summary

Table IV Significant Indications

Appendices
A. NIS-1 Owners Data Report
B. NDE Results
C. Repair/Replacement Listing
NIS-2 Data Reports

Page 1

Page 2

Page 3

Page 8 


\section{SUMMARY}

Approximately $77 \%$ of the first Inservice Inspection Interval requirements have been completed. Nuclear Regulatory Commission (Commission) augmented examinations in high energy lines, core spray spargers, jet pump beams, feedwater spargers, snubber testing and in lines covered by Generic Letter 88-01 were completed per coinmitments.

One surface indication was found that required corrective measurss. This indication was blended out and re-examined with acceptable results. Additional surface examinations of similar welds did not reveal any additional unacceptable indications.

A suspected IGSCC flaw, discovered at R6, was re-examined. Results did not show any significant change from R6. The analysis performed at R6 for continued operation is still valid. The weld will be examined again in $R 8$.

\section{EXAMINATION RESUITS}

This report summarizes the results of Inservice Inspection (ISI) of ASME Class 1,2 and 3 components and supports performed at Washington Public Power Supply System (Supply System) Nuclear Plant No. 2 (WNP-2) between September 30, 1991 and July 18, 1992. Both General Electric (GE) and Supply System personnel performed the examinations. During this period, WNP-2 completed the seventh scheduled refueling outage, RF92A (R7).

This report includes the NIS-1 Owner's Report of Inservice Inspection. A copy can be found in Appendix A.

The following table lists the ISI inspection periods and outages for the first interval.

$\begin{array}{llll}\begin{array}{c}\text { Inspection } \\ \text { Period }\end{array} & \begin{array}{l}\text { Refueling } \\ \text { Qutage }\end{array} & \text { Erom } & \text { To } \\ 1 & & \frac{12 / 13 / 84}{03 / 31 / 86} & \frac{09 / 15 / 88}{06 / 10 / 86} \\ & \text { RF86A (R1) } & 04 / 13 / 87 & 06 / 25 / 87 \\ & \text { RF87A (R2) } & 05 / 02 / 88 & 06 / 27 / 88 \\ & \text { RF88A (R3) } & & \\ 2 & & \frac{09 / 16 / 88}{04 / 28 / 89} & \frac{09 / 30 / 91}{06 / 30 / 89} \\ & \text { RF89A (R4) } & 04 / 21 / 90 & 08 / 07 / 90 \\ & \text { RF90A (R5) } & 04 / 15 / 91 & 09 / 30 / 91 \\ 3 & \text { RF91A (R6) } & 10 / 01 / 912 & 12 / 13 / 94 \\ & & \frac{10 / 18 / 92}{07 / 18 / 92} \\ & \text { RF92A (R7) } & 04 / 15 / 93 & 06 / 15 / 93 \\ & \text { RF93A (R8) } & 04 / 15 / 94 & 06 / 15 / 94\end{array}$

(1) Assumes one refueling or maintenance outage each year. Actual timing of the spring outage for R8 and R9 may vary due to BPA's hydroelectric capacity or outage scope.

(2) R6 outage was extended 
The ISI examinations are specified in ASME Section XI and required by 10CFR50.55a. In addition, the following examinations were performed to meet augmented Nuclear Regulatory Commission requirements.

- pipe break exclusion areas (high energy lines penetrating containment, but not within ASME Section XI examination boundary)

- IGSCC (intergranular stress corrosion cracking) detection in stainless steel welds, based on Generic Letter 88-01.

- visual examination of Core Spray Spargers and supply piping in RPV

The ASME Section XI examinations comply with the 1980 Edition, Winter 1980 Addenda upgraded as follows:

o IWA-2300(a)(1), 1983 Edition, Winter 1983 Addenda

- Code category C-F, 1983 Edition, Winter 1983 Addenda

o IWF-3400, 1980 Edition Winter, 1981 Addenda

o IWB-3600, 1986 Edition no Addenda (to comply with GL88-01)

Documentation supporting this Summary Report is included in the WNP-2 ISI Program Plan or is located in the WNP-2 Operations File. Table I lists all ASME Section XI and augmented examinations completed during R7. Appendix B contains a more detailed summary of the results by system and ISI drawing. The ISI drawings referenced are included in the ISI Program Plan previously submitted to the Commission.

The examinations, tests, repairs and replacements were witnessed or verified by Authorized Nuclear Inspector-Inservice (ANI-I) D.E. Hoggarth. He is employed by Factory Mutual Systems, a subsidiary of Arkwright Mutual Insurance Company, Norwood, Massachusetts.

\section{COMPONENTS EXAMINED}

The following components were examined:

\section{Component}

RPV

RCIC.V-65

RHR-V $41 C$

RHR-V-50B

\section{Manufacturer}

CBIN Nuclear 2700 Channel Ave

Memphis, TN

Velan Engineering Co.

2125 Ward

Montreal QUE

Velan Engineering Co.

2125 Ward

Montreal QUE

Velan Engineering Co.

2125 Ward

Montreal QUE
Serial National

Number Board No.

$\mathrm{T}-45$

0334

NA

8

67

NA

414

NA 
ISI SUMMARY REPORT RF92A

\begin{tabular}{lllc} 
Component & Manufacturer & $\begin{array}{l}\text { Serial } \\
\text { Number }\end{array}$ & $\begin{array}{c}\text { National } \\
\text { Board No }\end{array}$ \\
\hline RRC-V-67A & $\begin{array}{l}\text { Atwood \& Morrill Co. Inc. } \\
285 \text { Canal St }\end{array}$ & $3-336$ & NA \\
Salem, Mass & & \\
RRC-V-67B & $\begin{array}{l}\text { Atwood \& Morrill Co. Inc. } \\
\text { 285 Canal St } \\
\text { Salem, Mass" }\end{array}$ & $4-336$ & NA \\
& $\begin{array}{ll} \\
\text { Salem }\end{array}$ & &
\end{tabular}

\section{PIPING EXAMINATIONS}

- Twenty-five (25) safe end welds (GL 88-01 category " $D$ " and "G") were examined using the GE SMART 2000 inspection system. No unacceptable indications were found. See Generic Letter 88-01 summary below under "AUGMENTED EXAMINATIONS" for further details.

- Two hundred four (204) class 1 and 2 examinations were completed by UT, PT or MT methods. One weld, $12 R R C(1)-\mathrm{N} 2 \mathrm{~K}-4$, had a rejectable surface indication. The indication was blended out and reexamination resulted in an acceptable result. Additional welds of this type were examined with acceptable results. The indication was attributed to silicon inclusions or porosity in the original weld that was opened up during operational thermal cycling.

\section{RPVEXAMINATIONS}

- Interior visual examinations were performed by General Electric. Various augmented and Section XI category B-N-1 VT-3 items were examined. See augmented examination section below for further details. No unacceptable indications were found.

- Nozzle to vessel welds were examined by GE using their GERIS examination system and manual scanning. Top head welds were completed manually by $G E$ and Supply System personnel. The RPV weld ultrasonic examinations were performed in accordance with ASME Section XI 1980 Edition Winter 1980 Addendum and NRC Regulatory Guide 1.150 Revision 1 alternate method. No unacceptable indications were detected.

Full ASME Section XI Code coverage of the nozzle to vessel welds could not be obtained. The nozzle blend radius configuration prevents full coverage. Table II lists the nozzle type and the percent examined.

\section{AUGMENTED EXAMINATIONS}

The Supply System performed augmented examinations per the ISI Program Plan section 5.3, "Mandatory Augmented Inservice Inspection".

- High energy lines that penetrate containment (section 5.3.1)

Dye penetrant or ultrasonic examination of 14 welds in the high energy line augmented examination program was performed. No reportable indications were found. This brings the total welds examined in this category to 57 . 
A visual examination of the core spray spargers and their supply piping was performed per the requirements of IE Bulletin 80-13, "Cracking in Core Spray Sparger". The examination was performed using an underwater closed circuit TV system capable of resolving a 0.001 inch diameter wire in-situ. No relevant indications were observed.

o Jet pump beam visual (section 5.3.3)

The jet pump beams were visually examined using the VT-1 technique. No reportable indications were found.

\section{o Generic Letter 88-01 (section 5.3.4)}

General Electric examined 25 IGSCC category "D" and "G" welds (safe-ends) and 1 category " $F$ " weld using the GE SMART 2000 automated system. The category " $F$ " weld, 20RRC(6)-8, had a reportable indication detected at $R 6$. The results of this exam determined that the flaw size had not changed significantly. The analysis performed at $\mathrm{R} 6$ for continued operation is still valid. The results of this examination and analysis for continued operation was submitted to the Commission for review and approval for continued operation.(ref. letter GO2-92-123, dated May 14, 1992) The Commssions approved operation for one more cycle. (ref. letter dated June 25, 1992, TAC M83721) This weld will be examined again at R8 to determine any change in flaw size. No indications were recorded for the category " $D$ " and " $G$ " welds. In addition 18 category "B" and 4 category " $A$ " welds were examined using either the SMART 2000 system or manually. No indications were recorded.

Status of GL 88-01 commitment:

\begin{tabular}{lccc}
$\begin{array}{l}\text { Category } \\
\text { (Total \#) }\end{array}$ & $\begin{array}{c}\text { Required } \\
\text { within 6yrs }\end{array}$ & $\begin{array}{l}\text { Required } \\
\text { within 10yrs }\end{array}$ & $\begin{array}{c}\text { WNP-2 Statys thru R7 } \\
\text { (After 4 yrs) }\end{array}$ \\
\hline A (54) & $12 \%$ & $25 \%$ & $47 \% 2$ \\
B (147) & $25 \%$ & $50 \%$ & $21 \%$ \\
D (8) & $100 \% 3$ & $100 \% 3$ & $100 \% 3$ \\
G (17) & $100 \% 4$ & $100 \% 4$ & $100 \% 4$ \\
F (1) & $100 \% 6$ & $100 \% 6$ & $100 \% 6$
\end{tabular}

Notes

1 WNP-2 commitment began at R4.

2 WNP-2 requirements exceed GL 88-01 because of ASME Section XI requirements .

$3100 \%$ of welds require examination every 2 refueling outages

4 All welds require examination every refueling outage. All welds classified as "G" in $R 7$ are now reclassified as "D".

5 This category "B" weld was reclassified to category "F" at R6.

$6100 \%$ of welds require examination every refueling outage.

WNP.2 has met or is on schedule with its GL 88-01 commitments for the first six years. 
- $\quad$ Feedwater spargers (section 5.3.2)

The feedwater spargers were visually examined by VT-1 technique per Supply System ISI Program Plan and FSAR commitments. No reportable indications were found.

o Snubber testing (section 6.5)

An initial sample of 37 snubbers was selected from the WNP.2 general population of 564 safety related snubbers. These snubbers were randomly selected by compute1 sub-routine which is part of the Snubber Test and Examination Program (STEP). The selected snubbers were then reviewed to determine if the sample was representative as required by Technical Specification 4.7.4.e.

Testing of snubbers was performed using portable testing devices "Validators". These devices were supplied by the snubber manufacturer. Testing results summary are found in Table III.

Snubber MD-1285-14D S/N 4047 passed the functional test, but drag was over 2\% To preclude further service life degradation it was replaced with another tested snubber S/N 2528 deleted from RCIC-970S under MWR AR6826.

The next testing is required within 18 months.

\section{LIMITED EXAMINATIONS}

Full ASME Section XI required coverage of the examination volume or surface could not be accomplished on 23 welds. Table II is a summary of the coverage obtained. The remaining volume or surface will be examined at a future outage or if necessary relief will be requested.

\section{SIGNIFICANT INDICATIONS}

Significant indications found during ISI examinations are summarized in Table IV. All significant indications were evaluated. Rejectable indications/items were repaired or replaced. Evaluation and/or re-examination data sheets are attached to the original data reports. 


\section{REPAIRS AND REPLACEMENTS}

Eight (8) significant repair and replacement activities were performed during the RF92A refueling outage: 1) Modified valves RRC.V-67A and $R \cdot C \cdot V \cdot 67 B, 2)$ Installed new multiholed orifices in the HPCS system, 3) Installed new multiholed orifices in the FPC system, 4) Rerouted RHR retum lines, 5) Replaced LPRM's, 6) Overhauled and replaced CRD's, 7) Replaced disc inserts and nozzles for five (5) main steam relief valves and replaced four (4) main steam relief valves, 8) Continuation of the snubber optimization program and 9) Modified vent/drain/test connections. A listing and summary of these and all other repairs and replacements accomplished between October 1, 1991 and July 18, 1992 are provided in Appendix C.

\section{1) Reactor Recirculation Cooling (RRC) System}

Installed new modified valve bonnets and internals for valves RRC-V.67A and RRC.V. $67 \mathrm{~B}$ to improve resistance to flow induced wear failures. Performed VT-3 visual examinations for ISI on the internal accessible surfaces of the new modified bonnets and tite existing valve bodies.

\section{2) High Pressure Core Sprav (HPCS) System}

Installed new multiholed orifices HPCS-RO-8 and HPCS-RO-9 to prevent vibration caused by cavitation in the HPCS full tlow test return line to the suppression pool. Performed surface and volumetric examinations on the new welds for ISI (Preservice Inspections - PSI).

\section{3) Fuel Pool Cooling (FPC) System}

Installed new multiholed orifices FPC-RO-5A and FPC-RO-5B to reduce cavitation during operation of the RHR - Assist mode of FPC system.

\section{4) Residual Heat Removal (RHR) System}

Rerouted RHR return lines trom hydrogen recombiner skids to eliminate the potential tor water to back up the drain lines to CAC recombiner skids when the RHR system test return line is operated.

\section{5) LPRM's}

Replaced four (4) Local Power Range Monitoring (LPRM) incore assemblies. 
ISI SUMMARY REPORT RF92A

6) $\subseteq R D$ 's

Overhauled eleven (11) Control Rod Drives (CRD's) and replaced thiny one (31) Control Rod Drives (CRD's).

7) Main Steam (MS) System

Replaced disc inserts and nozzles for four (4) spare main steam relief valves with Serial Numbers N63790-00-0046, N63790-00-0050, N63790-00-0052 and N63790-00-0056. These four (4) spare main steam relief valves were installed in place of the existing main steam relief valves in the plant as follows:

\begin{tabular}{lr} 
EPN No & Serial No \\
\hline MS-RV-1C & N63790-00-0046 \\
MS-RV-1D & N63790-00-0050 \\
MS-RV-3B & N63790-00-0052 \\
MS-RV-4B & N63790-00-0056
\end{tabular}

Replaced disc insert and nozzle for one (1) additional spare main steam relief valve with Serial Number N63790-00-0053. This spare relief valve was installed in place of MSRV-3B, S/N N63790-00-0052 because this relief valve was inoperable during plant star up.

\section{8) Snubber Optimization Program}

As part of the Supply System's effort to reduce the number of safety related snubbers at WNP-2, twenty three (23) snubbers were replaced with rigid struts and forty six (46) snubbers were deleted. The new struts received Preservice Inspections (PSI) after installation.

\section{9) Vent/Drain/Test Connections}

Modified eight (8) vent/drain/test connections for RHR, LPCS and HPCS systems to reduce susceptibility to fatigue induced tailures at socket welds. 
TABLE IV

Significant Indications

\begin{tabular}{|c|c|c|}
\hline Data sheet & Identification & \\
\hline No. & No. & Description \\
\hline 1RPV-160 & CRD HOUSING 42.59 BLT & CRD Housing Bolking \\
\hline $1 R \mathbb{U}-047$ & $6 \mathrm{RCIC}(1)-72$ & ELL TO PIPE \\
\hline 1HPU-015 & $16 \mathrm{HPCS}(1)-42$ & ELL TO PIPE \\
\hline 1LPU-028 & $12 L P C S(1)-2$ & PIPETO ELL \\
\hline 1LPM-016 & 24LPCS(2)-8 & PIPE TO ELL \\
\hline $1 \mathrm{HV}-0223$ & LPCS-902N & SPRING \\
\hline 1MSV-143 & MS(12)-1BD & FLANGE BOLTING \\
\hline 1RRP-098 & 12RRC(1)-N2K-4 & PIPE TO SAFE-END \\
\hline 1RRU-166 & $20 \mathrm{RRC}(6)-8$ & PIPE TO VALVE \\
\hline $1 \mathrm{HV}-0220$ & $S W-430$ & STRUT \\
\hline
\end{tabular}

Remarks

Corrosion pitting attack along shank Metalurgical evaluation acceptable for use.

125\% DAC due to ID geometry.

$125 \%$ DAC due to ID geometry.

130\% DAC due to ID geometry.

Linear indication found by MT. Acceptable by full thickeness

UT of indication surface area as permitted by ASME Section XI IWC-3514.

Spring can alignment off approximately 5 degree. Evaluated as accetable.

Bolts damaged during disassembly.

Rounded PT indication. Blended out and re-examined by PT acceptable.

Re-sized indication found at R6 and found insignificant difference in size from previous outage. Will re-size at R8.

Race displaced from paddle $1 / 4^{\text {" }}$ on pipe side. Evaluared as acceptable. 
ISI SUMMARY REPORT RF92A

TABLE IV

Significant Indications

Data sheet

No.

Identification

1HV-0219

SW-941N

1HV-0218

SW-940N

1HV-0217

SW-933N

1HV-0216

MS-324
Description

BOX SUPPORT

BOX SUPPORT

BOX SUPPORT

SPRING
Remarlos

Baseplate nuts corroded.

Evaluated as scceptable. Nuts replaced and coated.

Baseplate nuts corroded.

Evaluated as acceptable. Nuts replaced and coated.

Baseplate nuts corroded.

Evaluated as acceptable. Nuts replaced and coated.

Clamp bolting loose. Evaluated as acceptabie. 
ISI SUMMARY REPORT RF92A

\author{
APPENDIX C \\ ASME SECTION XI REPAIR AND REPLACEMENT LISTING \\ NIS-2 OWNER'S REPORTS
}

This appendix summarizes all ASME Section XI repairs and replacements work completed between October 1, 1991 and July 18, 1992. The status of the NIS-2 Owner's Report is stated for each repair and replacement work performed. For repairs and replacements completed during R-7 but for which an NIS-2 Owner's Report has not been issued yet, the NIS-2 Owner's Report will be issued in the next ISI Summary Report. 
2-0629 AR 0381 Replaced body to bonnet nuts for valves RHR-V-27A and RHR.V-27B

$2-0653$

$2-0654$

$2-0855$

$2-0656$

$2-0657$

2-0658

$2-0659$

$2-0660$

$2-0668$

$2-0667$

2-0675

$2-0676$

$2-0677$

2-0678

$2-0679$

$2-0680$

2-0691

$2-0692$

2-0693

2-0701

$2-0712$

2.0713

$2-0714$

2-0717

2-0722

$2-0723$

2-0724

$2-0725$

2-0726

2-0727

$2-0730$

$2-0731$

$2-0732$

2-0737

$2-0738$

$2-0739$

2.0740

$2-0741$

$2-0750$

$2-0751$

$2-0752$

$2-0753$

$2-0754$

$2-0755$

$2-0756$

2-0757

$2-0758$

$2-0759$

$2-0760$

2-0761

$2-0763$

2.0764

$2-0765$

2.0768

$2-0767$

2.0769

2-0770

$2-0773$

2.0774

$2-0776$

$2-077$

2-0778
AR 2188

AR 2189

AR 2190

AR 2191

AR 2192

AR 2193

AR 2194

AR 2195

AR 5711

AR 3178

AR 3722

AR 3723

AR 3721

AR 3724

AR 3720

AR 1095

AR 0904

AR 0905

AR 0906

AR 3567

AR 3795

AR 3793

AR 3794

AR 5341

AR 5544

AR 5544

AR 7052

AR 6985

AR 7156

AR 6116

AR 7157

AR 7157

AR 7156

AR 7283

AR 7298

AR 7285

AR 7299

AR 7300

AR 5998

AR 6615

AR 6032

AR 6386

AR 6388

AR 6387

AR 6389

AR 3556

AR 3557

AR 4043

AR 4044

AR 5675

AR 5675

AR 6489

AR 6488

AR 5797

AR 5798

AR 6317

AR 1359

AR 5668

AR 7159

AR 6912

AR 7431

AR 6913

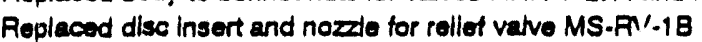

Replacod rollef valvo MS-RV-1C with spare S/N N63790-00-0120

Replaced disc insert and nozde for relief valve MS-FV-2B

Replaced dise insert and nozzlo for reliet valvo MS.RV-2C

Replaced rellof valve MS-RV-2D with spare S/N N63790-00-0124

Replaced disc insert for reliof value MS.FN-4D

Replaced dise insert and nozlo for rellof valvo MS-RV-5B

Replaced disc insert and nozie for rellef valve MS-FV-5C

Roinstalled and wolded accesss cut out plates on shell for CCH-CR-1A

Replaced evaporator tubes for CCH.CR-1A

Modified test connection for valves RFW.V-45A and RFW-V 458

Modified tost connection for valves RFW-V-119 and RFW-V-120

Modified test connection for valves RFW-V-44A and RFW.V.44B

Modified test connection for RHR-V-161A and RHR-V-162A

Modified drain connection for valves HPCS.V-21 and HPCS-V-22

Modified test connection for vatues RFW-V.121 and RFW.V-122

Body to bonnot seal wold and roplaced stem/disc for value MS-V-1

Body to bonnet soal wold and replaced stem/disc for valve MS-V-2

Body to bonnot soal weld and replaced stom/disc for value MS-V.5

Replaced bolting material for flange joints on Dwg RCIC-659-27.28

Modified now bonnet assemblies for valves RRC-V-67A and RRC-V-678

Installed now parts valve RRC.V-67A

Installed now parts valve RRC-V-67B

Repleced condenser tubes for CCH-CR-1A

Cut and rowelded wold Dwg SW-506-1.8

Cut and rowolded weld Dwg CCH-101-1.6

Rerouted instrument piping $\mathrm{PI}(1)-45-X 788$

Installod piping for sot pressure verification for MSRV's

Modified test connection for values HPCS-V.57 and HPCS-V.718

Installed valve RCIC-V-215 for prossure gege RCIC-PI.11

Fabricated restriction orifice for HPCS.RO-6 and HPCS.RO-9

Fabricated spool pieces for HPCS-RO-8 and HPCS-RO-9

Installed HPCS-RO-8 and HPCS-RO-9

Modified test connection tor HPCS.V-37 and HPCS.V-38

Modified test connection for RHR-V-157A and RHR-V-158A

Modified test connection for LPCS-V.37 and LPCS.V-38

Modified toot connection for RHR-V-157C and RHR-V-158C

Modified test connection for RHR-V-161A and RHR-V-102A

Replaced mechanical sed for pump RRC-P.1B

Installed valve for RHR-PI-18

Installed cathodic protection of spray pond siphon piping

Modified test connection for RHR.V.161A and RHR.V-162A

Modified test connection for HPCS-V.37 and HPCS.V-38

Modified test connection for RHR-V-1578 and RHR-V-158B

Weld built up for valves RHR-V.163 and RHR.V-164

Replaced disc insert and nozde for follof valve SN 63790-00-0056

Replaced disc insert and nozde for reliof valve S/N 63790-00-0050

Replaced parts for rellef valve SNN 63790-00-0052

Replaced disc insert and nozde for relief valve SN 63790-00-0046

Installed flanges for DCW-HX-1A2 drain line

Repaired corroded areas on cover plato for DCW-HX-1A2

Deactivated valve SW-V.223A

Deactivated valve SW.V.223B

Modified piping for relief value SW-RV-1A

Modified piping for rolief valve SW.PV-1B

Bocty to bonnot seal wotd for valvo SW-V-931A

Assombled stom disc and disc piston assomblies for MSIV

Reinstalled drain connection with valvo SW-V-e34B and CCH.V-702B

Installed pipe cap for connection with valvo HPCS.V.718

Installed pipe cap for connection with valve HPCS-V-70

Replaced body to bonnet bolting material for valve RHA-V.50B

BDC-88-0138-2D work for JCl support B-220-1077-145
Valve

Relief Valve

Relief Valvo

Rolief Valvo

Roliof Valvo

Rollet Valvo

Reliof Valvo

Reliof Valvo

Rellof Valve

Heat exchanger

Heat exchanger

Piping

Plping

Piping

Piping

Piping

Piping

Valvo

Valvo

Valve

Piping

Valves

Valve

Valve

Heat oxchanger

Piping

Piping

Tubing

Piping

Plping

Piping

Plping

Piping

Piping

Plping

Piping

Plping

Piping

Piping

Pump

Tubing

Piping

Piping

Piping

Piping

Piping

Rellof Valvo

Roliof Valve

Reliof Valve

Relief Valvo

Piping

Heat Exchanger

Valve

Valvo

Piping

Piping

Valve

Valve

Piping

Piping

Piping

Valve

Support

RF92A Summary Report RF92A Summary Roport RF92A Summary Report RF92A Summary Report RF92A Summary Report RF92A Summary Roport RF92A Summary Report RF92A Summary Report RF92A Summary Report RFg2A Summary Report RF92A Summary Roport AF92A Summay Roport RF92A Summary Report RF92A Summary Report Soo Plan No 2-0741 RF92A Summary Roport RF92A Summary Report RF92A Summary Report See Plan No 2-0807 RF92A Summary Roport RF92A Summary Report RF92A Summary Report RF92A Summary Roport RF92A Summary Report RF92A Summary Report RF92A Summay Report RF92A Summary Report RF92A Summary Roport RF92A Summary Report RF92A Summay Report RF92A Summary Report RF92A Summary Report RF92A Summary Report AF92A Summary Roport 


\begin{tabular}{|c|c|c|c|c|}
\hline 2.0779 & AR 6913 & BDC-88-0138-2D work tor PDM reinforcement structural steol & Supports & Soe Note 1 \\
\hline $2-0780$ & AR 7435 & Modified test connection for RHR-V-157B and RHR-V-158B & Plping & See Note 1 \\
\hline $2-0781$ & AR 7436 & Modified test connection for RHR.V.163 and RHR.V.164 & Piping & RF92A Summary Report \\
\hline 2-0782 & AR 7425 & Modified test connection for HPCS.V-713 and HPCS.V-714 & Piping & See Note 1 \\
\hline 2.0783 & AR 7564 & Fabricated restriction orifice for FPC-RO-5A and FPC-RO-5B & Plping & RF92A Summary Roport \\
\hline 2.0784 & AR 7531 & Fabricated spool pieces tor FPC-RO-5A and FPC-RO-5B & Piping & RF92A Summary Report \\
\hline $2-0785$ & AR 7617 & Installed FPC-RO.5A and FPC.RO-5B & Piping & RF92A Summary Roport \\
\hline $2-0788$ & AR 7788 & Modified connection for valve FPC-V-611 & Piping & RF92A Summary Report \\
\hline $2-0792$ & AR 6826 & Machined under sized pins & Supports & RF92A Summary Report \\
\hline 2.0793 & AR 6826 & Replaced snubbers with nigid struts for MS supports & Supports & RF92A Summary Report \\
\hline $2-0794$ & AR 6828 & Ropleced snubbers with rigid struts for MSRV supports & Supports & RF92A Summary Report \\
\hline $2-0795$ & AR 6828 & Ropleced snubbers with rigid struts for RCIC supports & Supports & RF92A Summary Roport \\
\hline 2.0796 & AR 6828 & Replaced snubber with rigid strut for HPCS support & Support & RF92A Summary Report \\
\hline $2-0797$ & AR 7791 & Replaced Local Power Range Monitoring (LPRM) in core assemblles & RPV & RF92A Summary Report \\
\hline 2-0798 & AR 7748 & Rerouted RHR retum line trom rocombiner skdd, RHR - Loop A & Piping & RF92A Summary Report \\
\hline $2-0799$ & AR 7740 & Rerouted RHR rotum line trom recombiner skdd, RHA - Loop B & Piping & RF92A Summary Roport \\
\hline $2-0800$ & AR 7781 & Modified flanges for RHR - Loop A & Piping & RF92A Summary Report \\
\hline $2-0801$ & AA 7782 & Modified flanges for RHR - Loop B & Piping & RF92A Summary Report \\
\hline $2-0802$ & AR 7617 & Modified connection for vatue FPC-V-612 & Piping & RF92A Summary Raport \\
\hline $2-0804$ & AR 7834 & Modified hydrogen recombiner CAC-HR-1A skid piping & Piping & RF92A Summary Roport \\
\hline $2-0805$ & AR 7835 & Modified hydrogen recombiner CAC-HR-1B skid piping & Piping & RF92A Summary Report \\
\hline $2-0808$ & AR 4035 & Replaced stem/disc assembly for valve MS.V-1 & Valve & See Note 1 \\
\hline $2-0807$ & AR 4944 & Body to bonnet seal wold for valve MS-V-2 & Vave & Sev Plan No 2.0849 \\
\hline $2-0808$ & AR 7068 & Installe J pipe cap for connection with valve RCIC-V-603 & Piping & Soe Note 1 \\
\hline $2-0809$ & AR 7825 & Installed spring steps for relief valve CIA-RV-SA & Rellot valvo & RF92A Summary Report \\
\hline $2-0810$ & AR 7825 & Installed spring steps for rellet valve CIA-AV-SB & Rellof valve & RF92A Summary Report \\
\hline 2.0813 & AR 6532 & Replaced rellef valve MS-RV-1C with spare S/N N63790-00-0046 & Relief valve & RF92A Summary Report \\
\hline 2.0814 & AR 6533 & Replaced relief valve MS.AV-1D with spare S/N N63780-00-0050 & Relief valve & RF92A Summary Roport \\
\hline $2-0815$ & AR 6534 & Replaced relief valvo MS-RV.38 with spare SNN N63790-00-0052 & Rellot vaive & RF92A Summary Roport \\
\hline $2-0816$ & AR 6535 & Replaced relief valve MS-RV-48 with spare S/N N63790-00-0056 & Relief valve & RF92A Summary Report \\
\hline $2-0817$ & AR 7595 & Replaced disc insert for relief valve CCH-RV-2A & Relief valve & See Note 1 \\
\hline $2-0818$ & AR 7044 & Removed socket weld pipe cap and instulled threaded pipe cap & Plping & RF92A Summary Report \\
\hline 2.0819 & AR 8428 & Installed test port for rellof valve HPCS.RV.35 & Relief Valve & See Note 1 \\
\hline $2-0820$ & AR 6609 & Removed scratches on the disc seating surface for valve MS.V-41 & Valve & See Note 1 \\
\hline 2-0821 & AR 7478 & Replaced bolting material for flanged joints on Dwg RCIC-659-27.28 & Piping & RF92A Summary Report \\
\hline $2-2622$ & AR 8363 & Replaced parts for vatwo SLC-V.4B & Vaive & RF92A Summary Report \\
\hline $2-0823$ & AR 5436 & Replaced bolting material for OG.HX.1B & Heat Exchanger & See Note 1 \\
\hline 2-0824 & AR 8531 & Rerouted instrument line $P I(1)-45 \cdot x$ & Tubing & AF92A Summary Report \\
\hline 2.0825 & AR 6300 & Repleced U & Support & RF92A Summary Report \\
\hline $2-0826$ & AR 5436 & for OG.HX-1B & Heat Exchanger & See Note 1 \\
\hline $2-0828$ & AR 7478 & Replaced bolting material for RPV Nozede NB & Vossel & RF92A Summary Report \\
\hline $2-0829$ & R 8630 & Removed vent valves SW-V.168A and SW-V.169A & Piping & RF92A Summary Report \\
\hline 2-0831 & AR 8660 & Rerouted pipinghubing for LPCSFE-2 & Piping/Tubing & RF92A Summary Report \\
\hline $2-0832$ & AR 6353 & Repleced rear disc assembly for valve & Valve & See Note 1 \\
\hline $2-0833$ & AR 1672 & Installed pipe nipple and pipe cap to & Plping & AF92A Summary Roport \\
\hline $2-0834$ & AR 4989 & Replaced disc, nozzie and stem for relief value SLC-RV.29A & Rollet valve & RF92A Summary Roport \\
\hline $2-0835$ & AA 4990 & Replaced diac, nozede and stom for reliof valve SLC-RV-29B & Rellet vaive & RF92A Summary Report \\
\hline $2-0836$ & AR 7141 & Repleced bolting material for decon flanged joint & Plping & RF92A Summary Report \\
\hline $2-0837$ & AR 8646 & Bocty to bonnet seal wold for valve SLC-V.7 & Valve & RF92A Summay Roport \\
\hline $2-0841$ & AR 7735 & Machined gaskot seating surtace on the bonn & Valve & RF92A Summary Roport \\
\hline $2-0842$ & AR 8755 & Removed PT indication from RPV nozzle safe end N2-K-SE-330, Wold 5 & Piping & RF92A Summary Report \\
\hline $2-0843$ & AR 3793 & Reinstalled bonnet vent connection for valvo RRC V $-67 \mathrm{~A}$ & Piping & RF92A Summary Report \\
\hline 2-0844 & AR 3794 & Reinstalled bonnet vent connection for valve RRC V-57B & Piping & RF92A Summary Report \\
\hline $2-0845$ & A月 8856 & Repleced sato ond tor valve CIA-SPV.1A & Vatve/Piping & RF92A Summary Report \\
\hline $2-0846$ & AA 8760 & Body to bonnot seal weid tor valve CIA-V-56B & Vaive & RF92A Summary Report \\
\hline $2-0849$ & AR 4944 & Repleced valve MS.V.2 & Piping & RF92A Summary Report \\
\hline $2-0850$ & AR 8737 & Replaced bolting material tor cover plate bolted joint for DCW.HX-1B2 & Heat Exchanger & RF92A Summary Report \\
\hline 2.0851 & AR 8960 & Machined surfece defects on valve plug for valve RHR.FCV-64B & Valve & See Note 1 \\
\hline $2-0852$ & AR 8990 & Repleced wedge for valve RHR.V-27B & Vaive & Soe Note 1 \\
\hline $2-0853$ & AR 9103 & Replaced relief vatvo HPCS-RV.35 inlet piping material & Piping & See Note 1 \\
\hline $2-0854$ & AR 8986 & Replecod reliof valve RHA AV-1A & Rolliof valvo & RF92A Summary Report \\
\hline $2-0855$ & AR 8988 & Repiecend dise for reliet valve RHA-RV-25A & Reliof valve & See Noto 1 \\
\hline 2.0856 & AR 9283 & Body to bonnet seal weld for valve RHR.V.143A & Valve & RF92A Summary Repon \\
\hline
\end{tabular}




\begin{tabular}{|c|c|c|c|}
\hline 20857 & AR 9525 & Replaced disc insert and nozze for rollef valve S/N $83790-00-0053$ & Relief Valve \\
\hline $2-0858$ & AR 9529 & Replaced reliaf valve MS.RV 3 B with spare S/N N63790-00-0053 & Rellef valve \\
\hline $2-0861$ & AR 7534 & Installed pipe cap for connection RCIC.V.103 & Plping \\
\hline $2-0862$ & AR 7568 & Instulled pipe cap for connection LPCS.V-36 & Plping \\
\hline 20863 & AR 7567 & Installed pipe cap for connection LPCS.V.59 & Plping \\
\hline $2-0864$ & AR 7286 & Installed pipe cap for connection LPCS.V.55 & Piping \\
\hline 2.0866 & AR 9970 & Removed and reinstalled elbow shown on Dwg SW-1525-1 & Piping \\
\hline N/A & AR 6828 & Deleted snubbers & Supports \\
\hline N/A & AR 5782 & Repleced Control Rod Ditves (CRO's) & CAD \\
\hline$N / A$ & AR 0572 & Overhauled and repleced part(s) for Control Rod Drtve (CFD) & CRD \\
\hline N/A & AR 0841 & Overhauled and repleced part(s) for Control Rod Drtve (CRD) & CAD \\
\hline N/A & AR 5867 & Overhauled and replaced part(s) for Control Rod Drtve (CRD) & CRD \\
\hline N/A & AR 5869 & Overhauled and replaced part(s) for Control Rod Drtve (CRD) & CRD \\
\hline N/A & AR 5870 & Overhauled and replaced part(s) for Control Rod Drtve (CAD) & CRD \\
\hline N/A & AR 5873 & Overhauled and replaced part(s) for Control Rod Driv (CRD) & CRD \\
\hline$N / A$ & AR 5878 & Overhauled and repleced pert(s) for Control Rod Drive (CRD) & CRD \\
\hline N/A & AR 5879 & Overhauled and replaced part(s) for Control Rod Drive (CAD) & CRD \\
\hline N/A & AR 5889 & Overhauled and replecod part(s) for Control Rod Drive (CAD) & CRD \\
\hline$N / A$ & AR 5891 & Overhauled and repleced part(s) for Control Rod Drive (CRD) & CRO \\
\hline N/A & AR 8522 & Overhauled and repieced part(s) for Control Rod Drive (CAD) & CFD \\
\hline
\end{tabular}

RF92A Summary Roport RF92A Summary Roport RF92A Summary Report RF92A Summary Roport RF92A Summary Report RF92A Summary Report RF92A Summary Report AF92A Summary Report RF92A Summary Report RF92A Summary Roport RF92A Summay Report RF92A Summary Report RF92A Summay Report RFg2A Summary Roport RF92A Summey Report RF92A Summary Report RF92A Summary Roport RF92A Summary Roport RF92A Summary Report RF92A Summary Report 


$$
\text { AnO-1 }
$$

$1 R 10$

\section{OUTAGE SUMMARY REPORT}

The regularly-scheduled ISI examinations performed during $1 R 10$ are listed in the attached table. 1R10 was the second and last refueling outage in the second period of the second 10-year Interval. The attached table includes the non-destructive examinations other than the pressure tests and associated VT-2 exams. The pressure tests are summarized below.

\section{Pressure Tests}

All remaining second-period pressure tests, as required by the ASME Code and by the ISI Program, were performed during this outage. In addition, the following 10-year ISI hydrostatic tests were completed during Cycle 10:

I. Both Service Water loops including supply and suction headers except the following components within the supply and return isolation valves:

1. Emergency diesel generator coolers (E2OB1 \& E2OB2)

2. Auxiliary Building Electrical Rooms Emergency Chillers (E-175 \& E-177)

3. Auxiliary Building Decay Heat Removal Unit Coolers (VUC-1A, 1B, 1C, \& 1D).

II. Emergency Feedwater Pump suction piping.

\section{Component Supports (Hangers)}

The current ISI Program requires inspection of $100 \%$ of the component supports (hangers) during each period. This requirement is carried over from the first 10-year ISI Program. Consequently, a very large number of hangers were inspected during this outage. All but a few of the hangers were found to be in satisfactory condition and these few hangers had only minor problems. Most of the problems had to do with loose bolts and nuts, probably due to vibration associated with an operating plant. A fow hanger welds were found to be undersized and one spring hanger was discovered to be carrying no load. All of these conditions were either corrected or resolved by engineering evaluation.

In the case of the spring hanger with no load, additional supports were inspected and found to be satisfactory. Therefore, the condition appears to have been an isolated case. Due to oversight, four of the hangers $(24-082,24-092,50-020$, and 53-010) with loose bolts and nuts did not receive a visual inspection after the maintenance was performed to tighten the loose parts. Consequently, a Condition Report (CR-1-92-486) was issued to have the reinspections performed during the next refueling outage. The 
CR also requires that the process of assigning post-maintenance testing requirements be reviewed for adequacy.

\section{Interaranular Stress Corrosion Cracking (IGSCC)}

In addition to the ASME Code-required examinations, an augmented program of examinations was performed on thin-wall stainless steel piping connected to the Borated Water Storage Tank (BWST). This piping was selected for examination due to the discovery of a cracked weld during plant restart from refueling outage 1R9. A few months after completion of 1R9, another crack was discovered in thin-wall stainless steel piping in the Spent Fuel Pool Cooling (SFP) System. Since both of these cracks were in similar piping carrying the same borated water, a common cracking mechanism was believed to exist. These cracks were the basis for initlation of Condition Reports CR-1-91-131 and CR-1-91-199.

The basis for the selection of welds to include in the augmented program was NRC Bulletin 79-17 which addresses Intergranular Stress Corrosion Cracking (IGSCC) in stainless steel piping in Pressurized Water Reactors (PWRs). The original scope for this outage was 26 welds, which was a $10 \%$ sample of thin-wall piping welds that were not already in the ISI Program. The BWST piping was examined using ultrasonic techniques specially designed for the detection of IGSCC in thin-wall stainless steel. During the examinations, one weld was found to have a small IGSCC indication. The same weld that had the crack in 1R9 still contained a small crack that had not been detected by radiography performed in $1 R 9$ and subsequently had not been repaired. The small indication is believed to have existed from the original startup timeframe of the early 1970s. The entire weld was removed, along with the adjacent elbow, and two new welds were added. Two additional welds, one on either side of the cracked weld, were added to the scope of the augmented program. In addition, one of the original 26 welds was found to be partially obstructed due to a pipe hanger; consequently, another adjacent weld was added to the scope. Thus, the final scope of this augmented program was 29 welds. It was determined from the examination results, which were reviewed by NRC Region IV inspectors, that IGSCC is not a significant concem at ANO-1 at this time. On-going IGSCC examinations will be performed as part of our augmented ISI Program.

In order to determine the root cause of the cracking, a cracked weld from the SFP system was sent to Southwest Research Institute (SWRI) for metallurgical evaluation. The SwRI report (06-4722-001, contract A-2071) concluded that the crack was indeed IGSCC and that the probable cause was sulfides. The sulfides are believed to have been introduced into the borated water systems during the original startup of ANO-1 in the 19708. The original design of the plant included a Sodium Thiosulfate Tank in the Reactor Building Spray (BS) System. During startup, this tank either leaked or was dumped into the BS System which communicates directly with the BWST which, in turn, feeds the SFP System. The sulfates in the Sodium Thiosulfate solution break down 
into sulfides which then cause cracking in sensitized stainless steel welds. During the early 1970s, ANO-1 and other B\&W plants with Sodium Thiosulfate Tanks had cracking problems in thin-wall stainless steel piping systems. These results were reported to the NRC who then initially issued IE Circular 76-06 and later issued IE Bulletin 79-17.

The SFP System also received a visual (VT-2) inspection to determine if any other IGSCC cracks existed. One indication was found on the body of valve SF-8B. It is a through-wall seepage, but is not located in the weld or heat-affected zone. Therefore, the seepage is probably not caused by IGSCC, but may simply be a casting defect in the valve body. Another Condition Report (CR-1-92-0077) has been generated to track this indication. This minor seepage can be repaired in a non-outage timeframe and poses no reactor safety or spent fuel pool cooling problems.

\section{Pure Water Stress Corrosion Cracking (PWSCC)}

Other augmented examinations occurred during 1R10. One of these involved an ultrasonic examination of a repair weld installed during 1R9. When ANO-1 was heating up at the end of 1R9, a leak was detected in one of the three upper level taps on the Pressurizer. The level tap is a 1-inch Inconel pipe inserted through a drilled hole in the side of the Pressurizer. The Inconel pipe is secured in place with a single weld on the inside diameter of the Pressurizer. After discovery of the leak, the unit was shut down and cooled down in order to repair the weld. Rather than go inside the Pressurizer, a repair weld was installed on the outside. In making this repair, the Inconel pipe had to be cut off within the Pressurizer wall and a new section of pipe welded in place with the exterior repair weld. A gap of approximately 0.060 -inch had to be left between the old and new sections of piping. This gap could allow borated water to come in contact with the carbon steel Pressurizer wall. Even though calculations qualified the repair until 1R11, ANO committed to perform an ultrasonic examination of the suspect area during $1 R 10$ to determine if any corrosion of the base material was taking place. This examination was performed by SWRI personnel and witnessed by ANO NDE personnel. No corrosion was detected during the operating cycle between $1 R 9$ and $1 R 10$. The Pressurizer upper level tap repair weld is tracked in the ISI Program as A-10173. The SwRI report is filed in the ANO Calc Room as report number 91-R-1017-02.

The root cause of the cracked wold is presently believed to be Pure Water Stress Corrosion Cracking (PWSCC), which is a cracking mechanism that can attack Inconel materials in a very pure water environment such as the pressurizer steam space in the Reactor Coolant System (RCS). In order to determine if any other Inconel materials in the RCS are experiencing cracking problems, another augmented program was performed during 1R10. Ten areas on the Pressurizer that contain Inconel, including the repair weld, were visually (VT-2) inspected after the plant had been heated up to normal operating pressure and temperature at the end of the outage. No leakage was detected. This same exam is scheduled to be repeated each outage for the near future. 


\section{Other Pipina Weld Indications}

Additional stainless steel piping cracks were found near the end of the refueling outage. Workers in the Reactor Building noticed that one of the welds in the Pressurizer Safety Valve Discharge lines ("tailpipe") appeared to be dripping water. The horizontal runs of piping on top of the Pressurizer were ultrasonically examined. Five of the 19 welds were found to have crack-like indications. Consequently, the horizontal runs of piping on both safely valve discharges were replaced with new piping. One of the cracked welds has been sent to SwRI for metallurgical evaluation to determine the root cause of the cracking. The evaluation is currently underway. It should be noted that although this safety valve discharge piping was originally built to ASME Class 2 standards, it does not have a nuclear safety function. However, the piping will be inspected in the future as part of the augmented ISI Program. This activity is also being tracked by CR-1-92-0244.

\section{Reactor Coolant Pumpe "A" and "B" Re-examinations}

During provious outages, flaws were detected in the casing welds of Reactor Coolant Pumps (RCPs) A and B. Per requirements in Section XI of the ASME Code, these flaws must be reexamined three times in the ten years following their discovery. These flaws, which are believed to be slag inclusions left over from the original fabrication of the pumps, were reexamined during this refueling outage. The examinations were performed by B\&W using an improved version of the same ultrasonic equipment utllized several outages ago to find and size these indications. The inclusions did not grow in size from the previous inspections performed during 1R8. In fact, due to the refinements made in the UT equipment, the slag inclusions appeared to shrink in size. From this examination, it is concluded that the RCP casing welds remain in a satisfactory condition. These exeminations are contained in the ISI Program and in this report as 43-001A, 44-001, 44-001A, and 44-002.

\section{Reactor Coolent Pump "D" Fluwhed}

During the coast-down from power to the refueling outage, the bearings in RCP D were damaged. Consequently, during the outage the pump and motor were disassembled. Since ANO-1 has a Tech Spec requirement to perform a ten-year examination on the RCP Flywheels, the flywheel on RCP D was examined while the motor was disassembled and sitting on the motor stand. The motor stand provides better access to the flywheel and therefore a more thorough exam can be performed. The flywheel received an ultrasonic and a magnetic particle (MT) exam. The examinations revealed no recordable indications. 


\section{Reactor Coolant Pump "D" Casina Welds}

ANO-1 committed to the NRC in a letter dated October 27, 1988 (1CAN108805) to radiograph $C$ and $D R C P$ casing welds any time that either pump is disassembled. However, since RCP D was not planned to be disassembled, but rather discovered during the outage to be damaged, it was decided that the unexpected radiography would be a hardship on the plant. At the time of the outage, ASME had recently published Code Case N-481 which allows a nuclear plant owner to substitute an engineering evaluation for the radiographic inspection. ANO approached the NRC to obtain approval of the use of the Code Case. The NRC granted approval for the use of the Code Case for 1R10. The engineering evaluation was performed by a contractor, Structural Integrity Associates, with assistance by ANO personnel. Code Case N-481 was submitted to the NRC after the outage in letter dated June 12, 1992 (1CAN069201). If the NRC approves of the conclusions drawn in the Code Case, then all future radiographs of the RCP casing welds on all four RCPs will also be deleted as stated in ANO letter 1CAN069201.

\section{Beactor Pressure Vessel Studs and Nuts}

Magnaflux, a manufacturer of magnetlc particle testing (MT) materials, issued a recall notice in 1991 to their customers. Some of the eerosol cans of fluorescent MT materials may not have contained the proper amounts of suspended solids. ANO-1 had used some of the questionable materials during the previous outage, $1 R 9$, on 20 Reactor Pressure Vessel (RPV) studs and 10 RPV nuts. These studs and nuts were reexamined during $1 R 10$ using now MT materials from Magnaflux. In addition, a magnetic field indicator, sometimes referred to as a "pie gauge", was utilized to verify both field strength and direction. The examinations revealed no recordable indications. This re-examination was tracked by CR-C-91-0102. 


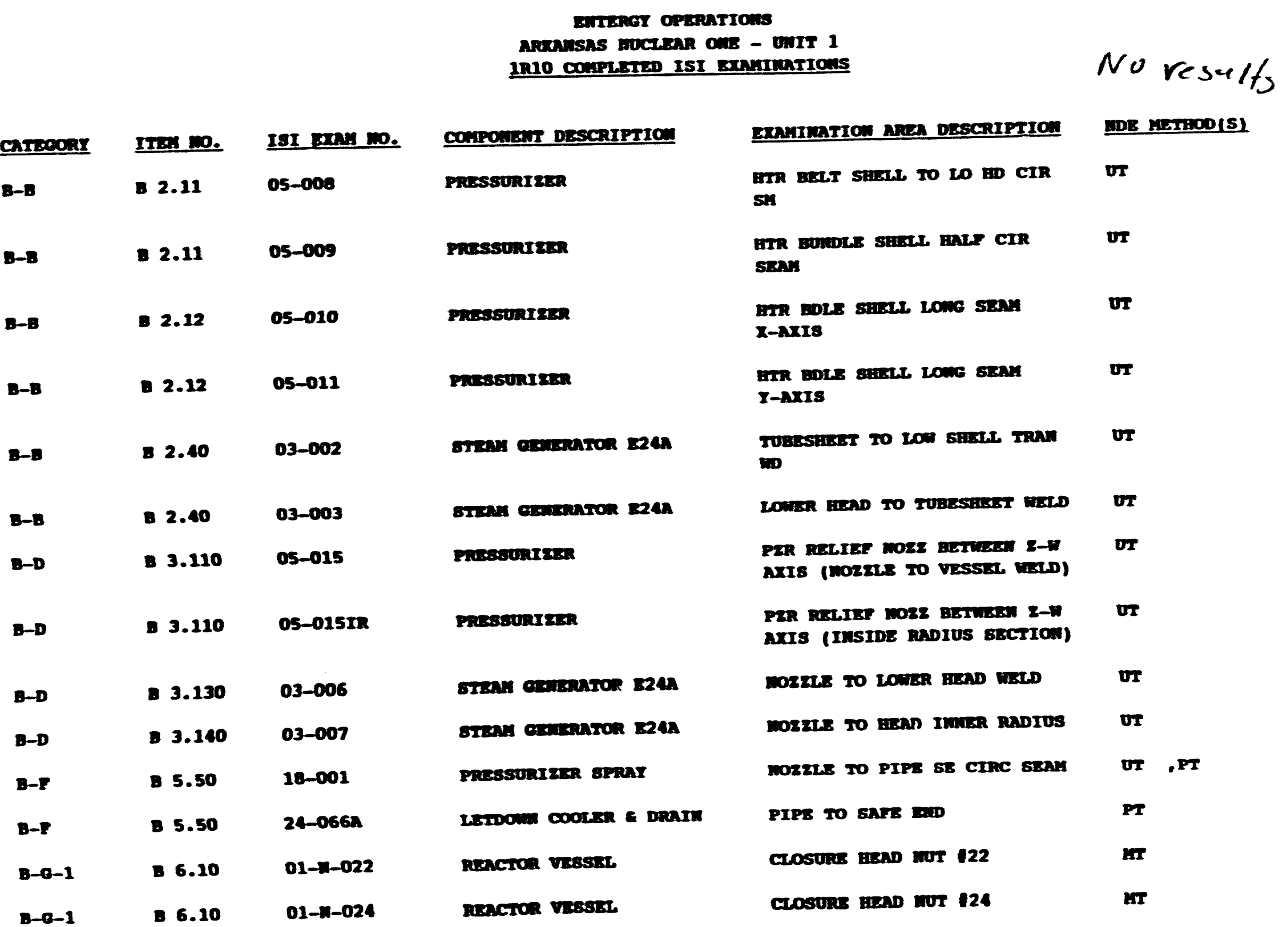


Plant D

INSERVICE INSPECTION REPORT

UNIT 1 CATAWBA 1992 REFUELING OUTAGE 6

Location: 4800 Concord Road, York, SC 29745 NATIONAL BOARD NO. 130

COMMERCIAL SERVICE DATE: JUNE 29, 1985

Owner: Duke Power Company $422 \mathrm{~S}$. Church St. Charlotte, NC 28201

Revision 0

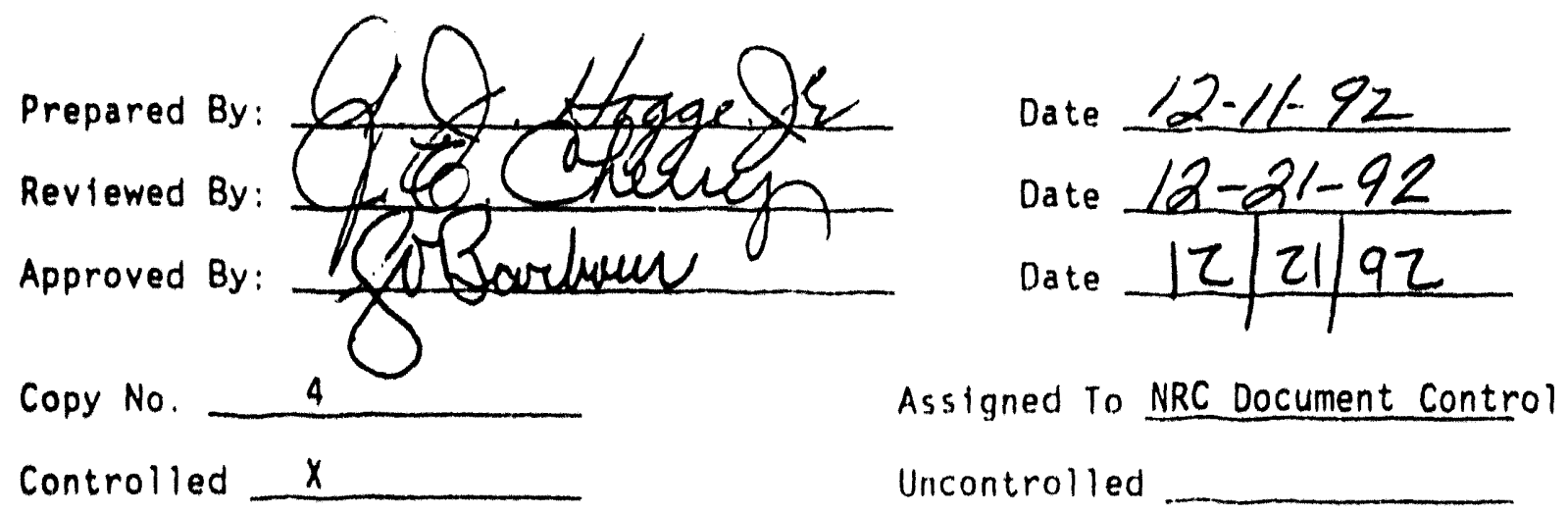

$C-37$ 
TABII OF CONIENTS

Sectlon

It le

Reviston

1. Summary of Inservice Inspection

11

2. Status of Required Inspections il

3. Final Inservice Inspection Plan for Outage $6 \quad$ "

4. Results of Inspections Performed During Outage 6 II

5. Class 1 Inspection Results II

6. Class 2 Inspection Results

7. Augmented Inspection Results 0

8. Personnel, Equlnment, and Matertal Certifications

9. Problem Investigation Reports "

10. Reference Documents "

11. Class 1 and 2 Repairs and Replacements 1 


\subsection{Summary of Inservice Inspection}

This report describes the Inservice Inspection of Duke Power Company's Catawba Nuclear Station Unit 1 during the 1992 Refueling Outage (also referred to as Outage 6 , which is in the Third Inspection Period of the First Inspection Interval).

Included in this report are the final Inservice Inspection Plan, the inspection results for each item, a summary for each category of examination and corrective action taken when unacceptable conditions were found. In addition, there is a section included for repairs and replacements required since June 9, 1991.

\subsection{Class 1 Inspection}

The Class 1 Inservice Inspection included examinations on the Reactor Vessel CRD Housing Welds, Steam Generator 1A Channel Head to Tubesheet Weld and on Pressurizer Safety Nozzle To Safe End Butt Welds. Examinations were performed on Class 1 Dissimilar Metal Butt Welds of the Upper Head Injection System, and on circumferential butt welds in the Reactor Coolant (NC), and Safety Injection (NI) Systems. Also, examinations were performed on Reactor Coolant Pump 1C Main Flange Bolting and 1NC-27 Valve Body Weld.

Visual examinations were performed on the Class 1 Pressure Boundary during System Leakage Tests. Reactor Coolant Pumps 1A, 1B, IC and 1D Flange, Reactor Coolant Pump IC Seal Gland and Seal Housing Bolts, Valves $1 N C-1,1 N C-2$ and $1 N C-3$ Studs and Nuts and the internal surfaces of Valves $1 N C-27$ and $1 N I-29$ also were examined. In addition, visual examinations were performed on Class 1 Component Supports of Reactor Coolant (NC), Residual Heat Removal (ND), Safety Injection (NI) Systems and on Pressurizer Support Skirt, Support Lugs, Upper Support and Lower Support Frame.

The Inconel 600 tubing in Steam Generators $1 \mathrm{~A}, 1 \mathrm{~B}, 1 \mathrm{C}$ and 10 was inspected by eddy current during Outage 6 . The results are shown in the Catawba Unit 1 July 1992 Refueling Outage Eddy Current Examination Report.

Reportable indications were found on the Class 1 Inspections shown in this section. Inspecion and evaluation data for each reportable indication is found in the Catawba Unit 1 July 1992 Refueling Outage Eddy Current Examination Report.

A detailed description of each inspection is found in the final Inservice Inspection Plan in Section 3 of this report. Results of each examination are found in Section 4. 


\subsection{Class 2 Inspection}

The Class 2 Inspections included examinations on RHR Heat Exchanger 1A Inlet Nozzle "A," and Outlet Nozzle "B" Nozzle to Shell Welds, Steam Generator $1 B$ Main Steam Nozzle to Upper Head Weld and Steam Generator 10 Auxiliary Feedwater Nozzle to Shell Weld. Examinations were performed on circumferential butt welds of the Auxiliary Feedwater (CA), Main Steam Supply to Auxiliary Equipment (SA), Main Steam (SM) and Main Steam Vent to Atmosphere (SV), Main Feedwater (CF) and Safety Injection (NI) Systems. Examinations were performed on piping integrally-welded attachments of Main Feedwater (CF) System.

Visual examinations were performed on the Class 2 Pressure Boundary during System Functional Tests. Also, visual examinations were performed on Class 2 Component Supports of Auxiliary Feedwater (CA), Main Feedwater (CF), Refueling Water (FW), Safety Injection (NI), Main Steam Supply to Auxiliary Equipment (SA) and Main Steam (SM) Systems.

A detailed description of each inspection is found in the final Inservice Inspection Plan in Section 3 of this report. Results of each examination are found in Section 4.

\subsection{Augmented Inspection}

Augmented Inspections at Catawba 1 consisted of Reactor Coolant Pump Flywheel examinations, Steam Generator Tubing examinations, Pipe Rupture Protection examinations, and Thermal Stress Piping examinations. A detailed description of each examination is found in the final Inservice Inspection Plan in Section 3 of this report. Results of each examination are found in Section 4.

\subsection{Alternate Inspection}

No alternate examinations were performed during Outage 6 .

\subsection{Identification Numbers}

Owner: Duke Power Company, 422 S. Church Street, Charlotte, NC 28201 Plant: Catawba Nuclear Station, 4800 Concord Road, York, SC 29745 Plant Unit: 1

Owner Certification of Authorization: N/A Commercial Service Date: 6/29/85 


\subsection{Status of Required Inspections}

The completion status of inspections required by the 1980 ASME Section XI Code, including addenda through Winter 1981, is summarized in this section. The requirements are listed by the ASME Section XI examination category as defined in Table IWB-2500-1 for Class 1 Inspections and in IWC-2500-1 for Class 2 Inspections. Augmented inspections are also included.

\section{Class 1 Inspections}

jection

$X I$

Gategory Description

Inspections Required

$B-A$

$B-B$

B-D

$B-E$

$B-F$

$B-G-1$

$B-G-2$
Pressure Retaining Welds in Reactor Vesse 1

14 Welds

8 Welds

Pressure Retaining

Welds in Vessels Other than Reactor Vesse 1

Full Penetration Welds of Nozzles in Vessels

Pressure Retaining Partial Penetration Welds in Vessels

Pressure Retaining Dissimilar Metal Welds

55 Welds

46 Welds
Pressure Retaining 370 Items

Bolting Greater

Than 2 Inch

Diameter
Inspections Percentage Deferral Completed Completed Allowed

2.5 Welds

$17.85 \%$

Yes

$75 \%$

No

36 Inspections

18 Inspections

$50 \%$ Partial

55 Weids

$67 \%$

No

32.5 Welds

$70.65 \%$

No

250 Items

$67.56 \%$

Yes
Pressure Retaining Bolting 2 Inches and
*59 Connections
42 Connections
$71.18 \%$
No

\footnotetext{
*Total connections includes CRDMS that are disassembled
} 


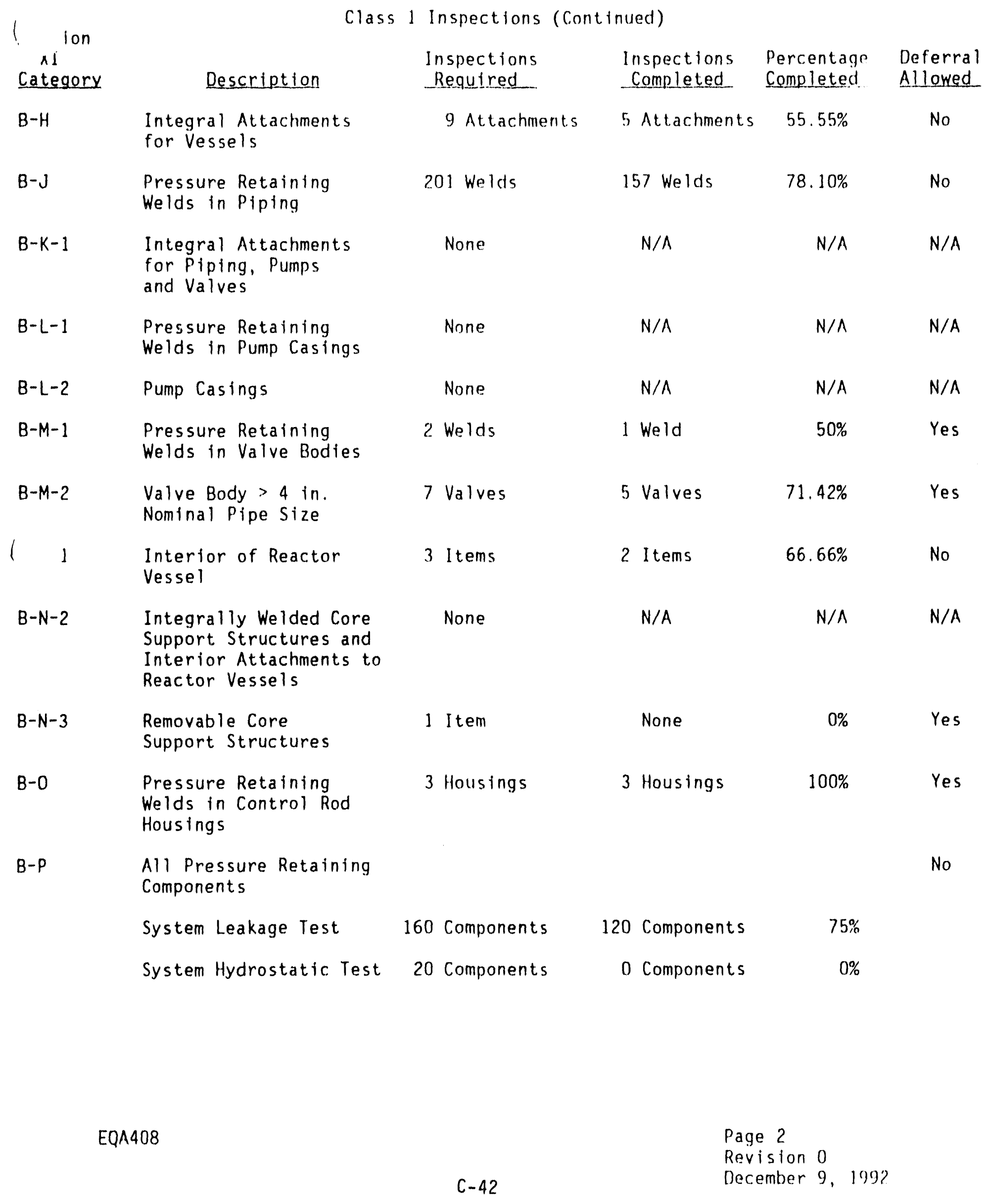




\section{Class 2 Inspections}

secution

Sategory

$\hat{\imath}-A$

$C-B \quad$ Pressure Retaining Nozzle Welds in

Vessels

C-C Integral Attachments

for Vessels, Piping,

Pumps and Valves

C-D Pressure Retaining

Bolting Exceeding

2 Inches in Diameter

$C-F$

Pressure Retaining Welds in Piping

Pressure Retaining Welds in Pumps and

Valves

$\mathrm{C}-\mathrm{H}$

All Pressure Retaining

Components

System or Component

Functional Test

System Hydrostatic Test

F1.02
Class 2 Component

Supports
Inspections Required

9 Welds

6 Welds

33 Attachments

None

$N / A$

$N / A$

N/A

343 Welds

25 Welds

15 Welds

$60 \%$

No

No

70 Components

90 Components

0 Components

437 Supports

568 Supports

69 Components

$98.57 \%$

$0 \%$

76. $93 \%$

No 


\section{Augmented Inspections}

\section{Description}

Reactor Coolant Pump Flywheels:

Steam Generator Tubes on Preheater Section

Main Steam Pipe Rupture Protection

Containment Spray System

Thermal Stress Piping

Safety Injection Accumulator Nozzles

\section{Percentage Complete}

$100 \%$ of Technical

Speciffcations met

$100 \%$ of requifrements for Outages $1,2,3,4,5$ \& 6.

$100 \%$ of requirements for Outages $1,2,3,4,5$ \& 6.

$100 \%$ of requirements for Outages $1,2,3,4,5$ \& 6.

$100 \%$ of requilrements for Outage $3,4,5 \& 6$.

$100 \%$ of requirement for Outages $5 \& 6$. 
3.0 Einal Inservice Inspection Plan for Outage 6

The final ISI plan presented in this section lists all examinations credited for Outage 6 at Catawba 1. This Includes ASME Sectlon XI Cias 1,2 and augmented inspections required by the plant technical specifications.

The information shown below is a fleld description for the reporting format included in this section of the report:

Item Number

= ASME Section XI Tables IWB-2500-1 (Class 1), IWC-2500-1 (Class 2), IWD-2500-1 (Class 3). IWF-2500-1 (Class 1 , Class 2 and Class 3 ), and Augmented Requirements

I0 Number

$=$ Unique Identification Number

Drawing Number

= Location and/or Detall Drawing

Locs.

= Location

Insp. Req.

= Examination Technique - Magnetic Particle. Dye Penetrant, etc.

Proc. Numbers

= Examination Procedures

Material Type/Grade

= General Description of Material

Diam./Thlck

= Diameter/Thickness

Callb. Block

$=$ Calfbration Block

Comments

= General and/or Detall Description 


\subsection{Valves}

Twelve (12) Studs and Nuts on Valves $1 N C-1,1 N C-2$ and $1 N C-3$ recelved a visuai examination. No reportable conditions were found.

Valve body weld on Valve INC-27 recelved an Ultrasonic examination. No reportable indications were found.

The internal surface of valves $1 N C-27$ and $1 N I-129$ received a visual examination. No reportable conditions were found.

\subsection{System Leakage_test}

The Class 1 Pressure Boundary was subjected to a system leakage test as required by ASME Section XI, Article IWB-5000. No reportable conditions were found.

\subsection{Class 1 Repairs and Replacements}

Repairs and replacements for work performed from June 10, 1991 to October 15, 1992 are itemized in Section 11 of this report. 


\subsection{Class 2 Inspection Results}

Inspections were performed during Outage 6 on RHR Heat Exchanger 1A, Steam Generators $1 B$ and $1 D$, piping integrally-welded attachments on Main Feedwater (CF) System and on Piping Welds of Auxlliary Feedwater (CA), Main Steam Supply to Auxll lary Equipment (SA), Main Steam (SM), Ma in Steam Vent to Atmosphere (SV). Main Feedwater (CF) and Safety Injection (NI) Systems. Examinations were also performed on Component Supports.

\subsection{Residual Heat Remeval Heat Exchanger and Steam Generators}

Residual Heat Removal Heat Exchanger $1 A$ Inlet Nozzle $A$ and Reinforcing Pads, Outlet Nozzle $B$ and Reinforcing Pads to Shell Welds recelved a dye penetrant examination per Problem Investigation report \#0-C91-0439. No reportable indications were found.

Steam Generator 1B Main Steam Nozzle to Upper Head Weld and Steam Generator 10 Auxiliary Feedwater Nozzle to Shell Weld recelved a magnetic particle examination per Problem Investigation Report \#0-C910439. No reportable indications were found.

A copy of Problem Investigation Report \#0-C91-0439 is included in Section 10 of this report.

\subsection{Ploing}

Welds one-half inch and less nominal wall thickness:

Twenty-six (26) circumferential welds and one (1) longltudinal weld received a magnetic particle examination. No reportable indications were found.

Welds greater than one-half inch nominal wall thickness:

Twelve (12) circumferential welds received an ultrasonic and a magnetic particle examination. Thirteen (13) circumferential welds recelved an ultrasonic and a dye penetrant examination. Three (3) circumferential welds recelved a radiographic and a magnetic particle examination. No reportable indications were found.

Piping Integrally-Welded Attachments:

Three (3) Integrally-welded attachments on Main Feedwater (CF) System received a magnetic particle examination. No reportable indications were found.

\section{3 Component Supports}

Sixty-one (61) Class 2 Component Supports received visual examination as required by ASME Section XI, Article IWF-2000. No reportable conditions were found. 


\subsection{Results of Inspections Performed During Dutage 6}

The results of each inspection shown in the final ISI Plan (Section 3 of this report.) are included in this section. The completion date and status for each inspection are shown. All inspections revealing reportable indications are described in further detall in Section 5, 6, or 7 as applicable.

The information shown below is a fleld description for the reporting format included in this section of the report:

I tem Number

I0 Number

Inspection Date

Inspection Status

$\begin{array}{ll}\text { CLR } & =\text { Clear } \\ \text { REC } & =\text { Recordable } \\ \text { REP } & =\text { Reportable }\end{array}$

Inspection Limfted

$\begin{aligned} L & =\text { Limited } \\ & =N_{0}\end{aligned}$

Geo. Ref.

Comments
= ASME Section XI Tables IWB-2500-1 (Class 1). IWC-2500-1 (Class 2), IWO-2500-1 (Class 3), IWF-2500-1 (Class 1, Class ? and Class 3), and Augmented Requirements

- Unique Identification Number

= Date of Examination 
PRosenas: MISTm surstos

FILE: Coons

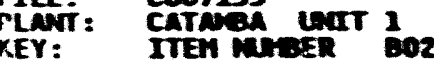

aniry ore posen conpar

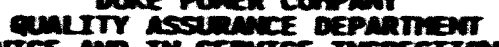

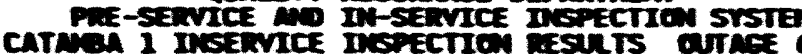

PATE $127 \mathrm{I}^{\prime}$

ITEA Mriber

Date

Inspection mspection ce

IIIITE Cof. conans

Iren naspes

1sen-01-02

$07 / 2692$

cir in:

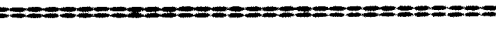

ș 


\subsection{Sxstem or Component Eunctional Test}

Class 2 Functional Tests were performed as required by ASME Section XI, Article IWC-5000. No reportable conditions were found.

6.5 Class 2 Repairs ind Replacements

Repalrs and replacements for work performed from June 10, 1991 to

October 15, 1992 are itemized in Section 11 of this report. 


\subsection{Augmented Inspection Results}

Augmented inspections were performed on Reactor Coolant Pump Flywheels, Steam Generator Preheater Sertions. Main Steam Systen for Pipe Rupture Protection and on Thermal Stress Piping (NRC. Bulletin 88-08).

\subsection{Reactor Coolant Pump Flywheels}

Reactor Coolant Pump $1 \mathrm{~A}$ Flywheel recelved an ultrasonic examination. Reactor Coolant Pump $1 B$ Flywheel recelved an ultrasonic and a magnetic particle examination. No reportable indications were found.

\subsection{Steam Generator Iube Preheater Section}

All four steam generators were examined by eddy current methods. Results and evaluation data for examinations are shown in the Catawba Unit 1 July 1992 Refueling Outage Eddy Current Examination Report.

\subsection{Pipe Rupture Protection}

Eleven (11) welds on the Main Steam (SM) System recelved an ultrasonic and a magnetic particle examination. No reportable indications were found.

\subsection{Thermal Stress Piping}

Nine (9) welds and seven (7) bends were examined by ultrasonics on Reactor Coolant (NC) System, as required by USNRC Bulletin 88-08. No reportable indications were found. 


\subsection{Problem Investigation Reports}

A copy of each Problem Investigation Report resulting from reportable items, originated against scheduled inservice inspections performed during Outage 6 , is included in this section. All were resolved and found acceptable before returning Unit 1 to service. The following Problem Investigation Reports were issued.

P.I.R NO.

Description

Date Issued

None 


\subsection{Reference Documents}

The following reference documents apply to the inservice inspection performed during Outage 6 at Catawba 1:

- Duke Power Company Problem Investigation Report 0-C91-0439

- Duke Power Company Technical Documentation \#90-1 dated March 6, 1990 
CATAWBA NUCLEAR STATION PROBLEM INVESTIOATION PROCESS PROBLEM IDENTIFICATION FORM

$$
\begin{aligned}
& \text { monere: } \quad 0-091-0439 \\
& \text { mo smens na: C9L-087-0 }
\end{aligned}
$$

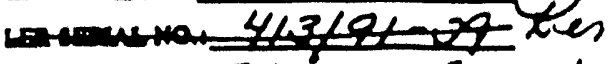

$$
\begin{aligned}
& \text { Itation leport }
\end{aligned}
$$

I. Problem Inveatigation: (See Attached)

Ocourred-Time/Dak:

Diecovend-Time/Date

Unik(s) Unit(0) Stum a Tim Problon Occurnd:

Location of Probleme:

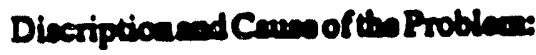

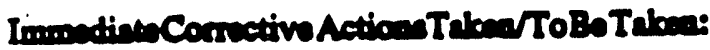

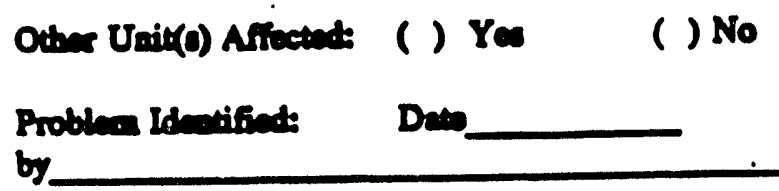

II. Sipifican (See Atrached)

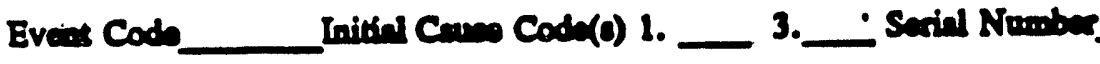

2. 4.

Is this problon armificand ( ) Yw

( ) No : ( ) Dalus

Repocaible suction(o) 1. 2. 3. 4.

Servond By: Dewas

Reondar

\begin{tabular}{|c|c|c|c|c|c|c|c|}
\hline DNMUL & onvonator & Juclenn & BCFutrell & 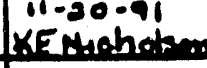 & LR weedlus & EMCadde & Jisforbes \\
\hline 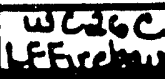 & & & CSRE & NRC & $E G(2)$ al & ITPYherell & SRFrue \\
\hline PQNAY & onconsation & & & & & & \\
\hline & & & ${ }^{\circ}$ & & & & \\
\hline & & & & & & & \\
\hline
\end{tabular}

\section{DSTREUTrowe}


- Problem ID

CATAWBA NUCLEAR STATION

PROBLEM INVESTIGATION PROCESS

PROBLEM IDENTIFICATION FORM

scurred TIme/Date UNKN

/ 1

Disc Time/Date

$09 / 30 / 91$

$n+t(s) \quad 0$

Status at Time Occurred U1M1,U2EOC4

scation of Problem CNS

ascription c Cause:

I a result of. ONS PIR 4-091-0093, a data review of the Catawba Nozzle

o Vessel Welds revealed that the following 1 tem numbers were

nspected using the 1ncorrect acceptance standard: Unit 1

$32.011 .001,002.011 .002,002.021 .004 A$, and $002.021 .012 \mathrm{~A}$, Undt 2

$32.011-001,002.011 .002$ and $02.021 .051 \mathrm{~A}$

nmedlate Corrective Actlons:

re correct Unit 2 Inspections are belng done at 2 EOCA

m Ident1f1ed BY: RNGILEs Date $11 / 18 / 91$ Section NON

ce vther Units Affected? (Y/N) N

I. Signiflcance

vent code

nltlal Cause Code(s): Alb D1

erlal Number 91 NONO177

esponsible Section(8): QA

creened BY: GBROBINS Date 11/19/91

- the problem significant? 


\section{COMPLIANCB BVALOATION FORH}

$$
\begin{aligned}
& \text { PROBLEM DNVESTIOATION REPORT SERIAL NO.: } 0 \text { - } 091.0439 \\
& \text { LICENSE EVENT REPORT NO.: } 4 / 4 / 0 \text { tofthere } \\
& \text { C91-087. } \\
& \text { Station Report }
\end{aligned}
$$

III. COMPLIANCE FYALUATUON:

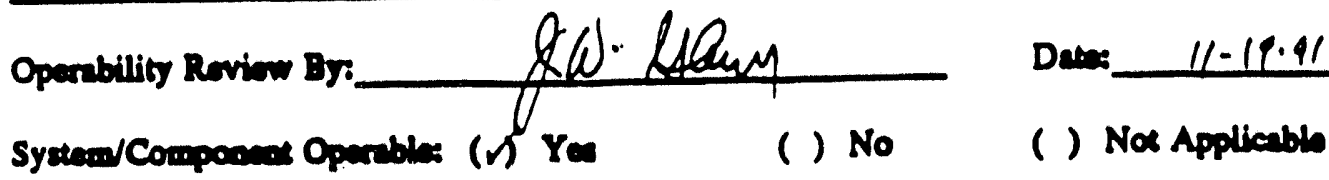

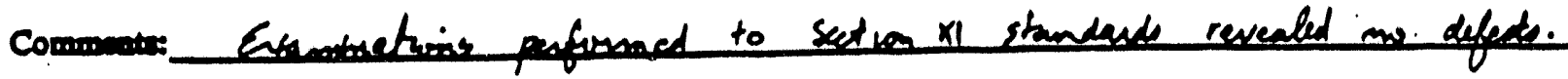

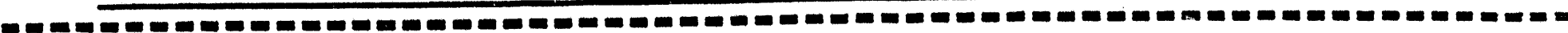

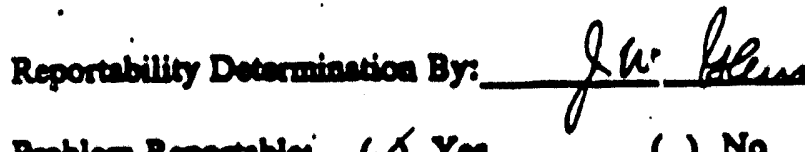

Problom Reportublex: (

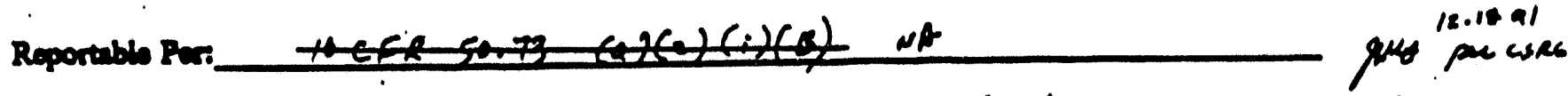

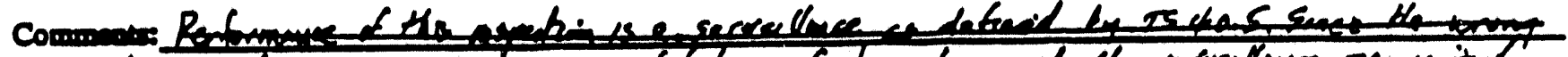

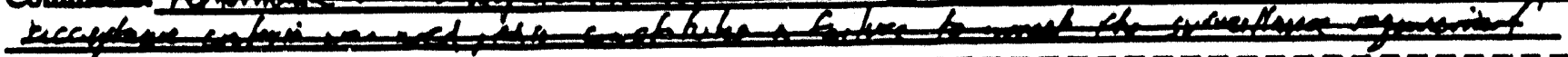

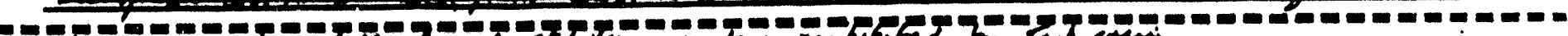

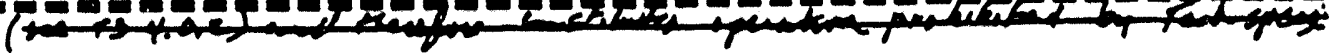

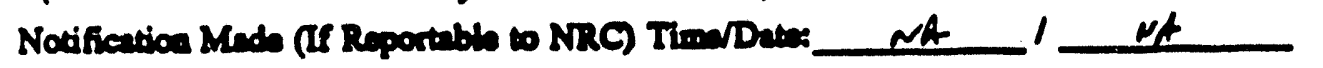

NRC Cootaction: 14

DPC Contunetor.

Nr

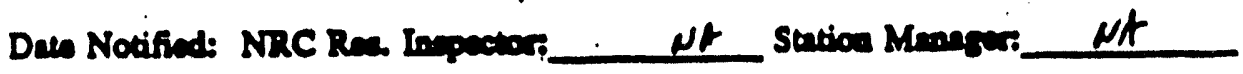

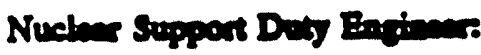

St

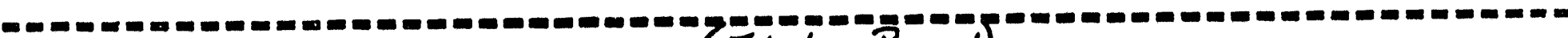

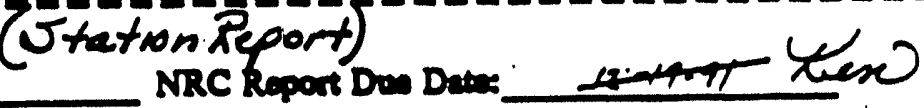

Invectigation Arapod To csea

Dace

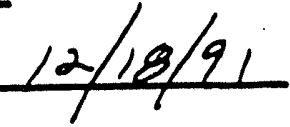

Dute Dus to Complinases Arier Evaluetion:

Reportublo Eveot PLR Reviow:

Complimos Mrangre

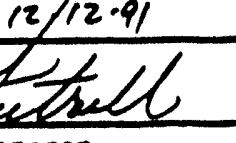

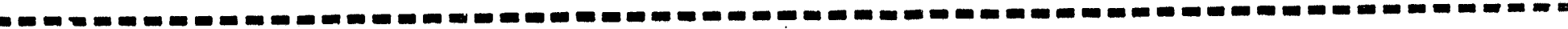

Upper Tier Evaluation Ascipod Tos

NR

Comonatr:

$N A$ 
December 18,1991

MEMO TO FILE

SUBJECT: Catawba Nuclear Station

Station Report

IIR C91-087-0; PIR 0-C91-0439

File NO: $\mathrm{CN}-815.04$

The attached report is being submitted as a station Report concerning USE OF INCORRECT ACCEPTANCE STANDARDS DURING WEID INSPECTIONS DUE TO DEFECTIVE PROCEDURES.

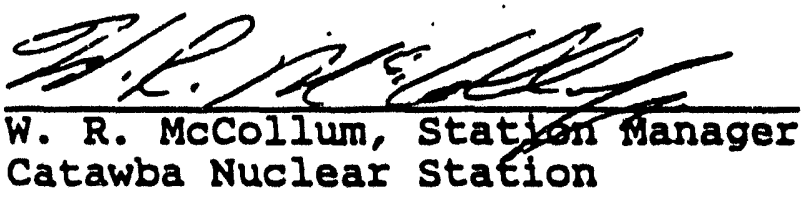

ken:STATION.RPT

XC: G. B. Robinson

J. W. Glenn

S. T. Rose

IIR C91-087-0 


\author{
DUKE POWER COMPANY \\ CATAWBA NUCLEAR STATION \\ PROBLEM INVESTIGATION REPORT NO: 0-C91-0439
}

USE OF INCORRECT ACCEPTANCE STANDARDS DURING WELD

INSPECTIONS DUE TO DEFECTIVE PROCEDURES

\title{
ABSTRACT
}

On November 18, 1991, Unit 1 was operating in Mode 1, Power Operation, and Unit 2 was in refueling outage 2EOC4. A station Quality Assurance (QA) Specialist was reviewing weld inspection data, due to problems discovered with weld data at the Oconee Nuclear Station, when it was determined that the wrong acceptance standards had also been applied to the Catawba inspections. Under Technical Specification 3/4.0, Limiting Conditions For Operation And Surveillance Requirements, in-service inspection and testing of ASME Code Class 1, 2, and 3 equipment shall be performed in accordance with the ASME code, or as specified by Nuclear Regulatory Commission requirements. Inadvertently, the procedures directing the weld exams allowed application of less stringent acceptance criteria. A review of weid inspection data revealed that no flaw indications were present on the subject welds. Regardless of the applied acceptance criteria, inspectors record any relevant flaw indications on the weld inspection data sheets. This event has been attributed to Defective Procectures. The applicable Unit 2 welds have been re-inspected with satisfactory results. The remaining Unit 1 welds will be re-inspected during 18OC6. Appropriate inspection procedures were revised with future revisions pending. Training on the procedure changes will be provided for the appropriate inspectors. This report is being submitted as a station Report. 
PIR 0-C91-0439/Station Report

Page 2

\section{BACKGROUND}

Technical Specification ( $T / S$ ) 4.0.5 requires in-service inspection of ASME Code Class 1, 2, and 3 components and in-service testing of ASME Code Class 1. 2, and 3 pumps and valves to be performed in accordance with section XI of the ASME Boller and Pressure Vessel Code, and applicable Addenda, as required by $10 \mathrm{CFR}$ Part 50 , Section $50.55 \mathrm{a}(\mathrm{g})$, except where specific written relief has been granted by the commission.

Per the Duke Power ASKR Section XI Manual, Quality Assurance (QA) is responsible for weld Inspection activities. All inspections shall meet the requirements of a ASKE Section XI specified or as allowed in specific Code Cases or Rellef Requesta. Catawba's In-service Inspection Plan utilizes the 1980 Edition of ASKE Code Section XI, with Addenda through WInter 1981.

Examination Categories for nozzle to vessel welds are given in Table IWB-2500-1 of Section XI, Art1cle IWB-2000. At least 16\% of the nozzle to vessel welds shall be examined by the end of the first inspection period (first 3 years of the first 10 years of operation), and a minimum of 50 at the end of the second period (years 4-7).

The General office (GO) QA ISI Speciallst who oversees Catawba's ISI Program uses the information obtained from ASKE Section XI, and other sources, and works with the QA Catawba S1te ISI Coordinator to establish the timetables for all welds that require in-service inspection at Catawba.

The examination techniques used for in-service inspections include Radiographic (RT), Ultrasonic (UT), Magnetic Particle (MT), Iiguid Penetrant (PT), Eddy Current, and V1sual examination methods. For all examinations, both remote and manual, speciflc procodures are prepared describing the equipment, inspection technique, operator qualifications, calibration standards, flaw evaluation, and records. The In-service Inspection Plan for Unit 2 was submitted on August 18, 1986. The In-service inspection interval is every 10 years ( 4 total). Detailed inspection listings and scheduling are contained within the Catawba In-service Inspection Plan.

The Non-Destructive Examination procedures (NDE-25 and NDE-35) states "For Class 1 or Class 2 components where acceptance standards are not specified. one of the following acceptance standards shall be used:

(1) ASME Section III edition applicable to the construction.

(2) ASKE Section XI Class 1.

(3) The original construction code (excludes NDE-35). 
rLK U-LYL-U4Jy/SLALION keport

Pag̨e. 3 .

The Inspections involved with this incident are; Residual Heat Removal Heat Exchanger $(\mathrm{Hx})$ 1A/2A Inlet and Outlet Nozzles; Steam Generator 1B Upper Main Steam Nozzle; Steam Generator 1D Auxillary Feedwater Nozzlo To Shell; and the Safety Injection Accumulator Tank 2B outlet Nozzle.

\section{EVENT DESCRIPTION}

On Septamber 9, 1991, an Oconee Nuclear Station (ONS) QA Specialist assigned to the General offlce was reviewing ISI data when it was discovered that a flaw Indication recorded during an inepection was initially determined to be acceptable. The dimensions of the llaw were recorded on the inspection data sheet were compared to the Inspection acceptance criterla. It was determined that the flaw was actually ungosepteble. It was concluded that the wrong accoptance criteria had been appiried to the Inspections that had been performad. ONs Problem Investigation Report (PIR) 4-091-0093 was Init1ated.

On November 18, 1991, Catawba QA performed a reviow of their ISI data recoryd for the nozzle to vessel welds in response to the ONS PIR. This revief revealed that the CN8 Inspections also amployed the wrong acceptance criteria.

The three Unit 2 welds were re-inspected using the correct acceptance criterla between November 19th and 20th. No flaw Indlcations exceeded the acceptable ilmits of the inspections.

The Unit 1 ND Hx welds were Inspected on November 27, 1991. No unacceptable indications were discovered. The Unit $18 / 6$ iB upper main steam nozzle and $8 / 0$ ID CA weld inspections have been scheduled for 18OC6.

\section{CONCLUSION}

This Incident is attributed to Defective Procedures because the procedures listed multiple acceptance criteria for the inspections.

The inftial nozzle to vessel weld inspections were performed using the wrong acceptance criteria because QA selected ASME section XI acceptance criteria for the inspections instead of the more stringent construction code standards.

A subsequent review of the weld inspection data sheets revealed that no flaw indications were observed by'the inspectors. Weld inspectors record any flaw indications ( $>1 / 16^{\prime \prime}$ ) regardless of the acceptance criteria 1 imits applied to the inspection. Therefore, it was determined that the welds inspected under the subject circumstances are acceptable under the criteria established from the construction code. 
PIR 0-C91-0439/Station Report

Page 4

Due to the problem discovered at ONS, NDE-25 and NDE-35 were revised on October 15, 1991, to require use of Appendix A (section 16.5.1 of NDE-25 and 13.4.1 of $\mathrm{NDE}-35$ ) to specify acceptance criterla when acceptance 8 tandards are not specifled for Clase I and II components. Further revisions to $\mathrm{NDE}-25$ and $\mathrm{NDE}-35 \mathrm{~W} 111$ add the requirement for documentation of any relevant indications regardlese that the indlcation does not exceed the applied accoptance criterla.

\section{CORRECTIVE ACTION}

SUBSEQUENY

1) The affected Unit 2 nozzle to vessel welds were re-Inupected using the proper accoptance criteria.

2) Unit 1 RHR HX IA nozzle to veseel welde ware re-Inopected using the proper accoptance criterla.

PLANRED

1) NDE-25 and NDE-35 w111 be rovised to require that all relevant Indicatione exceeding $1 / 16 "$ w111 be recorded.

2) QA Inspectors $W 111$ be tralned on solecting accoptance criteria for componente that do not have specifled standurds.

3) Unit $18 / 6$ IB Main steam nozzle to upper head weld will be re-Inspected using the pruper accoptance ciriterla.

4) Unit $18 / 0$ 1D Auxillary Feedwater nozzle to sholl weld w1ll be ro-inapected using the proper accoptance criterla.

\section{SAFETY ANALYSIS}

No flaw indications were detected during subsequent reinepections using the correct acceptance criteria. No adverse Impact was inilicted upon the performance or operability of the systems affected by this incident.

The health and safety of the public wore not affected by this incident. 


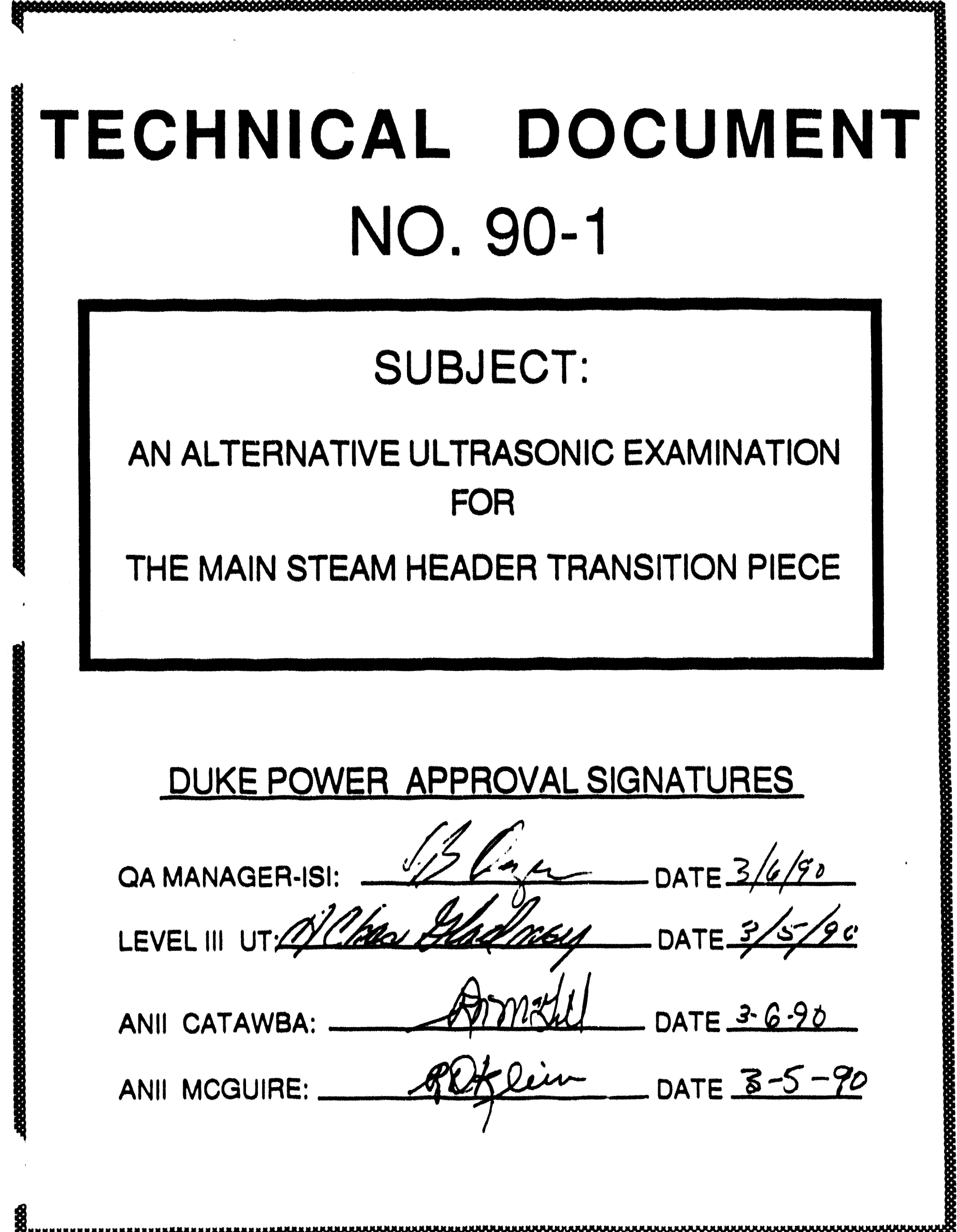


Technical Document 90-1

Main Steam Header Alternative

Examination Qualitication

March 1, 1990

\subsection{PURPOSE:}

This paper pertains to the qualification of an alternative ultrasonic technique that will be employed at both McGuire and Catawba Nuclear Power Stations. The component is the main steam system. The weld joint of import is the main steam header (1) 10 transition piece (2) weld (see figure \#1).

In accordance with Section XI of the American Society of Mechanical Engineers Boiler and Pressure Vessel Code (ASME), an alternate examination technique may be substituted for techniques specilled in the Code, provided that the Authorized Nuclear Inservice Inspector is satisfled that the results are demonstrated to be equivalent or superior to those of the specified method (see paragraphs III-1100 (d) and IWA-2240 for inore detall).

\subsection{BACKCBOUND}

Inservice examinations are conducted in accordance with the 1980 edition of ASME Seotion XI, including all addenda through Winter 1980 at the McGuire Nuclear Station. At the Catawba Nuclear Station, all inservice examinations are conducted in accordance with the the 1980 edition of ASME Section XI, including all addenda through Winter 1981. Appendix III, in both editions of above mentioned Codes, stipulates that an ultrasonic examination calibration block, for Class 1 and 2 ferritic piping, be of the same nominal diameter as the piping component to be examined.

Due to the unique design of the transition plece, locating representative material to produce a calibration standard of the same dimensions has not been possible to date. The transition piece tapers from a $10^{\prime \prime}$ outside dimension (O.D.), on the main steam header side, to 9.0" O.D. on the valve side. Ninety-six welds are of this configuration (forty-eight at each unit). The header side weld's O.D. varies from 11.5" to 12.0". 
Technical Document 90-1

Main Steam Header Alternative

Examination Qualification

March 1, 1990

\subsection{SUPPOSITION:}

The valve side of the transition piece calibration is established with a 9.0" O.D. calibration block. The supposition is that this calibration block will provide a examination sensitivity equivalent or superior to one that would be obtained from a calibration block designed to the specifications of the Code. This supposition is based on the following:

3.1 Due to the geometric configuration of the header to transition piece weld joint, the examination shall only be pertormed from the transition side of the weld.

3.2 The thickness of the 9.0" O.D. callbration block and the header side of the iransition plece are the same. Therefore, the callbration block reflector size and depth location requirements would be the same for a 12.0" O.D. calibration block as are in the 9.0" O.D. block.

3.3 The surface area of the 9.0" O.D. block would tend to reflect more of the sound transmitted from a given transducer than the surface area of a 12.0" O.D. block. This would allow less sound to reach the reflective surface of the calibration bock reflectors. This means that more gain would be required to obtain the same amplitude from the callibration reflectors in the 9.0" O.D. calibration block than 12.0" block. Therefore a calibration from the 9.0" O.D. block should provide a more sensitive examination.

\subsection{OUALIFICATION PROCESS}

The 9.0" O.D. callbration blocks from both the McGuire Nuclear Station (50249) and Catawba Nuclear Station (50356) were compared to a 12" O.D. calibration block (50252). All the calibration blocks are of the same thickness and contain the same 
Technical Document 90-1 Main Steam Header Alternative Examination Qualification March 1. 1990

\section{QUALIFICATION PROCESS (CONTU)}

size calibration reflectors. The only difference is block 50252 does not have a notch reflector. The same instrumentation (UT instrument, transducer, and cable) were utilized throughout the qualification process. Without changing the UT instrument settings, callbrations were constructed in accordance with the Babcock and Wilcox piping examination procedure $|S|-120$, revision 25 . Each calibration was documented and any deviations were noted (see Calibration Sheets 90-1A through 90-1F).

The comparisons were accomplished using a certified 2.25. $\mathrm{MHz}, .50^{\text {" diameter, }}$ transducer (32908) coupled to a $6^{\prime}$ microdot cable. The ultrasonic instrument was a Tokyo Kelki, model SM-100. No thermometer was used. The comparisons were performed in a environmentally controlled location. Each of the calibration blocks was in this environment 24 hours prior to the start of the comparisons and remained there throughout the process.

\subsection{BESULTS:}

The initial distance amplitude correction (DAC) curve was performed on the 9.0" O.D. calibration block 50356 using the side drilled holes. The I.D. notch was compared to this DAC curve. The notch is use to determine the calibration curve's sensitivity to I.D. surface initiated degradation. The DAC curve was 10 Decibels (dB) more sensitive than the notch at reference level. This means that the DAC curve's sensitivity is more than 3 times greater than the calibration sensitivity obtained from the notch. Without changing the sensitivity of the instrument, a calibration was established from the side drilled holes in the 12" O.D. block, 50252. The amplitude obtained from these reflectors was less than $2 \mathrm{~dB}$ greater than the reference level of block 50356 (The SM100 adds and subtracts gain sensitivity in 2 dB increments). Block 50252 does not have a notch, so no notch comparison was made. 
Technical Document 90-1

Main Steam Header Alternative

Examination Qualification

March 1, 1990

\subsection{RESULTS (CONT.):}

A calibration was then generated from the other 9.0" O.D. block, 50249. The DAC curve obtained was identical to the one obtained from the 12" O.D. block, 50252. It was not possible to measure the difference in sensitivity between these two calibration curves with the instrument control settings. A graph of all 3 DAC curves depicts these results in Figure No. 2. The I.D. notch was then compared to this DAC curve. The DAC curve was again $10 \mathrm{~dB}$ more sensitive than the notch at reference level.

DAC curves were generated on each calibration block in the axial and circumferential direction. In each case the calibration obtained from the DAC curve was at least $10 \mathrm{~dB}$ greater in sensitivity than the sensitivity obtained from the notch.

\subsection{CONCLUSION :}

The 9.0" O.D. calibration block can be used for the examination of both welds attached to the the transition piece on main steam at both the Catawba and McGuire Nuclear Stations. The difference in examination sensitivity using any of the three blocks was < $2 \mathrm{~dB}$. A $2 \mathrm{~dB}$ shange is recognized by Code and throughout the industry to be an insignificant change in a calibration sensitivity. In any case, calibration blocks 50356 and 50249 provided an examination sensitivity equal to or greater than that obtained from the 12" O.D. calibration block, 50252.

Using a calibration block that has no notch reflector for this comparison did not hinder the results. A DAC calibration obtained from side drill holes normally results in a more sensitive calibration than one obtained from a notch. In all cases where a notch was available the DAC calibration sensitivity was $10 \mathrm{~dB}$ more sensitive than that obtained from the notch reflectors. 
Technical Document 90-1

Main Steam Header Alternative

Examination Qualification

March 1, 1990

\subsection{CONCLUSION (CONT.):}

This comparison was performed with a .50 diameter $2.25 \mathrm{MHz}$ transducer. Since no other transducers were demonstrated, this alternative examination technique shall only be performed with the transducer frequency and size demonstrated.

This comparison shall not be used as a justification for any other alternative examination technique other than the main steam header to transition piece valve weld. 
(1) MAIN STEAM HEADER

(2) 10"X9" TRANSITION PIECE

(3) NOZZLE TYPE SAFETY VALVE (POP-OFF VALVE)

CROSBY REFRENCE DWG'S

SA-G-K56314 (10" OUTLET)

SA-G-K56315 (8" OUTLET)

FOR INFORMATION ONLY

İ

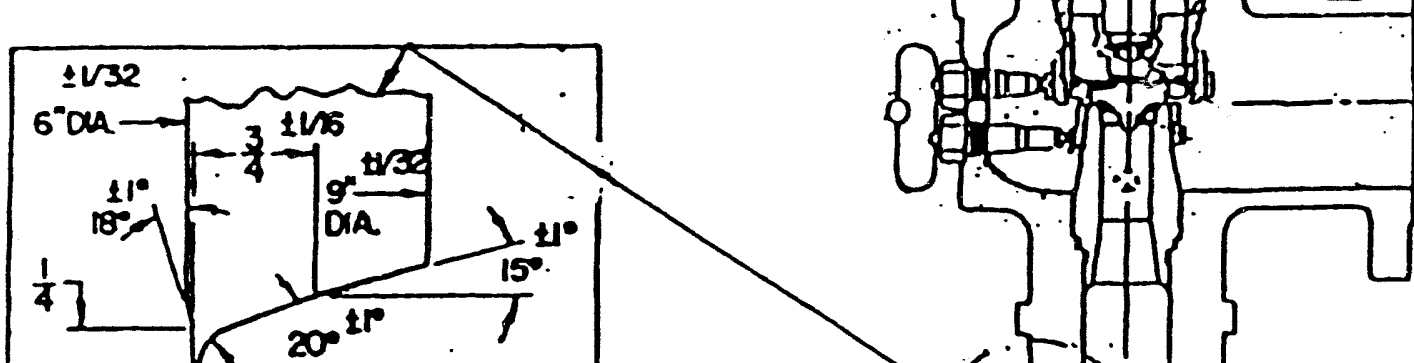

(1)

(1)

FIGURE \# 1

$\stackrel{0}{\circ}$ 


\section{CALIBRATION SHEET}

TIME: 8:00 HRS

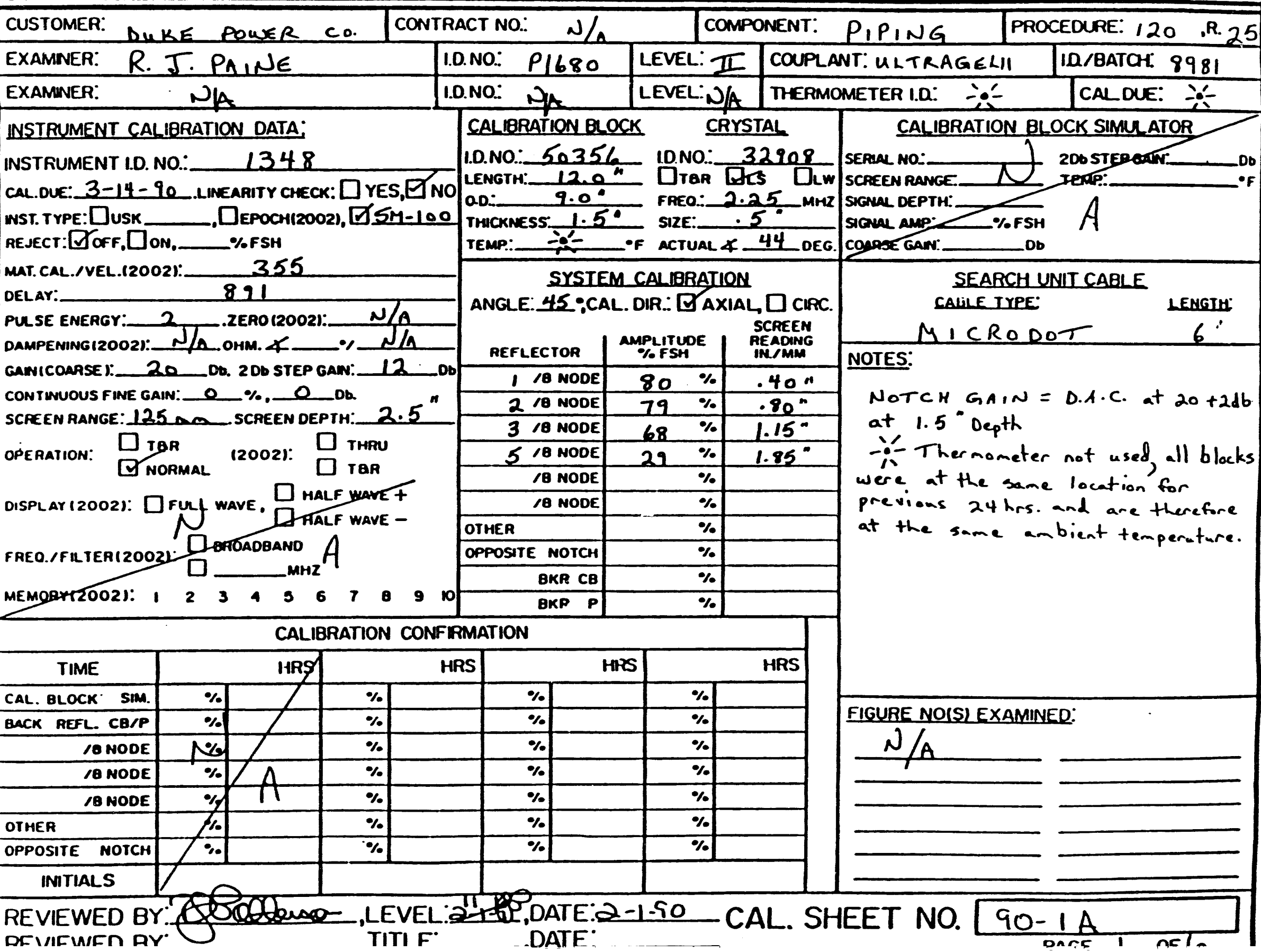




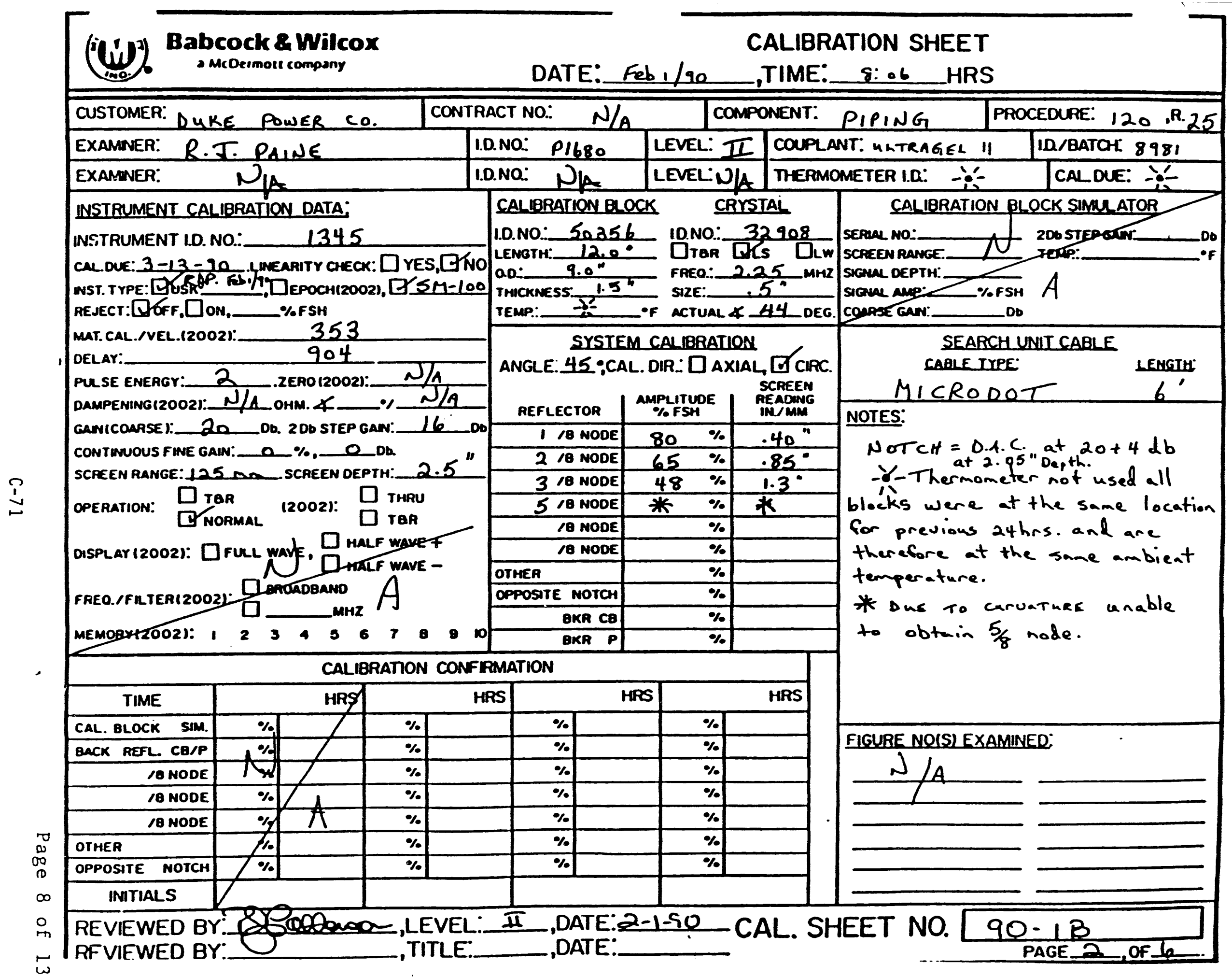




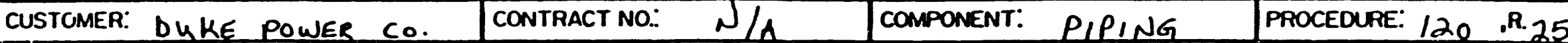
EXAN.NER: R.J. PANE EXAMNER: N/A INSTRUMENT CALIBRATION DATA: INSTRUMENT 1.D. NO: 1348

CAL OUE: 3-14 - 90 LNEAAITY CHECK: $\square$ YES, 7 KNO wST. TYPE:DUSK REJECT:[DOFF, DON, Depochi(2002), [S/SH-100 mAT.CAL./VEL.(2002): $\quad 355$ DELAY: 891

PULSE ENERGY: 2 .ZERO (2002): N/a dampening(2002): N/L онm. \&_ N/a GANICOARSE I: 20 Do. 200 STEP GAN: 12 :

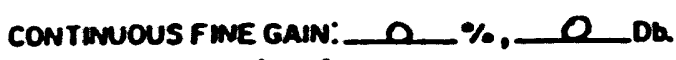
SCFEEN RAMGE: 125 mOA SCREEN DEPTH: 2.5 " OPERATION: D TBR (2002): D TihaU OPERATION: Drormal 12002): 口 TER

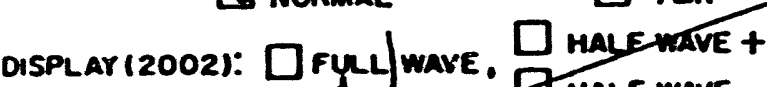
FREO./FRTER120021: DOFOADBAND A

MEMgSX(2002): 1234567896 \begin{tabular}{|l|l|l|l|l} 
1.D.NO: $P 1680$ & LEVEL: II & COUPLANT: ULTRAGEL II & IR/BATCH 8981
\end{tabular}

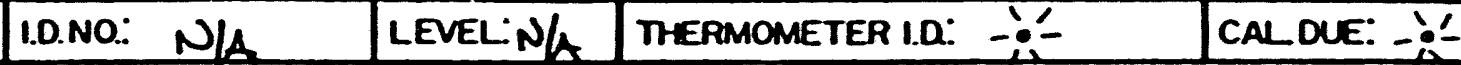

\section{CALIBRATION CONFIRMATION} CALLBRATION BLOCK CRYSTAL 1.D.NO: 50252 ID.NO: 32908 SERal Ma: SERaA Na:_ I 200 STEPPoTK WLS DLW SCREEN RANGE. N TERP: TH: $\frac{120}{12}$ FREO:-2.25 MHZ SIGNML DEPTH:

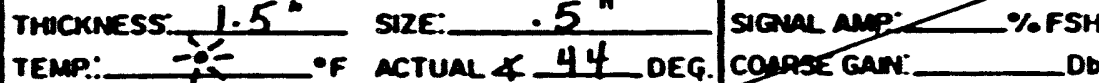

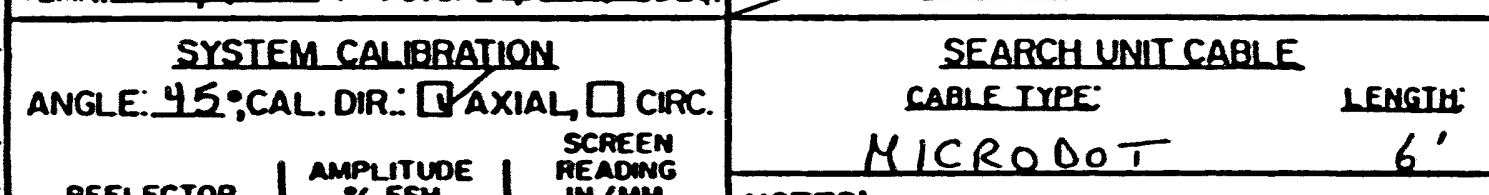

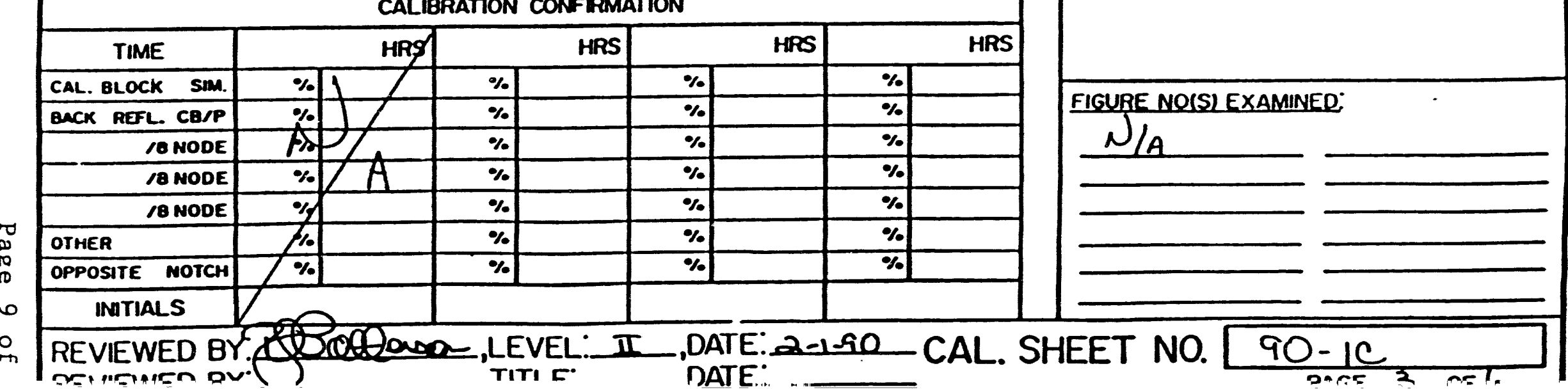


DATE: Feb //90 ,TIME: 8:45 HRS

\begin{tabular}{|l|l|l|l|l|l|l|}
\hline CUSTOMER: DUKE PQWER CO. & CONTRACT NO: N/A & COMPONENT: PIPING & PROCEDURE: 120 & .R. 25 \\
\hline
\end{tabular}

\begin{tabular}{|l|l|l|l|l|l|l|l|}
\hline EXAMNER: $R$. J. PA.NE & 1.0.NO: P1680 & LEVEL: II & COUPLANT: ULTRAGEL II & LO/BATCH 8981 \\
\hline
\end{tabular}

INSTRUMENT CALIBRATION DATA:

INSTRUMENT LD. NO: $\quad 1345$

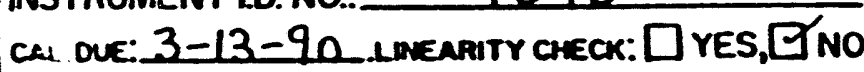

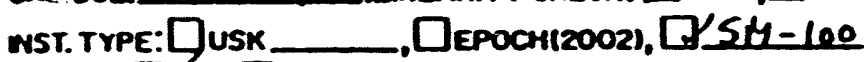

REJECT: D GFF, DON, _ \%FSH 1.0.NO: NA LEVEL:NIA THERMOMETER I.D:

CALDUE:

CALLBRATION BLOCK CRYSTAL

1.D.NO: 50252 IDNO: 32908

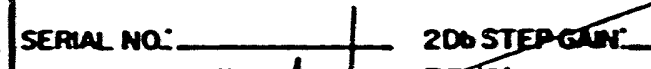

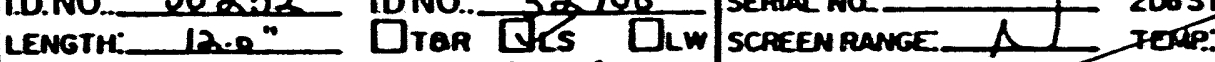

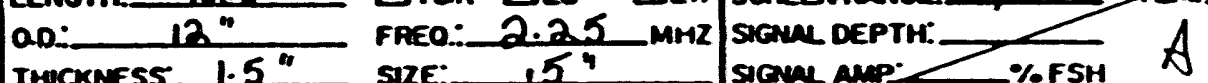

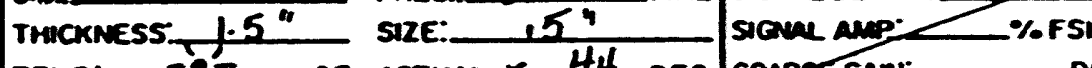

TEMP: - $-2-$ - ACTUAL $\& 44$ OEG.

conpse Gar:

MAT. CAL./VEL.(2002):_ 353

DELAY:

904

PUSE ENERGY: 2 .2ERO(2002): N/A

DAMPENING(2002): N/A OHM. \& $\because$ N/A

GUNICONASE): 20 Do. 200 STEP GAN: 16 - Do

CONTINUOUS FINE GAIN: Q Q $2 \%, 0$ - Dh

SCFEEN RANGE: $125 \mathrm{~mm}$ SCREEN DEPTH: $2.5^{\prime \prime}$

OPERATION: D JUR

口TH: 2.5

Orormal (2002):

D rap

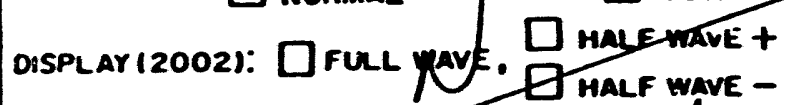

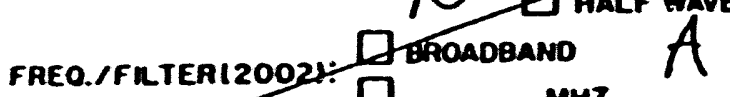

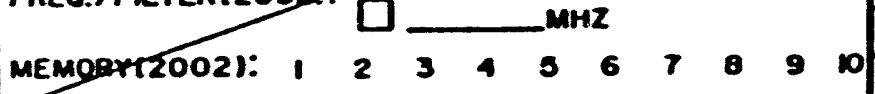

SYSTEM CALIBRATION

ANGLE:45:CAL. DIR:: DAXIAL, Q CIRC.

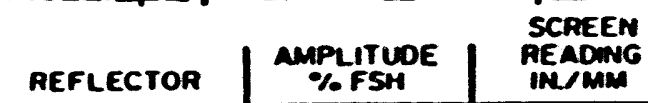

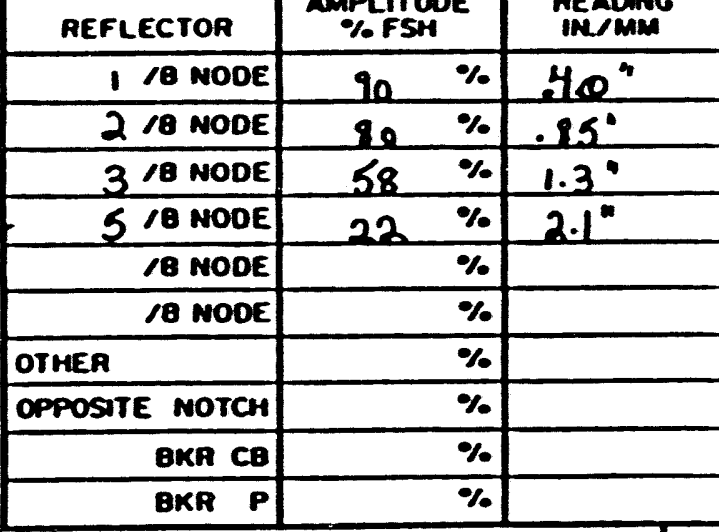

CALBBRATION CONFIRMATION

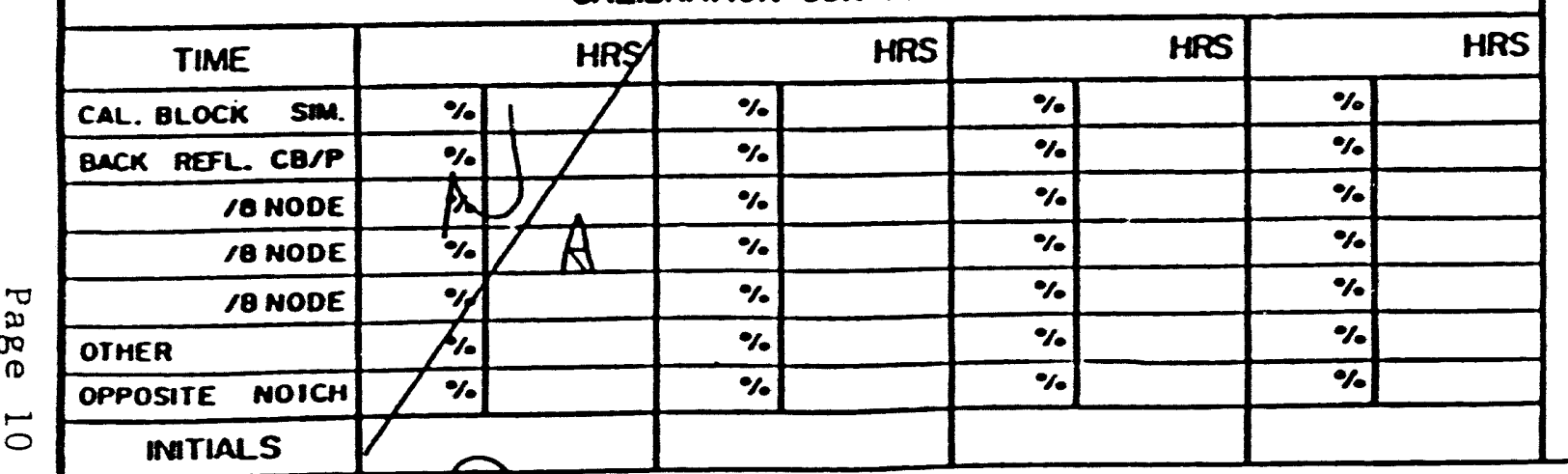

$\circ$ REVIEWED BY Oforderom,LEVEL: II

REVIEWED BY: TITLE:

\section{SEARCH UNIT CABLE} CABLE TYPE: LEMGIH: MICRODOT $6^{\prime}$ NOTES:

no notches in block

$\because$ - Thermameters not used, all block were at the same location for previous 24 hrs. and are therofore at the sane ambient temperature.

FIGURE NO(S) EXAMINED:

N/A 


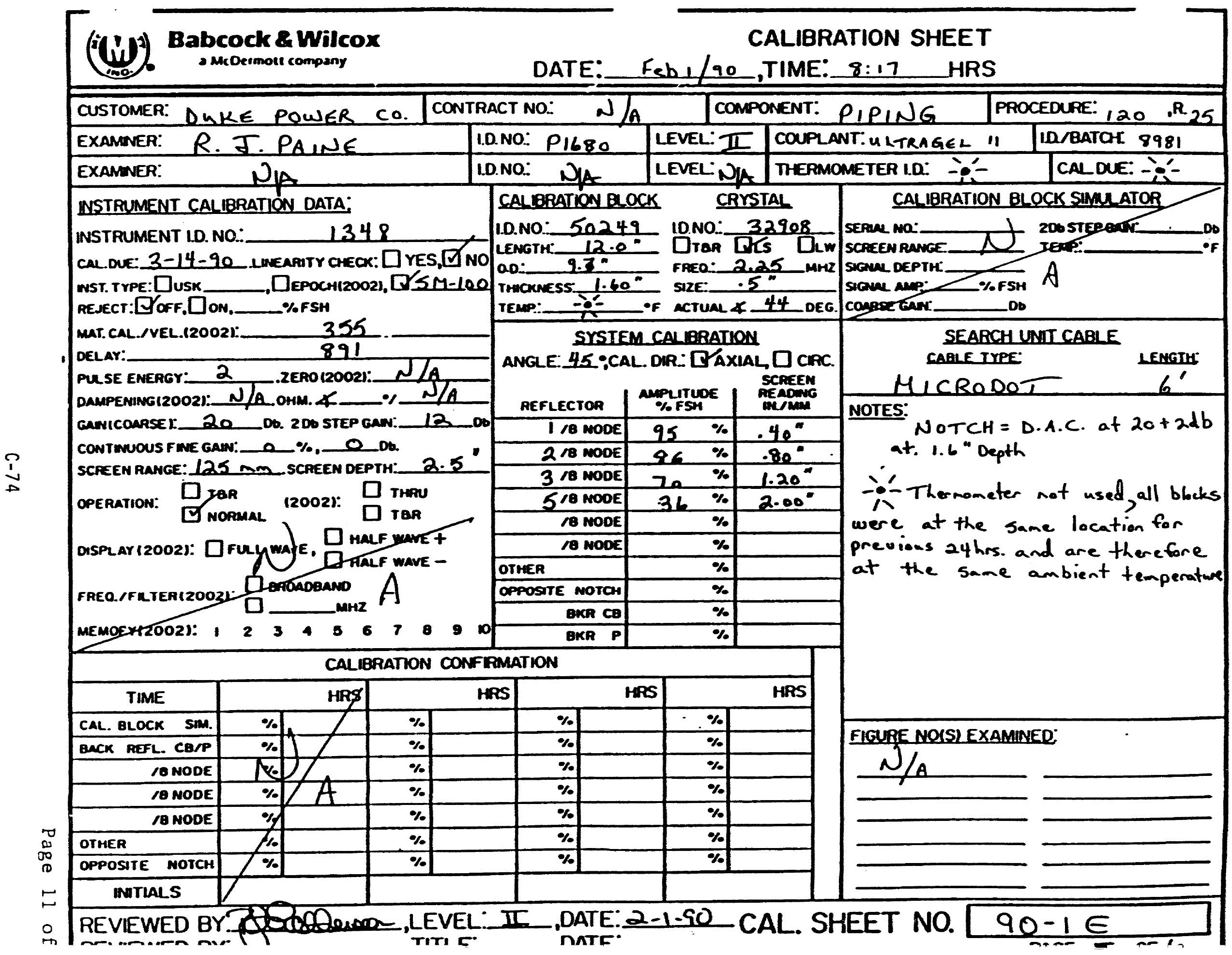




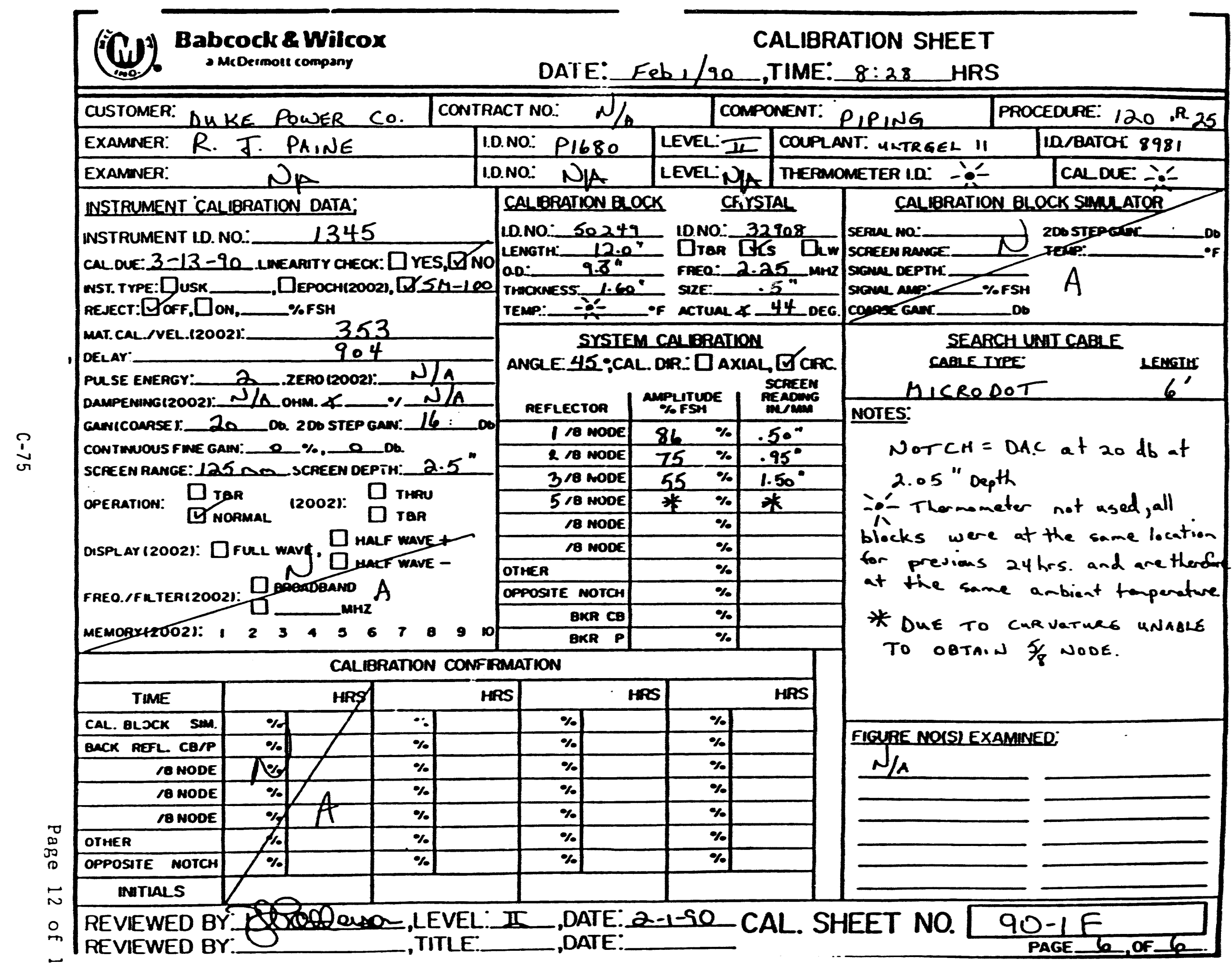




\section{CALIBRATION BLOCK CUPVE COMPARISON}

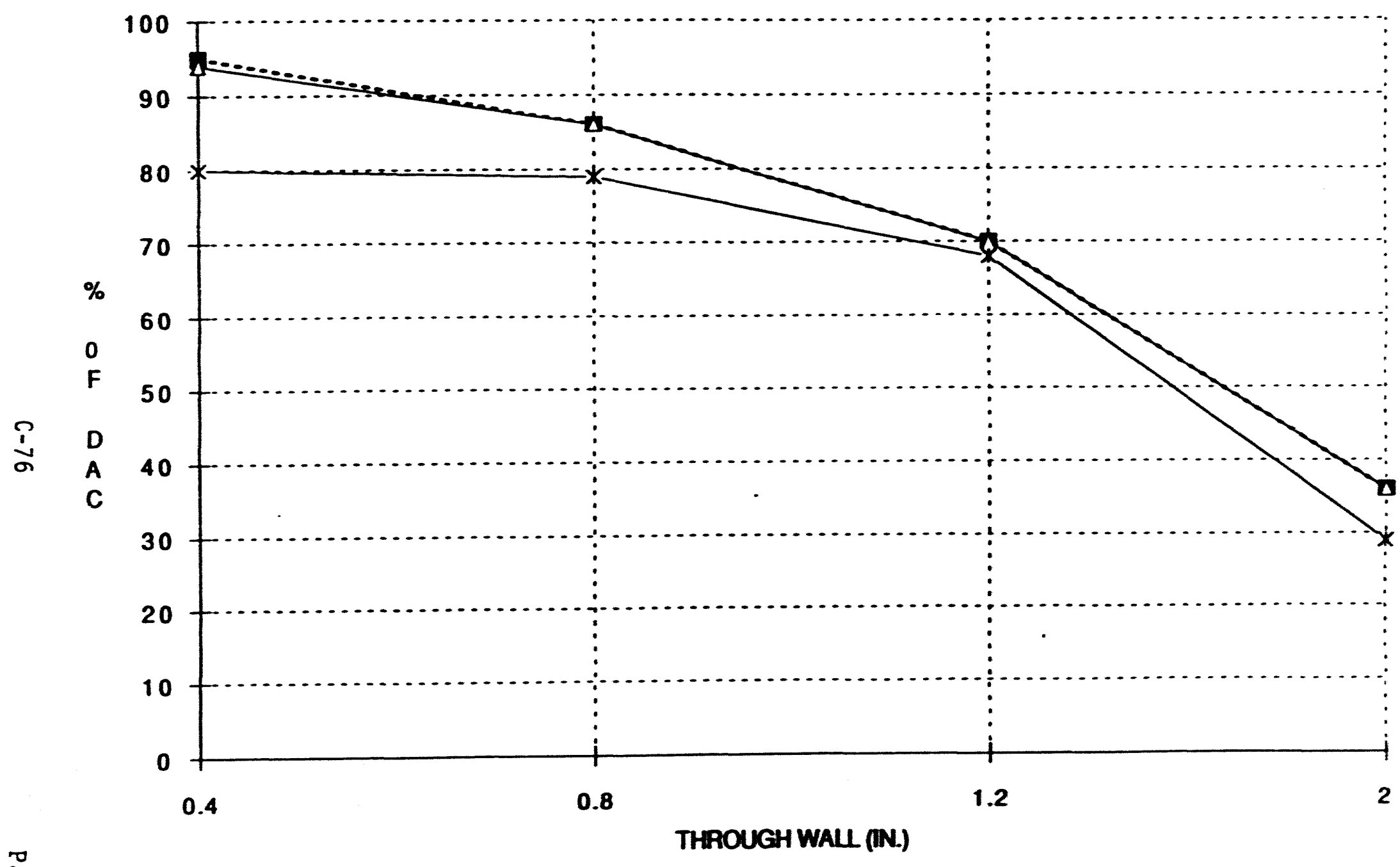




\subsection{Class 1 and 2 Repairs and Replacements}

As required by ASME Section XI, 1980 Edition, a record of the Class 1 and 2 Repalrs and Replacements for work performed from June 10,1991 to October 15, 1992 is provided and is included in this section of the report. The individual work request documents are on flle at the Catawba Nuclear Station. 


\section{CATAWBA NUCLEAR STATION UNIT 1 EOC 6 REPAIR / REPLACEMENT LOG ASME SECTION XI-1981}

Examination Dates: From: 06/10/91 To: 10/15/92

Prepared By: QA Technical Support

Transmitted By: R.C. Sen Date: 10.22.92

$$
\begin{aligned}
& \text { T/le fullowing is } \\
& \text { easier tu read } \\
& \text { than a steck of } \\
& \text { NIS - } 2 \text { forms. }
\end{aligned}
$$


REPAIR/REPLACEMENT LOQ

ASME SECTION XI 1981

U1EOC6

\begin{tabular}{|c|c|c|}
\hline WR\# & Class & Description \\
\hline 4193 MES & $\mathrm{B}$ & REPLACED SNUBBER 1-R-ND-0596 \\
\hline 4281 MES & $\bar{B}$ & REPLACEDLOAD PIN, 1-R-CF. 1567 \\
\hline 4918 MES & $\bar{B}$ & REPLACED SNUBBER BODY $1 \cdot R \cdot N D-0226$ \\
\hline 4918 MES & $\bar{B}$ & REPLACED SNUBBER BODY 1-R.ND.0596 \\
\hline $13716 \mathrm{NSM}$ & $\bar{B}$ & REPLACED PLATE 1-R-ND-0332 \\
\hline 13716 NSTM & $\bar{B}$ & $\begin{array}{l}\text { REPLACEDSTRUT, REAR BRACKET, PTPE } \\
\text { CLAMP, TUBE STEEL 1-R-ND-0331 }\end{array}$ \\
\hline 13730 NSM & $\bar{B}$ & $\begin{array}{l}\text { REPLACED STRUT \& PIPE CLAMP, } \\
\text { 1-R.CA.1552 }\end{array}$ \\
\hline $82028310-01$ & $\bar{B}$ & $\begin{array}{l}\text { REPLACED TRUNION ASSEMBLY ONS.W.I. } \\
\text { FILTER HOUSING }\end{array}$ \\
\hline 91014154-01 & B & REPLLACED BONNET STUDS VALVE 1SV27A \\
\hline $91014155-01$ & $\bar{B}$ & REPLACED BONNET STUDS VALVE 1SV28A \\
\hline $91036863-01$ & $\bar{B}$ & NVPUMP TA (REPLACED MECH. SEALS) \\
\hline 91036868-01 & $\bar{B}$ & $\begin{array}{l}\text { VALVE 1NV294 REPLACED BONNET STUD } \\
\text { NUTS }\end{array}$ \\
\hline $91061495-01$ & $\bar{A}$ & $\begin{array}{l}\text { BROKE AND REMADE BONNET JOINT ON } \\
\text { VALVE IN1157 }\end{array}$ \\
\hline 91061797.01 & $\bar{B}$ & $\begin{array}{l}\text { VALVE 1NV186A (REPLACED YOKE AND } \\
\text { BONNET) }\end{array}$ \\
\hline 91079959-01 & & $\begin{array}{l}\text { REPLACED VALVE } 1 \text { ND.03 } \\
\text { OLD SERIAL\#TD89405 NEW SERIAL\#TD89407 }\end{array}$ \\
\hline 91079977.01 & $\bar{B}$ & REPLACED VALVE $1 N V-14$ \\
\hline $92003090-01$ & $\bar{B}$ & $\begin{array}{l}\text { REPLACE VALVE 1NV291, 3"-CUT-OUT } \\
\text { WELDS, } \\
\text { 1NV43-12,13 } \quad \text { (NSM11162) }\end{array}$ \\
\hline
\end{tabular}


REPAIR/REPLACEMENT LOG

ASME SECTION XI 1981

U1EOC6

\begin{tabular}{|c|c|c|}
\hline $92010120-01$ & $\bar{A}$ & $\begin{array}{l}\text { REACTOR COLLANT PUMP 1C (REPLACED } \\
\text { SEALS) }\end{array}$ \\
\hline 92014280.01 & $\bar{A}$ & REPLACED VALVE 1 NC-2 \\
\hline $92014280-01$ & $\bar{A}$ & VALVE 1NC002 (REPLACED) \\
\hline 92014312.01 & $\bar{A}$ & $\begin{array}{l}\text { REMOVAL/REPLACED REACTOR VESSEL } \\
\text { HEAD (REPLACED RV STUDS) }\end{array}$ \\
\hline 92014312.01 & $\bar{A}$ & $\begin{array}{l}\text { REMOVED THREADS - REACTOR VESSEL } \\
\text { FLANGE }\end{array}$ \\
\hline $92014320-01$ & $\bar{A}$ & $\begin{array}{l}\text { RX THERMO COUPLE ASSEMBLY (REMOVE } \\
\text { AND REPLACE }\end{array}$ \\
\hline 92015141.04 & $\bar{A}$ & $\begin{array}{l}\text { DISASSEMBLED VALVE } 1 \text { NIT1 (NO } \\
\text { PRESSURE BOUNDARY PARTS REPLACED) }\end{array}$ \\
\hline $92015253-01$ & $A$ & $\begin{array}{l}\text { DISASSEMBLED VALVE } 1 \text { NI129 (NO } \\
\text { PRESSURE BOUNDARY PARTS REPLACED) }\end{array}$ \\
\hline $92015254-01$ & $\bar{A}$ & $\begin{array}{l}\text { DISASSEMBLED VALVE INI180 (NO } \\
\text { PRESSURE BOUNDARY PARTS REPLACED) }\end{array}$ \\
\hline $92019184-01$ & A & REPLACED STEM ONVALVE INC31B \\
\hline 92019185-01 & A & REPLACED STEM ONVALVE 1 NC33A \\
\hline $92019186-01$ & $\bar{A}$ & REPLACED STEM ON VALVE INC35B \\
\hline $92019564-01$ & $\bar{B}$ & $\begin{array}{l}\text { REPLACED ANCHORS, PIPE CLAMP, LEFT } \\
\text { HAND ROD EYE, 1-R-SV-1620 }\end{array}$ \\
\hline 92022273.01 & A & VALVE INCOO3 (REPLACED) \\
\hline 92022274.01 & $\bar{A}$ & $\begin{array}{l}\text { DISASSEMBLED VALVE } 1 \text { NITO (NO } \\
\text { PRESSURE BOUNDARY PARTS REPLACED) }\end{array}$ \\
\hline $92022459-01$ & $\bar{A}$ & REPLACED TWO SNUBBER $1-R-N 1-1384$ \\
\hline $92022460-01$ & $\bar{B}$ & $\begin{array}{l}\text { REPLACED SNUBBER, 1-R-SM-1578, \& } \\
\text { 1-R-CF-1519 }\end{array}$ \\
\hline $92032839-01$ & $\bar{A}$ & $\begin{array}{l}\text { DISASSEMBLE AND REASSEMBLE PRIMARY } \\
\text { MANWAY SG1C }\end{array}$ \\
\hline
\end{tabular}




\section{REPAIR/REPLACEMENT LOG \\ ASME SECTION XI 1981 \\ U1EOC 6}

\begin{tabular}{|c|c|c|}
\hline $92032851-01$ & $A$ & $\begin{array}{l}\text { DISASSEMBLE AND REASSEMBLE PRIMARY } \\
\text { MANWAY SG-1B }\end{array}$ \\
\hline $92032858-01$ & $\bar{A}$ & $\begin{array}{l}\text { DISASSEMBLE AND REASSEMBLE PRIMARY } \\
\text { MANWAY SG-1A }\end{array}$ \\
\hline $92032858-05$ & $\bar{A}$ & $\begin{array}{l}\text { REPLACED SNUBBER 1-R-NI-1314,REPLACED } \\
\text { SNUBBER, LOAD STUD LOCK NUT, EXT } \\
\text { PIECE SCREWS, 1-R-NI-1314 }\end{array}$ \\
\hline $92032869-01$ & $A$ & $\begin{array}{l}\text { DISASSEMBLED SG ID MANWAY COVER } \\
\text { (REMOVE AND REPLACE) }\end{array}$ \\
\hline $92033968-01$ & $A$ & VALVE 1NC001 (REPLACED) \\
\hline $92046405-01$ & $\bar{B}$ & VALVE 1CF053 (REPLACED BONNET) \\
\hline $92050396-02$ & $\bar{B}$ & REPLACED LOAD STUD, 1-R-NI-107 \\
\hline $92052097-01$ & $\bar{B}$ & $\begin{array}{l}\text { REPLACE VALVE 1NV307, 3"-CUT-OUT } \\
\text { WELDS, } \\
\text { 1NV39-10,11 (VN 3773) }\end{array}$ \\
\hline $92052373-01$ & $\bar{B}$ & REPLACED SNUBBER 1-R-ND-0391 \\
\hline $92052913-01$ & & REPLACED STUDS NUTS, 1ND1-MJ1 \\
\hline $92054065-01$ & $\bar{B}$ & REPLACED LOAD BOLT, 1-R-SM-1011 \\
\hline $92054349-01$ & $\mathrm{~B}$ & $\begin{array}{l}\text { REPLACED PIN IN REAR BRACKET, 1-R-CF- } \\
1567\end{array}$ \\
\hline $92054350-01$ & $\bar{B}$ & $\begin{array}{l}\text { REPLACE SNUBBER 1-R-SM-1565, REPLACED } \\
\text { PIN IN REAR BRACKET, 1-R-CF-1567 }\end{array}$ \\
\hline $92055498-01$ & $\bar{B}$ & VALVE 1NV223 (REPLACED) \\
\hline $92055879-01$ & $\bar{A}$ & $\begin{array}{l}\text { DISASSEMBLE AND REASSEMBLE VALVE } \\
1 \text { NC27 }\end{array}$ \\
\hline $92060161-01$ & $A$ & SG ID ACCESS HOLE-MACHINED \\
\hline 92060945-Cí & $\bar{A}$ & $\begin{array}{l}\text { REPLACED VALVE INI119 } \\
\text { NEW SERIAL\# TD89439 ITEM\# CSR-128 }\end{array}$ \\
\hline $92062213-01$ & $A$ & REPLACED SNUBBER, 1-R-NC-1655 \\
\hline
\end{tabular}


REPAIR/REPLACEMENT LOG

ASME SECTION XI 1981

U1EOC6

\begin{tabular}{|l|c|l|}
\hline $92065299-01$ & A & $\begin{array}{l}\text { VALVE 1NC32B (NO PRESSURE BOUNDARY } \\
\text { PARTS REPLACED) }\end{array}$ \\
\hline $92072880-01$ & A & $\begin{array}{l}\text { DISASSEMBLED REACTOR COOLANT PUMP } \\
\text { 1C (NO PRESSURE BOUNDARY PARTS } \\
\text { REPLACED) }\end{array}$ \\
\hline
\end{tabular}




$$
80-181
$$

TABLE OF CONTENTS

\begin{tabular}{|c|c|c|}
\hline SECTION & DESCRIPTION & PAGE(S) \\
\hline 1.0 & INTRODUCTION & $1-5$ \\
\hline 2.0 & $\begin{array}{l}\text { SUMMARY OF ASME CLASS } 1 \text { AND AUGMENTED } \\
\text { EXAMINATIONS } \\
\text { (INCLUDES ASME SECTION XI CREDIT-IWB) }\end{array}$ & $6-17$ \\
\hline 3.0 & $\begin{array}{l}\text { SUMMARY OF ASME CLASS } 2 \text { AND AUGMENTED } \\
\text { EXAMINATIONS } \\
\text { (INCLUDES ASME SECTION XI CREDIT-IWC) }\end{array}$ & $18-21$ \\
\hline 4.0 & $\begin{array}{l}\text { SUMMARY OF ASME CLASS } 3 \text { AND AUGMENTED } \\
\text { EXAMINATIONS }\end{array}$ & $22-24$ \\
\hline 5.0 & SUMMARY OF NON-CLASS EXAMINATIONS & 25-26 \\
\hline 6.0 & $\begin{array}{l}\text { SUMMARY OF COMPONENT SUPPORT } \\
\text { EXAMINATIONS }\end{array}$ & $27-30$ \\
\hline 7.0 & SUMMARY OF AUGMENTED EXAMS & $31-33$ \\
\hline 8.0 & $\begin{array}{l}\text { ABSTRACT OF CONDITIONS NOTED } \\
\text { AND CORRECTIVE ACTIONS TAKEN }\end{array}$ & $34-37$ \\
\hline 9.0 & $\begin{array}{l}\text { PROGRAM STATUS, ASME SECTION XI } \\
\text { CREDIT - IWB, IWC. IWD \& IWF }\end{array}$ & $38-89$ \\
\hline 10.0 & PROGRAM PLAN TABLES & $90-98$ \\
\hline 11.0 & WELD AND SUPPORT ISOMETRICS & $99-103$ \\
\hline 12.0 & NIS-2 FORMS & $104-108$ \\
\hline
\end{tabular}


8.1 Refuel-01

\subsubsection{RPV Internals}

During inspection of the RPV internals/internal components several conditions were reported to Detroit Edison for review/disposition. The reported indications are listed as follows:

- Tack weld on feedwater sparger bracket at $180^{\circ}$ for attachment nut/pin was not visible.

- Unusual surface conditions (arc strikes and pitting) were noted on Loop A Core Spray piping at approx. $140^{\circ}$. Additional light scratches were noted on both LoOp A and Loop B Core Spray Internal piping.

- Small arc strikes were noted on the Core Spray internal piping/sparger brackets at $15^{\circ}$ and $150^{\circ}$.

- A small arc strike was noted on the upper Core Spray sparger (shroud area) at $145^{\circ}$.

The above conditions were evaluated using prudent engineering practices and were determined not to be nonconforming to the original design requirements or detrimental to continued service.

No corrective action was taken to repair these indications. These areas will be monitored during future Inspections of the RPV internals as required by ASME Section XI Table IWB-2500-1 (B13.10).

\subsubsection{Component Supports}

Hanger T48-2097-G21 was found to have insufficient clearances. Deviation Event Report (DER) 89-1315 was initiated for evaluation. It was determined that this was not reportable. The hanger was reworked to provide acceptable clearances as specified on the hanger sketch. Additional adjacent supports were visually inspected with no discrepancies identified. 
8.2 Refuel-02

\subsubsection{RPV Internals}

During inspection of the RPV internals/internal components an additional indication to the ones previously identified during RF-01 was reported to Detroit Edison for review/disposition. The reported indication is listed below:

- Apparent arc strike was noted on core spray internal piping at $310^{\circ}$ this was not recorded in the previous inspection.

This condition and those previously identified during RF-01 were evaluated using prudent engineering practices and were determined not to be nonconforming to the original design requirements or detrimental to continued service.

No corrective action was taken to repair these indications. These areas will be monitored during future inspections of the RPV internals ss required by ASME Section XI Table IWB-2500-1 (B13.10).

\subsubsection{Piping Welds}

During the inspection of piping wolds, 2 welds having rejectable Indications were reported to Detroit Edison for review/disposition. The welds are identified below:

- Weld SW-E11-3151-IWH had rejectable surface indications identified during the magnetic particle examination. DER 91-0262 was initiated for evaluation.

- Weld SW-RD-2-B3-W5LU-B had rejectable surface indications identified during the liquid penetrant examination. DER 91-0234 was initiated for evaluation.

Both welds were subsequently blend ground to remove the indications and reexamined by both surface and Volumetric techniques with acceptable results. The initial indications on bath welds were mast likelv loft over from construction. No additional welds were inspected as a result of these minor indications.

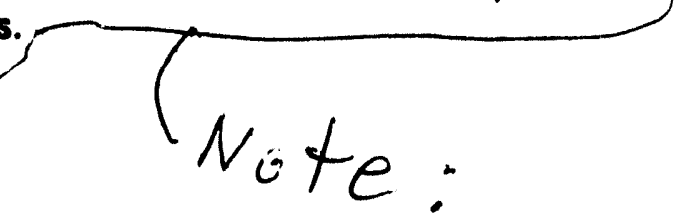

Detroit Edison Co., 2000 2nd Ave., Detrolt, MI. 48226

Fermi-2 Nuclear Power Plant, 6400 N. Dixie Highway, Newport MI 48166

Commercial Service Date: 1-23-88, NB* 21085 (RPV) 


\subsubsection{RPV Internals}

During inspection of the RPV internals/internal components two cracks were reported to Detroit Edison for review/disposition. The reported conditions are listed as follows:

- Crack Number 1 was located in hood to end plate weld HE-B-1. The crack was approximately 50" long, with a maximum gap of $1 / 2$ inch. The crack ran through the throat of the weld and was caused by high cycle fatigue. This crack is not uncommon to the industry, having occurred at other plants.

- Crack Number 2 is located in the end plate of dryer bank " $A$ " Just above the weld to the end plate of the drain trough. The crack is in the weld heat uffected zone (HAZ) between Tie Rods TR-A-7 and TR-A-8. The crack is caused by Intergranular Stress Corrosion Cracking (IGSCC).

Crack Number 1 was repaired by grinding out the existing falled weld and preparing the base metal edges for the new weld, clamping the crack closed, rewelding the hood to end plate joint, and welding a new reinforcing plate over the replaced/existing weld With the exception of the original failed weld repair, this repair process was repeated at three (3) similar locations where the potential future weld fallure was high. This was performed as a preventive measure to preclude future joint fallure, higher personnel exposure, and higher future repair costs.

An evaluation was performed on Crack Number 2, and it was determined that this crack did not require repair as there is a low probability that this crack will propagate into weld or base metal outside the HAZ. The crack will tend to grow at a slow rate as the stresses at this crack location during dryer operation are low. Crack Number 2 will continue to be monitored during future outages.

The indications previously identified during inspections performed in RF-01 and RF-02 were again reinspected with no change in conditions noted. These areas in addition to the cracks identifled and repairs performed during RF-03 will be monitored during future inspections of the RPV internals as required by ASME Section XI Table IWB-2500-1 (B13.10).

\subsubsection{Component Supports}

Several hangers were found with discrepancies between the installed condition and their conflguration documents. Deviation Event Report (DER) 92-0573 was initiated for evaluation. It was determined that their nature was such that it did not effect the components operability and was not reportable. No additional supports were inspected as a result of these observations. 


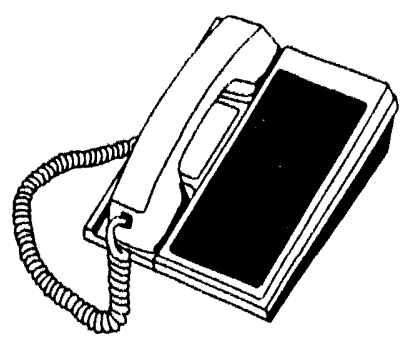

DATE: Eebruary 24, 1993

\section{NDE ENGINEERING ANALYSIS \& APPLICATIONS}

INEL/EG\&G IDAHO

IDAHO FALLS, IDAHO 83415-2209

Telecopier Telephone: 208/526-0690

Verification Telephone: 208/526-6122
TO: Winston LiU, NRC RES

FROM: Jeff cook, sr. leff
FAX: $\quad 3014923696$

TELEPHONE: $208526 \quad 6414$ office 2085227339 home

ASME Section XI Code Violation, Task 24

Per our telecon the following is provided for you to discuss with NRR. The licensee is using the 80-W81 Section XI. The violation was noted during review of Paragraph 8.2.2 of the Summary Report. Both IWB-2130 and IWC-2430 require additional examinations when rejectable indications are revealed. Note that the licensee characterized the indications as "minor."

Number of Pages (including cover page): $\mathbf{3}$ 
Eebruary 26, 1992

U.S. Nuclear Regulatory Commission ATTN: Document Control Desk Washington, D.C. 20555

\author{
PLANT HATCH - UNIT 1 \\ NRC DOCKET 50-321 \\ OPERATING LICENSE DPR-57 \\ INSERVICE INSPECTION ASSOC IATED \\ WITH THE EALL 1991 MAINTENANCE/REFUELING OUTAGE
}

\title{
Gentlemen:
}

Pursuant to the requirements of Article IWA-6000 of the ASME Code, Section XI, enclosed for your review is the Owner's Data Report for Inservice Inspection (Form NIS-1) for the inservice inspection activities conducted at Plant Hatch Unit 1 during the Fall 1991 maintenance/refueling outage. The Owner's Data Report is included as Enclosure 1.

Georgla Power Company (GPC) has performed several inspections not specifically required by ASME Code Section XI, on selected Class 1,2 , and 3 components. The results of the code and augmented inspections performed at Unit 1 are summarized below and reported in the Owner's Data Report.

- Ultrasonic examinations of austenitic stainiess steel piping welds in the primary coolant pressure boundary per Generic Letter 88-01 and NUREG-0313, Revision 2. Results are discussed in the Enclosure under "Class I Examinations." A detalled report on flaw evaluations and weld overlay designs was submitted to the NRC via letter dated January 21, 1992.

- Ultrasonic examinations of eight (8) welds in the nonsafety-related portion of the reactor water cleanup (RWCU) piping were performed per commitments to the NRC related to Generic Letter 88-01. No reportable indications were detected.

- Ultrasonic thickness measurements were performed on selected components in the extraction steam and condensate/feedwater system piping per GPC's ongoing erosion/corrosion program. A portion of these components were selected due to their similarity in design and operating conditions to components involved with the "Surry pipe break incident".

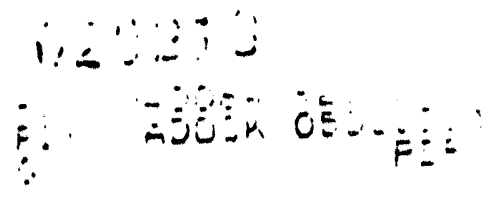




\section{Georgia Power $\mathbf{L}$}

U.S. Nuclear Regulatory Commission

February 26, 1992

Page Two

- Eddy current testing was performed on several feedwater heaters, Diesel Generator IA \& IC coolers, and motor generator "A" air cooler.

- The core spray sparger and associated piping was visually examined per Bulletin 80-13. No reportable indications were detected.

- One shroud support access hole cover weld was ultrasonically examined per GE SIL-462. No reportable indications were detected.

If you have any questions in this regard, please contact this office at any time.

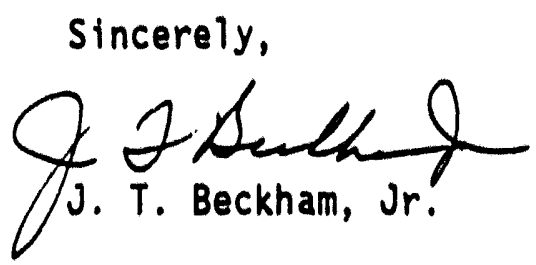

SRM/ Id

003002

Enclosure: Owner's Data report for Inservice Inspection - Edwin 1. Hatch Nuclear Plant Unit 1 - September 1991 - November 1991

cc: Georgia Power Company

Mr. H. L. Sumner, General Manager - Nuclear Plant

NORMS

Nuclear Requlatory Commission. Washington. D.C.

Mr. K. Jabbour, Licensing Project Manager - Hatch

U.S. Nuclear Requlatory Commisrion

Mr. S. D. Ebneter, Regional Administrator

Mr. L. D. Wert, Senior Resident - Hatch

\section{References:}

1. Letter, J. T. Beckham to NRC, IGSCC Flaw Evaluations and Weld Overlay Designs Unit 1, Fall 1991 Maintenance and Refueling Outage, HL-2000, Dated January 21, 1992. 
I. ASME NIS-1 FORM AND SUPPLEMENTARY INFORMATION

$1-6$

II. ABSTRACT

$7-14$

III. EXAMINATION SUMMARY
A. CIASS 1 EXAMINATIONS
$16-57$
B. CLASS 2 EXAMINATIONS
$58-66$
C. PRESSURE TESTING
$67-69$
D. COMPONENT SUPPORTS
$70-79$
E. AUGMENTED EXAMINATIONS
$80-82$
F. REACTOR PRESSURE VESSEL INTERNALS
$83-92$
G. REPAIRS AND REPLACEMENTS
$93-104$ 
NOTE: Portions of this report are complled from Southern Nuclear Operating Company issued report; "Nondestructive Examination of Selected Class 1, 2 , and 3 Components", for the Fall 1991 Refueling Outage at E.I. Hatch Nuclear Plant, Unit 1 . This report is avallable for review in the Records Management Department at the plant site. 
FORM NIS-1 OWNERS' DATA REPORT FOR INSERVICE INSPECTIONS As Required By the Provisions of The ASME Codes Rules

1. Owner: Georaia Power Company, 333 Piedmont Ave, $N E, P .0$, Box 4545 , Atlanta Georgia 30302

2. Plant: Edwin I. Hatch Nuclear Plant, Route 1 , Box 278 , Baxley GA 31513

3. Plant Unit 14 . Owner Certificate of Authorization (if req.) N/A

5. Commercial Service Date $12 / 31 / 75$ 6. National Board No. for Unit N/A

7. Components Inspected:

Component or

Appurtenance

or system

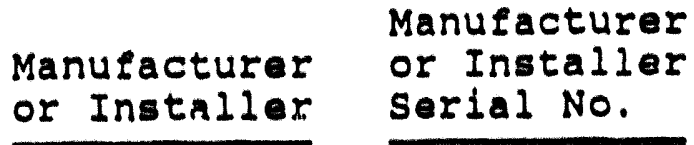

or Installex
State or

Province

Number

National

Board No.

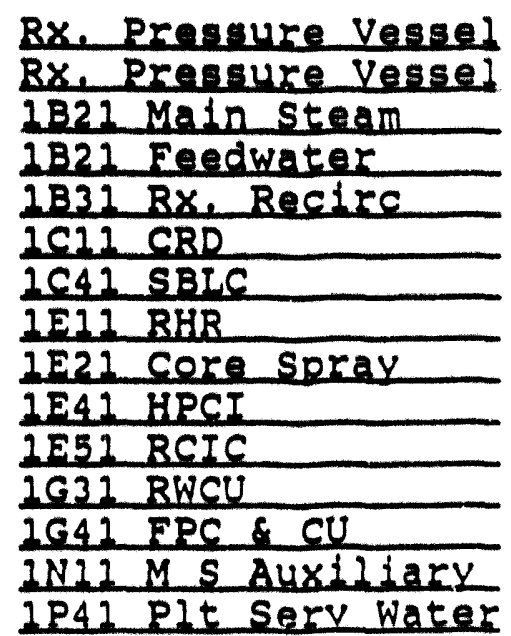

Combustion Eng.

Combustion Eng.

Pullman Power Prod.

Pullman Power Prod.

Puliman Power Prod.

Pullman Power Prod.

Pulliman Power Prod.

Pulliman Power Prod.

Pulliman Power Prod.

Pulliman Power Prod.

Puliman Power Prod.

Puliman Power Prod.

Puliman Power Prod.

Puliman Power Prod.

$\frac{\frac{67205}{67205}}{\frac{\hbar}{\hbar}} \frac{\frac{\hbar}{\hbar}}{\frac{\hbar}{\hbar}}$

$\frac{\frac{N / A}{N / A}}{\frac{N / A}{N / A}} \frac{\frac{N / A}{N / A}}{\frac{N / A}{N / A}} \frac{\frac{N / A}{N / A}}{\frac{N / A}{N / A}} \frac{N / A}{\frac{N / A}{N / A}}$

20769

20769

$N / A$

$N / A$

$N / A$

$N / A$

$N / A$

$N / A$

$N / A$

$N / A$

$N / A$

$N / A$

$N / A$

$N / A$

$N / A$

Note: Supplemental sheets in form of lists, sketches, or drawings may be used provided (1) size is $81 / 2$ in. $x 11$ in., (2) information in items 1 through 6 on this data report is included on each sheet, and (3) each sheet is numbered and the number of sheets are recorded at the top of this form.

* - spool piece of fitting numbers too numerous to list for each specific system. Material certifications for all piping, fittings, etc., are available for review in the Records Management Department at the plant site.

** Exception taken to note 2. 
An Inservice Inspection of selected Class 1,2 and 3 components at Georgia Power Company's Edwin I. Hatch Nuclear Plant Unit 1 was performed during the Fall 1991 Maintenance/Refueling outage. The components were examined in accordance with the applicable ISI Outage Plan, including any changes made during the outage as approved by GPC.

Edwin I. Hatch Unit 1 is currently in the second period of the second 10-Year Inspection Interval. The required examinations are presently on schedule as specified in the second Ten-year Inspection Slan.

The nondestructive examinations were performed using VT, PT, MT and UT examination techniques. SNC personnel and their contractors; IMT, GE, Seimens, and Ebasco performed NDE of the selected welds and components. In addition, GE assisted SNC personnel with VT examination of selected RPV internal components. SNC, GE, or GPC NDE procedures were utilized for all ASME Section XI Examinations. LMT, Ebasco, and seimens personnel were qualified to the applicable SNC procedures. EPRI qualifled inspectors were utilized for all examinations involving IGSCC susceptible materials. SNC and GE procedures were used for mechanized ultrasonic examination and exams were performed by SNC, Seimens, Ebasco, and GE inspectors.

SNC and CEL personnel performed eddy current examinations of non ASME Section XI components per a request from GPC. C\&L procedures were utilized for the performance of the eddy current examinations.

In addition to NDE testing of Class 1 and 2 welds and components, pressure testing, visual examination of class 1 component internal surfaces and visual examination of pipe supports and hangers were also performed. Third party review (e.g. an ANII) was utilized for all examinations of ASME section XI components.

Selected components were examined in accordance with GPC commitments to the following documents:

- Section XI of the American society of Mechanical Engineers (ASME) Boiler and Pressure Vessel Code, "Rules for Inservice Inspection of Nuclear Power Plant Components," 1980 Edition with Addenda through Winter 1981.

- United States Nuclear Regulatory Commission, Generic Letter 88-01, "NRC POsition on IGSCC in BWR Austenitic Stainless Steel Piping" which invokes much of NUREG 0313, Revision 2, "Technical Report on Material Selection and Processing Guidelines for BWR Coolant Pressure Boundary Piping".

- United States Nuclear Regulatory Commission, Generic Letter 81-11, which modifies and invokes NUREG 0619," "BWR Feedwater Nozzle and Control Rod Drive Return Iine Nozzle Cracking".

- United States Nuclear Regulatory Commission, I\&E Bulletin 80-13 Visual Examination of core Spray spargers.

- Sic "Inservice Inspection Outage Plan, Edwin I. Hatch Nuclear Plant, Unit l 1991 Fall Refueling Outage, Revision 1."

- SNC "Second Ten-year Examination Plan, Edwin I. Hatch Nuclear Plant Unit 1."

- United States Nuclear Regulatory Commission NUREg 0803, "Generic Safety Evaluation Report Regarding Integrity of BWR SCRAM System Piping." 
Representative samples of the following systems, comprised of selected Class 1, 2, and 3 components, were examined using various NDE techniques, in accordance with the above documents:

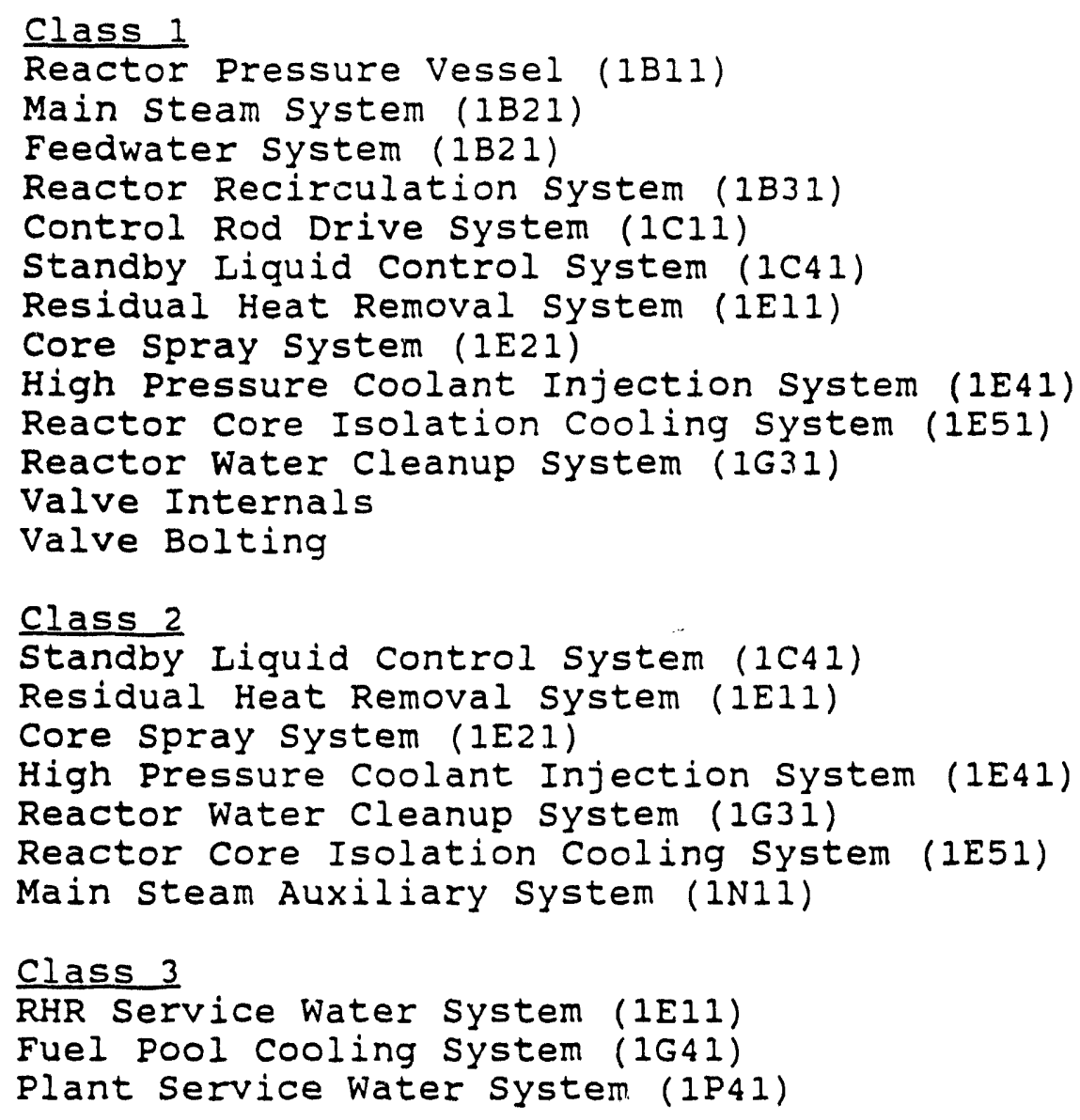

Eddy-current examinations were performed on the following components: Unit 1 Feedwater Heaters 5A, 5B, 7A, 7B, 8A, 8B, 10A, 10B, and Emergency Diesel Generator $I A$ and $1 C$ Jacket Water Coolers, Iube oil Coolers, Air Coolers and the Motor Generator "A" Air Cooler.

UT thickness measurements were performed on selected components in the Extraction steam and condensate Feedwater Piping systems. A portion of these components were selected due to their similarity in design and operating conditions to components involved with the "surry pipe break incident".

Eight (8) Non-Safety RWCU system welds were examined using ultrasonic examinations techniques (UT) due to commitments made by GPC. These augmented exams are not required by the ASME section XI code but were performed due to commitments to GL 88-01. 


\section{NUREG 0313}

GPC is committed to the performance of surface and volumetric examinations on IGSCC susceptible welds in accordance with NUREG 0313 . This commitment is formalized in GPC response to NRC Generic Letter 88-01. The below listed summary gives the total number of exams performed by outage end. A detailed report on flaw evaluation and overlay design was submitted to the NRC by letter HL-2000 dated January $21,1992$.

\section{Category A}

Thirty-nine (39) Category A welds were examined. Twenty-five (25) of these welds were examined using UT and PT techniques and the remaining fourteen (14) were examined using UT techniques only. No rejectable indications were found.

\section{Category C}

The original examination scope included fourteen (14) Category C welds. A scope expansion was required due to one (1) weld being found unacceptable for continued operation and was overlay repaired, resulting in a total of twenty-eight (28) Category $C$ welds being examined. Fourteen (14) of these welds were examined using UT and PT techniques and the remaining fourteen (14) welds were examined using UT techniques only.

The Category $C$ weld which was overlay repaired was $1 B 31-1 R C-28 B-2$.

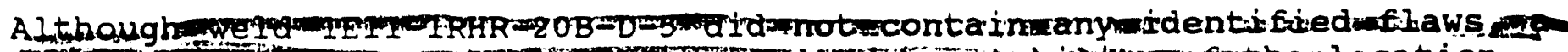

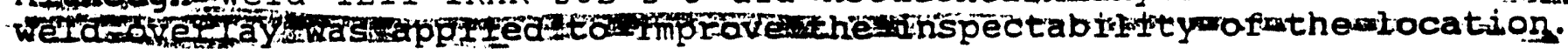

The classification of these welds is now Category E per NUREG-0313 and will be examined as such in future outages.

\section{Category D}

Twelve (12) Category D welds were examined. No rejectable indications were detected. Five (5) of these welds were examined using UT and PT techniques and the remaining seven (7) were examined using UT techniques only.

Six (6) RINTSA welds were examined by UT and no rejectable indications were detected.

\section{Category E}

The original examination scope included twenty-five (25) of the total forty-six (46) Category E (overlayed) welds. UT examinations revealed new IGSCC indications and some original cracks with new growth which warranted examination scope expansion. By outage end, all forty-six (46) Category E welds had been examined by UT NDE techniques. All results for new indications or crack growth were evaluated by structural Integrity Associates, Inc. and found to be acceptable for continued service. 
Note that six (6) new overlays were added during this outage which results in a total of fifty-two (52) Category E overlays. Preservice examinations were performed on each of these six (6) new overlays. No rejectable indications were found. See sections on Category $C$ and Category $F$ examinations for the additional overlay weld numbers.

\section{Category $F$}

All Category $F$ welds require examination each refueling outage. All four (4) of these welds were examined during the outage and a change in indications or apparent crack growth was detected in all four (4) of these welds which were unacceptable for continued service. All four (4) welds were overlay repaired and will be examined as category $E$ welds in future outages. Eisted below are the Category $F$ welds which were overlay repaired:

$$
\begin{aligned}
& 1 B 31-1 R C-12 B R-A-4 \\
& 1 B 31-1 R C-12 B R-E-4 \\
& 1 B 31-1 R C-12 A R-G-4 \\
& 1 E 11-1 R H R-20 B-D-4
\end{aligned}
$$

A preservice baseline examination was performed or all welds which were overlay repaired during the outage.

\section{Other Class 1 Examinations}

Two-hundred-eighteen (218) ASME section XI component examinations were performed utilizing UT, MT, PT and VT as applicable. These examinations included; RPV welds, piping welds, valve internals, and valve bolting materials.

Per I\&E Bulletin 80-13, the core spray sparger and associated piping were VT examined. No reportable indications were detected.

Per ASME section XI, selected RPV internals were examined. These examinations included portions of the vessel interior, interior attachments beyond the beit line region and the RPV internal components. See the Invessel Inspection section of this report for more detailed information.

Four (4) Class 1 valves were disassembled for maintenance/inspection during the outage. The internals of these valves were VT inspected by GPC Q.C. personnel. None of the valves exhibited any unacceptable conditions relevant to the visual examination.

Twenty (20) CRD's were replaced during the outage which facilitated visual examination $(\mathrm{VT}-1)$ of the bolts, studs, and nuts.

Per SII 462, one Shroud Support Access Hole Coverplate was examined.

\section{Class II Examinations}

Forty-seven (47) welds were examined using surface and/or volumetric NDE techniques as applicable. Two (2) of these welds were examined per NUREG 0619 (UT only), eleven (11) examinations were for the GPC augmented examination commitments, and the remaining thirty-four (34) examinations were per ASME section XI requirements.

Unacceptable linear indications were found in three (3) welds and were removed by controlled grinding. 
One (1) Class 1 hydrostatic test, two (2) class 2 hydrostatic tests, three

(3) Class 2 functional tests, two (2) Class 3 hydrostatic tests, three (3) Class 3 inservice tests, and the class 1 system Leakage Test were all performed satisfactorily. See Pressure Test section of Report for specific test identifications and details.

\section{Augmented Examinations}

Eight (8) welds in the non-safety 3 portion of the RWCU system were examined by UT per a GPC commitment to the NRC for NUREG 0313 Rev. 2 augmented requirements. No reportable indications were detected.

Component support Examinations (Class 1,2 and 3 )

One hundred and forty-nine (149) component supports were VT examined per the requirements of ASME section XI during the outage. seventeen (17) produced unacceptable results. After maintenance and/or engineering evaluation, all of the unacceptable component supports were determined to be acceptable. Where maintenance was required, the component supports were re-examined to confirm acceptability.

Repairs and Replacements (Class 1 and 2)

Numerous repair/replacement activities were performed prior to and during the outage. Major repair/replacement activities included weld overlay of six (6) Reactor Recirc. welds. An itemized list of the repair/replacement activities is included in the Repair/Replacement section of this report.

Reportable Indications

Following is an itemized list of all welds and components which were reported with indications or were considered unacceptable. All of these items were either repaired and/or evaluated and then determined to be acceptable. 


\section{Identification}

Steam Dryer

Upper and Lower

Guides

Upper Support Bracket IEII-2HX-A-USC-2

Upper Support Bracket IEII-2HX-A-USC-3

Weld

IB3 I-1RC-12BR-D-3

Weld overlay

1B31-1RC-28A-7

Weld overlay

1B31-1RC-28B-15

Weld overlay

1E11-1RHR-24B-R-12

Weld

1B31-1RC-28B-2

Weld

$1 Z 11-2 R H R-2 O A-D-4$

Weld

IEII-1RHR-24B-R-7

Weld

$1 B 31-1 R C-12 B R-A-4$

Weld

1B3 1-1RC-12BR-E-4

Weld

1B3 1-1RC-12AR-7-4

Weld

IEII-1RHR-2OB-D-4

Support

1B21-FDH-5

Support

1B21-EDH-10
Indication

Rub marks,

displaced metal

.3" linear indication

.6" and . 4" linear indications

spot indication

6 interbead lack of fusion indications

.3" Iinear indication

7 interbead lack of fusion indications

$.5 ", .42 "$, and . $25 "$

linear indications

3.5" linear MT

indication

2.5" linear MT

indication

UT indication

UT indication

UT indication

UT indication

Broken fillet welds

Bent paddle, slipped bearing
Corrective Action

Acceptable as is per GPC and GE engineering

Indication removed, area re-welded MWO 1-91-5805

Indication removed, area re-welded

MWO 1-91-6395

Acceptable as is per GPC Engineering

Acceptable as is per SIAI

Acceptable as is per SIAI

Acceptable as is per SIAI

Weld overlay

MWO 1-91-4832

Indication removed, area re-welded MWO 1-91-6265

Indication removed, area re-welded MWO 1-91-6264

We?d overlay

MWO 1-91-4832

Weld overlay

MWO 1-91-4832

Weld overlay

MWO 1-91-4832

Weld overlay

MWO 1-91-4832

Acceptable as is per Bechtel letter

Replaced paddle, reset bearing MWO 1-91-6468 
Identification

support

1CI1-SKI-H3

Support

1C11-SK1-H5

Support

ICII-SK1-H6

Support

1CI1-SK1-H14

Support

1C11-SK2-H24

Support

1C11-SK2-H26

Support

IEII-RHRH-407

Support

IEII-RHRH-407A

Support

IEII-SM-1

Support

IP4 1-SDGH-4

Support

1P4 1-SDGH-7

Support

IP4 I-SWH-19

Support

IP4 I-ISH-33

Support

IEII-RHRH - 60

Support

1E41-HPSEH-78

held

1B3 I-1RC-12AR-H-3
Indication

Bent rod

No load on support

light load on support

Bent rod

No load on clevis

No load on clevis, loose nut

Slipped bearing

Slipped bearing

Restricted movement of paddle

Improper spring can setting

Improper spring can setting

Bent rod

Bent paddle, slipped bearing

slipped bearing

Improper spring can setting

3.8 " and 1.3 "

linear indications
Corrective Action

Acceptable as is per Bechtel letter

Readjusted rod MWO 1-91-6504

Readiusted rod *MWO 1-91-6570

Acceptable as is per Bechtel letter

Readjusted rod *MWO 1-91-6570

Readjusted rod, tightened loose nut *MWO 1-91-6570

Reset bearing

MWO 1-91-6129

Reset bearing

MWO 1-91-6129

Acceptable as is per Bechtel letter

Reset spring can

MWO 1-91-5455

Reset spring can

MWO 1-91-5455

Repaired rod

MWO 1-91-5456

Replaced paddle, bearing acceptable as is per Bechtel letter MWO 1-91-5454

Reset bearing

MWO 1-91-5457

Reset spring can

*MWO 1-91-5458

Acceptable as is per SIAI 
Identification

Weld

1B3 1-1RC-12AR-J-3

Weld

IEII-1RHR $-2 \div B-R-13$

\section{Indication}

1.3" linear indjcation

$.4 ", .15 ", .25 ", .61$, .6" and . 3" I inear indications
Corrective Action

Acceptable as is per SIAI

Acceptable as is per SIAI

* These MWOs did not require initial/final ANII review. 
E.1. HATCH UNIT 1 FALL 1991 REFUELING OUTAGE

CLASS 1 COMPONENTS

ASME EXAM

ICIIIN XI FIGURE NO. EXAMINAIION/AREA RPV FXAMINAIIONS

$\begin{array}{lll}\text { MR. } 10 & A-1 A / 02 & C-6(120-270) \\ \text { A } & & \text { SUPPORI SKIRT-MZD } \\ \text { A.ME } & (120 \text { DESREE }) \text { IO M2H } \\ & & \text { (270 DEGREE) C.M. }\end{array}$

(1). 10 CLASS 1 (PI)

PRESSURE REIAIMING

BOMWOARY LEAKAGE

IEST

$$
\begin{aligned}
& \text { H } 7.80 \\
& \text { H G. } 2 \\
& \text { A. ME }
\end{aligned}
$$

.. Flange bolitimg

CRO HOUSING

M2A (RIMISA)

RIMTSR WELD

SIIREG $0: 130$

$\begin{array}{ll}\text { Dodonts } & \text { M-1/04 (IR) } \\ & \text { B LOOP RECIRCULATION } \\ \text { IMLET WOZZLE AT } 60 \\ \text { DEGREES }\end{array}$

A-1/04 N2B (in-5i)

B lOOP RECIRCULATION

IMLET MOZZ TO SHELL

$\begin{array}{ccc}\text { EXAMINATION } & \text { CAL } & \text { EXAM/CAL } \\ \text { PROCEDURE } & \text { BLOCK } & \text { SHEET MO. }\end{array}$

RESUL IS

REMARKS

$\begin{array}{lllll}M T-H-500 / 05 & 61-H & \text { S91H1M044 } & \text { NRI } & \\ \text { UT-H-410/04 } & & \text { S91HIC106 } & \text { M/A } & \text { UT CAL } \\ & & \text { S91H1U157 } & \text { MRI } & \end{array}$

VT-H- 720/03

n/A

SEE PRESSURE IESI SECIION OF IHIS REPORT.

450C-IMF-

M/A

012-0S

UT-M-415/05 125-H

S91н1C169 S91н1U231

w/a

UI CAL

N/A

EXAM PERFGOMED BY GPC OC DEPI.

UT $-1-480 / 04$

$61-1$

S91H1C106 S91н1บ155

M/A

UT CAL

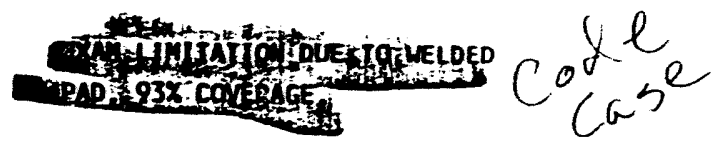

\begin{tabular}{|c|c|c|}
\hline s91н1с115 & m/A & UT CAL \\
\hline 591н101/57 & MRI & \\
\hline 591н1с118 & $m / A$ & UT CAL \\
\hline 591н1บ171 & MRI & \\
\hline s91н1с121 & $M / a$ & UT CAL \\
\hline S9141บ175 & mRI & \\
\hline
\end{tabular}

UT - H-410/04

61-H

\section{TESTPEO EXAM OUEXIO;MOZ2LE \\ Tecificuparion,}


Dr. Thomas E. Murley, Director

Office of Nuclear Reactor Regulation

U.S. Nuclear Regulatory Commission

Washington, D.C. 20555

Attn: Document Control Desk

Subject: Braidwood Station Unit 1

Inservice Inspection Report for

Interval 1, Period 2, Refuel Outage 1

NRC Docket Nos. 50-456

Reference:(a) December 15, 1988, S.C. Hunsader to letter to T. E. Murley

Dear Dr. Murley:

Reference (a) provided the complete Braidwood Station Units 1 and 2 Inservice Inspection (ISI) program for NRC review that is currently being implemented at the station. In accordance with the requirements of this program and Article IWA-6000 of Section XI of the ASME Boiler and Pressure Vessel Code (1983 Edition through and including the Summer, 1983 Addenda) Commonwealth Edison is submitting the report of the ISI performed at Unit 1 from May 19, 1991 through November 3,1992 . This report is required to be submitted within 90 days of the completion of a refueling outage. The Unit 1 refueling outage was completed on November 3, 1992.

Please address any questions regarding this submittal to this office.

Very truly yours,

$1.9002:$

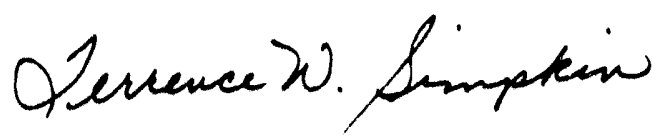

T.W. Simpkin

Nuclear Licensing Administrator

cc: J. Hickman - NRR w/o attachment

B. Clayton - RIII w/o attachment

Braidwood Resident Inspector w/o attachment 
COMMONWEALTH EDISON

BRAIDWOOD NUCLEAR GENERATING STATION

UNIT 1

INSERVICE INSPECTION SUMMARY REPORT

INTERVAL 1

PERIOD 2

OUTAGE 1

STATION ADDRESS:

BRAIDWOOD NUCLEAR GENERATING STATION

R.R. \#1 BOX 84

BRACEVILLE, ILLINOIS 60407

COMMERCIAL SERVICE DATE: JULY 29, 1988

OWNER'S ADDRESS:

COMMONWEALTH EDISON COMPANY

P.O. BOX 767

CHICAGO, ILLINOIS 60690 


\section{INDEX}

\section{DESCRIPTION}

INTRODUCTION

EXAMINATION SUMMARY

PIPING/COMPONENTS

SUPPORTS / SNUBBERS

PRESSURE TESTS

FORM NIS-1

(OWNER'S REPORT FOR INSERVICE INSPECTION)

FORM NIS-1 (SUPPLEMENTAL SHEETS)

MANUFACTURER/INSTALLER ADDRESS

EXAMINATION SUMMARY TABULATION

$$
\begin{aligned}
& \text { WELD/COMPONENTS } \\
& \text { COMPONENT SUPPORTS } \\
& \text { PRESSURE TESTS }
\end{aligned}
$$

SUMMARY OF NIS-2 FORMS

FORM NIS-2

(OWNER'S REPORT FOR INSERVICE INSPECTION)

\section{PAGE}

I to II

III

III to IV

V

VI

VII

1 thru 18

VIII

IX

1 thru 12

1 thru 24

1 thru 9

TAB 1

TAB 1 


\section{INTRODOCTION}

Braidwood station performed Inservice Inspections on ASME class 1 and 2 components and piping for Unit 1 from May 19, 1991 to November 03, 1992. The majority of the inspections were performed during Braidwood Station's Unit 1 third refueling outage (AIRO3). Examinations were performed in compliance with the American Society of Mechanical Engineers (ASME) Boiler and Pressure Vessel Code, 1983 Edition through the summer 1983 Addenda of Section XI, Division 1, "Rules for Inservice Inspection of Nuclear Power Plant Components", as required by the Code of Federal Regulations (10CFR50.55a). This summary report addresses the inspection results on Class 1 and 2 components and piping.

Braidwood's Nondestructive Examination (NDE) ISI Program Plan for Class 1 and 2 components and piping was developed in accordance with ASME Section XI, Division 1, subsections IWA, IWB, and IWC. In addition to the ASME Section XI examination requirements, certain Nuclear Regulatory Commission (NRC) augmented inspections were included. Braidwood's Unit 1 augmented ISI requirements included:

- Examination of High Energy Lines in compliance with NUREG 0800, Section 6.6, "Standard Review Plan".

- Regulatory Guide 1.83, Revision 1, "Inservice Inspection of Pressurized Water Reactor Steam Generator Tubes".

- NRC Bulletin 88-09, "Thimble Tube Thinning in Westinghouse Reactors".

- NRC Bulletin 88-08, "Thermal Stresses in Piping Connected to Reactor Coolant systems".

Braidwood developed and submitted specific relief requests, for the commission's review, where code and/or augmented requirements were deemed impractical. 


\section{Identification of Examination Requirements}

The ISI Program contains NDE tables, presented in a tabular format, consistent with the ASME section XI subsections IWB and IWC tables. The NDE program tables include the corresponding code category, item number, and coinfonent/weld selection in compliance with ASME Section XI Class 1 and 2 examination requirements.

\section{Exempted components}

The ISI NDE Program Plan identifies ASME Class 1 and 2 components exempt from examination as specified in ASME section XI, Subsections IWB and IWC, Paragraph 1220, "Components Exempt from Examination" along with technical justifications for these exemptions.

\section{ISI Program Implementation}

Braidwood station performed visual examinations (VT-1, VT-2, and VT-3/4) on ASME Class 1 and 2 components and their supports identified in the ISI program due to repairs or replacements under ASME section XI requirements. The examinations were performed by personnel qualified to Commonwealth Edison's "Special Process Procedure (SPP 2-1-0)" developed in compliance with the American Society of Nondestructive Testing (SNT-TC-1A), 1984 Edition, and American National standards Institute (ANSI), 1973/1978 Edition, N45.2.6.

All NDE Examinations, including evaluations of the results, were performed by personnel qualified to the American Society of Nondestructive Testing (SNT-TC-1A) and in compliance with ASME Sections V and XI, 1983 Edition through Summer 1983 Addenda.

\section{NDE EXAMINATIONB}

Braidwood performed all the ISI nondestructive examinations, including the evaluations of flaw indications, in accordance with ASME Section XI, subarticle IWA-2200, "Examination Methods". 
Inservice Inspections were performed from May 19, 1991 to November 3, 1992. The Inspector was Mr. Librado Malabanan from Hartford Steam Boiler Inspection and Insurance Company of Hartford, Connecticut, Chicago Branch, 2443 Warrenville Road, Suite 500 Lisle, Illinois 60532 .

The following is a summary of the examinations performed during the Braidwood Unit 1 third refueling outage. Refer to the summary tables for additional information on specific welds, components, supports and pressure test examinations and their respective results.

\section{PIPING BY8TEX8}

\section{CHEXICAL AND VOLUKE CONTROL (CV)}

A total of 2 augmented pressure retaining welds were examined (ref. Note 10 of the ISI Program Plan). One valve received a VT-1 exam (B7.70)

\section{FEEDWATER (FW)}

A total of 23 pressure retaining welds were examined. of these 12 received a volumetric and surface exam (C5.21) and 11 received a volumetric exam only (ref. Note 5 of the ISI Program Plan).

\section{KAINSTEAY (MS)}

A total of 20 weldments were examined. Of these 4 received a surface exam $(2-C 3.20,2-C 5.22), 4$ received both a volumetric and surface exam (C5.21) and 12 received a volumetric exam only (ref. Note 5 of the ISI Program Plan).

\section{REACTOR COOLANT (RC)}

A total of 59 components were examined. Of these 18 welds were examined by surface \& volumetric (15-B9.11, 2-B5.70, 1B9.31), 35 welds received a surface exam (28-B9.40, 1-B9.21, 6-B9.32), and 6 mechanical bolting connections received a VT$1(3-B 7.50,3-B 7.70)$.

\section{RESIDOAL HEAT REMOVAL (RH)}

A total of 12 pressure retaining welds received a surface exam $(3-C 5.12,9-C 5.11)$ and 8 received a volumetric examination (ref. Note 10 of the ISI Program Plan). 
SAFETY INJECTION (BI)

A total of 6 pressure retaining welds were examined. Four welds received a volumetric and surface exam (B9.11), and 2 welds received a surface exam (B9.40).

\section{COMPONENTS}

\section{REACTOR VESSEL (1RCO1R)}

A VT-3 was performed on the accessible surfaces of the vessel (B13.10).

\section{REACTOR COOLANT PUXP (1RCO1PD)}

1 reactor coolant pump flywheel was examined per Reg Guide 1.14 (ref. Note 6 of the ISI Program Plan).

\section{RESIDUAL HEAT REYOVAT HEAT EXCHANGER (1RH02AA, 1RH02AB)}

Four nozzle-to-shell (C-B C2.21) pressure retaining welds received a volumetric and surface exam.

\section{STEAY GENERATOR (1RCO2BA)}

One volumetric examination was performed (B2.40). GTEAY GENERATORB (1RCO1BA, 1RCO1BB, 1RCO1BC, 1RCO1BD)

Eddy Current examination was performed on all 4 steam generators. Fifty percent of each generator's tubes received $100 \%$ full length examination. The remaining tubes were examined from the hot leg tube end thru the top support plate on the cold leg side. Based on Eddy current results, 174 tubes were plugged.

Additional information concerning the steam generator eddy current inspection can be obtained from the report submitted to the Nuclear Regulatory Commission as required by Braidwood Station Technical Specifications 4.4.5.5. 


\begin{tabular}{lr} 
\#NSSS & 8 \\
AF & 2 \\
CS & 4 \\
CV & 56 \\
FW & 4 \\
MS & 12 \\
RC & 94 \\
RH & 39 \\
RY & 33 \\
SD & 15 \\
SI & 65 \\
& \\
\hline
\end{tabular}

\#STEAM GENERATOR SNUBBERS 
SYSTEM PRESSURE TESTS

\section{EXAMINATION SUMMARX}

TABULATION 
SYSTEM PRESSURE TESTS

A total of 1 Class 1 system Pressure Test and 68 Class 2 Subsystem Pressure Tests were performed.

The Class 1 system Boundary includes the Class 1 portions of Chemical Volume Control system (CV), Reactor coolant (RC), Residual Heat Removal system (RH), Pressurizer system (RY), and the safety Injection system (SI).

The Class 2 system boundaries are divided into convenient test boundaries and are described briefly below:

\section{SUBSY8TEY CLABS DESCRIPTION}

$\begin{array}{ll}C C-1 & 2 \\ C C-2 & 2 \\ C S-1 & 2 \\ C S-2 & 2 \\ C S-3 & 2 \\ C S-4 & 2 \\ C V-1 & 2 \\ C V-2 & 2 \\ C V-3 & 2 \\ C V-4 & 2 \\ C V-5 & 2 \\ C V-6 & 2 \\ C V-7 & 2 \\ C V-8 & 2 \\ C V-9 & 2 \\ C V-10 & 2 \\ C V-11 & 2 \\ C V-12 & 2 \\ C V-13 & 2 \\ C V-14 & 2 \\ C V-15 & 2 \\ C V-16 & 2 \\ C V-17 & 2 \\ C V-18 & 2 \\ C V-19 & 2 \\ C V-20 & 2 \\ C V-21 & 2 \\ C V-22 & 2 \\ C V-23 & 2 \\ C V-24 & 2 \\ C V-25 & \end{array}$

Component cooling IRC/ORC Component cooling IRC/ORC

1A Train Containment Spray system

1B Train Containment spray system

1 A Train Spray Additive system

1B Train Spray Additive System

Volume Control Tank

Positive Displacement Pump

$1 \mathrm{~A}$ Centrifugal Charging Pump

IB Centrifugal Charging Pump

control volume Charging Header

IA Seal Water Injection Filter

$1 B$ Seal water Injection Filter

Seal Water Injection

Seal Water Return

Chemical Volume Charging to RC Loops

Charging Pumps Regenerative Heat Exchanger

IA Regenerative Heat Exchanger

1B Regenerative Heat Exchanger

CV Charging Inside Containment

Letdown Inside containment

1B Letdown Regen. Heat Exchanger

$1 \mathrm{~A}$ Letdown Regen. Heat Exchanger

Letdown Outside Containment

1A Letdown Heat Exchanger

IB Letdown Heat Exchanger

Letdown Downstream of Letdown Heat Exchanger

RC Filter up to volume Control Tank

1 A Excess Letdown Heat Exchanger

$1 B$ Excess Letdown Heat Exchanger

Letdown Downstream of Excess Letdown Heat Exchang 


\begin{tabular}{|c|c|c|}
\hline \multirow{2}{*}{\multicolumn{3}{|c|}{$\begin{array}{l}\text { Class } 2 \text { portion of Fuel Pool cooling } \\
\text { Mainsteain A Loop }\end{array}$}} \\
\hline$M S-2$ & 2 & \\
\hline MS - 3 & 2 & $\begin{array}{l}\text { Mainsteam B Loop } \\
\text { Mainsteam C Loop }\end{array}$ \\
\hline MS - 4 & 2 & Mainstean D Loop \\
\hline$O G-1$ & 2 & Hydrogen Recombiner \\
\hline$O G-2$ & 2 & Hydrogen Recombiner suction Piping \\
\hline OG-3 & 2 & Hydrogen Recombiner Discharge Piping \\
\hline $\mathrm{RC}-1$ & 2 & Instr./Sampling Lines Loop A \& Reactor Vessel \\
\hline $\mathrm{RC}-2$ & 2 & Instr./Sampling Lines, Loop b \\
\hline $\mathrm{RC}-3$ & 2 & Instr./Sampling Lines, Loop C \\
\hline $\mathrm{RC}-4$ & 2 & Instr./Sampling Lines, Loop D \\
\hline $\mathrm{RC}-5$ & 2 & Reactor Coolant \\
\hline RH -1 & 2 & 1A Train Residual Heat Removal Pump \\
\hline RH -2 & 2 & 1A Train Residual Heat Removal Heat Exchanger \\
\hline RH -3 & 2 & IB Train Residual Heat Removal Pump \\
\hline RH -4 & 2 & 1B Train Residual Heat Removal Heat Exchanger \\
\hline RH -5 & 2 & Residual Heat Remova? Heat Exchanger \\
\hline$R Y-1$ & 2 & Pressurizer Sample System \\
\hline$R Y-2$ & 2 & Pressurizer, Instrumentation lines \\
\hline $\begin{array}{l}R Y-3 \\
R Y-4\end{array}$ & 2 & ORC Portion of RY to PRT \\
\hline $\begin{array}{l}R Y-4 \\
S D-1\end{array}$ & $\begin{array}{l}2 \\
2\end{array}$ & $\begin{array}{l}\text { ORC Portion of RY to PRT } \\
\text { Lorp A Steam Gen. Blowdown Lines }\end{array}$ \\
\hline$S D-2$ & 2 & Lcop B Steam Gen. Blowdown Lines \\
\hline SD-3 & 2 & Loop C Steam Gen. Blowdown Lines \\
\hline$S D-4$ & 2 & Loop D Steam Gen. Blowdown Lines \\
\hline $\begin{array}{l}S I-1 \\
S I-2\end{array}$ & 2 & ECCS suction Piping \\
\hline $\begin{array}{l}S I-2 \\
S I-3\end{array}$ & $\begin{array}{l}2 \\
2\end{array}$ & Safety Injection Accumulator \\
\hline $\begin{array}{l}S I-3 \\
S I-4\end{array}$ & $\begin{array}{l}2 \\
2\end{array}$ & 1A Safety Injection Accumulator \\
\hline $\begin{array}{l}S I-4 \\
S I-5\end{array}$ & $\begin{array}{l}2 \\
2\end{array}$ & 1B Safety Injection Accumulator \\
\hline $\begin{array}{l}S I-5 \\
S I-6\end{array}$ & 2 & $\begin{array}{l}\text { 1C Safety Injection Accumulator } \\
\text { ID Safety Injection Accumulator }\end{array}$ \\
\hline$S I-7$ & 2 & Accumulator Fill Lines \\
\hline $5 I-8$ & 2 & Safety Injection To Accumulator Tank \\
\hline$S I-9$ & 2 & Safety Injection Test Iines \\
\hline $5 x-1$ & 2 & $\begin{array}{l}\text { ORC/IRC Essential Service Water "B" Train } \\
\text { Return Header }\end{array}$ \\
\hline $5 x-2$ & 2 & ORC/IRC Essential service water "A" Train \\
\hline
\end{tabular}


FORM NLS-1 OWNER S REPORT FOR INSERVICE DSPPECTIONS

As required by the Provtsions of the ASME Code Rules

1. Owner Commonwealth Edison, one Fijst National Plaza, Chicaco, Illinois (Name and Address of Owner)

2. Plant Braidwood Station, R.R. 1, Box 84, Braceville. IL 60407 (Name and Address of Plane)

3. Plant Unit 4. Owner Certificate of Authorization (if required)

$\mathrm{N} / \mathrm{A}$

5. Commercial Service Date 7-29-19886. National Board Number for Unit $N / A$

7. Componenes Inspected Class 1 and 2 componsnts as described in supplemental shants (pages 1 thru 18).

\begin{tabular}{|c|c|c|c|c|}
\hline $\begin{array}{l}\text { Component or } \\
\text { Appurtenance }\end{array}$ & $\begin{array}{l}\text { Manufacturer } \\
\text { or Installer }\end{array}$ & $\begin{array}{l}\text { Manufacturer } \\
\text { or Installer } \\
\text { Serial No. }\end{array}$ & $\begin{array}{c}\text { Seste or } \\
\text { Province No. }\end{array}$ & $\begin{array}{l}\text { National } \\
\text { Board No. }\end{array}$ \\
\hline & See supplemental sheets & (paqes 1 thru & 181 & \\
\hline & & & & \\
\hline & & & & \\
\hline & & & & \\
\hline & & & & \\
\hline & & & & \\
\hline & & & & \\
\hline & & & & \\
\hline & & & & \\
\hline & & & & \\
\hline & & & & \\
\hline & & & & \\
\hline & & & & \\
\hline & & & & \\
\hline
\end{tabular}

Note: Supplemental sheets in form of lists, sketches, or drawiogs may be used, provided (1) size is 842 in, $x 11$ in., (2) information in items 1 through 6 on this report is included on each sheet, and (3) each sheet is numbered and the number of sheets is recorded at the top of this form. 


\section{WELD/COMPONENT \\ COMPONENT SUPPORTS \\ PRESSURE TESTS \\ EXAMINATION SUMMARY \\ TABULATION}


CHEMICAL \& VOLUME CONTROL

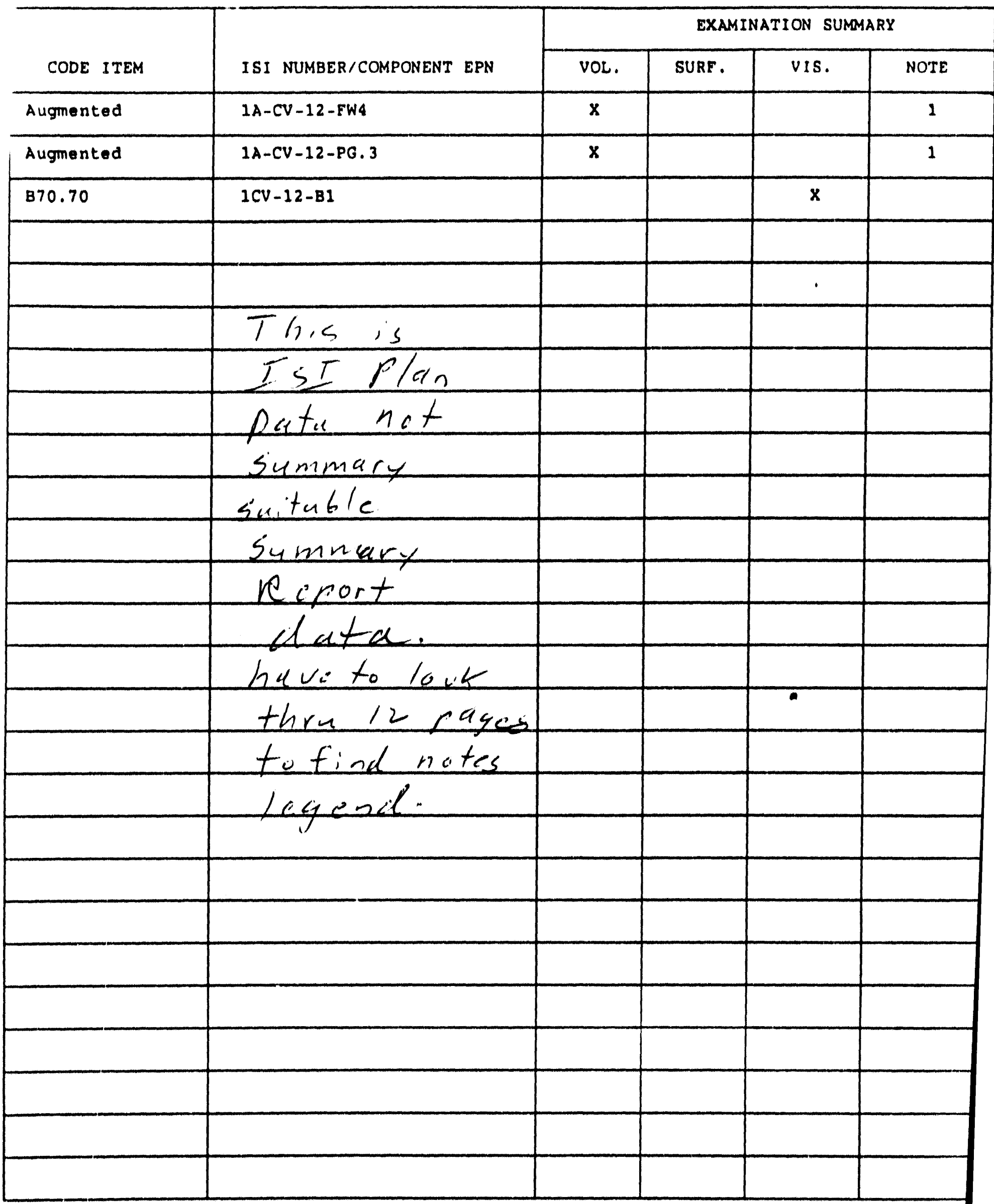




\section{MEWD/COYPONMIT NAAYHATIOd NOTES}

1. These are augmented volumetric examinations on $71 / 28$ of the circumferential welds Whin the ECCS systems (ref. Note 10 of the ISI Program PIan).

2. Braldwood station will utilize Code Case N-426 (ref. Note 3 of the IsI Program Plan).

3. Indications exceeding Section XI acceptance criteria were detected on two (2)

pazle-to-vessel welds. Fracture mechanics analysis was performed and found acceptable. (ref. RC Docket No. STN 50-457).

4. Ultrasonic examinations were performed on high energy lines not postulated for line reaks (ref. Note 5 of the ISI Program Plan).

5. Augmented NDE exams were performed on 1 reactor coolant pump flywhel. (ref. Note 6 f the ISI Program Plan).

6. Only 25 thru wall indications can be detected on cast stalniess steel welde (ref. llef Request NR-2 of the ISI Program PIan). 
A total of 1 Class 1 system Pressure Test, 68 Class 2 subsystem Pressure Tests were performed.

The Class 1 system Boundary Includes the Class 1 portions of Chemlcal volume Control System (CV), Reactor Coolant (RC), Residual Heat Removal system (RH), Pressurizer System (RY), and the Safety Injection System (SI).

The Class 2 system boundaries are divided into comvenlent test boundarles and ire described briefly below:

\section{Subsystem}

CC -1

CC -2

Cs-1

CS-2

C8-3

C8-4

CS-23

C8-24

CS-25

\section{CV - 1}

CV -2

CV -3

CV-4

CV-5

CV -6

CV -7

CV-8

CV-9

CV -10

CV-11

CV -12

CV -13

CV-14

CV -15

CV-16

CV -17

CV-18

CV -19

CV -20

CV-21

CV.-22

CV-25

rC-1

\section{Clase}

2

2

2

2

2

2

2

2

2

2

2

2

2

2

2

2

2

2

2

2

2

2

2

2

2

2

2

2

2

2

2

2

\section{Description}

Component Cooling IRC/ORC

Component Cooling/IRC/ORC

1A Train Contalnment Spray System

18 Irain Contalnment Spray syotem

1 A Train Spray Additive Syotem

1B Train Spray Additlve Syatem

1A Excess Letdown Heat Exchanger

1B Excess Lotdown Heat Exchanger

Letdown Downetruan of Excese Letdown Heat

Exchanger

Volume Control Tank

Positive Displacement Pump

1A Centrifugal Charging Punp

1B Centrifugal Charging Pump

Control Volume Charging Header Outside

Contalnment

IA Seal Water Infection Filter

1B Seal Water Infection Filter

Sead Water Injection

Sead Water Retura

Chemical Volume Charging to Reactor

Coolant Loops Inside

CV Portion of charging Punpe Regenerative

Heat Exchanger

1A CV Regenerative Heat Exchanger

1B CV Regenerative Heat Exchanger

CV Charging Inside Containment.

Letdown Inside Conteinment

1B Letdown Regen. Heat Exchanger

1A Letdown Regea. Heat Exchanger

Letdown Outside Containment

1A Letdown Heat Exchanger

18 Letdown Heat Exchanger

Letdown Downstrean of Letdown Heat

Exchangers

RC Filter up to Volume Control Tank

Letdown Downstream of Excens Lotdown Heat.

Exchanger

Class 2 Portlons of ruel Pool Cooling 


\begin{tabular}{|c|c|c|}
\hline MS - 1 & 2 & Main steam A Loop \\
\hline MS - 2 & 2 & Main Steam B Loop \\
\hline MS - 3 & 2 & Main Stean C Loop \\
\hline MS - 4 & 2 & Main Stean D Loop \\
\hline OG-1 & 2 & Hydrogen Recombiner \\
\hline OG - 2 & 2 & Hydrogen Recomisiner Suction Plping \\
\hline OG-3 & 2 & Hydrogen Recombiner Discharge Piping \\
\hline RC -1 & 2 & $\begin{array}{l}\text { Instrumentation/Sampling Lines Loop A and } \\
\text { Reactor Vessel }\end{array}$ \\
\hline$R C-2$ & 2 & Instrumentation/Sampling Lines, Loop B \\
\hline RC - 3 & 2 & Instrumentation/Sampling Lines Loop C \\
\hline $\mathrm{RC}-4$ & 2 & Instrumentation/Sampling Lines Loop D \\
\hline RC -5 & 2 & Reactor Coolant \\
\hline RH-1 & 2 & 1A Train Residual Heat Removal Pump \\
\hline RH - 2 & 2 & $\begin{array}{l}\text { 1A Train Resldual Heat Removal Heat } \\
\text { Exchanger }\end{array}$ \\
\hline RH - 3 & 2 & 18 Train Residual heat Removal Pump \\
\hline RH-4 & 2 & $\begin{array}{l}\text { 1B Train Residual Heat Removal Heat } \\
\text { Exchanger }\end{array}$ \\
\hline $\mathbf{R H}-\mathbf{5}$ & 2 & Resldual Heat Removal to safety Injection \\
\hline$R Y-1$ & 2 & Pressurizer Sample System \\
\hline$R Y-2$ & 2 & Pressurizer, Instrumentation Lines \\
\hline $\mathbf{R Y}-\mathbf{3}$ & 2 & ORC Portion of RY to PRT \\
\hline $\mathbf{R Y}-4$ & 2 & ORC Portion of RY to PRT \\
\hline SD-1 & 2 & Loop A stean Gen. Blowdown Lines \\
\hline SD-2 & 2 & Loop B Steam Gen. Blowdown Lines \\
\hline SD-3 & 2 & Loop C Steam Gen. Blowdown Lines \\
\hline SD-4 & 2 & Loop D Steam Gen. Blowdown Lines \\
\hline SI - 1 & 2 & $\begin{array}{l}\text { Refueling Water Storage Tank ECCS Suction } \\
\text { Plping }\end{array}$ \\
\hline$S I-2$ & 2 & Safety Injection Pumps \\
\hline SI - 3 & 2 & 1A Safoty Injection Accumulator \\
\hline$S I-4$ & 2 & IB Safety Injection Accunulator \\
\hline $8 I-5$ & 2 & IC Safety Injection Accumulator \\
\hline SI-6 & 2 & 1D Safety Injection Accumulator \\
\hline SI -7 & 2 & Accumulator F111 Lines \\
\hline$S I-8$ & 2 & $\begin{array}{l}\text { Safoty Infection To Accumulator Tank ORC } \\
\text { Portion }\end{array}$ \\
\hline $\mathbf{S I}-9$ & 2 & Safety Injection Test Lines \\
\hline $\mathbf{s x}-2$ & 2 & $\begin{array}{l}\text { ORC/IRC Essential Service Water "B" Train } \\
\text { Return Header }\end{array}$ \\
\hline $8 x-1$ & 2 & $\begin{array}{l}\text { ORC/IRC Essentail Service Water "A" Train } \\
\text { Return Header }\end{array}$ \\
\hline
\end{tabular}


STETYY PRESSURE TYSTS

Class 1

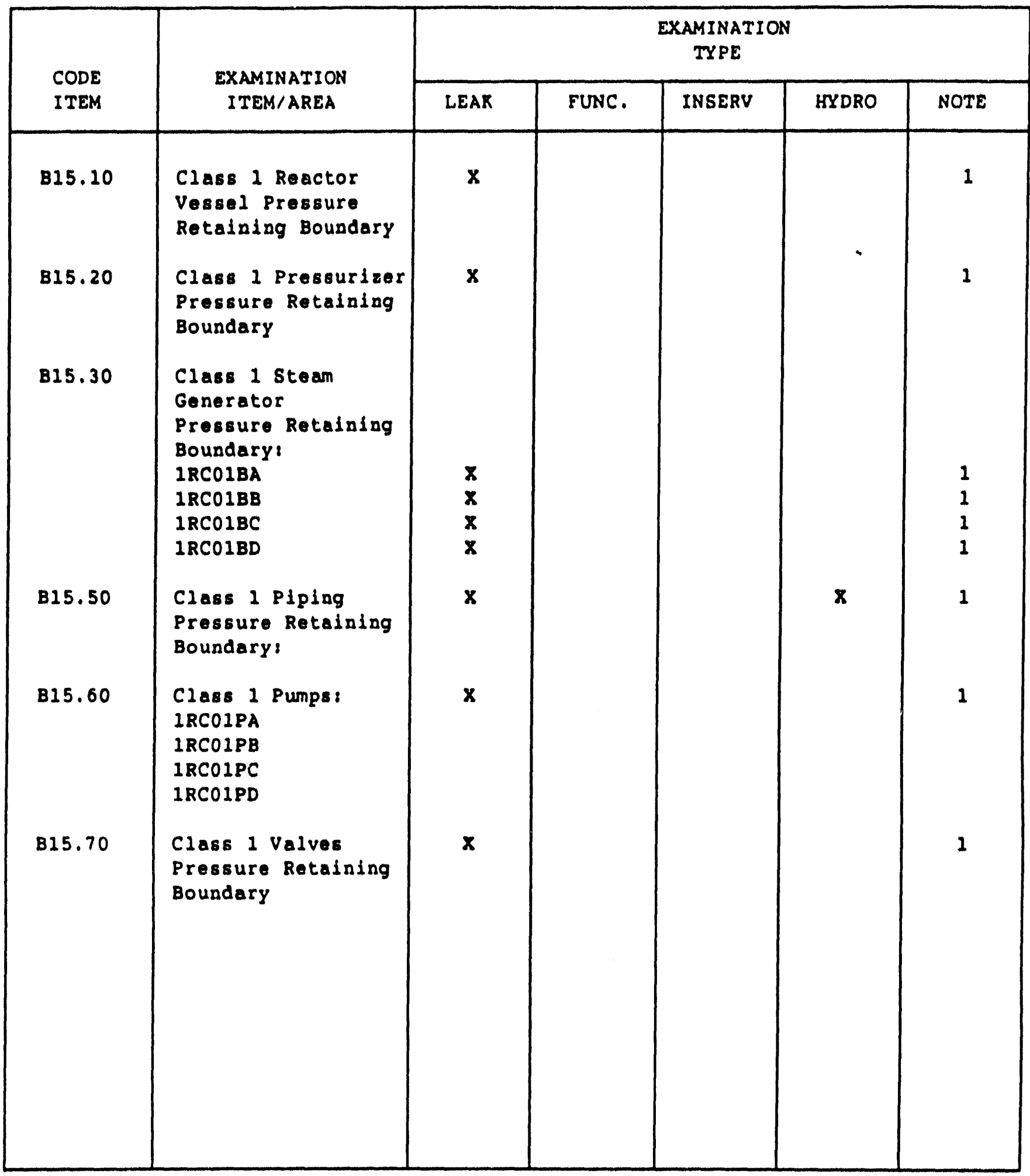


SYSTRY PRESSURE TESTS

Class 2

\begin{tabular}{|c|c|c|c|c|c|c|}
\hline \multirow{2}{*}{$\begin{array}{l}\text { CODE } \\
\text { ITEM }\end{array}$} & \multirow{2}{*}{$\begin{array}{l}\text { EXAMINATION } \\
\text { ITEM/AREA }\end{array}$} & \multicolumn{5}{|c|}{$\begin{array}{l}\text { EXAMINATION } \\
\text { TYPE }\end{array}$} \\
\hline & & LEAR & FUNC. & INSERV & HYDRO & NOTE \\
\hline $\begin{array}{l}\mathrm{C2.33} \\
\mathrm{C} 7.10\end{array}$ & $\begin{array}{l}\text { Nozzle-to-Shell } \\
\text { (or Head) when } \\
\text { inside of vessel } \\
\text { is inaccessible: } \\
\text { Residual Heat } \\
\text { Removal Heat } \\
\text { Exchangers: } \\
\text { 1RH02AA 1RH-2 } \\
\text { 1RH02AB 1RH-4 } \\
\text { Pressure Vessels } \\
\text { Pressure Retaining } \\
\text { Components } \\
\text { Seal Water Heat } \\
\text { Exchangers: } \\
\text { 1CV02A 1CV-9 } \\
\text { Letdown Heat } \\
\text { Exchanger: } \\
\text { 1CV04AA 1CV-19 } \\
\text { 1CV04AB 1CV-20 } \\
\text { Seal Water Return } \\
\text { Filter: } \\
\text { 1CV02F 1CV-9 } \\
\text { Residual Heat } \\
\text { Removal Heat } \\
\text { Exchangers: } \\
\text { 1RH02AA 1RH-2 } \\
\text { 1RH02AB 1RH-4 } \\
\text { Volume Control Tank } \\
\text { 1CV01T 1CV-1 }\end{array}$ & & $x$ & $\begin{array}{l}x \\
x \\
x\end{array}$ & & $\begin{array}{l}2 \\
2 \\
2\end{array}$ \\
\hline
\end{tabular}


NIB-2

OWNER'S REPORT FOR

REPAIRS AND REPLACEMENTS

SY8TEY

Chemical volume Control

Main steam

Reactor Coolant

Pressurizer

Steam Generator Blowdown (SD)

(MS)

(RC)

(RY)

\section{NI8-2 TOTAI TOTAL PAGEB}

5

5

3

3

4

4

3

3

4

4 


\section{COMMONWEALTH EDISON BRAIDWOOD NUCLEAR STATION UNIT 2}

INSERVICE INSPECTION SUMMARY REPORT

INTERVAL 1 PERIOD 1 OUTAGE 2

STATION ADDRESS:

R.R. \#1 BOX 84

BRACEVILLE, ILLINOIS 60407

COMMERCIAL SERVICE DATE: OCTOBER 17, 1988 OWNER'S ADDRESS:

COMMONWEALTH EDISON COMPANY

P.O. BOX 767

CHICAGO, ILLINOIS 60690 


\section{INDEX}

DESCRIPTION

INTRODUCTION

EXAMINATION SUMMARY

PIPING / COMPONENTS

SUPPORTS / SNUBBERS

PRESSURE TESTS

FORM NIS-1

(OWNER'S REPORT FOR INSERVICE INSPECTION)

FORM NIS-1 (SUPPLEMENTAL SHEETS)

EXAMINATION SUMMARY TABULATION

WELD/COMPONENTS

COMPONENT SUPPORTS

PRESSURE TESTS

SUMMARY OF NIS-2 FORMS

FORM NIS-2

(OWNER'S REPORT FOR INSERVICE INSPECTION)
PAGE

I to II

III to IV

$\mathrm{V}$

VI

VII

1 thru 8

1 thru 14

1 thru 27

1 thru 10

TAB 1

TAB 1 


\section{INTRODOCTION}

Inservice inspections of ASME Class 1 and 2 components and piping were conducted at Braidwood Station Unit 2 from May 28,1990 to November 26, 1991. The majority of these inspections were performed during Braidwood stations's Unit 2 second refueling outage (A2R02). The examinations were performed in compliance with the rules and regulations of Bection XI, Division 1, "Rules for Inservice Inspection of Nuclear Power Plant Components", of the American society of Mechanical Engineers (ASME) Boiler and Pressure Vessel Code, 1983 Edition through the summer 1983 Addenda, as per the requirements of Title 10, Part 50.55 a of the Code of Federal Regulations (10CFR50.55a). This summary report will address inspection results on Class 1 and 2 components and piping.

The Nondestructive Examination (NDE) ISI Program Plan for Class 1 and 2 components was developed in accordance with the requirements and intent of subsections IWA, IWB, and IWC of Section XI Division 1, of the ASME Code. In addition to the ASME Section XI requirements of examination, certain augmented inspections were required by the Nuclear Regulatory Commission. The Braidwood Unit 2 augmented ISI requirements included:

- Examination of High Energy lines in conformance with NUREG 0800, "Standard Review Plan", Section 6.6.

- Regulatory Guide 1.83 Revision 1, "Inservice Inspection of Pressurized Water Reactor Steam Generator Tubes".

- Regulatory Guide 1.150 Revision 1, "Ultrasonic Testing of Reactor Vessel Welds During Preservice and Inservice Examinations".

- Regulatory Guide 1.14 Revision 1, "Reactor Coolant pump Flywheel Integrity".

- NRC Bulletin 88-09 "Thimble Tube Thinning in Westinghouse Reactors".

Where the code and/or augmented requirement(s) were deemed to be impractical, specific requests for relief were developed and submitted for the Commission's review.

\section{Identification of Examination Requirements}

The ISI Program contains the NDE program tables. These tables are presented in a tabular format consistent with Tables IWB and IWC of the ASME Code. The NDE program tables include the corresponding code category, item number, and component/weld selection in conformance with class 1 and 2 examination requirements. Program notes and relief requests are identified in the remarks column. 


\section{Exempted Components}

Class 1 and 2 components (or parts of components) which were not included in the NDE program tables and are exempt from examination, as specified in section XI Paragraph IWB and IWC-1220 "Components Exempt from Examination" are identified in the NDE Program Plan together with the technical justification(s) for exempting the component/system.

\section{Implementation of the ISI Program}

Visual examinations (VT-1, VT-2, and VT-3/4) of Class 1 and 2 components and their supports, identified under the ISI

Program Plan and/or requiring reexamination(s) due to repairs or replacements under section XI, were performed by Commonwealth Edison Company, or their designee.

All NDE examinations, including evaluation of results, were performed by personnel qualified to the appropriate levels in the various NDE methods, per the requirements of the American Soclety for Nondestructive Testing SNT-TC-1A, and in conformance with ASME Sections $V$ and XI, 1983 Edition through Summer 1983 Addenda.

Visual examinations (VT-3 and VT-4) of Class 1 and 2 component supports including evaluation of results, were performed by examiners qualified to ANSI N45.2.6-1973 and/or ASME section XI, 1983 Edition through Summer 1983 Addenda, as applicable.

\section{NDE Examinations}

All ISI nondestructive examinations, including evaluation of flaw indications, were performed in accordance with the requirements stipulated under section XI subarticle IWA-2200, "Examination Methods".

The Inservice Inspections were performed from May 28, 1990 thru November 26, 1991. The Authorized Nuclear Inservice Inspector was Mr. Librado Malabanan from Hartford steam Boiler Inspection and Insurance company of Hartford, Connecticut, Chicago Branch, whose address is 2443 Warrenvilie Road, Suite 500 Iisle, Illinois 60532 . 


\section{EXAYINATION SUYYARY}

The following is a summary of the examinations performed during the Braidwood Unit 2 second refueling outage. Refer to the summary tables for additional information on specific welds, components, supports and pressure test examination $\mathbf{s}$ and their respective results.

\section{PIPING BY8TEYS}

CHEMICAI AND VOLUME CONTROL (CV)

A total of 5 pressure retaining welds were examined. Of these 5 received a surface exam (B10.10). One valve received a VT-1 $\operatorname{exam}(B 7.70)$

\section{EEEDWATER (FW)}

A total of 30 pressure retaining welds ware examined. of these received a volumetric and surface exam (C5.21) and 2 recelved surface exam only $(63.20)$. (see note 5 \& 8 )

MAINSTEAY (MS)

A total of 37 weldments were examined. Of these 17 received a surface exam $(12-C 3.20,5-C 5.31), 18$ recelved both a volumetric and surface exam $(11-C 5.22,7-C 5.21)$ and 2 received volumetric exam only (note 5)

REACTOR COOTANT (BC)

A total of 38 components were examined. Of these 12 welds were examined by surface volumetric $(10-B 9.11,2-B 5.70)$, 24 welds received a surface exam (6-B9.32, 4-B9.21, 12-B9.40, 2-B10.10), and 2 bolting connections received a VT-1 (B7.50)

(see note 7 )

RESIDUAL HEAT REMOVAI (RH)

A total of 3 pressure retaining welds received a surface exam $(2-C 5.12,1-C 5.11)$

\section{SAFETY INJECTION (SI)}

A total of 10 pressure retaining welds were examined. One weld received a volumetric and surface exam (C5.21), and 9 welds received a surface exam (7-B9.40, 1-B10.10,7-B9.40)

\section{EMERGENCY CORE COOLING SYSTEMS}

Five safety injection and 5 chemical and volume control weldments received a volumetric examination (see note 1 ) 
REACTOB VESSEL (2RCO1R)

A volumetric exam was performed from 0 to 180 degrees on the reactor vessel shell-to-flange weld (B1.30) and the threads in the flange (B6.40)

REACTOR COOLANT RUMPS

One (B7.60) bolting assembly was visually examined (VT-1), 4 reactor coolant pump flywheels were examined per Reg Guide 1.14 (see note 6 ).

PRESSURTZEB (2RYO1S)

One VT-1 was performed on the primary manway (B7.20)

RESTDUAL HEAT REMOVAL HEAT EXCHANGER (2RHO2AA, 2RHO2AB)

Four nozzle-to-shell (C-B C2.21) pressure retaining weids received a volumetric exam and 2 welds received a surface exam (see note 4 )

RESTDUAL HEAT REMOVAL PUMP

3 pump lug welds (C-C C3.30) recelved a surface examination (Bi. note 2 )

STEAY GENERATOR (2RCO2BA)

One VT-1 was performed on the primary manway (B7.30)

STEAY GENERATORS (2RCO1BA, 2RCO4BB, 2RCO1BC, 2RCO1BD)

Eddy Current examination was performed on all 4 steam generators. Fifty percent of each generators tubes received ioof full length examination and the ramaining tubes were examined from the hot leg tube end thru the top support plate on the cold leg side. Based on Eddy Current results 11 tubes were plugged.

Additional information concerning the steam generator eddy current inspection can is obtained from the report submitted to the Nuclear Regulatory Commission as required by Braidwood station Technical Specifications 4.4.5.5. 


\section{NI8 -2 \\ OWNER'B REPORT FOR \\ REPAIRB AND REPIACWENTS}

Tornt pAçs

1

9

5

1

14

1

1

2

3

.

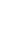

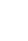

1.

\section{BYRTy}

Containment spray

Chemical volume control

Feedwater

Main Steam

Reactor Coolant

Residual Heat Removal

Pressurizer

Steam Generator Blowdown

safety Injection
NT8-2 Tomar

(Cs)

(CV)

(FW)

(MS)

(RC)

(RH)

(RY)

(SD)

(SI)
1

9

4

1

14

1

1

2

3

$3 \sqrt{3}$

Containment spray
Chemical Volume control
Feedwater
Main steam
Reactor coolant
Residual Heat Removal
Pressurizer
Steam Generator Blowdown
Salety Injection

(SI)




\section{IFID/COMPONFNT EXAKTNATION NOTHB}

1. These are augmented volumetric examinations on $71 / 28$ of the circumferential welds within the ECCS systems (refer to Note 10 of the ISI Program Plan)

2. Pump lug obstructions on the RHR pump (refer to NR-15 of the ISI Program Plan)

3. Braidwood Station w111 ut1lize Code Case N-426 (refer to Note 3 of the ISI Program Plan)

4. Indications exceeding section XI acceptance criteria wera detected on all (4) nozzle-to-vessel welds. Fracture mechanics analys is was parformed and found acceptable. (ref. NRC Docket No. STN 50-457)

5. Ultrasonic examinations were performed on high energy ines not postulated for Ilne breaks (refer to Note 5 of the ISI Program PIan)

6. Augmented NDE exams were performed on 4 reactor coolant pump Ilywhels (refer to Note 6 of the IsI Program Plan)

7. Only 25 thru wall indications can be detected on cast stainless steel welds (refer to Relief Request NR-2 of the ISI Program plan)

8. A fabrication defect was detected on the 90 degree elbow adjacent to weld number $2 \mathrm{FW}-02-22$ which exceeded the ASME section XI ultrasonic testing criteria. The elbow was cut out, the indiaation removed and rewelded back into the system. The indication in the kain reedwater orow was not
service induced therefore no sample expansion was performed.

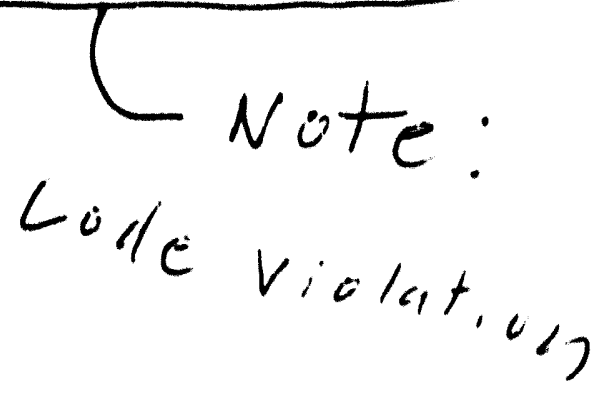




$$
\text { Braidwodd } 2
$$

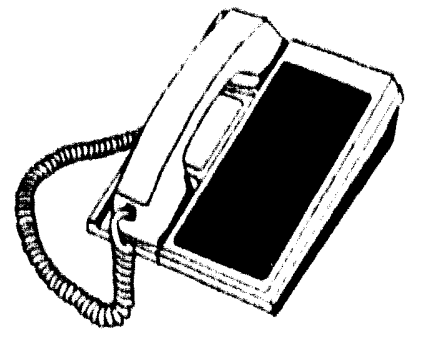

DATE: Eebruary 25, 1993

\section{NDE ENGINEERING ANALYSIS \& APPLICATIONS INEL/EG\&G IDAHO IDAHO FALLS, IDAHO 83415-2209}

Telecopier Telephone: 208/526-0690 Verification Telephone: 208/526-6122

TO: Winston L14. NRC RES

FROM: Jeff cook. sr. fefl
FAX: $\quad 3014923696$

TELEPHONE: 2085266414 office 2085227339 home

\section{ASME Section XI Code Violation 12, Task 24}

Per our telecon the following is provided for you to discuss with NRR. The licensee is using the 83-S83 Section XI. The violation was noted during review of the examination summary notes page. Both IWB-2430 and IWC-2430 require additional examinations when rejectable indications are revealed, and say nothing about exempting fabrication defects.

Number of Pages (including covor pago): 3 


$$
\underset{⿱ 亠 䒑}{*}
$$




\title{
INSERVICE EXAMINATION OF SELECTED CLASS 1, CLASS 2, AND CLASS 3 COMPONENTS AT THE CALVERT CLIFFS NUCLEAR POWER PLANT, UNIT 1
}

\author{
VOLUME I \\ FINAL REPORT \\ WITH APPENDICES \\ SwRI Project 4863
}

Prepared for

\begin{abstract}
Baltimore Gas and Electric Company Materials Engineering - Nuclear Unit Calvert Cliffs Nuclear Power Plant

Lusby, Maryland 20657
\end{abstract}

November 1992

Written by

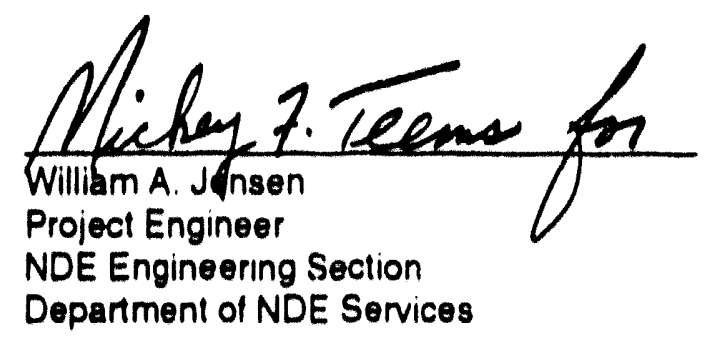

Approved by

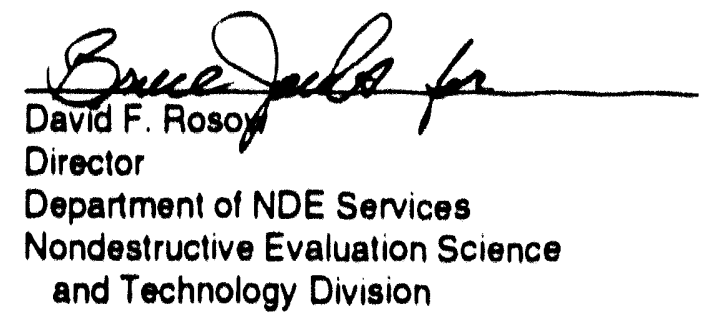




\begin{abstract}
An inservice examination (ISI) of selected Class 1, Class 2, and Class 3 components of Baltimore Gas and Electric Company's (BG\&E) Calvert Cliffs Nuclear Power Plant, Unit 1, was performed by BG\&E and Southwest Research Institute (SwRI) personnel during the 1992 refueling outage. The ISI was performed using visual, manual ultrasonic, magnetic particle, and liquid penetrant techniques. This examination constituted the second ISI performed in the second 10-year interval of commercial operation. The components were examined in accordance with SwRI "Examination Plan for the 1992 Inservice Examination of Calvert Cliffs Nuclear Power Plant, Unit 1," including any changes made during the ISI as approved by BG\&E.
\end{abstract}


VOLUME I-FINAL REPORT WITH APPENDICES

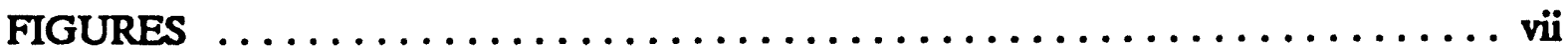

ABBREVIATIONS $\ldots \ldots \ldots \ldots \ldots \ldots \ldots \ldots \ldots \ldots \ldots \ldots \ldots \ldots$ ix

I INTRODUCTION $\ldots \ldots \ldots \ldots \ldots \ldots \ldots \ldots \ldots \ldots \ldots \ldots \ldots \ldots$,

A. Applicable Documents $\ldots \ldots \ldots \ldots \ldots \ldots \ldots \ldots \ldots \ldots \ldots \ldots \ldots$

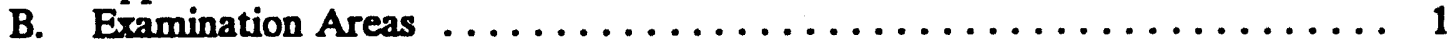

II. DISCUSSION OF EXAMINATION ACTTVITIES $\ldots \ldots \ldots \ldots \ldots \ldots \ldots, \ldots$

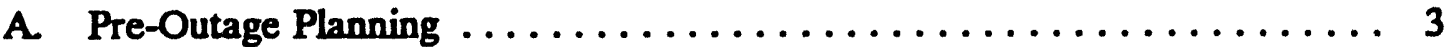

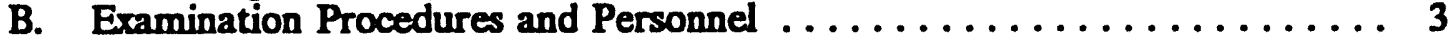
C. Examination Activities $\ldots \ldots \ldots \ldots \ldots \ldots \ldots \ldots \ldots \ldots \ldots \ldots, 3$
D. Summary of Examination Results $\ldots \ldots \ldots \ldots \ldots \ldots \ldots \ldots \ldots, 4$
E. Data Comparison $\ldots \ldots \ldots \ldots \ldots \ldots \ldots \ldots \ldots \ldots \ldots \ldots \ldots, 5$
F. Equipment $\ldots \ldots \ldots \ldots \ldots \ldots \ldots \ldots \ldots \ldots \ldots \ldots \ldots \ldots \ldots \ldots \ldots \ldots \ldots \ldots, 5$
G. Materials $\ldots \ldots \ldots \ldots \ldots \ldots \ldots \ldots \ldots \ldots \ldots \ldots \ldots \ldots \ldots, 6$
H. Ultrasonic Calibration Blocks $\ldots \ldots \ldots \ldots \ldots \ldots \ldots \ldots \ldots \ldots, 6$

III. SUMMARY OF EXAMINATIONS $\ldots \ldots \ldots \ldots \ldots \ldots \ldots \ldots \ldots \ldots, 7$

A. Explanation of Field Data Records $\ldots \ldots \ldots \ldots \ldots \ldots \ldots \ldots \ldots, 7$

B. Nondestructive Examination Summary Table $\ldots \ldots \ldots \ldots \ldots \ldots \ldots, 7$

\section{APPENDICES}

A Weld Identification Drawings - Class 1

B W'eld Identification Drawings - Class 2

C Southwest Research Institute Nuclear Projects Operating Procedures

D Ultrasonic Calibration Block Drawings

E Certificates of Personnel Qualifications

F Material and Equipment Certifications

G Baltimore Gas and Electric Company Field Data Records

VOLUME II - APPENDICES (CONT'D)

G Baltimore Gas and Electric Company Field Data Records (Cont'd)

VOLUME III - APPENDICES (CONT'D)

H Southwest Research Institute Field Data Records 


\section{FIGURES}

Eigure No.

Title

Page

1 Conceptual Drawing Showing the Operation of the Manual Stud Probe Device ........................ 6

2 Explanation of the Summary Table Format $\ldots \ldots \ldots \ldots \ldots \ldots \ldots$ 


$\begin{array}{lll}\text { ASME } & \text { - } & \text { American Society of Mechanical Engineers } \\ \text { BG\&E } & \text { - } & \text { Baltimore Gas and Electric Cornpany } \\ \text { ICN } & \text { - } & \text { Interim Change Notice } \\ \text { ISI } & \text { - } & \text { Inservice Examination } \\ \text { Calvert Cliffs } 1 & \text { - } & \text { Calvert Cliffs Nuclear Power Plant, Unit 1 } \\ \text { MT } & - & \text { Magnetic Particle } \\ \text { NDE } & - & \text { Nondestructive Examination } \\ \text { NPOP } & - & \text { Nuclear Projects Operating Procedure } \\ \text { NQAPM } & - & \text { Nuclear Quality Assurance Program Manual } \\ \text { PT } & - & \text { Liquid Penetrant } \\ \text { QA } & - & \text { Quality Assurance } \\ \text { RCP } & - & \text { Reactor Coolant Pump } \\ \text { RPV } & - & \text { Reactor Pressure Vessel } \\ \text { SSI } & - & \text { Sonic Systems International, Inc. } \\ \text { SwRI } & - & \text { Southwest Research Institute } \\ \text { UT } & - & \text { Ultrasonic } \\ \text { VT } & - & \text { Visual }\end{array}$




\section{INTRODUCTION}

During the spring 1992 refueling outage, Southwest Research Institute (SwRI) and Baltimore Gas and Electric Company (BG\&E) personnel performed nondestructive examinations (NDE) on selected Class 1, Class 2, and Class 3 components and their supports at BG\&E's Calvert Cliffs Nuclear Power Plant, Unit 1 (Calvert Cliffs 1). This report discusses the results of those examinations.

\section{A. Applicable Documents}

The inservice examination (ISI) was performed in accordance with the following documents:

- Section XI of the American Society of Mechanical Engineers (ASME) Boiler and Pressure Vessel Code, "Rules for Inservice Inspection of Nuclear Power Plant Components," 1983 Edition with Addenda through Summer 1983 (83S83)

- Section V of the ASME Code, "Nondestructive Examination," 83583

- SwRI document, "Program Plan for the Second Inspection Interval for Calvert Cliffs Nuclear Power Plant, Units 1 and $2^{n}$

- SwRI document, "Long-Term Plan for Calvert Cliffs Nuclear Power Plant, Unit 1"

- SwRI Final Plan, "Examination Plan for the 1992 Inservice Examination of Calvert Cliffs Nuclear Power Plant, Unit 1," with changes made on site and approved by BG\&E personnel

- ASME Code Case N-307-1, "Ultrasonic Examination of Class 1 Bolting from CenterDrilled Holes"

- ASME Code Case N-408, "Alternative Rules for Examination of Class 2 Piping"

- SwRI Nuclear Quality Assurance Program Manual (NQAPM), Revision 3, with all applicable changes

- BG\&E Program 5, Nondestructive Examination

\section{B. Examination Areas}

Selected components in the following Class 1, Class 2, and Class 3 areas were examined by SWRI and BG\&E personnel utilizing NDE techniques:

Class 1 Components and Systems

\section{Reactor Pressure Vessel}

Upper Guide Structure

Core Barrel (In Place)

Flange Seal Surface and Ledge Area

Closure Head Nuts

Closure Head Surface-to-Expansion Compensating Ring

Closure Head Alignment Keyways 
Piging

Shutdown Cooling

Safety Injection

Pressurizer Spray

Pressurizer Safery and Relief

Letdown Lines

Charging Lines

Drain Lines

Vessels

Pressurizer Manway - Studs and Nuts

Steam Generator No. 11 Manway - Studs and Nuts

Steam Generator No. 12 Manway - Studs and Nuts

Pumps

Reactor Coolant Pump Studs (Baseline)

Reactor Coolant Pump Flywheel

Reactor Coolent Purnp Cap Screws

Valves

Bodies - Groups 2 and 4

Bolting

Class 2 Components and Systems

Piping

Safety Injection

Feedwater (Baseline)

Main Steam System

Pressure Retaining Components

Vessels

Piping

Pumps

Valves

Class 3 Components and Systems

Auxiliary Feedwater

Service Water

Component Cooling

Salt Water

Pressure Retaining 


\section{DISCUSSION OF EXAMINATION ACTTVTTIES}

\section{A. Pre-Outage Planning}

In order to assure efficient performance of the ISI at Calvert Cliffs 1, SwRI devoted a concentrated effort toward planning and preparing for the examination activities. This included preparation and review of nuclear projects operating procedures (NPOPs), review of ultrasonic (UT) calibration blocks for compliance to ASME Code and procedure requiremerts, and developing an Examination Plan. Such planning activities were conducted by SwRI's NDE Applications and NDE Engineering Sections with assistance from the Quality Assurance (QA) organization.

The Examination Plan was developed in one comprehensive document to provide all the technical information required to perform the ISI. It provided a listing of the examination areas, procedures, UT calibration block drawings, weld identification drawings, and other information pertinent to the performance of the ISI. Selection of Class 1, Class 2, and Class 3 components for examination was based on the Long-Term Plan for Calvert Cliffs 1. Additional components were scheduled for examination at the request of BG\&E.

Communication was maintained between $B G \& E$ and SwRI engineers to review examination areas, discuss site support requirements, and develop the Examination Plan.

\section{B. Examination Procedures and Personnel}

The NDE activities were performed utilizing visual (VT), liquid penetrant (PT), magnetic particle (MT), and UT techniques. The reactor coolant pump bywheel (RCP11A) UT, all of the PT, and a large percentage of the VT and MT examinations were performed by BG\&E personnel in accordance with BG\&E procedures. These procedures were written and controlled in accordance with BG\&E's QA program and are on tile with BG\&E.

The UT (except RCP11A flywheel), remote VT, and a portion of the VT and MT examinations were performed by SwRI personnel in accordance with SwRI procedures. The VT procedure and the UT procedure for the examination of studs were amended for specific examination purposes with Interim Change Notices (ICNs). Where an ICN was used, it was noted on the applicable individual examination data sheets and NDE Summary Table. Copies of the ICNs are included with the applicable procedures in Appendix $C$.

SwRI examination personnel were certified and qualified by SwRI in accordance with the requirements of SwRI NPOP 2.0-NDES-101, "Nondestructive Examination Personnel Qualification and Certification." Five Sonic Systems International, Inc. (SSI), personnel were employed by SwRI to assist in the performance of the ISI. They were under the control of SwRI and were considered a part of the SWRI examination team during this ISI at Calvert Cliffs 1. SSI personnel were certified, trained, and qualified by SSI in accordance with SSI's QA program. Copies of the SwRI and SSI examination personnel certifications are included in Appendix E. BG\&E examination personnel were certified, trained, and qualified in accordance with BG\&E's QA program. Copies of the BG\&E examination personnel certifications are on file with BG\&E.

\section{Examination Activities}

This section provides a discussion of the various onsite NDE activities performed during the ISI. Data records for examinations performed by BG\&E are included in Appendix G. SWRI examination data records are included in Appendix $\mathrm{H}$. A discussion of the equipment used for these examinations appears in Subsection $F$ (Page 5) of this volume. While performing examinations, SWRI and BG\&E personnel were subject to QA surveillance by BG\&E QA personnel. The Authorized Nuclear Insurance Inspector and a representative of the United States Nuclear Regulatory Commission also performed surveillance of certain examinations performed by SWRI and BG\&E personnel. 


\section{Reactor Preasure Veasel}

SwRI Level II and Level III examiners used remote VT techniques to examine the interior of the reactor pressure vessel (RPV) and recorded the examinations on videotape. The interior portions of the RPV closure head were examined utilizing direct VT techniques. The RPV closure head nuts were examined utilizing an alternating current yoke and fluorescent MT material.

\section{Class 1 and Class 2 Piping Pumps, and Vatves}

SWRI and BG\&E Level II and Level III examiners used MT, PT, and VT techniques to examine Class 1 and Class 2 components, including austenitic piping, ferritic piping dissimilar metal welds, tlange bolting, valve bolting, and pumps. Various techniques were utilized by SwRI personnel to perform the manual UT examinations, dependent upon the material type and weld thickness. For a typical piping weld, the following techniques were used:

a. If this was the first examination of the weld, a 0-degree lamination scan (UTOL) was performed to detect any laminar reflectors which may have affected the interpretation of angle-beam results. Also, an outside surface weld contour and accompanying thickness measurements were obtained and documented.

b. For austenitic and ferritic piping welds, angle-beam scans of 45 degrees (UT45) were used for the detection of reflectors oriented parallel to the weld.

c. Angle-beam scans, using 45-degree search units directed parallel to the weld (UT45T) were used on piping for the detection of reflectors oriented transverse to the weld. In ferritic piping where previous UT45T examinations had revealed no recordable indications, this examination is not required by ASME Section XI Code or ASME Code Case N-408.

d. In austenitic piping welds, angle-beam scans using 45-degree search units directed tangentially to the weld (UT45TAN) were used for the detection of reflectors branching from a transverse or circumferential flaw.

\section{Bolting}

The reactor coolant pump ( $R C P$ ) bolting was examined in accordance with ASME Code Case N.307-1.

(a) For the baseline UT examinations of four RCP studs, a UTO, UT50, and UT70 were used to provide complete coverage of the examination area.

(b) A UT88 surface wave was utilized for detection of reflectors propagating from the RCP stud heater holes.

\section{Summary of Examination Results}

UT indications determined to be recordable were investigated by SwRI to determine the nature of the reflector.

During the remote VT examination of the reactor vessel, weld-like indications, tool marks, scratches, and debris were noted. All indications, scratches, and tool marks were determined to be nonrelevant. The debris was recorded on Issue Report IRO-003-298 and subsequently removed by BG\&E personnel. In addition to the videotape recordings, further details of the VT examination areas and results are recorded in Engineering Test Procedure 86-24 in Appendix $C$. 
Details of the examinations performed by BG\&E personnel are presented in boat indic ourti Copies of these data records are contained in Appendix G.

\section{E. Data Comparison}

In accordance with IWB-3121 of Section XI, examination data were compared with recorded results of the preservice examination and/or prior ISIs. When the comparison was performed by SwRI, the examination records were annotated with the following statement: "Resules have been compared to previous data." Comparisons made by BG\&E are listed in Report No. 92.50-194 located in Volume II.

\section{F. Equipment}

Various NDE equipment was used during the ISI to perform examinations of the selected components. The major equipment items are discussed below.

\section{Sonic FIS MR I and Sonic 136 Ultrascope}

Sonic FTS MR I and Sonic 136 UT instruments were used for manual UT examinations and thickness measurements of materials.

To assure proper instrument linearity and operation, SwRI certified each SwRI. owned Sonic prior to use at Calvert Cuiffs 1 , as specifled in the NQAPM. Copies of certifications for SwRJ-owned instruments utilized at Calvert Cliffs 1 are contained in Appendix F. Additionally, instrument linearity was checked and documented by SwRI personnel on site prior to and after the performance of the manual UT examinations.

\section{Transducers}

Various brands, sizes, types, and frequencies of UT transducers were used to perform the manual UT examinations at Calvert Cliffs 1. A transducer frequency of 1.5, 2.25, or 5.0 $\mathrm{MHz}$ was used as specified in the applicable NPOP.

Prior to use at Calvert Cliffs 1, each SwRI-owned transducer was tested and certified to be within SwRI's acceptance standards. This certification is performed within 12 months of use to verify that each transducer is still performing within the specified limits. A copy of each SwRI-owned transducer's certification is contained in Appendix F.

Information on the actual transducer utilized for any specific examination may be determined by reviewing the copies of the data sheets and referenced calibration sheets in Appendix $\mathrm{H}$.

\section{Stud Probe}

Baseline UT examinations of four RCP studs were performed using the SwRI-designed Stud Probe (see Figure 1). The Stud Probe is inserted into thu heater hole of the stud and is moved up and down by the examiner with a slight rotation after each pass. This process is continued until 100 percent of the accessible volume of the stud is examined.

\section{Magnetic Particle Examination Equipment}

MT examinations were performed utilizing hand-held alternating current magnetic particle yokes. In the case of the RPV closure nuts, duorescent MT spray and blacklights were used with the yokes to perform the examinations. Prior to and after each examination, the 
blacklight and yoke characteristics were checked by SwRI examiners and demonstrated to be satisfactory in accordance with the applicable NPOPs. All equipment and materials utilized by SwRI examiners for the MT examinations were provided by BG\&E. All appropriate certifications are on file with BG\&E.
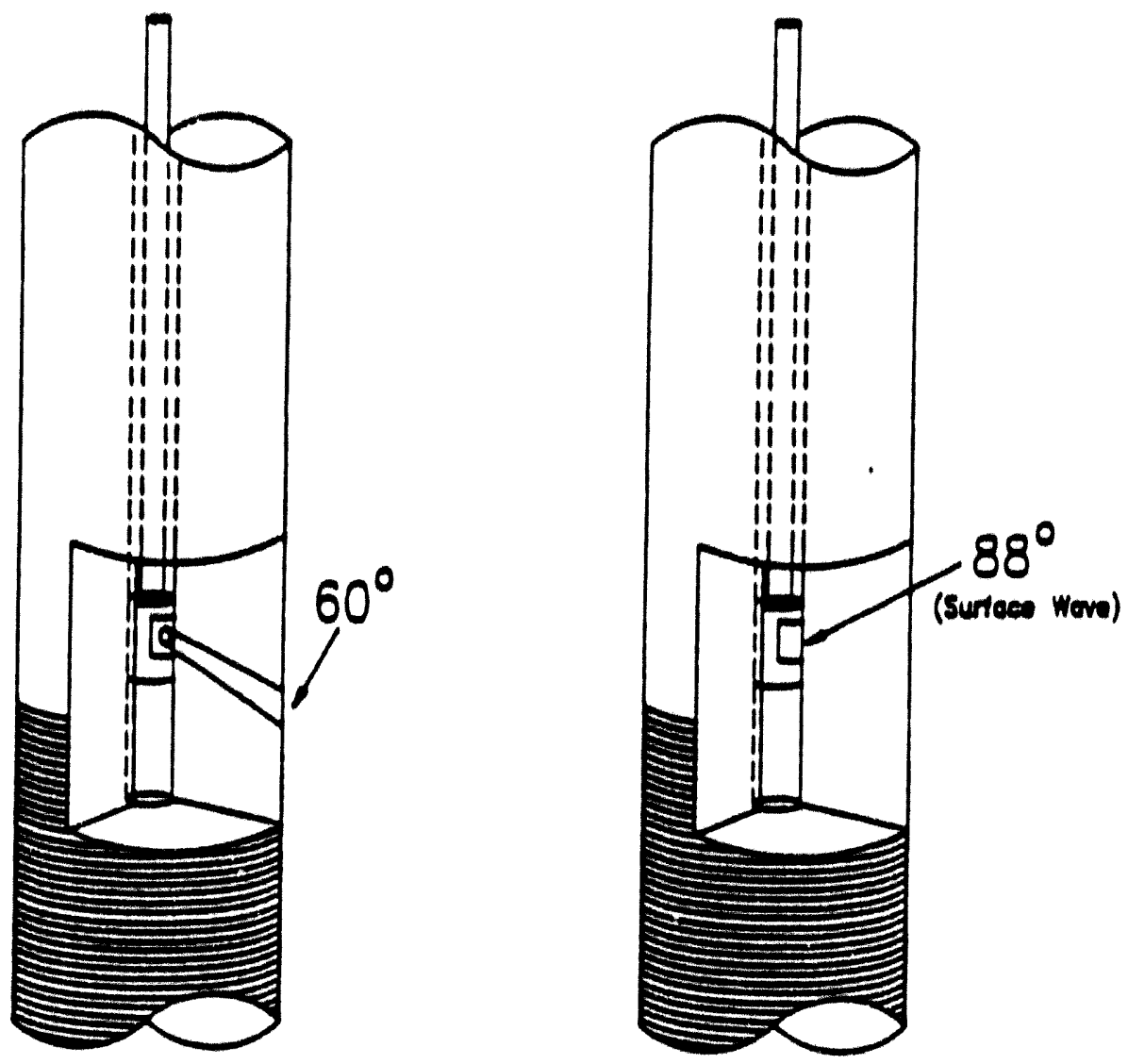

Figure 1. Conceptual Drawing Showing the Operation of the Manual Stud Probe Device

\section{G. Materials}

In addition to the equipment previously discussed, certain materials were required in the performance of the examinations. All materials contacting the examination surface (i.e., ultrasonic couplant, piping marking devices, liquid penetrant, etc) are required by the ASME Code to be tested and certified to be within acceptable sulfur and halogen limits prior to their use. Ceroifinas cin in fip $F$. C

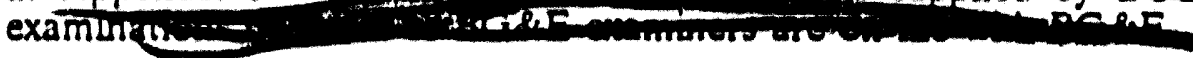

\section{H. Ultrasonic Calibration Blocks}

Pipe calibration blocks owned by BG\&E were used to calibrate manual UT instruments prior to the examination of the selected welds. Drawings of the various calibration blocks used are contained in Appendix D. Certifications for the blocks are on file with BG\&E. 


\section{SUMOMARY OF EXAMMNATIONS}

This section provides a discussion of the field data records and a summary of the NDE activities performed at Calvert Cliffs 1.

\section{A. Explanation of Field Data Records}

The resules of the examinations and calibrations performed by SWRJ personnel were recorded on standard SwRI forms. The results of the examinations performed by BO\&E personnel were recorded on eitter SWRI or BG\&E forms. Copies of the completed SWRI documents constitute Appendix $H$ of this report. Completed BO\&E forms are included in Appendix $G$. The original SwRJ records will be retained in the SwRI Records Vault. The oripinal BG\&E records will be retained by BG\&E.

The tield data records for each weld or area are assembled in a package proceeded by an SwRI Examination Summary Record (summary sheet). The examination areas and summary sheet numbers correspond to those listed in the Summary Table. A general explanation of the individual Eield data forms follows.

The instruments utilized to perform the UT examinations were calibrated prior to use, then verified again at intervals specitied in the applicable NPOPs, and upon the completion of the examinations. The calibration parameters were recorded prior to examination on the appropriate calibration record sheet as speciffed by the applicable NPOP. The documented calibration and calibration verification provide immediate assurance that the examinations were performed using properly calibrated instruments.

The examination resules were recorded on the applicable data record sheets as specified in the applicable NPOP. The information documented on these forms describes the parameters associated with those indications which were greater than the recording levels specified in the applicable NPOP.

The size, location, and nature of indications were determined by analyzing the indication parameters recorded on the forms described above. The analysis is documented on SWRI Indication Resolution Record Sheets, which are included as part of each data package, when required.

\section{B. Nondestructive Examination Summary Table}

The following section is the Nondestructive Examination Summary Table (Summary Table). The Summary Table lists the areas at Calvert Cliffs 1 that were examined by SWRI or BG\&E during this ISl. See Figure 2 for an explanation of the Summary Table format. Weld identification drawings depicting the location of RPV and Class 1 piping components are contained in Appendix A. Class 2 piping components are contained in Appendix B. 


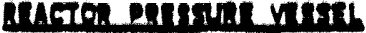

ermur cxarturton anch

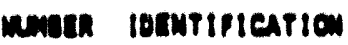

Aant

anc. $x t$

eator

ITEM wo

\section{our}

mernes
10

001

1 1

- I nemanx

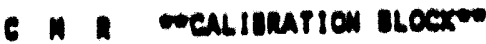

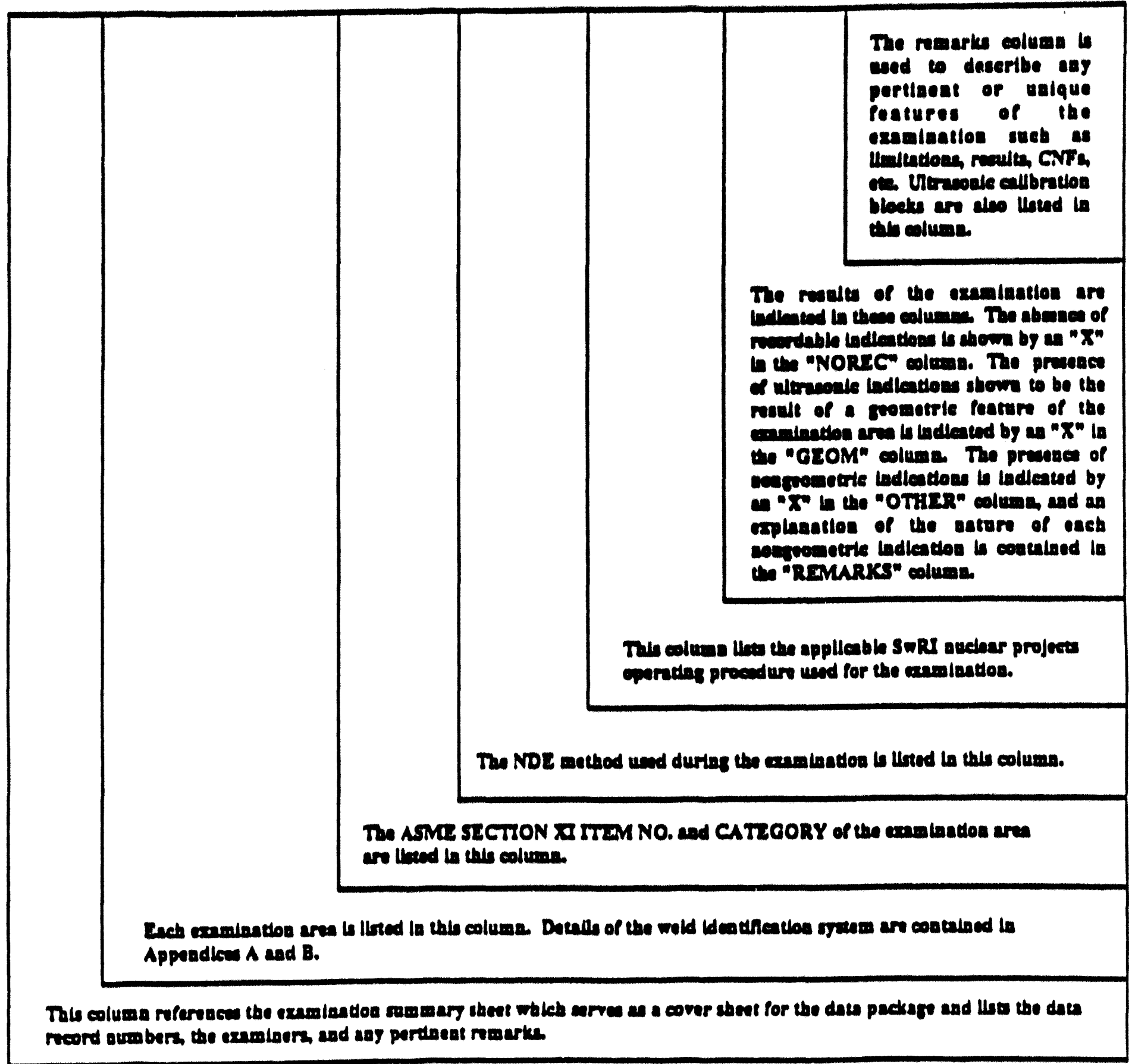

Figure 2. Explanation of the Summary Table Format 
DAF: $11 / 05 / 92$

REVISION: 0

BEACTOR PQESSURE VESSEL

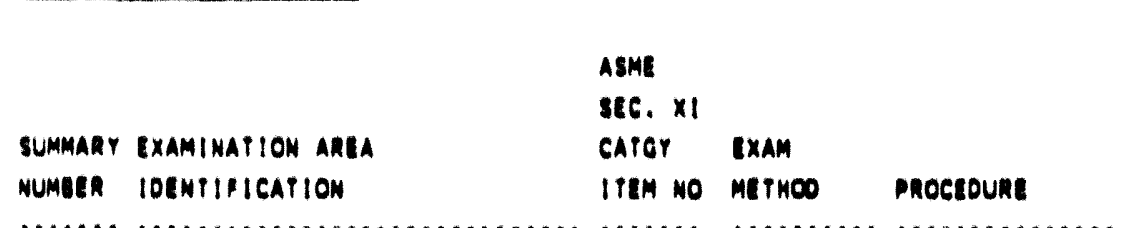

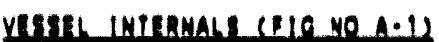

003300 vesset intenion

003630 cone suppont structunes

Muis (19. MO $A .1+1.23$

003530 NUT MUMUERs I PMrowON 36
L.N.1 $\quad$ R.

$813.10 \quad V i \cdot 3$

$n \cdot n \cdot 3 \quad v+1$

$013.70 \mathrm{Vi} \cdot 3$

etp.es-26 nev. 1 CCN-VI7
CTP.86. 26 Rev. 1 CEN-VT7
CALVERT CLIPRS MUCLEAR POUtK PLANT UNIT I SUMMARY Of nONOESTRUCTIVE ExAMINATIONS secono intenval, Hirst pen100, stcono outace (1992) CLASS I COMPLETED COMPONENTS

N 0

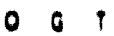

a $n$

- O nemanks

c a mecalimbafion mlock"o

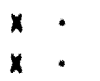

CORE BARALL IN PLACE, HOUR (4) I WELD.LIKE AMLAS NOTEO anOUNO thE DEQRE QULLE NOZzLE. VARIOUS LI SCRATCHES ARQUNO PHE OULET NOZZL SEL ETP MEPORT B.26 IN APPEHOIX
$0.0 .1 \quad$ at

10.10
101. $1412 / 0$

5.107, Rev. 2 $x$.

EXAMIMATION PERPOAMEO OY SWRI L
PIRSOMNEL. EXAMINED WUP NUMGERS
IMROUOK 18. SEE MOE REPORT 92.50 IN APPENOIX 0 . 
OAt: $11 / 05 / 92$

atvision: 0

DESTERLZRE

SUMMARY EXAMINATION AREA

mumatR loENTIRICAPIOM

......................................

\section{STUPS AMP MUIS (E1O NO $A \cdot 3)$}

006350 mangar studs 1.20

8.0.2 Vi.1 3.712, nev. 0

37.20

sec. $\times 1$

Cator ExaM

IrEm no METHOO

Pnoctount

CLASS 1 COMPLETEO COMPONENTS

secono IntERVAL, finst perioO, secono outage (1992)

$\quad B 7.20$

004600 MAMWAY MUTS 1.20

$\begin{array}{lll}0.0 .2 & \text { Vi.1 } \\ 17.20 & & \end{array}$

17.20
N 0

001

a. $H$

- 0 memarks

c m mealigmafion olocx"*

EXAMTATION PERFORMED OY DGE PERSOHNEL. SEE nOE nepont $92 \cdot 50 \cdot 0091 \& 92 \cdot 50.0106$ IN APpINOIX 0 . 
OATE: $11 / 05 / 92$

REVISION: 0

STEAM GEMERAIOR MUMBER 11

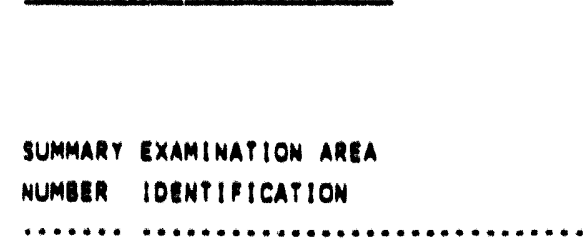

ASME

SEC. XI

CATGY EXAM

ITEM NO METHOO
CALVERT ClIFPS MUCLEAR POUER PLANT UNIT 1 SUMMARY OF NONDESTRUCTIVE EXAMINATIONS

SECONO InTERVAL, PIRST PERICO, SECONO OUTAGE (1992)

CLASS I COMPLETED COMPONENTS
SIUPS ANO MUTS (E1O NO A.5)

OOS700 OUTLET SIDE MAMGAY STUDS

8.0 .2

vi 1

3.712, REV. O

$\times$.

EXAMINATION PERFORMED GY GORE PER!

87.30

N 0

$\begin{array}{lll}0 & 0 & 1\end{array}$

R $\mathrm{H}$

E O REMARKS

c ll "calibration block"*

PROCLOURE

005730 CUTLE S10R manHaY nUTS

B.0.2 VP.1

3.712, REV. O

$\times$.

EXAMINATION PERFORMEO BY BOBE PER!

87.30

SEE NOE REPORT $92 \cdot 10 \cdot 1257$ IN APPEA

005800 INLET SIDE MANGAY STUDS

$B \cdot 0 \cdot 2$

$v+\cdot 1$

S.712, REV. O

$x$

EXAMINATION DERFORMED GY BOSE PER!

87.30 SEE NOE REPORT $91 \cdot 10 \cdot 1257$ IN APPEA

O0S8SO INLET S10E MAMGAY RUTS

B.G.2 VP.1

B7. 30

3.712, REV. O

$x$.

EXAMINATION PERRORMED OY BCLE DER: SEE NOE REPORT $92 \cdot 10 \cdot 1257$ IN APDEA 
DATE: $11 / 05 / 92$

REVISION: 0

STEAM GENERATOR NUMBER 12

SUMMARY EXAMINATION AREA

NUMBER TDENTIFICATION

STUDS ANO MUTS (FIG NO A-5)

007000 OUTLET SIDE MANHAY STUDS

007050 OUTLET SIDE MANHAY MUTS

007100 INLET SIDE MANGAY STUDS

OO7150 INLET SIDE MANWAY NUTS

CALVERT CLIFFS NUCLEAR POUER PLANT UNIT I SUMMARY OF NONDESTRUCTIVE EXAMINATIONS SECONO INTERVAL, FIRST PERIOO, SECOND OUTAGE (1992)

CLASS 1 COMPLETED COMPONENTS

ASME

SEC. XI

CATGY EXAM

ITEM NO METHOO

PROCEDURE

$B \cdot G \cdot 2 \quad V T \cdot 1$

87.30

$B \cdot G \cdot 2 \quad V T-1$

B7.30

$B \cdot G \cdot 2 \quad V T \cdot 1$

5.712, REV. $O$

$\times$ -

examination performed by bG\&E PERSONNEL.

B7.30

5.712, REV. O $\times$

EXAMINATION PERFORMED BY BG\&E PERSONMEL. SEE NOE REPORT 92-10-1256 IN APPENDIX $G$. n 0

O $G$ T

RE H

E O E REMARKS

C M R "CALLIBRATION BLOCK"* 


\section{OWNER'S DATA REPORT FOR INSERVICE INSPECTION}

(As Required by the Provisions of the ASME Code Rules)

1. Owner: Baltimore Gas and Electric Company

P. O. Box 1475

Baltimore, MD 21203

2. Plant: $\quad$ Calvert Cliffs Nuclear Power Plant

1650 Calvert Cliffs Parkway

Lusby, MD 20657-4702

3. Plant Unit:

One (\#1)

4. Owner Certification of Authorization:

N/A

5. Commercial Service Date:

May 8, 1975

6. National Board Number for Unit:

20911

7. Components Inspected:

\begin{tabular}{|c|c|c|c|c|}
\hline $\begin{array}{c}\text { COMPONENT } \\
\text { OR } \\
\text { APPURTENANCE }\end{array}$ & $\begin{array}{c}\text { MANUFACTURER } \\
\text { OR } \\
\text { INSTALLER }\end{array}$ & $\begin{array}{l}\text { MANUFACTURER } \\
\text { OR INST.ALLER } \\
\text { SERIAL \# }\end{array}$ & $\begin{array}{c}\text { STATE } \\
\text { OR } \\
\text { PROVINCE \# }\end{array}$ & $\begin{array}{c}\text { NATIONAL } \\
\text { BOARD } \\
\text { NUMBER }\end{array}$ \\
\hline $\begin{array}{l}\text { Reactor Pressure } \\
\text { Vessel }\end{array}$ & $\begin{array}{l}\text { Combustion } \\
\text { Engineering }\end{array}$ & CE-67107 & $14000 \mathrm{NV}$ & 20911 \\
\hline Pressurizer & $\begin{array}{l}\text { Combustion } \\
\text { Engineering }\end{array}$ & $C E-67602$ & $14000 \mathrm{NV}$ & 20915 \\
\hline $\begin{array}{l}\text { Reactor Pressure } \\
\text { Vessel Closure Head }\end{array}$ & $\begin{array}{l}\text { Combustion } \\
\text { Engineering }\end{array}$ & CE-67207 & $14000 \mathrm{NV}$ & 20911 \\
\hline $\begin{array}{l}\text { Steam } \\
\text { Generator } \# 11\end{array}$ & $\begin{array}{l}\text { Combustion } \\
\text { Engineering }\end{array}$ & $C E-67504$ & $14000 \mathrm{NV}$ & 20922 \\
\hline $\begin{array}{l}\text { Steam } \\
\text { Generator } \# 12\end{array}$ & $\begin{array}{l}\text { Combustion } \\
\text { Engineering }\end{array}$ & $C E-67505$ & $14000 \mathrm{NV}$ & 20923 \\
\hline $\begin{array}{l}\# 12 \text { A Reactor } \\
\text { Coolant Pump }\end{array}$ & Byron Jackson & SN-0439 & $14000 \mathrm{NV}$ & \\
\hline $\begin{array}{l}\text { \#12B Reactor } \\
\text { Coolant Pump }\end{array}$ & Byron Jackson & $\mathrm{SN}-0440$ & $14000 \mathrm{NV}$ & \\
\hline $\begin{array}{l}\text { \#11A RCP } \\
\text { Motor Flywheel }\end{array}$ & Westinghouse & SN-2S-79P528 & & \\
\hline $\begin{array}{l}\text { Safety Injection } \\
\text { Piping/Supports }\end{array}$ & Bechtel & & & \\
\hline
\end{tabular}


DATE: November 9, 1992

NIS-1

7. Components Inspected: (con't.)

\begin{tabular}{|c|c|c|c|c|}
\hline $\begin{array}{c}\text { COMPONENT } \\
\text { OR } \\
\text { APPURTENANCE }\end{array}$ & $\begin{array}{c}\text { MANUFACTURER } \\
\text { OR } \\
\text { INSTALLER }\end{array}$ & $\begin{array}{c}\text { MANUFACTURER } \\
\text { OR INSTALLER } \\
\text { SERIAL \# }\end{array}$ & $\begin{array}{c}\text { STATE } \\
\text { OR } \\
\text { PROVINCE \# }\end{array}$ & $\begin{array}{l}\text { NATIONAL } \\
\text { BOARD } \\
\text { NUMBER }\end{array}$ \\
\hline $\begin{array}{l}\text { Main Steam } \\
\text { Piping }\end{array}$ & Bechtel & & & \\
\hline $\begin{array}{l}\text { Pressurizer Spray } \\
\text { Piping }\end{array}$ & Bechtel & & & \\
\hline $\begin{array}{l}\text { Shutdown Cooling } \\
\text { Piping/Supports }\end{array}$ & Bechtel & & & \\
\hline $\begin{array}{l}\text { Pressurizer Safety \& } \\
\text { Relief Piping }\end{array}$ & Bechtel & & & \\
\hline $\begin{array}{l}\text { Charging } \\
\text { Piping }\end{array}$ & Bechtel & & & \\
\hline Drain Piping & Bechtel & & & \\
\hline Letdown Piping & Bechtel & & & \\
\hline $\begin{array}{l}\text { Auxiliary Feedwater } \\
\text { Piping/Supports }\end{array}$ & Bechtel & & & \\
\hline $\begin{array}{l}\text { Service Water } \\
\text { Piping/Supports }\end{array}$ & Bechtel & & & \\
\hline $\begin{array}{l}\text { Component Cooling } \\
\text { Water Piping/Supports }\end{array}$ & Bechtel & & & \\
\hline $\begin{array}{l}\text { Salt Water } \\
\text { Piping/Supports }\end{array}$ & Bechtel & & & \\
\hline
\end{tabular}

8. Examination Dates: Luly 5,1988 to August 20,1992

9. Inspection Interval: April 1.1987 to April 1. 1998

10. Abstract of Examinations: (Include list of exams and statements concerning status of work required for current interval)

(See Enclosure 3)

The examinations reported herein constitute the tenth such report of Inservice examination performed at Calvert Cliffs Unit 1, and the second report within the first period of the second interval of commercial operation. The examinations for the second interval as required by the Long-Term Examination Plan for Calvert Cliffs Unit 1, were performed in accordance with the 1983 Edition of ASME Code Section XI with Addenda through Summer, 1983. Hydrostatic and System Pressure Testing Procedures are available at the plant site for review. 


\section{Abstract of Conditions Noted:}

(See Enclosures 2 \& 3)

a. Eddy current examinations of $\# 11$ and $\# 12$ Steam Generators in 1992 revealed signs of steam generator tube degradation. Results of \#11 Steam Generator examinations showed that of the 8,412 tubes examined, ten (10) were defective ( $\geq 40 \%$ wall loss), 112 were degraded ( $220 \%$ wall loss, but $<40 \%$ ), 162 had imperfections ( $<20 \%$ wall loss). Inspection of $\# 12$ Steam Generator revealed that of the 8,449 tubes examined, five (5) were defective, 120 were degraded, 172 had imperfections. As a result of this inspection, eleven (11) tubes were plugged in \#11 Steam Generator and seven (7) tubes were plugged in \#12 Steam Generator.

b. A remote visual examination of the Reactor Pressure Vessel (RPV) interior was performed. The RPV Core Barrel interior surfaces revealed scratches and tool marks above outlet nozzles. Additionally, several foreign materials were found inside the RPV on top of Core Plate.

c. Visual examinations of supports revealed 15 supports with construction/installation deficiencies; 3 supports with missing or loosened items; 1 support with improper spring settings; and 7 supports with other deficiencies.

d. Due to administrative and clerical problems, 63 NIS-2's are not included with this submittal.

12. Abstract of Corrective Measures Recommended and Taken:

(See Enclosure 3)

a. Eleven (11) tubes were plugged in $\# 11$ Steam Generator and 7 tubes were plugged in $\# 12$ Steam Generator.

b. The surface scratches and tool marks were resolved as nonrelevant indications. All foreign material was retrieved and removed.

c. The supports were either accepted by evaluation in accordance with IWF-3122.4 or repaired to bring them into conformance with their original design.

d. Issue reports have been generated to address the delayed NIS-2's. Corrective measures and actions to preven recurrence will be determined in accordance with the Calvert Cliffs Issue Assesment System process. The outstanding NIS-2's will be submitted with the next Unit \#1 Summary Report.

13. Names of Inspectors:

R, W, Lawrence and N, S. Hewitt

Employer of Inspectors: Factory Mutual Engineering

401 City Avenue, Suite $\$ 420$

Bala Cynwyd, PA 19004

We certify that the Statements made in this report are correct and the examinations and corrective measures taken conform to the rules of the ASME Code, Section XI.

DATE: L'PEMR? $17,1992$.

SIGNED:

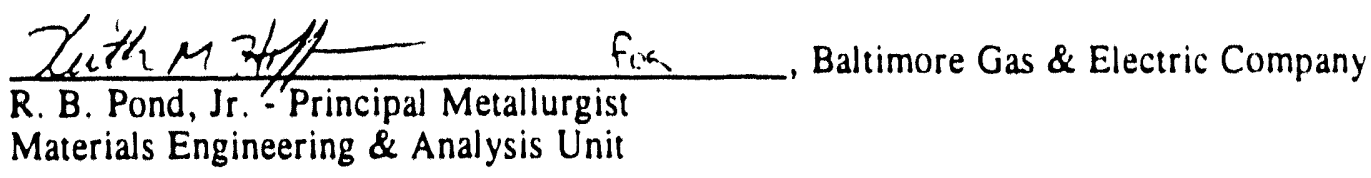

Certificate of Authorization No. N/A Expiration Date N/A 
CALVERT CLIFFS NUCLEAR POWER PLANT

SUIMMARY OF NIS-2 REPORTS

UNIT 1

MO NUMBER

18801458

18806194

18806322

18806594

18806880

18807219

18808008

18808029

18808032

18808228

18808424

18808480

18808736

18809812

18809889

18809889

1880989

18900902

18900902

18901783

18901786

18902423

18903720

Snubber $1-52-18$

DR-5 Flow oriface

$1-C V-3939$

Pipe

Check Valve

Snubber 1-52-9

snubber 1-61-1

Snubber $1-52-10$

Snubber 1-52-11

RCP seal

Snubber 1-83-69

Reactor Coolant Pump

Valve (Main Plug) support

piping system

piping system

Piping system

Discharge Gate Valve

Snubber 1-52-13

Snubber 1-61-1

Discharge Desurger Supp.

Snubber 1-52-58
COMPONENT

DATE: $11 / 17 / 92$

PAGE:

1

Component cooling system pipe

Charging Pump discharge line support 
MO NUMBER

18904343

18904344

18904673

18905056

18905198

18905376

18906134

18907210

18907241

18907269

18907321

19001282

19002157

19002160

19002262

19002267

19002270

19002368

19002371

19002374

19002376

19002391

19002393

19002405

19002422

19002454

19002470

19002519

\section{COMPONENT}

PAGE:

CC-2 piping to LT-110Y \& LT-103

CC-2 Piping to LT-110Y \& IT-103

Snubber $1-52-22$

snubber $1-41-8$

Snubber 1-64-12

Hanger rod on 2" EB-6-1008

Heat Exchanger

Pipe support $14^{n}$ GC-5-1004 R-2

BOTTOM BLOWDOWN CONTROL VALVE

Pressurizer

Snubber 1-52-57

Snubber 1-52-34

snubber 1-41-4

snubber 1-41-7

snubber 1-45-7

Snubber $1-52-16$

Snubber 1-52-21

Snubber $1-52-25 A$

Snubber 1-52-26

snubber $1-52-32 A$

Snubber 1-52-36

Snubber 1-52-42A

Snubber 1-52-45

Snubber 1-60-18

Snubber 1-61-17

Snubber 1-63-28

snubber 1-64-8

Snubber 1-52-42A 
MO NUMBER

19002589

19003727

19004165

19004237

19005335

19005465

19005469

19005484

19005530

19005589

19005642

19005642

19005664

19009100

19009177

19009208

19009265

19009447

19009511

19009535

19009548

19009557

19009620

19009621

19009650

19009848
COMPONENT

Snubber $1-64-26$

Piping

Snubber $1-52-36$

snubber $1-52-50 A$

Snubber $1-64-2$

Snubber $1-64-20$

Snubber $1-64-23$

snubber $1-64-11$

Snubber $1-64-17$

snubber 1-52-42

piping

piping

Snubber $1-64-31$

Piping

REfueling Water Tank

Snubber $1-63-17$

Snubber 1-64-45

support 10" GC-1-1003-H18

PIPE SUPPORT SK-1422

PIPE RESTRAINT 14" HC-3-1011-R7

$6^{n G C-3-1006-H 16}$

MS PIPING BETWEEN LINER PIATE \& ISOL. VALVES

Support Rod 6" GC3-1006-H16

Rod for support piping $4^{n}$ GC 3-1005-H53

REACTOR COOLANT PUMP SEAL (UPPER SEAL GLAND)

Valve 
MO NUMBER

19009851

19009873

19010229

19100237

19101234

19101572

19102799

19102886

19102887

19102888

19102889

19102890

19102895

19102912

19102912

19102913

19102914

19102918

19102919

19102920

19103186

19103230

19103230

19103230

19103230

19103230

19103230

19103475

\section{COMPONENT}

valve

valve

Pressure Veseel

Snubber 1-60-25

snubber 1-63-20

Snubber 1-63-27

Pressure Vessel

SNUBBER 1-41-5

SNUBBER 1-45-1A

Snubber 1-52-7

SNUBBER 1-52-46

SNUBBER 1-52-62

SNUBBER 2-50-26

SNUBBER 1-83-48

Snubber 1-83-48

Snubber 1-83-47

Snubber 1-64-16

SNUBBER 1-64-18

SNUBBER 1-64-97

SNUBBER 1-64-17A

supports

Pressure Vessel

Pressure Vessel

Pressure Vessel

Pressure Vessel

Pressure Vessel

Pressure Vessel

SNUBBER 1-64-32 
MO NUMBER

19103653

19103716

19103727

19103786

19103815

19103816

19103819

19103881

19104544

19105344

19105347

19105348

19105349

19105351

19105352

19105353

19105354

19105355

19105356

19105357

19105359

19105366

19105368

19105369

19105370

19105371

19105372

19105373 snubber 1-83-69A

SNUBBER 1-63-13

SNUBBER 1-63-18

Snubber 1-63-19

SNUBBER 1-41-3

SNUBBER 1-52-29

SNUBBER 1-63-9

snubber 1-52-6

valve

snubber 1-52-24

snubber 1-41-15

snubber $1-52-25 B$

snubber 1-52-28A

snubber 1-52-32

Snubber 1-52-38

snubber 1-52-43A

Snubber $1-52-46 A$

Snubber 1-52-57

snubber 1-52-58A

snubber 1-52-59

Snubber 1-52-60

snubber 1-63-10

snubber $1-63-14$

Snutber $1-63-15$

snubber $1-63-19$

Snubber 1-63-25

Snubber 1-63-26

Snubber 1-64-7 
MO NUMBER

19105374

19105375

19105376

29105377

19105379

19105380

19105383

19105387

19105538

19105539

19105540

19105541

19105542

19105559

19105566

19105829

19106531

19106704

19106705

19106909

19107001

19107002

19107351

29107351

19200418

29200449

19200483

19200487

\section{COMPONENT}

8nubber 1-64-10

snubber 1-64-15

8nubber 1-52-39

snubber $1-64-35$

snubber 1-64-99

snubber 1-64-100

snubber $1-83-4$

snubber 1-83-70

8nubber 1-41-12

8nubber 1-52-3

8nubber $1-52-43$

snubber 1-52-48

snubber 1-52-15

Valve

Valve

snubber 1-52-13A

8nubber 1-45-7

snubber $1-60-20$

snubber 1-60-27

Check Valve 1-SI-245

Snubber 1-52-17

Snubber 1-52-74

valve

Valve

Reactor coolant Piping

Pressure Vessel

Valve

Snubber 1-64-96 
MO NUMBER

19200490

19201268

19201269

29201885

19201889

19202923

19202998

19203529

19203529

19203531

19203638

19203929

19203951

19204793
COMPONENT

PAGE:

8nubber 2-52-56

Preseure Veseel

Preseure Vesed

8nubber 1-52-39

8nubber 1-64-12

8nubber 2-52-30

Reactor coolant Plping

piping syotam

piping syotom

Plping syetam

Valve

snubber $1-45-2$

valve

snubber 1-64-97 
ACCELERATED DOCUMENT DISTRIBUTION SYSTEM

REGULATORY INFORMATION DISTRIBUTION SYSTEM (RIDS) plant K

ACCESSION NR: 9301270178 DOC.DATE: $93 / 01 / 22$ NOTARIZED: NO DOCKET FACIL:50-315 Donald C. Cook Nuclear Power Plant, Unit 1 , Indians $M 05000315$ AUTH. NAME AUTHOR AFFILIATION

RUTKOWSKI,J.E. Indiana MIchigan Power CO. (Formerly Indiana Michigan Ell RECIP. NAME DAVIS, ABB. RECIPIENT AFFILIATION

Document Control Branch (Document Control Desk)

$\mathbf{R}$

SUBJECT: Forwards "DC Cook Nuclear Plant Unit I Rept of ISI from 910127-921028."

1

DISTRIBUTION CODE: AO47D COPIES RECEIVED:LTR 1 ENCL 1 SIZE: $1+250$ TITLE: OR Submittal: Inservice Inspection/Test Ing/Relief from ASME Code NOTES :

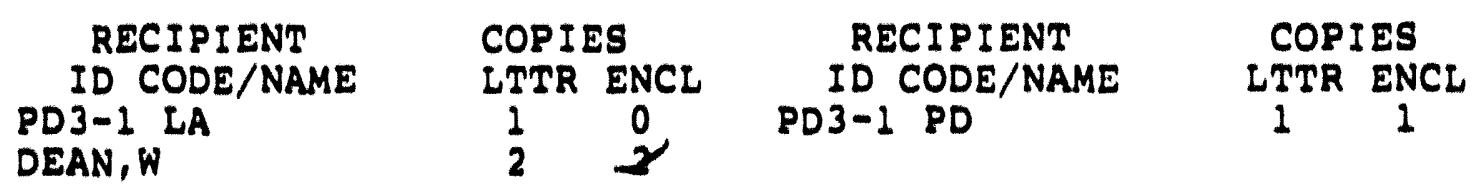

S

INTERNAL: NRR/DET/ECMB PH NUDOCS-ABSTRACT OGC/HDS2

RES GILMAN, G EXTERNAL: YEGG G BROWN IS
NRC FDR

$S-M S-2209$

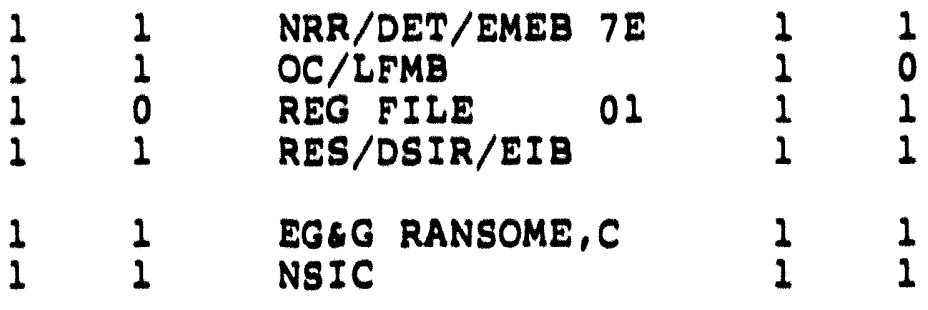

$$
\begin{aligned}
& \begin{array}{l}
1 \\
0 \\
1 \\
1 \\
1 \\
1
\end{array}
\end{aligned}
$$$$
\text { Mics reports }
$$

in:lcile nom-cocle it ions

1

Tryout trans

Ene tee 4 "ice

\%u lit testing

lin in fir li festive

Inter

dices noted

hut No KR

Tie hark.

D

D

$\mathbf{S}$

$\mathbf{R}$

I

D

S

no Index of nIs-2's

I

A

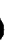

NOTE TO ALL "RIDS" RECIPIENTS:

PLEASE HELP US TO REDUCE WASTE! CONTACT THE DOCUMENT CONTROL DESK, ROOM PI.37 (EXT. S04.2065) TO ELIMINATE YOUR NAME FROM DISTRIBUTION LISTS FOR DOCUMENTS YOU DON NEED!

TOTAL NUMBER OF COPIES REQUIRED: STR 16 ENCL 13

C-161 


\section{$\operatorname{Tin}$ \\ INIANA mentan ming}

U. S. Nuclear Regulatory Commission

Attn: Document Control Desk

Washington, D. C. 20555

Attn: A. B. Davis

January 22, 1993

Dear Mr. Dav1s:

Attached please find a copy of the ISI NIS-1 Report for Inservice Inspection activities performed at the Donald $C$. Cook Nuclear Power Plant, Unit 1, state of Michigan, Number $M-09672-M$, located in Bridgman, Michigan. The Plant is owned by Indiana Michigan Power Company, one summit square, Ft. Wayne, Indiana 46802 .

The unit's commercial service date 1s August 23, 1975 and has a gross generating capacity of 1080 MWe.

The Authorlzed Code Inspector was Mr. M. K. Muterspaugh from Factory Mutual Engineering, whose address is 30150 Telegraph Road, Bingham office Park Sulte 141, Bingham Farms, Michigan 48010-4250.

The examinations, tests, replacements and repairs performed, conditions observed, and corrective measures taken are summarized in the attached report. ISI activities were performed in accordance with the rules and requirements of ASME Code Section XI 1983 Edition, summer of 1983 Addenda.

Respectively,

\section{J. E. Rutekowsk1}

Assistant Plant Manger

D. C. Cook Nuclear Plant

/cbm

Attachment

c: File

\section{$\{50136$}




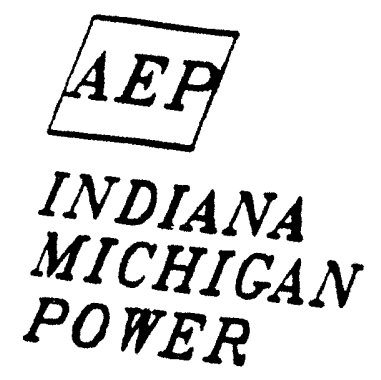

$$
\begin{aligned}
& \text { DONALD C. COOK } \\
& \text { NUCLEAR PLANT }
\end{aligned}
$$

$$
\text { UNIT } 1
$$

REPORT OF INSERVICE INSPECTIONS

$$
\begin{aligned}
& \text { FROM JANUARY 27, } 1991 \\
& \text { THROUGH OCTOBER 28,1992 }
\end{aligned}
$$


INDIANA MICHIGAN POWER COMPANY COOK NUCLEAR PLANT, BRIDGMAN, MI. UNIT 1 COMMERCIAL SERVICE DATE 8-23-1975 NATIONAL BOARD NUMBER 20761

REPORT OF INSERVICE INSPECTIONS FROM JANUARY 27, 1991 TO OCTOBER 28,1992

\section{TABIE OF CONTENTS}

section 1

Introduction

Section 2

NIS-1 Inservice Inspection Summary Report

Section 3

Examination of Class 1 and Class 2 systems and Components

Section 4

Steam Generator Eddy Current Examinations, Tube Plugging and Tube sleeving.

Section 5

System Pressure Tests

Section 6

NIS-2 Repair and Replacement Reports 
INDIANA MICHIGAN POWER COMPANY

COOK NUCLEAR PLANT, BRIDGMAN, MI.

UNIT 1 COMMERCIAL SERVICE DATE 8-23-1975

NATIONAL BOARD NUMBER 20761

\section{INTRODUCTION}

This report summarizes the Inservice Inspection activities performed at the cook Nuclear Plant, Unit 1 for the period of January 27, 1991 through October 28, 1992. These activities were performed in accordance with the requirements of the ASME Boiler and Pressure Vessel Code, section XI, Rules for Inservice Inspection of Nuclear Power Plant Components. As of July 1, 1986, the second ten-year inspection interval began and the applicable code for ISI activities then became the 1983 edition through the summer 1983 addenda.

The purpose of this report is to satisfy the requirements of IWA-6000 for the submittal of an Inservice Inspection summary report at the completion of each refueling outage. Examinations and tests conducted since the preceding summary report (January 26, 1991) are included in this report. Repairs and replacements are also included in this report per the requirements of the 1983 Edition of ASME Section XI IWA-6220(b) 10. Also, contained within this report are the supplemental information requirements of IWA-6220.

Contents of this report have been reviewed and verified correct with supporting documentation available at the plant for review if required. 


\author{
INDIANA MICHIGAN POWER COMPANY \\ COOK NUCLEAR PLANT, BRIDGMAN, MI. \\ UNIT 1 COMMERCIAL SERVICE DATE 8-23-1975 \\ NATIONAL BOARD NUMBER 20761
}

\title{
EXAMTNATION OF CIAASS 2 AND CLASS 2 COMPONENTS
}

Inservice examinations were performed during the 1992 Unit 1 Refueling outage during the period of January 27, 1991 through October 28, 1992. All examinations were in accordance with ASME Section XI, 1983 Edition through 1983 summer Addenda.

Examinations were scheduled and performed according to the second Ten-Year Interval Long-Term Inservice Examination and Testing Plan for Class 1,2 and 3 Systems and Components for Donald C. Cook Nuclear Plant, Unit 1 . This is the currently approved ISI examination plan, which identifies specific activities to be performed on a refueling outage basis.

Nondestructive examinations were performed by Southwest Research Institute (SWRI), MQS Inspections and Indiana Michigan Power (IMP) personnel in accordance with procedures which were approved for use at the Cook Nuclear Plant. SWRI performed the required volumetric ultrasonic examinations and surface examination if one was needed in addition to the volumetric examination. MQS and IMP personnel performed all other surface and visual examinations except for the reactor vessel visual examination which was performed by Westinghouse.

A reactor vessel visual examination was performed of areas accessible during a normal refueling outage. In addition, the upper internals and accessible areas of the lower internals was visually examined. No recordable indications were noted.

Snubber examinations and functional testing were performed in conjunction with maintenance procedures for technical specification surveillance of snubbers.

IMP personnel performed VT-3 and VT-4 visual examinations on ISI component supports. Design sketch nonconformances and other discrepancies found were evaluated by AEPSC structural and Analytical Design section. All discrepant pipe supports and associated systems were found to be functional and met operability limits. However, some of the pipe supports were repaired to be in accordance with the original design intent.

The summary pages in this section lists the examinations, tests performed and results. In the following summary pages, "NOREC" is no recordable indications, "GEOM" is geometric indications, and "OTHER" are indications other than geometric indications. 
D.C. COOK PULULEÁTY PLANT. CIRIDCMAN, MI

UNIT 1 COMAGERCInL SESiVICE CATE 8.23.1975

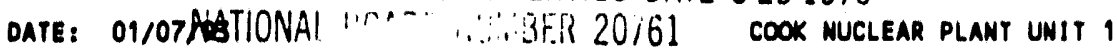

PAGE: 2

REVISIOW: 0

SLMWARY OF NONDESTRUCTIVE EXAMINATIONS

OUTAGE 2 (1992), SECOND PERIOD, SECOND INTERVAL

CLASS 1 COMPONENTS

BEACTOR COOLANI SYSTEY

SUMUARY EXAMINATION AREA
MUMBER IDENTIFICATION
$\ldots \ldots \ldots \ldots \ldots \ldots \ldots \ldots \ldots \ldots \ldots \ldots \ldots \ldots \ldots$

ASME

SEC. $X I$

CATGY EXAM

ITEM NO METHOO PROCEDURE
$\begin{array}{lll}M & & 0 \\ 0 & G & T\end{array}$

R E H

E O E REMARKS

C M R "CALIBRATION BLOCK"*

LINE $1-R C-10$ (FIC NO A-15)

038400 P-RC- $10 \cdot 07 \$$
PIPE TO TEE

$038500 \quad 1-R C-10-08 F$

TEE TO PIPE

$038600 \quad 1 \cdot R C \cdot 10-09 F$ TEE TO PIPE

$038700 \quad q-R C-10-10 S$ PIPE TO ELBOW

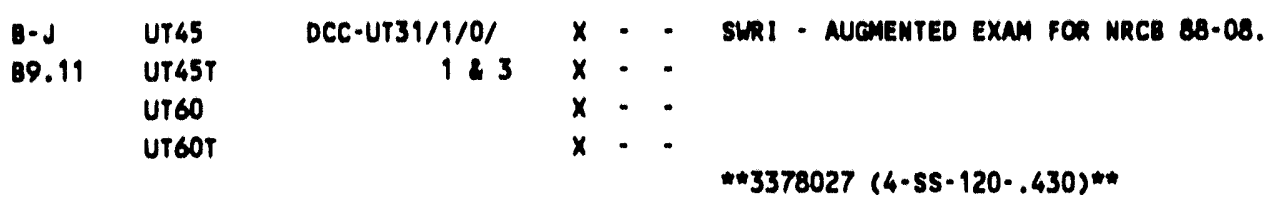


DATE: 01/07/93

REVISION:

SAEETY IMUECIION SYSTEH

SUMUARY EXMIIMATION AREA

MLMBER IDENTIFICATION

HIIF $1-51-23$ (EIC MO $A-33)$

$093500 \quad 1 \cdot 81 \cdot 23-05 \%$

COLLAR TO PIPE
O.C. COCI RULL:A O MiT. BRIDGMAN, MI

UNIT I COBHERT: SERVICE DATE 8.23.1975

VATIONAI iP .... "i,IRER 20761

COOK MUCLEAR PLANT UNIT I

PAGE:

SUMMARY OF MONDESTRUCTIVE EXAMIMATIONS

OUTAGE 2 (1992), SECOND PERICO, SECONO INTERVAL

CLASS 1 COMPONENTS
ASME

SEC. XI

CATOY EXAM

ITEM NO METHOO

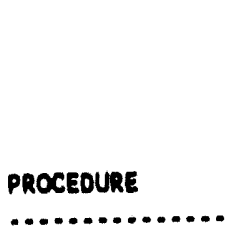

10

O 01

R $E$

E $O$ E REMARKS

C M R mCALIBRATION BLOCK"t
.......................................

\begin{tabular}{|c|c|c|c|c|c|}
\hline $\begin{array}{l}B-k-1 \\
B 10.10\end{array}$ & $\begin{array}{l}\text { PT } \\
\text { UTOL } \\
\text { UT45 }\end{array}$ & $\begin{array}{l}\text { 128HP505ONDEOO1 } \\
\text { DCC-UT } 49 / 1 / 0 / 1 \\
\text { DCC-UT31/1/0/3 }\end{array}$ & $\begin{array}{l}x \\
x\end{array}$ & $\begin{array}{l}\cdot \quad x \\
\cdot \quad \cdot \\
\cdot \quad \cdot\end{array}$ & 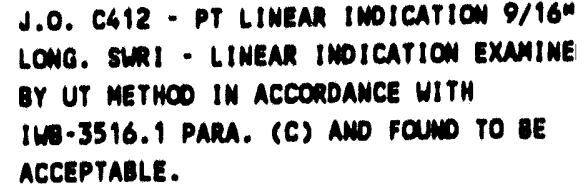 \\
\hline
\end{tabular}
ACCEPTABLE.

LIIF 1.51 .546 (EIC NO A.62A)

$117600 \quad 1-81 \cdot 546-315$ COLLAR TO PIPE
$B-k-1$ PT

B10.10
12SHP5OSONDEO01

$x$

\author{
J.O. C412 - LIMITED EXAM AREA OUE YO \\ BOLTING.
}


INDIANA MICHIGAN POWER COMPANY COOK NUCLEAR PLANT, BRIDGMAN, MI.

UNIT 1 COMMERCIAL SERVICE DATE 8-23-1975 NATIONAL BOARD NUMBER 20761

Technical specification/Inservice Inspection

Surveillance of Hyaraulic snubbers

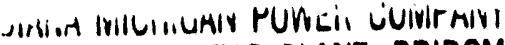

ڤ. COOK NUCLEAR PLANT, BRIDGMAN, MI

iIT 1 COMMERCIAL SERVICE DATE 8.23.19;

"ATIONI' ANAON MIIIAARFR 20761 
INDIANA MICHIGAN POWER COMPANY

COOK NUCLEAR PLANT, BRIDGMAN, MI.

UNIT 1 COMMERCIAL SERVICE DATE 8-23-1975

NATIONAL BOARD NUMBER 20761

\section{TS/ISI SNUBBER EXAMINATION AND TESTING}

Snubber visual examinations are separated into three (3) categories: Grinnell "Accessible", Grinnell "Inaccessible", and "Steam Generator". The functional test surveillances are separated into two (2) categories: "Grinnell" and "Steam Generator".

Lists of those snubbers classified as "Accessible", "Inaccessible", and "Steam Generator" are attached.

\section{Visual Examinations}

Category

a.Grinnell "Accessible"

b.Grinnell "Inaccessible"

c.Steam Generator

Functional Testing

Category

a.Grinnel1

b.Steam Generator

Comple Date
$06-16-92$
$09-25-92$
$08-27-92$
$10-03-92$
$07-18-92$
$09-19-92$

Compl. Date 09-28-92

$08-11-92$
Comments/Results

all acceptable

all acceptable

all acceptable

all acceptable

all acceptable

all acceptable

\section{Comments/Results}

all acceptable, see attached sheet three tested, all acceptable, see attached sheet 


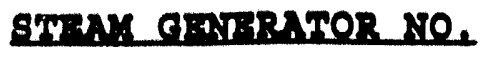

$8 / 0 * 11$
TFCH, SPFC, No.

79

80

81

82
SPRTAT NDORER

$25.12620 .007-1$

$25.12620 .007-5$

$25.12620 .007-7$

$25.12620 .007-14$

$8 / 0 * 12$

85

84

86

83
25 . $12620.007-9$

$25.12620 .007-6$

$25.12620 .007-15$

$25.12620 .007-3$

$8 / 0 \# 13$

88

$25.12620 .007-4$

87

$25.12620 .007-2$

90

$25.12620 .007-16$

89

$25.12620 .007-8$

s/c $\$ 14$ 


\section{FUNCTIONAL TEST SURVEILLANCES}

\begin{tabular}{|c|c|c|c|}
\hline Snubber Mark No. & Date Removed & Date Ratingtaliled & An-Found \\
\hline 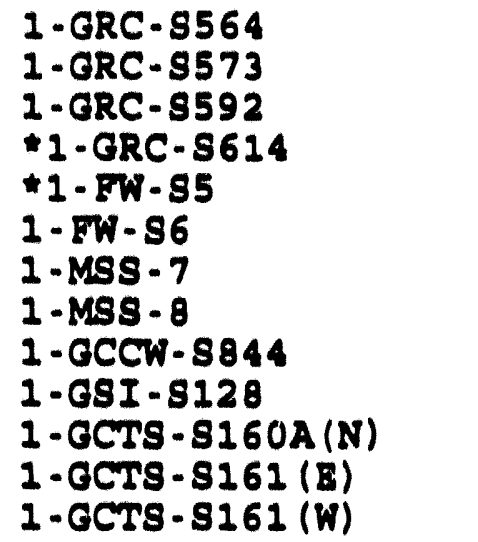 & $\begin{array}{l}08-21-92 \\
08-21-92 \\
08-18-92 \\
08-22-92 \\
08-22-92 \\
08-13-92 \\
08-19-92 \\
08-19-92 \\
07-31-92 \\
08-06-92 \\
08-14-92 \\
08-07-92 \\
08-07-92\end{array}$ & $\begin{array}{l}08-27-92 \\
08-27-92 \\
08-26-92 \\
09-08-92 \\
08-27-92 \\
09-02-92 \\
08-26-92 \\
09-08-92 \\
08-05-92 \\
08-14-92 \\
08-20-92 \\
08-14-92 \\
08-14-92\end{array}$ & 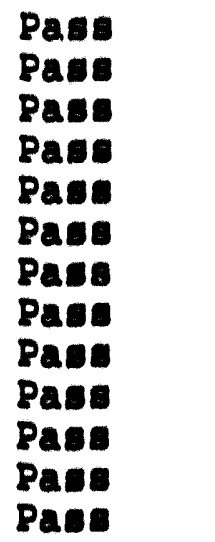 \\
\hline $\begin{array}{l}S / N 25.12620 .007-1 \\
s / N 25.12620 .007-5 \\
s / N 25.12620 .007-6\end{array}$ & $\begin{array}{l}07 \cdot 18.92 \\
07-18.92 \\
07-18-92\end{array}$ & $\begin{array}{l}09-12-92 \\
09-12-92 \\
09-12-92\end{array}$ & $\begin{array}{l}\text { Pase } \\
\text { Pase } \\
\text { Pase }\end{array}$ \\
\hline
\end{tabular}

* These nubbero were tested due to functional fallures at the previous testing period (last outage). 
UNIT 1 GRINNELL "INACCE88IBLE" SNUBBERS

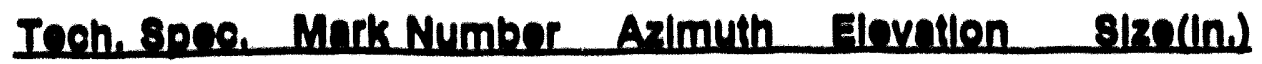

\begin{tabular}{|c|c|c|c|c|}
\hline $\begin{array}{l}1 \\
2 \\
3 \\
4 \\
5 \\
6 \\
7 \\
8 \\
9 \\
10 \\
11 \\
12 \\
13 \\
14 \\
16 \\
16 \\
17 \\
18 \\
10 \\
20 \\
21 \\
22 \\
23 \\
24 \\
28 \\
26 \\
27 \\
28 \\
29 \\
30 \\
31 \\
32 \\
33 \\
34 \\
35 \\
36 \\
38 \\
39 \\
40 \\
41 \\
42 \\
43\end{array}$ & 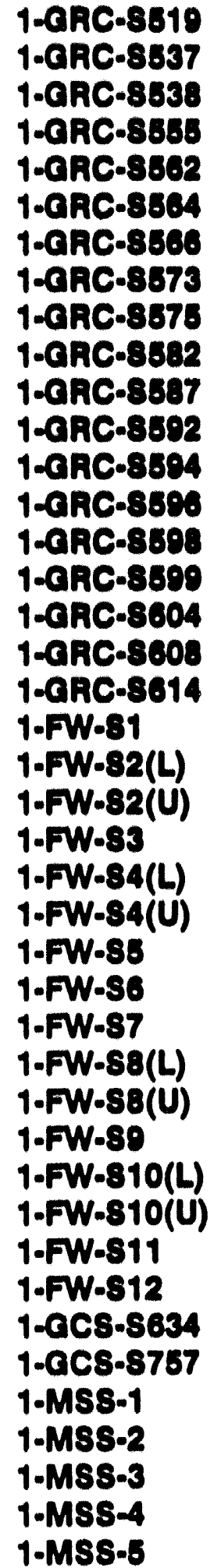 & $\begin{array}{c}310 \\
25 \\
41 \\
141 \\
184 \\
313 \\
332 \\
223 \\
208 \\
212 \\
280 \\
202 \\
202 \\
285 \\
202 \\
287 \\
286 \\
286 \\
381 \\
31 \\
26 \\
26 \\
20 \\
164 \\
164 \\
163 \\
157 \\
204 \\
200 \\
200 \\
194 \\
334 \\
334 \\
330 \\
343 \\
292 \\
128 \\
8 \\
17 \\
172 \\
165 \\
191\end{array}$ & $\begin{array}{l}683 \\
610 \\
614 \\
614 \\
610 \\
614 \\
610 \\
614 \\
610 \\
617 \\
682 \\
683 \\
6119 \\
691 \\
670 \\
672 \\
688 \\
693 \\
681 \\
634 \\
633 \\
636 \\
629 \\
638 \\
640 \\
634 \\
629 \\
634 \\
633 \\
638 \\
629 \\
633 \\
636 \\
634 \\
629 \\
613 \\
612 \\
630 \\
638 \\
639 \\
635 \\
635 \\
\end{array}$ & 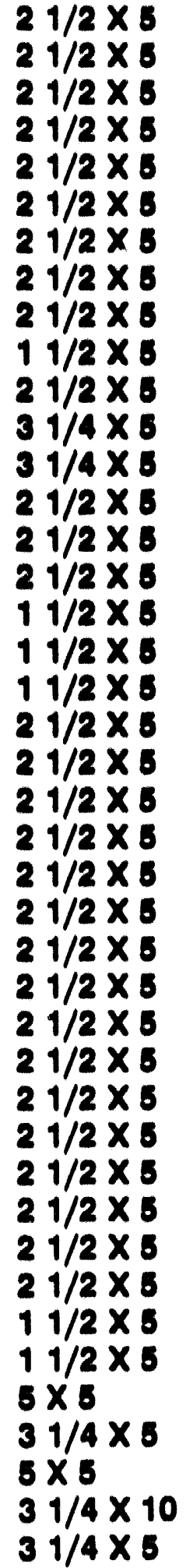 \\
\hline
\end{tabular}


808

$31 / 4 \times 8$

$4 \times 8$

$11 / 2 \times 8$

INDIAMA MICHIGAN POWER COMPANY

O.C. COOK NUCLEAR PLANT, BRIDGMAN, MI

UNIT I COMMERCIAL SERVICE DATE 8.23.1975

NATIONAL BOARD NUMBER 20761

$$
\text { C- } 174
$$




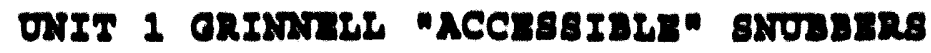

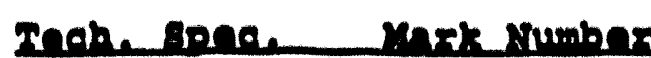

37

47

48

49

30

51

32

33

84

83

56

57

38

89.

60

62

62

63

64

63

66

67

68

69

71

72

73

74

75

76

77

78
$1-068-8637$

$1-\operatorname{cCCW}-8278$

1- CCCW- 8309

1- CCCW- 8837

1- $\operatorname{ccc} 1-8838$

1- $6 \mathrm{CCW}-8839$

1- $\operatorname{cCCH}-8840$

1 - $\operatorname{ccc} 1-8841$

1- $\operatorname{ccc} W-8842$

1-CCCW- 8844

1-020-8563

$1-020-8569$

1-020-8573

1-00D-8574

$1-02 \pi-87 x$

1-025-875

1-0n - 847

$1-0 n x-848$

1- ODG-813

1. CDG-814

1.08I-8103

1-08I- 8128

1-08I-8575

1-085-8637

$1-\cos s-873(\mathrm{I})$

1- $\cos 8-873$ (i)

$1-\cos \theta-876(2)$

1 - $\cos 5-876(\mathrm{~A})$

$1-\cos 8-8160 \lambda(\mathrm{r})$

1- $\cos 8-81602(8)$

$1-\cos 8-8161(\mathrm{z})$

1-cors-8161(n)
Antmuth merntion

71

608

609

597

621

621

621

621

621

621

$277 \quad 608$

278

181

181

66

183

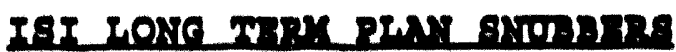

608

607

607

581

381

581

580

596

603

573

573

598

610

582

582

579

379

582

582

579

579

1-0Tw-8852

$1-0 \% 1-8854$

1-0.m-8861

$1-0 \mathrm{~m}-8862$

1-Grw-8866

$\sin (1, n \cdot)$

$11 / 2 \times 10$

$11 / 2 \times 5$

$4 \times 5$

$11 / 2 \times 5$

$11 / 2 \times 5$

$11 / 2 \geq 5$

$11 / 2 \times 5$

$11 / 2 \times 3$

$11 / 2 \times 5$

$11 / 2 \times 5$

$11 / 2 \times 5$

$11 / 2 \times 5$

$11 / 2 \times 5$

$11 / 2 \geq 5$

$21 / 2 \times 3$

$21 / 2 \times 5$

$21 / 2 \times 5$

$21 / 2 \times 5$

$21 / 2 \times 5$

$21 / 2 \times 5$

$31 / 4 \times 3$

$31 / 4 \geq 5$

$21 / 2 \times 5$

$11 / 2 \times 5$

$21 / 2 \times 5$

$21 / 2 \geq 5$

$21 / 2 \times 5$

$21 / 2 \times 5$

$21 / 2 \times 5$

$21 / 2 \times 5$

$21 / 2 \times 5$

$21 / 2 \times 5$ 
INDIANA MICHIGAN POWER COMPANY

COOK NUCLEAR PLANT, BRIDGMAN, MICHIGAN

UNIT ONE COMMERCIAL SERVICE DATE 8-23-1975

NATIONAL BOARD NUMBER 20761

STEAM GENERATOR INSPECTIONS AND REPAIRS

Unit one steam Generator inspections and repalrs were performed from July 11, 1992 to september 11, 1992 in accordance with plant Technical specifications. Eddy current bobbin coll testing was performed on 100 of the inservice tubes in all four steam generators. Selected areas of the tubes were also inspected with rotating pancake (RPC) probes. All tubes with indications exceding Tech spec limits were repaired either by sleeving or plugging. Llsted below are the number of tubes repalred per steam generator:

Steam Generator 11:

827 sleeves installed in the hot leg

135 tubes removed from service by piugging

Steam Generator 12:

180 sleeves installed in the hot leg

96 tubes removed from service by plugging

Steam Generator 13:

459 sleeves installed in the hot leg

72 tubes removed from service by plugging

Steam Generator 14:

374 sleeves installed in the hot leg

51 tubes removed from service by plugging

INDIANA MICHIGAN POWER COMPANY

D.C. COOK NUCLEAR PLANT, BRIDGMAN, MI

UNIT I COMMERCIAL SERVICE DATE 8.23.1975

NATIONAL BOARD NUMBER 20761 


\section{SYSTEM PRESSURE TESTS}

Inservice Inspection System Pressure Tests were performed during the Summer 1992 Unit One Refueling Outage. These tests were in accordance with the requirements of ASME Section XI Articles IWA-5000, IWB-5000, IWC-5000, and IWD-5000 as applicable.

A total of thirty-eight (38) hydrostatic tests were performed during the outage with the results of all tests within allowable acceptance criteria. The tests performed were:

PROCEDURE

$\star \star$ I-OHP 5070. ISI.006

$\star \star$ ]-OHP 5070. ISI.009

$\star \star 1-O H P \quad 5070$. IS1.010

$\star \star$ ]-OHP 5070. ISI.011

$\star \star 1-$ OHP 5070. ISI.013

$\star$ \#-OHP 5070. ISI.020
DESCRIPTION

Pressurizer and Reactor Head Post Accident Vents

Component Cooling Water:

East and West Trains

Component Cooling Water Piping

Misc Supply/Return Headers

Component Cooling Water Piping at $C P N-25$ and 72 serving $C P N$ \& CEQ Fan Motor Cooling

Component Cooling Water Piping Excess Letdown Heat Exchanger, RCP Thermal Barriers, 0 il Coolers

Non-Essential Service Water: CPN's to/from Containment

Ventilation Units

RHR: Normal Pump Suction
NUMBER OF

IESTS COMPLETED

2

2

1

4

3

13

1

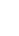

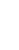

1

3

\section{INDIANA MICHIGAN POWER COMPAYY \\ J.C. COOK NUCLEAR PLANT, BRIDGMAN, MI \\ UNIT 1 COMMERCIAL SERVICE DATE 8.23.1975 \\ NATIONAL BOARD NUMBER 20761}


PROCEDURE

$\star \star 1-O H P \quad 5070.151 .023$

$\star \star$ 1-OHP 5070. ISI.045

**1-OHP 5070. ISI.048
Containment Purge Piping at

CPN's $59,61,62,63,64,65$

DESCRIPTION

Nitrogen Piping to Accumulators at $\mathrm{CPN}-32$

Plant and Control Air

Piping at CPN's
NUMBER OF

TESTS COMPLETED

1

7

4

In addition system functional, inservice and leakage tests were conducted on class one, two and three systems. This included the entire Reactor Coolant System and associated piping per the rejuirement of IWB-5221. The results of the system functional, inservice and leakage tests were all within allowable acceptable range.

All procedures satisfy the testing and documentation requirements set forth in ASME Section XI, 1983, Summer 1983 Addendum for Class 1, Class 2, and Class 3 components and systems for Cook Nuclear Plant.

All procedures were satisfactorily completed by Indiana Michigan Power Company, ISI Hydro Testing, Quality Control, and NDE Personnel. 


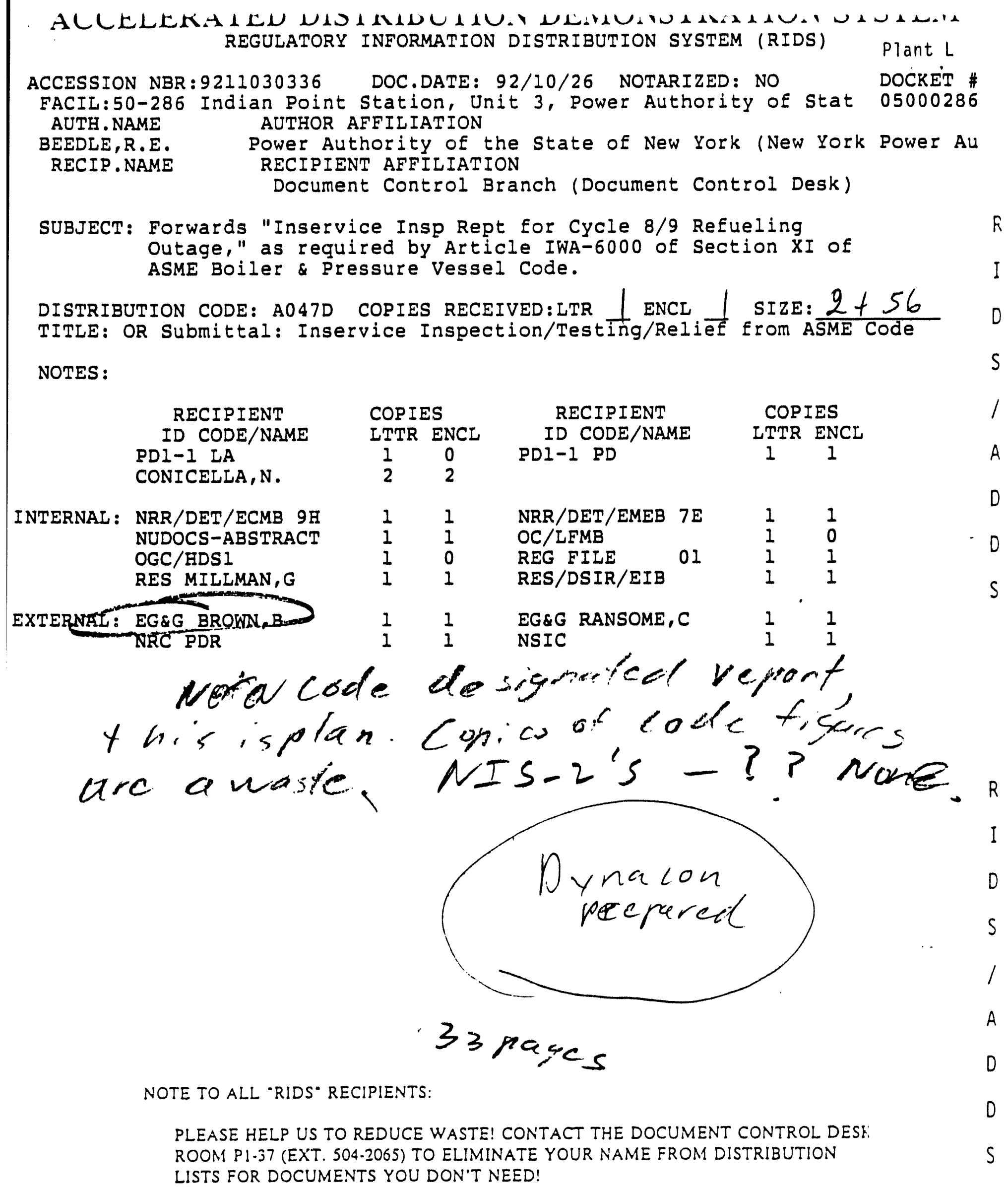

TOTAL NUMBER OF COPIES REQUIRED: STR 16 ENCL 13 C- 179 
U.S. Nuclear Regulatory Commission

ATTN: Document Control Desk

Mail Station P1-137

Washington, DC 20555

Subject: Indian Point 3 Nuclear Power Plant

Docket No. 50-286

Inservice Inspection Report for

Crcle $8 / 9$ Refueling Outage

Dear Sir:

This letter submits the Inservice Inspection (ISI) Report (Attachment I) as required by Article IWA-6000 of Section XI of the ASME Boiler and Pressure Vessel Code.

This inspection is the second examination of the second 40month period of the second 10-Year Indian Point 3 ISI Program Interval and was conducted during the Cycle $8 / 9$ Refueling outage. The report consists of extracts from Tabs $A, B$, and $C$ of the Final Weld and Component Examination ISI Report.

If you have any questions, please contact Mr Kokolakis.

Attachment.

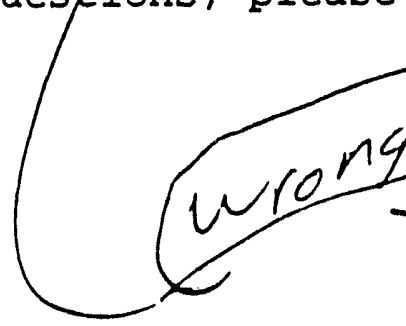

eytracts

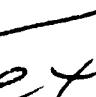

very truly yours,

cc: see next page

200019

$$
\begin{aligned}
& \text { No resalts, exeent } \\
& \text { Ver skafehy summar }
\end{aligned}
$$

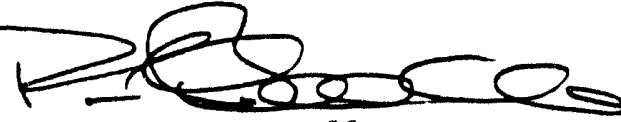




\author{
NEW YORR POWER AOTHORITY \\ INDIAN POINT ONIT NO. 3 \\ 2ND ODTAGE 2ND PERIOD 2ND INTERVAI \\ 1992
}

\title{
INTRODUCTION
}

An Inservice Examination Program was performed at the Indian Point Unit No. 3 Nuclear Power Plant from August 23, 1991 thru May 30,1992 by Westinghouse Electric Corporation, Dynacon Systems Inc. and New York Power Authority - Indian Point Unit No. 3 , of Class 1, Class 2 and Class 3 components and piping. The examinations were performed in accordance with an approved Examination Program Plan located under Tab $c$ of the Final Report.

Examinations were performed to satisfy the requirements of:

- ASME Boiler and Pressure Vessel Code Section XI, 1983 Edition up to and including summer 1983 Addenda

- ASME Boiler and Pressure Vessel Code Section XI, 1986 Edition, Appendix VI

- United states Nuçlear Regulatory Commission, Nuclear Regulatory Guide 1.14

- Surface examination of Class 1 Steam Generator Manway Bolting per Indian Point Unit No. 3 commitment to the United states Nuclear Regulatory Commission

Examination procedures were approved prior to the examinations, and certification documents relative to personnel, equipment and materials were reviewed and determined to be satisfactory. Inspection, review, witnessing and surveillance of the examinations and related activities were conducted by personnel from: The Nuclear Regulatory Commission, the Hartford Steam Boiler Inspection and Insurance Company and the New York Power Authority Quality Assurance Department.

\section{RESOLTS}

Examinations based on the Examination Program Plan noted 36 recordable indication areas on the basis of Westinghouse procedure recording criteria, which, generally are more critical than specified section XI acceptance criteria. These indications consisted of (a) 10 surface, hich were either accepted or eliminated during investigation and (b) 26 visual of which all were IWF components. All indications were evaluated and corrected or accepted as appropriate to maintain integrity of the individual components. 
Specific data relative to all the indications including dispositions, NCR's and Acceptance standards are located under $T a b D$ and $T a b$ of the Final Report.

\section{EXANINATION}

Examinations were conducted to inspect as much of the specified surface/volume as reasonably practical. In some instances, examinations were limited by geometric, metallurgical or design access restrictions. In each case, the occurrence and the cause of various ifmitations have been noted and the resulting coverage is the maximum that is reasonably achlevable.

Some of the arrangements and detalls of the piping systems and components were designed and fabricated before the access and examination requirements of section XI Code were established. specified limitations and restrictions for all examinations are indicated on the examiners data sheets, under $\mathrm{Tab} D$ of the Final Report.

The following items were examined by New York Power Authority Indian Point No. 3 personnel:

- Class 1 system Leakage Test

- Class 2 system Leakage Test

- Class 3 system Leakage Test

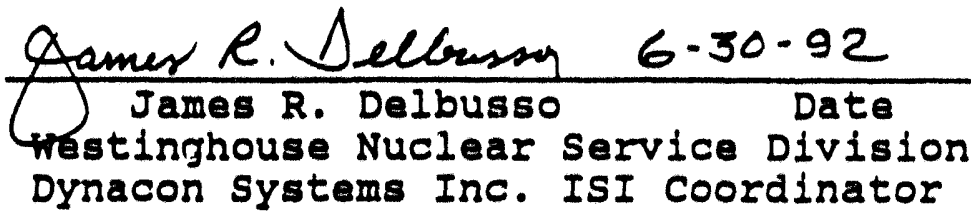

Page 2 of 2 


\section{Inservice Examination program plan For \\ New York Power Authority \\ Indian point onit No.3 \\ 2nd Outage: 2nd period: 2nd Interval \\ 1992}

This document details the proposed planned scope of examination by Festinghouse Nuclear services Division Inspection services for the 2nd outage,2nd perlod,2nd Interval, including items and areas selected for examination and documentation procedures and sketches containing identifications of all areas to be examined.

Qualifications of examiners, materials and equipment will be availabla on site prior to the start of examinations.

Efforts should be"made to provide access to all planned examinations, however, due to circumstances such as enviroment, access, radiation levels, etc., some variations may occur.

This program and the procedures incorporated herein require approval of New York Power Authority and the Authorized Inspector prior to the start of examinations.

Prepared BY: WESTINGHOOSE ELECTRIC CORPORATION * Approval: $\frac{\text { Aquer R. (eeluma }}{\text { Bjto coordinator }} \frac{4-23-92}{\text { Date }}$

New York Power Authority Approval: Title:

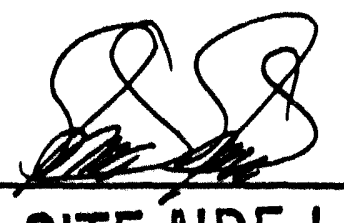

SITE NDE LEVEL III

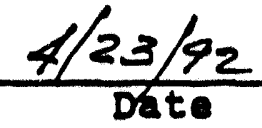

Authorized Inspector Review:

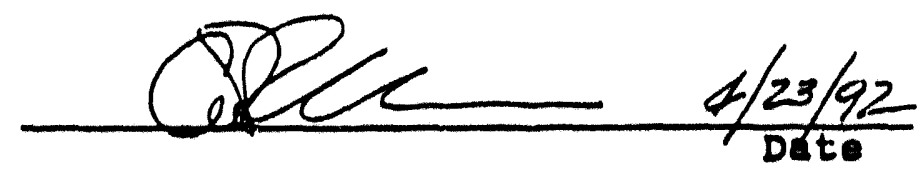

Agency:

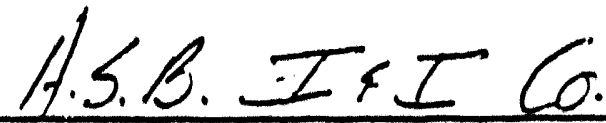


NEW YORK POWER AUTHORITY

INDIAN POINT UNIT NO. 3

2ND OUTAGE; 2ND PERIOD; 2ND INTERVAL

INSERVICE EXAMINATION PROGRAM

1992

All items listed below were examined, as indicated, in accordance with the requirements of the ASME Boiler and Pressure Vessel Code Section XI-1983 Edition up to and including Summer 1983 Addenda and Plant Technical Specification to the extent practical with the access provided and the limitations of component geometry.

Program IWB-2500-1

Item Reference
Area and Extent of Examination

$$
\begin{gathered}
\text { Examination } \\
\text { Procedure }
\end{gathered}
$$

Skotch

Reference

Vol. Surf. Vis

\section{Benctor Yeasel}

$1 . \quad B 6.30$

2. $\quad B 6.30$

3. B15.10

Closure Head Studs - 19 thru 36

115

-. 1.1400

Closure Heed Stud-Replacement 18

11570

.. 1.1400

Pressure Retaining Boundary

(1) (1)

Pressurizar

4.

B2.11

Circumferential Weld 17

$-$

(2) (2)

5.

B2.12

Longitudinal Weld 16

$-$

(2) (2)

6.

B3.120

Nozzle Inside Redius Section -

$-$

(2) (2) 20IR, 21IR, 22IR, 23IR, 24IR and 25IR

7. B15.20

Pressure Retaining Boundary

$-$

(1) (1)

Replecement Stenm Cenerntor 31, 32, 33 and 34

8.

B7.30

Manway Bolting-4 From Each

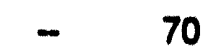

1.3101

Hotleg and Coldleg Manway

Pressure Retaining Boundary

Pressune Rethining Bolting

10.

B7.50

6" Pressurizer Safety-Flange A-

12 Studs and 24 Nuts

Piping

11.

B15.50

Pressure Retaining Boundary 
United States Nuclear Regulatory Commission Document Control Desk

Washington, DC 20555

Gentlemen:

INSERVICE INSPECTION ACTIVITIES - 90 DAY REPORT

TENTH REFUELING OUTAGE

SALEM GENERATING STATION

UNIT NO. 1

DOCKET NO. 50-272

Public Service Electric \& Gas Company (PSE\&G) hereby provides in the enclosure to this letter, the Ninety (90) Day Report for Inservice Inspection (ISI) activities conducted at salem Generating Station Unit No. 1 during the tenth refueling outage. This report is submitted in accordance with section 4.0.5 of Appendix A to the Technical specifications for Salem Generating Station, Unit No. 1 and Article IWA-6220(b) of Section XI of the ASME Boiler and Pressure Vessel code.

Enclosure 1 of this submittal consists of Form NIS-1, "Owners Data Report for Inservice Inspection", Forms NIS-2 and/or NR-1 "Owner's Report for Repairs or Replacements," and pertinent sections of Volume 1 of the "Examination of Selected Components at Salem Generating Station Unit No. 1".

Should there be any questions with regard to tris submittal, please do not hesitate to contact us.

Enclosure

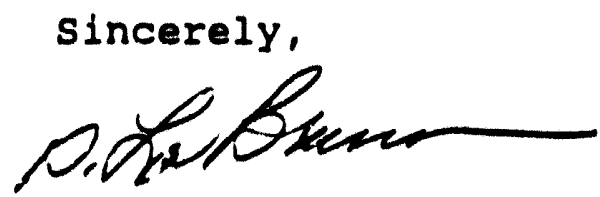

$\therefore 30050$ 
1. Owner: Public service Electric Gas Co., 80 Park Plaza Newark, N.J. 07101

2. Plant: Salom Generating station P.O. Box 236, Hancock's BrIdge, N.J. 08038

3. Plant Unit 1

4. Owner's Certiflcate of Authorization (1f required) $N / A$.

5. Commercial Service Date $7 / 1 / 77$.

6. Natlonal Board Numbar for Unit: $N / A$.

7. Examination Dates: 2-26-91 through 4-17-92.

8. This report covere the examinations that were conducted during the 10th Refueling Outage.

9. Componente Inepected.

COMPONENTS OR MANUFACTURBR APPURTENANCE OR INSTALLER

\section{Reactor Vesel}

11 steam Generator

$$
\begin{aligned}
& \text { Combuetion } \\
& \text { Engineering }
\end{aligned}
$$

Westinghouse Tampa Div. P.O. Box 19218 Tampa, FI 33616

12 steam Generator

13 Steam Generator

14 steam Generator

11 Regen. Ht. Exch.

\section{MANUTACTUR:RR STATION OR OR INSTALIER PROVINCE NATIONAL SIRR. NO. NUSXBER BOARD NO.}

\section{Head}

66201 Vessel

$\boldsymbol{N} / \boldsymbol{A}$

20757

1003

$\boldsymbol{N} / \boldsymbol{A}$

$68-10$
1022

1023

1203

Sentry Equip. Corp. Oconomowoc, WI
4195-A4

$7,8,9$
$N / A \quad 68-08$

$N / \boldsymbol{A}$

68-09

$N / \boldsymbol{A}$

$68-51$

$N / A$ 385,386 , 387 


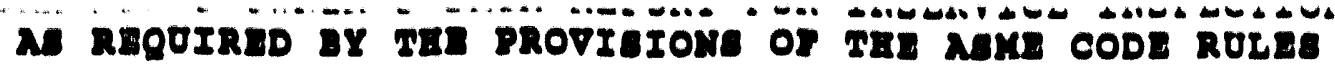

1. Owner: Public service Electric a Gas Co., 80 Park Plaza Newark, N.J. 07101

2. Plant: Salem Generating station P.O. Box 236, Hancock's Bridge, N.J. 08038

3. Plant Unit 1

4. Owner's Certificate of Authorization (if required) N/A. 5. Commercial service Date $7 / 1 / 77$.

6. National Board Number for Unit $N / A$.

7. Examination Dates: 2-26-91 through 4-17-92. 9. Components Inspected (contd):

COMPONENTS OR APPURTENANCE

1 Proserier

Chemical

volume :

Control

Piping

system

Containment

spray piping system

Mainstream Piping eyes.

1 Volume

Control

Tank

1 Excess

Letdown Heat Exchanger

1 Letdown Heat Exchanger

1 RHR Heat Exchanger
MANUFACTURER

MANUFACTURER OR INSTALLER

OR INSTALLER SER. NO.

Delta Southern

United Engineer:

4 Constructors

(UPC) 30 south 17 th st.. Phil. PA 19101

UEeC

vEsT

Joseph Oat

- Sone, Inc. Camden, N.J.

Atlas Industries 81 Somerset Place clifton, N.J.

Atlas Industries

Engineer: Fabricators, Inc.

1011

$N / A$

$N / A$

$N / A$

$1781-2 \lambda$

850

$N / \boldsymbol{A}$
STATION OR PROVINCE NUmBER

N/A

N/A

NRA

NRA

NRA

NRA

S15860-C

$N / A$

NRA

694

NRA

$\boldsymbol{N} / \boldsymbol{A}$

374

NRA

NATIONAL BOARD NO.

68-8

al! this on

ever page is en

was tc of siree ind

privluees an unnecilecl

paperwork kur.len.

C- 187

Page 2 of 21 
1. Owner: Public Service Electric a Gas Co., 80 Park Plaza Nowark, N.J. 07101

2. Plant: Balom Gonerating station P.0. Box 236, Hancock'e BrIdge, N.J. 08038

3. Plant Onit 1

4. Owner' Certiflcate of Authorization (1f required) $N / A$.

5. Commerolal Service Date $7 / 1 / 77$.

6. National Board Numbar for Unit $N / A$.

7. Examination Dates 2-26-91 through 4-17-92.

9. Componente Inopected (cont'd).:

\begin{tabular}{|c|c|c|c|c|}
\hline $\begin{array}{l}\text { COYMONENTS OR } \\
\text { APPURTENANCE }\end{array}$ & $\begin{array}{l}\text { MNNUFACTURER } \\
\text { OR INSTALIER }\end{array}$ & $\begin{array}{l}\text { MANUEACIURER } \\
\text { OR INSTALIER } \\
\text { SER. NO. }\end{array}$ & $\begin{array}{l}\text { STATION OR } \\
\text { PROVINCE } \\
\text { NUNBER }\end{array}$ & $\begin{array}{l}\text { NATIONAL } \\
\text { BOARD NO. }\end{array}$ \\
\hline $\begin{array}{l}\text { Preseurlzer } \\
\text { Relief } \\
\text { Plping sye. }\end{array}$ & Uace & $N / \boldsymbol{A}$ & $N / \lambda$ & $N / \boldsymbol{A}$ \\
\hline $\begin{array}{l}\text { Reactor } \\
\text { Coolant } \\
\text { Piping syo }\end{array}$ & UEEC & $N / \lambda$ & $N / \boldsymbol{A}$ & $N / \boldsymbol{A}$ \\
\hline $\begin{array}{l}\text { steam Gen. } \\
\text { Feed Piping } \\
\text { syotem }\end{array}$ & UEEC & $N / \boldsymbol{A}$ & $N / A$ & $N / x$ \\
\hline $\begin{array}{l}\text { safety } \\
\text { Injection } \\
\text { Plping sye. }\end{array}$ & UEec & $N / \lambda$ & $N / A$ & $N / \boldsymbol{A}$ \\
\hline
\end{tabular}




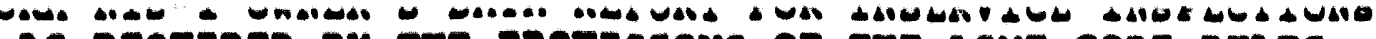

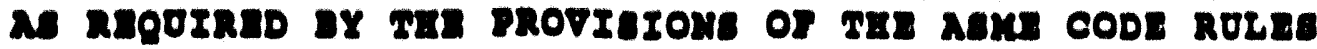

1. Owner: Public service Electric Gas Co., 80 Park Plaza Newark, N.J. 07101

2. Plants salom Gonerating station P.O. Box 236, Hancook's Bridge, N.J. 08038

3. Plant Onit 1

4. Owmer's Certificate of Authorization (1f required) $N / A$.

5. Commerolal service Date $7 / 1 / 77$.

9. National Board Numbar for Unit $N / A$.

7. Examination Dates: 2-26-91 through 4-17-92.

10. Abetracte of Examinations:

10.1 Examinations were conducted by PgEce as well as companies under contract to PSEce. The following examination cummary (soction 11) to a bries summary with further details cound in the attached report and on 11. at the salom Gonerating station.

since noarly all inservice examination requirements can be found in salem's Technical specifloations, this oummary liste these reguiroments flrot arranged by Tech. 8pec. paragraph number followed by applicable NRC clroulare and bulletins.

\section{Examination summary:}

11.1 Technical specification 4.0.5 - AsMr section XI

The examinatione were conducted during the tenth reEueling I8I outage at salom Unit 1. These examinations conotituted the third ISI pertormed at salom Unit 1 during the second - ten yoar interval of operation. The componente were examined in ocoordance with "Examination Plan for the 1992 Inservice Examination of salom generating station, Undt $1 \%$. 


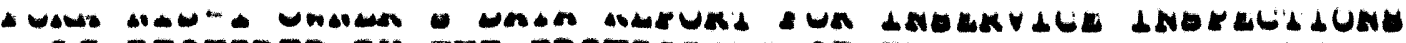

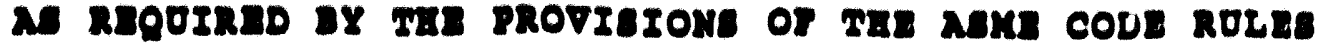

1. Owner: Public service Electric a Gas Co., 80 Park Plaza Nowark, N.J. 07101

2. Planti salem Generating station P.O. Box 236, Hancook' Bridge, N.J. 08038

3. Plant Unit 1

4. Owner's Certifleate of Authorization (1f required) $N / A$.

5. Commerolal service Date $7 / 1 / 77$.

6. National Board Number for Unit $N / A$.

7. Examination Dates: 2-26-91 through 4-17-92.

11. Examination summary (cont'd):

11.1 (cont.)

\subsubsection{I8I Examination}

8outhwest Researoh Inotitute (8WRI) under the direction of the sulen IBI Group conduoted elghty-two (82) ultrasonie, one hundred thirtyone (131) 11quid penetrant, elfty-a1x (56) magnetic particle, and one (1) vieual examination. The examinations were conducted on the collowing welds and componentes

\section{Clase 1 Componente}

\section{Veesele}

Renctor Preseure Vessel Closure head Proseur 18er

Piping

Chemloal and Volume Control syotem

Preseure Relies systom

Proseurizing syetem

Reactor Coolant system

Renldual Heat Romoval syotem

safety Injection syotom

Pumpe

Reactor Coolant Pump Bolts and Flywheels

clase 2 componente

Vessele

Steam Generator

Boron Infection Tank

Piping

Foedwater system

Main Steam syotom

$$
C-190
$$


1. Owner: Public service Electric Gas Co., 80 Park Plaza Newark, N.J. 07101

2. Plant: Salem Ganerating Station P.0. Box 236, Hancock's Bridge, N.J. 08038

3. Plant Unit 1

4. Owner's Certificate of Authorization (if required) $N / A$.

5. Commercial Service Date $7 / 1 / 77$.

6. National Board Number for Unit $N / A$.

7. Examination Dates: 2-26-91 through 4-17-92.

11. Examination Summary (cont'd):

11.1 .2 UT examination of 12 steam Generator transition cone to shell weld per PSELG's response to I.E. Notice 90-04.

11.1.3 The following recordable indications were reported during the course of the examinations.

A. During the PT examinations, recordable indications were revealed in nine examination areas. These indications were reported to PSECG on Customer notification Forms (CNFs) SAM 1-1 through 1-6, 1-6A, 1-6B, 1$6 \mathrm{C}$ and 1-7 through 1-9. One indication was resolved as "Code allowable" and accepted "as 18". Seven indications were removed with cosmetic buffing. One was mechanically removed after confirmation and acceptance with the UT method.

B. During the MT examinations, recordable indications were revealed in three areas. One was resolved as "code allowable" and accepted "as is". One indication was mechanically removed after sizing with the UT method. The other was recorded as being outeide the American Society of Mechanical Engineers Section XI examination area on the adjacent valve casting. These indicatlone were reported to PSECG on CNFs SAM 1$10,1-11,1-11 A, 1-11 B$ and $1-12$.

11.1.4 There were no other reportable indications identified during this ISI. 


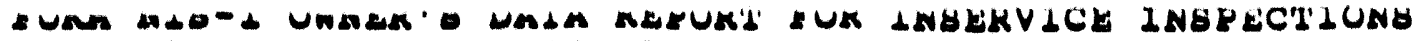

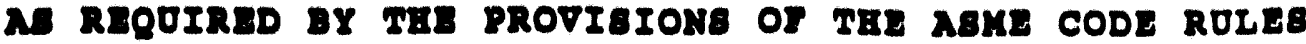

1. Owner: Public service Electric Gas Co., 80 Park Plaza Newark, N.J. 07101

2. Plant: Salem Generating Station P.0. Box 236, Hancock' Bridge, N.J. 08038

3. Plant Unit 1

4. Owner's Certiflcate of Authorization (if required) $N / A$.

5. Commercial Service Date $7 / 1 / 77$.

6. National Board Number for Unit $N / A$.

7. Examination Dates: 2-26-91 through 4-17-92.

11. Examination Summary (cont'd):

\subsubsection{Visual Examinations}

A. Contract personnel under the direction of the Salem ISI Group conducted visual examinations on seventy-six Nuclear Class I, eighty-two Nuclear Class II eighty-eight Nuclear Class III supports. There were several minor discrepancies noted including; wrong spring settings, rust, loose bolts, etc.. Work orders and/or deficiency reports were generated to document and correct all discrepancies. As a result of some of the discrepancies, tweinty-one additional support exams were scheduled and performed satisfactory.

B. PSEEG conducted VT-1 visual examinations of Nuclear Class 1 bolting on ive components (valves and/or flanges) satisfying ASME Section XI B-G-2 examination requirements. Results of these examinations were satisfactory.

C. PSEEG conducted VT-3 visual examinations of Iive components (vessel and/or pump) supports to satisfy examination category $D-A$, $D-B$, and $F-A$ of ASME Section XI. Results of these examinations were satisfactory. 


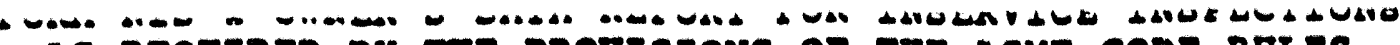

M REOUIRED BY TRE PROVIBIOYB OF TEE ABKS CODE ROLEB

1. Owner: Public Service Electric \& Gas Co., 80 Park Plaza Newark, N.J. 07101

2. Plant: Salem Generating Station P.O. Box 236, Hancock's Bridge, N.J. 08038

3. Plant Unit 1

4. Owner's Certificate of Authorization (if required) N/A.

5. Commercial Service Date $7 / 1 / 77$.

6. National Board Number for Unit $N / A$.

7. Examination Dates: 2-26-91 through 4-17-92.

11. Examination Summary (cont'd):

\subsubsection{System Pressure Tests}

Summary

system leakage exams were performed in accordance with ASME Section XI on all Nuclear Class 1 systems.

System functional Tests/system inservice tests were performed on those Nuclear Class 2 and 3 systems required to satisfy a percentage of the requirements for the second inspection period.

\section{Resulte}

None of the systems tested exhibited any excessive leakage. There was some minor mechanical leakage which was identified and work orders were written to correct.

11.2 Technical Specification 4.7 .9 (a) Visual Inspection of Hydraulic and Mechanical Snubbers

\section{2 .1 Summary}

Contract and PSESG personnel under the direction of the Salem ISI Group conducted visual examinations on one hundred and sixteen mechanical snubbers and twenty-four hydraulic snubbers.

\subsubsection{Results}

There were no discrepancies noted which would affect snubber operability. There were some minor items noted including reservoirs not full, missing washers, loose spherical bearings and binding around the bearings, and some light corrosion. These conditions were all noted and corrected.

All snubbers which were removed and reinstalled for functional testing received an "As-Left" visual examination. 
1. Owner: Public Service Electric \& Gas Co., 80 Park Plaza Newark, N.J. 07101

2. Plant: Salem Generating station P.O. Box 236, Hancock's Bridge, N.J. 08038

3. Plant Unit 1

4. Owner' Certificate of Authorization (ir required) N/A.

5. Commercial Service Date 7/1/77.

6. National Board Number for Unit $N / A$.

7. Examination Dates: 2-26-91 through 4-17-92.

11. Examination Summary (cont'd):

11.3 Technical specification 4.7 .9 (c) "Functional Testing of Selected Hydraulic and Mechanical Snubbers"

11.3.1 Summary - Hydraul1c Snubbers

Per Technical Specifications, 10 of the installed hydraulic snubbers as well as all previous outage functional test failures are required to be tested. The 108 sample included one $200 \mathrm{KIP}$ Main Steam snubber and two $1000 \mathrm{KIP}$ steam Generator snubbers. There were no previous outage test failuras.

11.3.2 Results - Hydraul1c Snubbers

There were noted discrepancies in the Tech. spec. sample.

11.3.3 Summary - Mechanical Snubbers

Per Technical specifications, 10 of the total installed mechanical snubbers as well as previous outage functional test failures were tested utilizing the WYLE Model 150 snubber Testing machine. The 108 sample is broken down by snubber category size (small and medium) with 108 from each size selected each outage. All selected snubbers are detalied below:

A. The 10 sample of the medium size snubbers included four (4) PSA-1's, 8 ix (6) PSA-3's, one (1) PSA-10 and one (1) PSA-35.

B. Due to previous outage fallures, 100 of the small size snubbers (PSA-1/4's, PSA$1 / 2^{\prime \prime}$ ) and equiv. hydraulic snubbers are tested each outage. This resulted in tests being performed on one Model 1/4, three Model $1 / 2$ and one Lisega HSML. 
1. Owner: Public Service Electric \& Gas Co., 80 Park PJaza Newark, N.J. 07101

2. Plant: Salem Generating Station P.0. Box 236, Hancock's Bridge, N.J. 08038

3. Plant Unit 1

4. Owner' Certificate of Juthorization (if required) $N / A$.

5. Commercial Service Date $7 / 1 / 77$.

6. National Board Number for Unit $N / A$.

7. Examination Dates: 2-26-91 through 4-17-92.

11. Examination Summary (cont'd):

\subsubsection{Results - Mechanical Snubbers}
A. All the medium size Tech. Spec. sample snubbers were tested satisfactory.
B. All the small size snubber and equivalent hydraulic snubbers were tested satisfacto- ry.

11.4 NRC Circular 76-06 and NRC Bulletin 79-17 "Commitment to Examine and/or Flush Stainless steel Lines Containing Borated Water.

11.4.1 Southwest Research Institute (SwRI) under the direction of the Salem ISI Group performed ultrasonic examinations on fourteen welds. No recordable indications were noted.

11.4 .2 Quarterly chemistry samples were taken by the PSE\&G Chemistry Department and the results were transmitted to the salem ISI Group per the Chemistry procedure. During the past 18 months, this program identified a few nonconformances. The nonconforming pipe was flushed and a new sample taken to verify it met the acceptance criteria.

11.5 Technical Specification 4.4.11.1 Reactor Coolant Pump Flywheel Examination (USNRC Regulatory Guide 1.14,

- "Reactor Coolant Pump Flywheel Integrity").

\section{5 .1 Summary}

Southwest Research Institute (SwRI) performed examinations on Reactor Coolant Pump (RCP) Flywheels. Flywheels are tracked by RCP Motor serial number and original pump location, however, many have been moved to different pump locations throughout outages. The exam results are as follows:

A. Performed "UT" examination of the top side of serial *35-76P-917 which was originally installed in 23 pump and is now installed in 12 pump. Exam performed in-place.

$$
\text { C- } 195
$$


YUAM MLO-2 UWEEK' LA'A'A KLPORT YOR INBERVICE INBPECTIONB

AS REOUIRED BY TES PROVIBIONB OP THE ABME CODE ROLEB

1. Owner: Public Service Electric Gas Co., 80 Park Plaza Newark, N.J. 07101

2. Plant: Salem Generating Station P.O. Box 236, Hancock'a Bridge, N.J. 08038

3. Plant Unit 1

4. Owner' Certiflcate of Authorization (if required) N/A.

5. Commerclal Service Date $7 / 1 / 77$.

6. National Board Number for Unit $N / A$.

7. Examination Dates: 2-26-91 through 4-17-92.

11. Examination summary (cont'd):

B. Performed "UT" examination of the top side of serial 45-75P-790 which was originally installed in 14 pump and is now installed in 11 pump. Exam performed inplace.

\subsubsection{Results}

No discrepancies were noted.

11.6 NRC Bulletin 87-01 "Thinning of Pipe Walls in Nuclear Power Plante".

\subsubsection{Summary}

Southwest Kesearch Institute (SWRI) and General Electric Co. under the direction of the salem ISI Group performed ultrasonic thickness measurements on eighty-one piping components as identified by PSE\&G engineering.

\section{6 .2 Results}

Any areas identifled having a wall thickness below minimum wall were submitted to PSE\&G Engineering Department for disposition.

11.7 NRC Bulletin 82-02 "Degradation of Threaded Fasteners - in the Reactor Coolant Pressure Boundary of Power Plants".

\subsubsection{Summary}

Visual (VT) and Magnetic Particle (MT) exams were performed on the primary manway bolts for all four Steam Generators. In addition, a VT exam was performed on all four Reactor coolant Pumps main flange bolting. 
1. Owner: Public Service Electric Gas Co., 80 Park Plaza Newark, N.J. 07101

2. Plant: Salem Generating Station P.O. Box 236 , Hancock's Bridge, N.J. 08038

3. Plant Unit 1

4. Owner's Certificate of Authorization (if required) N/A.

5. Commercial Service Date $7 / 1 / 77$.

6. National Board Number for Unit $N / A$.

7. Examination Dates: 2-26-91 through 4-17-92.

11. Examination Summary (cont'd):

\section{7 .2 Results}

One bolt on 14 steam Generator hot leg had minor indications observed during the visual examinations. Deflelency Reports and Code Job Packages were prepared to replace these bolts in kind. There were no discrepancies noted on the Reactor Coolant pump flange bolting.

11.8 NRC Bulletin 88-08 "Thermal stresses in Piping Connected to reactor Coolant system".

11.8.1 Southwest Research Institute (SWRI), under the direction of the Salem ISI Group, performed augmented ultrasonic and dye penetrant examinations on seventeen $1.5^{\prime \prime}$ Safety Infection welds, two $2^{\prime \prime}$ and two $3^{\prime \prime}$ Chemical and volume Control system welde for the third consecutive outage. No discrepancies were noted.

11.9 NRC Bulletin 88-11 "Pressurizer Surge Line Thermal stratification".

\subsection{1 summary}

The Salem ISI Group performed visual examinations on all the existing surge line pipe supports/HEBA restraints and any insulation damage. A total of nine supports were examined.

\subsubsection{Results}

No discrepancies were noted. Results were forwarded to system engineering. 


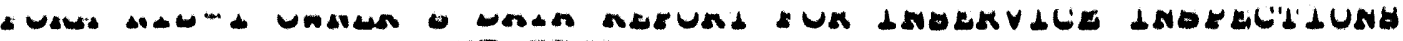

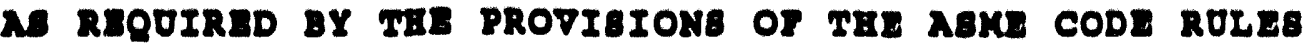

1. Owner: Public Service Electric Gas Co., 80 Park Plaza Newark, N.J. 07101

2. Plant: Salem Generating Station P.O. Box 236, Hancock's BrIdge, N.J. 08038

3. Plant Unit 1

4. Owner' Certificate of Authorization (if required) $N / A$.

5. Commercial Service Date $7 / 1 / 77$.

6. National Board Number for Unit $N / A$.

7. Examination Dates: 2-26-91 through 4-17-92.

11. Examination Summary (cont'd):

11.10 Technical Specification 4.4.5.0 - Steam Generator Tube eddy current inspection.

11.10.1 The original eddy current examination scope is detalled below:

A. Three percent Tech. Spec bobbin coll examination in $11,12,113$ and 14 steam generatore (102 tubes per steam generator).

B. A non-tech spec sample of six hundred ten tubes in 11 eteam generator per Engineering's recommendation to comply with EPRI recommended gutdelines of performing $100 \%$ examination of all staam generator tubes over a ix year period. This sample combined with the tech spec sample brings the total percentage of tubes inspected in this generator for this outage to 218.

C. A non-tech. spec. sample of six hundred forty-one tubes in 12 steam generator per Engineering's recommendation to comply with EPRI recommended guidelines of performing 1008 examination of all steam generator tubes over a six year period. This sample combined with the tech. Spec. sample brings the total percentage of tubes inspected in this generator for this outage to $22 \%$.

D. A non-tech. spec sample of six hundred and nine tubes in 13 steam generator per Engineering's recommendation to comply with EPRI recommended guidelines of performing 1008 examination of all steam generator tubes over a six year period. This sample combined with the Tech. Spec. sample brings the total percentage of tubes inspected in this generator for this outage to 21 . 


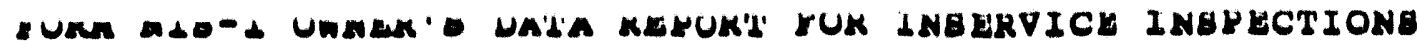

$M$ REQUIRDD BY TRE PROVIEIONB OY TEE ABKE CODE ROLEB

1. Owner: Public service Electric Gas Co., 80 Park Plaza Nowark, N.J. 07101

2. Plant: Salem Generating Station P.O. Box 236, Hancock's BrIdge, N.J. 08038

3. Plant Unit 1

4. Owner's Certiflcate of Authorization (if required) $N / A$.

5. Commercial Service Date $7 / 1 / 77$.

6. National Board Number for Unit $N / A$.

7. Examination Dates: 2-26-91 through 4-17-92.

11. Examination Sumary (cont'd):

D. A non-tech. spec sample of six hundred thirty-one tubes in 14 steam generator per Engineering's recommendation to comply with EPRI recommended guldelines of performing 1008 examination of all steam generator tubes over a ix year period. This sample combined with the rech. Spec. sample bringe the total percentage of tubes inspected in this generator for this outage to 218 .

E. A twenty percent inspection (approximately 680 tubes) in $11,12,13$ and 14 steam generator with rotating pancake probe to address the concern of Expansion zone Pure Water stress Corrosion Cracking at the hot leg tube sheet (WETEX) for steam generators manufactured ueing explosive tube expansion techniques.

F. A seven percent inspection (approximately 240) in $11, \$ 12, \$ 13$ and 14 steam generators with rotating pancake probe at multiple support plate intersections.

11.10.2 The results of the eddy current inspections are as follows:

A. The Tech. Spec. sample in $11,112,113$ and 14 steam generators revealed no indication equal to or exceeding the plugging limit and satisfied the lese than $5 f$ of the inspected tubes being degraded therefore no scope expansion was required.

B. zero tubes in 11 steam generator were required to be plugged due to eddy current indications.

c. One tube in 12 steam generator was reguired to be plugged due to an eddy current indication on the non-tech. spec. sample exceeding the plugging limit. 


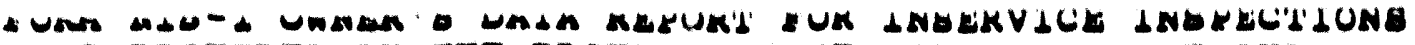

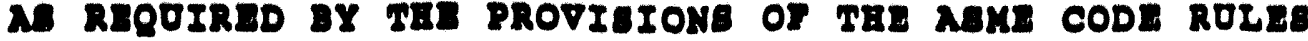

1. Owner: Public service Electric Gas Co., 80 Park Plaza Newark, N.J. 07101

2. Plant: Salom Generating station P.O. Box 236, Hancock's Bridge, N.J. 08038

3. Plant Unit 1

4. Owner's Certificate of Authorization (1f required) $N / A$.

5. Commercial Service Date $7 / 1 / 77$.

6. National Board Number for Unit $N / A$.

7. Examination Dates: 2-26-91 through 4-17-92.

11. Examination Summary (cont'd):

D. Two tubes in 13 steam generator were required to be plugged due to addy current indications in the non-tech. spec. sample exceeding the plugging limit. In addition, one tube was preventively plugged due to an addy current indication in the 358 to 398 through wall range.

E. zero tubes in 14 steam generator were required to be plugged due to eddy current indications exceeding the plugging limit however two tubes were preventively plugged due to eddy current indications in the 358 to 398 through wall range. 
1. Owner: Public service Electric \& Gas Co., 80 Park Plaza Nowark, N.J. 07101

2. Plant: Salow Generating Station P.O. Box 236,

$$
\text { Hancock's Bridge, N.J. } 08038
$$

3. Plant Onit 1

4. Owner's Certiflcate of Authorization (if required) $N / A$.

5. Commercial Service Date $7 / 1 / 77$.

6. National Board Number for Unit $N / A$.

7. Examination Dates: 2-26-91 through 4-17-92.

11. Examination Summary (cont'd):

\begin{tabular}{|c|c|c|c|c|c|}
\hline $\begin{array}{c}\text { Steam } \\
\text { Generator }\end{array}$ & $\begin{array}{l}\text { Extent of } \\
\text { Exam. }\end{array}$ & $\begin{array}{l}\text { No. of Tubes } \\
\text { Inspected }\end{array}$ & $\begin{array}{l}\text { Tubes } \\
<\text { 208 }\end{array}$ & $\begin{array}{l}\text { with Indicat } \\
20-398\end{array}$ & $=10$ ne \\
\hline \multirow[t]{3}{*}{11} & $\begin{array}{l}\text { Full Length } \\
\text { Bobbin coill }\end{array}$ & 712 & 9 & 16 & 0 \\
\hline & $\begin{array}{l}\text { RCP at support } \\
\text { Plates }\end{array}$ & 237 & 0 & 0 & 0 \\
\hline & RCP of Tubesheet & 680 & 0 & 0 & 0 \\
\hline \multirow[t]{3}{*}{12} & $\begin{array}{l}\text { Full Langth } \\
\text { Bobbin coll }\end{array}$ & 743 & 20 & 41 & 1 \\
\hline & $\begin{array}{l}\text { RCP at support } \\
\text { Plates }\end{array}$ & 240 & 0 & 0 & 0 \\
\hline & RCP of Tubesheet & 678 & 0 & 0 & 0 \\
\hline \multirow[t]{3}{*}{13} & $\begin{array}{l}\text { Full Length } \\
\text { Bobbin coil }\end{array}$ & 711 & 8 & 10 & 1 \\
\hline & $\begin{array}{l}\text { RCP at support } \\
\text { Plates }\end{array}$ & 241 & 0 & 0 & 0 \\
\hline & RCP of Tubesheet & 687 & 0 & 0 & 0 \\
\hline \multirow[t]{3}{*}{14} & $\begin{array}{l}\text { Full Length } \\
\text { Bobbin coll }\end{array}$ & 733 & 15 & 39 & 0 \\
\hline & $\begin{array}{l}\text { RCP at support } \\
\text { Plates }\end{array}$ & 241 & 0 & 0 & 0 \\
\hline & RCP of Tubesheet & 678 & 0 & 0 & 0 \\
\hline \multirow[t]{4}{*}{ sub-Total } & Full Length & 2899 & 52 & 106 & 2 \\
\hline & Support Plates & 959 & 0 & 0 & 0 \\
\hline & Tubesheet & 2723 & 0 & 0 & 1 \\
\hline & TOTAL & 6581 & 52 & 106 & 3 \\
\hline
\end{tabular}




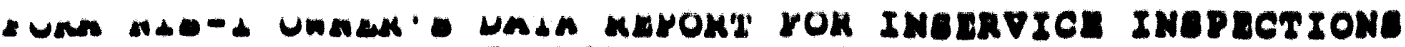

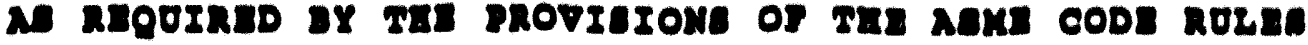

1. Owner: Public service Electrle Gas Co., 80 Park plaza Nowark, N.J. 07101

2. Plant: salem Genarating station P.O. Box 236, Hancock's Bridge, N.J. 08038

3. Plant Unit 1

4. Owner' Certifloate of Authorization (12 required) $N / A$.

5. Commerolal service Date $7 / 2 / 77$.

6. Natlonal Board Number for Unit $N / A$.

7. Examination Dates: 2-26-91 through 4-17-92.

11. Examination summary (cont'd):

\subsubsection{Additional steam Generator Work}

A. Hellum leak detection wa performed on 121 otean generator to locate the cource of primary to cecondary loukage. No positive evidence of primary to ceoondary leakage was observed uning the Hellum Ieak Detection Technique however tubechent video sean during hellum preseurleation revealed an exceseive amount of boron doposits obeerved surrounding the explosive pluge located in Row 1 colum 91 hot 109 and Row 1 Colunn 2 in the cold leg. The explosive pluge in these locatione were remotely machined and replaced with short standard type Inconel 690 mechanical pluge.

B. A11 explosive pluge in both lage of 12 eteam generator were echeduled for replecement. These pluge were located at Row 1 Columine 1-5 and 90-94 in both legn, twonty total. Due to difeloulties encoul tered while attompting to machine the explosive pluge and time constralnte, only eix of the twenty pluge ware ramoved. Four of these pluge were reported as having both boron deposite eurrounding them during hellum pressurization and were euccesefuliy removed (see above). In addition the exploive plugs in Row 1 Column 5 hot and cold were removed and raplaced with a short standard typa Inconel mechanical plug. 
1. Owner: Public Service Electric \&as Co., 80 Park Plaza Nowark, N.J. 07101

2. Plant: 8alom Gonerating Station P.O. Box 236, Hancook's Bridge, N.J. 08038

3. Plant Undt 1

4. Owner's Certiflcate of Authorization (if required) $N / A$.

5. Commerclal service Date $7 / 1 / 77$.

6. National Board Number for Unit $N / A$.

7. Examination Dates: 2-26-91 through 4-17-92.

11. Examination summary (cont'd):

\subsubsection{Current status of Steam Generators}

At this time, the total number of tubes plugged in the Salem Unit 1 Steam Generators are as Lollowe:

\begin{tabular}{|l|c|c|c|c|}
\hline & S/G 11 & S/G 12 & S/G 13 & S/G 14 \\
\hline Pluge repaired this outage & 6 & 0 & 0 & 0 \\
\hline Now tubes plunged this outage & 0 & 1 & 3 & 2 \\
\hline Tubes previously plugged & 104 & 120 & 109 & 141 \\
\hline Total tubes plugged & 104 & 121 & 112 & 143 \\
\hline
\end{tabular}

11.11 Technical Specification 4.6 .1 .2 (d) Containment Type "B" (Penetrations) and "C" (Valves) Leak Rate Testing.

\subsection{1 .1 Summary}

The PSESG Research Corp. under the field supervision of the Salem ISI Group, conducted leak rate tests on sixty-three Type "B" Electrical Penetrations, seven Type "B" Mechanical Penetrations and fifty-five Type "C" Mechanical penetrations ( 113 valves).

11.11 .2 Results

A. Several Type "C" valves exceeded the recommended leak rate acceptance criteria. These valves were reworked to an acceptable condition and retested satisfactorily.

B. A total As-Found leakage of $32,432.7$ SCCY was measured through all Type "B" and "C" containment penetrations. After corrective maintenance, a total As-Left leakage of $22,338.2$ was measured through all Type "B" and " $C$ " penetrations. 
FORM MIB-1 OWNER'B DAIA REPORT FOR INBERVICE INBPECTIONB

IS REQOIRED BY TEE PROVIBIONB OF THE ABME CODE ROLEB

1. Owner: Public Service Electric \& Gas Co., 80 Park Plaza Newark, N.J. 07101

2. Plant: Salem Generating Station P.O. Box 236, Hancock's Bridge, N.J. 08038

3. Plant Onit 1

4. Owner's Certificate of Authorization (if required) $N / A$.

5. Commercial Service Date $7 / 1 / 77$.

6. National Board Number for Unit N/A.

7. Examination Dates: 2-26-91 through 4-17-92.

11. Examination Summary (cont'd):

11.12 Technical Specification 4.6.1.3b Elevation $100^{\circ}$ and 130' Airlock Leak Rate Teste

11.12 .1 Summary

PSEEG Research Corp. under the field supervision of the Salem ISI Group, conducted leak rate tests on the $100^{\prime}$ and $130^{\prime}$ containment personnel airlocks.

\subsection{2 .2 Results}

The combined As-Found leakage for these airlocks was 8,340.0 SCCY. After scheduled preventative maintenance, the combined $A s-L e f t$ leakage for the airlocks was $9,500.0 \mathrm{sCCy}$. Both of these measured combined leakage rates satisfy the Technical specification acceptance criteria of $\leq 0.05 \mathrm{La}(10,812 \mathrm{SCCM})$.

11.13 NUREG 0578 - "MYI Lessons Learned - Performing Service Leak Exams, measuring leakage outside Containment, and take corrective actions necessary to reduce leakage as low as possible on systems likely to contain radioactive liquids in the event of an accident.

\subsection{3 .1 Summary}

A. The Salem ISI Group performed service pressure leak exams on the safety injection, Chemical and Volume Control, Residual Heat Removal and Containment Spray systems.

B. The PSErG Research Corp., under the direction of the Salem ISI Group conducted the Waste Gas System Leak Test in accordance with Site Service procedure SC.SS-IS.WG$0003(R)$. 
FORY MIB-1 ONNER'B DATA REPORT FOR INBERVICE INBPECTIONB

AB REQUIRED BY THE PROVIBIONB OF TEE ABME CODE ROLEB

1. Owner: Public Service Electric \& Gas Co., 80 Park Plaza Newark, N.J. 07101

2. Plant: Salem Generating Station P.0. Box 236, Hancock's Bridge, N.J. 08038

3. Plant Unit 1

4. Owner' Certificate of Authorization (if required) N/A.

5. Commercial Service Date $7 / 1 / 77$.

6. National Board Number for Unit $N / A$.

7. Examination Dates: 2-26-91 through 4-17-92.

11. Examination Summary (cont'd):

\subsection{3 .2 Results}

A. The Waste Gas Decay Tanks, Waste Gas Suction and Discharge Headers and 11 Waste Gas Compressor showed no adverse findings relative to this bulletin.

B. 12 Waste Gas Compressor could not be tested because it is out of service awaiting breaker maintenance. The activity to perform a leak rate check remains open until the breaker is repaired.

C. The leak rate test on the 1 WG41 valve was acceptable with a measured leakage of 1,629 scar which is below the acceptance criteria of 1,850 sCCY.

11.14 Field Directive, S-C-R700-MFD-288, "Leak Rate test Program for the Steam Generator Blowdown Isolation Valve (GB4)

11.14.1 PSESG Research and Testing Lab under the field supervision of the Salem ISI Group, conducted leak rate tests on all four steam Generator Blowdown valves $\left(\mathrm{GB}-4^{\prime} \mathrm{s}\right)$ in accordance with site service procedure SC.SS-IS.GB-0004(Q).

\subsection{4 .2 Results}

All four valves had an acceptable leak rates below the test acceptance criteria of $\leq 30,000$ scCy. No discrepancies were noted. 
1. Owner: Public Service Electric \& Gas Co., 80 Park Plaza Newark, N.J. 07101

2. Plant: Salem Generating Station P.0. Box 236, Hancock's Bridge, N.J. 08038

3. Plant Unit 1

4. Owner' Certificate of Authorization (if required) N/A.

5. Commercial Service Date $7 / 1 / 77$.

6. National Board Number for Unit $N / A$.

7. Examination Dates: 2-26-91 through 4-17-92.

11. Examination Summary (cont'd):

We certify that the statements made in this report are correct and the examinations and corrective measures taken conform to the rules of the ASME Code, section XI.

Date Nor 3, 19 22 signed PSEce owner By Shathiounom Certificate of Authorization No. (if applicable) N/A Expiration Date N/A

\section{CERTIFICATE OF INSERVICE INSPECTION}

I, the undersigned, holding a valid commission issued by the National Board of Boiler and Pressure Vessel Inspectors and/or the State or Province of New Jersey and employed by Arkwright Nutual Insurance Company, Norwood, Massachusetts, have inspected the components described in this Owner's Data Report during the period 02-26-91 to 04-17-92 and state that to the best of my knowledge and belief the owner has performed examinations and taken corrective measures described in this Owner's Data Report in accordance with the requirements of the ASME Code, Section XI.

By signing this certificate neither the Inspector nor his employer makes any warranty, expressed or implied, concerning the examinations and corrective measures described in this owner's Data Report. Furthermore, neither the Inspector nor his employer shall be liable in any manner for any personal injury or property damage or a loss of any kind arising from or connected with this inspection.

Date nov. 6.1992

Factory Mutual Systems

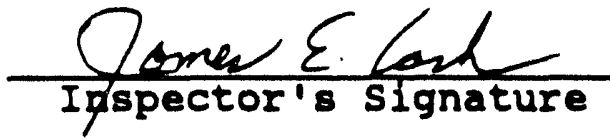

\begin{tabular}{|c|c|}
\hline unissions & NJ $379^{\prime \prime} I^{\prime}$ \\
\hline
\end{tabular}




\section{DISCUSSION OF EXAMINATION ACTIVITIES}

\section{A. Pre-Outage Planaing}

In order to assure efficient performance of the ISI, SwRI devoted a concentrated effort toward planning and preparation for the examination activities. This included review of the Long-Term Plan, scrutinizing calibration block configuration to ensure that they met the requirements for the $83 / \mathrm{S} 83$ Code, and developing nuclear projects operating procedures (NPOPs) to supplement the PSE\&G preapproved listing of NPOPs. These activities were accomplished by SwRI's NDE Engineering Section with assistance provided by the NDE Applications Section culminating in the development of an Examination Plan.

The Examination Plan was developed to provide the uasis for the ISI in one comprehensive document. It provided a listing of the examination areas, copies of all procedures, calibration block drawings, weld identification figures, and other information pertinent to the performance of the ISI. The Examination Plan was reviewed and approved by PSE\&G prior to SwRI's arrival on site.

\section{B. Examination Procedures and Personnel}

The NDE activities were performed using visual (VT), liquid penetrant (PT), magnetic particle (MT), and manual ultrasonic (UT) techniques. These examinations were performed by SwRI and Sonic Systems International, Inc. (SSI), personnel in accordance with SwRI NPOPs which had been preapproved by PSE\&G personnel.

SwRI NPOPs were utilized to provide guidelines and controls for performance of onsite examination activities. This included procedures for weld joint identification marking indication recording, records control, and resolution of indications.

NPOPs were written to conform to the requirements of the applicable sections of the ASME B\&PV Code and SwRI's NQAPM. Some procedures were amended for specific examination purposes with Interim Change Notices (ICNs). These ICNs were necessary to incorporate examination requirements unique to particular examinations at Salem 1. The ICNs used are noted on the individual examination data sheets, NDE Summary Tables, and copies of the ICNs and their respective NPOPs are located in Appendix C.

SwRI examination personnel were certified in accordance with SwRI NPOP 2.0-NDES-101, "Nondestructive Examination Personnel Qualification and Certification." which incorporates the guidelines of SNT-TC-1A of the American Society for Nondestructive Testing and ASME Section XI B\&PV Code. The SSI examiner was certified in accordance with SSI's training, qualification, and certification procedure number SSI-A-005, which complies with SNT-TC-1A. A copy of each examiner's certifications is included in Appendix E.

\section{Examination Activities}

This subsection provides a discussion of the various NDE activities performed during the ISI. SwRI examination data records are included in Volumes III through V. A discussion of equipment and materials used for these examinations appears in Subsections $E$ and $F$ of this section of the report.

\section{VT Examinations}

washers.

VT examinations were performed on the reactor pressure vessel (RPV) closure head 


\section{$2 \quad P T$ Exominations}

Solvent removable visible dye penetrant examinations were performed by SwRI personnel on selected Class 1 and Class 2 piping and support welds.

\section{MT Examinations}

Examination personnel used an AC yoke and dry particle MT to examine supports on the boron injection tank and piping welds within the Feedwater and Main Steam Systems. Fluorescent MT was performed on the RPV studs and nuts.

\section{UT Exaninations}

UT examinations were performed on Class 1 and Class 2 components, including vessels, studs, austenitic piping ferritic piping and dissimilar metal welds. Various techniques were used to perform the UT examinations, depending on material type and weld thickness. For typical vessel and piping examinations, the following techniques were used:

2. A 0-degree lamination scan (UTOL) was used for detection of laminar reflectors which might affect interpretation of angle-beam results.

b. A 0-degree scan (UTOW) was used for detection of reflectors in the weld for vessel examinations.

c For austenitic and ferritic welds, angle-beam scans of 45 degrees (UT45) were used for detection of reflectors oriented parallel to the weld.

d. Angle-beam scans, using 45-degree search units directed parallel to the weld (UT45T) were used on piping for detection of rellectors oriented transverse to the weld. For vessel examinations, 45- and 60-degree scans parallel to the weld were performed for detection of transverse rellectors.

e. For selected dissimilar metal welds, augmented 45-degree refracted longitudinal ecaminations were also used for detection of reflectors oriented parallel and transverse to the weld.

\section{TDAS Exomitritions}

Thickness measurements were recorded using SwRI's Thickness Data Acquisition System (TDAS) at 58 pipe locations to identify possible corrosion/erosion. Results of the TDAS examinations in the form of thickness plots for each fitting were reported to PSE\&G personnel during the examinations, and a separate summary report was submitted.

\section{Special Examinations}

At the request of PSE\&G, two special series of examinations were performed:

a. In response to Nuclear Regulatory Commission (NRC) Bulletin 76-06, "Stress Corrosion Cracks in Stagnant, Low Pressure Piping Containing Boric Acid Solution at PWR's" one 14-inch Residual Heat Removal, two 10-inch Safety Injection, one 8-inch Safety Injection, seven 6-inch Safety Injection, and three 4inch Safety Injection welds were examined. 
b. In response to NRC Bulletin No. 88-08, Thermal Stresses in Piping Connected to Reactor Coolant Systems," seventeen 1.5-inch Safety Injection and two 2-inch and two 3-inch Chemical and Volume Control welds were examined with UT for the third consecutive outage.

D. Enmination Results

PT examinations revealed the following indications:

Ares

2.SJ-1137-12

Pipe to Vatve

2SJ-2160-10

Elbow to Pipe

2-5J-2160-9

Pipe to Ellow

2-CV-2147-14

Pipe to Elbow

4.SJ-2150-14

Pipe to Valve

6-PR-1103-12

Elbow to Flange

6-PR-1105-1

Nozale to Safe

End

1-1/2-SJ-1132-40

Valve to Pipe

6-5J-1141-1

Reducer to Elbow
Description

7/32-inch linear indication on base material of pipe

Two linear indications, one 3/8-inch, one 9/32-inch on base material of elbow

1/8-inch linear indication on base material of elbow

3/8-inch linear indication on base material of elbow

3/16-inch round indication $1 / 2$ inch from fusion line on pipe side of weld

Four linear indications, one $3 / 4$ inch, one $1 / 8$ inch and two $3 / 16$ inch on Flange side $1 / 2$ inch from weld centerline.

3/16-inch linear indication on nozale side, $1 / 4$ inch from weld centerline

1/4-inch linear indication on base material of valve

9-inch linear indication on weld
Resolution

CNENo.

Reexamination after cosmetic buffing revealed no recordable indications.

SAM 1.1

Reexamination after cosmetic buffing revealed no recordable indications.

Reexamination after cosmetic bufing revealed no recordable indications.

SAM 1.2

SAM 1.3

Reexamination after cosmetic buffing revealed no recordable indications.

Reexamination after cosmetic buffing revealed no recordable indications.

Reexamination after mechanical removal revealed no recordable indications.

SAM $1-4$

SAM 1.5

Indication is allowable by Code. Accepted "as is" by PSE\&G personnel.

Reexamination after cosmetic bufing revealed no recordable indications.

Reexamination after cosmetic buffing revealed no recordable indications.
SAM 1.7

SAM 1.8

SAM 1-6, 1-6A, 1-6B, $1-6 \mathrm{C}$

SAM 1.9 
MT examinations revealed the following indications:

Ares

34-MS-2131-1PL-

19 Pipe Lug

34-MS-2121-2

Pipe to Valve

34-MS-2141-2

Pipe to Valve
Descriotion

1/4-inch linear indication on lug side

1-inch linear indication at fusion line on valve

$13 / 16$-inch linear indieation outside Coderequired examination area on value body
Resolution

Indication is allowable by

Code. Accepted "as is" by

PSE\&G personnel.

Reexamination after mechanical removal revealed no recordable indications.

PSE\&G personnel forwarded to their Engineering for disposition. Seat 92-322.
GNF No

SAM $1 \cdot 10$

SAM 1-11,

$1.11 \mathrm{~A}$

$1 \cdot 11 B$

SAM $1-12$

VT and UT examinations revealed no reportable indications.

At the request of PSE\&O personnel, each examination area was checked to ensure that the appropriate identification number and $L_{0}$ was etched or stamped on it. PSE\&G-developed forms were used to report variances from the requirement.

Copies of the CNFs are included in Appendix G.

\section{E. Equipment}

Various NDE equipment was used during the ISI to perform the examinations of the selected components. The major equipment items are discussed below.

\section{UT Inowoments}

Sonic 136 and FTS Mark I UT instruments were used for the NDE activities. To assure proper instrument linearity and operation. SwRI certified each instrument prior to use at Salem Unit 1 , as specified in the NQAPM. Copies of certifications for those instruments utilized at Salem Unit 1 are contained in Appendix F. In addition, instrument linearity measurements were taken before and after completion of site activities as specified in SwRI NPOP SwRI.NDES, "Ultrasonic Linearity Measurements."

\section{Traneduces}

Various brands, sizes, and frequencies of UT transducers were used to perform the examinations. A transducer frequency of $1.5,2.25,5.0$, or $10.0 \mathrm{MHz}$ was used as specified in the applicable NPOP.

Prior to use at Salem 1, each transducer was tested and certified to be within SwRI's acceptance standards. This certification is performed within 12 months of use to verify that each transducer is performing within standards. A copy of each transducer's certification is contained in Appendix F.

Information on the actual transducer used for any specific examination may be determined by reviewing the data sheets and referenced calibration sheets in the field data volumes. 


\section{Magnetic Particle Examination Equipment}

Hoad-held alternating current magnetic particle yokes were used for MT examinations.

\section{F. Materials}

In addition to the equipment previously discussed, certain materials were required in the performance of the examinations. All materials contacting the examination surface (i.e., glycerine, pipe marking pencils, penetrants, etc.) were tested and certified to be within acceptable sulfur and halogen limits prior to use at Salem 1. Certifications for these materials are contained in Appendix $F$.

\section{G. UT Calibration Blocts}

Pipe and vessel calibration blocks were utilized to calibrate the UT instruments prior to examinstion of the selected welds. Drawings of the various calibration blocks used are contained in Appendix $\mathrm{D}$. 


\section{SUMOMARY OF EXAMINATIONS}

This section provides a discussion of the field data records and a summary of the NDE activities performed at Salem 1.

\section{A. Explanation of Field Data Records}

The results of the examinations and calibrations performed by SwRI personnel were recorded on standard SwRI forms. Copies of these completed documents constitute Volumes III through V of this report. The original records will be retained in the SwRI Records Vault.

The field data records for each weld or area are assembled in a package preceded by a summary sheet. The examination areas and summary sheet numbers correspond to those listed in the Nondestructive Examination Summary Table provided in Subsection B below.

The instruments used in performing UT examinations were calibrated prior to use, then verified again at speciffed intervals during the examinations and upon completion of the examinations. The calibration parameters were recorded on the appropriate calibration record sheet as specified in the applicable NPOP. The documented calibration and calibration verification provide immediate assurance that the examinations were performed using properly calibrated instruments.

The results of the examinations were recorded on the applicable data record sheets as specified in the Examination Plan. The information documented on these forms describes the parameters associated with those indications which were greater than the recording levels speciffed in the applicable NPOP.

The size, location, and nature of rellectors were determined by analyzing the indication parameters recorded on the forms described above. The analysis is documented on SwRI Indica. tion Resolution Record Sheets, which are included as part of each data package, when required.

\section{B. Nondestructive Emmination Summary Table}

The following section is the Nondestructive Examination Summary Table (Summary Table). The Summary Table lists the areas that were examined by SwRI personnel during this ISI. See Figure 1 for an explanation of the Summary Table format. Weld identification drawings depicting the location of Class 1 and Class 2 components are contained in Appendices A and B, respectively. 
OATE:

Rtvistow:
SALEM MUCLEAR poute station untr 1 gumary of MONDEstRuet IV Exuimations

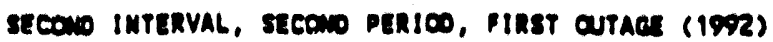
CLASS I CONPLETD COMPONENTS

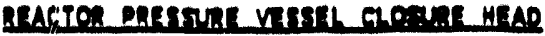

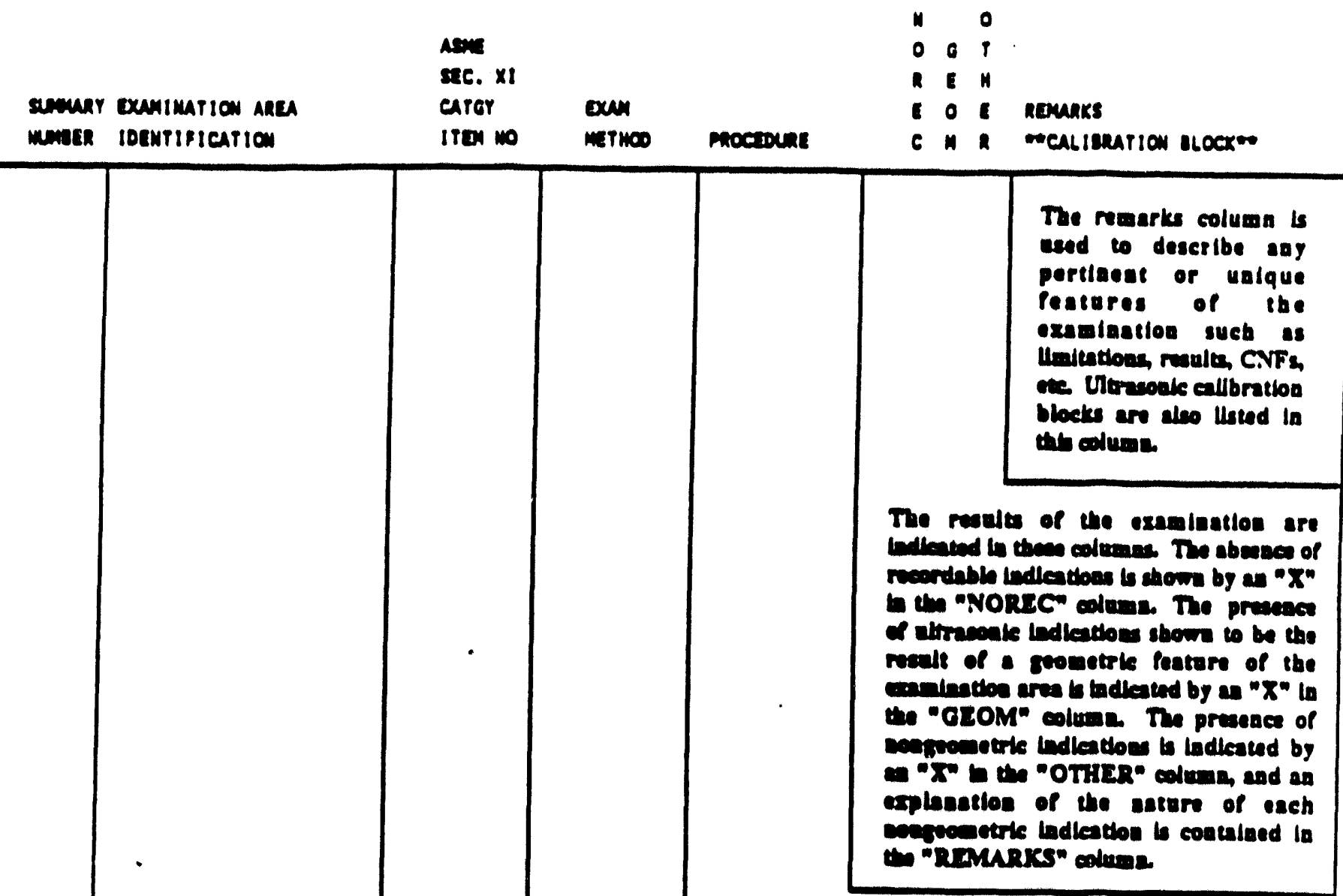

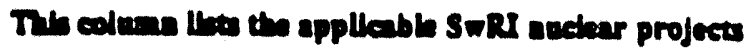

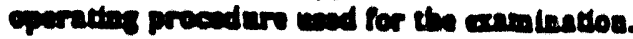

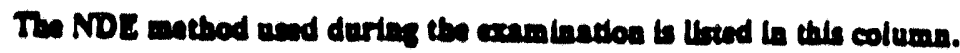

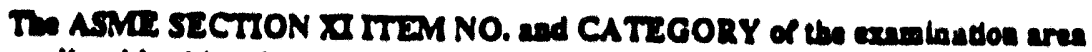
ars theed th this colvens.

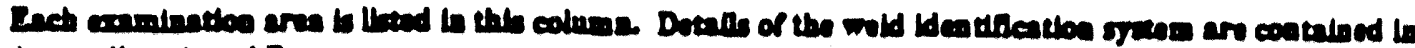
Appeadion A and B.

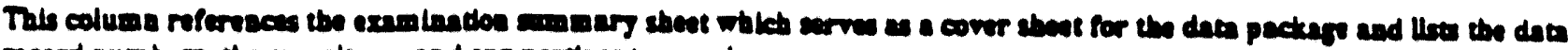

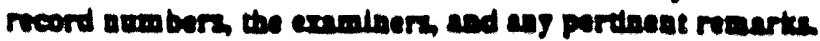

Figure 1. Explanation of Summary Table Format 
DATES 08/27/92

cevisioni 0

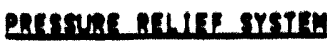

sumury Examikation aneA

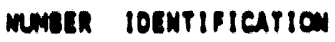

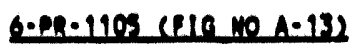

022200

6-ph-110s-1

nozze to sare-eno

$0223006-02-1105-2$

sure-tio to elcon

2000 6-02-110s-11

eleor ro plane:

0.21.110\% (110.40.16)

$0264006-196-196 \cdot 11$

elcor ro rlaver

a.d ot

9.11
Asine

sec. $X I$

caror exan

Iren wo netroo
-. PT

0.11

SALEM MUCLEAR pOTER STATION UNIT I gumuar of nOwOEstRuerive Examimarions second Intenval, secono perioo, pIRst OUTACE (1992) CLASS 1 COMLLETED COMPONENTS

Proctoune

N 0

0 O 01

$2 \pi$

- O remars

C 1 mecaliokation locx"e

PAQE:

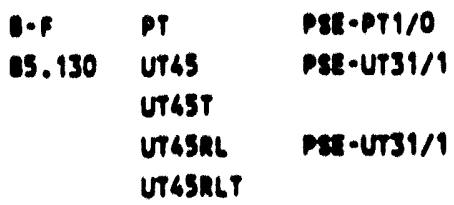

\begin{tabular}{|c|c|c|}
\hline 0.5 & $\begin{array}{l}\text { Dr } \\
\text { UTGS } \\
\text { UTAST } \\
\text { UTGSTAN }\end{array}$ & $\begin{array}{l}\text { pet-pr1/0 } \\
\text { pa-ur31/1 }\end{array}$ \\
\hline
\end{tabular}

pex - Pr1/0

$x \cdot$

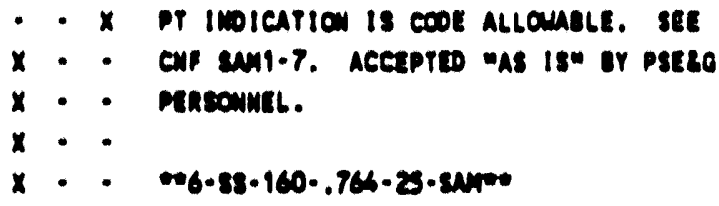

$x$ - uTas indeation is a ezomitric reflecton

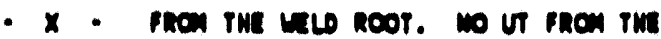

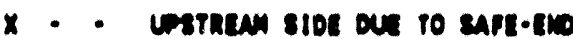

$x$ - conplentarion. outainid loos os cooe revithed covinace.

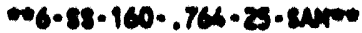

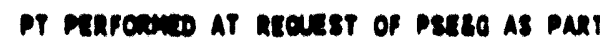

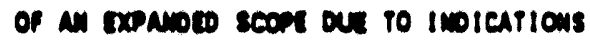
C) 6-MR-1103-12.

$006 \cdot 88 \cdot 160 \cdot .74 \cdot-23 \cdot 84 \times 0$

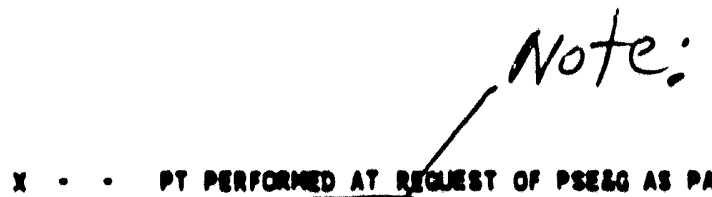

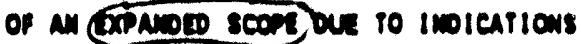
on 6-m-1103-12. $06-88 \cdot 160-.744 \cdot 23 \cdot 24900$

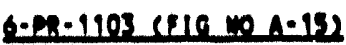

$025700 \quad 6 \cdot M \cdot-1103 \cdot 12$ eleor ro plumet

\begin{tabular}{|c|c|c|}
\hline b.d & Dr & pse-pr1/0 \\
\hline 09.11 & pr & \\
\hline & $\begin{array}{l}\text { urbs } \\
\text { unsst } \\
\text { ursstan }\end{array}$ & pex-UT31/2 \\
\hline
\end{tabular}

\footnotetext{
- x or trun revaldo one inotcarion unich

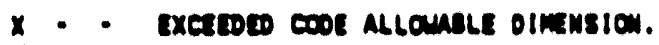

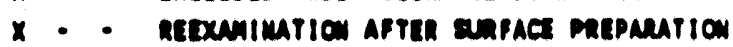

$x$ - - arvaled no atcomale inolcations. set

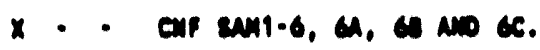
$06-88 \cdot 160-.766-23-84 m$
} 
OATE: $08 / 27 / 92$

REVISIOW: 0

MAIL STEAM SYSTEH

SUMMURY EXAMIMATIOW AREA

NUMBER IOENTIFICATIOU

$30 \cdot 45 \cdot 2131$ (F10.40 -26$)$

236460

$30 \cdot M 5 \cdot 2131 \cdot 860 \cdot 0$

LONGITLOINAL

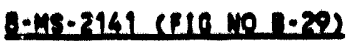

$2620008 \cdot 45 \cdot 2161 \cdot 1$

VELDOLT TO ELDON
SALEM NUCLEAR POWER STATION UNIT 1

SUMMARY OF NONOESTRUCTIVE EXAMINATIONS

SECONO InTERVAL, SECOND PERIO0, First OUTAGE (1992)

CLASS 2 COMPLETED COMPONENTS
ASAE:

sec. $x 1$

CAror EXAM

ITEM MO METHOO
N 0

- 0 i

R. $H$

E $O$ REMARKS

C I R mealibration blocx"

PAGE: 4

....... ..........................

- .

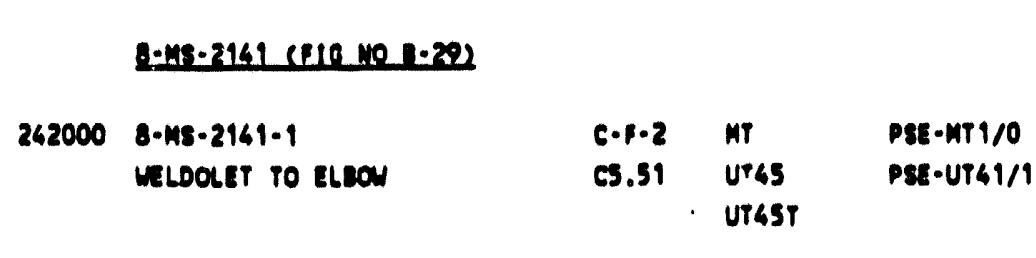

C.p.2 MT

CS.52 UT45

UT45T

PSE - UT61/1

Pst.

$8 \cdot 45 \cdot 2126 \quad 810.40+312$

$2435008 \cdot M 8-2126-2$

ELEON TO VALV

$\begin{array}{lll}\text { C.P.2 } & \text { MT } & \text { PSE-MTY/O } \\ \text { CS.51 } & \text { UTOL } & \text { PSE-UTG9/1 } \\ & \text { UTGS } & \text { PSE-UTG1/1 } \\ & \text { UTGST } & \end{array}$
$x$ - - LIMITED ht Exan ove to surroumotmo
$x$ - - pipino ano expport structures. Examine!
$X$ - S6\% OF the reOUIRED area.
$x \cdot \cdot$
$+8 \cdot c 5 \cdot 160-.906 \cdot 46 \cdot 54 M=$

EXAMINED 12" OF MELD LENGTH.

$\because \oplus P L \cdot 1.5 \cdot c 5 \cdot 65 \cdot 5 A 4 m$

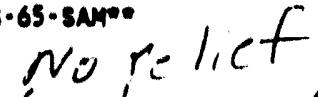
reterencel

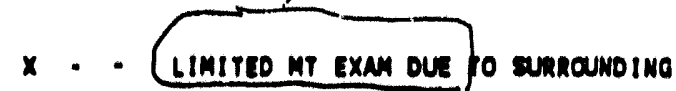

$x$ - - pIPING ano suppont struetures. Examine

$X$ - - 65\% OF TME RECUIRED AREA. NO UT UPSTREAK.

$\rightarrow 6 \cdot 68 \cdot 160 \cdot .906 \cdot 46 \cdot \operatorname{sen}=0$ 


\section{APPENDDX 0}

CUSTOMER NOTIFICATION FORMS

\section{Table of Contense (Coni'd)}

CNENo Aren

SAM 1.11,

$11 \mathrm{~A}$, and $11 \mathrm{~B}$

SAM 1.12

\section{4-MS-2121-2}

Pipe to Valve

34-MS-2141-2

Pipe to Valve
Indication(s)

1-inch linear indication at tusion line on valve

13/16-inch linear indication outside Code-required conmination area on valve body
Opened Closed

$5 / 13 / 92 \quad 5 / 19 / 92$

$5 / 16 / 92 \quad 5 / 19 / 92$ 


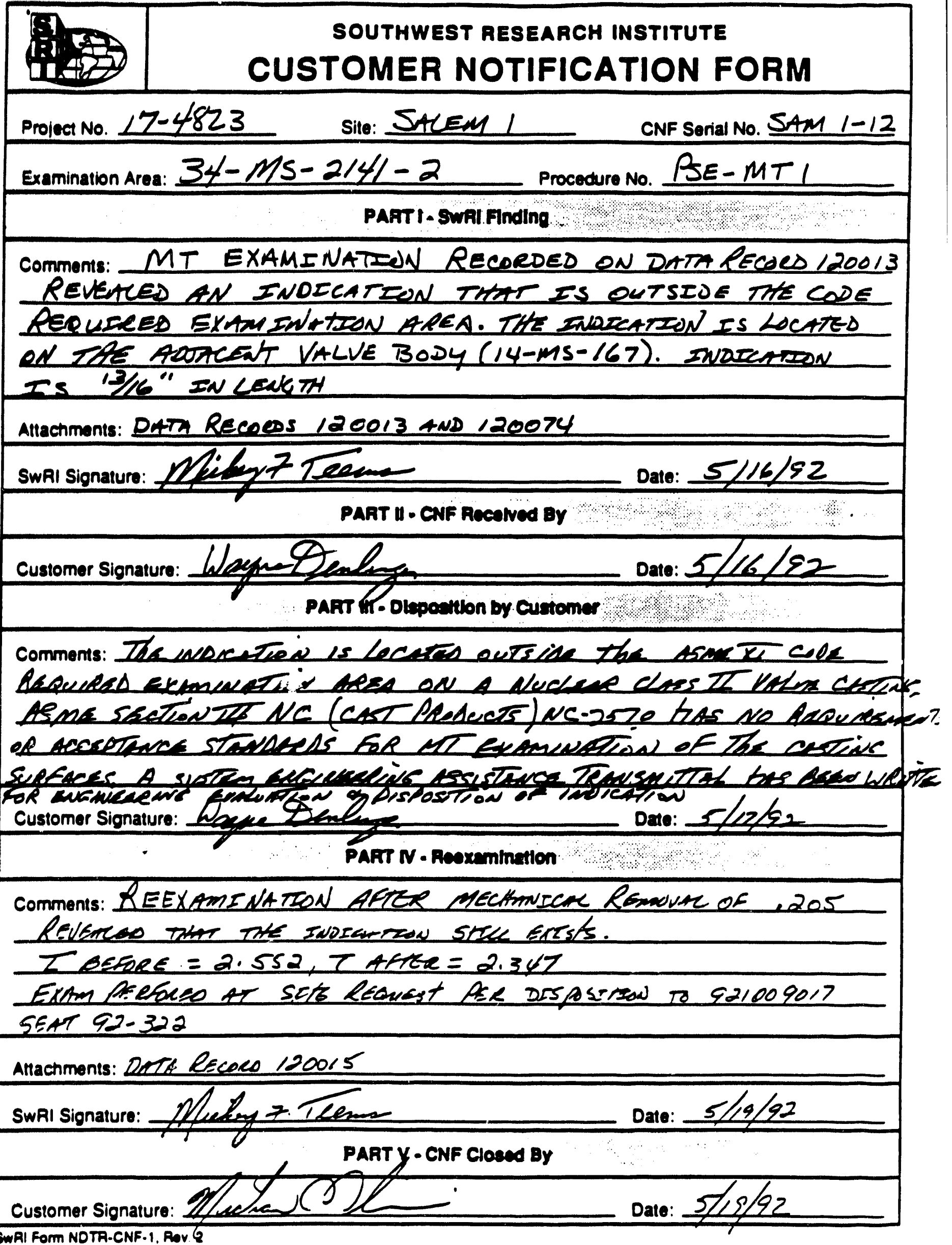


DISPOSITION TO 921009017

BEAT $92-322$

14MS167 IINEAR INDICATION IN AREA OF PIPE TO VAIVE FELD

THIS DISPOSITION WIIL ADDRESS THE REPAIR OF $14 M S 167$ VALVE. THE VALVES ARE PART OF THE PSEG PIPE SPEC. 1S12A, WHICH IS SAFETY REIATED, SEISMIC I NUCLEAR II AND QA REQUIRED. THE MAINT. REQUIRED TO REMOVE THIS INDICATION DOES NOT REQUIRE A CODE JOB PACKAGE.

1. LOCATE AND CLEARLY DEFINE THE AREA TO BE WORKED.

2. UT AREA FOR INITIAL WALL THICKNESS

3 USE MECHANICAL MEANS TO REMOVE INDICATION. DO NOT REMOVE MORE THAN 0.400 WITH OUT SYSTEM ENG APPROVAL.

4 NDE AS REQUIRED TO INSURE THAT THE INDICATION HAS BEEN REMOVED.

5 BY USING MECHANICAL MEANS CONTOUR THE AREA TO A 3/1 SLOPE.

6 FINAL NDE REQUIRED AFTER AIL MECHANICAL WORK HAS BEEN COMPLETED TO INSURE THAT THE INDICATION HAS BEEN REMOVED AND THE SURROUNDING AREA IS FREE OF DEFECTS.

7 FORWARD AS FOUND AND FINAL WALL THICKNESS TO SYSTEM ENG FOR DISPOSITION OF THE DR.

TESTINO

1. PERFORM A MT OR PT EXAMS AFTER THE REMOVAL OF INDICATION IN ACCORDANCE WITH ANSI B31.7.

2. PERFORM A UT FOR AS FOUND AND AS LEFT WAIL THICKNESS IN THE AREA OF THE INDICATION. ACCORDANCE WITH ANSI B31.7.

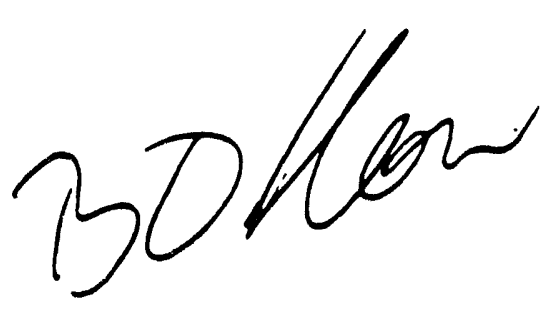

$\frac{1}{4} 18 / 92$

$C-218$ 
Index of NIS-2 and NR-1 Forms

I. NIS-2 Forms

Component Brief Description

IAF 128

11 MS15

$115 J 39$

1SJ67

Replaced spring washer, spring and nozzle

Machined nozzle

Replaced disk insert and spindle assembly

Replaced nozzle, disk and bellows

II. NR-1 Forms

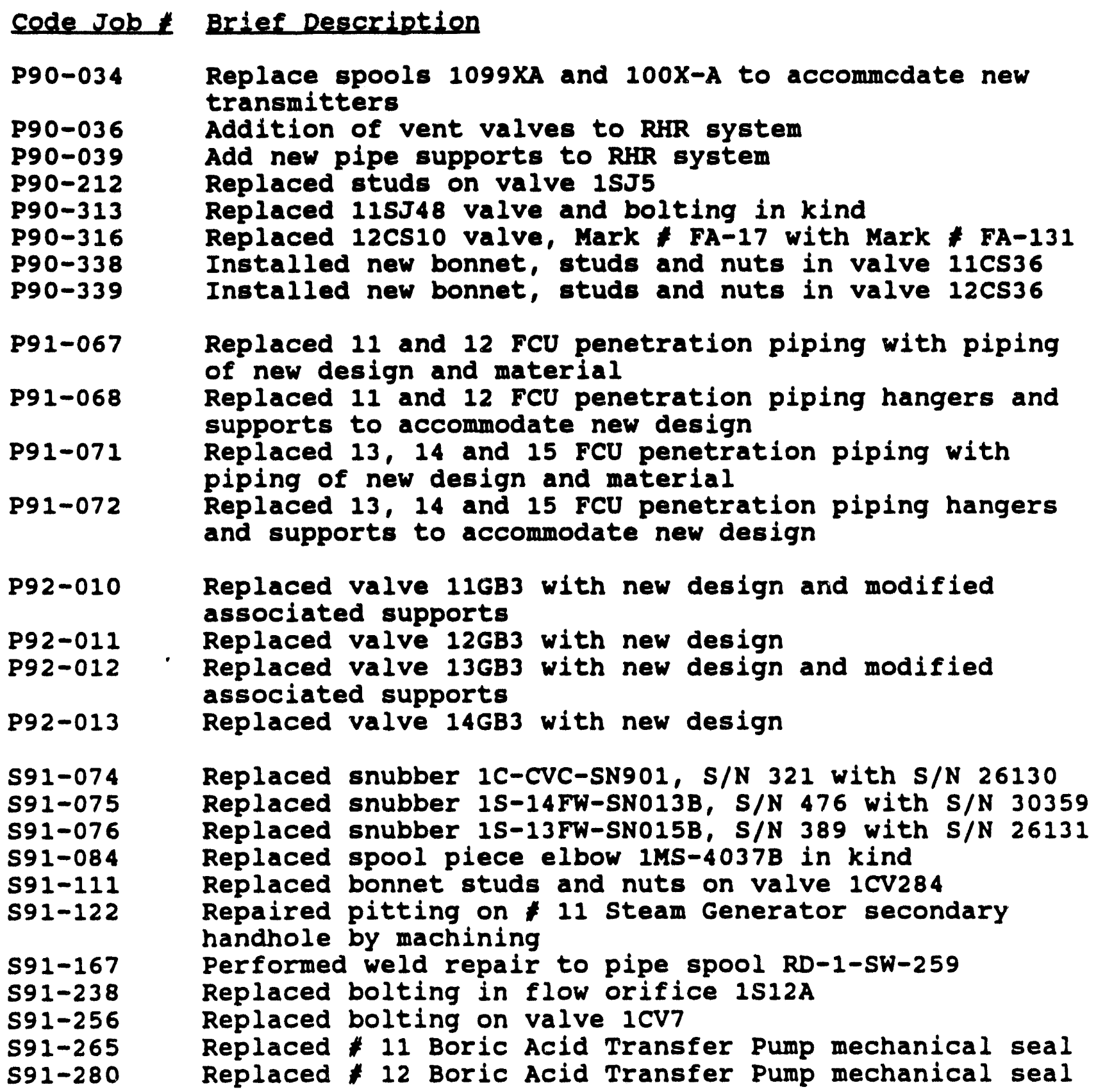


$591-287$

s91-306

592-097

s92-155

592-168

S92-179

S92-188

S92-190

s92-191

s92-192

S92-193

S92-200

S92-202

s92-203

s92-215

S92-216

S92-218

S92-226

S92-227

592-228

592-229

592-232

s92-235

S92-236

S92-241

s92-246

S92-247

s92-254

S92-256

S9? -264

S92-269

S92-270

S92-272

S92-280

S92-285

S92-291

S92-296

592-297

S92-300
Weld repaired 155 5 8 valve body and replaced flange bolting

Replaced cage, plug and stem assembly on valve 1PS1

Performed weld repair on $155 w 72$ valve body

Replaced ( 8 ) bonnet studs and nuts and (16) flange nuts and (8) studs on valve 1DR29

Performed weld repair of airlock personnel hatch hinge Replaced bolting on valve 1CV171

Replaced snubber IA-SI-SNI00A, S/N 450 with S/N 25872

Replaced snubber *1S14-FWSN-15B, S/N 488 with $S / N$ 27911

Replaced snubber 1S11-FWSN-12B, S/N 440 with S/N 25893

Replaced snubber $1 S-11 F W-S N 012 A, S / N 389$ with $S / N$ 25856

Replaced snubber \# 1C-PR-SN007, S/N 623 with S/N 17676

Replaced stem and plug assembly on valve $12 M S 171$

Performed weld repair on $125 w 72$ valve body

Performed weld repair on $125 w 58$ valve body and replaced valve bolting

Replaced disk in valve 1 CV52

Replaced plug and stem assembly in valve $13 G B 4$

Replaced plug and seat in kind in valve $116 B 4$

Replaced flanges and bolting in orifice $13 \mathrm{MS} 200$

Replaced bolting, plug and stem assembly in valve

14MS169. Hanger removed and reinstalled to facilitate maintenance

Performed weld repair to valve 13 SW58

Performed weld repair on valve $135 w 72$

Replaced plug and stem assembly on valve $1 P S 3$

Rewelded valve canopy after maintenance on valve $115 J 144$

Rewelded valve canopy after maintenance on valve $14 \mathrm{SJ} 17$

Replaced bolting on valve 1SJ3

Rewelded valve canopy after inspection on valve 14 SJ139

Replaced valve canopy by welding on valve $125 J 144$

Replaced bolting on valve 11SJ34

Replaced bolting on valve $1 \mathrm{CV} 7$

Replaced helicoil in bolthole \# 1 of \# 11 steam

Generator

Replaced bolting in valve $115 J 55$

Replaced primary manway bolting on \# 14 Steam Generator hot leg

Replaced bolting and seal plate on valve 13 SJ56

Replaced valve $14 S J 144$ with valve $S / N$ CD-569

Replaced pipe clamp on support $\$ 1 C-P R H-179$ due to corrosion

Replaced stem assembly and bolting on valve 1 PR6

Performed weld repair on hanger 1 C-CVCS -587 which was removed to facilitate maintenance

Replaced plug and stem assembly on valve 1 CV75

Replaced rear bracket by welding on snubber 1C-PRSN-007 


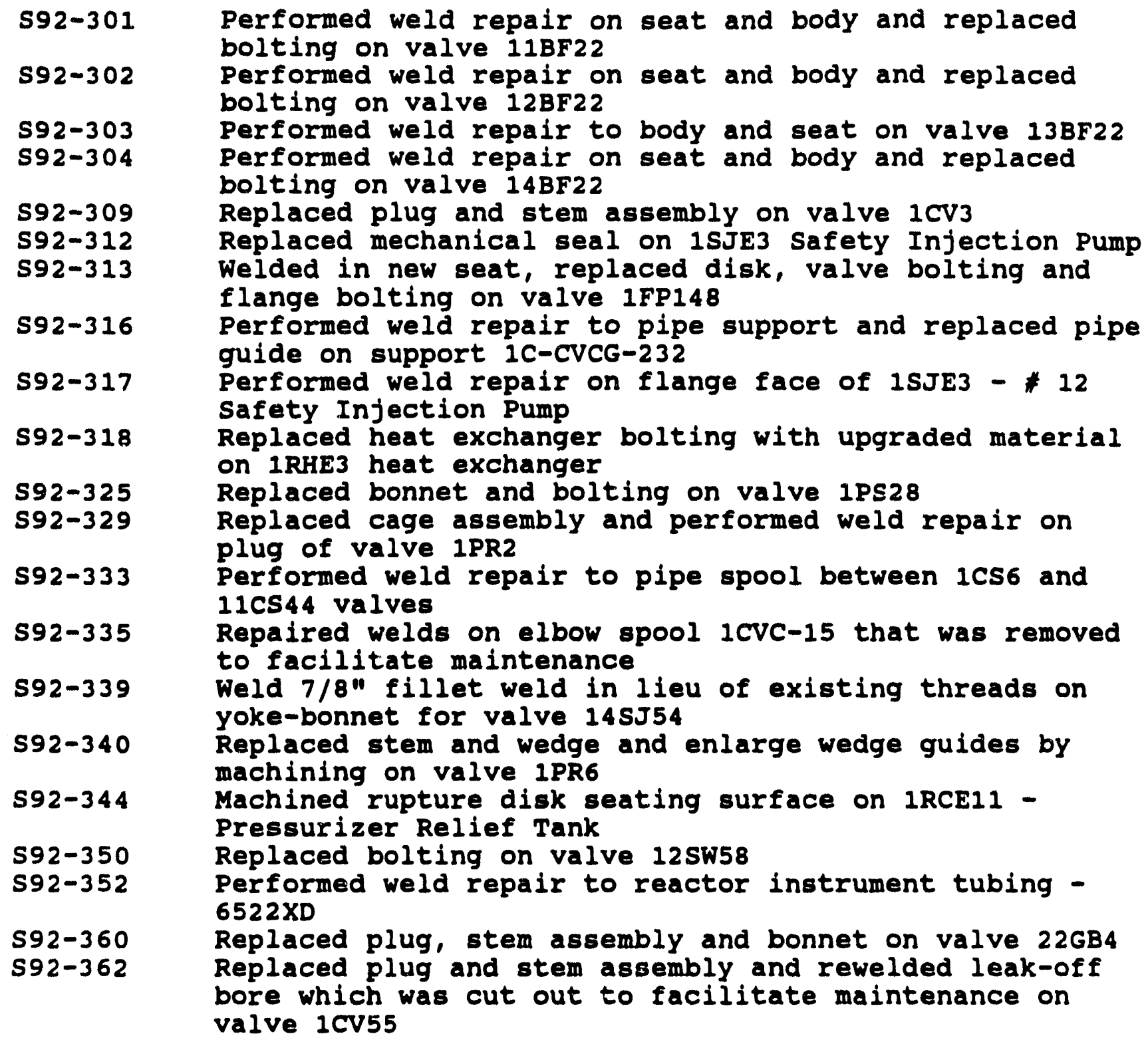

III. Vendor NR-1 Forms

\section{Work Order Brief Description}

920627062 Repair \# 11 Steam Generator nozzle and replace piping 920627064 Repair * 12 Steam Generator nozzle and replace piping 920627066 Repair * 13 Steam Generator nozzle and replace piping 920627067 Repair 14 Steam Generator nozzle and replace piping 


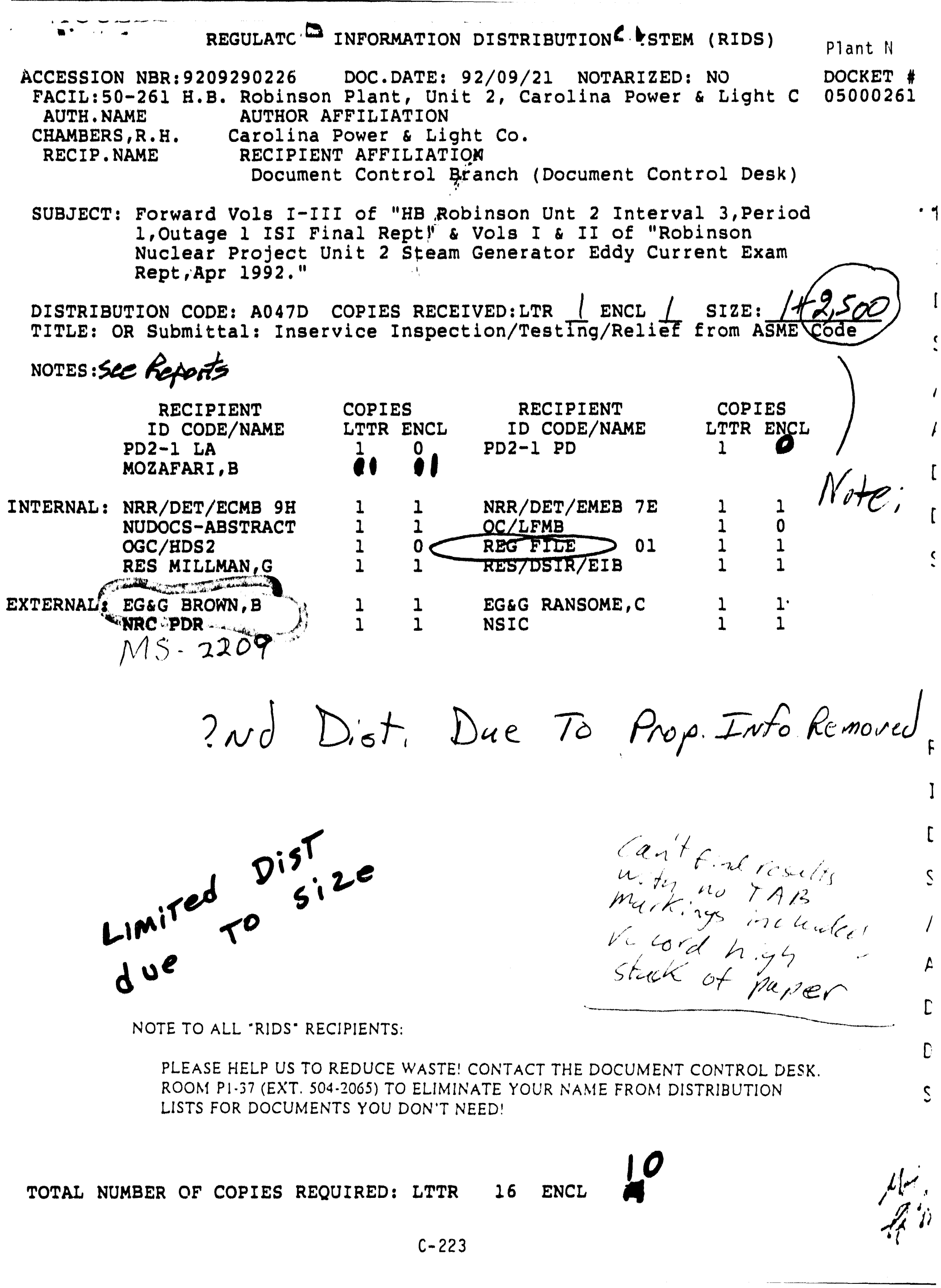




\section{TABLE OF CONTENTS}

TAB A

TAB B

TAB C

TAB D

TAB E

TAB F

TAB G

TAB Consumables

TAB UT Equip.

TAB Transducers

TAB Personnel

TAB Cal. Blocks
NIS Forms

Summary

Program Plan

Data Sheets

Exams by Others

Indications and Resolutions

Procedures

PT, MT and Couplant Certification

Instrument Certification

Listing of Transducers

NDE Personnel Certifications

Listing of Calibration Blocks 
This report presents the results of the Inservice Inspection (ISD) of the first outage, first period, third interval at the H. B. Robinson Steam Electric Plant, Unit 2. These examinations were conducted from March through June 1992. Nuclear Energy Services conducted these examinations in accordance with the program plan located under $\mathrm{Tab} C$ of this report. The program plan was derived from the Inservice Ten Year Inspection Plan. This plan is based on the requirements of the ASME Code, Section XI 1986 Edition and the Carolina Power \& Light Specification No. HBR-ISI-1.

\section{RESULTS}

All scheduled nondestructive examinations performed during this ISI are documented on examination data sheets. Included on these examir.ation data sheets are the component or system identification, examination method and procedure employed, unique data sheet number, and all applicable equipment settings and examination conditions. The data sheets, together with applicable isometric sketches, are presented in numerical order under Tab $D$ of this report. In the event that a recordable indication was detected, all pertinent information was documented on the appropriate data sheet for evaluation. The evaluations of any recordable indications are located under Tab F of this report. A summary of indications is as follows:

\section{CLASS I}

Visual examinations were scheduled for the Reactor Coolant Pump Flywheels A, B, C, and 1 Spare. Flywheel " $\mathrm{A}$ " was deferred. The Spare Flywheel had a recordable indication that was dispositioned by Westinghouse. This indication is summarized under Tab $F$ of this report.

\section{CLASS II}

Volumetric examinations revealed no flaw indications that exceeded the standards of ASME, Section XI IWA-3000. Included under Tab F are the final results of the Nuclear Regulatory Commissions concerns with Steam Generator "C" Nozzle Weld I (CP\&L-217-1).

Surface examinations revealed several components with recordable indications. After engineering evaluation all but one was found to be acceptable. The one component support was unacceptable and declared inoperable. As a result, an additional number of examinations were performed in accordance with IWF-2430. The data for the additional workscope can be found in the Expanded Scope section under Tab D of this report. All indications are summarized under Tab F of this report. 


\section{CLASS III}

Visual examination of Class III component supports revealed several items with recordable indications. After engineering evaluation all were determined to be acceptable. All indications are summarized under Tab F of this report. 


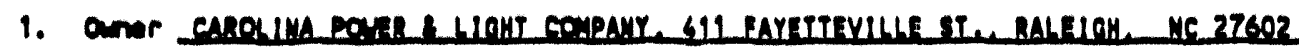
(Neme and Adarese of amer)

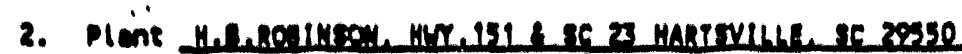
(Neme and Address of Plent)

3. Plent unit HMBR 6. Ouner Certifleate of Authorization (if required) W/A.

3. Cemerelal service bate 3/7/79 6. National laard Mumer for Units M/A

7. Componente Inupected

\begin{tabular}{|c|c|c|c|c|}
\hline $\begin{array}{l}\text { comenent or } \\
\text { Acourtencese }\end{array}$ & $\begin{array}{l}\text { Menufecturer } \\
\text { or Inveller }\end{array}$ & $\begin{array}{l}\text { Menuf ecturer } \\
\text { or Installer } \\
\text { enerlal Mo. }\end{array}$ & $\begin{array}{l}\text { state or } \\
\text { provinse Ho. }\end{array}$ & $\begin{array}{l}\text { National } \\
\text { Leerd No. }\end{array}$ \\
\hline R.C.Min a & nerinomeyes & celncegect & $n / A$ & $M / A$ \\
\hline R.c.tan 0 & mertmoneve: & streperes & $N / A$ & $N / A$ \\
\hline R.c.num 6 & merinamous: & cplncpepas & $N / A$ & $n / A$ \\
\hline coger ind. Tank & entu. panteatone & $\operatorname{cose}$ & $\underline{n} / \mathbf{A}$ & 36 \\
\hline $\operatorname{ann}$ H.X. A & nerimanos: & clacanasi & $n / A$ & $B 1$ \\
\hline S.W.Ind.PILTE A & cerinamoves & getenPLIII & $\omega / a$ & 929 \\
\hline Ieroen n.x. & Eerinanens: & celemanun & $n / A$ & as \\
\hline Diping & Ineses nes. inc. & w/a & $M / A$ & $N / A$ \\
\hline expente & enseo ves. Ine. & $\mathbb{N} / \boldsymbol{a}$ & $N / A$ & $M / A$ \\
\hline smeging wis in & unter was $\infty$. & 276158 & w/A & $w / a$ \\
\hline DuLs.oumpenen a & jounery conrnous & $\mu-0391$ & $N / A$ & $\omega / A$ \\
\hline stean esurearon a & serinanose & eptrepesol & 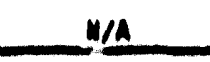 & $n / A$ \\
\hline STEAM CENERATO C & Metimenouse & curcpesas & $n / A$ & $M / A$ \\
\hline & & & & \\
\hline
\end{tabular}

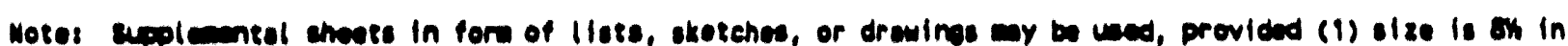

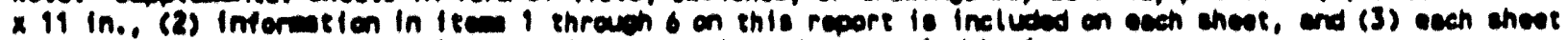
is metered and the number of encests is recorded ot the top of thle form.

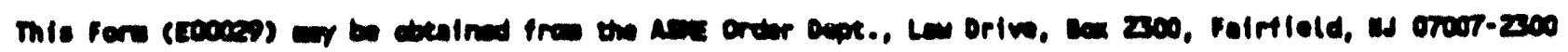


row Mis-1 (Reck)

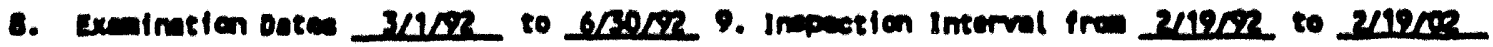

10. Appliceble Edition of sestion XI 199. acting $M$

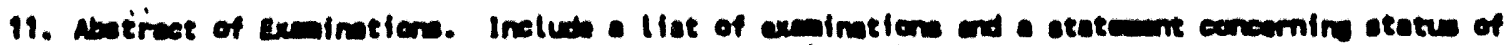

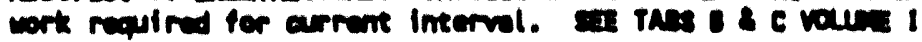

12. Aberest of condition woted. SEE TAE I volunt I

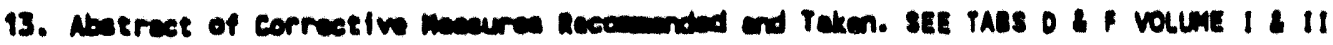

We certify that the stotcments and in shis report are correct and the exeainations and corrective mesures taken conform to the rules of the Atw cods, section XI.

Certifleate of Autheriention wo. (if aplienbla) M. oate $9 / 18 / 92$ is signd Bpiration Date

r.

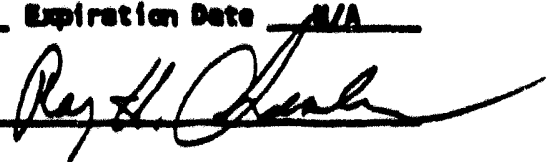

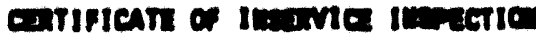

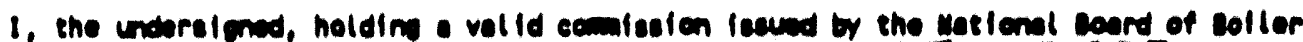

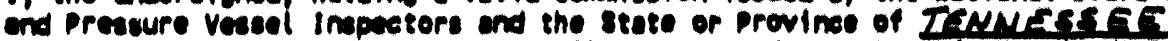

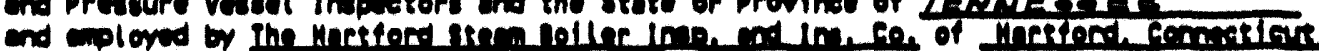

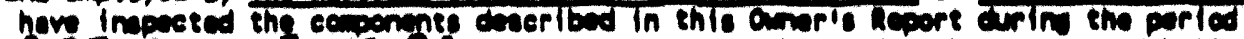

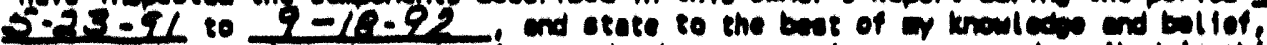

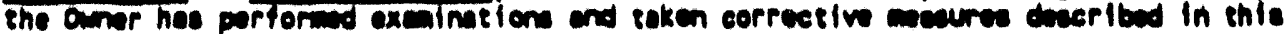

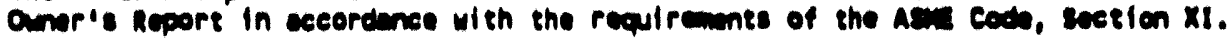

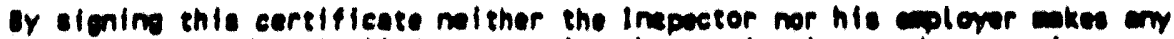

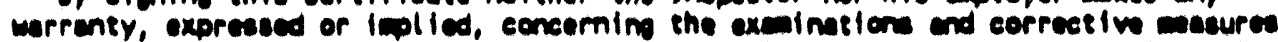

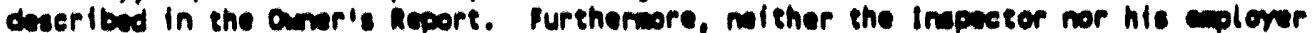

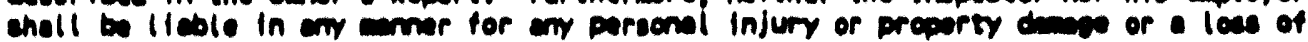
an kind orising frow or cermeted with thle impoetion.

$$
\begin{aligned}
& \text { Pannechlendares comission TN971 }
\end{aligned}
$$

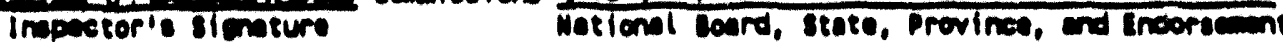

$$
\begin{aligned}
& \text { Dote } 9 \cdot 18
\end{aligned}
$$




\section{H. B. ROBINSON UNIT 2 \\ STEAM GENERATOR "C" FEEDWATER NOZZLE WELD 1 \\ MAY 16, 1992}

To investigate low amplitude reflectors that had been recorded during previous examinations, an ultrasonic examination was conducted on May 13, 1992 by Mr. J. Coley, NRC Region 2, and Mr. A. Pennanen, Nuclear Energy Services.

This examination was conducted with a 45 degree shear wave (detection technique), RTD 70 degree refracted longitudinal wave (flaw tip detection technique) and a 30-70-70 mode converted longitudinal wave (ID flaw detection technique).

Calibration for the 45 degree and the 30-70-70 degree technique was performed on an ASME $18^{\text {" OD }}$ calibration block. The 70 degree tip detection technique calibration was performed on a carbon steel 1 " thick step block.

The 45 degree examination produced a reflector with a through wall dimension of $.150^{n}$ at $16^{\prime \prime}$ clockwise from top dead center of the nozzle facing the generator. A tip. .450" from the OD surface was also seen with the RTD 70 degree transducer (See plot on page 4).

To confirm the presence of this reported flaw, CP\&L performed several additional examinations which are discussed as follows.

\section{CP\&L CONFIRMATORY EXAMINATIONS}

On May 14, 1992, a radiographic examination of the subject area was performed with Iridium 192 using Kodak Type M film. 100 percent on the subject weld was radiographed.

A second series of ultrasonic examinations were conducted on the subject area by Mr. E. Black and Mr. A. Pennanen on May 14, 1992 using the CP\&L NDE procedure for sizing planar flaws (NDEP-426). A 1.5" notched block was used for calibration. (See page 5 for sketch of block.)

Angles/Wave Modes/Techniques used were:

1. 45 degree shear wave (detection)

2. 45 degree shear wave (tip diffraction)

3. 45 degree refracted longitudinal wave (tip detection)

4. 60 degree refracted longitudinal wave (tip detection)

5. 70 degree refracted longitudinal wave RTD (tip detection)

6. 0 degree longitudinal (thickness)

7. $30 \cdot 70 \cdot 70$ mode converted longitudinal wave technique (ID connected flaw) 
The following is a discussion of the examinations conducted and the results obtained.

\section{CP\&L EXAMINATION RESULTS}

1. Radiography - This examination revealed a counterbore at the same location as the UT reflector in question. Comparison with fabrication radiographs revealed no significant differences with respect to the counterbore indication.

1. 45 degree shear wave (Detection Technique). The reflector could be seen from both sides of the wold. From the nozzle side, an additional $20 \mathrm{~dB}$ was needed to see the reflector. The signals produced by this scan consisted of a corner reflector and two associated multiples (typical of a geometric type reflector).

2. 45 degree shear wave (Tip diffrected Technique) - Scans from both sides of the reflector produced no tip signal.

3. 45 degree RL (Tip Detection Technique) - Scans from both sides of the weld produced a reflector tip at .600" from the OD surface.

4. 60 degree RL (TIp Detection Technique) - Scans from both sides of the weld produced no reflectors.

5. 70 degree RL (Tip Detection Technique) - From the reducer side, this scan produced a reflector .450" from the OD surface. From the nozzle side, this scan produced a reflector .500" from the OD surface.

6. 0 degree longitudinal (Thickness Tochnique) - A detalled proflle of this weld at location $L-18^{n}$ is attached. A thickness of .645" exists at the location of the reflector.

7. 30-70-70. This examination produced signals that could not be associated with wave modes normally produced by the WSY 70.

\section{CONCLUSION}

Based on the results obtained and recorded using the above examination techniques, this reflector does not appear to be associated with a crack. The characteristics exhibited are indicative of reflectors associated with geometric reflectors.

This conclusion is based on:

- Results obtained from the 45 degree shear wave, 45 degree RL, and 60 degree RL tests. See attached profile for full scale cross section of this indication (Attached Page 6).

- Radiography revealed a geometric condition (counterbore) in the same location as the reported ultrasonic reflector. Also, comparison with fabrication radiographs revealeo no significant changes. 
- The 70 degree RL results did not correspond with the results of the other tests. Using the $\mathbf{7 0}$ degree RL transducer, accurate depth measurements could not be obtained from the $.600^{\prime \prime}$ deep remaining ligament and/or deeper notches on the sizing block used for calibration. Only the .200" and .400" notches were used. The .450" and $.500^{\prime \prime}$ depths were outside the calibration range. (See attached sketch of the sizing block.)

As recommended by Mr. J. Coley on May 15, 1992, Mr. Stan Walker, EPRI NDE Center, performed a technical review of the ultrasonic methodologies used to confirm/deny the presence of a flaw. Mr. Walker also examined the subject weld using 45 degree shear, 70 degree longitudinal and 60 degree longitudinal wave modes and found no evidence of flaws within the subject weld. Mr. Walker will provide a trip report to Carolina Power \& Light.

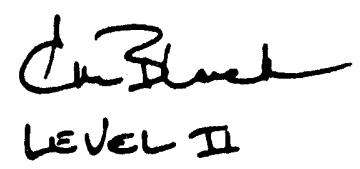




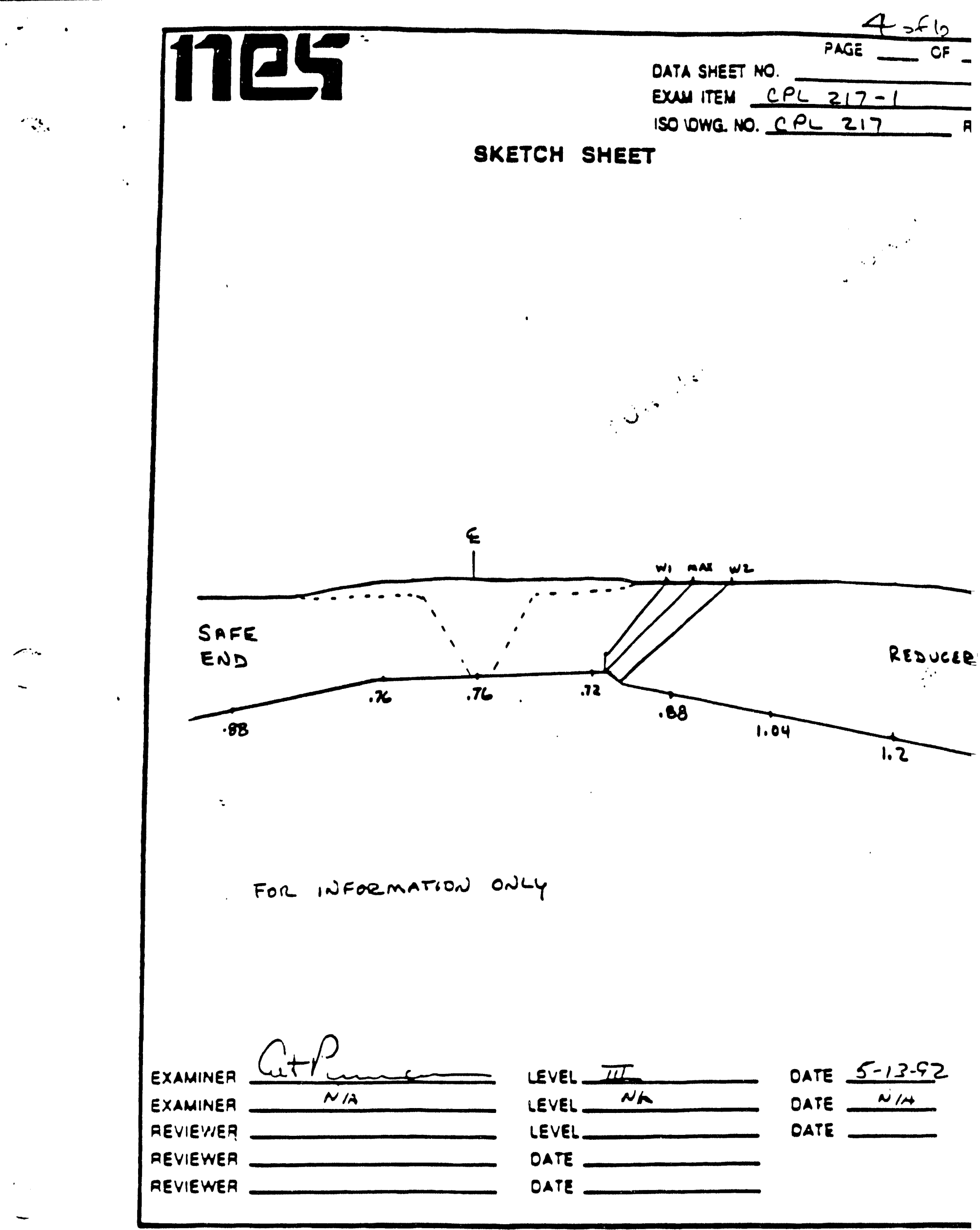



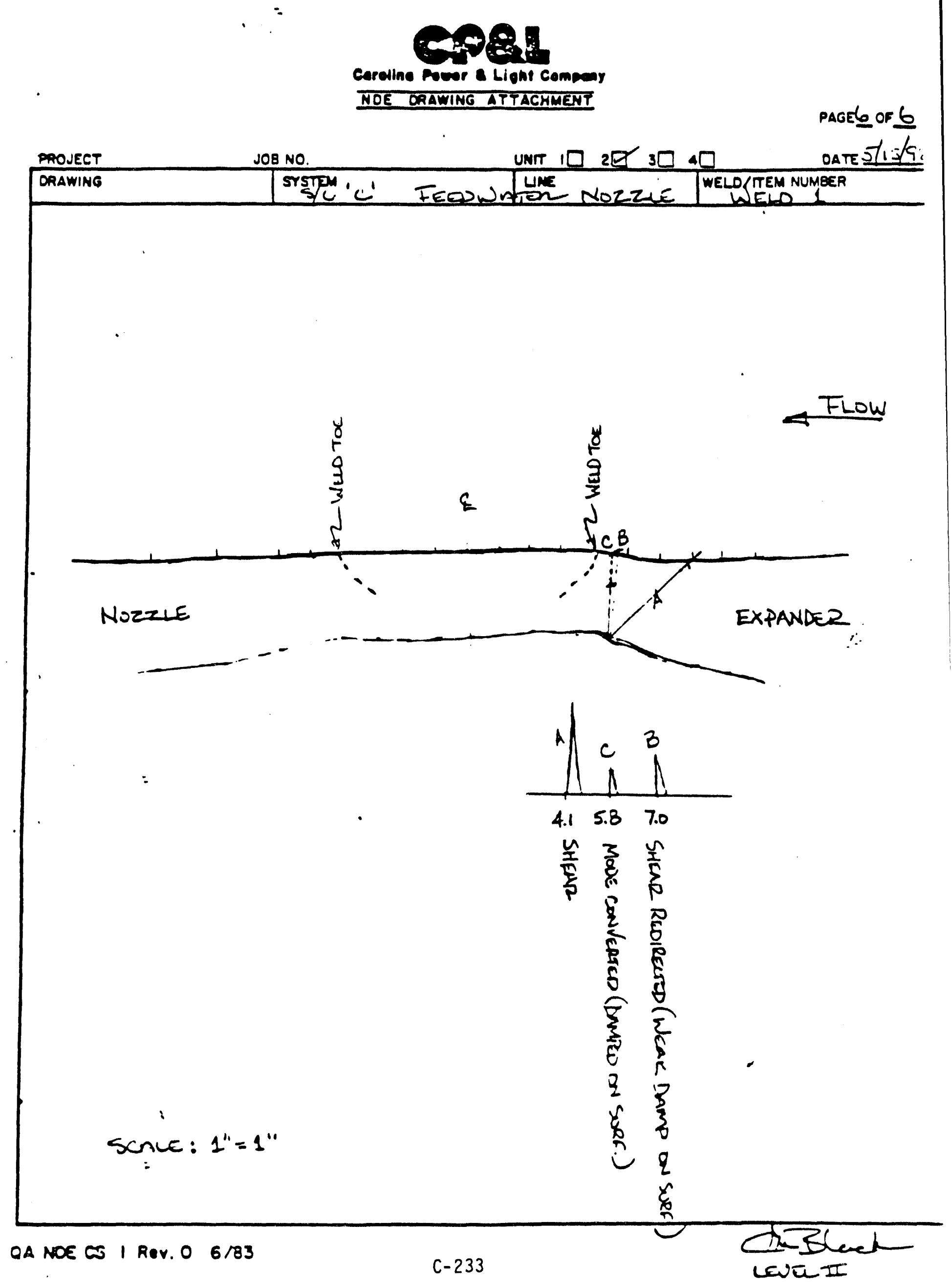
TIP DIFFRACTION $2.25 \mathrm{mmz}$

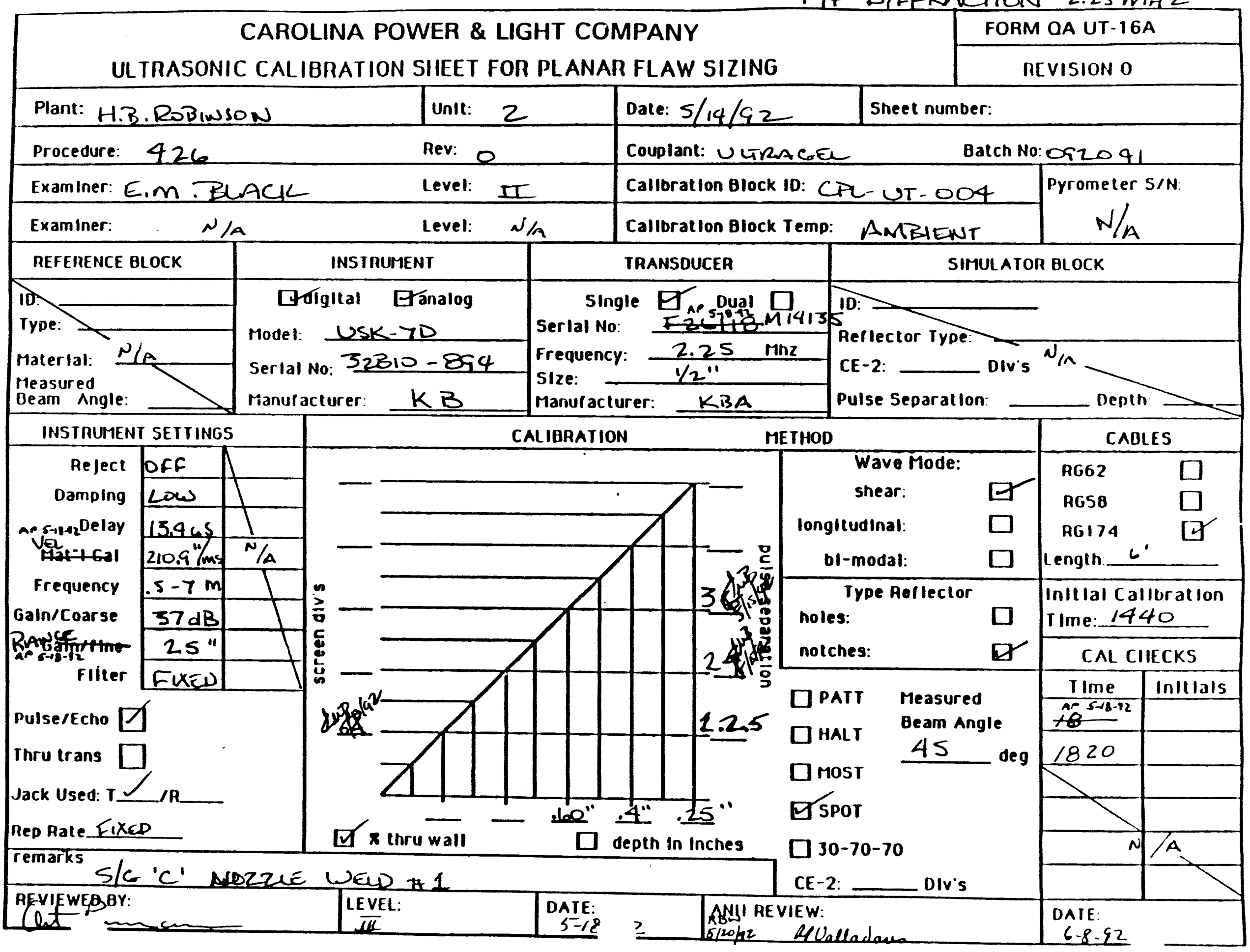


CAROLINA POWER \& LIGHT COMPANY

\section{ULTRASONIC CALIBRATION SHEET FOR PLANAR FLAW SIZING}

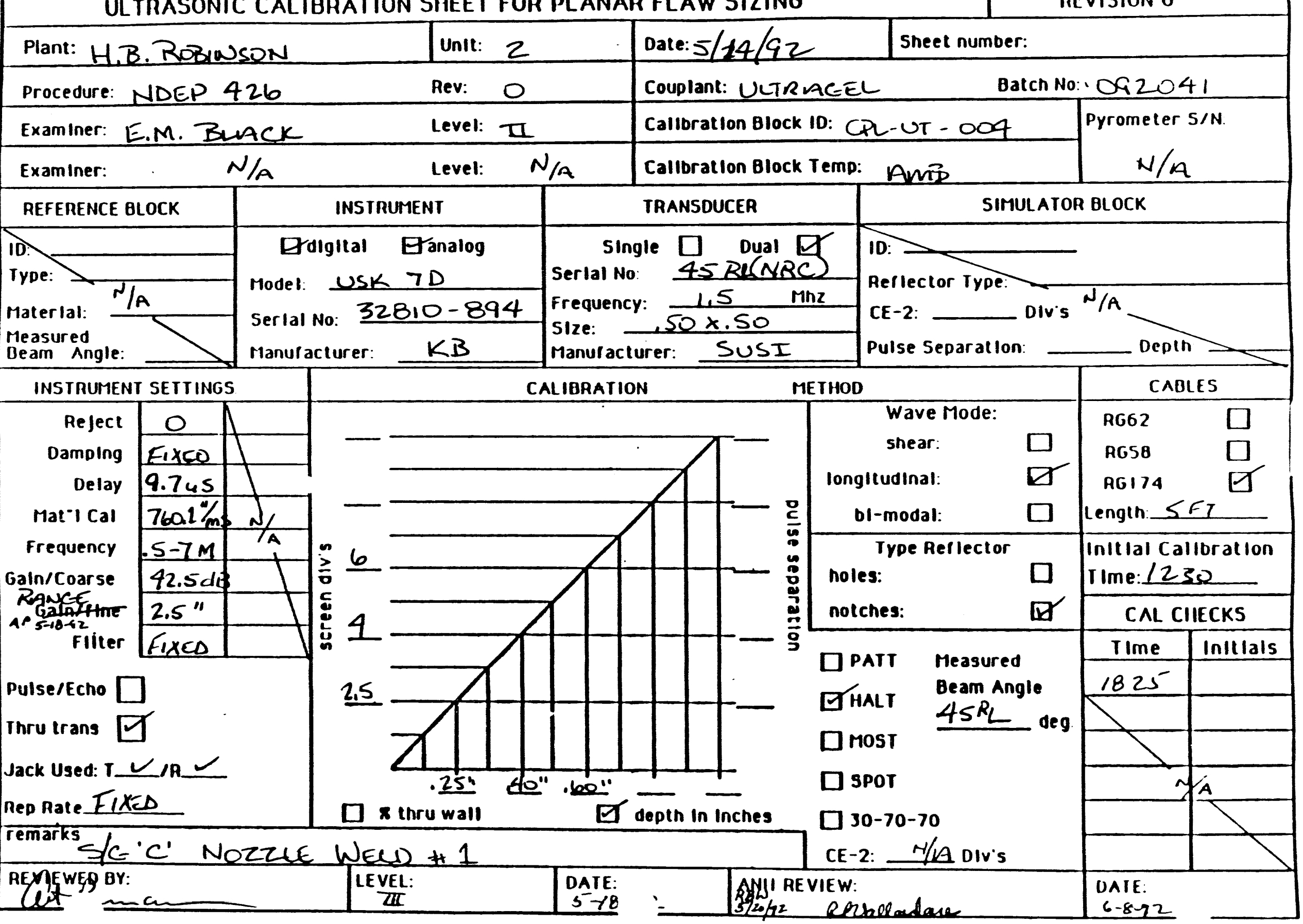

FORM OA UT-16A

REVISION 0 


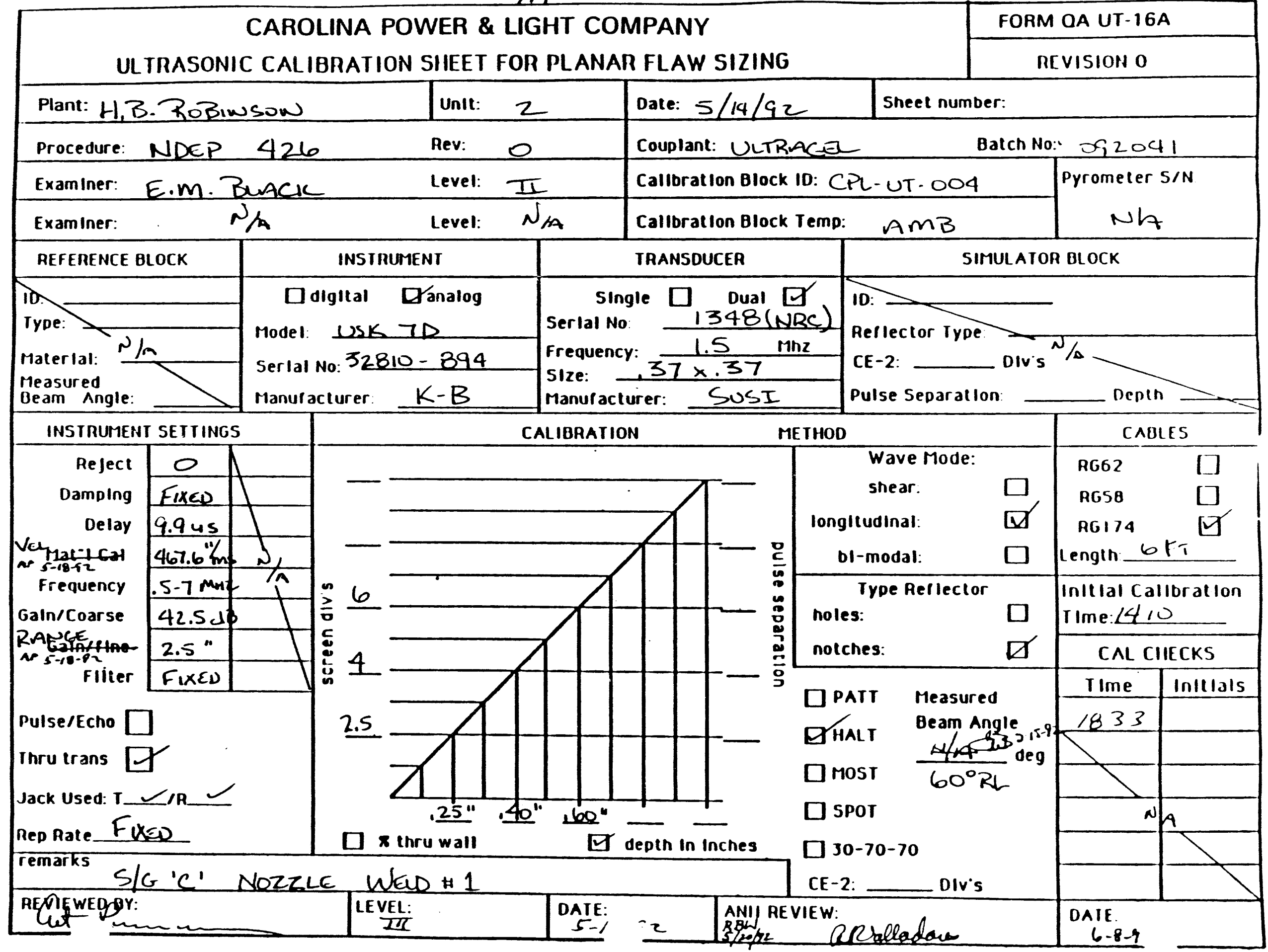




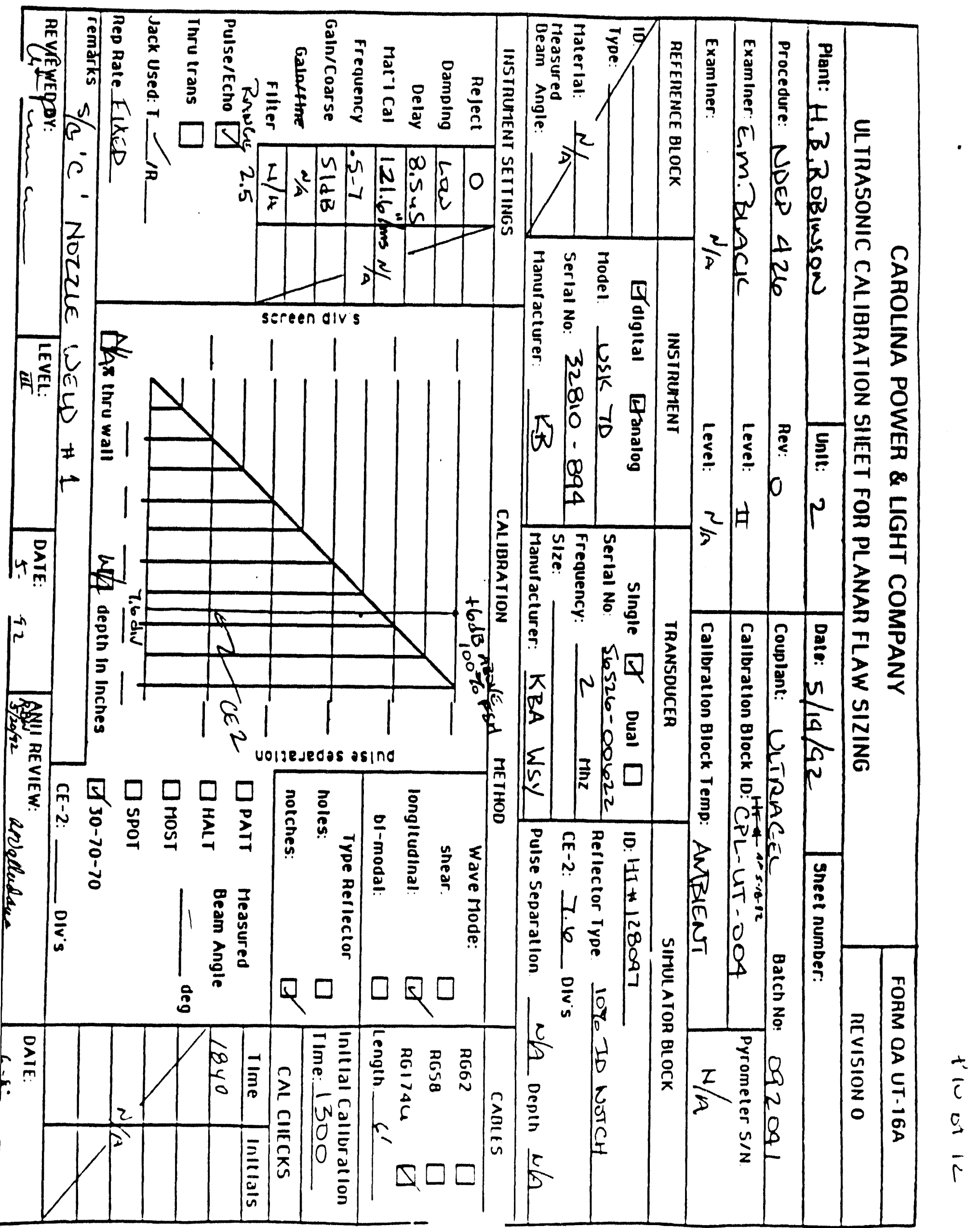




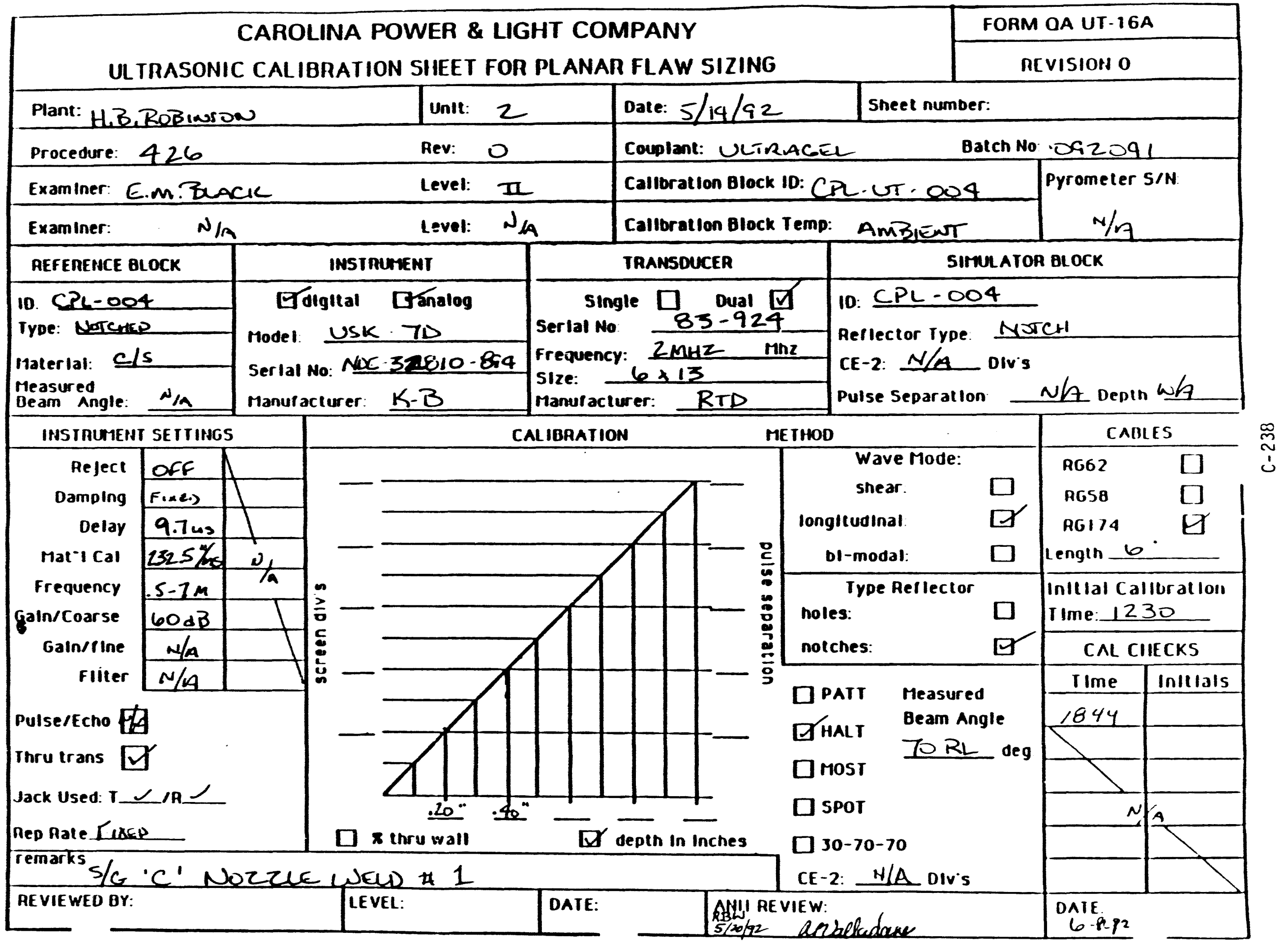




\section{THICKNESS CALIBRATION SHEET}

aArinur: HR.ROBWSOW

procusure : 426 Eev. 0

CulBention \& $00 x+1$ 39-012

component: $\frac{5 / G^{\prime} C^{\prime} E N \text { NozzLe Wav }}{* 1}$ 2 UoCK niexness $.25 \rightarrow 1.5^{\prime \prime}$ uocx nulexizss

IMSTRUMANT: USK $7 D$

CAb. OUE OATE: 12.592

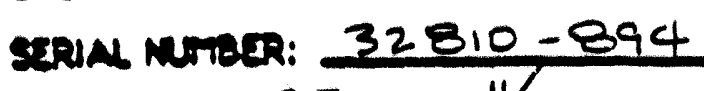

swess: $230.7 \mathrm{1} / \mathrm{ms}$

Drar: 3.6 us

Rance:

$1.0 "$

Trunsoucza preatricy: 5.0

Trursouces sesial no.: $\frac{H 28181}{K 31 A}$

Transouces BRAND: $\frac{K B A}{1 / 4}$

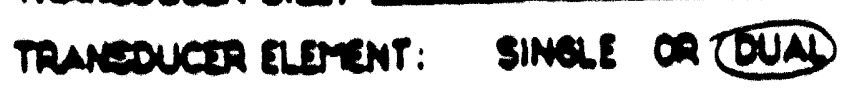

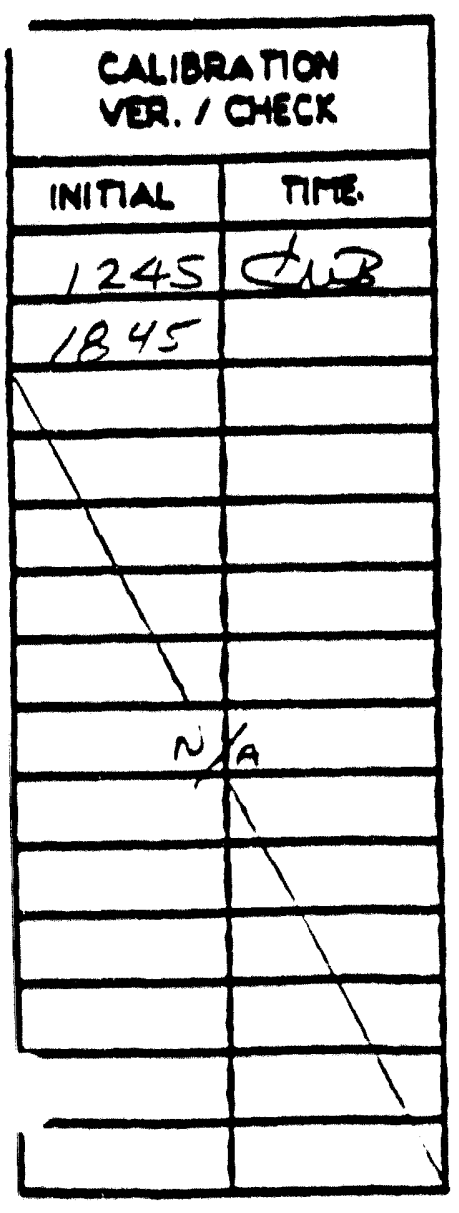

COMTINTS:

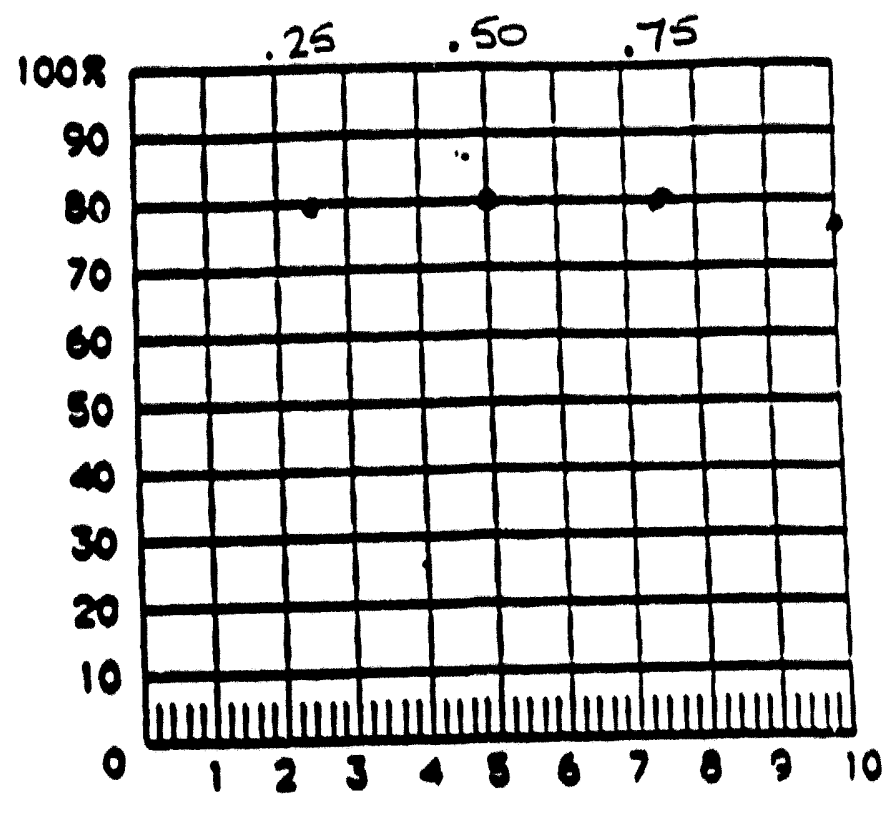

cain maven scertin DIVISION: $100^{\prime \prime}$

$G_{A N}=53 d B$

ZERO $=3.79$ us (DAGTIAL)

EXAMINERS I E.M BuACK OAT $\frac{5 / 14 / 92}{N \text { LEVEL II }}$

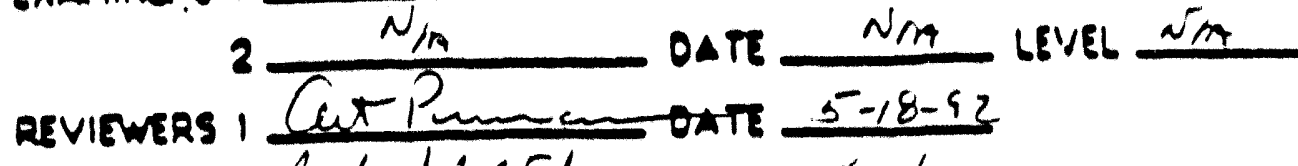

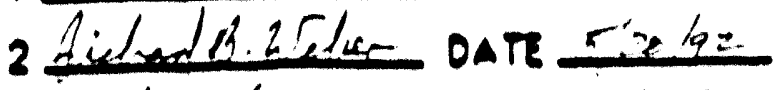
3 ereblladacans oAT 6.8 .92 
PROJECT HBR JOBNO. N/A UNIT $\square, \square, \square, \square$

\begin{tabular}{|c|c|c|c|c|c|}
\hline TLTYG & MTL. THEKNESS & O.DLENGTH & $\begin{array}{l}\text { SURFECE FINISH: GAS.WELOEO } \\
\text { DOROUNO DOTHER }\end{array}$ & $\begin{array}{l}\text { Nor Pnocepouns } \\
\text { No. } 101\end{array}$ & nev $/ 4$ \\
\hline
\end{tabular}

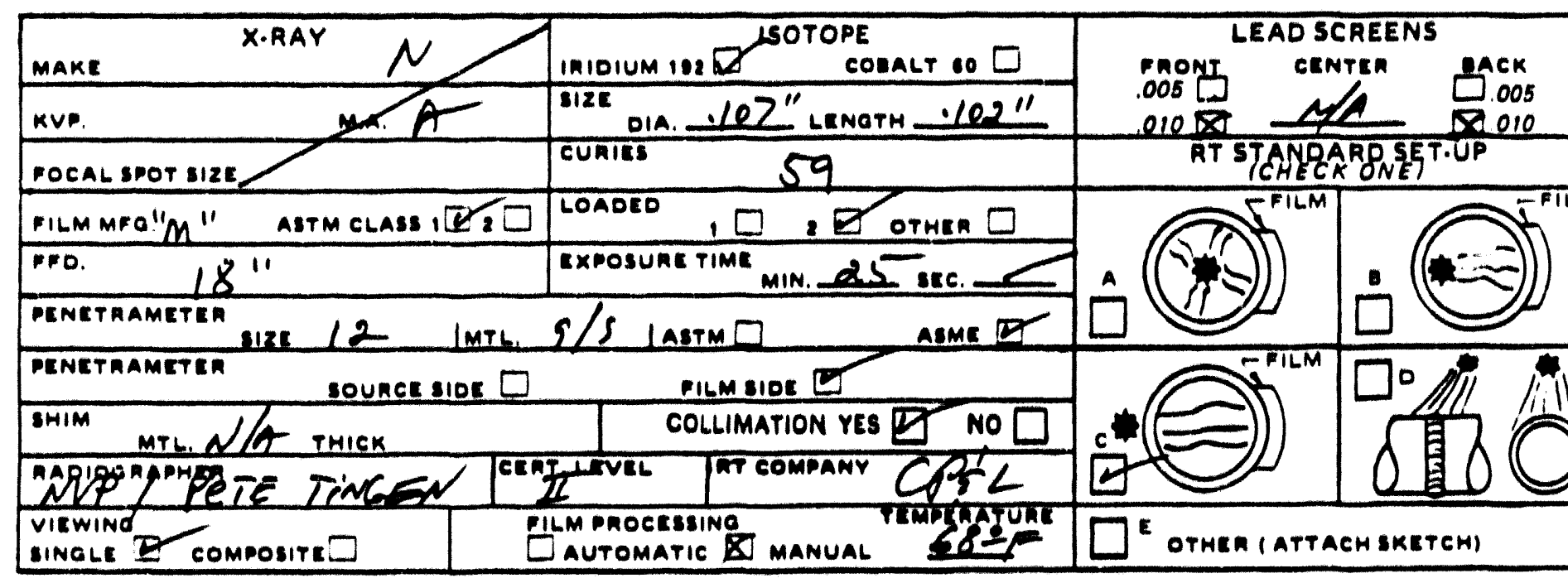

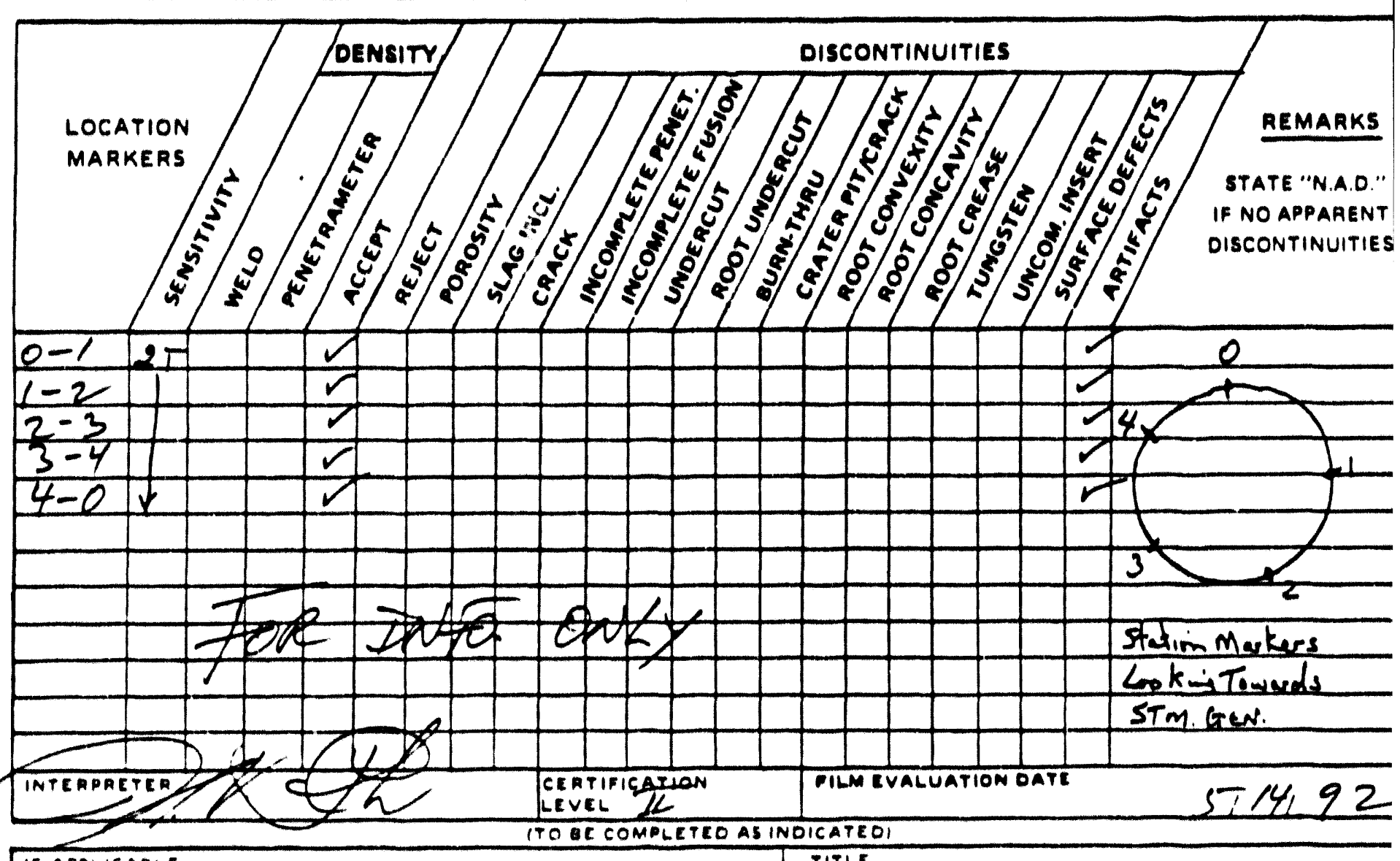




\section{SUPPLEMENTAL REPORT FOR \\ H. B. ROBINSON UNIT 2 \\ STEAM GENERATOR "C" FEEDWATER NOZZLE WELD 1 \\ SUMMARY DATED MAY 16, 1992}

The purpose of this attachment is to evaluate the .450" from outside diameter (OD) signal produced on May 14, 1992 using RTD transducer, S/N 83-924 during inspection of FW nozzle weld 1.

Attached are full scale plots and profiles of transducer exit point relative to holes, notches and counterbore to illustrate amplitude and screen positions of the $70^{\circ}$ refracted longitudinal (RL) and the $34^{\circ}$ shear (S) beam angles from the dual element RTD transducer, S/N 83-924 (enclosed).

The exit point and beam angles were measured using a type II, carbon steel IIW block and verified on various side drilled holes as shown on pages 2 and 3 . Reflected $70^{\circ}$ RL signals can easily be seen from side drilled holes with depths of up to $.600^{\prime \prime}$ from the OD surface with no other accompanying signals that could confuse the operator.

As shown on page 4, using a one inch thick notched block, each tip diffracted RL signal is accompanied by a trailing $34^{\circ}$ corner reflected shear wave signal at screen position 10. With a thinner block or component, the shear signal would be closer in time to that of the tip diffracted signal whish could confuse the operator. (Notice the amplitude difference between the longitudinal and shear signals.)

On page 5, using a carbon steel block close in thickness to that of the feedwater nozzle weld 1 at H. B. Robinson, $870^{\circ} \mathrm{RL}$ and $34^{\circ} \mathrm{S}$ signal could be obtained from the inside diameter (ID) notch. Because the metal path of the corner reflected shear component is almost half that of the RL tip signal, the screen position of the $34^{\circ}$ shear component appears almost in the same location as that of the longltudinal signal.

Page 6 shows the approximate RTD probe location during the May 14 examination relative to the counterbore. It is possible that the counterbore signal was the cause of the signal seen at .450" from the OD surface. This is based on the signal presentation from the .600" deep hole shown on page 2. The sweep positions of the shear and longitudinal components are too close to avoid possible operator confusion. Also, the short echo dynamic response noted from the .450" deep signal on May 14 was characteristic of a shear signal; longitudinal signals exhibit long echo dynamic responses.

According to the EPRI Text, UT Operator Training for Sizing IGSCC. "The primary interit when sizing with the high-angle, L-wave method, is to limit the penetration of the beam into the metal in order to avoid confusion from unidentifled ultrasonic signals." (Module 3, page 11, 10/89 Edition.)

We conclude that for the feedwater nozzle in steam generator $\mathrm{C}$, weld 1 at $\mathrm{H}$. B. Robinson Unit 2, this transducer should be used for flaws that penetrate within .300" of the outside surface ( 3 screen divisions) to reduce the possibility of shear wave encroachment of the calibrated region. $(5.2$ screen divisions on page 2.$)$ This will prevent possible misinterpretation of shear signals caused by internal weld geometry.

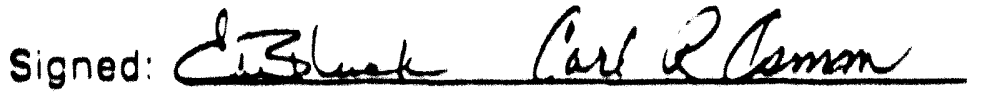

Date: 1952 


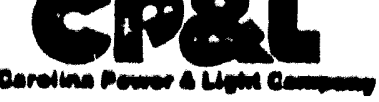

SCREEN PRESENTATIONIS RELATIIE TO TRANSTULER DLALEMENT FOR $70^{\circ}$ REFRALTES LONGITUANAL AND TRRILNG $32^{\circ}$ SHEAR COMPONENT

$A T 52 d B$

5.2 Sulesp

6.0 sulesp

S.o sukep

$\frac{5.0 \text { SWlesp }}{80708+1}$

$60 \% \mathrm{FSH}$

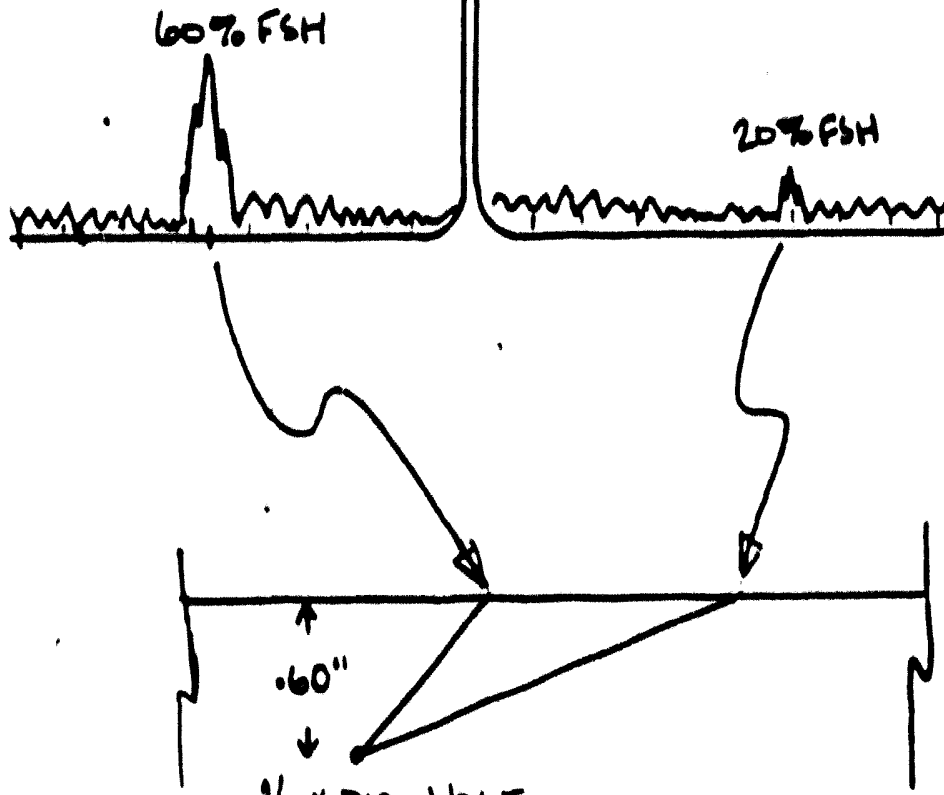

H/16" DIA HoLE

In

IEW TYPCI

Eock

CARBON STEEL

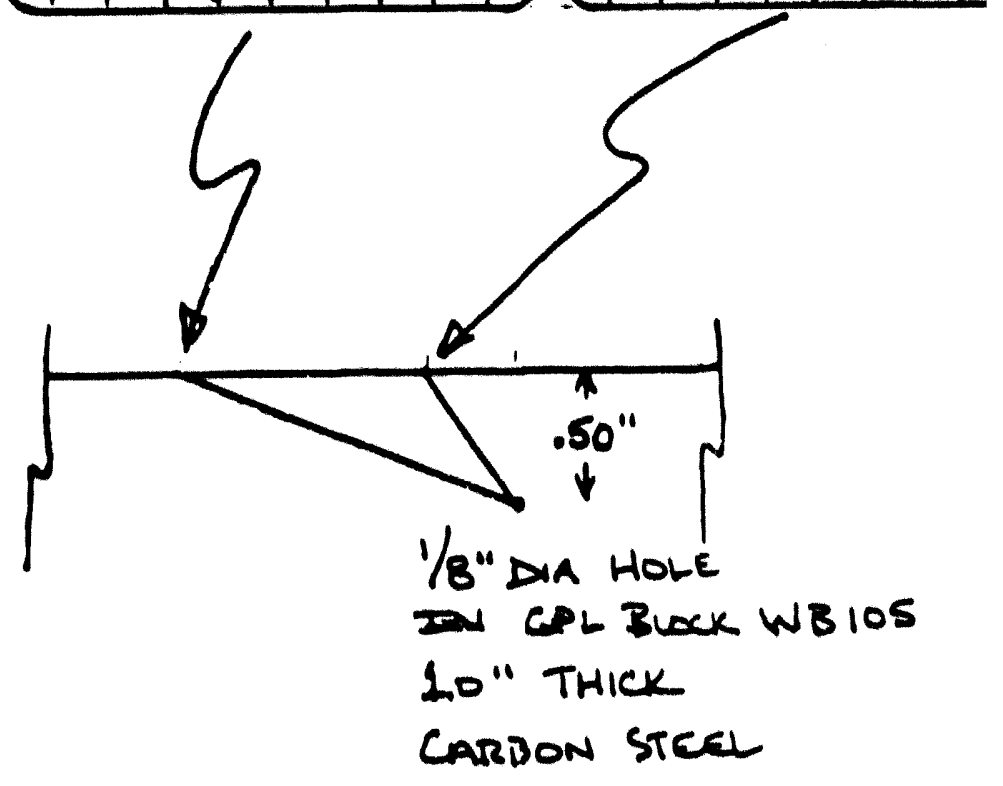

JoTE: THE SCREEN WAS CALIBRATEU SO THIM EACH MASOR DIVISION $=.100^{\circ}$ DETTH FROM QD. SURTACE- USING $70^{\circ}$ RL.

Cunance

$C-242$

Lever II 52004 
corelium Power A blght campeny

SCREEN PRESENTATIONS RELATIIE TO TRANSAUCER DLAGEMENT

AT $52 \mathrm{~dB}$

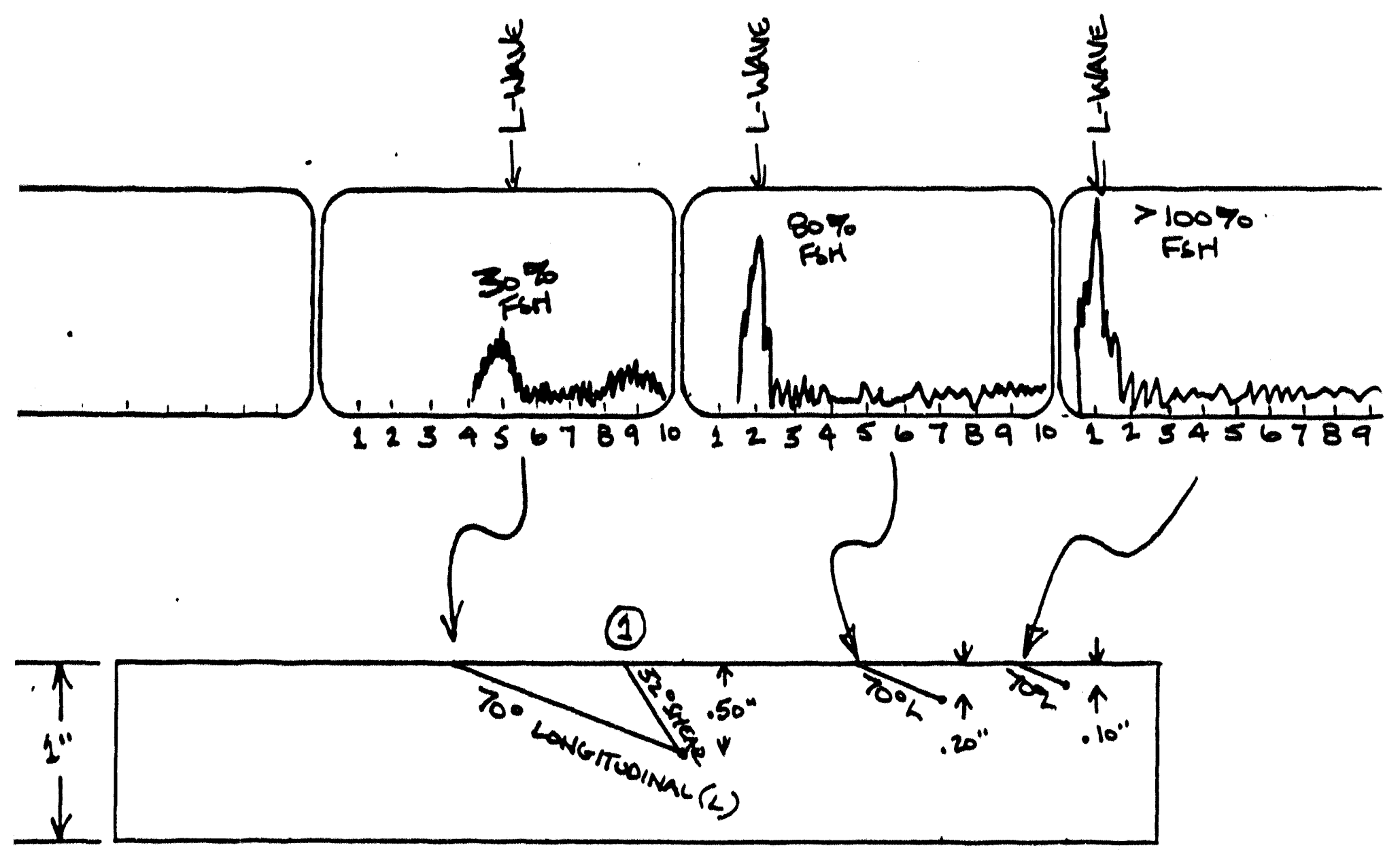

(1) $32^{\circ}$ SHEAR COMPONENT PEAKS AJ $1^{\prime \prime}$ IN FROM 70 $\mathrm{L}$

(2) ENCH SCREON DUVISION = .100" FM OD. SURFACE.

(3) REFLCCTOSS = 1/10"DIA. S1DCDRILLa) HOLES

CuBland

$C-243$

LeVeuII, $520 / 92$ 


\section{CPRL}

SCREEN PRESENTATIONIS RELATIIE TO TRANSSULER DLACEMENT

$A T 52 d B$

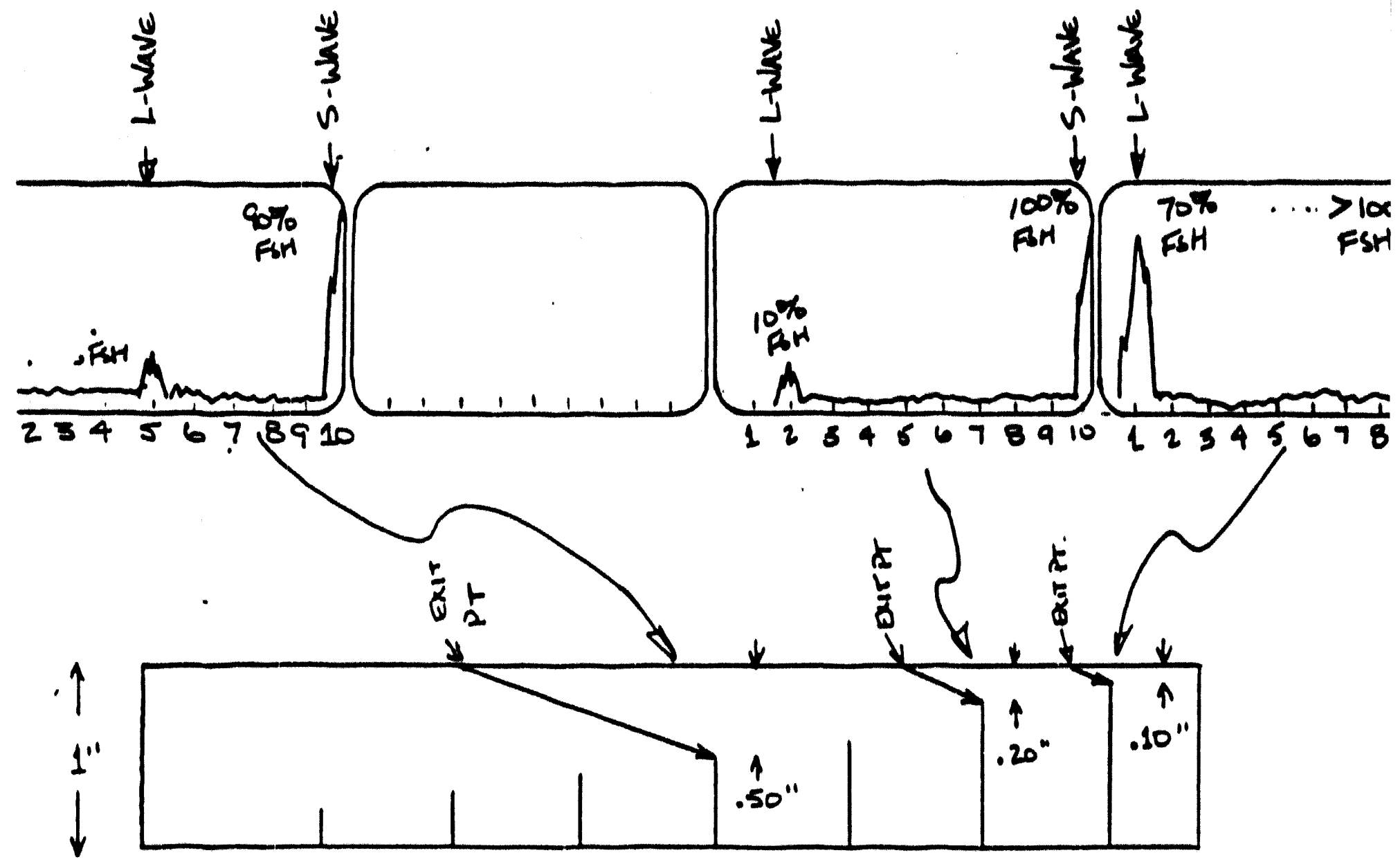

1. REFLETTORS = NOTCHES

2. FOR L-WAVE: EACH SCREEN DIV =.100" FM OD. SURFACE 
SCREEN PRESENTATIONIS RELATIIE TO TRANSTULER DLACEMENT FOR $70^{\circ}$ REFRACTED LONGITUDIWALL AND TRAILNSE $32^{\circ}$ SHEAR COMPONENT

$$
\text { Ar } 58 \text { d } B
$$
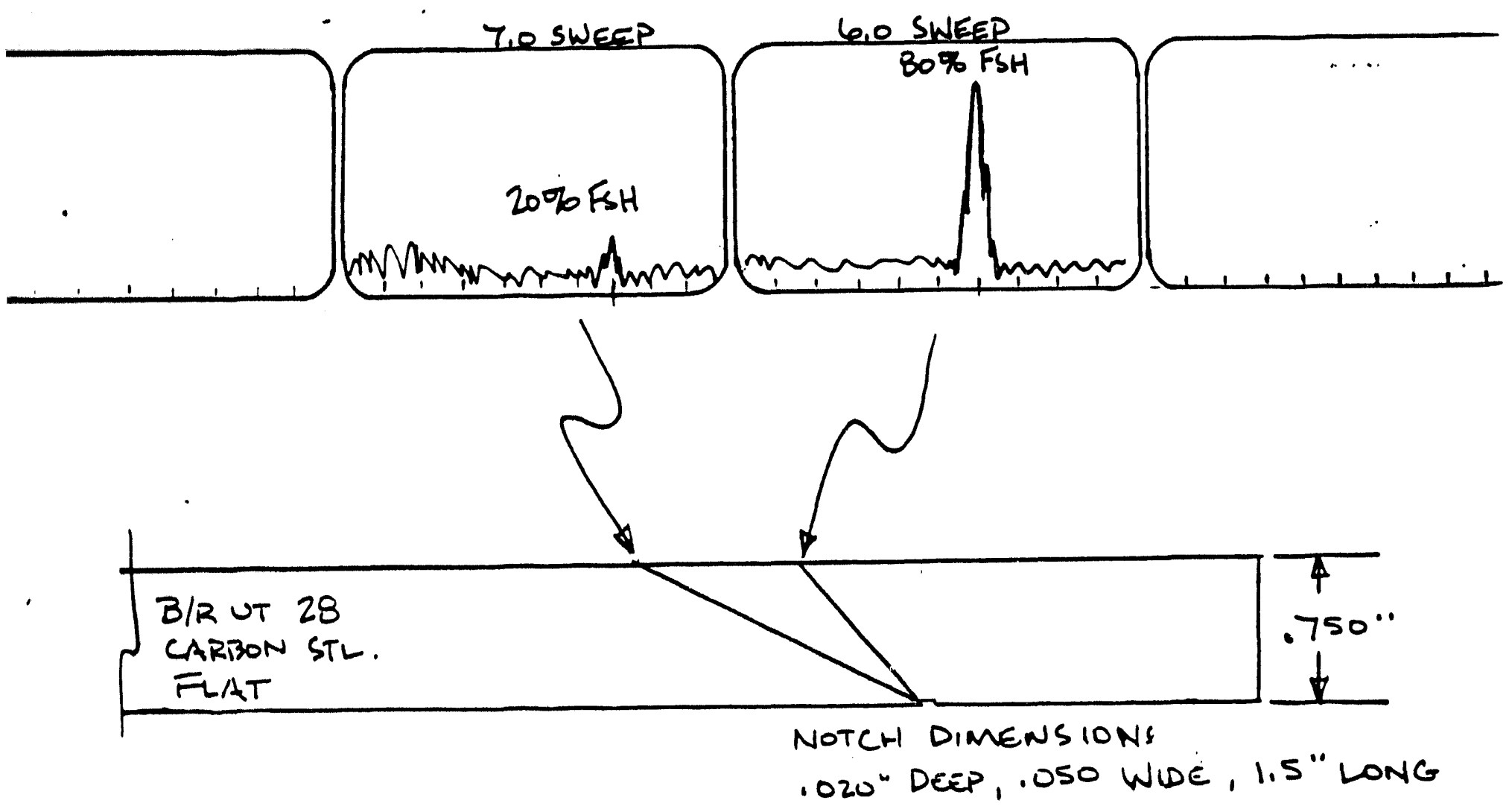
PROJECT H.B. ROBINSON JOB NO. UNIT $1 \square \quad 2 \square \quad 3 \square$ 4 PAGE_ of

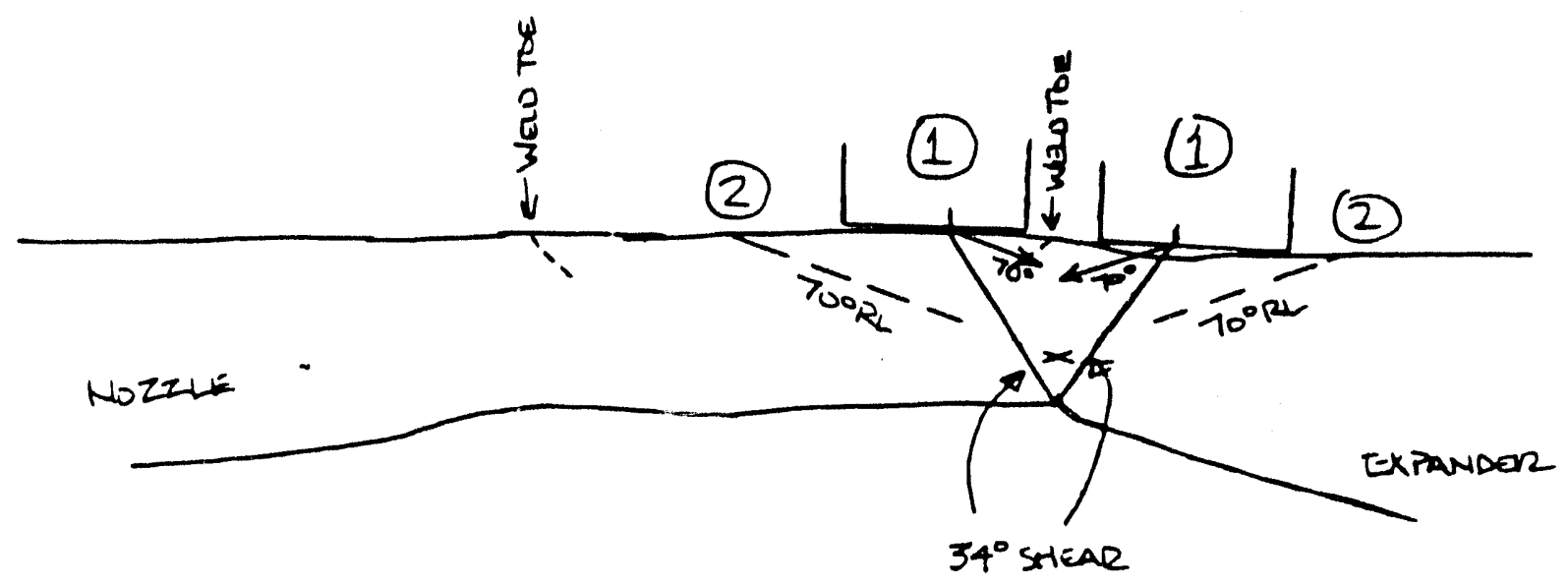

(1) approximate locations of Probe Durine $5 / 14$ Exam.

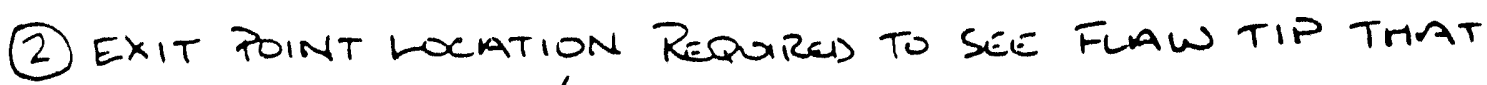
was REPORTED $5 / 13$. 


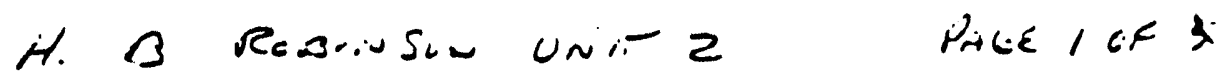
Sisain Gevescation C FEED watER NOZZLE TO REDUCE, WELD

InTtio OCCTIUN!

PERraimes ET Ex.7mintitiad of THIS WEU AND AD JACENT BASE MATERIAL FIZTM $2 \% "$ "UDSTZEATU O." WELD 2 TO $24 \mathrm{C}^{4}$

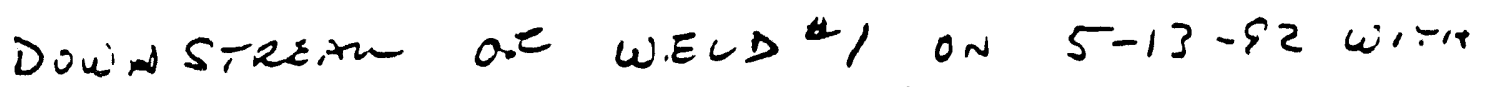

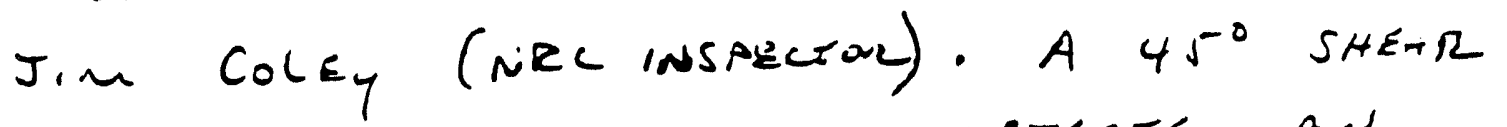
WAJE AXIAL Exituination DETECTEA AN INDICATRON OR.G.NATING FROM TWE WASTREATU COU.JTEZ BODE AT $16^{*}$ CLOCKWISE AND

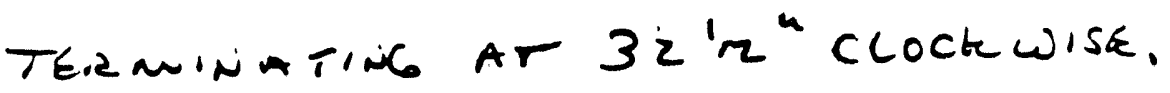

ON 5-14-92 TIE INBICATION AREN WAS REINUESTIGATED BY MY SELF AN'S E. N. BLACK (CPL) TO VERIIE TRE INDICATION ANA ITS S.2E.

ExגMUnation:

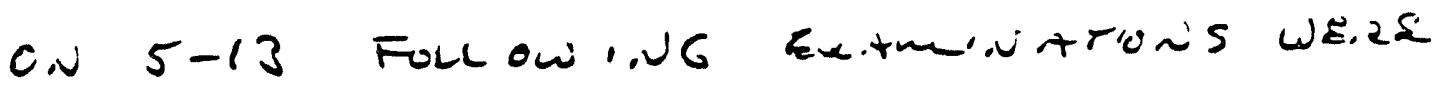
PEZForn Ka.

(1) 45 Shetic wite Axitc (DETECTION TRCHNiav)

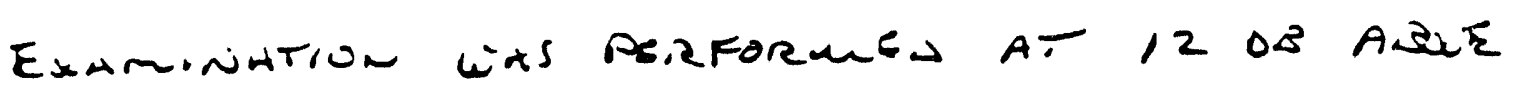

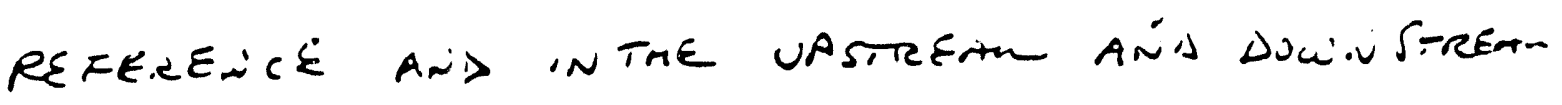
DIRECTIONS. SINCE THE INOICATICA DAS NCT Excekd 5C\% DHC, Size THeOUGH wakl has dFiezm.

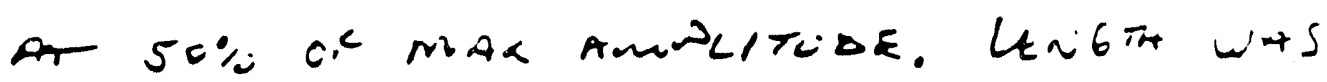

C-247

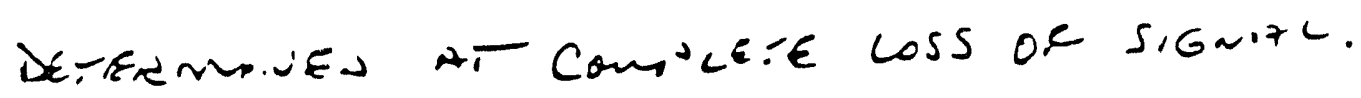


PACE 2 i

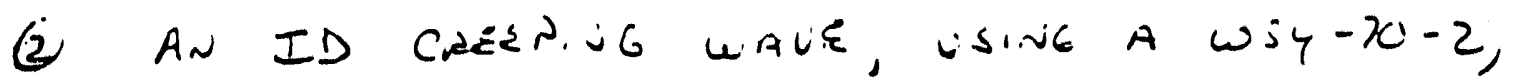

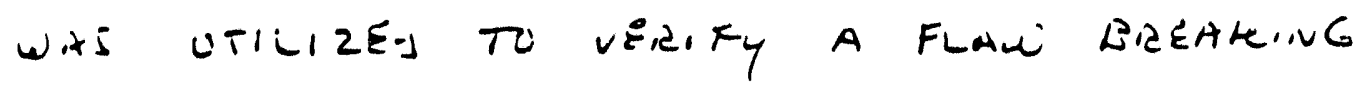
THE ID Suzfrtck. A S.6.uth was SER.V,

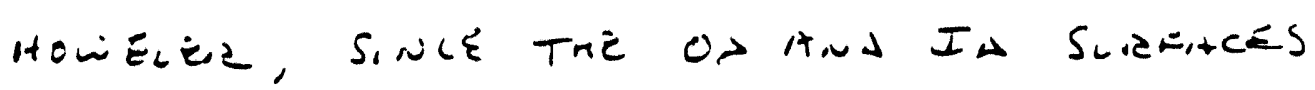

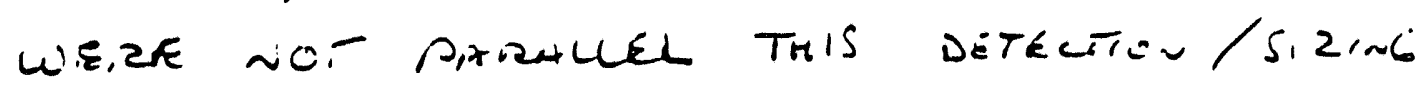

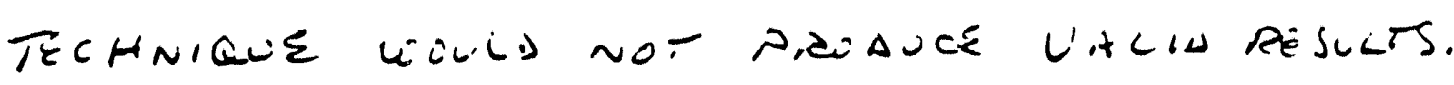

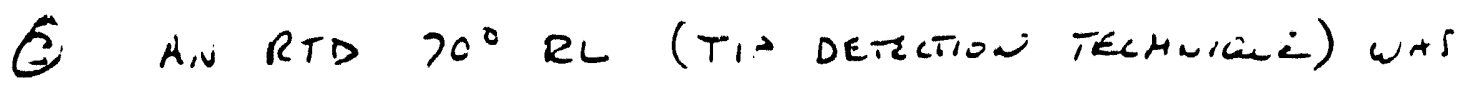

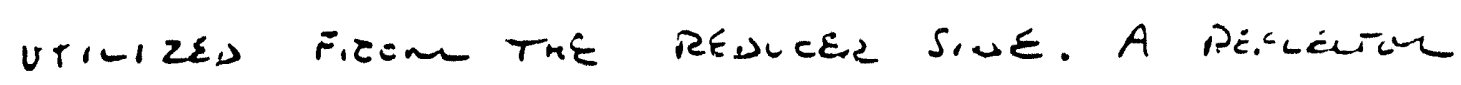

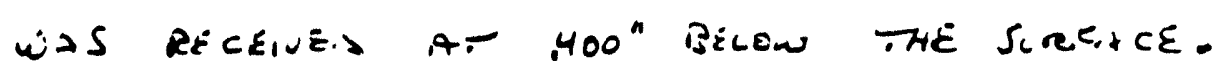

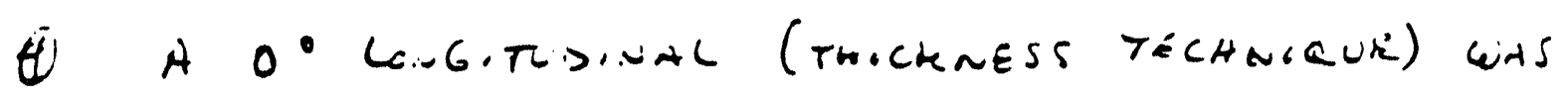

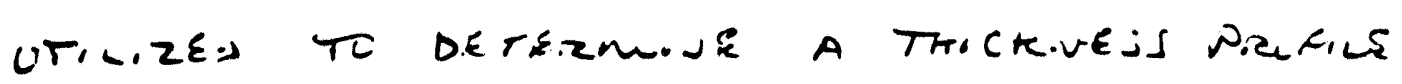
Fur PLOTING THE indicttion.

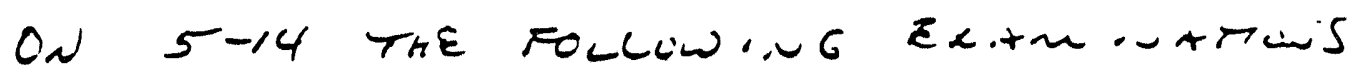
witie pg, forem Ex

(1) 45 Shear wave CuULD EASILY DE-ECT the lovidaried Fizem REDUCE.L. A.J AODITICOAL $20 \mathrm{~d}:$

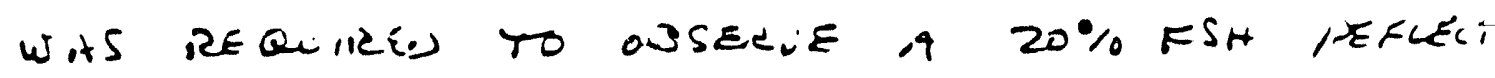

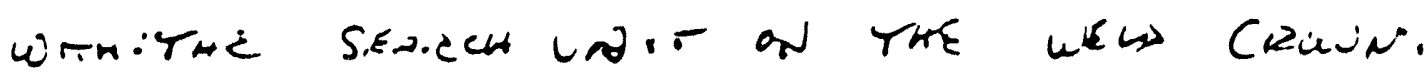

(2) 45 SHEtre wave (TR Disiraction tícisilaia)

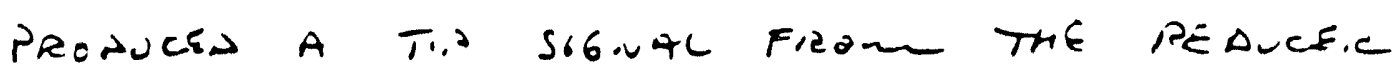

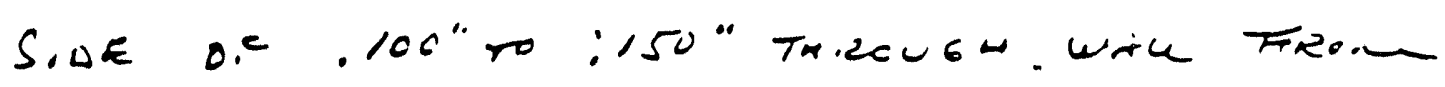
Ture Ia Surator.

$C-248$ 
$P+6=30 .=4$

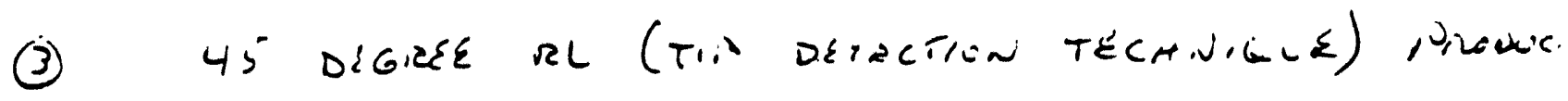

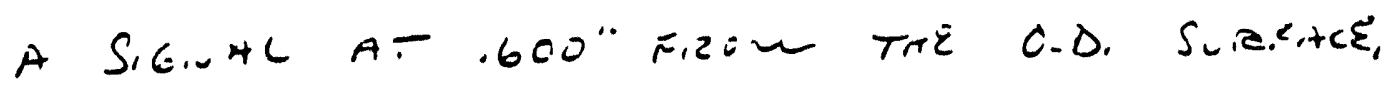

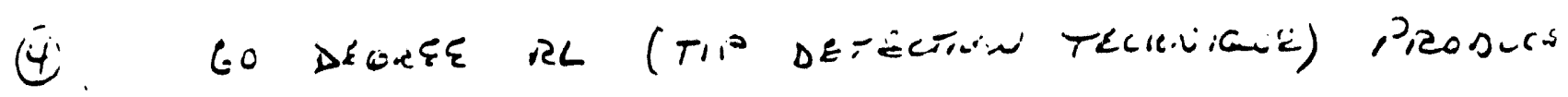

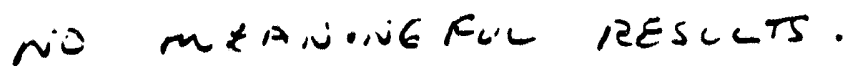

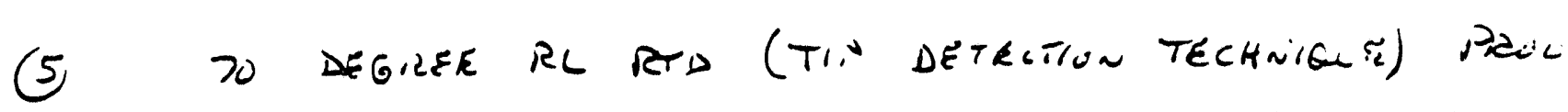

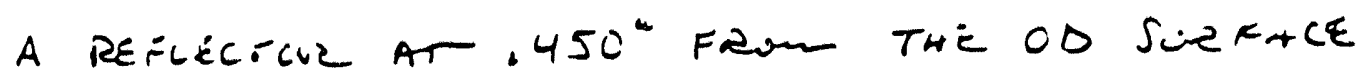
WHE.V SCONDEA FreOn THE REAUCEIL SIDE.

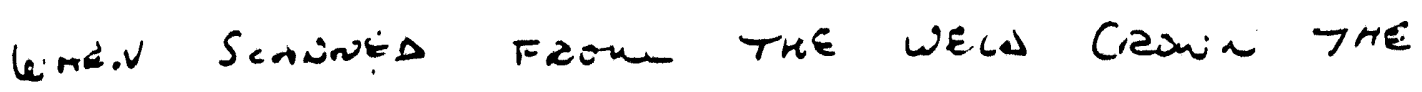

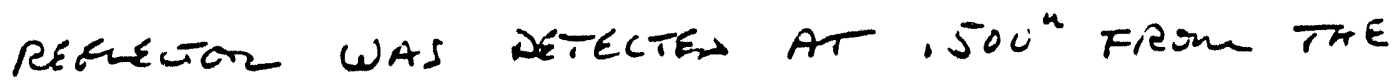
C.) Surface.

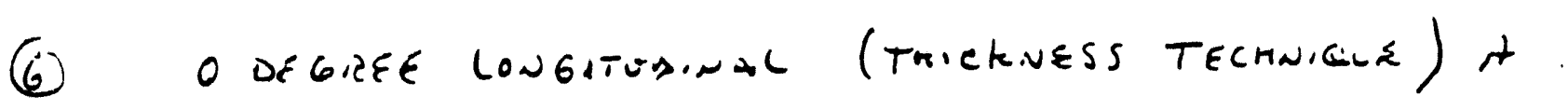

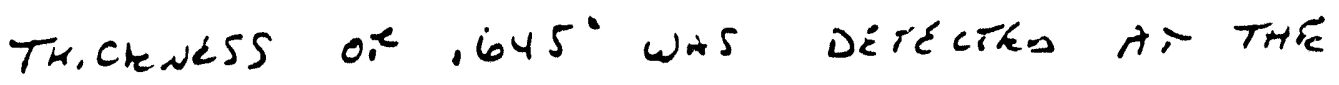

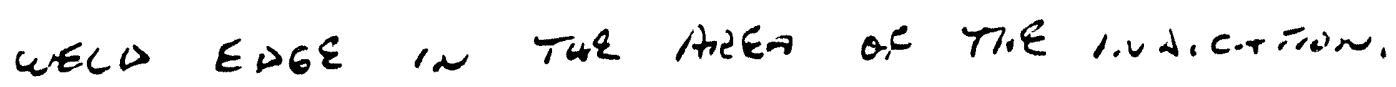

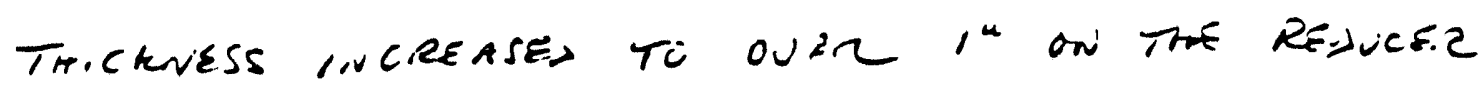

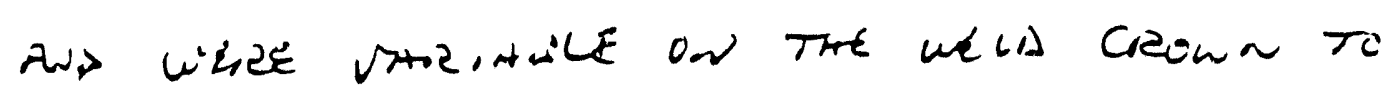

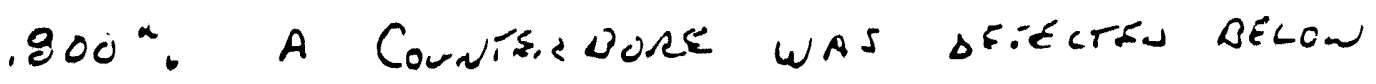
TWE WEU RD GE.

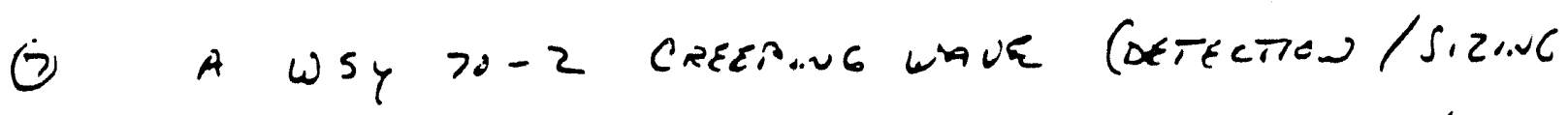

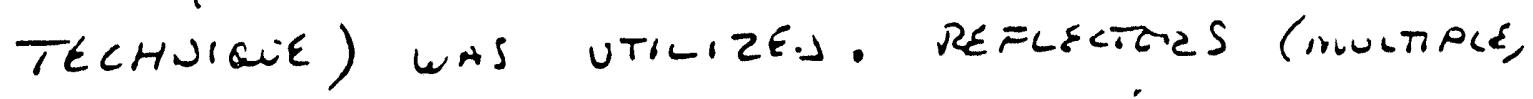

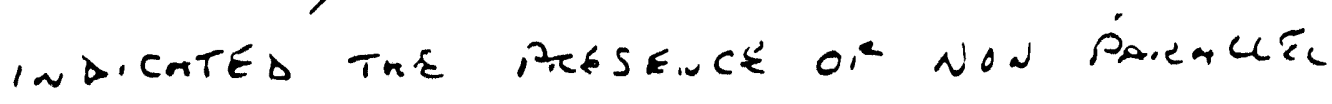

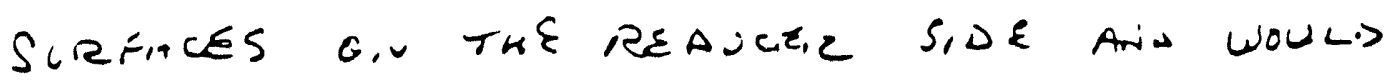

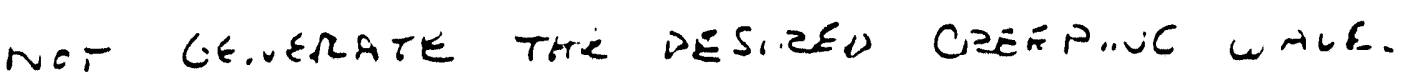

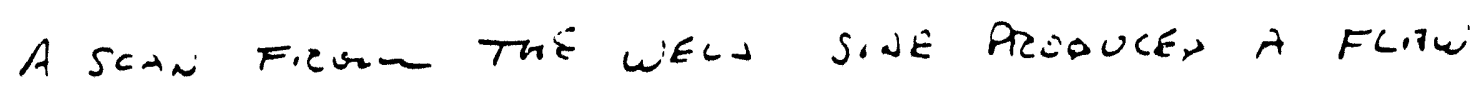

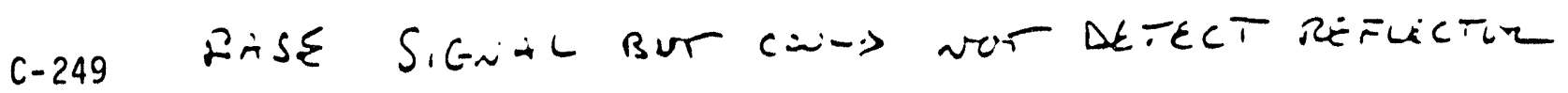


POE F Y $0:=9$

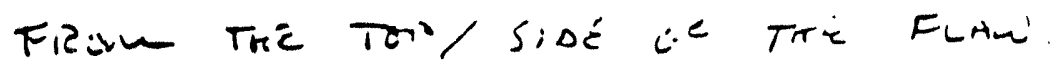

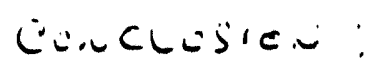

TH.S REFLECTCL HNPEARS TO PE A SArtCh

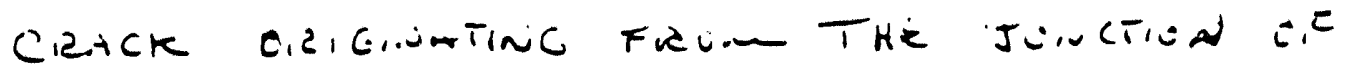

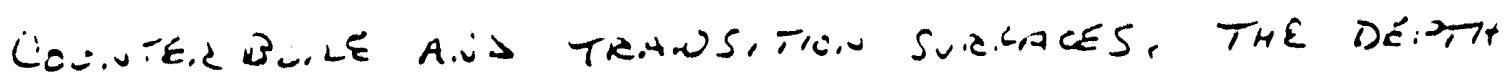

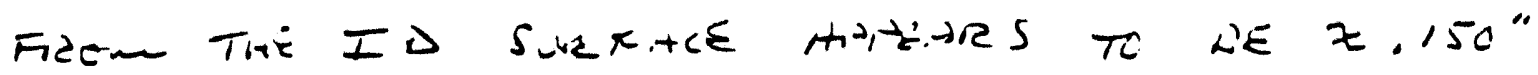

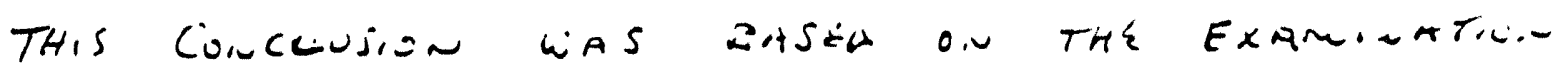
RESELTS O,K 5-13 A.JS 5-14, IN ADSITIOU THE cie.tck Is Cirvistedr WITH THE LUCATILU O.

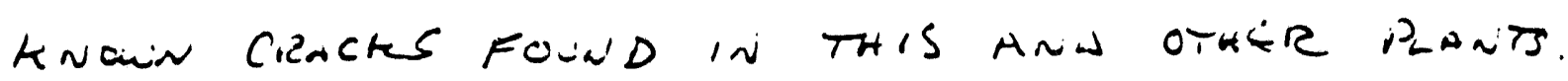

Cet Pum_un ut \&Ek $5-15-92$

C-250 
GPU Nuclear Corporation

Posi Office Box 480

Roule 441 South

Middletown, Pennsylvania 17057.0191

717944.7621

TELEX 84.2386

Writer's Direct Dial Number:

(717)

$948-8005$

February 13, 1992

C311-92-2014

U.S. Nuclear Regulatory Commission Attn: Document Control Desk Washington, DC 20555

Dear Sir:
Note;

sec

Subject: Three Mile Island Nuclear Station, Unit 1 (TMI-I)

Operating License No. DPR-50

Docket No. 50-289

Inservice Inspection (ISI) Data Reports

In accordance with 1OCFR $50.55 \mathrm{a}(\mathrm{g})$ and TMI-1 Technical Specifications, enclosed are GPU Nuclear's Forms NIS-1, "Owner's Data Report for Inservice Inspection" and NIS-2 "Owner's Data Report for Repairs or Replacements."

Two NIS-1 Forms are enclosed. One NIS-1 Form covers ISI first interval examinations conducted between (March 5, 1990 and November 15, 1991) which werg conducted in accordance with the ASME Code, Section XI, I974 Edition through Summer 1975 Addenda. The second NIS-1 Form covers ISI second interval examinations conducted between AprTI 19, 1991 through Novembor 15, 1991, in accordance with the ASME Code, Section XI, 1986 Edition with no Addenda. Table 1 of the NIS-1 provides an abstract of the examinations performed. Table 2 provides an abstract of the corrective measures recommended and taken. All conditions listed on Table 2, where Code acceptance criteria were exceeded, were determined to be operable upon inspection and evaluation. Repairs were performed as indicated in the table to meet Code requirements. These reports are being submitted in compliance with Subarticle IWA-6220 of the Code.

The enclosed NIS-2 reports cover those repairs or replacements where the documentation was completed between April 4, 1990 and January 10, 1992. In accordance with Subarticle IWA-6220, only the NIS-2 reports describing Class 1 or 2 component repairs or replacements need be submitted. 
1. OWNER: Metropolitan Edison Company, 2800 Pottsville PIke,

2. Plant: Three Mile Ieland Nuclear Generating station

3. PLANT UNIT: 1

Route 141 south. Nuclear Generating stat

4. OWNER CERTIFICation or AUrHORIzarion (le requlred), wone

5. COMABERCIAL gERVICE DATE; 09/02/7

6. MATIONAL BOARD MUMBER FOR UNIT: Reactor Vessel N-109

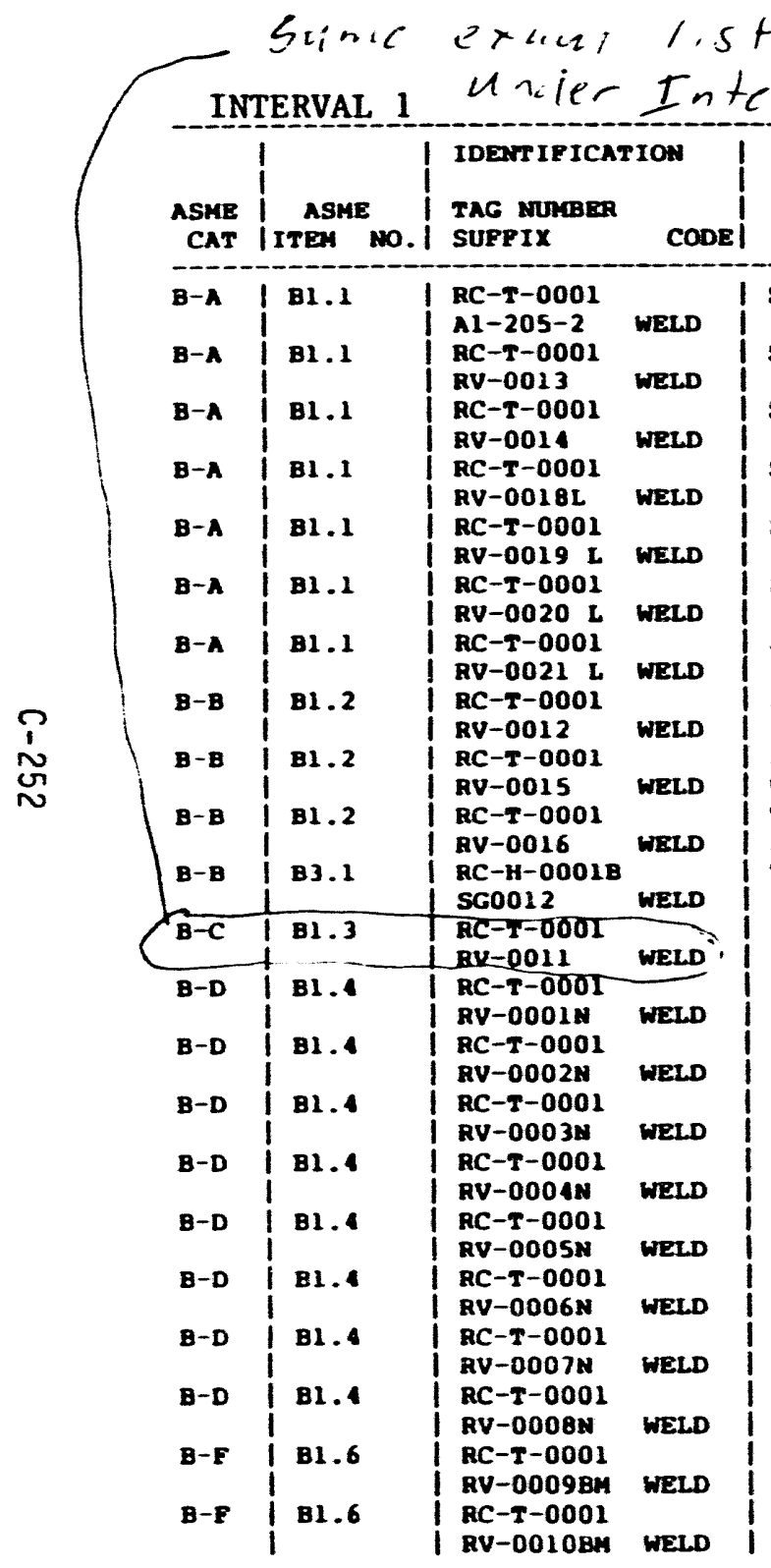

Ourracs 98

TABLE 1

tral 2

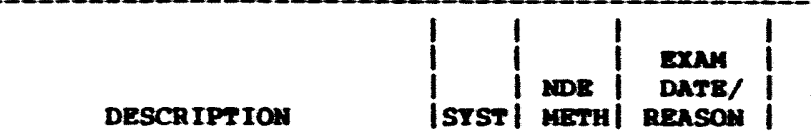

rRom DIN.
ro DINH.

REMaras

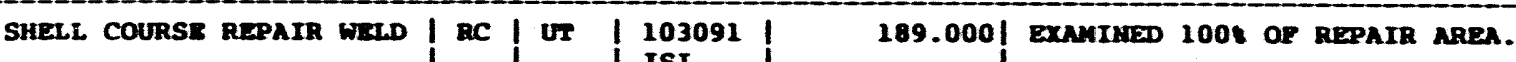

SHELL, TO SHELL CIRC WELD $\left\{\begin{array}{l|l|l}103091 \\ \text { ISI } \\ 103091\end{array}\right.$

189.000 I EXMMIMED 1008 OF REPAIR AREA.

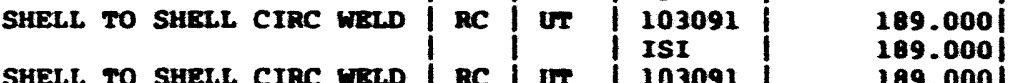

189.000 EXanimed 100 of CIRCURPEREACE.

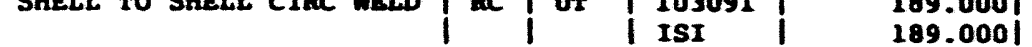

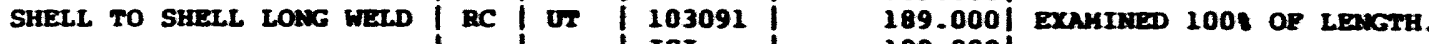

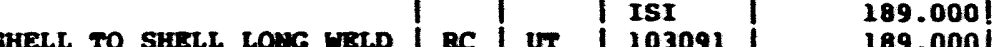

189.000 ExAMTMED 1008 of Lencts.

189.000

SHELL TO SHELL LONG WELD I RC I UT $\left\{\begin{array}{l}103091 \\ \text { ISI }\end{array} \mid \begin{array}{l}189.000 \\ 189.000 \mid \text { LIMTTED DUE TO CORF GUIDE LUGS. }\end{array}\right.$

SHELL TO SHELl LONG WBLD I RC I UT 103091 | 189.000 IIMITED DUE TO CORE GUIDE LUGS.

| I ISI | $189.000 \mid$ EXNMIMED 1008 OF ACCRSSIBLE LENIGTH.

$192.000 \mid$ EXMMIMED 58 OF CIRCUAFBrance.

suret to

RIONG AC UT 103091

TRANSITION RING TO HEAD WI RC UT 103091

ELD

TUBESHEET TO HEND WEID F I UT ISI

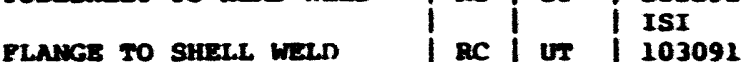

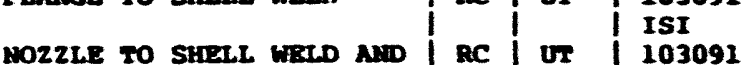

INAER RADIUS

\begin{tabular}{l|l|l|l|l|l|l|l|l} 
INAER RADIUS \\
WOZZLE TO SHELL WELD AND \\
INAER RADIUS
\end{tabular}

MO22LE TO SHELL WELD AND I RC I UT I 103091

IMBTER RADIUS

MOZZLE TO SHELL WELD ASD I RC I UT | 103091

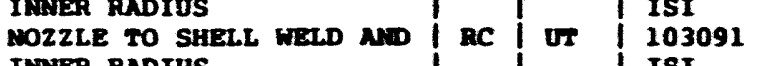

IST ISI

The or 103091

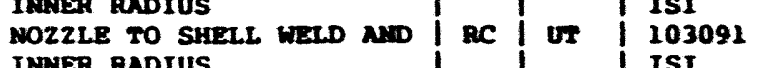

\begin{tabular}{l|l|l|l|l|l|l|l|l} 
ISI &
\end{tabular}

HO22LE TO SHET

SAFE RATUS

182.000 LTMTED DUE TO CORE GUIDE LUGS AND

FLOW VAMES. EXAMIMED S\& OF CIRC.

102.000 I EXAMTHED 58 OP CIRCUMFEREACE.

182.0001

137.000 LIMITED DUE TO OBSTRUCTIOn

137.0001 BXAMINED SE OR CIRC LEMGTH

192.000| LIMITED DUE TO TAPER AMD ADJACENT

$192.000 /$ WOZZLES. BXAMINED 1001 OR CIRC.

$192.000 \mid$ LIHTED DUE TO TAPER.

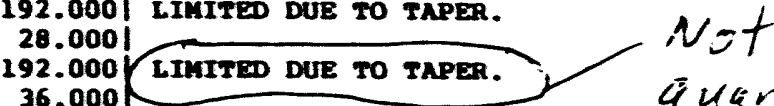

192.000 LIMITED DUE TO TAPER.

28.000 LITIED DUE TO TnPER.

192.000 LTMTED DUE TO TAPER.

$28.000 \mid$

192.000 LIMTED DUE TO TAPER.

36.0001

$192.000 \mid$ LIMITED DUE TO TAPER.

28.0001

$192.000 \mid$ LIMITED DUE TO TAPER AMD VEATURI.

14.0001

192.000 LIMTTED DUE TO TAPER AND VEATURI.

14.0001

$15.620 \mid$ LIMITED DUE TO TAPER.

15.6201

$15.620 \mid$ LIMTTED DUE TO TAPER.

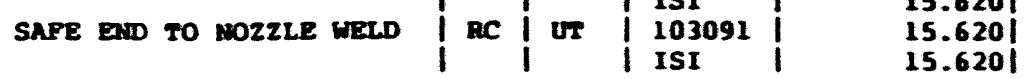


1. OMER, metropolitan Edison Company, 2000 Pottevilie Pike,

2. PLarr, Three Milo Isiand Muclear Generating Station

3. PLant UNIT:

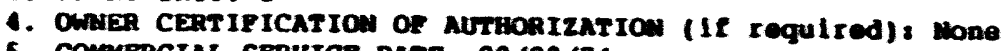

5. COMbercial SERVICE DATE, 09/02/7e

6. MATIOMAL BOARD wURER FOR UMIT, Reactor Vessel u-109

\section{OOTACE 98}

INTERVAL 1

\begin{tabular}{|c|c|c|c|c|c|c|c|c|c|}
\hline $\begin{array}{l}\text { ASNE } \\
\text { CAT }\end{array}$ & I ASES & $\begin{array}{l}\text { IDENIFICA } \\
\text { TAC meder } \\
\text { SUFFIX }\end{array}$ & $\begin{array}{r}\text { Tros } \\
\text { cooe }\end{array}$ & DESCRIPTIOA & Istsri & me i & $\begin{array}{c}\text { Exan } \\
\text { antry } \\
\text { genson }\end{array}$ & $\begin{array}{l}\text { Foom Dran. } \\
\text { ro Diak. }\end{array}$ & REmaxs \\
\hline 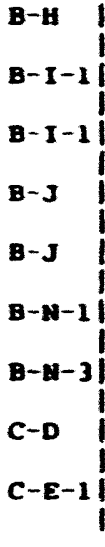 & $\mid \begin{array}{l}83.7 \\
81.14 \\
81.14 \\
84.5 \\
81.5 \\
81.15 \\
\mathrm{c2.4} \\
\mathrm{c2.05}\end{array}$ & $\begin{array}{l}\text { AC-H-0001B } \\
\text { SG-0013 } \\
\text { RC-T-0001 } \\
\text { RV-0003CL } \\
\text { RC-T-0001 } \\
\text { RV-0006CL } \\
\text { CF-0012 } \\
\text { RC-0007 } \\
\text { RC-T-0001 } \\
\text { RC-T-0001 } \\
\text { CSA } \\
\text { KS-00928T } \\
\text { DE-0019wA }\end{array}$ & 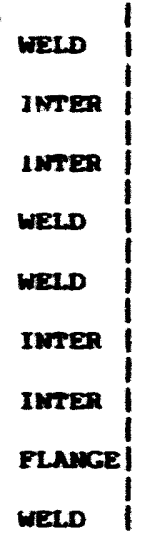 & 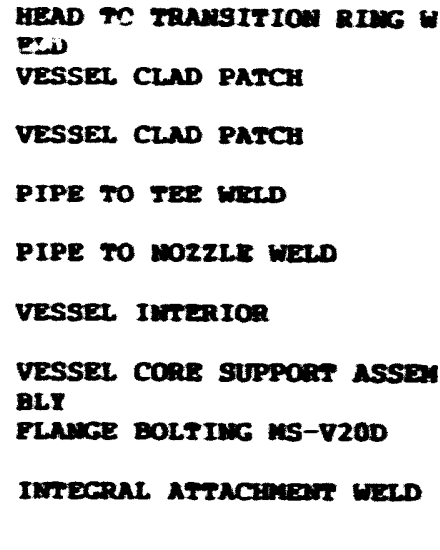 & $\left\{\begin{array}{l}\text { BC } \\
\text { ac } \\
\mathrm{CC} \\
\mathrm{BC} \\
\mathrm{BC} \\
\mathrm{BC}\end{array}\right.$ & $\begin{array}{l}\text { ur } \\
\text { vis } \\
\text { vis } \\
\text { ur } \\
\text { ur } \\
\text { vis } \\
\text { vis } \\
\text { vis } \\
\text { Pr }\end{array}$ & $\begin{array}{l}111291 \\
\text { ISI } \\
103091 \\
\text { ISI } \\
103091 \\
\text { ISI } \\
103091 \\
\text { ISI } \\
103091 \\
\text { ISI } \\
103091 \\
1 S 1 \\
103091 \\
1 S 1 \\
1 S 1 \\
110191 \\
\text { ISI } \\
100291 \\
\text { ISI }\end{array}$ & $\begin{array}{r}146.000 \mid \\
146.000 \mid \\
14.000 \mid \\
14.000 \mid \\
28.000 \\
28.000 \mid \\
6.000 \mid \\
14.000 \mid\end{array}$ & \\
\hline
\end{tabular}


1. Chuser motropolitan Edison Compay, 2000 Potteville Pike.

2. PLurr, Threo mile Island muclear cenerating station

Route it1 South, midaletom. Penasyivanla

3. PLANT Unit: 1

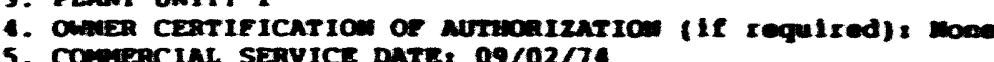

5. Comencial Senvice Date, 09/02/7

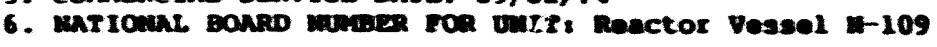

ourruce 9

Note:

TABLE 2

Morc s-ipport prublems

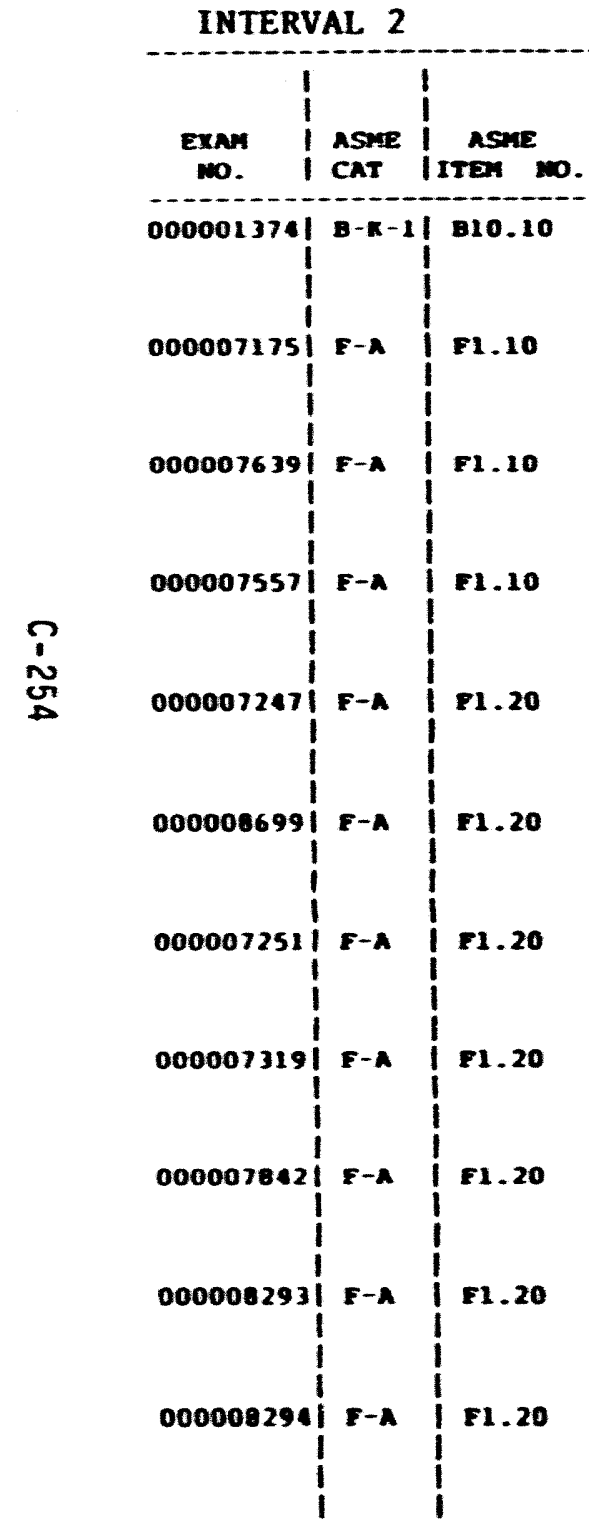

IDeartification

rac muser

SUFt IX coosi

o00001374| B-k-1| B10.10 | CF-0052wa

CF-0052wn wewd

De-0004

suraer

mave-0039

m-0139-3

Den-0187

Dera-018

Dan-0197

EP-0116

ex-0163

ns-0193

MS-0232

surcer!

suroar

suromi cooei Descaiption

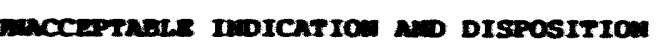

Da menowal sureoder

De movoras suppons

ba nasoval surpoer

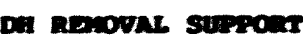

exencenct rewores

en-0116

min srean suppox

suroar!

min sten surrom muxeup monaric swabed

maxere suproat

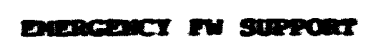

\section{Istsy ine}

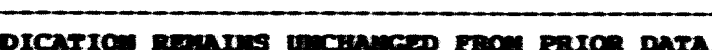

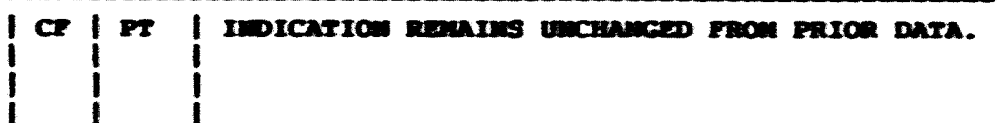

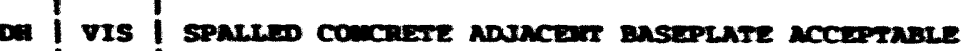

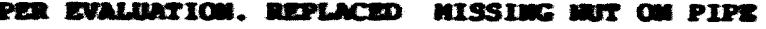
cunis.

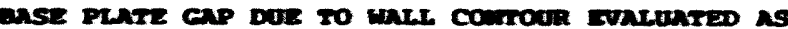
recternare.

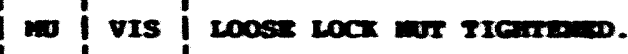

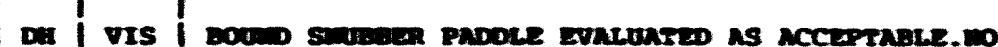

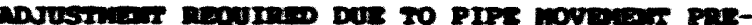
Drerions.

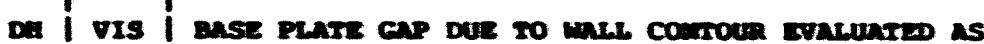
accirenes.

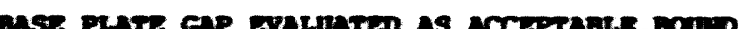

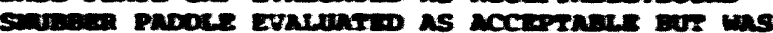
narusre.

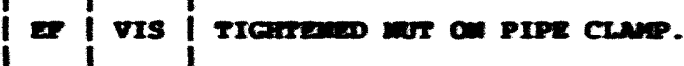

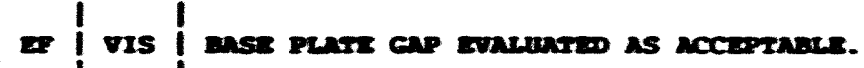

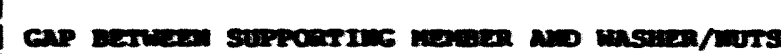

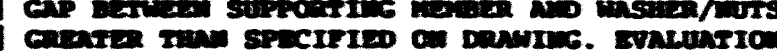

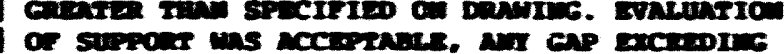
or surpour ans nce

.25- uns abusrio.

suroar i

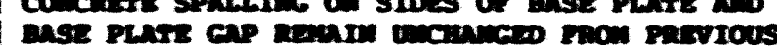
exanumions. 
1. amasi metropoliten edison Compang, 2900 potteville pike.

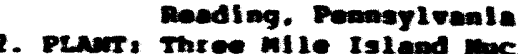

Three wile Island moclear Conerating station

houte ill South, Middletom, Penany ivale

. plave unit: 1

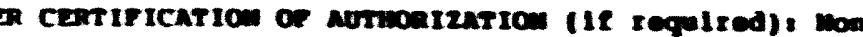

5. Conaderial savice onte، $09 / 02 / 74$

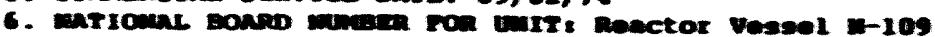

\section{raner sa}

\section{INTERVAL 2}

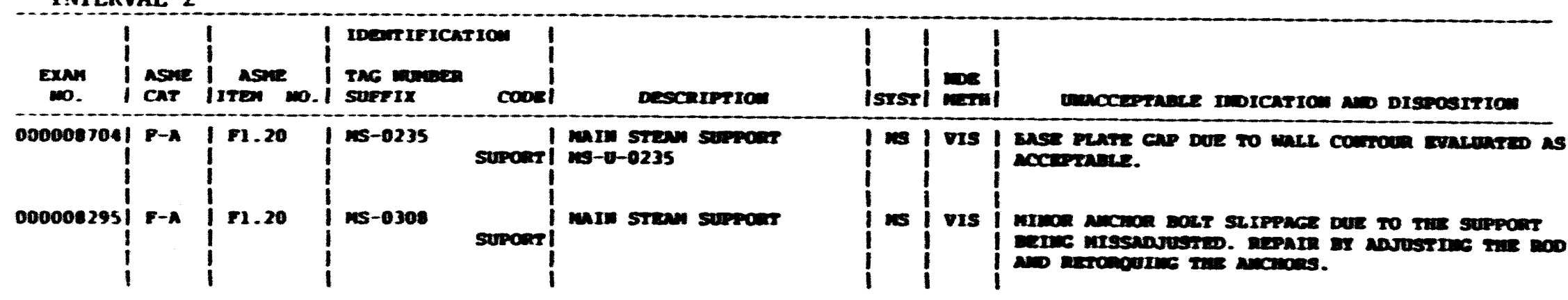


ป̊.

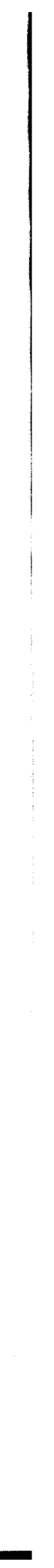


Appendix D

Inquiry on Overlap of ISI Intervals

D.1 
D. 2 


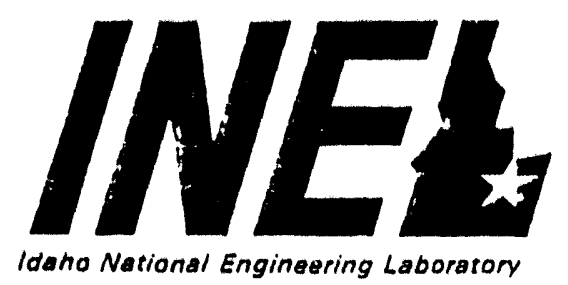

January 13,1993

Secretery

ASME Boiler and Pressure Vessel Committee

345 East 47 th Street

New York, NY 10017

SECTION XI IWA-2400 INQUIRIES - JFC-04-93

Reference: Section XI, IWA-2400, 1974 Edition through 1992 Edition

Dear Mr. Secretary:

Consideration of the following inquiries, to clarify Section XI inspection interval requirements, is requested.

Inquiry 1 - Is it the intent of Section XI that IWA-2400, which permits flexibility in the length of an inpection interval, permits overlap of inspection intervals, i.e. a subsequent interval may be started before the existing inspection interval is over?

Proposed 1 reply - No.

Inquiry 2 - Is it the intent of Section XI that, in the case of a new inspection intervai starting during a plant outage, examinations for the new interval may be performed and credited during the same plant outage, i.e. perform inservice examinations for the new interval prior to the piant operating during the new interval?

Proposed 2 reply - No, it is the intent of Section XI that examinations in the new interval be performed following plant operation in the new interval.

Sincerely,

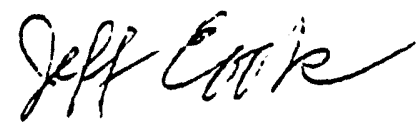

J. F. Cook, Sr.

Principal Investigator

cjs

Nondestructive Materials Characterization

cc: $\quad$ O. F. Hedden

S. D. Weinman

T. J. Mawson

T. M. Zwick

R. J. Tamminga 


$$
\text { - }
$$

\section{$-4$




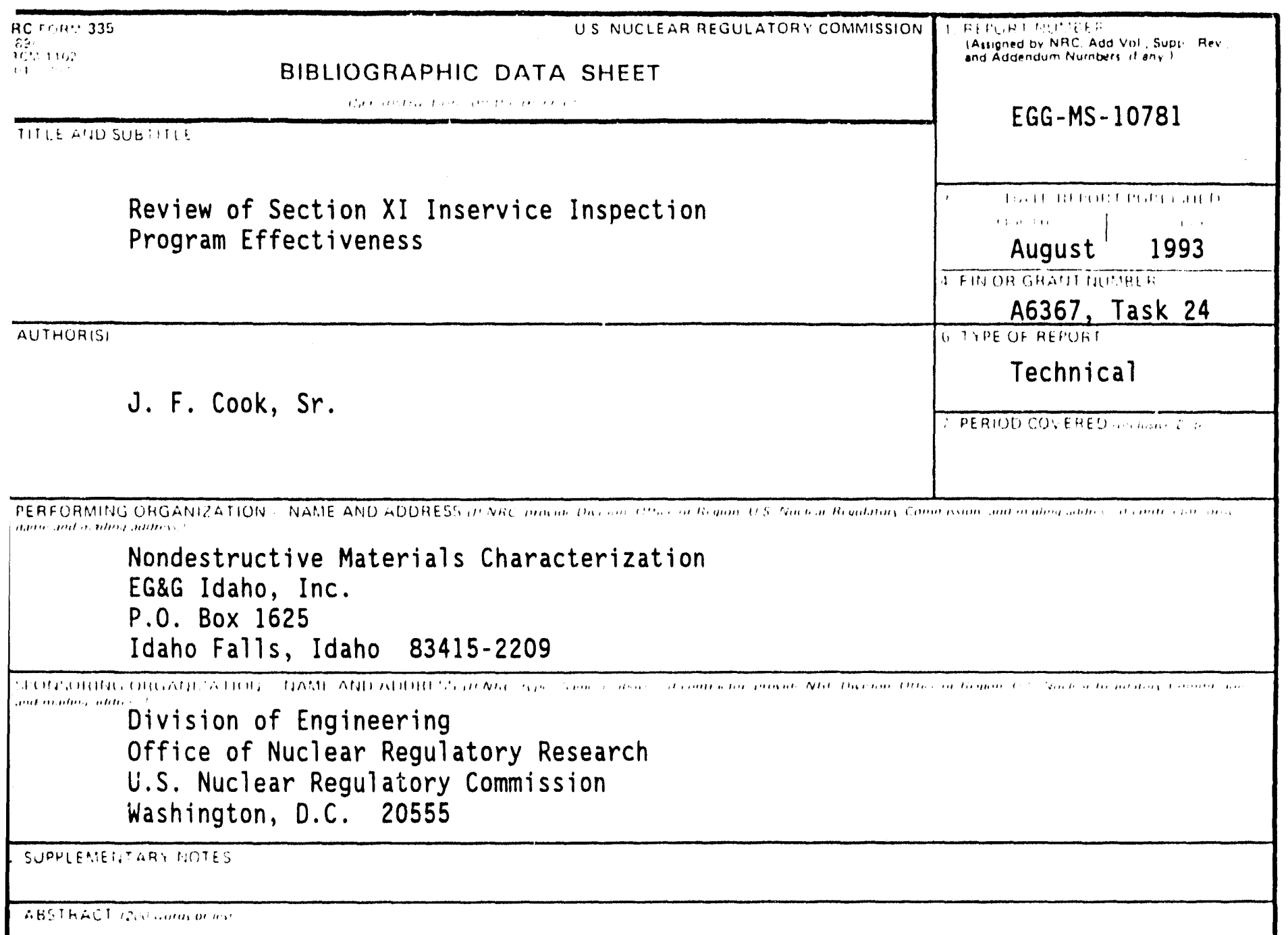

To evaluate the effectiveness of Section XI, Division 1, "Rules for Inservice Inspection of Nuclear Power Plant Components," of the American Society of Mechanical Engineers Boiler and Pressure Vessel Code, searches were performed of the Licensing Event Report and Nuclear Plant Reliability Data System computerized data bases, and a review was made of inservice inspection summary reports. It was found that the section $X I$ examinations and tests detect flaws in welds and plant components and result in subsequent corrective action. This study also shows that the format and topics of information provided in Section XI-prescribed inservice inspection summary reports vary widely. 

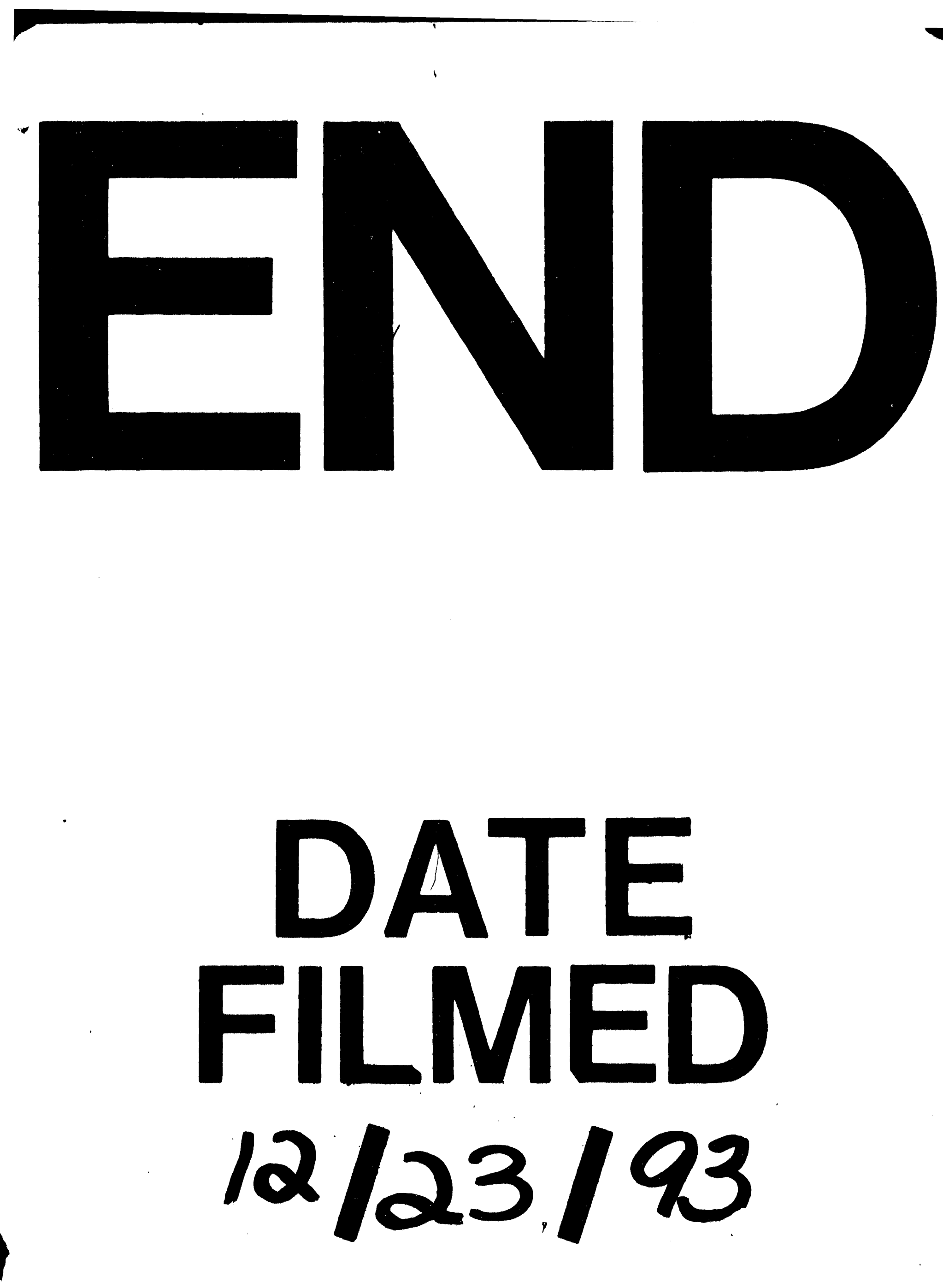
